\title{
Gevangen in moederschap : 'gedetineerde vrouwen en het recht op family life'
}

Citation for published version (APA):

Wolleswinkel, M. W. (1997). Gevangen in moederschap : 'gedetineerde vrouwen en het recht op family life'. [Doctoral Thesis, Maastricht University]. Gouda Quint. https://doi.org/10.26481/dis.19970523mw

Document status and date:

Published: 01/01/1997

DOI:

10.26481/dis.19970523mw

Document Version:

Publisher's PDF, also known as Version of record

\section{Please check the document version of this publication:}

- A submitted manuscript is the version of the article upon submission and before peer-review. There can be important differences between the submitted version and the official published version of record.

People interested in the research are advised to contact the author for the final version of the publication, or visit the DOI to the publisher's website.

- The final author version and the galley proof are versions of the publication after peer review.

- The final published version features the final layout of the paper including the volume, issue and page numbers.

Link to publication

\footnotetext{
General rights rights.

- You may freely distribute the URL identifying the publication in the public portal. please follow below link for the End User Agreement:

www.umlib.nl/taverne-license

Take down policy

If you believe that this document breaches copyright please contact us at:

repository@maastrichtuniversity.nl

providing details and we will investigate your claim.
}

Copyright and moral rights for the publications made accessible in the public portal are retained by the authors and/or other copyright owners and it is a condition of accessing publications that users recognise and abide by the legal requirements associated with these

- Users may download and print one copy of any publication from the public portal for the purpose of private study or research.

- You may not further distribute the material or use it for any profit-making activity or commercial gain

If the publication is distributed under the terms of Article $25 \mathrm{fa}$ of the Dutch Copyright Act, indicated by the "Taverne" license above, 
Gevangen in moederschap 
Schilderij omslag:

'Lofzang', Siiri Spronken (1995)

Fotografie:

Frank van Helfteren 


\section{Gevangen in moederschap}

'Gedetineerde vrouwen en het recht op family life'

\section{Proefschrift}

ter verkrijging van de graad van doctor aan

de Universiteit Maastricht,

op gezag van de Rector Magnificus, Prof.mr. M.J. Cohen

vollgens het besluit van het College van Decanen,

in het openbaar te verdedigen

op vrijdag 23 mei 1997 om 14.00 uur

door

Maria Willemina Wolleswinkel

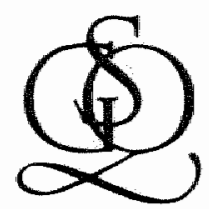

Gouda Quint

(S. Gouda Quint - D. Brouwer en Zoon)

Deventer 
Promotor:

Prof.mr. G.P.M.F. Mols

Co-promotor:

Dr.P.L. Bal

Beoordelingscommissie:

Prof.mr. Th.A. de Roos (voorzitter)

Prof.mr. J.E. Goldschmidt (Rijksuniversiteit Leiden)

Mr. G. de Jonge

Prof.mr. C. Kelk (Universiteit Utrecht) 
"..ik geloof dat het iets geweldig goeds is, als men wroeg went aan de eenzaamheid. Dat leert een mens, in zekere mate tenninste, om het zonder anderen te kunnen stellen. Het leert een mens ook on meer wan anderen te houden. Bovendien is er diep in het kind een onverschilligheid, die je maar heel zelden windt besclireven. It weet niet of de menssen zich gegeneerd woelen als ze die onverschiligheid merken, maar het treft mij altijd als ik naar kinderen kijk: ze lewen in hun eigen wereld. En ik heb hel gevoel dat ik in minn eigen wereld leefde. Ik gelloof dat de meeste sichnijwers die het over de kindertijd hebben, zells de 'serienze', zich attijd op dat pusu verkijken. Ze zien het kind vanuit het standpunt wan de volwassent, of ze doen een enome poging on zidn te weplaatsen in wat een kind naar hun idee is. Dat is allemaal weel ie systematisch, het gaat tevel wit van onze eigen conventies. Ik geloof dat een kind zich op een heel vage manier in het leven oriênteert, met de verwondering van het jonge dier dat iets voor de eerste - of voor de tweede of derde keer-ziet; de grote mensen om hem heen, van wie de identiteit niet alijd even duidelijk is, wan wie de een, zeggen ze, blijkbaar zijn vader is en 'papa' heet (noar wie is voor hem ent vader?'), en de ander zïn moeder en een derde het dienstmeisje of her kenkenneisje, of de postbode, - al die mensen zijn 'grote mensen', die op Jun manier belangrijk zijh, en die tevens geen bijzonder sterke band wet hen hebben, hij heefi zijn eigen leven en dar kunnen die mensen niet bij. En dat soort relaties, die wil niemand ontkennen. Men wil dat kinderen hun ouders verachten of hen vereren."

(M. Yourcenar (1991) p. 20-21) 


\section{Inhoudsopgave}

Lijst van afkortingen $\quad$ xiii

Algemene Inleiding $\quad 1$

Hoofdstuk 1. Verklaring voor het aantal gedetineerde wrowwen

Inleiding

$\begin{array}{lll}1.1 & \text { Een historisch perspectief } & 13\end{array}$

$\begin{array}{lll}1.2 & \text { Statistische vertekening } & 16\end{array}$

$\begin{array}{lll}\text { 1.2.1 Wat is criminaliteit, wat is strafbaar gedrag? } & 17\end{array}$

$\begin{array}{ll}\text { 1.2.2 Interpretatie van cijfers. } & 19\end{array}$

1.3 Strafproces en straftoemeting 22

$\begin{array}{lll}\text { 1.3.1 Psychiatrisering } & 22\end{array}$

1.3.2 De ridderlijkheidshypothese 32

1.4 Criminologische theorieën 37

$\begin{array}{lll}1.4 .1 & \text { Biologische theorieën } & 37\end{array}$

$\begin{array}{lll}\text { 1.4.2 Psychologische theorieën } & 39\end{array}$

1.4.3 Socialisatietheorieën 41

$\begin{array}{lll}1.4 .4 & \text { Politieke machtstheorieën } & 47\end{array}$

1.5 Samenvatting 51

Hoofdstuk 2. De gevangeniscultuur: empirie en theorie 53

Inleiding $\quad 53$

$2.1 \quad$ Locaties 56

2.2 Impressies van gedetineerden 60

2.2.1 Onderlinge verhoudingen 63

$\begin{array}{lll}2.2 .2 & \text { Relatie tot het personeel } & 70\end{array}$ 
$\begin{array}{lll}2.2 .3 & \text { Dagbesteding } & 72\end{array}$

2.2.4 Contact met relaties 'buiten' $\quad 73$

$\begin{array}{lll}2.2 .5 & \text { Seksualiteit/intimiteit } & 81\end{array}$

$\begin{array}{lll}2.2 .6 & \text { Evaluatie op hoofdpunten } & 82\end{array}$

2.3 Theorievorming over gevangeniscultuur 82

$\begin{array}{lll}2.3 .1 & \text { Psychosociale processen } & 84\end{array}$

2.3.1.1 Deprivatiemodel $\quad 85$

$\begin{array}{lll}2.3 .1 .2 & \text { Importmodel } & 87\end{array}$

2.3.1.3 Geïntegreerd model 88

2.3.2 Sociaalemancipatorische processen 90

2.3.3 Politisering en macht 93

$\begin{array}{ll}2.4 & \text { Samenvatting }\end{array}$

Hoofdstuk 3. Detentiebeleid na WO II 97

$\begin{array}{ll}\text { Inleiding. } & 97\end{array}$

$3.1 \quad$ Kenmerken van het overheidsbeleid 98

3.2 Kenmerken van het overheidsbeleid ten aanzien van vrouwen 103

$\begin{array}{lll}3.2 .1 & \text { Locaties } & 108\end{array}$

$\begin{array}{lll}3.2 .2 & \text { Familierelaties } & 111\end{array}$

$\begin{array}{lll}3.2 .2 .1 & \text { Kinderen } & 111\end{array}$

$\begin{array}{lll}3.2 .2 .2 & \text { Partners } & 119\end{array}$

$\begin{array}{lll}3.2 .3 & \text { Gemengde detentie } & 121\end{array}$

$\begin{array}{lll}3.2 .4 & \text { Seksualiteit } & 126\end{array}$

$\begin{array}{lll}3.2 .5 & \text { Activiteiten } & 127\end{array}$

$\begin{array}{lll}3.2 .6 & \text { Medische zorg } & 128\end{array}$

$\begin{array}{lll}3.2 .7 & \text { Penitentiair inrichtingswerk } & 130\end{array}$

$\begin{array}{lll}3.3 & \text { Samenvatting } & 132\end{array}$

Hoofdstuk 4. De materiële rechtspositie van gedetineerde vrouwen 135

$\begin{array}{ll}\text { Inleiding } & 135\end{array}$

$\begin{array}{lll}4.1 & \text { Het klachtrecht } & 138\end{array}$

4.2 Grondrechten 142

$\begin{array}{lll}4.3 & \text { Materiële rechten } & 147\end{array}$

4.3.1 Correspondentie, bezoek, telefoneren 148

$\begin{array}{lll}\text { 4.3.2 Strafonderbreking en verlof } & 151\end{array}$ 


$\begin{array}{llr}\text { 4.3.3 } & \text { Overplaatsing } & 153 \\ 4.3 .4 & \text { Vervoegde invrijheidsstelling/gratie } & 155 \\ 4.3 .5 & \text { Arbeid/scholing } & 156 \\ 4.3 .6 & \text { Medische zorg } & 157 \\ 4.4 & \text { Speciale rechtspositie vrouwen } & 161 \\ 4.4 .1 & \text { Art. 31 Gevangenismaatregel } & 162 \\ 4.4 .2 & \text { Art 12 Penitentiaire Beginselenwet (ontwerp) } & 163 \\ 4.5 & \text { Samenvatting } & 169\end{array}$

Hoofdstuk 5. Zorgen in het gezin

$\begin{array}{ll}\text { Inleiding } & 171\end{array}$

$5.1 \quad$ Het gezin 173

$\begin{array}{lll}\text { 5.1.1 De universele waarde van het gezin } & 173\end{array}$

5.1.2 Functieverschuiving en individualisering : $\quad 176$

$\begin{array}{lll}5.1 .3 & \text { Individualisering in het gezin } & 178\end{array}$

$\begin{array}{lll}\text { 5.1.4 Verdeling van functies binnen het gezin } & 179\end{array}$

5.1.5 Ambivalenties ten aanzien van het gezin 181

$\begin{array}{lll}5.2 & \text { Moederschap } 181\end{array}$

$\begin{array}{lll}5.2 .1 & \text { Opoffering en moederplicht } & 184\end{array}$

$\begin{array}{ll}\text { 5.2.2 Opvoeding en ontplooiing } 185 & 184\end{array}$

5.2.3 Veranderend moederschap en het belang van het kind 188

5.2.4 Ambivalenties ten aanzien van het moederschap 191

5.3 Het 'normale' kind 194

$\begin{array}{lll}\text { 5.3.1 Hechting } & 195\end{array}$

5.3.2 Het heteroseksuele ouderpaar: afstamming en identiteit 197

$\begin{array}{lll}\text { 5.3.3 Loyaliteit } & 199\end{array}$

5.3.4 De continuïteit in de opvoeding: het verbrede opvoedingsmilieu 201

$\begin{array}{lll}\text { 5.3.5 De eigen leefwereld } & 202\end{array}$

5.3.6 Opvoeding als sociale politiek: overheidsbemoeienis 205

$\begin{array}{lll}5.4 & \text { Samenvatting } & 207\end{array}$ 
6.1 Autonome rechten van kind

6.3.1 Europese rechtspraak met betrekking tot het belang van kind"

6.4 De Nederlandse overheid en 'het belang van het kind' 228

$\begin{array}{lll}6.4 .1 & \text { Arbeid } & 234\end{array}$

6.4.1.1 Kinderopvang 236

$\begin{array}{lll}6.4 .2 & \text { Onderwijs } & 238\end{array}$

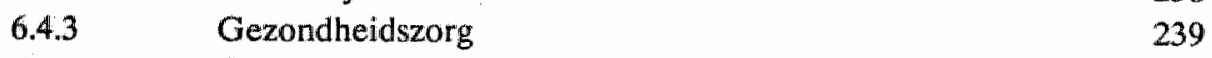

6.5 Conclusie : 243

Hoofdstuk 7. 'Het belang van het kind'. Privacy of family life? 245

Inleiding

$\begin{array}{lll}7.1 & \text { Een vrouwelijke moraal? } & 248\end{array}$

$\begin{array}{ll}7.2 & 250\end{array}$

7.3 'Ethics of care' in het familierecht? 254

7.4 Afstamming: de wortels van het bestaan? 255

7.5 Art. 8 EVRM en het belang van het kind 258

$\begin{array}{lll}\text { 7.6. Feitelijke zorg } & 262\end{array}$

7.7 Ouderlijk gezag bij scheiding 264

$\begin{array}{lll}7.7 .1 & \text { Een-oudergezag na echtscheiding } 268\end{array}$

7.7.2 Gezamenlijk gezag na echtscheiding en buiten huwelijk 274

$\begin{array}{lll}7.8 & \text { Verblijfplaats } & 275\end{array}$

$\begin{array}{lll}7.9 & \text { Omgangs-, informatie- en consultatierecht } & 277\end{array}$

$\begin{array}{lll}7.10 & \text { Verhouding tot derden/pleegouders } & 278\end{array}$

$\begin{array}{ll}7.11 & \text { Samenvatting en conclusies } \\ & 280\end{array}$ 
$\begin{array}{lll}8.1 & \text { Het leefsysteem } & 288\end{array}$

$\begin{array}{lll}\text { 8.1.1 Family life } & 288\end{array}$

$\begin{array}{lll}\text { 8.1.2 Belang van het kind } & 289\end{array}$

8.1.3 Vermijden van seksestereotypering 290

$8.2 \quad$ Het leefsysteem van gedetineerden 293

8.2.1 Kinderen en partners 293

$\begin{array}{lll}\text { 8.2.2 Primaire verzorgers } & 297\end{array}$

$\begin{array}{lll}8.2 .3 & \text { Buitenlandse vrouwen } & 299\end{array}$

8.3 Preventieve fase 302

8.3.1 Aanhouding 303

$\begin{array}{lll}\text { 8.3.2 Voorlopige hechtenis } & 305\end{array}$

8.4 Terechtzitting: straftoemeting 307

$\begin{array}{lll}8.5 & \text { Tenuitvoerlegging } & 312\end{array}$

8.5.1 Alternatieve vrijheidsbeneming 312

$\begin{array}{lll}\text { 8.5.2 Gevangenisstraf } & 314\end{array}$

8.5.2.1 Voorzieningen tijdens detentie 316

8.5.2.2 Verblijf van kinderen bij hun ouders in detentie 322

8.5.2.3 Co-detentie in het buitenland 326

$\begin{array}{lll}8.6 & \text { Tot slot } & 330\end{array}$

Samenvatting 333

$\begin{array}{ll}\text { Summary } & 343\end{array}$

$\begin{array}{ll}\text { Resumé } & 351\end{array}$

$\begin{array}{ll}\text { Literatuur } & 361\end{array}$

$\begin{array}{ll}\text { Jurisprudentieregister } & 387\end{array}$

$\begin{array}{ll}\text { Trefwoordenregister } & 391\end{array}$

$\begin{array}{ll}\text { Bijlagen } & 399\end{array}$

$\begin{array}{ll}\text { Naschrift } & 409\end{array}$

$\begin{array}{ll}\text { Curriculum vitae } & 411\end{array}$ 


\section{Lijst van afkortingen}

\begin{tabular}{|c|c|}
\hline AAe & Ars Aequi \\
\hline$A V G$ & Algemene Verlofregeling Gedetineerden \\
\hline BC & Beroepscommissie van de Centrale Raad voor Strafrechtstoepassing \\
\hline BOPZ & Bijzondere Opneming Psychiatrische Ziekenhuizen \\
\hline BSD & Bureau Sociale Dienstwerlening \\
\hline BW & Burgerlijk Wetboek \\
\hline BWG & Beginselenwet Gevangeniswezen \\
\hline CEDAW & Committee on the Elimination of Discrimination Against Women \\
\hline \multirow[t]{2}{*}{ CPT } & Committee for the Prevention of Torture and Inhuman or Degrading \\
\hline & Treatment or Punishment \\
\hline CRDU & Children's Rights Development Unit \\
\hline CWI & Clara Wichmann Instituut \\
\hline DD & Delikt en Delinkwent \\
\hline$D$ en $J$ & Directie Delinquentenzorg en Jeugdinrichtingen \\
\hline DJI & Dienst Justïtiële Inrichtingen \\
\hline DVA & Drugswrije afdeling \\
\hline ECHR & European Court on Human Rights \\
\hline ECRM & Europese Commissie voor de Rechten wan de Mens \\
\hline EEM & Extramuralle executiemodaliteiten \\
\hline EHRM & Europees Hof voor de Rechten van de Mens \\
\hline EK & Eerste Kamer \\
\hline EPR & European Prison Rules. \\
\hline ER & Emancipatieraad \\
\hline EU & Europese Unie \\
\hline EVRM & $\begin{array}{l}\text { Europees Verdrag tot bescherming van de Rechten van de Mens } \\
\text { en de fundamentele vrijheden }\end{array}$ \\
\hline FIR & (Tijdschrift voor) Familie- en jeugdrecht \\
\hline FOBA & Forensische observatie- en begeleidingsafdeling \\
\hline GGD & Geneeskundige Gezondheidsdienst \\
\hline GM & Gevangenismaatregel \\
\hline $\mathrm{HBO}$ & Hogere beroepsopleiding \\
\hline HHR & Huishoudelijk reglement \\
\hline HIV & Human Inmunodeficiency Virus \\
\hline h.o.i. & hallfopen inrichting \\
\hline HR & Hoge Raad \\
\hline $\mathrm{H} v B$ & Huis vam Bewaring \\
\hline JDVG & Justitiele Documentatie en de verklaring omtrent thet gedrag \\
\hline IBA & Individuele begeleidingsafdeling \\
\hline
\end{tabular}




\begin{tabular}{|c|c|}
\hline nO & International Labour Organisation \\
\hline IND & Immigratie- en Naturalisatie Dienst \\
\hline IVBPR & Intermationaal Verdrag inzake burgerrechten en politieke rechten \\
\hline JV & Justitiële Verkenningen \\
\hline KG & Kort Geding \\
\hline LoI & Leidse onderwijsinstellingen \\
\hline $\mathrm{MBO}$ & Middeibare beroepsopleiding \\
\hline MGV & Maandbiad Geestelijke Volksgezondheid \\
\hline mim.k. unit & moeder met kind unit \\
\hline MvT & Memorie van Toelichting \\
\hline NACRO & National Assaciation for the Care and Resettlement of Offenders \\
\hline NGO & Non-Governemental Organization (nongouvernementele organisatie) \\
\hline NI & Nederlandse Jurisprudentie \\
\hline NJB & Nederlands Juristen Blad \\
\hline NJCM & Nederlands Juristen Comité voor de Mensenrechten \\
\hline NJV & Nederlandse Juristen Vereniging \\
\hline NTOR & Nederlands Tijdschrift voor Onderwijsrecht \\
\hline OCAS & Overleg- en Adviescommissie alternatieve sancties \\
\hline $\mathrm{OM}$ & Openbaar Ministerie \\
\hline OvJ & Officier van Justitic \\
\hline PBW & Penitentiaire Beginselenwet \\
\hline PG & Procureur(s)-Generaal \\
\hline PI & Penitentiaire Informatie \\
\hline p.i.v. & penitentiaire inrichting voor vrouwen \\
\hline p.i.w.er & penitentiair inrichtingswerker \\
\hline p.o.i.p & penitentiaire open inrichting \\
\hline $\mathbb{R b}$ & Rechtbank \\
\hline REP & Relais Enfants Parents \\
\hline RIAGG & Regionaal Instituut voor Ambulante Geestelijke Gezondheidszorg \\
\hline RM Themis & Rechtskundig Magazijn Themis \\
\hline RN & Rechtspraak Nemesis \\
\hline RO & Rechterlijke Organisatie \\
\hline $\mathbf{R}$ en $\mathbf{R}$ & Tijdschrift voor Rechtstheorie en Rechtsfilosofic \\
\hline RvdK & Raad woor de Kinderbescherming \\
\hline RVR & Rechtspraak Vrouw en Recht \\
\hline RvS & Raad van State \\
\hline SMR & Standard Minimum Rules for Prisoners \\
\hline $\mathrm{Sr}$ & Wetboek van Stralrecht \\
\hline Sv & Wetboek van Strafvordering \\
\hline TGP & Tijdschrift voor Gezondheid en Politiek \\
\hline TK & Tweede Kamer \\
\hline TuCr & Tijdschrift voor Criminologie \\
\hline Tuv & Tijdschrift voor Vrouwenstudies \\
\hline UCV & Uitgebreide commissievergadering \\
\hline UNHCR & United Nations High Commissioner for Refugees \\
\hline VBA & Verslaafdenbegeleidingsafdeling \\
\hline VN-Kinderverdrag & Verdrag inzake de rechten van het kind \\
\hline
\end{tabular}


VN-Vrouwenverdrag

v.i.

VOS

WGB

WODC

WOTS

WPR

ZtStVo
Verdrag inzake de uitbanning van alle wormen van discriminatie van vrouwen

vervroegde inwrijheidsstelling.

Vrouwen oriënteren zich op de samenleving

Wet geneeskundige behandelingsovereenkomst

Wetenschappelijk Onderzoek- en Documentatie Centrum van het Ministerie van Justitie

Wet overdracht tenuitvoerlegging strafvonnissn

Wet persoonsregistraties

Zeitschrift fur Strafvollzug 


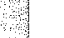




\section{Algemene inleiding}

In dit onderzoek staat de (rechts)positie van gedetineerde moeders centraal en met name de vraag in hoeverre zij aan hun positie van feitelijk verzorgende ouder rechten kunnen ontlenen ten aanzien van de overheid of derden.

Het moederschap wordt in de huidige tijd niet meer eenduidig ingevuld. Tot ver na de Tweede Wereldoorlog waren in Nederland seksualiteit, voortplanting en zorgfuncties van vrouwen nauw met elkaar verbonden en geplaatst binnen de context van huwelijk en gezin. Inmiddeis is het moederschap feitelijk steeds minder gerelateerd aan huwelijk, gezin en heteroseksualiteit. Om vast te stellen wanneer er sprake is van moederschap speelt de waardering van de feitelijke situatie waarin moeders en kinderen zich bevinden een belangrijke rol. Bij het definiëren van zorgrelaties blijken ook mannen steeds meer te "moederen", maar de grootste inzet en differentiatie in zorg is nog altijd bij vrouwen te vinden en dat lijkt ook in de komende jaren niet te zullen veranderen. ${ }^{1}$ Hoewel het moederschap niet per se aan jonge kinderen gebonden is, lijkt met betrekking tot die leeftijdsfase, ook op biologische gronden, nog de meeste eenduidigheid te bestaan over de onlosmakelijke band tussen moeder en kind. Hoe zorgrelaties gedurende het verdere leven worden ingevuld is steeds meer een kwestie van individuele vrijheid en keuzes, al dan niet contractueel vastgelegd.

De gevolgen van de verschillen in invulling en waardering van zorgrelaties komen scherp aan het licht als door een corzaak van buitenaf tot dan toe vanzelfsprekende arrangementen worden verstoord. Het detineren van een verzorgende ouder, met name de moeder, is zo'n externe ingreep die zelfs plaatsvindt onder verantwoordelijkheid van de staat en dus alleen al om die reden om nadere invulling en legitimatie vraagt.

De in de aanhef gestelde vraag wordt binnen dit onderzoek vanuit drie invalshoeken uitgewerkt:

1. Vanuit de concrete positie van de gedetineerde moeders.

2. Vanuit het abstractere niveau waar maatschappelijke, wetenschappelijke en dus ook juridische concepten van zorg, het belang van het kind, moederschap en familierelaties een invulling krijgen.

1 Zie onder meer Van Doorne-Huiskens (1992), Hooghiemstra en Niphuis-Nell (1993) p. 237. 
3 Vanuit de overheid die op grond van diverse verdragsartikelen familierelaties dient te respecteren.

Ad 1. De positie van gedetineerde moeders.

De gedetineerde vrouwen vormen binnen het penitentiaire recht een vrijwel vergeten groep, onder andere door hun relatief gezien geringe aantal. Ongeveer één op de twintig gedetineerden is een vrouw. Hoewel er dus weinig vrouwen in detentie zijn, is er in absolute zin sprake van een snelle groei. Na de opening van de laatste nieuwbouwgevangenissen voor vrouwen in 1994 zijn er inmiddels 465 cellen voor vrouwen. In 1987 waren dat er nog maar 134. Gemiddeld duurt het verblijf in detentie ongeveer 150 dagen. ${ }^{2}$ Rond zestig procent van de vrouwen heeft voor hun detentie de directe zorg voor kinderen.

Hoewel het de vraag is of er in zijn algemeenheid enig doel met het detineren van mensen gediend wordt, dringt deze vraag zich bij deze groep gedetineerden in het bijzonder op. Zowel het pretentieuze streven naar 'resocialisatie' als het minder pretentieuze 'voorkomen van de detentieschade' lijken in tegenspraak te zijn met het isoleren van vrouwen uit hun leefomgeving, omdat zij in hun 'normale socialisatie' sterk op primaire leefrelaties gericht zijn. Ook wanneer niet een strikt individueel doel van straf gehanteerd wordt, maar een meer maatschappelijk bepaald doel als 'het herstel van de orde en veiligheid', is het de vraag of het middel, de gevangenhouding, well het doel dient. Er wordt immers doelbewust een primaire verzorger uit haar leefomgeving gehaald, terwijl in diverse onderzoeken, al dan niet terecht, een relatie tussen jeugdtrauma's, gebroken gezinnen en criminaliteit gelegd wordt. ${ }^{3}$ Voor de directe veiligheid hoeven vrouwen ook niet gedetineerd te worden. Zij zijn over het algemeen first offender. $\mathrm{Zij}$ doen geen ontsnappingspogingen, tenzij de wlucht naar huis daaronder begrepen wordt en zij plegen nauwelijks geweldsdelicter. Het detineren van moeders leidt tot een dilemma. Hoe verhoudt het algemeen belang van opsluiting zich tot de bescherming van het family life? Enerzijds speelt de vraag of een verblijf in de gevangenis hoe dan ook zinvol kan zijn, welke rol het gezinsleven van de vrouw speelt en wat haar plaats daarin zou moeten zijn. Anderzijds is het een vraag hoe in concrete gevallen het belang van haar kind(eren) meegewogen moet worden. Afhankelijk van de leeftijdsfase en de individuele aard en ontwikkeling

2 Dit cijfer dateert van 1991 (Fuldauer (1995-1, p. 78). Kester en Junger-Tas (1994, p. 71) komen op een reèlle verblijfsduur van 4,8 maanden. $\mathrm{Zij}$ hebben de beschikking over cijfers van 1990 . Beide bronnen signaleren een enorme stijging in de gemiddelde detentieduur tussen 1982 (gemiddeld 80 dagen) en begin jaren negentig.

3 Zie onder meer Junger-Tas (1996), Goudena (1996). 
van het kind, zal ook vanuit diens perspectief naar de invulling van een, onder de omstandigheden, optimale relatie met de ouder gezocht moeten worden.

Als vrouwen geweld plegen, doen zij dat overigens veelal in eigen kring dus in die gevallen wordt het dilemma nog aangescherpt. Hoe verhouden de belangen van de moeder en het kind zich tot elkaar?

Zou de kwantiteit van het geschetste probleem al een -aanvechtbare- reden zijn om de gedetineerde moeders te beschouwen als een "te verwaarlozen categorie", dan nog kan een nadere bestudering van hun lot en leven waardevol zijn voor andere groepen onzichtbare vrouwen die min of meer gedwongen in instituties verblijven, en die daar kwantitatief gezien helemaal geen duidelijke minderheid vormen. Ik denk dan aan vrouwen die in psychiatrische ziekenhuizen zijn opgenomen of in afkickcentra voor verslaafden. Voor een deel lopen hun belangen parallel. Hoewel de reden voor het verblijf vaak zal verschillen, delen deze vrouwen in gesloten instituties gevoelens van zorg, schuld en schaamte ten opzichte van hun kinderen. Daarnaast speelt bij hen de angst om te falen in hun moederrol en om geconfronteerd te worden met maatschappelijke vooroordelen omtrent hun verzorgingskwaliteiten. Gevoelens die zo machteloos maken en die zo diep ingrijpen dat het ook voor hen vaak de vraag is hoe een verder verblijf zinvol ingevuld kan worden.

Ik wil niet bepleiten dat moeders nooit gedetineerd of gedwongen opgenomen mogen worden en ook niet stellen dat moeders en kinderen niet gescheiden kunnen worden. Het gesignaleerde dilemma kan echter niet over het hoofd gezien worden, omdat iedereen die ermee te maken krijgt (als moeder, kind, vervangende verzorger, beleidsmaker, wetgever, rechter, gevangenisdirecteur, hulpverlener, onderzoeker etcetera) het op zijn of haar eigen niveau moet kunnen hanteren.

Het recht blijkt via rationele analyse juist in maatschappelijk omstreden en niet uitgekristalliseerde kwesties vaak een belangrijke katalyserende rol te vervullen. ${ }^{4} \mathrm{Op}$ dit concrete niveau verwacht ik dan ook niet zozeer tot een materiële regel te komen ten behoeve van gedetineerde moeders en hun kinderen maar wellicht wel tot een 'weging', die in concrete gevallen kan leiden tot alternatieve uitkomsten voor verzorgende ouders. Dit impliceert dat de materiële voorzieningen dan wel zodanig gedifferentieerd moeten zijn dat het resultaat van zo'n procedure geëffectueerd kan worden.

4 Vgll de discussie over euthanasie en hulp bij zelfdoding. 
Ad 2. Concepten van moederschap, zorg en familierelaties.

Om tot een materiële invulling van voorzieningen te komen is het belangrijk eerst het stereotiepe beeld van moederschap te analyseren dat de praktijk van alledag beheerst: de (biologische) moeder, die geacht wordt 'er voor het kind te zijn'. Een beeld dat ook wordt weerspiegeld in de levens van veel vrouwen die buiten eerdergenoemde gesloten instituties, in de 'vrije' maatsehappij, leven. Een beeld dat echter steeds diffuser wordt doordat de wensen van moeders en van de hen omringende wereld steeds minder eenduidig zijn. Opvattingen over opvoeding lijken cultureelbepaald en met al hun onderlinge verschillen stevig verankerd te zijn. De praktijk van gezin en moederschap is echter sterk aan verandering onderhevig. Na de Tweede Wereldoorlog lijkt ook in Nederland het stevige bouwwerk van het traditionele gezin te wankelen, maar alternatieve opvoedingsstructuren zijn nog nauwelijks gevonden. ${ }^{5}$ Onder ouders van jonge kinderen lijkt in het huidige tijdsgewricht, ondanks de beschikbare gedragswetenschappelijke kennis en ondersteuning, een enorme opvoedingsonzekerheid te bestaan. ${ }^{6}$ Ook binnen de groep gedetineerde vrouwen zullen cultuurbepaalde verschillen en praktijken optreden, die de beoordeling van feitelijke situaties kunnen beïnvloeden.

In het recht werken maatschappelijke opvattingen over kind, gezin en moederschap door. Vooral in het familierecht en via de doorwerking van dat recht in andere rechtsgebieden worden oude en nieuwe concepten van moederschap, ouderschap, zorg, family life, private life, gelijke en autonome rechten gehanteerd.

Daarbij speelt de theorievorming binnen het aandachtsgebied juridische vrouwenstudies een belangrijke rol.' Vanuit juridische vrouwenstudies is geageerd tegen de patriarchale gezinsstructuur die levens van vrouwen en mannen, ook buiten het huwelijk, zeer sterk determineert, zowel in de publieke als in de privésfeer. In eerste instantie voelden vrouwen zich vooral maatschappelijk gezien buitengesloten. Mannen konden zich publiekelijk manifesteren, mede dankzij ondersteuning door hun betrekkelijk machte-(c.q. rechte-)loze vrouwen en kinderen. Na de tweede feministische golf, waarin sterk werd gepleit voor een eerlijke verdeling van betaalde en onbetaalde taken (en daarmee van macht) tussen mannen en vrouwen, bleken onder andere via wetgeving en rechtspraak mannen in een aantal opzichten sterker uit de strijd

5 Pessimistische geluiden over de gevolgen van het verval van het gezin werden aanwankelijk vooral vanuit de VS vernomen. Vgl. Lasch (1980), Lasch in: NRC, 10-11-1990:

"Als je de familie serieus neemt als het belangrijkste middel waardoor culturen worden overgebracht, dan kun je niet anders dan gereserveerd staan tegenover de richting die het feminisme is ingeslagen, omdat het zoveel overwinningen heeft behaald ten koste van de familie en eigenlijk ten koste vam kinderen. En vaak heel openitjk, alsof de rechten van vrouwen boven de rechten van kinderen gaan, een ongelukkige manier van denken."

6 O.a. Singer (1989), Van Beckhoven en Meeuwig (1992), Meulenbelt (1993).

7 Zie voor een uitgebreid overzicht Goldschmidt en Holtmaat (1993). 
te zijn gekomen dan vrouwen. ${ }^{8}$ Vrouwen zijn niet meer zozeer buitengesloten, maar ingesloten door de macht: arbeids(c.q. carrière-)plicht leidt, zolang loonarbeid, voortplanting en verzorging niet maatschappelijk, moreel en economisch, als gelijk te stellen voorwaarden tot in standhouding van de soort worden erkend, tot enerzijds dubbelbelaste of onder de maat presterende vrouwen en anderzijds tot verdergaande 'feminisering van de armoede'. Het blijkt moeilijk een sociale ontwikkelingsbenadering, waarbij affectieve relaties en de huiselijke context een belangrijke rol spelen en een economische ontwikkelingsbenadering, waarbij individuen louter in een economische rol worden gezien, te verbinden. Toch gaat het te ver om, uitsluitend op grond van de disciplinerende werking van het recht, alle juridische instrumenten af te wijzen. Dan verandert er zeker niets in de bestaande machtsverhoudingen." De discussie lijkt zich binnen juridische vrouwenstudies onder meer toe te spitsen op de vraag of er nog een 'vrije' privésfeer bestaat, waar mensen op grond van wederzijdse zorg en affectie tot gelijkwaardige inbreng van zorg kumnen komen of dat daarvoor een min of meer actieve bemoeienis van de overheid noodzakelijk is. ${ }^{10}$

Onderzoeksters gaan ook in zijn algemeenheid via de begrippen zorg en autonomie op zoek naar het specifiek vrouwelijke in het recht, hoewel inmiddels de theorie via het begrip 'gender' voor een deel geabstraheerd is van de concrete groep mannen en vrouwen. ${ }^{.}$Overheersende eigenschappen/waarden/normen worden mannelijk genoemd hoewel ze niet per se aan alle mannen verbonden hoeven te zijn. Daarnaast worden er ook steeds meer differentiaties aangebracht binnen de groep mannen en de groep vrouwen, onder meer verbonden met klasse, etniciteit, opleiding, seksuele geaardheid etcetera. ${ }^{12}$ Binnen de rechtstheorie worden vanuit het zorg-en-autonomie perspectief wegen gezocht voor een andere invulling van rechtvaardigheidstheorieën. Aan de hand van onder andere Gilligan's ethics of care-perspectief wordt gepleit voor een contextuele benadering van het recht, zowel in concrete casusposities als bij het benoemen van abstracte concepten. ${ }^{13}$

Wel is gebleken dat de patriarchale hegemonie in de verschillende rechtsgebieden telkens anders doorwerkt, waardoor vanuit vrouwenstudies moeilijk eenduidige 'oplossingen' te vinden zijn. Via de materiële invulling van het bestaande gelijkheidsbeginsel zijn wellicht de meeste concrete worderingen geboekt, met name binnen het arbeidsen sociale zekerheidsrecht en het familierecht. ${ }^{14}$ Door bij voorbeeld rekening te houden met zorgtaken kan een ongerechtvaardigd onderscheid tussen rechtssubjecten

8 Zie onder meer Pessers (1988-1), Pessers (1991).

9 Vgl. Smart (1989). Zij analyseert in dit boek in het bijzonder de werking van het strafrecht. Holtmaat (1990), Goldschmidt (1993-1).

10 Zie Sevenhuijsen (1993-1), Gunning (1993), Pessers (1993).

11 Zie voor een witwerking van het genderbegrip onder andere Holtmaat (1992), p. 23-31.

12 Zie Minow (1990), Smart (1991), Loenen (1992-2), Goldschmidt (1993-2).

13 Zie onder meer Gunning (1985), Sevenhuijsen (1990), Tigchelaar (1993).

14 Zie Goldschmidt (1989), Wentholt (1990), Loenen (1992-1), Holtrust (1993). 
vermeden worden. Niet de sekse als zodanig, maar het onderscheidend criterium is dan bepalend voor toepassing van regelgeving. Zo kan het sekseneutrale begrip 'primair verzorgende ouder' in belangenafwegingen binnen het familierecht, onder meer op grond van art. 8 en 14 EVRM, recht doen aan de feitelijke context van een casus.

Vooral in de sfeer van het strafrecht, bijvoorbeeld de reacties op seksueel geweld, en delen van het familierecht, zoals voortplanting en opvoeding buiten huwelijk, is het lastig wegen te vinden om de "ongerechtvaardigde uitsluiting" van vrouwen aan de kaak te stellen en daar via bijvoorbeeld wetgeving iets aan te doen. ${ }^{15}$ Op deze terreinen gaat het niet alleen om de doorwerking van patriarchale structuren, maar ook om de waardering van de heteroseksuele relatie als zodanig. Bovendien kan hier van de overheid geen beschermende rol geclaimd worden. Voor zover er (grond)rechten beschermd dienen te worden, gaat het om de horizontale werking van die rechten. Het strafrecht is qua aard echter bij uitstek individugericht en het familierecht contextgericht. Beide lijken in hun eigen aard 'gendered' te zijn. Het strafrecht stereotiep mannelijk, het familierecht stereotiep vrouwelijk. ${ }^{16}$ En juist de gedetineerde moeder bevindt zich qua rechtspositie op het snijvlak van deze rechtsgebieden. $\mathrm{Zij}$ past noch in de rol van de mannelijke rechtsburger in het strafrecht en het daaraan gelieerde penitentiaire recht, noch in de traditioneel vrouwelijke rol van het familierecht.

Ad 3 De overheid en het family life.

De rol van de overheid is in het strafrecht en het familierecht ook verschillend. In het strafrecht de aan strikte regels gebonden handelende, sturende actor, in het familierecht de beschermende, terughoudende actor.

Dit leidt tot rolconflicten van de overheid ten aanzien van gedetineerde moeders c.q. verzorgers en hun kinderen. De overheid die zich kan manifesteren als ordehandhaver en exponent van dominante waarden en regels maar ook als beschermer van klassieke en sociale grondrechten van individuele en groepen burgers. De overheid die sturend of passief kan zijn.

15 De term is ontleend aan Goldschmidt (1993-1), p. 15.

In het strafrecht wordt het verhaal van vrouwen via slachtofferbescherming 'binnengehaald', zie onder andere Lünnemann $(1992,1996)$.

Zie over voortplanting en opwoeding onder meer Van Vliet (1987), Holtrust en de Hondt (1987), Van Vliet (1992), De Ruiter (1993-1) p. 14-16.

Ook vanuit de vakgebieden zelf lijken de kenmerken wel enigszins onderschreven te worden. Zie hiervoor o.a. De Roos (1993), Cleiren (1993), Rutten-Roos (1993). 
Loenen wijst op het gevaar van ongenuanceerd gebruik van de begrippen staat en overheid. ${ }^{17}$ Duidelijk moet zijn of het bijvoorbeeld over de overheid als wetgever, beleidsmaker of rechter gaat. Binnen de onderzoeken van Wentholt, Loenen en Goldschmidt is vooral vanuit bestaande wettelijke en beleidskaders gekeken of er een materiële invulling gegeven kan worden aan het gelijkheidsbeginsel. Die kaders kunnen dan wel heel breed gezocht worden. Van grondrechten tot een beleidsplan Emancipatie. ${ }^{\text {1s }}$

Holtmaat heeft daarentegen een extern perspectief gekozen en gereflecteerd op het recht om ruimte te zoeken voor een "ander recht"."

"Het uiteindelijke doel van onderzoek naar de gender-lading van het recht is niet het realiseren van juridische gelijkheid, maar meer recht te doen aan de werkelijkheid van vrouwen en de complexe condities waaronder wrouwen -in een sekse-ongelijke samenleving-moeten leven. Het onderzoek naar gender-verhoudingen in thet recht staat in dienst van het opheffen wan verschillen in maatschappelijke en persoonlijke macht en autonomie van mannen en vrouwen. Dit betekent in ieder geval dat het recht verschillen tot zijn recht moet laten komen. Dit kan pas wanneer een eind komt aan de volkomen wanzelfsprekendheden die in het recht liggen besloten. Het blootleggen van ideologische overheersing is niet eenvoudig. In de feministische rechtstheorie is benadrukt dat het ontmantelen van de mannelijke dominantie in het recht bijzonder moeilijk is, omdat deze de vanzelfsprekendheden en de normaliteit vertegenwoordigt. Het is echter juist bijzonder belangrijk deze vanzelfsprekendheid en normaliteit te doorbreken. Wil de ander of het andere tot haar of zijn recht komen dan zal men zich werkelijk in die ander of dat andere moeten verdiepen. Een middel om die wanzelfsprekendheid te doorbreken kan zijn om het andere perspectief uitdrukkelijk tot uitgangspunt voor het onderzoek te nemen". 20

Een perspectief om vanzelfsprekendheden in het recht te doorbreken is mogelijk dat van gedetineerde moeders. Vanzelfsprekendheden die niet alleen met sekseongelijkheid te maken hebben maar ook met andere kenmerken zoals etnische achtergrond, sociaaleconomische positie, opleiding etcetera. Bij (juridische) vrouwenstudies zijn, net als bij ander wetenschappelijk onderzoek, eigen ervaringen, associaties en dilemma's belangrijke bronnen van inspiratie. Wellicht dwingt toetsing van theoretische opties aan de problematiek van de groep gedetineerde moeders tot de voor objectivering en verfijning noodzakelijke afstand. Juist binnen de groep gedetineerde vrouwen zullen immers cultuurbepaalde verschillen in opvoedingsidealen en praktijken optreden.

17 Loenen (1992-1), p. 260 e.v.

18 Zie Loenen (1992-1) p. 262.

19 Holtmaat (1992), p. 31-37 en p. 330-338.

20 Holtmaat (1992), p. 337-338. 
Tot slot: het plan van aanpak.

Om recht te doen aan de gecompliceerdheid van het in het voorgaande geschetste dilemma heb ik mij buiten het recht moeten begeven en gebruik gemaakt van gegevens uit andere wetenschapsgebieden. Voor een deel via het bestuderen van uitkomsten uit empirische studies, vooral die onderzoeken waar de betekenisgeving door vrouwen zelf aan bijvoorbeeld afwijkend gedrag, seksualiteit, voortplanting en moederschap aan de orde kwamen, maar ook via bestudering van theoretische verhandelingen die door professionals rond diezelfde onderwerpen gegeven worden en die vaak binnen het recht zo'n belangrijke rol spelen. Omdat er erg weinig methodologisch betrouwbaar wetenschappelijk onderzoek gedaan is onder de groep gedetineerde vrouwen, was ik soms genoodzaakt mijn toevlucht te nemen tot (auto)biografische verhalen, grijze literatuur, scripties en dergelijke. Meestal zijn de belangrijkste kenmerken die uit deze bronnen naar voren komen zo gelijkluidend dat ze een grote mate van betrouwbaarheid lijken te hebben.

Het onderzoek is niet extern (rechts)vergelijkend van aard. Tijdens het raadplegen van buitenlandse bronnen is mij gebleken dat juist de gevangeniscultuur in Nederland (nog) erg verschilt van die in het buitenland. ${ }^{21}$ Ook de ontwikkeling in het denken over gezinsvorming en emancipatie in Nederland is vrij uniek. ${ }^{22}$ Beide constateringen hebben ertoe geleid dat ik van het ambiteuze plan om ook (een deel van) het buitenland in kaart te brengen heb afgezien. Buitenlandse bronnen worden wel gebruikt voor zover ze invloed op de theorie- en beleidsvorming in Nederland hebben of naar mijn mening zouden kunnen hebben.

In het eerste gedeelte van het boek (hoofdstuk een tot met vier) staan de gedetineerde moeders als 'criminele vrouwen' in de schijnwerper: wie zijn ze, waarom zijn het er zo weinig, is de cultuur in een vrouwengevangenis anders dan die in een inrichting voor mannen, waar zitten de vrouwen precies, hoe ervaren zij het verblijf in de gevangenis, hoe gaat het met hun familierelaties, welk beleid voert de overheid en hoe zit het met de specifieke rechtspositie van gedetineerde vrouwen?

In het tweede gedeelte (hoofdstuk viff tot en met zeven) staat 'het moederschap in relatie tot het belang van het kind' centraal. Er wordt een algemeen resumé gegeven van verschillende opvattingen over opvoeding en de plek die daarin aan het gezin en/of de moeder toebedeeld wordt, zowel vanuit de ervaringskennis van 'afwij-

21 Er wordt momenteel wel criminologisch vergelijkend onderzoek gedaan, maar de resultaten daarvam moeten nog afgewacht worden. Zie Van Splunteren (1995) en Bhavnani en Davis (1995).

22 Zie ook: Schwegman en Withuis (1993). Schwegman en Withuis verwijzen naar cen aantal specifiek historische processen als werklaring, zoals de Tweede Wereldoorlog en de rol van wrouwen in het verzet, het herstel van de vooroorlogse verzuilde structuren en de na de oorlog snel inzettende Koude Oorlog, waarbij de thuiszittende moeder "het boegbeeld van het Vrije Westen" (p. 574) werd. 
kende moeders' (in Nederland met name werkende en/of alleenstaande moeders) als vanuit professionele deskundigen.

Welke betekenis hechten vrouwen zelf aan het moederschap, welke maatschappelijke functie hebben gezinnen en moeders en nog belangrijker: welke rolvervulling is in het belang van het kind? Wat is volwassenwording, identiteitsvorming? En: hoe verhouden belangen van moeders en kinderen zich in dat opzicht tot elkaar? Welke rol wordt de overheid toebedeeld?

Vervolgens wordt weergegeven welke betekenis grondrechten, wetgeving en recente rechtspraak op praktisch niveau kunnen hebben voor de groep gedetineerde moeders. Aan de hand van de daaraan voorafgaande beschouwingen wordt gekeken hoe de relatie van de overheid tot moeders is, met name nu de staat op grond van art. 8 EVRM en andere mensenrechtenverdragen verplicht is het family life en private life van zijn inwoners te beschermen. Hoe dient de overheid daarmee orn te gaan als zij op grond van andere verplichtingen een primaire verzorger moet straffen? Vervolgens wordt nagegaan in hoeverre aan art. 8 EVRM een horizontale werking wordt toegekend en wat dat zou kunnen betekenen voor gedetineerden. Wat is er in het recht terug te vinden aan diversiteit in praktijken en opvattingen rond opvoeding? Welke rol spelen 'derden' daarin? In dat kader komt ook een deel van de theorieworming binnen juridische vrouwenstudies aan de orde, met name de denkkaders die gezocht worden op het gebied van de al dan niet veronderstelde conflicterende belangen van moeders en kinderen.

In het laatste hoofdstuk worden de steken van het breiwerk samengepakt.

De verschillende rollen van de overheid en de betekenis daarvan worden vanuit het perspectief van gedetineerde ouders/verzorgers naar tijd en plaats onderscheiden. Waar mogelijk worden suggesties voor beleid en regelgeving gedaan, waarbij ook de vraag terugkomt of een sekse- of genderspecifieke benadering gewenst is in het licht van de in diverse hoofdstukken terugkerende visies op de identiteit en functie van vrouwen in relatie tot seksualiteit, voortplanting, zorg en opvoeding. 


\section{Verklaring voor het aantal gedetineerde vrouwen}

\section{Inleiding}

Hoewel het aantal gedetineerde vrouwen nog altijd ver achter blijft bij het aantal gedetineerde mannen neemt hun aantal absoluut gezien zeer snel toe: op 1 januari 1987 was er bezette capaciteit voor 134 vrouwen, in december 1996 voor ongeveer 465 vrouwen. ${ }^{1}$ Daarvan zijn ongeveer 131 plaatsen voor veroordeelde, langgestrafte vrouwen bestemd en de rest voor vrouwen die zich in voorlopige hechtenis bevinden of kortgestraft zijn.

De groei is vooral te verklaren uit het aantal vrouwen dat verdacht is van of veroordeeld voor overtreding van de Opiumwet. Daarnaast is de gemiddelde strafduur toegenomen. De meest gepleegde delicten zijn drugs- en vermogensdelicten. Geweldsdelicten komen weinig voor. ${ }^{2}$ Als vrouwen geweld plegen doen zij dit vaak binnen eigen kring. ${ }^{3}$

Over de achtergronden van de gedetineerde vrouwen kan gezegd worden dat:

1 Met name in de jaren zestig en zeventig vindt er een enorme daling plaats: bij de diverse bouwplannen spreekt men in 1956 ower 200 wrouwellijke gevangenen, in 1961 van 100, in 1964 van 75, in 1968 van 40. (bron: Franke(1990) p. 707) Vanaf 1973 verblitjven alle vrouwen in Rotterdam, in een hwb + gevangenis met een capaciteit van in totaal 47 plaatsen. (Balans, 1981) Pas in de tweede helft van de jaren zeventig neemt de capaciteit weer toe tot $59 \%$ in 1977 komen er 19 extra plaatsen bij in Amsterdam en bij de opening van de nieuwbouw in Amsterdam in 1978 is de capaciteit van 70 plaatsen al niet meer toereikend. In datzelfde jaar worden in Maastricht 37 plaatsen in gebruik genomen en in 1980 in Groningen 10 plaatsen. De stijging zet door tot de jaren negentig. Dan wordt door de commissie Greven een stabilisatie vastgesteld en ook in de nabije toekomst werwacht in het aantal vrouwelijke gedetineerden. (Projektgroep Structuurplan justitiële inrichtingen, Voorzieningenbeleid delinquentenzorg en jeugdinrichtingen 1990-1994). Inmiddels zijn de prognoses bijgesteld en wordt voor het jaar 2000 gesproken van ongeveer 652 cellen woor vrouwen. (Bron Ministerie van Justitie).

2 Junger-Tas (1995) constateert dat het patroon bij vrouwen en meisjes de laatste twintig jaar wel gevarieerder wordt. Diefstal met geweld, beroving en inbraak komen nu vaker voor Met name bij meisjes een duidelijke stijging bij de categorie 'mishandeling' waar te nemen, maar 'diefstal met geweld' komt onder jongens nog altijd twee keer zoweel voor als onder meisjes. Zie ook Bouw (1996).

3 Vgl. Fuldauer (1994), Römkens (1995).

4 Ontleend aan De Borst (1991), Ketelaars. (1991), Fuldauer (1995). 


\section{Hoofdstuk I}

- de helft van de vrouwen de Nederlandse nationaliteit heeft;

- de grootste groep binnen de categorie buitenlandse vrouwen wardt gevormd door Zuidamerikaanse vrouwen en vrouwen uit het Caraibisch gebied, hoewel de laatste jaren een lichte verschuiving naar Afrika is waar te nemen.s

- driekwart van de vrouwen voor hun detentie geen inkomen uit werk of een sociale uitkering had;

- meer dan de helft ongehuwd en bijna een kwart gescheiden was. ${ }^{6}$

- zestig procent van de vrouwen kinderen heeft, waarvan een kwart drie of meer;

- iets meer dan de helft van deze kinderen in Nederland verblijft. (dus $49 \%$ in het buitenland!);

- van de in Nederland verblijvende kinderen $61 \%$ onder de achttien jaar is.

Veel feitelijke gegevens zijn niet voorhanden. Enerzijds zijn er vragen met betrekking tot de gepleegde delicten: is er sprake van deelnemingsvormen of van een zelfstandig, ongeorganiseerd optreden? Anderzijds ontbreken relevante gegevens over sociaaleconomische achtergronden: wat is de hoogst genoten opleiding, de hoogte van het zelfgenoten inkomen, is er een vaste woonplaats etcetera.

De vrouwen in Nederlandse gevangenissen lijken op grond van de genoemde kenmerken vooralsnog niet te passen in het beeld van de geëmancipeerde vrouw en/of moeder met een autonome levensloopbaan, werkkring en inkomen, noch in dat van de burgerlijke vrouw en/of moeder met een afgeleide levensloopbaan van een mannelijke kostwinnende partner. Een verdere verdieping in de inhoudelijke karakteristieken van gedetineerde vrouwen komt in hoofdstuk twee aan de orde.'

In dit hoofdstuk wordt de vraag behandeld waarom er in Nederland getalsmatig nog steeds zo weinig vrouwen in vergelijking tot mannen in aanraking komen met justitie. Allereerst is het de vraag of dat altijd zo geweest is of dat het een typisch eigentijds verschijnsel is. En daarmee verbonden de vraag of het een universeel of cultuurgebonden verschijnsel is. Zijn de beschikbare cijfers ook betrouwbaar, hoe moeten ze geïnterpreteerd worden? Is het al of niet in aanraking komen met justitie

5 Zie Fuldauer (1995) p. 105. In 1994 kwam ongeveer $20 \%$ van de gedetineerde vrouwen uit ZuidAmerika en $8 \%$ uit Afrika. 13\% verbleef illegaal in Nederland.

6. Samenleven is in de cjffers van het ministerie als aparte categorie opgenomen, dus ik kan concluderen dat driekwart van de vrouwen officieel alleenstaand is.

7 Aan wrouwen die lid zijn van een "terroristische organisatie" zal ik geen aandacht besteden, omdat zij in Nederland geen aparte categorie vormen. Hun gedrag in relatie tot moederschap en seksualiteit, zoals dat elders beschreven wordt, is wel intrigerend. Vgl. MacDonald (1994) met name p. 373-381. Zij constateert op grond van haar interviews dat deze vrouwen welbewust afstand van de vrouwelijke rol, inclusief het moederschap, hebben gedaan. Zij kozen voor eent politick ideaal. Hun fanatisme wordt met die vergaande keus in verband gebracht: juist omdat vrouwen zoiets wezenlijks in hun levensvervulling hebben opgegeven zijn zij in staat de gruwelijkste dingen te doen. Anderen menen dat zij zich door uiterst agressief gedrag willen of moeten bewijzen om serieus genomen te worden binnen de -door mannen gedomineerde- organisatie. 
wel een graadmeter voor de criminaliteit van vrouwen of is de werkelijke mate van crimineel gedrag van vrouwen door allerlei oorzaken niet zichtbaar?

Maar als de cijfers toch iets zeggen over de mate van criminalliteit bij vrouwen: hoe kan dat dan verklaard worden? Is sekse het belangrijkste onderscheidend criterium om criminaliteit in zijn algemeenheld te verklaren en te voorspellen? Past crimineel gedrag in feite bij stereotiep mannelijk gedrag en bij non-stereotiep vrouwelijk gedrag waardoor criminaliteitsbestrijding bij vrouwen niet opportuun is? Of zou er meer informatie beschikbaar komen door het normoverschrijdend gedrag van vrouwen niet vamuit de bestaande kaders (strafrecht, criminaliteit) te bestuderen maar als zelfstandig object van onderzoek; waardoor mogelijk andere uitingswormen en andere maatschappelijke effecten zichtbaar worden?

Deze vragen wordem in bovenstaande volgorde afgewerkt. Er is niet naar compleetheid gestreefd, wel naar een overzicht van de belangrijkste criminologische stromingen en verklaringstheorieën omtrent het criminele gedrag van vrouwen.

\subsection{Een historisch perspectief}

De groep gedetineerde vrouwen is tot de jaren tachtig in Nederland altijd tamelijk onderbelicht gebleven. Argumenten die hiervoor worden aangevoerd zijn dat het aantal gedetineerde vrouwen klein was en de criminaliteit onder vrouwen meer in het algemeen zo gering en onbetekenend. ${ }^{8}$

Van de Pol toont via een historische studie aan dat dat niet altijd zo geweest is." In de zeventiende en achttiende eeuw kwam er in de steden net als nu veel meer criminaliteit voor dan op het platteland. Maar daarin was het aandeel van vrouwen veel groter dan nu. In het achttiende-eeuwse Londen, Parijs en Amsterdam maakten vrouwen 22-35\% van het aantal arrestanten voor de rechtbank uit. ${ }^{10}$ In de Republiek,

8 O.a. De Vries (1979) p. 211. "Van de kant van de (mannen) wetenschap wordt echter als legitimatie woor deze geringe belangstelling aangevoerd, dat het aandeel van vrouwen zowel in de geregistreerde als in de ongeregistreerde criminaliteit zeer klein is, terwijl het karakter van vrouwencriminaliteit over het algemeen als. weinig bedreigend wordt gezien". De Vries zelf denkt echter dat een van de belangrijkste corzaken wan deze lacume in het onderzoek ligt in het feit dat tot voor kort wetenschappers (bijna) uitsluitend van het mannelijk geslacht waren.

Zie ook: Smart (1976) p. 2, Goethals, Maes en Klinckhamers (1995), p. 420 .

9 Van de Poll (1987). Zie ook Van Schaik (1996).

10 Zie ook Feeley and Little (1991). Door Feeley en Little wordt in een Brits/Amerikaanse studie ook aangetoond dat vroeger de criminaliteit van vrouwen helemaal niet zoveel lager was dan die van mannen. Zo maakten vrouwen in de achttiende eeuw soms well $45 \%$ uit wan het aantal criminelen. De latere enorme teruggang wordt door de schrijvers, na uitsluiting van allerlei andere factoren, verklaard uit een verschuiving van sociale controle naar de private sfeer specifiek voor vrouwen hetgeen weer te weer maken heeft met de rolveranderingen van wrouwen in de economie, het gexin etc. Dit alles viel samen met de opkomst wan de industrialisatie. In Nederlandse studies is 
met name de provincie Holland, was de vrouwencriminaliteit hoger dan elders in Europa, zowel op het platteland als in de steden. Vooral de Amsterdamse cijfers springen eruit: veertig procent in de tweede helft van de zestiende eeuw, wijftig procent in de tweede helft van de zeventiende eeuw, $35 \%$ gemiddeld over de achttiende eeuw ( $42 \%$ in het eerste, $28 \%$ in het laatste decennium). In de negentiende eeuw daalde het Amsterdamse cijfer tot twintig procent.

Uit het onderzoek van Van de Pol blijkt dat vrouwen in de zeventiende eeuw in Amsterdam weliswaar evenveel, maar een ander soort criminaliteit pleegden dan mannen Vrouwen werden bijvoorbeeld gearresteerd wegens prostitutie, infanticide, het te vondeling leggen van kinderen en mannen wegens het aanmonsteren en vervolgens de dienst niet voltrekken en muiterij. Heling werd voornamelijk door vrouwen gepleegd. En als misdrijven onder dezelfde categorie vielen, verschilde de manier waarop vrouwen het delict begingen nogal eens van die van mannen. Bij ontduiking van de accijnzen waren vrouwen meestal afneemsters, mannen leveranciers. Vrouwen pleegden vaker reeksen kruimeldiefstallen, mannen zetten een grote kraak. Vrouwen vervielen meer in herhaling en ze werden minder snel zonder straf vrijgelaten. Terwijl elders vrouwen vaak als handlangster of hulp van hun mannen fungeerden bij diefstal, trokken de Amsterdamse vrouwen er alleen of met andere vrouwen op uit. Vrouwen die geweld pleegden, deden dat over het algemeen ook alleen, mannen vaker in groepsverband. Vrowwen waren wel actief in de organisatie van de criminaliteit. Binnen de criminele netwerken die destijds in Amsterdam bestonden waren de zware jongens voornamelijk mannen, maar vrouwen bleken zowel als verbindingsfiguren (heelsters, herbergiersters, hoerewaardinnen) als in aantal (hoeren, dievegges) van vitaal belang te zijn.

Verklaringen voor deze verschijnselen zoekt de onderzoekster in de hoge graad van verstedelijking, de hoge gemiddelde huwelijkse leeftijd, het vrouwenoverschot in de volksbuurten en het grote aantal zeevarenden onder de mannelijke bevolking van Amsterdam.

"Kortom: cen groot deel van de vrouwen had meestal geen man in huis: noch om hen te commanderen, noch om then naar de buitenwereld te verdedigen, noch om het hoofdinkomen binnen te brengen. Deze vrouwen moesten voor zichzelf en woor ewentuele kinderen zorgen, zowell in economisch als psychologisch opzicht: niet verbazingwekkend dat ze intensief aan het economische en openbare leven deelnamen en dat ze een zelfstandig, assertief karakter ontwilkkelden....In buurten waar veel zeelieden woonden, ontstond zo een gemeenschap waar het, ook in niet-zeemansgezinnen normaal was dat vrouwen kordaat

de terugdringing van de vrouw in de private sfeer onder invloed wan de induslriële revolutie meer in het algemeen beschreven. Zie o.a. De Regt (1993).

Franke beeft het in zijn boek en passant over "vrouwelijke gevangenen, in de negentiende eeuw minder zeldzaan dan tegenwoordig". (Franke (1990) p. 277)

Rutenfrans (1989) besteedt in zijn boek geen aandacht aan historische vergelijkingen en anallyses, maar gaat uit van watt er "sinds het ontstaan van de criminologie, tegen het einde van de negentiende eeuw tot op heden' bekend is. 
en zelfstandig waren. Daar komt dan nog bij dat de afwezigheid en relatief hoge sterfte van de zeelieden het numerieke overwicht van vrouwen in deze buurten versterkte. Zo vallen de vele misprijzende opmerkingen van buitenlanders en mensen uît hogere klassen te verkllaren, dat mannen uit het gewone wolk bij hun vrouwen onder de plak zaten"."

De onderzoekster geeft tevens aan dat er (mede) door het vrouwenoverschot veel alleenstaande vrouwen waren, vaak ook immigrantes die niet zo gemakkelijk als plattelandsvrouwen een beroep konden doen op familie en de gemeenschap. Daar komt bij dat de vrouwenlonen zeer laag waren, terwijl (destijds) typische vrouwelijke bijverdiensten als het houden van een moestuin en kleirvee in de stad niet gerealiseerd konden worden.

De klantengroep van de Amsterdamse vrouwen bestond vaak ook weer uit zeelieden die graag herbergen, bordelen en tweedehandszaken bezochten. Van de Pol concludeert dan ook:

"De hoge wrouwencriminaliteit is, kortom, voor een belangrijk deel een onvermoed en tot nu toe onbelicht, maar zeker reëel gevolg van de Hollandse expansiedrift wan de Gouden Eeuw". ${ }^{12}$

Ter gelegenheid van de tentoonstelling 'De vrouw 1813-1913' in 1913 werd in een brochure melding gemaakt van de vrouwencriminaliteit in 1813 in Amsterdam en Rotterdam met als bijlagen een verkorte weergave van alle vonnissen die in 1810 in Amsterdam en van 1808-1811 in Rotterdam ten aanzien van vrouwen gewezen zijn. ${ }^{13}$ Uitgangsjaar was 1810 omdat toen een geheel op Franse leest geschoeide nieuwe rechterlijke organisatie in ons land was ingevoerd. Enige citaten uit de brochure:

"De criminaliteit der wrouw van 1813 uitte zich wal Amsterdam betrefl, ongeveer in dezelfde vorm als heden; diefstal en heling waren aan de orde van de dag; meestal waren het diefstallen van kleineren aard, eenig linnengoed of tafelzilver uit het huis van de meesteres".

"Waar de wrouw in complici met den man optreedt, daar zien wij de criminaliteil, ik rou willen zeggen, een zeker kenmerk van intelligentic dragen. Doet de vrouw het alleen dan is het plomp en ontiandig. men doorziet het bedrog dadelijk".

"Als verzwarende omstandigheid beschouwde men het feit dat de dievegge thet delict plecgde in het huis waar zij diende. En dat die werzwarende omstandigheid gewicht in de schaal legde, blijkt en uit de motiveering der wonnissen en uit de harde straf: geeseling, 2 jaar Spinhuis en 6 jaar verbanning".

11 Van de Pol (1987) p. 151

12 Van de Pol (1987) p. 153.

13 De Leeuw (1913). In het voorwoord wan de brochure wordt vermeld dat in de bijlagen de resultaten wan het historisch onderzoek werwerkt zijn 'die niet aanschouwelijk tentoongesteld konden worden'" 
In geval van recidive kwam daar -in Amsterdam- nog brandmerking bij.

"Ook zakkenrollerij scheen men als zwalar delict te beschouwen. Herhaaldelijk heb ik wonnissen gevonden: 2 jaar Spinhuis wegens zakkenrollerij wan een zakdoek ${ }^{\mathrm{in}}$.

Er traden wel grote verschillen op tussen Amsterdam en Rotterdam, zowel in aantallen vrouwen als in soorten delicten, waarbij ook hier de schrijfster het grote aandeel van vrouwen in de Rotterdamse criminaliteit in verband brengt met de Rotterdamse positie van havenstad. In dit onderzoek zijn geen vergelijkingen tot mannen gemaakt. Uit de schaarse cijfers is wel op te maken dat in 1810 in Rotterdam meer dan een kwart van het aantal veroordeelde personen uit vrouwen bestond. ${ }^{\text {th }}$

"In Rotterdam is, naast diefstal ontucht de domineerende vorm van criminaliteit. Talrijk zijn de veroordelingen wegens slechte levenswijze of medeplichtigheid aan het vervoeren van jonge meisjes. Misschien is de oorzaak van dit groote aantal wonnissen betreffende zoogenaamde hoererij, een aantal dat dat wan Amsterdam verre overtrof, daarin te vinden, dat Rotterdam een wettelijke regeling had op de prostitutie. En waar de handhaving van die regeling aan de politie was toevertrouwd aldus een bron van willekeur en inkomsten leverde voor de politicu".

"Evenmin als te Amsterdam waren de rechters te Rotterdam mild in hun oordeel. Vinden wij buj elk vonnis te Amsterdam gewezen bij de straf bepaald een te kaak stelling, in Rotterdam vond ik van 96 wonissen, slechts bij 3 een te kaak stelling en bij 3 een te pronk stelling op het schavot met roeden on den hals".

Vanaf het einde van de negentiende eeuw tot nu lijkt in het algemeen uit politiegegevens en selfreportstudies naar voren te komen dat vrouwen niet alleen veel minder strafbare feiten plegen dan mannen, maar ook dat zij minder ernstige delicten begaan en dat de variatie in delicten veel kleiner is. Bovendien blijkt zelfs winkeldiefstal dat doorgaans als een typisch 'vrouwendelict' wordt beschouwd, in Nederland relatief nog altijd vaker door mannen gepleegd te worden. ${ }^{\text {ss }} V$ rouwen recidiveren daarnaast minder dan mannen. Vrouwelijke recidivisten zijn in hoofdzaak verslaafde vrouwen. ${ }^{16}$

14 De Leeuw (1913) p. 46.

15 O.a. Bruinsma en Lissenberg (1987) p. 11-26, Rutenfrans (1989).

16 Fuldauer (1995) p. 104. 


\section{Statistische vertekening}

Uit het bovenstaande blijkt al dat verschillende registraties van gegevens over criminaliteit gehanteerd worden. Ter aanvulling op politiegegevens en officiele processtukken wordt onder meer gebruik gemaakt van zogenoemde selfreportstudies. Wat is de waarde van die registraties en wat kun je er wel en niet uit afleiden?

\subsubsection{Wat is criminaliteit, wat is strafbaar gedrag?}

Criminaliteitsstatistieken en het daaraan gekoppelde criminologisch onderzoek gaan uit van "krachtens de wet strafbaar gesteld gedrag" ${ }^{17}$ Uitgangspunt in al deze onderzoeken zijn waarden en normen zoals die neergelegd zijn in het strafrecht. Maar strafbepalingen zijn soms niet eenduidig. De publieksgebonden moraal maakt dat er een tijdsgebonden invulling aan gegeven wordt. Dat is te zien bij zaken als fraudebestrijding of kindermishandeling. Dat heeft niet alleen gevolgen voor de interpretatie van de delictsomschrijving sec, maar vooral voor het opsporings-vervolgings- en veroordelingsbeleid. Zo kunnen opportunistische en pragmatische motieven doorslaggevend zijn bij het besluit de opsporing of vervolging wel of niet te stoppen, bijwoorbeeld de moeizame bewijsgaring of het belang van 'stuccescijfers' ter beïnloeding van de publieke en politieke opinie. Als een soort correctie op de officièle registraties zijn er dan ook selfreport studies ontwikkeld, zodat mogelijke hiaten in de verslaglegging van de politie en het justitie-apparaat aan het licht zouden kunnen komen. Op de, met name methodologische, betrouwbaarheid van selfreportstudies is echter ook het een en ander aan te merken"

a. De meeste onderzoeken maken gebruik van minderjarige, schoolgaande respondenten. Het is dan moeilijk conclusies te trekken over het gedrag van volwassenen. Bovendien vallen spijbelaars en vroegtijdige schoolverlaters uit de boot.

b. De onderzoeken zijn beperkt tot een kleine gemeenschap. Generalisatie van. onderzoekgegevens is problematisch.

c. De meeste selfreportonderzoeken zijn niet goed onderling vergelijkbaar omdat het aantal en de soort strafbare gedragingen niet gestandaardiseerd zijn.

d. De onderlinge vergelijkbaarheid wordt extra bemoeilijkt door de verschillen in procedures die men volgt, vooral door de verschillende wijze warop men steekproeven trekt.

17 Bruinsma en Lissemberg (1987) p. 9, Van Delden (1987) p. 1.8.

18 Rutenfrans (1989) p. 1-22, Zie ower de betrowwbaarheid en validiteit van selfreportstudies ook Nijboer (1995). Slachtofferenquêtes worden hier niet besproken, omdal die over het algemeen niet ingaan op het selkse-onderscheid tussen (vermeende) verdachten en daders. Zie hiervoor Van Dijk, Sagel-Grande en Toornwiet (1996), p. 39-52. 
e. In de onderzoeken worden aantallen personen geregistreerd op grond van hun delinquent gedrag, ongeacht het aantal malen dat zij het delict pleegden.

In politiestatistieken worden aantallen zaken/delicten geregistreerd.

Toch veranderen deze kanttekeningen bij het selfreportonderzoek volgens Rutenfrans niet veel aan de algemene tendensen die zowel uit de officiële registratie als uit dit type onderzoek naar voren komen omtrent de vrouwencriminaliteit. De meer methodologische aspecten van het statistische onderzoek komen in de volgende paragraaf nog verder aan de orde. Het is eerst van belang iets langer stil te staan bij wat onder $c$ de standaardisering van het aantal en soort strafbare gedragingen werd genoemd. Hoe wordt er geregistreerd? Dat zal veelal gebeuren via de delictsomschrijvingen in het wetboek van strafrecht en het is de vraag of die registraties voldoende inzichten opleveren om meer gedifferentieerde en contextgebonden uitspraken te doen over de betekenis van de geconstateerde criminaliteit. De registratie van 'doodslag' of 'mishandeling' zegt nog niets over de plek en de omstandigheden waaronder het gebeurde: thuis in een partnerrelatie na jarenlange conflicten en pesterij of een afrekening om de familie-eer te redden, een afrekening in een zakelijke kwestie, een gevolg van een uit de hand gelopen overval met anoniem siachtoffer, een verdwaalde kogel met anoniem slachtoffer etcetera. Of in het geval wan 'fraude': stak iemand het geld in eigen zak of was het een wanhoopspoging een bedrijf en de werkgelegenheid te redden, ging het om een functionaris met een goede rechtspositie of om een 'vrije jongen' etcetera. Deze achtergrondgegevens hebben betekenis voor en in de loop van het casusge bonden strafproces. Er zouden echter ook structurele inzichten aan ontleend kunnen worden omtrent de aard van de criminaliteit en de cultuur-en gendergebondenheid ervan. Op grond daarvan kunnen, naast of in plaats van justitieel optreden, alternatieve beleidsinstrumenten worden ontwikkeld om de criminaliteit terug te dringen.

Van feministische zijde is inmiddels vele keren, overigens vooral vanuit slachtofferstandpunt, betoogd dat het strafrecht ontwikkeld is door en voor mannen en dat het een weerslag vormt van de dubbele moraal die gehanteerd wordt ten opzichte van gedragingen van vrouwen en mannen. ${ }^{20}$ Een dubbele moraal die verband houdt met de scheiding publiek-privé (het leven buitenshuis en binnenshuis) en die onder

19 Rutenfrans $(1989$, p. 7$)$ geeft ook een aantal voorbeelden van vertekeningen: "Vooral in de Amerikaanse selfreport-onderzoeken necmt men vaak items op die betrekking hebben op de zogenoende status offenses en het komt zelfs woor dat men vraagt naar gedragingen die nog trivialer zijn, zoals. spieken en het bekladden van muren. (in noot: state offenses zijn gedragingen dic cen overtreding vormen van de verordeningen van de Amerikaanse slata waarbinnen men hen begaat. Deze gedragingen zijn slechts strafbaar wannecr æij worden begaan door minderjarigem. Voorbeclden erwan zijn weglopen van huis en spijbelen)". Op p. $66 \mathrm{komt}$ ook de strafbaarheid van prostitutic in do Verenigde Staten nog aan de orde.

In Nederland o.a.: Verrijn Stuart (1990), Pessers (1991), Lünnemann (1992), Slotboom (1994). 
meer blijkt uit de verschillen in socialisatie tussen meisjes en jongens en vooral ook in de daaraan gerelateerde verschillen in verwachtingen ten aanzien van seksualiteit en ouder-(c.q. moeder-)schap. Smart benadrukte in 1976 wat de aard van de delicten betreft het onderscheid tussen seksespecifieke, dus seksegebonden en sekseverbonden criminaliteit. Ze introduceerde daarmee de gender-variant. ${ }^{21}$ Gesllachtsspecifieke delicten kunnen, op grond van de delictsomschrijving, uitsluitend door mensen van eén van beide geslachten worden gepleegd. Geslachtsgebonden delicten voor vrouwen in het Nederlandse strafrecht zijn nu nog doodslag en moord door de moeder op haar pasgeboren kind. ${ }^{22}$ Geslachtsverbonden delicten zijn delicten die eerder met daders van het ene dan van het andere geslacht in verband worden gebracht.

In Nederland komt de dubbele moraal tot uiting in bijvoorbeeld de moeizaam tot stand gekomen herziening van de zedelijkheidswetgeving. Met name de discussies over de strafbaarstelling van verkrachting binnen het huwelijk en de leeftijdsgrens en het klachtvereiste bij seksueel misbruik van minderjarigen op grond van een veronderstelde bescherming via een huwelijk zijn duidelijke voorbeelden van de dubbele moraal. Moeilijker te herkennen, maar wel degelijk gerelateerd aan discussies over de dominante heteroseksuele norm en de scheiding publiek-privé zijn terugkerende thema's rond prostitutie en pornografie.

\subsubsection{Interpretatie van cijfers}

Bij het vastleggen en interpreteren van cijfermatige registraties bestaan veel methodologische beperkingen. Om de betrouwbaarheid te verhogen en vertekeningen te beperken is van het belang precies te weten wat je wilt meten en welke variabelen wel of niet of voor welk deel aan elkaar gerelateerd kunnen worden. Vaak geven onderzoekers de begrenzingen van hun onderzoek goed aan. Soms doen zij dat niet. Nog vaker worden door anderen relatieve gegevens uit hun context gehaald en gaan deze als absolute resultaten een eigen leven leiden.

De twee belangrijkste constateringen die vooralsnog aan de criminaliteitsstatistieken ontleend worden, zijn $^{23}$ :

a. De criminaliteit stijgt;

b. Het aantal vrouwen dat, in vergelijking tot mannen, met justitie in aanraking komt blijft gering, hoewel hun aantal absoluut gezien sterk toeneemt.

21 Smart (1976) p. 6 e.\%.

22 Art. 290 en $291 \mathrm{Sr}$. Ook het te vondeling leggen van een pasgeboren kind door de moedere "uit wrees voor de ontdekking van haar bevalling" leidt tot strallvermindering (art. $259 \mathrm{Sr}$.)

23 Junger-Tas (1995), Fuldauer (1995), Römkens (1995). 
Ad a.

De stijging van de criminaliteit kan gerelateerd worden aan het aantal bezette cellen, het tekort aan cellen of de op grond daarvan geconstateerde noodzaak tot bouw van nieuwe gevangenissen. Wat daarbij uit het oog verloren kan worden is dat misschien niet het aantal veroordeelden, maar de lengte van de straffen toeneemt. Die toename kan dan vervolgens weer per delictsoort en naar sekse worden geanalyseerd $^{24} \mathrm{Er}$ is mogelijk meer veranderd in het gedrag en de houding van wetgever, politie, O. M. en rechter dan in het criminele gedrag van burgers. Ook het (de)criminaliserend beleid van de owerheid kan dus van belangrijke invloed zijn op de criminaliteitsciffers. Als voorbeeld kan het effect van de buitengerechtelijke afdoening van verkeersdelicten dienen of de uitkomst van het actuele debat rond regulering van soft drugs.

Verder is het van belang te weten wat er geregistreerd wordt: alle aangiftes, alleen veroordelingen of ook schuldigwerklaringen-zonder straf? ${ }^{3}$ Zeker wanneer er vergelijkingen gemaakt worden, bijvoorbeeld in de tijd of tussen landen, moet nauwkeurig gecontroleerd worden of precies dezelfde wariabelen gemeten zijn en zo niet of ze op onderlinge afwijkingen gecorrigeerd kunnen worden. Zo zijn er bij het CBS in 1981 belangrijke wijzigingen in de registratie doorgevoerd:

- er worden zaken in plaats van personen geregistreerd;

- er worden absolute getallen over de Nederlandse bevolking gebruikt, dus niet per 100.000 inwoners van een bepaalde categorie;

- er worden cijfers gegeven over schuldigverklaringen, een ruimer begrip dan veroordelingen.

Ad b.

Wanneer in de registratie de delicten alleen met de variabele 'sekse'verbonden worden, kunnen andere invloeden zoals maatschappelijke kenmerken en levensstijl uit het oog verloren worden. Interessant is juist dat die op hun beurt soms ook weer genderspecifiek zijn. Het onderscheidend criterium sekse hoeft niet het interessantste te zijn, juist het verborgen onderscheid biedt (beleids-)yrelevante inzichten. Van der

24 De gemiddelde verblijfsduur steeg tussen 1982 en 1991 van 80 dagen naar 150 dagen. Het aantal vrouwen dat langer dan twee jaar in de gevangenis zit is klein, maar relatief gezien groter dan het aantal mannen. Van de vrouwen die veroordeeld worden tot een onvoorwaardelijke gevangenisstraf zit $78 \%$ langer dan twee jaar vast tegen $50 \%$ van de mannen. Zie Fuldaver (1995) p. 78. Zie ook: Vegter (1993), Verhagen (1994).

25 Zie de kanttekening die het CBS en het Ministerie van Justitie kortgeleden gezamenlijk maakten byji de veronderstelde criminalliteitsstijging sinds 1984: er worden meer aangiftes gedaan van gedragingen die daarvoor ook al voorkwamen, maar of niet of anders werden alangepakt. Zie ook: Römkens (1995) p. 57. 
Heijden geeft hiervan een aantal voorbeelden. ${ }^{20} \mathrm{Bij}$ een selfreportstudie van het CBS in 1985 scoorden mannen tweemaal zo hoog als vrouwen bij rijden onder invloed, belastingfraude, meedoen aan een vechtpartij en vernieling. Het kleinst waren de sekseverschillen bij zwartrijden en diefstal. Maar zaken als autobezit en uitgaansgedrag blijken samen te hangen met de gevonden cijfers. Van de niet-autobezitters meldde tien procent in 1984 zonder kaartje in bus, tram of trein te hebben gezeten tegenover vijf procent van de autobezitters. Belastingfraude werd tweemaal zo vaak gerapporteerd door werkenden dan door personen zonder betaalde werkkring. Overigens bleven er, rekening houdend met persoonlijke levensstijl en omstandigheden, büj deze delicten significante verschillen tussen mannen en vrouwen bestaan.

Uit een winkeldiefstalenquête onder ruim driehonderd vestigingen van warenhuizen en grote textielzaken (CBS, 1977-1980) concludeert Van der Heijden, bij relatering van de cijfers aan sekse, leeftijd en dagvulling, dat winkeldiefstal eerdler een typisch scholieren-dan huisvrouwendelict genoemd kan worden. Het percentage minderjarige mannen dat dit misdrijf pleegt ligt dan overigens nog beduidend hoger dan dat van minderjarige vrouwen die dat doen. De aard van het gestolene vertoont vervolgens ook weer een sterke relatie met leeftijd, sekse en dagvulling. ${ }^{27}$

Ook wanneer er in de registratie alleen gekeken wordt naar de variabelen sekse en leeftijdscategorie, zonder rekening te houden met de leeftijdsverdeling in de gehele Nederlandse bevolking, volgen andere conclusies dan wanneer je dat wel doet. Vrouwen zouden dan bijwoorbeeld, gezien hun levensverwachting, zelfs relatief jong delicten plegen. Er zouden verbanden gelegd kunnen worden met relatienetwerken en levenscycli van vrouwen. Nu gebeurt dat soms met menstruatie of het premenstrueel syndroom, maar ook "de vruchtbare leeftijd" of "de overgang" als biologische en sociaalgeconstrueerde ijkpunten kunnen relevant zijn om meer inzicht te krijgen in de betekenis van normoverschrijdend gedrag van en de betekenis daarvan voor vrouwen zelf. ${ }^{28}$

Van der Heijden (1987). Zie ook Goethals, Maes en Klinckhamers (1995) p. 430-431. Zij refereren aan Duits onderzoek uit 1975, waaruit blijkt dat wrouwen vaker beboet werden wegens fout parkeren dan mannen, omdat zij geacht werden niei te werken en dus meer tijd te hebben om naar een parkeerplaats te zoeken. Verkeersfouten werden de wrouwen minder aangerekend gezien hun veronderstelde gebrek aan rij-ervaring.

27 Zie ook Bouw (1995).

28 Ook wanneer cijfermatige, bijwoorbeeld demogralische, gegevens van vrouwen in detentie besproken worden, worden soms terzijde dingen geconstateerd die mogelijk essentieel zijn voor de seksespecilieke beleving van detentie door wrouwen. Vgl. Layton MacKenzie e.a. (1989), p. 234: "The prisoners who had been in prison for a long period of time did have fewer children, but this is most likelly due to the time spent in prison."

Edwards is overigens, zeer kritisch over de cenzijdige medisch-pathologische invulling van menstruatie, zwangerschap, lactatie en de overgang als "crisisperiodes'. (Edwards (1984) p. 79-100). 
Statistisch gezien is het dus al met al de vraag of de meest relevante informatie over het gedrag van vrouwen wordt verkregen door hen voortdurend met mannen (en dan nog vaak mannelijke leeftijdsgenoten) te vergelijken en of het onderzoek binnen de groep vrouwen zelf niet meer zou moeten worden verfijnd en gedifferentieerd. Zolang dat niet gebeurt, zullen de statistieken nietszeggend of vertekenend ten aanzien van vrouwen zijn, omdat dan alleen aan de hand van de mannelijke criminaliteit relevante informatie gemeten wordt wat betreft afwijkend gedrag en sociale controle.

\subsection{Strafproces en straftoemeting}

Bij de betrouwbaarheid van de officiële criminaliteitsregistraties worden ook vraagtekens gezet omdat binnen het 'technisch' kader van het strafproces veel criminele gedragingen wan vrouwen niet boven water komen. In de opsporingsfase of later bij de vervolging, de berechting en straftoemeting worden gedragingen van vrouwen anders benoemd en gewaardeerd in vergelijking tot die van mannen. Ook zouden delicten van vrouwen moeilijker ontdekt worden, omdat deze over het algemeen niet gepaard gaan met geweld en er dus weinig sporen zijn. ${ }^{\star 4}$ Bovendien zouden slachtoffers van vrouwelijke daders uit schaamte niet snel bereid zijn tot het doen van aangifte..$^{30}$

\subsubsection{Psychiatrisering}

Een ander argument is dat afwijkend gedrag van vrouwen eerder psychiatrisch gelabeld zou worden dan dat van mannen. ${ }^{31}$ Dit zou blijken uit:

- het feit dat veel vrouwen die de normen overtreden in tegenstelling tot mannen niet in het justitiële kanaal terechtkomen maar in het psychiatrische ${ }^{32}$;

- de psychiatrisering van vrouwen die wel strafrechtelijk vervolgd worden. Crimineel gedrag van vrouwen wordt eerder pathologisch benoemd en als individueel probleem gezien dan dat van mannen. Crimineel gedrag van mannen wordt als (onderdeel van) een maatschappelijk probleem ervaren. ${ }^{33}$

In Nederland volgt uit een analyse van de verschillen in aantallen psychiatrisch opgenomen mannen en vrouwen geen duidelijke bevestiging van de eerste stelling. Alleen het aantal opnames in PAAZ (Psychiatrische Afdelingen van Algemene Ziekenhuizen)

29 Bonger (1916), herdruk onder redactic van Turk (1969) p. 60.

30 Pollak, in: De Vries (1979) p. 215.

31 Smart (1976). Zie ook: Quispel (1979).

32 Van Wijck (1982) p. 112. Van Wijck geeft hicrbij aan dat uit het -toenmalige- ontbreken van open en halfopen inrichtingen het weglekken naar do pychiatrie zou kunnen worden veriklaard. Zie bijy. Cloninger en Guze (1970) p. 79-87, Smart (1976, Allon (1987). 
ligt iets hoger bij vrouwen dan bij mannen. Wel is het verschil in burgerlijke staat tussen opgenomen mannen en vrouwen in de psychiatrie opvallend. Het aantal gehuwde vrouwen is daar relatief hoog. ${ }^{4}$

Vergelijk je echter de cijfers binnen de groep mannen en de groep vrouwen afzonderlijk dan treden er significante verschillen op in de relatieve aantallen mannen c.q. vrouwen die in het strafrechtelijke respectievelijk psychiatrische circuit terecht komen. In Nederland wordt aan de hand van een vergellikend onderzoek in de observatiekliniek van het Pieter Baancentrum voorzichtig geconcludeerd dat ook bij vrouwen die eenmaal verdachte zijn in een strafproces vaker een psychiatrische aanpak wordt geadviseerd dan bij mannen. De uitsplitsing in delicten en de uitschakeling van de variabelen burgerlijke staat en beroep verklaarden dit werschil miet. ${ }^{\text {as }}$ Later onderzoek in het Pieter Baancentrum naar het specifieke delict 'partnerdoding' laat zien dat vrouwen niet in de fase van de straftoemeting, maar later bij de executie iets vaker dan mannen naar het psychiatrisch circuit gesluisd worden. ${ }^{36}$

Directeuren van penitentiaire inrichtingen geven de laatste jaren wel aan dat het aantal vrouwen met een psychiatrisch ziektebeeld sterk toeneemt, over het algemeen in combinatie met verslavingsproblematiek. ${ }^{37}$ Dit laatste zou mijns inziens verklaard kunnen worden uit het feit dat steeds meer mensen, dus ook vrouwen, bij de traditionele psychiztrische hulpwerlening uit de boot vallen en geen alternatieve vormen van opvang kunnen vinden.

Het zou ook zo kunnen zijn dat met de groei van het aantal veroordeelde vrouwen, de tendens tot psychiatrisering van vrouwelijke verdachten in een eerder stadium van het strafproces afneemt of dat de toerekeningsvraag bij bepaalde delicten niet meer gesteld wordt, omdat er binnen de magistratuur een 'gewenning' plaatsvindt. $\mathrm{Al}$ in de jaren zeventig is door Chessler aangetoond hoe op het gebied van de geestelijke volksgezondheid het verschil in socialisatie tussen mannen en vrouwen leidt tot verschillend probleemgedrag en ook tot verschillende diagnoses en behandelingen. ${ }^{\text {* }}$ Vrouwen krijgen niet alleen andere idealen, doelstellingen en middelen om die te bereiken aangereikt dan mannen, ook wordt er anders gereageerd op hun onaangepast gedrag. Met name door mannelijke therapeuten wordt ten aanzien van vrouwen een dubbele standaard gehanteerd: een geestelijk gezonde vrouw moet 'vrouwelijk' zijn, maar tegelijkertijd wordt een geestelijk gezonde volwassene geïdentificeerd met 'mannelijke" eigenschappen.

34 Parlevliet en Sevenhuijsen (1992).

35 Van Dijk en de Wit (1982).

36 De Boer (1990) p. 160-161.

37 Zie ook Rapport Werkgroep Vrouwen in detentie (1991) p. 36-39.

38 Chessler (1974), in Nederland onder meer Komler (1978). 
Smart vindt dat door de psychiatrisering van vrouwelijke criminelen eenzelfde dubbele standaard in het strafproces gebruikt wordt. ${ }^{3 n}$ Criminaliteit is iets dat niet in het beeld van de 'normale vrouw' past. Het gedrag is onbegrijpelijk en dus zal er naar een psychopathologische verklaring gezocht worden. Ook Morris geeft in een weergave van verschenen onderzoek aan dat mannen veel meer aangesproken worden op hun verantwoordelijkheid voor de daad (normality and rationality) terwijl bij vrouwen onmiddellijk haar persoonlijke omstandigheden een rol spelen (pathological and irrational). In psychiatrische en psychologische rapporten wordt bij vrouwen veel aandacht besteed aan haar geestelijke gezondheid, terwijl bij mannen veel meer op uiterlijke aspecten van hun gedrag en manier van leven gelet wordt. ${ }^{\text {to }}$ In het kader van de psychiatrisering is de discussie over de mishandelde vrouwen die hun partner doden interessant. ${ }^{41}$

Vooral in de Amerikaanse en Canadese jurisprudentie worden vrouwen vaak vanwege het 'battered woman syndrome' verminderd toerekeningsvatbaar verklaard voor hun daad. Het battered woman syndrome is voor het eerst genoemd door Walker. ${ }^{43}$ Zij deed onderzoek bij vrouwen die langdurig mishandeld waren, maar waarvan overigens geen de partner had gedood. Kenmerkend is dat paren in een niet te doorbreken cyclus terechtkomen, waarbij de man na een geweldsuitbarsting vaak berouw en kinderlijk spijtgedrag vertoont waarop de vrouw affectief, vergevingsgezind en moederlijk troostend reageert, daarmee als het ware een volgende explosie over zich afroepend. Uiteindelijk is zij door deze zich herhalende cycli tot een toestand van 'learned helplessness' geconditioneerd, het eigenlijke syndroom. Symptomen daarvan zijn; verregaande apathie, extreme gevoelens van hulpeloosheid en diepgewortelde voortdurende angst voor het geweld van de partner. In de Verenigde Staten en Canada is het syndroom gebruikt om aan te tonen dat de mishandelde vrouw die haar partner doodt, ontoerekeningswatbaar is omdat er in haar beleving voortdurend sprake is van een onmiddellijke dreiging. De nadruk is daarmee dus zeer sterk komen te liggen op de subjectieve beleving van de vrouw, die vervolgens gepsychiatriseerd wordt. Ze had anders immers toch weg kunnen lopen $?^{43}$

Punten van kritiek die worden geuit op het gebruik van het 'syndroom' zijn'

39 Snart (1976) p. 146-175. Uiteindelijk zijn deye analyses terug te voeren tol de door De Beauvoir (1978) p. 295-304 in hatar standaardwerk "De weede sekse" (oorspr. 1948) aangetoonde projectie van de vrouw als "de Ander". Ook wrowwen zelf bekijken en beoordelen zichzelf via de ogen van de man als "de Ander".

40 Morris (1988) p. 165-166.

41 O.a. Edwards (1990) Ewing (1990), in Nederland: Römkens (1992), Römkens (1995), Ammons (1996).

42 Walker (1984).

43 O.a. Ewing (1990), Mahoney (1990).

44 Römkens (1992), Wiersinga (1993), Nicholson and Sanghvi (1993), Römkens (1995). 
- Vakinhoudelijk en methodologisch berust het onderzoek van Walker op een wankele basis:

1. De diagnostische waarde (als klinisch beeld) is beperkt. Je mag pas over een syndroom spreken als er een samenhangende geheel van klachten is. Dit is een bijeenraapsel van verschijnselen waarin samenhang ontbreekt.

2. Het onderzoek van Walker betrof een selecte steekproef: de groep was niet representatief en ook nooit bedoeld als model voor de verklaring van de toerekeningsvatbaarheid.

3. Het onderzoek verklaart niets over de gestoorde agressieregulering van vrouwen die hun partner ombrengen.

- Er onstaat een eenzijdig beeld van de psychische problematiek. Alleen de hulpeloosheid en passiviteit worden benadrukt. Daarmee wordt juist geen verklaring voor het handelen op dat moment gegeven.

- Bovendien wordt het beeld veralgemeniseerd, alsof mishandelde vrouwen een homogene groep vormen. Het kan daarmee ook als een boemerang werken: de meeste vrouwen vermoorden hun partner immers niet. Impliciet worden zelfs racistische tendensen versterkt. ${ }^{15}$ De uitstraling van zwarte vrouwen beantwoordt minder vaak aan het stereotiepe passieve en hulpeloze beeld. $\mathrm{Zij}$ hebben dan een beperkte kans op een mildere straf.

- De zaak wordt in plaats van op de straf-geconcentreerd op cle schulduitsluiting, waardoor niet de daad maar de dader centraal staat en haar abnormaliteit, haar verminderde toerekeningsvatbaarheid. Dan blijft het geweld van de man toch weer buiten beschouwing.

De populariteit van het syndroom in de Verenigde Staten is volgens Römkens te begrijpen vanuit pragmatische en politieke motieven. Het betreft een opportunistisch gebruik. De positie van de getuige-deskundige in het strafproces is in de Verenigde Staten dan ook heel anders dan in Nederland. ${ }^{46}$ Experts worden in het partijenproces strategisch ingezet en bovendien geworven op de private markt. Naarmate het Nederlandse strafproces meer contradictoir van aard wordt, zal de expert-witness overigens een belangrijker rol kunnen gaan spelen. Te denken valt aan de DNA-proef, de ooggetuige-expertise, de poppenmethode bij kinderen en het battered women syndrome. ${ }^{47}$

De annotatie van Röling bij de "Moord te Heer" (1958!) is in relatie tot de inbreng van deskundigen in het strafproces nog steeds het lezen waard":

45 Zie ook Ammons (1996).

46 Zie Nijboer (1992), Ammons (1996).

47 Zie Hielkema (1996). Zie voor de rol van getuïgedeskundigen in Noderland onk de casusheschrijvingen in: Crombag, Van Koppen en Wagcnaar (1992) p. 291-3\%3.

48 HR 13 mei 1958, N. 1958, 325, m.n. Röling. (Moord te Hecr) Het ging in doze casus om ecm vrouw die ervan werdacht werd haar man te hebben laten ombrengen. 
"De psychiater in foro. Het blifft een omstreden vraag, over welke punten een psychiater als deskundige, verklaringen kan afleggen omtrent dat wat rijn wetenschap hem leert. De praktijk omtrent wat aan de psychiater gewraagd word is zeer verschillend. Het zou de moite lonen de op dit punt bestaande formulieren te vergelliken. Uit het in thet atrest vermelde blijkt dat een psychiater verklaarde dat de verdachte lijdende was 0.a. aan een nymphomane driflpsychologie, terwijl later het Hof hicr "driftpsychopathie" voor in de plaats stelde. Inderdaad kan men zich eerder een psycholoog dan een crimincle als lijdend aan een bepaalde psychologie voorsteilen. Dat een onderzochte aan een bepaalde psychopathie lijdt behoort ongetwijfeld tot de antwoorden, die de medische wetenschap geven kan. Behoort daar ook toe de constatering dat de wil wrij was of onwrij? In ieder geval is het een terminologie die gemakkelijk wordt misverstaan, daar zij belast is door een philosophisch verleden. De functie van de psychiater is, de rechter duidelijk lie maken in howevere en in welke mate alwijkingen aanwezig zijn in de intellectuele, emotionele en wilssfeer, en in hoeverre de persoonlijkheid niet aangepast is in het menselijk contact. Op grond van de gegewens zal de rechter beoordelen, in hoeverre er sprake is van verminderde of witgesloten toerekenbaarheid. Dat laatste is cen oordeel, aan de rechter voorbehouden: Indien de psychater zich over al dan niet toerckenbaarheid, of ver mindering daarvan uitsprcekt- zoals in casu geschiedde- mag dit alleen dienen om de rechter duidelijk te maken in hoverre hij gestoordheid anwexig acht. Immers de vraag der toerekening is geen wraag waarop de psychiatric het antwoord kan geven. Het is een vraag, die niet alleen afhankelijk is van "de staat" van het misdadig indivictu maar ook van "de stagt" van de oordeel-vellende gemeenschap"."

De erkenning van de mishandelingsgeschiedenis als juridisch relevant feit is wel belangrijk. In het Nederlandse recht lijken de mogelijkheden daartoe door het brede arsenaal van strafuitsluitingsgronden juist minder beperkt dan in het Amerikaanse. Zo aanvaardt in 1992 het Hof in Den Haag het door de advocaat van de verdachte vrouw in verband met eerdere mishandelingen naar voren gebrachte "noodweerexces'. Het gaat in dit geval om een echtpaar dat in een echtscheidingspocedure is verwikkeld. De man is het niet eens met scheiding. De vrouw woont al niet meer met hem samen. Na de zoveelste ruzie en mishandeling komt hij bij haar om het weer eens uit te praten. Ze laat hem binnen in haar woning. Er onstaat opnieuw een ruzie waarbij de vrouw wordt geslagen en geschopt. Omdat zij in het verleden vaker is mishandeld, is de vrouw bang dat de man nog erger zal toeslaan. Zij ligt dicht bij een linnenkast waarin een geladen revolver ligt. Zij pakt de revolver. Als de man in dreigende houding op haar afkomt, richt zij op hem. Als hij weigert stil te staan, schiet zij hem dood. Van eerdere mishandelingen zijn bewijzen aanwezig: een aangifte op de dag voor de moord en doktersverklaringen uit het verleden.

49 Dat er niet weel nicuws onder de \%on ïs, blijkt ten aanzien van de door Röling gemaakle opmerkin. gen ook uit het onderzoek van DC Bocr (1990) p. 159-160. "De rapporten dic het PBC uitbrengt dienen meer gestandaardiseerd to worden..." $\mathrm{cn}$ "de sanctickeu/c van de rechter blijkt rechtst reeks te correleren aan de mate warin de toerckeningsvatbaarheid verminderd was".

50 Zie ook Verrijn Stuart (1995).

51 Art. 42 Sr., Hof 's-Graverhage, 16 maart 1992, RN 1992, 293. (Pistool in linnenkast). 
Cruciale vragen zijn: is hier sprake van voorbedachte rade, dus van moord of van doodslag? $\mathrm{Zij}$ heeft immers een pistool klaarliggen: is dat uit algemene preventie of met het doel hem op dat moment dood te schieten?

Kan een noodweerverweer opgaan gelet op de bestanddelen wederrechtelijkheid, ogenblikkelijkheid en proportionaliteit? Zij had de man immers ook uit kunnen schakelen door op zijn benen te richten.

Het Hof acht doodslag bewezen, maar besluit tot ontslag van rechtsvervolging op grond van noodweerexces. Römkens constateert:

"Het geweld van de man waartegen de vrouw zich op het fatale moment verweerde, en de voorgeschiedenis van geweld, zijn in de overwegingen wan het Hof uitgangspunt gebleven bij de beoordeling van de subjectieve reactie van de vrouw".".52 en: "De zaak zoals behandeld in het arrest wan het hof lat mijns inziens zien dat in bepaalde situaties ook andere juridische wegen denkbaar zijn die erkenmen dat langdurige mishandeling verregaand van invloed is op de motivatie tot het plegen van verdedigend geweld, en op de psychische conditie wan de vrouw die die daad plecgt, zonder dat de individuele verantwoordelijkheid van de wrouw woor haar daad-zowel in psychisch als morcel oprich- word weggedefinieerd" ${ }^{\text {sa }}$

Heel anders loopt het datzelfde jaar in de zaak van de Haarlemse stoeptegelmoord. ${ }^{\text {st }}$ Hier doet de advocaat een expliciet beroep op het battered woman syndrome. In dit geval keert de psychiatrisering van de vrouw zich uiteindelijk tegen haar. Uit het rapport van het Pieter Baan Centrum is op te maken dat haar verminderde toerekeningsvatbaarheid mede aan haar ongelukkige partnerkeus te wijten is. In dat opzicht bestaat er gevaar voor herhaling.

Aan het feit gaat een langdurige mishandelingsgeschiedenis vooraf. Niet alleen de vrouw is slachtoffer. Ook haar zoon wordt door de man bedreigd met zijn dienstpistool. In verband met de overplaatsing van de man verhuist het gezin van het zuiden naar het westen van het land. De vrouw belandt daar in een isolement. De man verbiedt haar ieder contact met de buitenwereld. De ramen en deuren worden door hem afgesloten. De mishandelingen gaan door. Hij brengt, volgens de vrouw, prostitueés mee naar huis en de vrouw wordt gedwongen tot seksueel verkeer met derden. Nadat hij volgens haar gedreigd heeft ook haar dochter te misbruiken, besluit zij te handelen. Als hij in slaap is gevallen, bindt zij zijn armen en benen vast. Als hij wakker wordt, slaat zij hem met een stoeptegel en een tang de schedel in. Op de verweren van de advocaat geeft het Hof gemotiveerd antwoord:

52 Römkens (1992) p. 12.

53 Römkens (1992) p. 14.

54 Gerechtshof Amsterdam, 30 december 1992, RN 1994, 408 (Stoeptegelmoord). Zie ook Wiersinga (1999). 
Het beroep op noodweer(exces) wordt door het Hof niet gehonoreerd. Het is niet aannemelijk geworden dater onmiddellijk dreigend gevaar was. De man was bovendien vastgebonden.

Op het beroep op overmacht, op grond van het battered woman syndrome, zegt het Hof dat het gelet op de getroffen voorbereidingen, de tijdstippen waarop die zijn geschied en de toestand waarin het slachtoffer zich ten tijde van de daad bevond feitelijk niet aannemelijk is geworden dat er voor de verdachte geen andere uilweg was.

Met het oog op het beroep op ontoerekeningsvatbaarheid meent het Hof in navolging van het Pieter Baan Centrum dat de vrouw verminderd toerekeningsvatbaar was. In het advies staat onder andere dat ook in de toekomst gevreesd moet worden voor het gevaar van escalerend geweld binnen relaties, "waarbij het plegen van een agressief delict door betrokkene jegens de nieuwe partner te vrezen is".

Het Hof rekent de vrouw bovendien zwaar aan dat zij haar dochter bij de voorbereiding en uitvoering van de daad betrokken heeft. Het vonnis luidt tweeëneenhalf jaar gevangenisstraf en terbeschikkingstelling wegens moord.

Hoewel de bovenstaande casus erg gecompliceerd en tragisch is, is zij wel typerend voor partnerdodingen door langdurig en systematisch mishandelde vrouwen, die op een moment van ogenschijnlijke rust, hun daad plegen. ${ }^{.5}$ Uit onderzoek blijkt overigens dat die vorm niet representatief voor de groep partnerdoodsters is. Het grootste aantal partnerdodingen vindt plaats in een directe confrontatie. Onder directe confrontatie vallen ook de gevallen waarbij de vrouw is weggevlucht, door de man wordt achtervolgd en waar hij dan bij een confrontatie door haar wordt gedood. ${ }^{56}$ Overigens is het aantal vrouwen dat slachtoffer van partnerdoding wordt, ook relatief, vele malen groter dan het aantal mannen. ${ }^{\text {s" }}$

In navolging van Schalken trekt Tigchelaar de vergelijking tussen het beroep op noodtoestand door de arts die beschuldigd wordt van euthanasie en het beroep op psychische overmacht door de van partnerdoding beschuldigde en in het verleden mishandelde en bedreigde vrouw. ${ }^{58}$ De emotie van de arts wordt volgens haar "ingevoegd in een rechtens erkende procedurele rationaliteit" terwijl "de emotie op grond waarvan de vrouw handelt en die er toe leidt dat ze juist geen alternatieven meer ziet" zelfs niet tot een schulduitsluitingsgrond als psychische overmacht leidt. Zij concludeert:

55 Ook in andere casus waarin de man tijdens zijn slaap werd gedood, is het beroep op een strafuitsluitingsgrond niet gehonoreerd. (vgl. HR 26 mei 1992, RN 1994, 374, HR 23 mei 1995, Rb Maastricht, 22 augustus 1995, RN 1996, 608, m.n. S. van der Maas).

56 Römkens (1995) p. 52, Verrỉjn Situart (1995) p. 162-163.

57 Fuldauer (1994) p. 151-166, Römkens (1995) p. 52.

58 Schalken (Volkskrant 29 november 1994), Tigchelaar (1995). 
"Paradoxaal genoeg, kan de rationaliteit in de publielke sfeer zich met de emoties van de sterkere partij verzoenen, waar in de private sfeer de rationaliteit zo streng gehanteerd wordt dat heltige emoties van een zwakkere partij wolledig "overruled" worden".

Het lijkt mij een vergelijking van appels met peren. De arts is niet de sterkere partij en niet de veroorzaker van het lijden, in feite zijn arts en patiënt samen de zwakkere partij ten opzichte van 'het ondraaglijk en uitzichtloos lijden' als zodanig. Het is niet zozeer de emotie waarop het beroep op strafuitsluiting zich richt maar het professionele conflict van plichten. $\mathrm{Hij}$ beroept zich op een rechtvaardigingsgrond voor het handelen. Er zijn geen professionele handelingsalternatieven, er rest een keuze uit kwaden. Bovendien spelen individuele euthanasiecasus zich miet in de publieke sfeer af. Integendeel..$^{\text {sa }}$

Verrijn Stuart maakt de vergelijking met een gijzeling.

"Ook gijzelaars zullen zich soms met geweld bevrijelen cn ook zij zullen daarbij mut voorbedachte rade te werk gaan. Maar dan heet het heldendom, terwijl de partnerdoodsters "slachtoffers' heten te zijn"

Niet het element van gekte, maar juist het normale van de reactie zou gezien moeten worden. Met instemming citeert zij Rermmelink:

"Denkbaar is zells, dat noodweer atanwexig geachl, wordit bij cen stralbatr feit, dat als moord dient te worden gekwalificecrd. Die bedreigden kunnen, "na kalm beraad en rustig overleg' (in elk geval met voorbedachte ralad in de zin van art. 289 ) hun belagers een dodelijke val zetten en vich aldus bevrijden ${ }^{2061}$.

In de rechterlijke uitspraken is nog geen lijn vast te stellen, noch wat betreft de kwalificatiebeslissing (moord of doodslag), noch wat betreft de strafuitstuitingsgronden. ${ }^{62}$ In een vergelijking tussen twee recente partnerdodingszaken, waarbij in het ene geval een man de dader was en in het andere een vrouw, merkt Van der Maas op dat bij de mannelijke verdachte veel meer aandacht wordt besteed aan de kwaliteit van de relatie dan bij de vrouw, hoewel er in de casus door de man geen strafuitsluitingsverweren zijn gevoerd. Er is dan ook geen jarenlange mishandelingsgescliedenis,

59 Ik zou mij overigens als strafuitsluitingsgrond bij partnerdoding wel de noodtoustand als "conllict wan plichten' kunnen woorstellen, als de wrouw handelt op het moment dat ook haar kinderen slachtoffer (dreigen te) worden van de mishandelingen.

60 Verrijn Stuart (1994) p. 102, Verrijn Stuart (1995).

61 Verrijn Stuart (1995), p. 173.

62 HR 26 mei 1992, RN 1994, 374, Rb Arrihem 15 april 1993, RN 1994, 375, HR 23 mai 1995, Rb Amsterdam, 28 juli 1995, RN 1996, 6077, Rb Matastricht, 22 august us 1996, RN 1996,608 mut mooi Van der Maas.

Zie ook Römkens (1995) p. 54, Verrijn Stuart (1995). 


\section{Hoofdstuk 1}

maar wel een cultureel probleem, waardoor het feit dat de vrouw zich niet wolgzaam opstelt bij de man tot een ziekelijke jaloezie leidt. ${ }^{63}$

Oberlies onderzocht de rol van de mishandelingsgeschiedenis en andere relevante factoren bij het verschil in (juridische) benadering van mannelijke en vrouwelijke partnerdoders in Duitsland. $\mathrm{Zij}$ vergeleek casus uit de periode $1975-1985$ en beoordeelde de constructie die achteraf over het gebeuren gemaakt werd. Het ging daarbij om 84 mannen (steekproef) en 93 vrouwen (totaal). Bij de kwalificatie van het delict verkeren vrouwen in een nadelige positie vergeleken bij mannen:

- Er is eerder sprake van (voorwaardelijk) opzet en voorbedachte rade omdat vrouwen een wapen gebruiken, waaronder dus ook een vleesmes, stoeptegel en dergelijke vallen. De man gebruikt vaker zijn blote handen, waardoor in ieder geval de schijn van een vooropgezet plan er niet is.

- De mishandelingsgeschiedenis werkt in het voordeel van de mannelijke dader: andere keren is de de vrouw niet gedood, dus hij zal het nu ook wel niet van plan zijn geweest.

- Het gedrag direct na de daad lijkt ook in het nadeel van vrouwen te werken. Vrouwen halen hulp terwijl mannen eerst tot zichzelf moeten komen (en dus zichzelf niet waren). Mannen schijnen relatief vaak naast hun slachtoffer in slaap te vallen. Dat wordt gezien als een teken dat ze nuet dachten dat zij dood was.

- Het direct hulp halen, leidt er ook toe dat vrouwen vaak nog verward en/of beneveld worden aangetroffen. Mannen slapen eerst hun roes uit en ogen dan 'verstandiger".

- Drankgebruik werkt bij mannen verontschuldigend, bij vrouwen verzwarend.

- Vrouwen worden door hun wapengebruik veel eerder wegens 'poging tot doodslag' veroordeeld, terwijl er dan bij mannen sprake is van een uit de thand gelopen mishandeling. Bij vrouwen wordt eerder de 'wil tot doden' vastgesteld. Daarvoor zijn geen gradaties vastgesteld, zoals bij mishandeling.

Als vrouwen uiteindelijk toch lichter gestraft worden heeft dat volgens Oberlies dan ook niet met de reconstructie en beoordeling van het gebeuren te maken maar met andere factoren. Factoren die in zijn algemeenheid bij mannen en vrouwen gunstig uitwerken, maar die bij vrouwen waker woorkomen, zoals het malschappelijk gebonden zijn, geen recidivist zijn en dergelijke.

Vanuit feministische zijde wordt soms op psycho-analytische gronden beweerd dat vrouwen hun agressie naar binnen richten en mannen naar buiten. Vrouwelijke criminaliteit wordt dan een soort 'uitzondering op de regel'. Die vrouwen hebben

63 Rb Amsterdam, 28 juli 1995, RN 1996, 607 en Rb Maastricht, 22 augustus 1996, RN 1996, 608, met noot Van der Maas.

64 Oberlies (1990).

65 Quispel (1979) p. 239-240. 
weliswaar een andere vorm gekozen, maar het gaat allemaal om afwijkend gedrag uit dezelfde oorsprong dus de vorm doet er niet zoveel toe. ${ }^{\text {ib }}$

Smart vindt juist wel dat de sociale betekenis van de verschillende vormen van deviant gedrag van vrouwen aangetoond moet worden. Als je een geestelijke inzinking niet wilt zien als irrationeel; onlogisch en impulsief gedrag, is het een uitdaging om de verschillende vormen van afwijkend gedrag te onderzoeken op hun betekenis en op de intenties van de vrouwen die het gedrag vertonen. ${ }^{67}$

Ook voor de formele rechtspositie lijkt het voor vrouwen wel degelijk uit te maken of zij in het penitentiaire of psychiatrische circuit terechtkomen. In het laatste wordt immers per definitie de medisch/psychiatrische interpretatie van het gedrag van de vrouw bij voorrang in de beoordeling van een klacht betrokken. ${ }^{60}$

Het benadrukken van het slachtofferschap van vrouwen in het strafrecht en de daaraan verbonden bepalende rol van (gedrags-) deskundigen zijn ter discussie gesteld door Verrijn Stuart, onder meer naar aanleiding van het proefschrift van Boutellier die aan het slachtofferschap de morele betekenis van het huidige strafrecht lijkt te ontlenen. ${ }^{\infty}$ De dichotomie slachtoffer-dader wordt juist door vrouwen steeds doorbroken. Door de slachtofferrol van vrouwen eenzijdig te benadrukken wordt een nieuwe afhankelijkheid gecreëerd. Disciplinering door de staat en "de professionals" leidt tot nieuwe machtsongelijkheid. ${ }^{00}$

66 Chessler (1974) p. 52-54 , Quispel (1979) p. 239-240.

67 Smart (1976). Zie ook: Andriessen (1982). Zie voor onderzoek in deze riehting: Van Reekum (1988) Zij toetst in haar onderzock de rollheoric van Gove en Tudor. Dic theorie gaat uil van de hypothese dat de rol wan de man, door het hebben van werk, vaster ligh dan die van de wrouw, terwijl de vrouw meer verzorgende rollen werwult. Conclusie is dat meer vrouwen dan mannen door het hebben van die rollen geesteszick xajm. Op basis wan haar onderzock verwerpt Van Reckum die hypothese. Als er al verschillen zijn in gecstelijke gezondheid, zijn die niet in eerste instamtic gerelateerd aan de sekse, maar voornamelijk aan het wel of niet hebben wan werk. Belangrijker nog, lijkt mij, zijn de verschillen die zij aantoont in de betekenisgeving tussen mannen en vrowwen aan zowel werk als verzorgende rollen en de effecten daarvan op het geestelijk welbevinden.

Zo werd in de 'prikpil affaire' aan de lichamelijke klachten die de grond vorndent woor de weigerung van de medicamenten (bijwerkingen van hat middel Depropovera; toen in versehillende landen al uil de handel genomen) voorbijgegaan doordat de rechter het criterium van de medicus overnam. (bestwilcriterium: 'zij ontbeert verantwoordclijkheidsgevoel"). Zie Isarin (1986), Veerman (1987), Isarin (1987), Soctenhorst (1987), p. 459-460.

69 Boutellier (1993), Verrijin Stuart (1994), zie ook Van Swaaningen (1995) p. 208-21\%.

70 Zie woor kritische beschouwingen ower de versterking van de positie van hed slachtoffer in thet strafproces/bewijsrecht Buruma (1994), vanuit de psychologie Crombag en Merkelbach (1996). 


\subsubsection{De ridderlijkheidshypothese}

De wrouwen die terecht komen in het strafrechtcircuit zouden vervolgens binnen het justitiële apparaat milder, hoffelijker behandeld worden dan mannen, hetgeen weer te maken zou kunnen hebben met de ridderlijke houding van de overwegend mannelijke justitiële autoriteiten." Ook mannelijke medewerdachten zouden een beschermende houding aannemen ten aanzien van vrouwen. ${ }^{72}$

Uit onderzoek van Van der Heijden in Nederland is gebleken dat er inderdaad verschillen bestaan in de afdoening van delicten tussen mannen en wrouwen. ${ }^{\text {ja }}$

"Hieruit kan worden geconcludeerd dat weel meer mannen dan vrouwen misdrijven plegen en dat verschillen in de cijfers over bekend geworden verdachten niet zonder mecr mogen worden toegeschrevem aan verschillen in politiele reactie op de criminalitcit van mannen en vrouwen. Bij de verdere aldoening van delicten zijn er duidelijke aanwijringen dat raken tegen mannen anders worden behandeld dan die tegen vrouwen. De zaken tegen vrouwen worden vaker geseponcerd, ongeach het soort misdrijf waarop de zaak betrekking heeft. Bovendien worden vrouwen die door de rechter schuldig worden bevonden gemiddeld lichter gestraft. Ze krüjgen vaker cen geldboete dan cen wrijheidssiraf $\mathrm{cm}$ als gevangemisstraf wordt opgelegd is deze veel vaker voorwaardelijk dan bij mannen. Voor zover kan worden magegaan laten deze verschillen zich nict werklaren uit werschillen uit de aard van de gepleegde criminaliteit".

Naar andere verklaringen of verfijningen is niet gezocht, zoals verschillen in regio's of de wachttijden onder invloed van het cellentekort. ${ }^{74}$

Bovendien is gekeken naar absolute verschillen in strafafdoening tussen mannen en vrouwen, niet naar relatieve, dus niet genderspecifiek en zonder rekening te houden met persoonlijke levensstijl en sociaaleconomische omstandigheden, die voor vrouwen vaak wezenlijk anders zijn, waardoor ook straffen relatief 'zwalarder' kunnen uitvallen. ${ }^{75}$

Op het congres "Vrowwen en Criminaliteit" in 1987, waar onder andere het onderzoek van Van der Heijden is gepresenteerd, betoogt Ties. Prakken dat het belangrijk is onderscheid te maken tussen de opsporings/ arrestatie-en vervolgingsfase en de

71 Pollak, in: De Vries (1979). Zie voor cen beschrijving en toetsing van de ridderlijk heidshypothese ook Goethals, Maes en Klinckhamers (1995).

72 Leonard (1982).

73 Van der Heijden (1987) p. 36-40.

74 Bruinsma, Dessaur en Van Herewijk (1981) p. 37. Hier wordt een verband gelegd met onder andere de beperkte beschikbaarheid van gewtingeniscapacileit voor vrouwen.

Rutenfrans (1989, p. 18) mecnt owerigens dat er geen reden is het hoge sepotpercentage aan icts anders toe te schrijven dan aan de relatief geringe ernst van de door vrouwen geplecgde delicten en aan de relatief geringe recidivegraad van vrouwelijke verdachicn.

75 Van der Heijden $(1987$, p. 38) geeft dit zelf ook heel kort aan. 
eigenlijke terechtzitting en straftoemeting maar ook tussen de soorten delicten. ${ }^{26}$ Zij constateert een milde houding zolang de vrouwen delicten plegen binnen de geijkte patronen (drugstransport, heling, winkeldiefstal), mat een stevige aanpak en onbegrip bij delicten waarbij vrouwen uit hun rol vallen. (openlijke geweldpleging, terroristische actie). ${ }^{\pi}$ Timmermans en Beembroek vinden in hun onderzoek (naar de afdoening van eenvoudige diefstah) dat de variabele 'burgerlijke staat" belangrijk is bij een mildere straftoemeting. ${ }^{77}$ Dit is interessant nu bij de psychiatrische opnames de burgerlijke staat in omgekeerde zin het verschil in behandeling tussen mannen en vrouwen lijkt te beïnvloeden.

Moonen en Postma die de invloed van de sekse van de dader op de beslissing van de officier van justitie beschrijven, zien een omgekeerd verband met een bepaalde rolverwachting:

"Vrouwen worden waarschijnlijk strenger behandeld als zij een delict plegen dat binnen het verwachte gedrag valt" en "Alls icmand een deliet plcegt dat om welke reden dan ook niet in de werwachting ligt, zal men geneïgd zijn dieper op de zaak in te gaan en veel eerder omstandigheden aandragen dic een coulantere behandeling van de verdachte rechivaardigen ${ }^{n}$.

Een vergelijkbare constatering doen Steffensmeier e.a. in hun onderzoek naar rechterlijke beslissingen in Pennsylvania (V.S.):

"females receive slightly longer sentences for minor offenses but receiwe slightly shorter sentences for serious offenses" .

Uit ander onderzoek blijkt overigens dat een mildere aampak ook wordt aangetroffen wanneer het gaat om delicten die slecht passen bij de vrouwelijke rol, maar waarbij de verdachte zich wel heel 'vrouwelijk' gedraagt.'

Daly onderzocht in een Amerikaanse studie in hoeverre de idee klopt dat rechters zich paternalistisch, dat wil zeggen beschermend en ridderlijk opstellen ten aanzien van vrouwen bij het opleggen van gevangenisstraffen. ${ }^{k 2} \mathrm{Zij}$ interviewde twintig manne-

76 Prakken pleit op het congres overigens ter doorbreking van de algelicle repressic ten aanzien van vrouwen in de politiesector voor posilicve adelic (personeelsbeleid) bij de politic.

77 Dit standpunt wordt in Duits criminologisch onderzock bevestigd. Stcin-Hilbers in: Timmerman en Beembroek (1985) p. 89.

78. Timmermans en Beembroek (1985) zic ook Morris (1988) p. 171:' there is some evidence that certain women and girls -for example, those who are divorced, sexual or black-are dealt with in a discriminat ory ay. In essence, those who fit stereotypical conceptions of 'ladics' and 'nice girls" seem to receive different sentences. from those who breach these expectations?.

79 Moonen en Postma (1992) p. 230.

80 Steffensmeier, Kramer, Streifel (1903) p. 435.

81 Visher (1983) in: Van Schic en Willemsen (1988) p. 7.

82 Daly (1989). Zie voor een beschrijwing wan recent onderzock van Daly, Lissenbcrg (1995-2). 
lijke en drie vrouwelijke rechters in twee verschillende rechterlijke colleges. Opmerkelijk is dat zij ontdekte dat rechters wel degelijk rekening houden met zorgtaken. Het lijkt er daarbij op alsof zij wrouwen beschermen, maar het eigenlijke doel is gezinnen te beschermen en in stand te houden. ${ }^{83}$ Zowel bij vrouwen als bij mannen die verbonden waren met gezinnen kijken de rechters naar de inhoud van die familiebanden. Bij mannen wordt aan het hebben van werk met name veel waarde gehecht wanneer zij materieel gezien voor een gezin moeten zorgen. Hoewel de rechters zeggen in het algemeen rekening te houden met de psychologische gevolgen voor kinderen bijgevangenisstraf van de veroordeelde, komt alleen bij de straftoemeting van vrouwen de zorg om de kinderen in psychologische zin aan de orde. Ook al moet de vrouw ook in economisch opzicht voor haar kinderen zorgen dan wordt door de rechters toch veel meer waarde gehecht aan het psychologisch belang van het in stand houden van de moeder-kindrelatie, respectievelijk aan haar onbetaalde werk als moeder. Bij dit laatste speelt overigens volgens Daly de kostenfactor een belangrijke rol. Een vrouw vastzetten brengt veell kosten voor de staat met zich, als het kind in een tehuis geplaatst moet worden en sowieso als het (onbetaalde) moederwerk inclusief kleden, eten etcetera door betaalde krachten gedaan moet worden. Het is als je het zo bekijkt gemakkelijker een kostwinner te vervangen, via een minimale uitkering, dan een verzorger.

Er wordt binnen de groep vrouwen wel onderscheid naar ras gemaakt. Zwarte vrouwen worden eerder geacht vervangsters in hun omgeving te hebben, een familienetwerk, waardoor hun zorgtaken onbetaald overgenomen kunnen worden. ${ }^{84}$ Met gezinsbanden van vrouwen wordt dus in volgorde van prioriteiten eerst met de psychologische ontwikkeling van het kind, dan met de zorgtaken van de moeder die niet overgenomen kunnen worden en dan pas met de broodwinning rekening gehouden. In alle gevallen wordt de reële invulling getoetst (om het verschijnsel baby-borrowing tegen te gaan) en wordt aan handhaving van de familiebanden via zorgtaken een preventieve functie toegedacht bij het voorkomen van recidive.

Overigens is de indruk van Daly dat er geen onbereikbaar middle-class gezinsideaal wordt geprojecteerd op de verdachten maar dat de gezinnen over het algemeen in de verbeelding van rechters worden geplaatst in economisch marginale omstandigheden, waar men met weel moeite probeert het gezin bij elkaar te houden en de touwtjes aan elkaar te knopen. ${ }^{85}$

Steffensmeier e.a. vinden in hun onderzoek dat de lengte van de straffen die rechters opleggen niet veel verschilt tussen mannen en vrouwen, maar dat vrouwen well een veel grotere kans hebben (negen tot twaalf procent) om niet naar de gevangenis

83 Zie ook Morris (1988) p. 166-167, Eaton (1986).

84 Zie ook: Morris (1988), p. 167. Zij dringt aan op onderzoek naar de interactic lussen de variabelen sekse, ras en klasse.

85 Daly (1989) p. $23-24$. 
te hoeven. ${ }^{*}$ Die bevoordeling van vrouwen is gestoeld op vijf legitimatiegronden. In volgorde van belangrijkheid zijn dat:

1. de verdachte heeft geen gewelddadige voorgeschiedenis;

2. de verdachte heeft geestelijke of gezondheidsproblemen;

3. de verdachte zorgt voor personen die van haar afhankelijk zijn of is zwanger;

4. de verdachte speelde een ondergeschikte rol in de misdaad of was alleen medeplichting;

5. de verdachte toont berouw.

Al met al vinden de rechters vrouwen minder gevaarlijk dlan mannelijke medeverdachten en ze oordelen daarnaast dat vrouwen meer verantwoordelijkheden en maatschappelijke banden hebben. De onderzoekersvermelden nadrukkelijk dat het hier om nieuw verzamelde data gaat en ergeren zich over het feit dat zoveel publicaties nog gebaseerd zijn op oude data, uit de jaren zeventig. De straftoemeting is in hun opinie in gunstige 'gendered' zin veranderd.

Toch lijken in Nederland de afgelopen jaren vrouwen steeds vaker tot een (deels) onvoorwaardelijke gevangenisstrafveroordeeld te worden. Tussen $1992 \mathrm{en} 1994$ was er een stijging van veertig procent tegen twintig procentbij de mannen. Hoewel de gemiddelde detentieduur tussen mannen en vrouwen niet verschilt (honderdvijttig dagen in 1991), is het aantal vrouwen dat tot een onvoorwaardelijke gevangenisstraf van langer dan twee jaar veroordeeld wordt relatief groter dan het aantal mannen. $(78 \% \text { respectievelijk } 50 \% .)^{87}$

Er lijken trouwens grote verschillen op te treden in strafafdoening tussen minderjarige vrouwen (adolescenten) en meerderjarige. Meisjes lijken, ook in vergelijking tot jongens, relatief hard aangepakt te worden. ${ }^{88}$ Rutenfrans geeft hier overigens inzichten weer die een duidelijk verband aantonen met de dubbele moraal die ten opzichte van jongens en meisjes gehanteerd wordt. In het algemeen verwacht men van jongens dat zij actief naar buiten treden en zelfvertrouwen ontwikkelen, terwijl men van meisjes verwacht dat zij afhankelijk van en gehoorzaam aan het ouderlijk huis blijven en verantwoordelijkheidsbesef ontwikkelen. Hetzelfde gedrag dat bijjongens wordt goedgekeurd of door de vingers wordt gezien, wordt bij meisjes afgekeurd of bestraft. Het gedrag van de jongens wordt gezien als een wat al te enthousiatst uiting geven aan hun mannelijke rol, terwijl meisjes juist handelen in strijd met hun geslachtsrol. Vaak gaat het dan (in Amerikaans onderzoek) om eerder genoemde 'status offenses',

86. Steffensmeier, Kramer and Streifel (1993) p. 411-446.

87 Lissenberg (1992) p. 268, Kester en Junger-Tas (1994) p. 69-72, Fuldauer (1995) p. 78. Voor cen deel zijn de cijfers te verklaren wit een verschuiving in thet soort delicten. Zie ook Junger-Tas (1995) p. 34. Römkens (1995, p. 49) spreekt over een disproportionele toename van misdrijven tegen het leven.

Rutenfrans (1989) p. 14-17, zie ook Leonard (1982) p. 36-39. 
zaken als spijbelen, weglopen van huis, zich laat op straat bevinden etcetera. Bovendien wordt het gedrag van meisjes dan ook nog eens benoemd als 'seksueel afwijkend'. Ook in West-Europees vergelijkend onderzoek is deze ongelijke behandeling tussen jongens en meisjes die zich schuldig hebben gemaakt aan strafbar gesteld gedrag waargenomen.

Van Schie en Willemsen gaan bij hun onderzoek uit van de bestaande seksestereotypen, dat wil zeggen de impliciete ideeën over mannen en vrouwen die de waarneming en interpretatie van eigenschappen en gedragingen beïnvloeden (attributietheorie). ${ }^{.0}$ Feminieme eigenschappen zijn dan afhankelijkheid en conformisme. Masculiene eigenschappen zijn avontuurlijkheid en agressiviteit. Via toepassing van deze eigenschappen op ongewenst gedrag maken zij een indeling in ongewenste masculiene, sekseneutrale en feminieme gedragingen. Geweldsdelicten, diefstal met braak, het nuttigen van grote hoeveelheden alcohol horen bij masculien gedrag (stoer doen). Spijbelen $_{i}$ weglopen van huis en winkeldiefstal zijn eerder sekseneutraal te noemen. Geen van de crimininele gedragingen kan, volgens de onderzoekers, feminiem genoemd worden.

De onderzoekers zien hun vooronderstelling dat er geen onderscheid tussen jongens en meisjes wordt gemaakt zolang het om sekseneutraal gedrag gaat niet bevestigd. Er zijn geen vergelijkingen te trekken doordat jongens en meisjes zeer verschillende delicten plegen. Alleen winkeldiefstallen komen bij meisjes vaak genoeg voor om te zien dat hierbij geen onderscheid bij de strafafdoening wordt gemaakt.

Bij hun analyse van "probleemgedrag' (vooral weglopen, want daarmee komt de politie in aanraking) valt op dat de directe opvoeders zich eerder of meer zorgen maken bij meisjes dan bij jongens en dat de jeugdpolitie deze ongelijke mate van bezorgdheid deelt. Over het algemeen wordt er van jongens veel meer getolereerd, vooral gedrag dat met seksuele contacten te maken zou kunnen hebben. Ook de kinderrechter besteedt meer aandacht aan weggelopen meisjes.

"Uitsluitend voor meisjes geldi dat zij wel ecns uill huis geplaatst worden zonder enig crimincel gedrag. vertoond te hebben, watarbij informatic ower ongewenste seksuele contacten een argunont lijkt tc zijn."w

Maar ook bij de straftoemeting spelen stereotype verwachtingen een rol. Jongens worden sneller formeel gestraft met het oog op het stereotiep te verwachten recidivegedrag. Boys will be boys. Bij meisjes wordt eerder aan gedragscorrectie gedacht. $\mathrm{Ze}$ is 'even' ontspoord.

Er lijkt niet zozeer een ridderlijke houding, maar een paternalistische genderspecifieke benadering in strafafdoening te bestalan. Deze is nogal diffuus, omdat zowel de leeftijd

89 Elzinga en Naber (1984).

90 Van Schie en Willemsen (1988).

91 Van Schie en Willemsen (1988) p. 61. 
van de verdachte als de aard van het delict gerelateerd worden aan de verwachting ombrent aanpassing aan de geslachtsrol.

\subsection{Criminologische theorieën}

Er zijn ook fundamentele theorieèn die, uitgaande van de registraties zoals ze zijn, verklaringen proberen de geven voor het verschijnsel 'vrouwencriminaliteit': Vaak doen zij dit door de vrouwencriminaliteit af te zetten tegen die van mannen. Ik beschrijf de voornaamste stromingen, zonder de pretentie te hebben volledig te zijn.

\subsubsection{Biologische theorieën}

De voorloper van de biologische theorievorming in de criminologie is Lombroso. Hij meent bij mannelijke criminelen uiterlijke kenmerken van degeneratie te zien, zoals een grote neus, een laag voorhoofd etc. Bij vrouwelijke criminelen kan hij dergelijke kenmerken nauwelijks vinden. Uit het feit dat krouwen niet in zijn theorie passen, leidt hij af dat vrouwen minder geëvolueerd zijn dan mannen. Vrouwen zijn. relatief primitiever en daardoor vallen de criminelen onder hen minder op..$^{93}$ Van nature acht hij de vrouw eigenlijk minder gevoelig voor pijn en minder hartstochtelijk dan de man. Verder is zij jaloers en wol wraakgevoelens. Deze negatieve kenmerken worden geneutraliseerd door onder andere het moederschap, de vrouwelijke zwakheid en haar lage intelligentie. Vrouwelijke criminelen missen die neutraliserende eigenschappen. Zij zijn losbandig en dat doet hen vijandig staan ten opzichte van de offers die vam een moeder gevraagd worden."

In later biologisch onderzoek worden oorzaken voor crimineel gedrag en verschillen in dat gedrag tussen mannen en vrouwen vaak gezocht in het chromosomenpatroon en de genetische constitutie, het rijpingstempo, de hersenfuncties en de productie en werking van hormonen.

Rutenfrans haalt uit het door hem bestudeerde onderzoek twee verschillen tussen vrouwen en mannen die volgens hem van belang kunnen zijn voor het verklaren van het verschil in crimineel gedrag fussen hen ${ }^{\text {*t. }}$

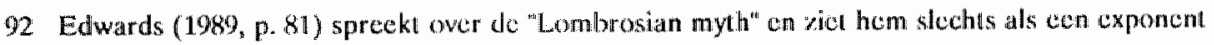
van de medische macht, die sinds de vorige ocuw het debat en de problecmdefinie ming rond (vrouwelijke) scksualiteit bepaalt.

93 In: Leonard (1982) P. 31-32.

94 In: Smart (1976) p.33.

95 Onder andere Bontekoe (1984).

96 Rutenfrans (1989) p. 37 . In hoofdstuk 4 wan sihn proefschrift gat Rutenfrate witgebreid in op de

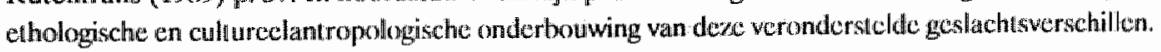
(p. $93-129$. 
"a. Vrouswen hebben meer dan mannen de neiging de gemeenschappelijke kenmerken wan de menselijke soort tot uitdrukking te brengen en zijn daardoor stabieler dan mannen. Deze vrouwelijke stabiliteit komt tot uting in cen relatiel sterke behoudzucht en een relatief groot weerstandsvermogen. Daartegenover staat de manlijke variabiliteit: de neiging af te wijken van dle gemeenschappelijke kenmerken.

b. Vrouwen kenuen een relationeel streven en mannen een dominantiestreven. Ritualisering bij vrouwen gebeurt door promiscuiteit en prostitutie en bij mannen door vechtgedrag."

Rutenfrans beschrijft promiscuïteit ook als mannengedrag. Het achterliggende streven verschilt echter tussen mannen en vrouwen. Het relationeel streven van vrouwen richt zich op gelijkwaardige relaties, dat van mannen op hiërarchische.

Rutenfrans verklaart de genoemde verschillen deels uit de anabolische stofwisseling bij vrouwen en de katabolische bij mannen. De verschillen worden nog verder verfijnd door de bestaande arbeidsverdeling.

Algemene kritiek op biologische theorieën is onder meer:

- dat stijgingen en dalingen in de criminaliteit niet parallel lopen met de bevolkingsgroei en de geslachtsverdeling tussen mannen en vrouwen daarin ${ }^{97}$;

- dat sommige risicofactoren juist aanwezig zijn in een fase waarin minder criminaliteit voorkomt, bijvoorbeeld wanneer de testeronproductie die agressieverhogend zou kunnen werken, bij vrouwen stijgt ${ }^{\text {;8. }}$;

- dat biologische kenmerken op zich nog niets zeggen over de directe oorzaken van gedrag. Ze kunnen slechts werken via een psychologisch correlaat. Je moet je er bewust van zijnin;

- dat er geen rekening wordt gehouden met de verschijnselen van differentiële categorisatie (door de reactie op je gedrag word je psychologisch in een hokje geplaatst) en differentiële attributie (het op grond van één kenmerk toekennen van talloze andere kenmerken) Bij een beoordeling op grond van uiterlijke kenmerken zullen deze beide effecten al gauw optreden. ${ }^{100}$

Een belangrijke factor bij het benoemen van gedrag vormt dus de reactie van de omgeving en de samenleving. 'Criminaliteit' is geen waardevrij begrip, 'agressie' ook niet en deze begrippen zijn zeker niet inwisselbaar. In iedere cultuur worden mogelijke biologische geslachtsgebonden verschillen dan ook anders ingevuld en gewaardeerd. ${ }^{100}$ Biologische theorieën sec zijn statisch en geven weinig of geen aangrijpingspunten tot beïnvloeding door het individu zelf en/of haar sociale omgeving. ${ }^{102}$

97 Bruinsma, Dessaur en Van Hezewijk (1981) p. 46.

98 Bruinsma, Dessaur en Van Hezewijk (1981) p. 47.

99 Van Hexewijk en Bruinsma (1979) p. 223-224, Rutenfrans (1984) p. 14-5.

100 Van Hezewijk on Bruinsma (1979) p. 224.

101. Adler (1975) p. 39-53, Smart (1976) p. 33-34. Zic over antropologische verschillen tussen mannelijkheid en vrouwelijkheid in het algemeen ook Willekens (1987)

102 De Beauvoir (1978) p. 29-61, Rocde (1992) p. 31-43. 
In dit kader is ook de neurofysiologie interessant. Sinds ongeveer vijftien jaar worden hersenen niet meer als statisch beschouwd. ${ }^{10}$ Leerervaringen geven fysiologische reacties en vice versa. Wellicht is hieruit ook de opleving van biologisch en fysiologisch onderzoek omtrent afwijkend gedrag te verklaren.

\subsubsection{Psychologische theorieen}

De ideeën van Freud hebben veel invloed gehad op het beeld dat over vrouwen bestond en bestaat. Freud zelf zegt weinig ower vrouwelijke criminaliteit en hij onderkent dat er maar weinig informatie bestaat over vrouwelijke persoonlijkheidskenmerken. Hij suggereert zelfs dat zijn ideeèn tamelijk speculatief zijn. ${ }^{104}$ Belangrijk gegeven in. Freuds theorie zou de 'penisnijd' van vrouwen zijn. Het ontdekken van het geslachtsverschil krenkt het meisje zo, dat zij zich tegen haar moeder keert en tot haar vader wendt. Penisnijd leidt bij velen tot neurotische klachten. Anderen ontwikkelen een mannelijkheidscomplex. Voorbeelden daarvan zouden zijn lesbiennes, prostituees, vaginistische vrouwen en feministes. De 'gezonde, volwassen vrouw' is nogal masochistisch (naar binnen gerichte woede vanwege penisnijd), narcistisch en passief (seksueel-ontvangend). ${ }^{105}$ In wezen acht dus ook Freud biologische aanleg en anatomie bepalend voor de psychologische ontwikkeling. Hij betrekt geen sociale factoren bij zijn theorie, of zoals De Beauvoir opmerkt."

"Freud geeft zell toe dal het prestige van de penis te danken is aan de socvereinitcil wan de vader en bekent dat hij niet weet waarin dic mannclijke suprematie haar oorsprong vindt". "akt

Pollak gebruikt in zijn theorie zowel ideeën van Lombroso als van Freud, met name de altijd gekoesterde wens van de vroww om een man te zijn. ${ }^{107}$ Centraal staat bij hem het 'masked character' van vrouwelijke criminaliteit. Hij meent dat 'bedrog en misleiding' karakteristieke eigenschappen van vrouwen zijn. De verklaring hiervoor zoekt hij in de seksuele eigenschappen van mannen en vrouwen. "Terwijl het voor een man onmogelijk is een gemis aan seksuele opwinding voor te wenden, kan een vrouw wel 'net alsof' doen. ${ }^{10 *}$ Bovendien zijn vrouwen geofend in het verbergen. $\mathrm{Zij}$ moeten immers iedere maand hum menstruatie verbergen. ${ }^{10 x}$ Pollak denkt dan

103 Zie ook Van Dijk, Sigel-Grande en Trornwliet (1996), p. 101-103.

104 In: Shoemaker (1984) p. 220.

105 Bruinsma (1985) p. 179, Mager (1980) p. 526-527.

106. De Beauvoir (1978) p. 72.

107 In: Smart (1976) p. 46-53.

108 In: Smart (1976) p. 47-48.

109 Dit ontloki aan 70 cl De Vrics $(1979$, p. 219) als Rutenfrans $(1989$, p. 4) con voct nowl wataria zij de vraag stellen wal de invlocd zou rijin van hot dagelijks moclen verbergen van bun cirectics op de criminaliteit van mannen. 
ook dat de feitelijke criminaliteit onder vrouwen groter is dan de statistieken aangeven. De rol van huisvrouw zou de perfecte dekmantel zijn waardoor misdrijven niet aan het licht komen, zoals het opstoken van mannelijke criminelen, het vergiftigen van echtgenoot en kinderen en het seksueel misbruiken van kinderen.

In andere psychologische theorieën worden juist de morele superioriteit en het grotere aanpassingsvermogen van vrouwen geaccentueerd. ${ }^{110}$ De man zou gericht zijn op de samenleving als geheel en de vrouw op aanpassing aan de man. De criminaliteit van vrouwen wordt dan verklaard vanuit misplaatste rebellie tegen de natuurlijke vrouwelijke rol. Zo meent Kempe dat het vervullen van deze natuurlijke rol voor haar geen offer of frustratie betekent maar "veeleer een daad van liefdevol begrip voor de relatiepartner"."."

Clara Wichmann noemt biologische en psychologische factoren:

"Wanneer er sprake is van biologische cigenschappen, die de criminaliteil der vrouw geringer doen zijn dan die der mannen, dan is de belangrijkste daarvan natuurlijk de minder agressieve aanleg, die reeds onder de hoogere dieren bij de vrouwelijke wezens kan worden waargenomen, en die samengaat met een sterker ontwikkeld altrü̈sme, althans een sterker gewoel van medelijden, en met minder physicke kracht. En wanneer we er ons rekenschap van geven, wat we eigenlijk verstaan onder de "andere plaats in het maatschappelijk leven", die de vrouw inneemt, dan is dit alweer hetzelfde: halar leven is minder daden-leven". ${ }^{\text {nn }}$ en zij vervolgt later:

"En zoollang de reaclics der vrouw minder daden-rcactics zijn dan dic van den man, hoolang haar leven-in of buiten beroep- minder een leven van strijd en 'Selbstbchauptung' is, zoolang rullen haar ingrijpende daden ten goede en ten kwade minder talrijk xijn dan de zijne".".,

Ook Hudig komt in haar studie uiteindelijk tot de conclusje

"dat het in den aard van de vrouw ligt, dat zij minder met de rechtsorde in conflict komt cn nict, althans

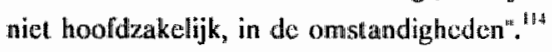

Zij denkt dat de vrouw door haar grote aanpassingswermogen in het algemeen minder dan de man in conflict raakt met haar omgeving. De vrouw blijkt daarbij relatief gevoeliger te zijn dan de man voor zowel gunstige als ongunstige condities. De omstandigheden spelen in die zin wel een grote rol, maar in kwantitatieve zin blijft haar aandeel in de criminaliteit betrekkelijk in vergelijking met die van de man. Kritiek op deze psychobiologische theorieën is dat zij geen rekening houden met machtsverschillen tussen mannen en vrouwen, zoals die ook in huwelijk en gezin bestaan. Te denken valt aan het seksueel misbruik wan vrouwen en dochters en aan

110 De Vries (1979) p. 214-215, Shoemaker (1984) p. 220-221, Smart (1976) p. 37-46.

111 In: De Vries (1979) p. 217.

112. Wichmainn (1918) p. 680.

113 Wichmann (1918) p. 690.

114 Hudig (1940) p. 190. 
het feit dat het weigeren van seks aan de echtgenoot langheen een echtscheidingsgrond was. ${ }^{\text {Is }}$

\subsubsection{Socialisatietheorieen}

In de socialisatietheorieên ligt de nadruk niet op seksegebonden maar op sekseverbonden (gender-) gedrag. Gedrag wordt aangeleerd. Door verschillen in opvoeding, toekomstperspectief en vrijetijdsgedrag krijgt crimineel gedrag bij jongens een heel andere betekenis dan bij meisjes. ${ }^{\text {ti6 }}$ Meisjes worden eigenschappen toegedicht en aangeleerd die in dienst staan van relationele doeleunden: passiviteit, afhankelijkheid, terughoudendheid, aampassing. Uiteindelijk doel is het sluiten van een huwelijk en hef stichten van een gezin. $\mathrm{Bij}$ jongens worden andere eigenschappen ontwikkeld zoals activiteit, autonomie en agressiviteit-in-ruime-zin dat wil ook zeggen extravert, enthousiast en ambitieus gedrag. Hun uiteindelijke doel is het bereiken van een goede maatschappelijke positie. ${ }^{11 ?}$

In het eerste criminologische onderzoek, rond de eeuwwisseling, komt al naar voren dat sekseverschillen in kwantiteit en aard van strafbaar gesteld gedrag voor een deel vanuit de maatschappelijke context verklaard worden.

Zo merkt Loosjes in 1894(!) op over de destijds relatief hoge recidivecijfers bij urouwen:

\footnotetext{
"Wanneer een man uil de gevangenis ontslagen is, staan verschillende wegen hem open om langs cerlijken weg zijn brood te verdienen; voor de ecnmaal gevallen wrouw sluiten zich reeds alle deuren, howveel te meer dus voor de een-, twee- en meermalige recidiviste! Niet zij is het die de misdaad zoekt, doch de misdaad, en in vele gevallen is hier de prostitutie het equivalen, is het die haar atangrijpt "zonder dat er buiten den zelfmoord een andere uitweg mogelijk is". ${ }^{118}$
}

Daarnaast geeft hij overigens ook nog aan dat de cijfers weinig betrouwbaar zijn. In. Nederland ziet ook Bonger al in het begin van deze eeuw als belangrijkste reden voor het verschil in omvang van criminaliteit tussen mannen en vrouwen het verschil in maatschappelijke positie tussen mannen en vrouwen. Hij denkt bovendien dat vrouwen door eeuwenlange onderdrukking hun "sociale instincten" onvoldoende hebben kunnen ontwikkelen en dkarom, als iedere onderdrukte groep, terugvallen op de enige wapens die zij hebben: leugens en bedrog. ${ }^{1.6}$

Clara Wichmann neemt stelling tegen de in haar tijd ook wel gehuldigde opvatting dat de handelingen van de man door zijn plek in het openbare leven, nu eenmaal

115 Leonard (1982) p. 4-5, Smart (1976) p. 48

116 Onder andere Bouw (1995).

117 Rutenfrans (1989) p. 70-72, zie ook Van Rcekum (1988)

118 Loosjes (1894) p. 73-74.

119 Bonger (1916) bewerki door Turk (1969) p. 56-66. 
gezien worden en bekend zijn. In feite zouden de vrouwen de delicten begaan of hun mannen daartoe aansporen. ${ }^{12}$ Zij denkt echter dat niet zozeer de kwantiteit van de delicten samenhangt met het binnens- of buitenshuis leven, maar wel de kwaliteit, de aard van de delicten. ${ }^{121}$ Zij onderscheidt binnen het destijds strafbaar gestelde gedrag weliswaar specifieke vrouwendelicten (als abortus en koppelarij), maar stelt daar tegenover specifieke mannendelicten die ook moeizaam in de openbaarheid komen (mishandeling en zedendelicten). Het verschil in kwantiteit kan in haar visie niet meer dan gedeeltelijk met het verschil in sociale positie samenhangen. $\mathrm{Zij}$ zoekt naar andere, innerlijke factoren:

"De vrouw als zoodanig verwerkt haar leed en hatar ellende anders dan de man". ${ }^{2 z}$ en

"Overwegen we deze cijfers dan komt het ons voor, alsof iedere levenspositic haar misdrijwen mecbrengt. De gehuwde vrouwen zonder beroep hebben cen groote, agressieve criminalitcit belecdigingen en mishandellingen- die we vanzelf met verdriet, met zorgen, met daardoor verhoogde arratibiliteit in verband brengen. De vrouwen in een beroep (gehuwden en ongehuwden) hebben cen sterker winstcriminaliteit. Niet zoozeer de quantiteit der delicten hangt er dus mee samen, of de vrouw binnenshuis blijf of buitemshuis komt, maar wel de qualiteit, de aard. ledere levensvorm heef zijn schaduwcijden, die, indien zij tot het uiterste worden verscherpt, tot misdrijf leiden. Het leven tchuis beschernt daarvoor niet, omdat dit lewen zijn cigen conflicten meebrengt. Een criminalist heeft in het algemeen geregd, dat bij verandering varn maatschappelijke omstandigheden het misdrij niet verdwijnt, doch zich wijzigt. Hetzelfde kunnen we met betrekking tot de vrouw zeggen, en dus ook het omgekeerde: bij verandering. van maatschappelijke omstandigheden wermeerdert haar criminaliteit nict zoozcer, doch verandert" ${ }^{123}$

Binnen de modernere socialisatietheorieën worden zowel de expliciete conditionering via ouderlijke en sociale controle als de internalisering van eigenschappen via voorbeeldrolgedrag van anderen bekeken.

Vanuit de socialisatie-optiek zijn onder meer de volgende criminologische theorieën te onderscheiden:

a. de emancipatietheorie;

b. de sociale controle theorie;

c. de differentiêle associatietheorie;

d. de politieke/machtstheorie.

\section{A. Emancipatietheorie}

Het is opvallend dat met name in Nederland al heel vroeg een meer sociologische benadering bij het verklaren van criminaliteit te zien is. Zo benadrukten Loosjes en Bonger ten aanzien van de vrouwelijke criminaliteit de sociale positie en de 
geringe participatie in het maatschappelijk leven van vrouwen. ${ }^{\text {t3 }}$ Bonger denkt dat de vrouwelijke criminaliteit zal toenemen bij verbetering van die positie. ${ }^{\text {tas }}$ In de jaren zeventig ontwikkelt Adler un de Verenigde Staten haar emancipatietheorie. ${ }^{13 \mathrm{Z}} \mathrm{Zj} \mathrm{denkt} \mathrm{dat} \mathrm{vrouwen} \mathrm{door} \mathrm{de} \mathrm{technologische} \mathrm{ontwikkeling} \mathrm{en} \mathrm{de} \mathrm{vrouwenbe-}$ vrijdingsbeweging assertiever zullen worden en sociaaleconomisch gelijke posities als mannen kunnen verwerven. Daardoor zal het verschil in misdadig gedrag verdwijnen.

Voor haar lijkt vrouwenbevrijd "ing hetzelfde te zijn als 'gelijk aan mannen worden', ${ }^{27}$ Inmiddels kan vastgesteld worden dat haar verwachtingen (nog) niet zijn uitgekomen ${ }^{128}$ :

- De gelijke maatschappelijke positie van mannen en vrouwen wordt niet of in ieder geval niet zo snel bereikt als zij verwachtte.

- De stijging van delicten als fraude en valsheid in geschrifte betreffen bij vrouwen vooral (steun)fraude en het gebruik van ongedekte cheques, dus niet de aan een hogere maatschappelijke status verbonden witteboordencriminaliteit.

- Het verband tussen bevrijding van vrouwen (de ideologie) en criminal iteit wordt betwijfeld. Meisjes met feministische opvattingen zouden zelfs minder geneigd zijn tot delinquent gedrag. ${ }^{|x|}$

- Als kenmerk van emancipatie werd in onderzoek vooral het 'buitenshuis werken' gebruikt. Dat het buitenshuis werken van vrouwen waarschijnlijk niet veel met de omvang van haar criminaliteit te maken heeft, toonde Wichmann in 1916 al aan. $\mathrm{Zij}$ vergeleek de statistiek bij drie volkstellingen (1889, 1899 en 1909) en zag dat 'het criminaliteitscijfer der vrouw daalde terwijl haar arbeidscijfer steeg. ${ }^{130}$ Naffine en Gale vinden dat de focus op de samenhang tussen criminaliteit, werk en werkloosheid typisch voor en door mannen is bedacht. Het is dus een voorbeeld van gendered criminologisch onderzoek.

"If crimimologists werc to commence their theorizing with female data, it is unlikelly that they would draw a connection between uncmployment and crime". ${ }^{13 \mathrm{t}}$

124 Loosjes (1894) p. 73-74, in: Wichmann (1918) p. 663-673 cn in: De Vrius (1979) p. 214-215.

125 Bonger (1916), bewerki door Turk (1969).

126 Adler (1975).

127 Leonard (1982) p. 9-11.

128 Zie o.a. Rutenfrans (1984) p. 3-17.

129 Rutenfrans (1989) p. 77-78.

130 Wichmann (1918) p. 668.

131 Naffine en Gale (1989) p. 154. 


\section{Hoofdstuk 1}

Emancipatie is een meeromwattend begrip. Hezewijk en Bruinsma onderscheiden vier aspecten aan emancipatie die in onderlinge samenhang de werkelijke graad van emancipatie bepalen ${ }^{132}$ :

1. de materiële emancipatiegraad, de feitelijke evenredige participatie van vrouwen aan het openbare leven;

2. de formele emancipatiegraad, de formele mogelijkheden tot participatie;

3. de autonomie van vrouwen, het zelfbeschikkingsrecht van de vrouw waarbij zij zich in haar gedrag noch door vrouwelijke noch door mannelijke wensen en projecties laat dieteren;

4. het collectief veranderen van attitudes van vrouwen. (de 'liberation')

Bovendien, veronderstellen zij, zou het effect van de vierde factor op de criminaliteit wel eens veel groter kunnen zijn dan de meer politiek in te vullen factoren.

Rutenfrans stelt ook dat Adlers theorie niet bevestigd is, maar hij doet dat vanuit de gedachte dat ondanks veranderde opvattingen over de emancipatie van de vrouw bij zowel vrouwen als mannen, de vrouwencriminaliteit relatief gezien nauwelijks is toegenomen. Hoewel hij de tijdsfactor als mogelijke verklaring inbouwt, vraagt hij zich ook af hoe het toch komt dat er in de feitelijke rolpatronen van vrouwen zo weinig verandert, ondanks de sinds de Tweede Wereldoorlog sterk veranderde maatschappelijke opvattingen. Hij veronderstelt, voortbouwend op de ideeën van de feministische psychoanalytica Chodorow, dat identificatieprocessen van meisjes en jongens in hun eerste levensjaren mogelijk ten grondslag liggen aan de latere criminaliteitsverschillen tussen mannen en vrouw. ${ }^{13}$ Daarbij omschrijft hij de vrouwelijke rol als "het geheel aan eigenschappen dat in dienst staat van relationele doeleinden".

Anders dan Chodorow meent hij echter dat er direct al sekseverschillen tussen jongens en meisjes zijn op grond van ontwikkelingsfysiologische factoren:

"ontwikkelingsfysiologisch bepaalde scxeverschillen in gedrag en de moederlijke perceptic dat haar kind manlijk of vrouwclijk is, resuleren in cen sexedifferentiejle moederlijke behandeling die wecr leidt tot de handhaving of versterking van de sexeverschillen" ${ }^{1.4}$

\section{B. De sociale controletheorie}

In de sociale controletheorie van Hirschi is de ontwankelijkheid woor afwijkend gedrag afhankelijk van de relatieve afwezigheid van de volgende factore $n^{\text {1.s. }}$ :

132 Van Hezewijk en Bruinsma (1979) p. 228-230.

133. Rutenfrans $(1989)$ p. $72-90$.

134 Ruten[rans (1989) p. 169. In haar bespreking van het proefschrift van Rutenfrans merkt Junger-Tas op dat de schrijver geen aandacht besteedt aan de toegenomen criminalitcit bij vrouwen on meisjes. Uit een selfreport studie uit 1989/1990 zou blijken dat er geen wersehil meer is tussen de geslachton als het om zwart rijden, graffti en winkeldicfstal gaat. (Junger-Tas (1992) p. 34-36).

135 Rutenfrans (1983) p. 83-85, zie ower Hirschi ook: Van Delden (1987) p. 77-83. 
- attachment: de emotionele binding die liemand heeft met iemand anders, met name de ouders. Hoe beter die relatie is, hoe gevoeliger men is voor de reactie van die ander(en);

- commitment: de (maatschappelijke)inzet. Dit is een rationele afweging. Hoe meer men geïnvesteerd heeft in iets, hoe meer men te verliezen heeft;

- involvement: de gebondenheid, betrokkenheid. Iemand die veel activiteiten ontplooit, houdt gewoon te weinig tijd over. (later door Hirschi verworpen in verband met de moeilijke toetsbaarheid);

- beliefs: waarden en normen, de mate waarin iemand overtuigd is van de juistheid en geldigheid van de wet. De mate waarin het geweten drukt.

De neiging tot criminaliteit wordt ingedamd door een samenspel van zelfcontrole, sociale controle en natuurlijke controle. Zelfcontrole betreft de mate waarin mensen korte-termijn-voordelen afwegen tegen-lange-termijn-kosten. Dit heeft zowel met het temperament als met de socialisatie van mensen te maken. Socialisatie blijft de belangrijkste bron, waarbij de leeftijd tot acht jaar essentieel is voor het aanleren van zelfcontrole. Mensen met een lage zelfcontrole zouden de volgende kenmerken hebben. Zij zijn georiënteerd op het hier en nu. Zij hebben gebrek aan doorzettingsvermogen. Ze zijn onvoorzichtig, impulsief en avontuurlijk. Ze hebben instabiele vriendschappen, huwelijken en arbeidspatronen. Ze zijn egocentrisch en onverschillig voor andermans lijden. Ze zijn gericht op fysieke, niet-verbale activiteiten. Ze hebben geen of een gebrekkige opleiding en een lage frustratiedrempel. Niet criminele uitingen van weinig zelfcontrole zouden roken, drinken, mislukken op school, risicogedrag en de gevolgen daarvan zijn. ${ }^{136}$

Volgens deze theorie zou de geringe criminaliteit van vrouwen ten opzichte van mannen in ieder geval te verklaren zijn, omdat vrouwen/meisjes een sterker 'attachment" hebben, vooral een sterkere emotionele gehechtheid aan de ouders. ${ }^{1.77}$ Bruinsma vindt voor deze stelling geen grond in zijn onderzoek voor zover het de identificatie met deviante ouders betreft. ${ }^{138}$ Junger-Tas merkt in zijn algemeenheid op dat op meisjes een veel grotere controle wordt uitgeoefend dan op jongens. Als meisjes uitgaan weten hun ouders met wie. Ze moeten eerder thuiskomen dan hun broers. Ze gaan vaker met het gezin uit en moeten thuis vaker een handje helpen. Ze besteden meer tijd aan hun huiswerk en brengen vaker hun vrije tijd thuis door. ${ }^{13 \%}$ Kok benadrukt naast de emotionele en de sociaaleconomische afhankelijkheid (commitment) het feit dat juist (huis)vrouwen het vaak te druk zullen hebben (involvement) om tot criminele gedragingen te komen. ${ }^{140}$ De informele sociale controle

136 Junger ${ }_{n}$ Terlouw, Van der Heijden en Rutenfrans (1995) p. 2-21.

137 Box (1981), p. 143.

138 Bruinsma (1985) p. 183.

139 Junger-Tas (1985) p. 260-262, Junger-Tas (1995) p. 36

140 Kok (1983) p. 94 (rcaclie op Rutenfrans). 


\section{Hoofdstuk I}

die door het gezin op de vrouw wordt witgeoefend is veel sterker en veell totaler dan die waaraan mannelijke leden zijn onderworpen. Ook Heidensohn schrijft de mate waarin vrouwen zich conformeren aan de maatschappelijke normen toe an de sociale controle waaraan zij blootstaan en die zij via hun sociale rollen ook zelf weer uitoefenen. ${ }^{\text {tat }}$ Hun dienstbare rol aan mannelijke partiners (zowel privé als zakelijk) wordt als het ware gecultiveerd. De privacy in de huiselijke sfeer brengt geen autonomie voor de vrouw met zich. $\mathrm{Zij}$ is verantwoordelijk voor het reilen en zellen van de kinderen, is dienstbaar aan de maatschappellike carrière van haar partner, onderhoudt de contacten met overige familie en kennissen en vervult een belangrijke sociale rol in 'de buurt". Financiële afhankelijkheid, mishandeling door de partner, problemen bij de opvoeding en de eenzaamheid en depressies die daarmee gepaard kunnen gaan, komen nauwelijks structureel boven tafel. Zelfs als vrouwen werken of buitenshuis actief zijn in vrijwilligerswerk en de charitatieve sfeer, verandert dat niets in de structurele machtswerhoudingen tussen mannen en vrowwen. Daarbij worden vrouwen in de openbare sfeer ook nog eens aan andere, strengere regels onderworpen dan mannen. Vrouwen moeten voortdurend op hun reputatie letten en krijgen stigma's opgeplakt, met name ook door andere vrouwen, naarmate ze afwijken van de stereotiepe vrouwelijke rol. Heidensohn geeft onder meer als voorbeeld dat 'stevig drinken' en alcoholisme bij vrouwen veel minder geaccepteerd wordt dan bij mannen.

\section{De differentiële associatietheorie}

Sutherland ontwikkelt de differentiële associatietheorie. ${ }^{1 / 2}$ Hij meent dat crimineel gedrag in groepsverband in primaire groepen wordt aangeleerd. Alle vormen van crimineel gedrag zouden verklaard kunnen worden door uit te gaan van een aantal proposities. De belangrijkste zijn: het in contact komen met personen met afwijkende gedragspatronen en het beschikken over vaardigheden en technieken die voor de uitvoering van criminele handelingen nodig zijn.

Van Hezewijk en Bruinsma analyseren aan de hand van deze theorie waarom vrouwen met name thet delict winkeldiefstal plegen ${ }^{1 / 3,3}$ :

- omdat meisjes in tegenstelling tot jongens minder technische vaardigheden leren;

- omdat door toename van het aantal zelfbedieningszaken de mogelijkheid tot

het plegen van diefstal ook groter werd;

Ook blijkt dat wrouwen andere goederen (kleding, bijouterieën, kledingaccessoires) stelen dan mannen (schrijfwaren, kleding, hobbymateriaal, gereedschap). ${ }^{\text {t* }}$

141 Heidlensohn (1986) p. 163 195.

142 Leonard (1982), p. 91-115. Zic over Suthorland ook: Van Delden (1987) p. 58-63.

143 Van Hezewijk en Bruinsma ( 1979$)$ p. 221-231. Zij gaan uit wan de herricne versic van de theorie
van Opp. 144 Zie ook Van der Heijden (1987), Bouw (1996). 
Het onderzoek geeft geen verklaring voor het feit dat toch nog relatief minder vrouwen dan mannen winkeldiefstal plegen. ${ }^{145}$

Kritiek op aanhangers van de socialisatietheorie in hel algemeen is dat die zich niet bezighouden met de oorsprong van specifieke relaties en dat zij daardoor ook geen inzicht kunnen verschaffen in de specifieke voonwaarden voor het ontstaan van afwijkend gedrag, en al helemaal niet toegespitst op vrouwen. ${ }^{\text {wo }}$

Andere kritiek luidt dat zowel psychobiologische als socialisatietheorieen:

- te vaak maatschappijbevestigend werken. Structurele en omgevingsfactoren worden slechts gebruikt als verklaring voor het individuele gedrag van vrouwen. Het omgekeerde: de betekenis van het gedrag van vrouwen als seksepolitiek verzet tegen structurele factoren komt te weinig aan de orde; ${ }^{147}$

- een nieuw determinisme introduceren, weliswaar niet op grond van aangeboren eigenschappen, maar als radertje in een sociaal mechanisme. De mens als" een (ten dele) zichzelf verwerkelijkend wezen' wordt daarmee ontkend. ${ }^{1+*}$

\subsubsection{Politieke/machtstheorieën}

Edwards merkt op, in nawolging van feministische schrijvers, dat vanaf 1940 de mannelijke criminaliteit vanuit verschillende sociologische invalshoeken is onderzocht maar dat tot voor kort het onderwerp vrouwencriminaliteit met name studie-object was woor niet-sociologen. Hoofdzakelijk psychiaters, psychologen en medische wetenschappers. ${ }^{149}$ Voorzover de vrouwencriminaliteit sociologisch beschreven wordt, is dat in afgeleide termen van het voor mannen relevant geachte onderzoek. In feministische

145 Rutenfrans (1983), p. 83.

146 Leonard (1982) p. 91-115. Bruinsma (1985) noot 3, p. 185. Bruinsma licht hier zijn stclling toc dat thet sociale leerproces voor meisjes en jongens identiek is, maar dat meisjes minder voldoen aan de initiele condities. "Voor de beantwoording van de vraag waarom dit laatste het geval is, moet een andere theorie zorgen".

147 Smart (1976 p. 69-70. Zij suggereert dat criminaliteit en sekserollen alleboi ieder voor zich gevolg kunnen zijn van bepaalde sociocconomische, politicke en historische factoren, in plaats van criminaliteit een (later) gevolg van aangelecrde rolpatronen. Zie ook Dessaur (1979) p. 208, Leonard (1982) ble. 11 c......

148 Dessaur (1979) p. 206. De Beauvoir (1978) p. 16-17. Zij meent dal juisd de vrouw zich mociztam als subject openbaart ondat

. ze niet over concrete middelen daartoe beschikt;

. ze de binding aan de man ervaart als noodzakelijk;

. ze vaak behagen schept in haar roll als de Ander.

Dat laatste verklatart zij met "het, naast de drang van ieder individu xich to doen gelden alls subject, bestaan van de neiging de wrijheid tc ontvluchton en een ding to worden, passief, vervreemd en werloren om op dic manier de angst en de spanning van een existentic dic bewust wordt aanvaard te ontwluchten." Zic hierover ook Vintgens (1992) p. 225-228.

149 Edwards (1989) p. 165-184. 
kring is fel gediscussieerd of het onderwerp 'Vrouw en criminaliteit' wel voorwerp van onderzoek mag zijn. Het is wellicht de zoveelste valkuil van "op een mannenmanier naar vrouwen kijken" waar vrouwen helemaal niets mee opschieten. ${ }^{150}$ De criminologie lijkt steeds maar te werken vanuit de perceptie 'het kwaad te bestrijden of wellicht uit te roeien' en gaat vanuit die optiek naar complexe verklaringen en oorzaken van het kwaad zoeken. Tegenover dit soort onderzoek is ook vanuit kritische criminologen (New Left) stelling genomen. Criminologen zouden niet vanuit de dominante politieke/economische/gender optiek naar verschijnselen moeten kijken, dus niet de bestaande 'orde' met zijn vooronderstellingen bevestigen, maar nieuwe kennis moeten ontwikkelen. ${ }^{\text {sst }}$

In Nederland pleit Dessaur ook voor het ontwikkelen van een fundamentele maatschappij-en cultuurkritiek vanwege het gereduceercle mensbeeld dat nu gehanteerd wordt in de criminologie en sociale wetenschappen. ${ }^{152} \mathrm{Zij}$ meent dat mannen op macro- en micronivo hun onderlinge gezags- en machtsverhoudingen onder andere via misdaad en misdaadbestrijding bevestigen. In dat machtsnetwerk is nauwelijks plek voor vrouwen, maar die zijn via deviante gedragingen op een heel andere manier bedreigend voor het establishment.

Of zoals Kersten zegt:

"As long as the social sciences, including criminology, and the investigative techniques used in these disciplines, masquerade as newtral in relation to the perception of male/fermalc, separatc observations of female life situations, biographics and so forth will not contribute anylhing more to answering the question of the role that 'maleness' and 'femalencss' play in relation to deviation and social control". 153

Nu de overheersende perceptie ten aanzien van vrouwen weinig aanknopingspunten biedt (vrouwen vertegenwoordigen immers 'het kwaad'-in criminologische zin- niet) en 'verklaringstheorieën' in al hun complexiteit tot niets nieuws lijken te leiden behalve tot de oeroude constatering dat er sekseverschillen zijn, is het misschien beter het heersende criminologisch onderzoek te Jaten voor wat het is en theoretisch en beleidsmatig uitsluitend voort te bouwen op verschijnselen en feiten die waarneembaar zijn. Carlen noemt dit realistisch onderzoek. ${ }^{.50}$

Leonard geeft een aantal stappen waarlangs een meer politieke en feministische analyse van vrouwelijke criminaliteit gemaakt kan worden. ${ }^{135}$

150 Onder andere Smart (1976), Heidensohn (1986), Allen (1987), Carlen and Worrall (1987), Carlen (1988), Cain (1990), Worrall (1990), Carlen (1990-2).

151 Zie ook Van Swaaningen (1995) p. 208-219.

152 Dessaur (1979) p. 208.

153 Kersten (1989) p. 129.

154 Carlen (1990-2).

155 Leonard (1982) p. 181-193. 
1. In de bestaande criminologische theorieën en onderzoeksresultaten moeten de inzichten in het voorkomen van criminaliteit en de oorzaken van crimineel gedrag opnieuw bekeken worden. Ook al wordt er nauwelijks aandacht aan vrouwen besteed, toch kunnen de beschrijvingen van de processen wel iets zeggen over juist het geringe aandeel van vrouwen.

2. De structurele implicaties van nieuw onderzoek over vrouwen en criminaliteit moeten bekeken worden. Met name socialisatieprocessen en sociale controle moeten begrepen worden in hun betekenis op macronivo op economisch, politiek en historisch gebied. Te denken valt aan het verband tussen seksuele exploitatie van vrouwen en haar economische en politieke afhankelijkheid. Ook zouden er meer casestudies bij vrouwelijke criminelen gedaan kunnen worden, waaruit wellicht een algemeen patroon gehaald kan worden. Via antropologische studies kunnen culturele interpretaties ontwikkeld en getoetst worden.

3. Om inzicht te krijgen in politieke en economische machtsverhoudingen kunnen labeling- en politicologische theorieën gebruikt worden. In termen van macht kan dan kritisch gekeken worden naar de rol van de wet, de clefiniëring van criminele gedragingen en de manieren waarop sociale controle plaatsvindt. Wie vormt de heersende macht en hoe wordt van (repressieve/disciplinerende) middelen gebruik gemaakt? Zo kan gekeken worden naar de rol van het seksisme in de kapitalistische maatschappij. Wat is de verhouding tussen criminaliteit en de rol van de vrouw en het gezin in de kapitalistische maatschappij?

4. Bij de analyse van vrouwen en criminaliteit moet gebruik gemaakt worden van feministische theorievorming op andere terreinen. Van belang is dat impliciete seksistische vooronderstellingen naar boven gehaald worden, zodat er niet alleen maar een radicale maar vooral een feministische analyse ontwikkeld kan worden. Leonard noemt zelf deze laatste stap de belangrijkste. ${ }^{.56}$

156 Rutenfrans (1989, p. 65-70) schaart Leonard onder de anomictheoric van Merton. Rutcnfrans geeft vanuit zijn onderzoek waardevolle aanvullingen op haar werk refererend wan het (eerdere) werk van Morris (p. 68-70). Het streven vanuit hun socialisatie van vrouwen te benoemen met 'relationele docleindem' (breder dan 'huwelijk en gezin', zoals Leonard) en dat van mannen met 'status-doeleinden' (breder dan 'financieel succes', zoals Leonard). "Zo zullen sommige mannen een status trachen te verwerven door financieel succes na te streven en andere door artistieke prestaties te leweren. Voor vrouwen geldt dat zij hun relationele doeleinden kunnen bereiken door een huwelijk te siluiten, maar evengoed door een promiscue llevenswijze. Ook is hei denkbaar dat de beroepskeuze vam vrouwen sterker zal worden bepaald door relationele dan door statusowerwegingen." 
Bruinsma en Lissenberg houden in 1987 een pleidoof om in onderzoek:

- vergelijkingen te maken tussen vrouwelijke daders onderling en tussen vrouwelijke daders en niet-daders en

- meer aandacht te besteden aan theoretische concepten als macht en vrijheid in verband met het doen en laten wan vrouwen. ${ }^{157}$

Ten aanzien van de eerste twee stappen van Leonard worden er, ook in Nederland, eerste aanzetten tot onderzoeken gedaan of kritieken geschrewen. ${ }^{\text {ws }}$ Ook worden de criminaliteitsregistraties en de opsporings-vervolgings-en straftoemetingspraktijk her en der vanuit het sekse- en genderperspectief bestudeerd. ${ }^{15 \%}$ Het blijkt echter toch erg moellijk te zijn om tot een paradigmawijziging te komen. ${ }^{\text {ia }}$

Carlen inspireert nog het meest met haar realistische beschrijving, waarin het gecombineeerde gender-class-race perspectief een belangrijke rol speelt.

"Because explanations of racism, class structure, and gender structure arc not reducible one to the other, it is likely that people wishing to engage in criminological work that may have some theoretical, policy, or campaigning payoff in relation to women's crimes and women's imprisonment, will not wish to rely solely on the insights of feminisno into gender structure when mounting there investigations".

Er lijkt, wereldwijd, immers een aantal structurele factoren bij gecriminaliseerde en/of gedetineerde vrouwen steeds terug te keren, zoals ook bleek tijdens de conferentie 'Women in detention' in Noordwijk. 'ki.

- er is een disproportioneel aantal vrouwen uit etnische minderheidsgroepen;

- onder de vrouwen heerst armoede en machteloosheid;

- conventionele normen over 'vrouwelijkheid' en 'moederschap'spelen een belangrijke rol bij de definiëring en verklaring van crimineel gedrag en bij de straftoemeting;

- problemen van deze vrouwen worden vaak gepsychiatriseerd.

- er lijkt vaak sprake te zijn van seksueel misbruik en geweld in de jeugd en/of woorafgaand aan de arrestatie.

'Ras of etniciteit' is als zelfstandige variabele zeker in Nederland nog nauweljjks uitgekristalliseerd. Dat kan een blinde vlek in 'blank onderzoek' zijn die leidt tot verkeerde vraagstellingen, vergelijkbaar met genderbias.

157 Bruinsma en Lissenberg (1987) p. 111-114.

158 Rutenfrans (1989), Van Ransbeck (1992), Junger-Tas (1995).

159 Zie tnet name Römkens $(1992,1995)$, Lünnemann $(1992,1996)$.

160 Zie ook: Lissenberg (1905-1).

161 Carlen (1990-2), p. 110.

162 Van Ransbeek (1992), Verrign Situart (1992-1). 


\subsection{Samenvatting}

In dit hoofdstuk kwam aan de orde hoe sinds het eind van de negentiende eeuw het aantal gedetineerde vrouwen laag blijft ten opzichte van het aantal gedetineerde mannen. In de periodes daarvoor lijkt dat immers anders te zijn. In het buitenland worden verklaringen voor die verandering gezocht in de verschuiving die de Industriële Revolutie teweeg brengt in het gezinsleven en de rol van de vrouw: $Z$ ij blijft voortaan meer in de besloten privésfeer. In dezelfde periode gaat men de misdaad registreren aan de hand van het gecodificeerde strafrecht. De criminologische wetenschap komt op. In het kielzog van de medische wetenschap wordt gezocht naar algemene verklaringen voor het geringe aandeel van vrouwen in de criminaliteit. Op grond van biologische en psychologische verklaringen wordt zowel beweerd dat de vrouw 'van aard" inferieur als superieur zou zijn aan de man. Juist in Nederland wordt er in het begin van de eeuw door criminologen relatief veel aandacht besteed aan de sociale omstandigheden die het criminele gedrag van mannen en vrouwen mede zouden beïnloeden. Na de Tweede Wereldoorlog komen de socialasychologische en sociologische theorieën in zijn algemeenheid meer naar voren. Niet alleen de aard en het karakter maar ook de reacties van de sociale omgeving beinvloeden het gedrag van de mens. Sociale controlemechanismen worden onderkend als belangrijke bepalers van crimineel gedrag. De vraag komt op waarom vrouwen dan zoveel gevoeliger zijn dan mannen voor sociale controle. Het antwoord wordt vooral gezocht in socialisatietheorieën. De rolverwachting ten aanzien van vrouwen is heel anders dan die ten aanzien van mannen. Vrouwen worden met relatiedoeleinden opgevoed, gericht op voortplanting, moederschap en zorg voor anderen. Mannen worden met statusdoelleinden opgevoed, gericht op kostwinnerschap en hiërarchische relaties. Criminaliteit van vrouwen wordt deels verklaard uit onaangepastheid en deels uit verzet tegen de voorbestemde rollen.

Voor zover er uit de verschillende criminologische verklaringstheorieën een seksespecifieke benadering te destilleren walt, speelt in alle analyses de moederschapsideologie een belangrijke rol. Enerzijds om op grond van de persoonlijkheids-en socialisatieleer het aangepaste, niet criminele gedrag van vrouwen te verklaren. Anderzijds om de deviantie gepsychiatriseerd als 'ontsporing' of gepolitiseerd als 'verzet' te werklaren. Als seksualiteit en moederschap, dankzij de voorbehoedsmiddelen en de legalisering van abortus, niet meer onlosmakelijk metelkaar verbonden zijn, leidt dat niet direct. tot een grotere vrijheid van vrouwen, althans niet én die wordt weerspiegeld in criminaliteitscijfers. In het latste decennium komt er een hausse aan onthullingen rond seksueel misbruik en mishandeling van vrouwen en kinderen boven tafel. Juist. ook 'criminele vrouwen' blijken daarvan slachtoffer te zijn of te zijn geweest. De dichotomie tussen dader en slachtoffer wordt doorbroken. Feminist ische criminologen tonen aan dat criminaliteit en ook cle criminologie niet sekse-en genderneutraal zijn. In feite worden mannen en uitwassen van mannelijk gedrag bestudeerd. Maar 


\section{Hoojdstuk I}

het blijkt moeilijk te zijn om tot een ander perspectief te komen. Registraties zijn gebaseerd op wettelijke delictsomschrijvingen. De strafwet, de criminaliteitsregistraties en de interpretatie van beide leiden tot veel discussies omtrent 'blinde vlekker'. Niet alleen onderscheid naar sekse en leeftijd, maar ook naar klasse en etnische afkomst wordt nog onvoldoende en zeker niet geïntegreerd onderkend. De ontwikkeling van met name het genderbegrip heeft wel duidelijk gemaakt dat er een veelheid aan dominante cultuurbepaalde constructies is die de beschrijving en bestudering van de criminaliteit beïnvloeden. 


\section{De gevangeniscultuur: empirie en theorie}

\section{Inleiding}

Van de vrouwen die met justitie in aanraking komen, komt uiteindelijk maar een klein deel in de gevangenis terecht. Vaak worden in het voortraject zaken geseponeerd of getransigeerd door het OM.' Van de schuldigverklaarde vrouwen krijgt ongeveer $30 \%$ een onvoorwaardelijke gevangenisstraf opgelegd. Dat percentage benadert dat bij de mannen (33\%) en dat betekent dat vrouwen in de afgelopen tien jaar relatief vaker dan daarvoor een gevangenisstraf kregen. In die periode is daarnaast de gemiddelde duur van de opgelegde gevangenissstraf verdubbeld. Van gemiddeld 3,2 maanden naar 6,4 maanden. Rekening houdend met de vervroegde invrijheidsstelling betekent dit een toename van 2,7 maanden tot 4,8 maanden. ${ }^{2}$ Zeer lange gevangenisstraffen (van een jaar of langer) worden met name gegeven bij gewelddelicten en misdrijven op grond van de Opiumwet. In dit hoofdstuk en de twee daarop volgende hoofdstukken komt de specifieke situatie van gedetineerde vrouwen in Nederland aan de orde. In dit hoofdstuk volgt na een korte beschrijving van de locaties waar de vrouwen verblijven, een aantal aparte paragrafen over de ervaringen van de gedetineerde vrouwen zelf, voor zover die uit onderzoek en andere publicaties bekend zijn. Vervolgens worden de centrale thema's die uit de impressies naar voren komen gekoppeld aan theoretische inzichten die ontwikkeld zijn omtrent de effecten op vrouwen van het verblijf in totale instituties, in het bijzonder in gevangenissen.

De reden om in dit hoofdstuk aandacht te besteden aan de ervaringen van gedetineerde vrouwen is dat ik wil proberen de problematiek tot herkenbare proporties terug te brengen. Abstraheren en generaliseren zijn kenmerken van wetenschappelijk onderzoek. Het is verleidelijk om personen te categoriseren en ze in grafieken en statistieken te rangschikken op gemeenschappelijke kenmerken. Dat geeft de illusie

1 Zie Fuldauer (1995), p. 78. In 1994 werden er 29.330 zaken tegen wrouwen door het O.M. en de rechter afgedaan. Er werden 1836 vrouwen tot een (deels) onvoorwaardlelijke wrijheidsstraf veroordeeld. Voor mogelijke verklaringen zie het voorgaande hoofdstuk. In feite liggen hier onderzoeksvragen woor criminologen en penologen.

2. Kester en Junger-Tas (1994) „p. 69-72. Zie ook Fuldauer (1995), p. 78. Zij spreekt ower een gemiddelde detentieduur van 150 dagen in 1991. 
wan beheersbaarheid: een richting in het vinden van oplossingen en daarmee van het afhandelen wan een probleem om vervolgens met een schone lei aan het volgende te gaan beginnen. Daarmee blifft het probleem buiten cle onderzoeker staan. Hoewel ik in de andere hoofdstukken niet zal ontkomen aan het generaliseren en abstraheren, ga ik er vooralsnog vanuit dat de problemen van gedetineerde vrouwen alles te maken hebben met de vragen en onzekerheden van vrowwen in de 'gewone" samenleving ${ }^{\text {" }}$ En ook dat er dus dezelfde duizend en een verschillen zijn in het benoemen en oplossen van die problemen tussen vrouwen onderling. Dat betekent niet alleen dat gedetineerde vrouwen niet allemaal over éen kam te scheren zijn, maar ook dat recht gedaan moet worden aan de individuele beleving van hun situatie. Doordat de problemen en zorgen van vrouwen echter in de kern zo universeel zijn, vormt de groep gedetineerde wrouwen, als spiegel van de maatschappelijke realiteit, wel een 'ideale' onderzoeksgroep."

In de voorfase van (juridisch) onderzoek speelt het eigen voorstellings- en inlevingsvermogen van de onderzoeker een grote rol. Wellicht ligt daar de kiem voor alle volgende stappen in het analyserend en oplossend onderzoeksproces. In feite kunnen alle controleerbare en zichtbare fasen in het onderzoek al of niet een bevestiging vormen voor het eerste intuittieve oordeel of de gezondverstandredenering van de onderzoeker. Dat is overigens helemaal niet erg en dus ook niet iets om te verbloemen. Integendeel: juist de versterking van dat eerste 'gevoel' tijdens het onderzoeksproces, maar ook de eventuele ondergraving ervan maken dat het onderzoek werkelijk controleerbaar is en in alle eerlijkheid de toets der kritiek kan doorstaan.

De jurist probeert echter ook afstand tot de gepresenteerde casus te nemen om daardoor de zaak in het systeem te kunnen passen en beheersbaar, dat wil zeggen oplosbaar te maken. ${ }^{5}$ Nadat het probleem is benoemd, worden de juridisch relevante feiten geselecteerd, althans die feiten die juridisch te kwalificeren zijn. Daarbij kun

3 Vgl. Cain (1990). Niet alle vrouwen zijn moeders. Een probleem in de dominante, maar ook in de feministische theorievorming is dat alle vrouwen wel veelal gedefinieerd worden als potenticle moeder en dat haar lichamelijke functies als eéndimensionaal verbonden aan zwangerschap en voortplanting gezien worden. Dat heeft weer te maken met het ontbreken van een 'vrouwelijke' visie op (hetero) seksualiteit. Uitzondering is misschien de radicaalfeministische stroming die heteroseks als bron wan alle kwaad af wijst.

4 Zie ook: Verrijn Stuart (1992-2) p. 1-4.

5 Cohen (1992), p. 7. Cohen spreekt in plaats van over "oplossen" liever over het "behandelen" van casusposities. Van oplossen gaat naar zijn mening teveel de suggestie uit dat een conflict in juridische zin slechts kan leiden tot eén oplossing. Nog afgezien wan de wrag of dit niet afhankelijk is van het rechtsgebied waarin de jurist opereert, vgl. strafrecht "laat ik 'oplossen' staán omdat juist die 'gewekte suggestie' de doorwerking van het recht in maatschappelijke discussies illustreert. VgI. Sevenhuijssen (1993-2), p. 133: "die hang naar eenduidigheid werkt niet zelden door in de 'publieke opinie", oftewell in de wijze waarop in de media en het publicke debat wordt gesproken over de betreffende kwesties. Als de rechter incest niet bewezen heeft geacht, wordt hiermee niet zelden de twijfel aan de betrouwbaarheid aan slachtofferverhalen in het algemeen gevoed." 
je je weleens afvragen of deze vertaalslag altijd te rechtvaardigen is. Wellicht vanuit pragmatisme. Maar ten principale gaat het natuurlijk vaak om praktische uitgangspunten en werkafspraken die op een gegeven moment slechts voor een kleine dominante groep inzichtelijk zijn en die aan verandering onderhevig zullen moeten zijn, willen ze nog kunnen appelleren aan enig 'rechtvaardigheidsgevoel'. ${ }^{6}$ Feiten spelen dus een belangrijke rol in het proces van juridisering. Door de, afhankelijk wan het rechtsgebied, soms strenge selectie van juridisch relevante feiten kunnen vertekeningen in het oorspronkelijke verhaal optreden. De juridische feitenvaststelling is een interpreterende constructie. Feiten bestaan niet zonder verhalen. Gedurende het juridiseringsproces wordt een nieuwe werkelijkheid gecreëerd die veelal aansluit bij het (ook maatschappelijk) dominante beeld. Andere interpretaties van de werkelijkheid kunnen daardoor buitengesloten worden. ${ }^{8} \mathrm{Er}$ wordt gepleit voor een andere, narratieve benadering van het recht. Een benadering die ook binnen juridische vrouwenstudies wordt aangemoedigd. ${ }^{9}$

Verhalen zijn echter per definitie subjectief, verschillend, onlogisch en intern tegenstrijdig. Er zijn andere wetenschappers die via empirisch onderzoek verhalen reflecteren. Als jurist moet je daarop kunnen vertrouwen, maar tegelijkertijd beseffen dat ook die andere deskundigen in hun methoden en onderzoeksprocedures steken laten vallen, dat er blinde vlekken en paradigma's zijn. Voor de rechter is dat vergelijkbaar met het laveren tussen naïef vertrouwen en scepsis ten aanzien van de inbreng van 'deskundigen' in de rechtszaal. ${ }^{10}$ In het besef van valkuilen en tekorten, waag ik het toch een tipje van de sluier op te lichten door vanuit niet-juridische bronnen, impressies te geven uit verhalen van gedetineerde vrouwen. Op die manier kan vanuit een (meerduidig) perspectief in andere hoofdstukken een blik worden geworpen op ontwikkelingen in het straf-, penitentair- en familierecht. Meer en beter invoelbare impressies worden overigens waarschijnlijk gevonden via andere niet-talige inspiratie-

6 Sevenhuijsen (1993-2), zie ook Smart (1991-1).

7 Zie ook "t Hart (1991) p. 53, Cohen (1992) p. 10-11.

8 O.a. Witteveen (1990), Minow (1990).

9 Goldschmidt (1993-2) in aansluiting op onder andere Leijten (1991) en 't Hart (1991).

10 Een stap verder gaat het wanneer (gedrags-)wetenschappers vervolgens hun licht laten schijnen op de juridische onderzoekmethodes in de rechtzaal. Vgl. de discussie die ontstond naar aanleiding van het boek "Dubieuze zaken", de psychologie van het strafrechtelijk bewijs (Crombag, Van Koppen en Wagenaar, 1992).

Hoe moeilijk het ook is inzicht te krijgen in elkaars jargon en werkwijzen, de uitdaging van interdisciplinair samenwerken ligt juist in het samen 'zeven' van de verzamelde kennis. (wgl. Forder en Wolleswinkel (1991) en "Het juridisch vertoog" beeld en werkelijkheid", interfacultair symposium naar aanleiding van de oraties van Goldschmidt, Utrecht, 1993). 
bronnen, maar daarop kunnen helaas geen rechtsregels en juridisch onderzoek worden gebaseerd."

\section{$2.1 \quad$ Locaties}

Als een vrouw gearresteerd wordt, brengt zij meestal enige tijd in een politiecel door Daarna moet zij worden overgebracht naar een huis van bewaring (HvB) ${ }^{12}$ Vrouwen met een korte straf zitten hun straf meestal in het HvB uit. Langergestraften, die na aftrek van het voorarrest meer dan drie maanden daadwerkelijke straftijd overhouden, worden na hun veroordeling in een gevangenis geplaats $t^{13}$. De laatste maanden van de detentie (minimaal drie, maximaal vijf maanden) worden soms doorgebracht in een open inrichting. Hierbij gaat het om gedetineerden die een gevangenisstraf van twaalf maanden of meer hebben gekregen en die tenminste de helft van die tijd in een gesloten inrichting zijn geweest. ${ }^{14}$ Daarnaast bestaat er de halfopen inrichting, waar veroordeelde vrouwen die geen voorlopige hechtenis hebben ondergaan zich op afroep moeten melden. Dat zijn de 'zelfmeldsters'. Ook sommige langgestrafte vrouwen kunnen er het laatste deel van hun gevangenisstraf doorbrengen. $\mathrm{Zij}$ worden "detentiefaseersters" genoemd. Sinds 1989 is er een mogelijkheid tot plaatsing in

11 "Door kunst kan men vaak waarheid ervaren, die men door wetenschap niel kan kennen." (stelling bij het proefschrift wan Loenen 1992).

"Kunst kan inderdaad doen invoelen wat de theorievorming analyseert" ('t Hart (1993) p. 7) en "Het is de kunstenaar die visueel het afschuwelijke en onmenselijke toont van de ontmenselijkte, tot stereotype gereduceerde gedetineerde." ("t Hart (1993) p. 19).

12 Zie over het voorarrest Reijntjes (1994), Er zijn vijf fasen gedurende het voorarrest wo onderscheiden: 1. het ophouden voor verhoor (art. $57 \mathrm{~Sv}$, art. $61 \mathrm{~Sv}$ ).

2. de inwerzekeringstelling (art. $57 \mathrm{~Sv}$ e.v.).

3. de inbewaringstelling (art. $60 \mathrm{~Sv}$ e.v.).

4. de gevangenneming en gevangenhouding (art. $65 \mathrm{~Sv}$ e.v.).

5. de gevangenhouding vanaf het onderzoek ter terechtzitting (art. 66 lid 2 Sv jo. art. 68 Sv). Tijdens de eerste twee fasen verblijft de verdachte op het politiebureau. Het bevel tot bewaring vermeldt de plats waar de voorlopige hechtenis zal worden ondergaan. Dat moet een Huis van Bewaring zijn (art. 78 lid $4 \mathrm{~Sv}$ jo. $133 \mathrm{~Sv}_{\text {; }}$ art. $9 \mathrm{BWG}$ ).

13 Art. 9 lid 2 BWG.

14 Zie voor uitgebreide objectieve criteria de circulaire 'Herziening selectie- en plaatsingsprocedure open inrichtingen', 26-9-1990, nr. 29469, DI 90, Sancties 1990, 81.

Datmaast spelen subjectieve criteria (motivatie, arbeidsgeschiktheid, gevaar voor verslavingsproblcem etc.) een rol. Zie hierower Beelen (1991) p. 13-21, Werkgroep interne en externe differentiatie (1991) p. 13-15, De Jonge en Verpalen (1992) p. 26-28. 
dagdetentie als er nog zes weken straf resten. In 1995 is er un het Noordoosten van het land een experiment met elektronisch huisarrest gestart:"

Tot 1987 zijn er drie plaatsen waar gedetineerde vrouwen verblijven: Groningen, Amsterdam en Maastricht. Hoewel krachtens art. 10 lid 1 Beginselenwet Gevangeniswezen gevangenissen en HvB afzonderlijke gestichten moeten zijn, kan tot die tijd aan dit wettelijk vereiste bij de detentie van vrouwen niet voldaan worden. Vrouwen worden daarmee 'bijzondere gevallen', waarvoor art. 10 lid 2 BWG een uitzondering maakt. Het wettelijk onderscheid tussen de typen inrichtingen is van belang omdat er verschillende beleidsdoelstellingen zijn en er andere regiems heersen. Ook de daarmee in verband staande rechtspositie voor de gedetineerde verschilt. Hierbij vall te denken aan het al dan niet verplicht werken, de bezoekmogelijkheden en de loonregeling. In hoofdstuk vier wordt verder op de rechtspositie ingegaan.

Krachtens art 7 lid 3 BWG kan de Minister afzonderlijke inrichtingen voor vrouwen. aanwijzen, maar kunnen inrichtingen ook voor vrouwen en mannen bestemd worden, mits die dan wel 'te allen tijde' gescheiden worden. Tot 1987 bestaan er geen aparte inrichtingen voor vrouwen; zij maken steeds deel uit van een groter complex, waar ook mannen opgenomen zijn."

$\mathrm{Na} 1987$ komen er door de toename van het aantal gedetineerde vrouwen echter nog drie inrichtingen bij: in Utrecht, Sevenum en Breda. Daarmee is niet alleen de capaciteit, maar ook de variatie in bestemmingen enigszins vergroot. De differentiatie in gevangenissen die voor mannen wettelijk is vastgelegd (titel III BWG) is er dan echter ook nog niet voor vrouwen.

De enorme uitbreiding van cellencapaciteit sinds 1993 betreft ook die voor vrouwen. In 1993 wordt De Singel in Amsterdam voor vrouwen gesloten. De Singel had in totaal vijfenzeventig plaatsen; twintig plaatsen als HvB en vijftig plaatsen als gevangenis. Daarnaast was er een aparte unit van vijf plaatsen als open inrichting in gebruik. Feitelijk bevond dit 'open' gedeelte zich binnen het ommuurde gevangeniscomplex Over-Amstel. De vrouwen uit De Singel verhuizen voor een deel naar Zwolle, waar in een nieuwe inrichting tachtig plaatsen gecreëerd zijn, zonder open deel. De tien plaatsen in Groningen worden opgeheven.

In 1994 worden er nog twee locaties geopend, in Heerhugoward en in Hoorn. In 1996 verhuizen de vrouwen uit Utrecht ook naar Zwolle, in afwachting van nieuwbouw." Alleen de open inrichting voor zes vrouwen blifft in Utrecht bestaan.

15 Tot november 1996 hebben daaraan zes vrouwen deelgenonnen. (Bron: Ministcric van Justitie)

16. Er zitten wel vrouwen in de gemengde t.b.s.inrichting maar die latat ik in dit onderzoek buiten beschouwing. Het betreft ongeveer 33 vrouwen. (Fuldawer, $1995_{\text {, }}$, 78) Op beleidsvoorstellen met betrekking tot (gematigde) gemengde detentie kom ik in een wolgend hoofdstuk terug.

17 De verwachting is dat het hierbij om feitelijke uitbreiding van capaciteit zal gaan. De prognose voor het aantal plaatsen voor wrouwen in 1997 is 500 , in 2000 zal dat oplopen tot 652 . (Bron: Ministerie van Justitie) 


\section{Hoofdstuk 2}

De capaciteit voor vrouwen, ongeveer 460 plaatsen, is nu als volgt verdeeld ${ }^{18}$ :

- Zwolle heeft een capaciteit van ongeveer 120 plaatsen, waarvan 24 bestemd zijn voor langgestraften. De overige plaatsen zijn aangewezen als HvB en gevangenis voor (kortgestrafte) vrouwen. Beide inrichtingen samen heten penitentiaire inrichtingen (p.i) woor vrouwen te Zwolle. ${ }^{19}$ Ze wormen een beheerseenheid met het HvB woor mannen te Zwolle.

- Breda heeft een capaciteit van 110 plaatsen. Die zijn bestemd tot zowel HvB als gevangenis voor kortgestraften. In de praktijk worden de plaatsen door elkaar gebruikt. De inrichting heeft varaf jull 1990 vrouwen opgenomen.

- Heerhugowaard (p.i. Amerswiel) heeft een capaciteit van 79 plaatsen, waarvan 53 zijn bestemd tot $\mathrm{HvB}$ en 26 tot gevangenis.

- Maastricht (p.i. Overmaze) heeft een capaciteit van 37 plaatsen, waarvan er 24 zijn bestemd tot $\mathrm{HvB}$ en 13 tot gevangenis.

- Sevenum (p.i. Ter Peel) heeft een capaciteit van 58 gevangenisplaatsen, waarvan er 42 bestemd zijn voor zelfmeldsters. Zelfmeldsters zijn veroordeelde vrouwen die geen voorlopige hechtenis hebben ondergaan en die zich op een bepaald moment, daartoe opgeroepen, moeten melden. ${ }^{20}$ De inrichting kent een halfopen regiem, waardoor ook sommige langgestrafte gedetineerde vrouwen het laatste gedeelte van de strafperiode in Ter Peel doorbrengen. De resterende strafperiode mag maximaal een jaar zijn. Er is geen minimumperiode, dus eventueel kunnen ook kortgestrafte vrouwen geplaatst worden. De vrouwen zijn (vrijwel) allemaal van Nederlandse afkomst of hebben de Nederlandse nationaliteit, waardoor zij eenmaal per vier weken met weekendverlof kunnen gaan.

Sinds april 1993 is er een moeder met kind unit (m.m.k. unit). ${ }^{2}$ Er is eerst een experimentele periode van twee jaar geweest. In de m.m.k. unit kunnen vier moeders met vier kinderen verblijven. Ook deze m.m.k. unit komt in een volgend hoofdstuk uitgebreider aan de orde.

- Utrecht (p.o.i. Het Spoor) heeft een apart huis, de vroegere directiewoning, als penitentiaire open inrichting met zes plaatsen in gebruik. Voor plaatsing komen geschikt geachte vrouwen in aanmerking, die een onvoorwardelijke straf hebben gekregen van twaalf maanden of meer en die nadat de helft van de totale detentietijd is verstreken, nog een strafrestant van drie tot wijf maanden hebben.

- Hoorn (Het Keern, gemengd regiem, p.o.i. en dagdetentie) heeft een capaciteit voor vrouwen van vijf plaatsen. Het betreft hier de combinatie van een open inrichting met dagdetentie.

18 Differentiatieschema penitentiaire inrichtingen (1996).

19 Circulaire van 6 oktober $1993,3948822 / 93 / \mathrm{DJ}$.

20 Het "lopende vonnis" van zelfmelders is, door de capaciteitsproblemen, feitelijk niet meer aan een bepaalde strafduur gebonden. Zie Werkgroep interne en externe differentiatie (1991) p. 10-11.

21. Experiment moeders met kinderen in Ter Peel (1995), Wolleswinkel (1995) p. 124-128, Bisschop (1996). 
- Rotterdam, Arnhem, Middelburg, Groningen, Breda Dagdetentie

Op 1 mel 1989 is er op het terrein van het oude HvB De Noordsingel in Rotterdam een experiment met de een mogelijkheid tot dagdetentie gestart. Inmiddels is deze detentievorm op diverse plaatsen ingevoerd. Gedetineerden die veroordeeld zijn tot een onvoorwaardelijke vrijheidsstraf van acht maanden of meer kunnen hier de laatste fase van hun detentie doorbrengen. Op werkdagen gaan gedetineerden van hun thuisadres naar de inrichting, waar zij een intensief programma volgen ter voorbereiding op en verbetering van hun maatschappelijk functioneren.'s Avonds, 's nachts en in de weekeinden zijn zij thuis. De reisduur mag niet langer één uur met het openbaar vervoer zijn. Het programma duurt zes weken. Het betreft een vorm van gemengde detentie, maar de plaatsen worden flexibel ingezet, zodat niet duidelijk is hoeveel vrouwen daadwerkelijk deelnemen. In de inrichtingen in Breda en Zwolle verblijven ook illegale vrouwen in vreemdelingenbewaring. ${ }^{22}$ Het gaat on negen plaatsen in totaal. Mede op aandringen van de Immigratie- en Naturalisatie Dienst (IND) wordt er in de nabije toekomst een aparte voorziening voor deze vrouwen gecreëerd. De vrouwen worden immers niet in bewaring gehouden omdat zij verdacht worden van een strafbaar feit. Bovendien. blijkt juist in hun geval de directe zorgafhankelijkheid van kinderen tot grote problemen te leiden. De bedoeling is dan ook dat de vrouwen hun kinderen in de nieuwe voorziening mee mogen nemen. ${ }^{23}$

Alle inrichtingen hebben vrijwel continu een volle bezetting. ${ }^{24}$ In Sevenum verloopt dat tijdens de week, omdat de meeste zelfmeldsters op maandag aankomen.

Hoewel er nu dus een open afdeling in Utrecht, een halfopen gevangenis in Sevenum en een klein open deel bij de inrichting in Hoorn zijn, is er nog steeds in beperkte mate sprake van differentiatie in de voorzieningen voor vrouwelijke gedetineerden in vergelijking tot die voor mannen. ${ }^{25}$ Dit is te verklaren vanuit het relatief gezien nog altijd geringe aantal vrouwelijke gedetineerden. Met name voor langgestrafte vrouwen kan dit extra problemen opleveren, doordat zij afhankelijk worden van een beperkt aantal personen en voortdurend in eenzelfde klimaat verkeren. De mogelijkheid de routine (relatief) te doorbreken door eens te wisselen van inrichting is beperkter dan bij mannen. Ook een psychiatrische opvang, zoals de FOBA-toren in Amsterdam voor mannen, is er niet voor vrouwen. ${ }^{26}$

22 Art. 26 lid 1 Vreemdelingenwet.

23 Bron: Ministerie van Justitie.

24 Planning en control Beleidsinformatie DJ1 (1996).

$25 \mathrm{Vgll}$ de artt. $16 \mathrm{l} / \mathrm{m} 20$ Beginsellenwet Gevangeniswezen.

26 Spronken en Wolleswinkel (1987), Brouwers en Sampiemon (1988), Vegter (1989), Franke (1990), Rapport Werkgroep Vrowwen in detentie (1991). Zie ook CPT 93/15, p. 44 en 61. 
Wel zijn er sinds 1994 een individuele begeleidingsafdeling (IBA) en een drugsvrije afdeling (DVA) in de vrouwengevangenis "Amerswiel" in Heerhugowaard."

In $1982 \mathrm{kwam}$ in Amsterdam als particulier initiatief het Tussenfasehuis voor exgedetineerde vrouwen tot stand. Het biedt vrouwen die een vrijheidsstraf hebben ondergaan een basis van waaruit zij een nieuw leven kunnen opbouwen. Soms kunnen zij ilmmers niet terug naar hun oude situatie omdat ze niet meer welkom zijn. Soms willen ze niet terug, omdat daar oude ellende en nieuwe uitzichtloosheïd wacht. In de loop van tien jaar waren er weehonderd vrouwen in het Tussenfasehuis geweest. Ze verbllijven er gemiddeld een half jaar. Er zijn in het huis zeven plaatsen. Een kamer is bestemd voor vrouwen die met weekendverlof mogen, maar geen vast adres hebben. De behoefte aan deze voorzlening lijkt groot te zijn. In 1995 werden 27 vrouwen afgewezen. Het huis draait wooral op twee betaalde beleidsmedewerkers en twee vrijwilligers. Het wordt niet structureel van uit het Ministerie van Justitie gesubsidieerd.

\subsection{Impressies van gedetineerden}

Het valt niet mee om in Nederland achter de verhalen van de gedetineerde vrouwen zelf te komen. Er zijn een paar autobiografische geschriften, interviews door journalisten en een aantal inventarisatiestudies. Van die laatste kun je je afvragen of ze methodologisch zo goed in elkaar zitten dat ze de toets van "betrouwbaar empirisch onderzoek' kunnen doorstaan. Nienhuis stelt vast dat het onderzoek van Ketelaars absoluut geen geschikte steekproef is gezien het aantall geinterviewde vrouwen. ${ }^{30}$ Zelf merkt Ketelaars in haar verantwoording overigens ook op dat de tijd en de gelegenheid er niet waren om een representatief onderzoek te doen." Zwering bekritiseert het WODC-onderzoek van Brouwers en Sampiemon met name op het punt van de vraagstelling en de interpretatie van de antwoorden. Verrijn Stuart conformeert zich geheel aan deze kritiek. ${ }^{32}$ Het onderzoek van Zwering zelf is een weerga-

27 Zie Nota Werkzame detentie (1993) p. 25. Circulaire 21 juni 1994, nr. 435839/94 DJ - 1, in: Sanctics $1994 / 5$, nr. 26. Beide afdelingen bieden plaats aan 13 nouwen. De DVA in Zwolle is formeel wel toegewezen, maar in de praktijk (nog) niet gerealiseerd.

28 Justitiekrant, 12 april 1996.

29 Boumans en Kayzer (1979), Solidariteitsgroep Vrouwelijke Gievangenen (1979, 1983), Brouwers en Sampiemon (1988), Zwering (1988), Beelen (1991), Ketclaars (1991), Janssen (1994), Fuldauer (1995).

30 Nienhuils (1992) p. 12.

31 Ketelaars (1991) p. 2-4. Ketelaars sprak van 27 van de 328 vrouwen.

32 Brouwers en Sampiemon (1988), Zwering (1989), p. 53-54, Vetrijn Stuart (1992-2) p. 3, Verrijn Stuart $(1992-3)$ p. $170-171$. 
ve van eigen indrukken, maar geeft geen representatief beeld van welke ondervraagde groep dan ook. ${ }^{33}$ Zelf spreekt ze in dit verband ook over "het kleine aantal ondervraagden en de onevenwichtige samenstelling van de groep". ${ }^{34}$ Het lastige bij de weergave van haar gegevens is dat het voortdurend onduidelijk is of het interpretaties van haarzelf zijn, van de gehele groep ondervraagden of van een deel daarvan, zoals van de (vijf!) ex-gedetineerden. Zwering doet bijvoorbeeld normerende uitspraken over de partnerrelaties van gedetineerde vrouwen:

"Deze vrouwen hebben vaak relaties met mannen die grotendeels gebaseerd zijn op uiterlijke, dat wil zeggen seksuele aantrekkingskracht. Intellektueel hebben partijen elkaar niet zoveel te bieden, de binding wordt door de vrouwen gestalte gegeven door seksualiteit als machtsmiddel te hanteren, bij voorbeeld door de rol van het superwrouwtjesdier, de stoeipoes, aan te nemen tijdens het bezoek wan de partner. (...) In hun verlangen naar symbiotische relaties zijn ze watbaar voor misbruik en moeten in de gevangenis met verbittering konstateren dat ze 'erin geluisd' zijn en dat de grote jongens buiten schot zijn gebleven". ${ }^{\text {. }}$

Het is nogal essentieel te weten of hier de onderzoekster aan het woord is, de hulpverleners of de ex-gedetineerde vrouwen, of dat dit een algemeen gedeeld beeld is. Zo staat het werkstuk vol interpretaties, die weliswaar op het eerste oog aannemelijk klinken, maar die nauwelijks onderbouwd worden "waardoor uit het onderzoek geen algemene uitspraken kunnen worden afgeleid. In die zin biedt haar onderzoek niet veel meer aanknopingspunten dan journalistieke artikelen, zij het dat daar de bronvermelding over het algemeen duidelijk is. De kritjek van Zwering op het nietdoorvragen en de interpretatiemethode van Brouwers en Sampiemon lijkt vooral moralistisch bepaald en niet methodologisch onderbouwd. De waarde van het WODConderzoek is mijns inziens dat het onder de gehele populatie van gedetineerde vrouwen is gehouden, dat de verslaglegging controleerbaar is en kwalitatief in die zin dat veel gebruik wordt gemaakt van representatieve citaten. Dit laatste geldt zeker ook voor het rapport van Ketelaars. Interessant is dat de WODC-onderzoeksters eerst met personeel vanuit diverse disciplines in de inrichtingen hebben gepraat en vervolgens de vrouwen hebben benaderd (een van de kritiekpunten) terwijl Ketelaars de suggestie wekt eerst de behoeftes bij de vrouwen te hebben gepeild en vervolgens of los hiervan met de hoofden van de Bureaus Sociale Dienstverlening is gaan praten. Mijns inziens levert dit verschil in volgorde geen significante verschillen op tussen de resultaten van beide onderzoeken.

Janssen heeft voor een geheel nieuwe vorm gekozen: de participerende observatie, hetgeen een nieuw en gedifferentieerd inzicht in de positie van de groep Latijns-Ame- 


\section{Hoofdstuk 2}

rikaanse vrouwen heeft opgeleverd. ${ }^{36}$ Deze specifieke groep komt in mijn onderzoek verder slechts zijdelings aan de orde. De buitenlandse vrouwen blijken sowieso moeilijk in kaart te brengen te zijn. De stroom Latijns-Amerikaanse vrouwen, veelal drugskoeriers die de aandacht van de echte grote transporten moesten afleiden, is afgenomen. De laatste jaren lijkt het aantal uit Afrika afkomstige vrouwen toe te nemen.Illegale vrouwen lijken weinig in het criminele circuit terecht te komen. ${ }^{37}$ Lissenberg noemt als één van de redenen dat er meer essayistische dan empirische onderzoekspublicaties zijn over criminele en gedetineerde vrouwen dat

"de verstrengeling van actiebereidheid en wetenschapsbeoffening het innemen van standpunten en het uitoefenen van kritiek meer stimuleert dan het werrichten van veelal tijdrovend onderzoek" ${ }^{38}$

Toch komen de 'hot items' uit de betreffende onderzoeken en interviews zo duidelijk en consistent naar voren dat er naar mijn mening wel een impressie van de gevangeniscultuur geboden wordt, ook al zijn de diverse interviews op verschillende momenten en locaties gehouden. Om de verhalen dichterbij te brengen wil ik enige citaten aan de reeds genoemde bronnen ontlenen en die onderbrengen bij de volgende thema's:

1. onderlinge verhoudingen:
a. drugs
b. buitenlandse vrouwen
c. psychische belasting

2. relatie tot het personeel:

a. mannelijk en vrouwelijke bewaarders

3. dagbesteding

4. contact met relaties 'buiten':
a. kinderen,
b. familie/sociale relaties
c. partners
d. mannelijke gedetineerden

5. seksualiteit/intimiteit

36 Janssen (1994), Aan de participerende observatie kleven weer andere methodologische bezwaren, zoals de onvermijabare beïnloeding van het autonome proces, maar daar ga ik nu verder niet op in. Zie ook Bos (1996).

37 In maart 1995 ging het om 13 vrouwen. Zie Fuldauer (1995), p. 105.

38 Lissenberg (1995-1) p. 9. 


\section{2 .1 Onderlinge verhoudingen}

In vrouweninrichtingen komt weinig openlijke onderlinge agressie voor. Men probeert zo goed mogelijk met anderen op te schieten en men helpt elkaar in praktische zaken. Er bestaat echter geen grote onderlinge solidariteit. Vaak gaan de vrouwen maar met é̂́n of enkele medegedetineerden intensief om. Een argument om niet met anderen op te trekken is "dat het heel andere types zijn dan zijzelf" ${ }^{x p}$ De gedetineerden zijn enigszins op hun hoede voor elkaar. Er is veel onderlinge jaloezie en er wordt veel geroddeld. ${ }^{\text {a }}$ Onderlinge conflicten komen door jennen en treiteren tot uiting. Zwering constateert dat er enerzijds vetes, pesterijen en wantrouwen bestaan en anderzijds innige vriendschappen en liefdesrelaties. ${ }^{43}$

"Cindy: Met vrouwen tja het moet maar. Er zit niks anders op. Ik had natuurlijk liever dat mijn vriend bij me was, dan dat ik de hele dag naast haar zit. Maar dat kan niet. Toch zou ik niet weten wat ik aan deze straf heb, iets goeds dan. Zodra ik buiten ben, pak ik toch gelijk m'n base-pijp weer".

"Fleur: We zitten hier met heel veel ongeschoolde wrouwen en die ontstijgen vaak hun eigen frustraties niet. Dan krijg je dat gemekker dat gezeik en gelul over elkaar. Als je daaraan niet mee wilt doen, ben jij de arrogante freule, de vreemde eend in de bijt".

"Jacky: Dat heeft niets met ongeschooldheid te maken, Fleur. Dat ben ik ook. Toevallig ben ik lesbisch, maar ik kan helemaal niet met vrouwen opschieten. Buiten leef ik in een mannenwereld. Afgezien dat het voor mij bepaalde voordelen heeft om hier te zitten, blijven vrouwen gewoon trutten. $\mathbf{Z}$ z zijn druk met niks. Die eeuwige lippenstift en mascara, altijd buikpijn, altijd hoofdpijn, altijd ongesteld, altijd een ander de schuld geven van iets....".

"Fleur: ....en zij mag het wel en ik niek....."

"Ollivia: ....en altijd jaloers op elkaar. Ik heb liever dat een wrouw me op m'n bek slat, dan vechten we het uit. Morgen zijn we weer grote vriendinnen. Alles liever dan dat gelul achter iemands rug, dat gelieg. En zo zijn vrouwen". ${ }^{42}$

Met vrouwen die zich agressief gedragen, gaan de medegedetineerden niet graag om. Sommige vrouwen zijn bang voor hun medegedetineerden, ook omdat ze hun deur van binnenuit niet op slot kunnen doen."

Soms speelt ook de aard van het gepleegde delict een rol in de onderlinge verhoudingen. ${ }^{4}$

"Onderling hadden we vaak ruzie. Dat "us logisch denk ik, ondat je er nou eenmaal niet woor gekozen hebt bij elkaar te zitten. En natuwrijk heb je er altijd een mikpunt bij, iemand dic or om wat woor reden dan ook uitspringt, die ga je treiteren, daar reageer je op af. Vrouwen die hun kind bijvoorbeeld

39 Brouwers en Sampiemon (1988) p. 27.

40 Brouwers en Sampiemon (1988) p. 2-3.

41 Zwering (1988) p. 21.

42 Fuldauer (1995) p. 89.

43 Ketelaars (1991) p. 31.

44 Brouwers en Sampiemon (1988) p. 27. 


\section{Hoofdstuk 2}

tets hebben aangedaan, worden gesard en gepest. Je kunt beter gestolen hebben, of tot aan je nek in de drugshandel hebben gezeten, dan zoiets te hebben gedaan. Dan word je namelijk door de andere krouwen met de nek aangekeken. Vrouwen horen lief en aardig te zijn voor hun man en kinderen. Dat geldl nu eenmaal binnen en buiten de gevangenis. Een geweldsdelict door een vrouw gepleegd, dat past niet in dat beeld."

\section{a. Drugs.}

Ongeveer eenderde van de gedetineerdenbevolking gebruikt drugs. Dat wordt door de overige gedetineerden maar matig gewaardeerd. Men vindt dat drugsgebruikers te veel aandacht opeisen. Ze klitten en hebben de neiging alleen met elkaar om te gaan. Ze lijken niet zoveel rekening te houden met mede-gedetineerden en roepen ergernis op door alleen maar over drugs te praten, keiharde muziek te draaien en dergelijke. ${ }^{46}$ Ook het regiem wordt strenger door de aanwezigheid wan drugsgebruikers. Als gevolg daarvan wordt iedereen onderworpen aan strenge controlemaatregelen ter voorkoming van invoer en gebruik in de inrichting. ${ }^{47}$ Met name de uitgebreide fouillering wordt als vernederend ervaren.

"Het laatste waar ik nog wat over wil zcggen is de mensonterende fouillering die je je seksegenoten oplegt. Alsof het allemaal nog niet erg genoeg is, moeten we ons ook nog op bevel tot op ons blootje witkleden. Helemaal siks is meer van onszilf, nict alleen bepaten jullie ons dagritme, nict alleen kontroleren jullie onze cmoties en gedachtem, 7 elfs ons lichatam, tot on $\%$ kut, ontcigenen jullic ons!nts

Toch komen er drugs de inrichting binnen. Sommige vrouwen gaan voor het eerst gebruiken in detentie.

"In de bajes ga je sowieso eerder gebruiken dan daarbuiten", zegt Anneke. "Hasj of weed had ik nog nooit gerookt. Maar daar doe je mee. Met elkaar in een cel zitten. Stickem roken. De spanning dat je iets had dat niet mocht; het doorbrak de slcur. In de gevangenis kun je, bij wijye van spreken, krijgen wat je wilt. Ook heroine, dat heb ik de liatste weck van mijn straftijd gebruikt. Dic laatste weck duurt to eindeloos lang, langer dan al die jaren daarvour. Je bent dan cnorm kwetsbatar, als dic tijd maar draaglijk wordt, daar doe je alles voor. Als heroinc je daarbij kan helpen, probeer je dat. Als je tnatar van de wereld bent. Ik hoefde dát spul niet eens te kopen, een van de gedetincerde vrouwen gaf het me gewoon. Anderen moesten ervoor betalen. Zc hoopten er weer cen klant bij te hebben, dat begreep ik achteraf pass. Toen ik voelde dat ik erom wilde gaan vragen, realiseerde ik me pas dat ik de verkeerde kant opging. Zou ik op het eind van mijn straf nog even werschut gaan! En dat terwijl ik nog iets met

45 Nijman (1983) p. 12.

46 Zwering (1988) p. 22

47 Brouwers en Sampiemon (1988) p. 3.

48 Uit: Afscheidsbrief aan de toenmalige dircetrice, Solidariteitsgroep Vrouwdijke gevangenen, (1983) p. 110 . 
mijn leven wilde, nog niet helemaal stuk was gegaan. Ik beb mezelf toen gedwongen in mijn cel te blijven en dat is gelukkig gelukt.

Drugsverslaafden oefenen soms veel druk uit op anderen. Medegedetineerden zeggen dat ze alleen bezig zijn met drugs en men vindt ze niet te vertrouwen. De in 1994 gestarte drugsvrije afdeling lijkt in een behoefte te voorzien:

"Linda: Op de DVA zijn wij verplicht aan alle activiteiten mee te doen. We moeten sporten, meedoen aan de CREA, de arbeid en gespreksgroepen. Ik heb daarvoor gekozen. Je doet het voor jezelf en je wordt er alleen maar beter van. De introductiegroep mag absoluut geen contact met andere afdelingen hebben. Want als ze op die afdelingen drugs willen hebben, laten ze bezoek komen en heb je zo drugs binnen. Dat is een kat en muis spel tussen het personeel en de gedetineerden. Als je wint, zit je te gebruiken op je kamer. Verlies je, dan ben je de lul en moet je een paar dagen op cel."

"Mariska: Er zijn drie fasen op de DVA. Tijdens de introductie-fase mag je niks. In lase twee mag je aangeven wat je zelf wilt en mag je wel met andere afdelingen praten en luchten. Maar op een discoavond moet ik helt contact afbreken met wrouwen van andere afdelingen en uitleggen waarom ik niet met ze kan praten. Want als er iets gebeurt, dan mogen alle dertien wrouwen van mijn afdeling niet meer naar de disco-avond. Je tekent voor je gedrag. In het begin dacht ik : 'Wat een flauwekul, die gespreksgroepen. Het lijkt het Pieter Baan Centrum wel:' Maar het werkt goed."

"Linda: Het werkt prima. Ik zit mu in fase drie en volg een studie MBO Activiteitenbegeleiding. Ik. leer de basis van creativiteit. In plaats van arbeid help ik de wrouwen op de CREA. Daar leer ik anderen stimuleren. Die DVA kost veel geld, want we hebben veel extra begeleiding en drie urinecontroles per week, maar volgens mij is dit een straff die helpt. Mij tenminste well."

"Mariska: Mij ook. Ik zit er nu anderhalve maand en ik heb er heel veel aan. Dit is echt de eerste keer dat ik iets aan mijn detentie heb. Buiten wil ik nu proberen clean te blijven. In bepaalde steden bestaan Escape-programma's, dan word je begeleid bij het zoeken naar een woning werk en leer je met geld omgaan. Daar ben ik nu bij ingedeeld. Het lastige is alleen dat het trefpunt het Consultatiebureau voor Alcohol en Drugs is. Daar kom je dus direct weer de gebruikers uit dat sceentje tegen. Dat kan moeilijk worden. Want als ik straks buiten ben, heb ik behalve die scene waar ik juist van moet wegblijven, niemand. ${ }^{\text {"st }}$

\section{b. Buitenlandse vrouwen.}

Ook het verschil in nationaliteit kan een gevoel van distantie oproepen tussen de vrouwen onderling. "Ze hebben een andere mentaliteit". ${ }^{52}$ Taalverschillen lijken daarbij meer bepalend te zijn dan de etnische achtergrond. ${ }^{53}$ De vrouwen vinden hun culturele achtergrond wel belangrijk. Daaraan hechten ze ook. Brouwers en Sampiemon constateren dat er op basis van spreektaal en culturele achtergrond

49 In: Nijman (1983) p. 12.

50 Brouwers en Sampiemon (1988) p. 27.

51. In: Fuldauer (1995) p. 112-113.

52 In: Brouwers en Sampiemon (1988) p. 27.

53 Ketelaars (1988), p. 27 Janssen (1994) p. 120. 
gescheiden groepen gedetineerden ontstaan. Sommige vrouwen kunnen daardoor geïsoleerd raken. ${ }^{\text {s* }}$ Door de taalbarrière kunnen zij niet altijd terecht bij functionarissen en daardoor worden zij soms belemmerd in hun activiteiten. Ook hun contacten met de buitenwereld zijn beperkter dan die van Nederlands of Engels sprekende wrouwen. Toch is er geen overheersend verlangen om de detentie in eigen land voort te zetten, als dat al zou kunnen. Soms willen ze dat niet uit schaamtegevoel, vaker is het hoge voorzieningenniveau en een betere bejegening van de gedetineerden in Nederland in vergelijking tot hun eigen land doorslaggevend. Veel buitenlandse gedetineerden sparen hier ook voor thuis.

Vooral de Latijns-Amerikaanse vrouwen hebben de neiging zich, door hun gebrekkige beheersing van het Nederlands, terug te trekken in de eigen groep. Dat geldt met name voor de oudere vrouwen.

"Nu de groep Latijnsamerikaanse gedetineerden niet meer zo groot is als enkele jaren geleden, hebben de overige gedetineerden daar verder geen problemen mee. Wel wordt de Latijns-Amerikanen nogal eens een arrogante opstelling verweten. Dit is niet geheel onterecht. Een aantal van hen heeft sterk de neiging zich als goede christenen te profileren. Dat wil zeggen dat zij zich openlijk distantiëren van de druggebruikers, verslaafden en homosekswelen. ${ }^{.55}$

Janssen heeft met name de verhoudingen tussen de verschillende Latijns-Amerikaanse groeperingen in kaart gebracht: ${ }^{.56}$

"De andere Latijins-Amerikanen voelden zich vaak weggedrukt door de Colombiaanse meerderheid. Ook beïnvloedden nationalistische sentimenten bij de andere vrouwen de sfeer in de groep. Tijdens de veldwerkperiode zat er slechts eén Boliviaanse. Zij had het duistere vermoeden dat haar Colombiaanse zusters Boliwia als een soort kolonie zagen; een Nicaraguaanse en een Guatemalteekse wilden niet tot de Zuid-Amerikanen worden gerekend. Zij waren immers Centraal-Amerikanen en dat is heel wat anders; een Argentijnse voelde zich meer verwant met het Europese culturele erfgoed dan de andere Latijns-Amerikanen in de Singel."

\section{c. Psychische belasting}

Individueel ziet een aantal vrouwen heel goed hoe ze in de gevangenis zijn terechtgekomen. ${ }^{57} \mathrm{Zij}$ zijn zich bewust van hun achtergronden en vani de rol die het gezin waar zij uitkomen eventueel heeft gespeeld. $Z$ ij zijn bezig te analyseren in.welk milieu 
ze terecht zijn gekomen, welke rol relaties daarin hebben en hoe ver hun eigen verantwoordelijkheid reikt.ss

"Ik ben gescheiden en moet in mijin eentje voor mijn vijf kinderen en mijn moeder zorgen. Mijn moeder is ziek, mijn dochter is zwanger. De jongste kinderen gaan nog naar school en de oudstie van begin twintig verdient niet genoeg om ons te helpen. Van de vaders van mijn kinderen heb ik ook geen steun. Ik zag gewoon geen uitweg meer. Op een gegeven moment werd mij door een kennis aangeboden een koffer naar Nederland te brengen. Ik wist waar ik mee bezig was, maar ik had geen andere mogelijkheden om rond te kunnen komen."

Voor sommigen heeft de detentie een katalyserende werking. Zij willen een nieuwe start maken, breken met het verleden. ${ }^{\infty}$

"Criminaliteit bekijk ik helemaal niet als iets heel negatiefs. Het is voor veel mensen, ook voor mij, een keerpunt in hun leven." ${ }^{\text {oll }}$

Bij anderen gaat het delict "spoken".

"Elisabeth is een alleenstaande moeder van twee jonge kinderen. Samen mel haar vriendin doodde ze diens man. "Mijn vriendin kwam elke dag bij me. Ze werd mishandeld. Als ze weg was zat ik vaak te janken: die brandplekken op haar lichaam, die blauwe plekken. Ik kon het gewoon niet aanzien. Op een dag zei ze: 'Ik wil hem van kant maken.' 'Doe normaal joh,' zei ik. Ze kwam er steeds op terug en op een gegeven moment, ik weet niet, - het is nu net alsof ik een film heb zitten kijken-, op een gegeven moment besloot ik te helpen." Later stond in de krant:"Bijna pleegden E. en F. de perfecte moord." Elisabeth: "Daar werd ik zo misselijk van. Alsof het daarom gaal."

Elisabeth werd vroeger mishandeld door haar ex-man. Volgens de psychiater is dit de reden waardoor zij zich zo in kon leven in de plannen van haar vriendin. Elisabeth kreeg een gevangenisstraf van vijf jaar. Haar vriendin zit in een andere gevangenis.

"Elisabeth: Ik had dit nooit van mezelf verwacht. Soms hoop ik dat het allemaal een nare droom is geweest en dat iemand me wakker knijpt. Ik kan het nog steeds niet geloven. Dat ik hier zit. Vroeger keek ik er "zo anders tegenaan. Zei ik altijd: mensen die dat soort dingen doen, moesten ze ophangen."' "Jacqueline: Op mijn vierde heb ik een auto-ongeluk gehad. Dat weet ik nog steeds. Dit, wat ik gedlaan heb, zal ook altijd bij me blijven. Ik zal dit nooit kunnen vergeten. Nooil kan dit meer uitgewist worden. Heel mijn leven zal ik het bij me dragen: ik ben een moordenares."

"Elisabeth: Ik wil dat stempel niet. Alleen dat woord al: moordenares. Daar kan ik niet Iegen, ik ben geen moordenares. Ik kan het niet accepteren. Het is iets dat zo ver van me af staat. Ik wil geen moordenares zijn."

"Jacqueline: In het begin ging het nog wel. Kon het me ook niks schelen. Ik deed heel stoer: "Ik heb mijn man wermoord, ja, maar het was toch een klootzak."

58 Zie ook Fuldauer (1995) p. 82-87.

59 In: Janssen (1994) p. 63.

60 Dit lijkt met name op te gaan voor de drugsverslaafde vrouwen, zie Fuldauer (1995), p. 103-114.

61 In: Nijman (1983) p. 9. 
"Elisabeth: Ik heb er nooit stoer over gedaan. Ik moest alleen de hele thjd lachen. Als de moord ter sprake kwaim, gierde ik het uit. Pure zenuwen."

"Jacqueline: Ik krijg nu therapie, daar word je van binnenuit afgebroken."

"Elisabeth: Ik kwel mezelf, zegr mijn psychiater. Ik denk steeds: wrat zou hij gevoeld hebben.",

"Jacqueline: Na een tijdje ga je denken: hij had toch ook goede dingen."

"Elisabeth: Vooral als ik films zie. Laatst werd er iemand vermoord op TV. Ik ben naar de w.c. gelopen en heb gekotst. Ik zie ook geesten."

"Jacqueline: Heb jij dat ook?"

"Elisabeth: 's Nachts, als ik in mijn cel lig, hoor ik soms van heel dichibij iemand ademhalen. Dan denk ik dat het de man van mijn vriendin is. Die ademhaling hoor ik steeds, "s nachts. Ik stop dan mijn hoofd onder mijn kussen. En laatst was er een vogel, die tikte tegen mijn celraam. Ik werd gek van angst. Ik dlacht" hij is teruggekomen in een vogel."

"Jacqueline: Eigenlijik ben ik nu wel in geesten gaian gelloven:"

"Elisabeth: Het is zo eng. Ik heb hel gedaan. Ik heb me laten meewoeren, ik ben bang van mezelf. Als ik straks wweer buiten ben en er gebeurt iets: wat doe ik dan? Je schrikt zo ongeloolijk van jezelf. Soms, de laatste tijd steeds waker, zit ik op mijn cel en zie daar mijn broodmes op tafel liggen. Dan kijk ik er naar en denk: het is zo gemakkelijk, dan ben ik wan alles af. Tot nu toe heb ik me steeds kumnen beheersen. Maar het gevoel is sterk. En ik ben bang dat er een dag komt, dat het gevoel sterker wordt dan ilk zelf. Daar ben ik bang woor.

Gedetineerden die psychisch in de war zijn, vormen een belasting voor hun omgeving. Inmiddels is er in Heerhugowaard een Individuele Begeleidings Afdeling, waar vrouwen intensiever begeleid worden. Naar de onderlinge verhoudingen daar is nog geen onderzoek gedaan. Wel zijn er enkele dagboekfragmenten beschikbaar. ${ }^{* 4}$ Illustratief lijkt het hele lage frustratieniveau waar het om geluiden, geuren en gedragingen van medegedetineerden en personeelsleden gaat. Het 'luchten' neemt niet voor niks een belangrijke plaats in de dagbesteding in.

Over de atmosfeer wordt sowieso veel geklaagd. ${ }^{65}$ Vooral de luchtplaatsen vindt men klein en benauwd. Ze zijn niet berekend op verschillende weersomstandigheden, er zijn geen bomen en er is nauwelijks groen. Ook wordt er geklaagd over de hygiëne. Het moeten slapen op matrassen, waar ook anderen op gelegen hebben; de strikte regels rond het douchen, terwijl je als je ongesteld bent of last van opvliegers hebt well eens vaker zou willen.

Veel vrouwen kunnen ook maar moeilijk wennen aan het eten.

"We krijgen vier keer per week gehakt. En die ene keer dat we een kippepoot kregen was deze niet eens gaar. Er zit heel weinig variatie in het eten. Bovendien is het valk zo gaar gekookt dat alle vitami-

63 Brouwers en Sampiemon (1988) p. 3.

64 In: Nemesis-essays -2 (1995) p. 95-100.

65 Zie vooral Sollidariteitsgroep Vrouwelijke Gevangenen (1979, 1983) en Ketelaars (1991) p. 30-31. 
nen zijn werdwenen." en "Het eten is $z 0$ anders dan het eten dat ik in mijn thuisiand krijg. Ik kan bijna niet wennen an het Nederlandse eten. Het is zo droog. ${ }^{\text {wo }}$

Volgens Zwering zijn veel problemen die met de detentie samenthangen, terug te brengen tot schuldgevoelens, angst om gek te worden en angst voor de eigen seksualiteitsbeleving, vooral de onzekerheid over het echte of vermeende lesbianisme bij zichzelf. ${ }^{\circ}$

De vrouwen hebben veel medische klachten en het medicijngebruik is hoog.

"Mijn lichaam is gevangen, maar niet mijn geest. In mijn hoofd ben ik altijd vrij geweest. Helaas, hebben ze me er uiteindelijk toch onder gekregen. Ik slik nu betablokkers, ondat ik wreselijk last van mijn hart lkreeg.

Door de Solidariteitsgroep Vrouwelijke Gevangenen zijn de veel voorkomende klachten geïnventariseerd en in verband gebracht met de slechte zuurstofvoorziening en de sllechte (vitamine-arme) voeding: ${ }^{* 3}$

- geirriteerde ogen;

- ontstoken ogen;

- slecht zien 's machts;

- oorsuizingen;

- duizeligheid;

- uitvallend haar;

- droge schilferige huid;

- slecht genezende wondjes;

- opgezette klieren;

- hoesten en bronchitis;

- slapeloosheid.

Vooral de Latijns-Amerikaanse gedetineerden hebben veel klachten over de medische dienst. $\mathrm{Zij}$ voelen zich vaak niet serieus genomen.

"Als ik met een klacht ga, dan zeggen ze altijd dat het zenuwen zijn, maar ik ben echt ziek!" en "Als je jonger dan veertig bent dan zeggen ze dat het waarschijnlijk menstruatiepijnen zijn en als je ouder dan veertig bent dan zall je wel in de overgang zijn; ze zeggen altijd thetzelfde en luisteren niet eens naar je! $!^{\text {m7t }}$

66 In: Ketelaars (1991) p. 30.

67 Zwering (1988) p. 41.

68 In: Fuldauer (1995) p. 90.

69 Solidariteitsgroep Vrouwelijke Gewangenen (1983) p. 42.

70 In: Janssen (1994) p. 90. 


\section{Hoofdstuk 2}

De vrouwen zijn in hun eigen land niet gewend om eerst een huisarts te bezoeken. Zij zouden liever direct contact opnemen met een specialist. Bovendien moeten zij wennen aan de meer informele relatie tussen arts en patiënt in Nederland. Dat komt op hen niet professioneel over. Dezelfde klacht bestaat over het maatschappelijk werk en de psychologische hulpverlening. ${ }^{7}$

Over de begeleiding van de medische dienst tijdens zwangerschap wordt positief gesproken. Vaak komt de dokter dan nog dezelfde dag als de gedetineerde hem nodig heeft. ${ }^{2}$

\subsubsection{Rellatie tot het personeel}

Vrouwen hebben het gevoel zich als modelgevangene te moeten gedragen, omdat ze afhankelijk zijn van het personeel. ${ }^{\text {"* }}$

"Met die machitspositic heb ik ook de meeste mocite. Als een personcelslid cen fout maakt, zal hij nooit zeggen" 'Hallo, foutje, sorry, zand erover.' Wij moeten altijd ons cxcuus aanbieden, en onze woorden terugtrekken. Wij mogen nooil kwaald worden. Wij moetcn alles slikken, alles opkroppen en met het uurtje sport kwijtraken. Als zij een fout maken waarover ik boos word, word ik achter de deur gezet. Dan mag je in je cel alles kort on klcin slaan, krijg jo nog rapport rook. ${ }^{\text {"7s }}$

De vrouwen voelen zich als kinderen bekeken en behandeld. Dat roept ambivalente reacties op, want het heeft ook prettige kanten.

"Verscheidene ondervraagden vonden dat de bewaking bij de vrouwclijke gedetinecrden zich overal mee bemoeit en bij gesprekken er voortdurend met de neus bovenop rit. (.......) Uit andere hock werd opgemerkt dat bewakers meestal licf en echt geïnteresseerd zijn, mar zelf vaak onheus worden behandeld en misbruikt woor elk pijntje of problcempje om medicijnen on aandacht te krijgen." ${ }^{775}$

Sommige vrouwen voelen zich "overgeleverd" aan het humeur van de bewaarders. Ze moeten daar steeds op inspelen en op hun hoede zijn. ${ }^{36}$

"Anneke: Een goeie bewaarster is icmand, dic je niet als gedetineerde behandelt, maar als mens. Die ook eens wat van zichrellf lat zien. Gelukkig ben ik in die vier jaar, dat ik gereten heb, wel twec of drie van die vrouwen tegengekomen. Dic yelf ook weleens over de rume met hun kercl vertelden. Die slippers van thuis voor me meenamen toen ik een ontstoken voet had. Natuurlijk is het mocilijk om

71 Janssen (1994) p. 122.

72 Ketelaars (1991) p. 18.

73 Zie: Afscheidsbricf in: Solidaritcitsgroep vrouwclijke gevangenen (1983) p. 109.

74 In: Fuldauer (1995) p. 87.

75 Zwering (1988) p. 24.

76. Ketelaars (1991) p. 30. 
wertrouwelijk met semand om te gaan die 's awonds de deur achter je op slot doet. Maar je hebt iets gedaan $_{n}$ anders zat je niet in de bajes, en zij zijn er nou eenmaal woor om die deur dicht te doen."

Het onderzoek van Beelen beperkt zich tot de ervaringen van vrouwen in de open inrichtingen. Hier bestaat een intensief contact tussen de vrouwen en de inrichtingswerkers. Niet de tenuitvoerlegging van straf staat centraal, maar een 'zinvolle' tijdsbesteding. Driekwart van de vrouwen ervaart dit intensieve contact als positief.

"In het begin zei ik bijna niets, ik vertrouwde het niet dat het personeel zo aardig was. Maar als je wat meer vertellt over jezelf en je laat wat van jezelf zien, zijn ze eigenlijk hartstikke tof!"

"Je voelt veel minder afstand als het personeel geen uniform aan heeft, door het uniform was het verschil veel groter." ${ }^{\text {m8 }}$

De anderen voelen zich juist te veel gecontroleerd en in de gaten gehouden.

"Het bligft uiteindelijk toch personeel van justitie, ze kunnen alles wat je gezegd hebt tegen je gebruiken," en "Je moet het personeel hier wel een beetje te vriend houden, anders doen ze niks voor je."rs

\section{a. Vrouwelijke en mannelijke bewaarders}

Vooral in de onderzoeken uit 1988 wordt aandacht besteed aan de sekse van de bewaarders. ${ }^{\text {o }}$ Over het algemeen zeggen de vrouwen dat het niet veel uitmaakt of de bewaarders van het vrouwelijk of mannelijk geslacht zijn. Leeftijd en ervaring zijn kenmerkender voor verschillen. Oudere, ervaren bewaarders worden als moederof vaderfiguur beschreven. $\mathrm{Zij}$ zouden gemakkelijker met agressie kunnen omgaan, terwijl jongere bewaarders eerder in paniek zouden raken. ${ }^{\text {Bn }}$ Sommige vrouwen willen wel graag een bepaalde taakverdeling zien. Zij vinden het bijvoorbeeld prettiger om maandverband aan een vrouw te vragen of vinden het vervelend om ongekleed of in nachtkleding door een man gezien te worden. ${ }^{32}$

Mannelijk bewaarders zorgen wel vaak voor een ontspannen sfeer. Ze doen vaker een spelletje en maken grapjes. Vrouwen zijn enerzijds vertrouwelijker en hebben meer begrip, maar anderzijds worden ze harder, strenger en bemoeizuchtiger genoemd dan mannen.

77 In: Nijiman (1983) p. 11.

78 In: Beelen (1991), p. 41-42. In de open inrichting draagt het personeel geen uniform.

79 In: Beelen (1991) p.

80 Brouwers en Sampiemon (1988) p. 28-30, Zwering (1988) p. 25.

81 Zwering (1988) p. 25.

82 Brouwers en Sampiemon (1988) p. $28-29$. 


\section{Hoofidstuk 2}

Zwering rept over ongewenste intimiteiten en verliefdheden tussen mannelijke bewaarders en vrouwelijke gedetineerden. ${ }^{2}$ Wederkerige verliefdheden en intimiteiten tussen personeel en gedetineerden worden door de vrouwen afgekeurd. De vrouwen hebben het soms wel moeilijk met de seksuele spanning."

"Ik beb een man nodig, ik ontpllof hiser zowat. Die verliefdheid is het leukste en het vervelendste op dit moment; het is heel frustrerend, je ontdekt je zwakheden, zoals je behoefte aan aandacht en je kunt er niets mee.

\subsection{Dagbesteding}

De dag is van uur tot uur ingevuld. Naast het luchten, het eten, de sport en de recreatietijd neemt de arbeid de belangrijkste plaats in.

Vrijwel alle vrouwen nemen deel aan de arbeid, ook in het HvB, waar dat niet verplicht is. Hun motivatie tot arbeid is vooral om hun tijd door te komen, om van de cel af te zijn en om geld te verdienen. Op het werk worden praatjes en grapjes gemaakt over alledaagse dingen. Soms komen meer persoonlijke zaken aan de orde. Een deel van de vrouwen zegt geen behoefte aan praatjes te hebben. Vaak is er dan een taalprobleem, soms mag men elkaar gewoon niet. ${ }^{\text {.6 }}$

Het arbeidsaanbod bestaat uit eenvoudig productiewerk, automatten maken, textielwerk, kantinewerkzaamheden, schoonmaken, huishoudelijke arbeid en tuinieren. ${ }^{\text {.7 }}$ De vrouwen die tevreden zijn met het werk, waarderen de gezelligheid en ze zien het als een manier om de tijd te verdrijven. De ontevredenen ergeren zich aan het soort werk.

Ketelaars constateert dat noch de arbeid noch de ontspanningsmogelijkheden van nut zijn om vrouwen na de detentie een zekere mate van op de arbeidsmarkt toegespitste mate van vakbekwaamheid te bezorgen.

\footnotetext{
"Alles is erop gericht om ons bij vrijlating zo af te leveren als deze maatschappij en de mannen ons vrouwen willen, zodat we niet mopperen als we thuis weer al 't werk moeten doen, zodat we ons maar blijven schikken en vooral niet kwaad worden maar oh zo ons best doen on 't allemal gezellig te maken. ${ }^{\text {w9 }} 0$
}

83 Zwering (1988) p. 25 .

84 Brouwers en Sampiemon (1988) p. 29-30.

85 In: Brouwers en Sampiemon (1988) p. 29-30.

86 Brouwers en Sampiemon (1988) p. 21.

87 Zwering (1988) p. 32-34, Ketelaars (1991) p. 25, Differentiatieschema, Ministeric van Justitie (1996).

88 Brouwers en Sampiemon (1988) p. 21.

89 Zwering (1988) p. 34 .

90 In: Afscheidsbrief Solidariteitsgroep Vrouwelijke Gevangenen (1983) p. 110. 
De door Fuldauer geïnterviewde vrouwen noemen zich 'bofkonten'.

"Wij komen voor onszelf op en krijgen studieverlof. Andere vrouwen zitten op werkzaal, en dat is erger dan een sociale werkplaats.

Ketelaars hoort veel gemopper op het cursusaanbod. Ze zijn van een te laag niveau, een HBO-opleiding of LOI-cursus moet je zelf betalen en de meeste vrouwen zitten te kort om een cursus af te maken. Er zouden goede korte cursussen moeten worden geboden met voldoende begeleiding. Ook de taal vormt nogal eens een drempel voor het doen van een cursus. ${ }^{92}$

\section{2 .4 Contact met relaties 'buiten'}

\section{a. Kinderen}

Ongeveer zestig procent van de vrouwen heeft kinderen. Tweederde deel van de moeders zorgde in de periode voorafgaand aan de detentie zelf voor hun kind. De kinderen zijn tijdens de detentie van hun moeder in de meeste gevallen bij hun familie. Vaak bij de grootmoeder, soms bij hun vader. Sommigen zijn bij vrienden, in een pleeggezin of in een tehuis. Een klein deel van de vrouwen heeft geen contact met hun kinderen. Soms wel met de verzorgers.

"Cindy: Als ik bij mijn kinderen ben, voel ik me eigen geen crimineel. Bij vroegere detenties kwamen ze wel op bezoek, nu vind ik ze te oud om mij in de gevangenis te bezoeken. Als ik vrij ben, zie ik ze. natuurlijk weer, maar ze blijven bij mijn ouders wonen. Hun vader zit gevangen, dat weten ze. Moeder zit gevangen, dat weten ze niet. Het zijn kinderen, dat is lastig woor ze."

"Rhonda: Dat is voor mij ook de belangrijkste reden om mijn kind niet te willen zien. Hij is nu tien jaar en wordt opgevoed door mijn ex. Ik ben gewoon een tijdje van de aardbodem verdwenen. Hij is in goeie handen, dat weet ik. We hebben geen contact, als ik daaraan zou gaan denken, word ik knettergek."

"Fleur: Mijn dochtertje had ik hier absoluut niet bij me willen hebben. Als het zo zou zijn als in Karlsruhe of in Denemarken, waar ze hele goeie faciliteiten hebben voor moeders met kinderen, ja. Maar hier of in Breda, nee. Ze woont nu bij mijn vader en moeder. Het liefst zou ik haar iedere nacht in mijn armen willen houden. Maar dat zou niet goed yoor haar zijn. Bovendien is het gebouwen de mentaliteit van de bewaking daar niet naar. Ze hebben al de igrootste mocitte dat zij een keer in de week twee uurtjes op de afdeling is. Nederland loopt gewoon achter wat betreft moeder en kind faciliteiten."

91 In: Fuldauer (1995) p. 88.

92 Ketelaars (1991) p. 22.

93 Brouwers en Sampiemon (1988) p. 32. Zie voor een gedetailleerder onderzoek onder 49 moedlers in gesloten detentie Van Kesteren (1996). 


\section{Hoofdotuk 2}

"Jacky: Mijn zoontje heef behalive als baby nooit bij mij gewoond. Dat was mijn eigen keus. Hij woont bij mijn ex-schoonmoeder. Hier kan ilk hem twee keer per maand op kinderbezoek zien, maar een keer in de maand is voor mij genoeg. Ik ben meer het type van de vader.

Iets meer dan de helft van de Nederlandse moeders krijgt bezoek van hun kinderen, de anderen telefoneren met hen en vooral buitenlandse vrouwen schrijven hun. Slechts negen procent van de moeders heeft helemaal geen contact met hun kinderen.

"Ik heb regelmatig contact met mijn kinderen. Ze kunnen helaas nooit alle vier tegelijk komen en dat zou ik juist theel fijn vinden. Voor mijn kinderen is dat ook goedkoper.

De vrouwen zijn erg bang het contact met hun kind kwijt te raken. Ze voelen dat de relatie verwatert en ze vinden dat ze alls moeder falen. ${ }^{97}$

"Ik heb regelmatig contact met mijn kinderen maar $\mathbf{i k}$ zou meer betrokken willen zijn. Mijn dochter heeft een kind gekregen en ik had graag bij de bevalling willen zijn maar dat mocht niet. Ik heb telefonisch contact met mijn kinderen. Op belangrijke dagen wil ik bij mijn kinderen zijn maar ik krijg hiervoor geen strafonderbreking.

"Nu ik vast zit zorgen mijn man en schoonmoeder voor de kinderen. Dat is niks. Mijn man kan niet goed koken en schoonmaken en mijn schoonmoeder is te oud. De leraren op de school van mijn kinderen zeggen dat mijn kinderen nu vaker spijbelen en dat ze er slecht verzorgd uitzien. Het zou beter zijn als ikzelf thuis zou kunnen zijn. ${ }^{409}$

"Mijn zoon is bij mijn vader en mijn zus. Dat is goed. Ik denk dat alleen familie goed genoeg is om voor mijn kind te zorgen. $\mathrm{Bjj}$ ons is de gehechtheid met de familie heel sterk. ${ }^{100}$

De buitenlandse moeders hebben nog minder contact met hun kinderen dan de Nederlandse moeders. De afstand is te groot om op bezoek te komen en andere communicatiemogelijkheden zijn duur. Niet alleen voor de moeders, maar ook voor de familie thuis.

"Ik heb eenmaal per 3 a 4 maanden contact met mijn twee kinderen en dat vind ik te weinig. Als ik weer vrij ben zullen de kinderen me niet meer kennen. Ik zal alleen een tante voor ze kunmen zijn." ${ }^{\text {"on }}$

94 In: Fuldauer (1995) p. 86.

95 Brouwers en Sampiemon (1988) p. 32, Van Kesteren (1996) p. 14-15.

96 In: Ketelaars (1991) p. 17.

97 Dalebout (1990) p. 28.

98 In: Ketelaars (1991) p. 17.

99 In: Ketelaars (1991) p. 15.

100 In: Ketelaars (1991) p. 15.

101 In: Ketelaars (1991) p. 17. 
"Mijn dochter is nu bijna drie jaar oud. Ik heb hier straks, twee jaar gezeten en weit je waar ik nou zo bang voor ben? Dat als ik straks weer thuis ben, ze me niet meer zal herkennen. In die tijd dat ik hier gezeten heb, is mijn dochter bij mijn moeder gebleven. Mijn moeder ziet ze nu natuurlijk als haar moeder, terwijl ik cen wolslagen vreemde voor haar zal zijn. Dat vind ik afschuwelijk......102

De buitenlandse moeders zijn vaak naar Nederland vertrokken met het idee dat ze na een aantal dagen weer terug zouden zijn in hun thuisland. De opvang van hun kind hebben ze voor een korte periode geregeld. Wat er daarna gebeurt, weten ze niet en wat erger is, ze kunnen daarop ook geen invloed meer uitoefenen. In de meeste gevallen zorgen familieleden voor de kinderen. ${ }^{103}$

"Mijn vader zorgt voor mijn kinderen, maar hij is heel arm. Ik had een baan en hielp mijn vader altijd. Hij is gewond aan zijn arm en kan moeilijk werk vinden. Hij is alleen. Ik ben heel bezorgd om mijn kinderen want ik weet niet hoe lang mijn vader het nog volhoudt. Maar ik kan niets doen." ${ }^{\text {you }}$

Een Zuid-Amerikaanse vrouw vertelt aan Brouwers en Sampiemon dat haar vijf kinderen, in leeftijd variërend van drie tot zestien jaar, alleen thuis zijn. Af en toe komt de buurvrouw even kijken. Een andere vrouw heeft geen idee watar haar kind op dat moment is. ${ }^{105}$

Tijdens inventarisatie-onderzoek zijn er meestal enkele vrouwen die hun baby bij zich in de inrichting hebben. ${ }^{106}$ Een Nederlandse vrouw die een kind heeft gebaard in detentie vertelt aan Ketelaars dat zij haar zwangerschap vreselijk vond. Ze werd medisch well goed opgevangen. Ze mocht wat meer rondlopen en luchten dan de anderen. En ze kreeg oefeningen van de fysiotherapeut, maar ze miste bijvoorbeeld de mogelijkheid om met andere zwangere vrouwen over de zwangerschap, de bevalling en de tijd daarna van gedachten te wisselen. Het was haar eerste zwangerschap. Ze had heel veel vragen. Daarom had ze er ook behoefte aan om bijvoorbeeld met haar moeder over haar zwangerschap te praten. Maar dat was weer moeilijk vanwege de beperkte gelegenheid tot telefoneren. ${ }^{107}$

"Ik zat dric jaar geleden met mijn baby in de gevangenis en dat vond ik heel moeilijk. Ik moest steeds van mijn baby vandaan om te werken. Ik wilde mijn kind ook hier binnen goed verzorgen. Ik was bang dat anderen mijn kind wat zouden aandoen. Ilk wil dat er opvang is voor kinderen, iemand die er cousstant bij is. Ik vind dat mijn baby hier niet goed kon worden verzorgd. In mijn cultuur (Hongaarse, GK) slaapt het kind tot vier jaar bij de moeder en als het kind honger heeft dan krijgt het direct voeding. Met dit cultuurverschil wordt geen rekening gehouden. Tijdens een weekendwerlof ben ik niet teruggeko-

102 In: Janssen (1994) p. 131.

103 Ketelaars (1991) p. 16.

104 In: Kettelaars (1991) p. 16.

105 Brouwers en Sampiemon (1988) p. 32.

106 Zie ook Brouwers en Sampiemon (1988) p. 32.

107 Ketelaars (1991) p. 18. 
men omdat ik niet langer met mijn kind in de gevangenis wilde zijn. Ik wilde dat mijn kind thuis werd opgevoed.

Een andere buitenlandse vrouw die het kind bij zich heeft gedurende haar detentie vindt dit juist prettig. Het kind zou anders naar een pleeggezin moeten en dat wil ze liever niet. $\mathrm{Ze} \mathrm{zou} \mathrm{het} \mathrm{nog} \mathrm{erger} \mathrm{vinden} \mathrm{als} \mathrm{het} \mathrm{kind} \mathrm{naar} \mathrm{haar} \mathrm{thuisland} \mathrm{wordt}$ teruggestuurd. ${ }^{109}$

Ten tijde van het onderzoek van Brouwers en Sampiemon vindt een hele kleine groep vrouwen dat kinderen bij hun moeder in detentie moeten kunnen verblijven. De meesten zijn daar tegen. Ze vinden de sfeer te hard en gespannen en ze vrezen dat teveel mensen zich met het kind gaan bemoeien. Het zou beter zijn de bestaande bezoekmogelijkheden te verbeteren en de moeder de mogelijkheid te geven zelf haar kind op te zoeken. De vrouwen die vinden dat er een langer, permanent verblijf voor kinderen mogelijk zou moeten zijn, vinden dat het kind bij de moeder hoort te zijn. Anderen nuanceren dat door een leeftijdsgrens aan te geven, tot een jaar of twee, drie. Maar dan zou de inrichting wel aangepast moeten worden. De kinderen moeten meer vrijheid hebben en ze moeten buiten en ook met andere kinderen kunnen spelen. ${ }^{110}$ In het onderzoek van Ketelaars zeggen de meeste vrouwen ook nee, tenzij het kind nergens anders terecht kan en de inrichting aangepast zou worden. Maar in principe hoort een kind niet in de gevangenis thuis." "Kinderen worden gestraft voor wat de moeder heeft gedaan en dat is onacceptabel. ${ }^{m 12}$ Van Kesteren, die haar onderzoek onder 49 moeders(!) in gesloten inrichtingen doet, vindt een grotere groep vrouwen ( $41 \%$ ) die voor een eventueel verblijf van een kind tot ongeveer vier jaar in een gesloten inrichting is. ${ }^{133}$ Naarmate de leeftijd lager is, vinden meer vrouwen dat acceptabel. Een overgrote meerderheid van de vrouwen vindt wel dat het dagprogramma dan zou moeten worden aangepast, maar kan, tot merkbare verbazing van de onderzoekster, nauwelijks tot enig voorstel daartoe komen. $\mathrm{Zij}$ constateert ook dat tachtig procent van de moeders tevreden is met de huidige opvang van hun kind buiten de inrichting. ${ }^{14}$

De vrouwen in de open inrichting die de weekenden naar huis mogen, beschrijven hun moeilijkheden met het hernieuwen van de contacten met hun kinderen:

\footnotetext{
"Het eerste weckend dat ik thuis was, was ik heel erg aan het mopperen op de kinderen (16 en 18 jaar) omdat ik het zo'n rommel vond in huis. De kinderen zeiden dat wanneer ik zo door zou gaan,
}

108 In: Ketelaars (1991) p. 19.

109 Ketelaars (1991) p. 18.

110 Brouwers en Sampiemon (1988) p. 32.

111 Ketelaars (1991) p. 18-19.

112 Ketelaars (1991) p. 18-19.

113 Van Kesteren (1996) p. 15-18.

114 Vam Kesteren (1996) p. 13. 
zuj de weekenden naar hun vrienden zouden gaan. Eigenlijk was ik ook wel trots op hen, want naast de school en het werk hebben ze al die tijd met $z^{\prime} n$ twee eten bij mijn zasje.":

Tijdens haar weekendverlof merkt een vrouw dat haar zoon van zestien jaar niet meer naar school gaat. Ze vindt toevallig briefjes van school. Hij heeft dat al die tijd verborgen weten te houden. In de weekenden gaat hij stappen en het lukt haar niet meer om greep op het schoolverzuim te krijgen. ${ }^{116}$

Wanneer de moeder de zorg voor de kinderen met de partner deelt of die aan hem overlaat, doen zich andere problemen woor:

"Het leek eerst wel of ik er niet meer bij hoorde. Als er wat aan de hand was ging mijn dochter (13) eerst naar haar vader, terwijl ze vroeger altijd naar mij toe kwam. Het hele huishouden werd door hen geregeld. $\mathrm{Zij}$ bepaalden wat er gekookt werd, de keukenkastjes waren anders ingedeeld, ik kon niets meer vinden. Ik voellde me een gast in mijn eigen huis. Ik vond ook dat mijn man veel te soepel voor het kind was, hij vond bijna alles goed. Ik heb daar gauw een einde aan genaakt. We hebben hier veel ruzie om gemaakt en ik heb daar veel verdriet door gehad. We wilden allemaal het beste voor elkaar, maar wisten niet meer hoe. Wij hebben toen een paar gezinsgesprekken gehad onder leiding van de reclassering. Vooral mijn kind dreigde er onderdoor te gaan. Zij heeft op een moment slaappillen ingenomen om een eind aan haar leven te maken. $\mathrm{Zij}$ dachi dat zij de oorzaak van alle ruzies was. Op zo'n moment voel je je pas machteloos. Je wilt naar dat kind toe en het kan niet. De periode in de P.O.l. is voor ons alledrie de moeilijkste tijd van mijn hele detentie geweest."117

In een ander geval heeft de partner, die ook veroordeeld was, zijn gevangenisstraf kunnen opschorten, totdat de vrouw de hare beëindigd had. Hij kan dus voor de kinderen van zestien en achttien zorgen.

"Mijn man heeft dit voor mij gedaan, maar de kinderen kunnen niet met hun vader opschieten. Hij is veel te streng voor de kinderen. In de weekenden moet ik alles weer goed praten. Ik vind het $z o$ zwaar. Ik heb het gevoel dat toch alles op mij neer komt."

Een andere partner kreeg een alternatieve straf:

"In het begin deed hij niets in huis. De kinderen hoefden niet uit huis, maar in de weekenden kon ik alles doen."

115 In: Beelen (1991) p. 58.

116 Beelen (1991) p. 59.

117 In: Beelen (1991) p. 59.

118 In: Beelen (1991) p. 59.

119 In: Beelen (1991) p. 59. 


\section{Hoofdstak 2}

In veel gevallen verblijven de kinderen bij familie, meestal moeders en zussen van de gedetineerden.

"Het is toch je eigen bloed, je weet wan je moeder dat ze een beetje hetzelfde denkt als juj. Voor mijn moeder is het ook fijn, ze heeft nu een beetje afleiding." en "Mijn zusje en haar vriend hebben zelf nog geen kinderen, ze hebben nu alvast een beetje kunnen wennen. Ik denk dat ze het straks wel moeilijk krijgen als ik thuis ben, want dan wil ik mijn dochtertje (anderhalf jaar) weer thuis hebben. Ik wil miet dat ze dan de eerste tijd op bezoek komen, want anders, went mijn dochter mooit meer aan mij. Ze denkt nu all dat mijn zus 'mama' is en dat ik een 'tante' ben." ${ }^{\text {"20 }}$

\section{b. Familie en sociale relaties}

Bijna alle vrouwelijke gedetineerden onderhouden wel enige vorm van contact met het gezin, de familie of vrienden. Meer dan eenderde van de vrouwen krijgt echter geen bezoek. Die groep bestaat wooral uit buitenlandse vrouwen. Zij onderhouden het contact meestal per telefoon of brief. Voor vrouwen die van ver komen, is het erg duur naar huis te bellen. Bij sommige vrouwen komt een vrijwillig(st)er op bezoek. $^{1.21}$

De meeste vrouwen klagen over de controle die er bij het contact met de intieme relaties plaatsvindt. Juist die contacten zijn zo prive en dan is het genant dat er liemand bij zit, meeluistert of de brieven controleert. ${ }^{122}$

Bij het bezoek levert de reisafstand tussen de inrichting en de plaats waar het bezoek woont, veel problemen op. Met name de reisduur, maar ook het tijdverlies worden genoemd. Het is voor de bezoekers niet altijd gemakkelijk om tijd vrij te maken.

"Mijn schoonzoon moet iedere keer als hij op bezoek wil komen een vrije dag opnemen. Hij heeft een eigen zaak en dan doe je dat niet zo gemakkelijk. lk begrijp dat wel." en "Ik vind het vervelend dat ik geen bezoek in het weekend kan krijgen. Nu moeten mijn kinderen een dag vrij nemen van school. En dat lukt niet altijd." ${ }^{\text {.123 }}$

Ook blijkt de reis vaak duur te zijn, wooral wanneer er geen of onvoldoende openbaar vervoer is.

"Mijn vriend moet uit Haarlem komen en de reis is vrij duur. Daaron komit hij maar een keer per maand. Ik wil best meer bezoek van mijn vriend als dat financieel mogelijk zou zijin." en "Ik heb maanden

120 In: Beelen (1991) p. 60.

121. Brouwers en Sampiemon (1988) p. 31-32.

122 Brouwers en Sampiemon (1988) p. 31-32.

123 In: Ketelaars (1991) p. 11. 
geen bezoek gehad omdat het te duur is. Ik zou wel bezoek willen maar ik vind het beter dat het geld woor de reis aan eten en kleren woor mijn kinderen wordt besteed." "iza

De telefoonregelingen blijken, volgens de gedetineerde vrouwen, nogal te verschillen per inrichting. ${ }^{135}$

Alle vrouwen maken gebruik van de telefoon om contact te onderhouden met familie en vrienden buiten. De telefoonkosten komen voor eigen rekening en vooral voor de buitenlandse vrouwen zijn de telefoontjes erg duur.

"Ik kan eenmaal per drie maanden kort bellen omdat het anders veel te duur wordt" en "Mijn familie heeft geen teliefoon. Ik kan well iemand bellen die dan met mijn vader afspreekt op een bepaalde tijd bij hem te komen. Als ik dan bel kan ik toch even met mijn vader spreken. Maar dit is waak te ingewikkeld.

De Nederlandse vrouwen bellen zo vaak mogelijk naar huis om het contact met familie en vrienden niet te verliezen.

"Ik vind bellen nog belangrijker dan de post. Soms bel ik alleen maar om de stem van temand te horen dat is dan al voldoende. $1 \mathrm{k}$ bell veel met de familie, ${ }^{20}$ kan ik contact houden." ${ }^{127}$

"Kwart voor 5. Terug naar de afdeling.

Snell even brood nemen en een bekertje melk en beleg, an dan achter de deur.

Tot 6 uur. Dan hebben we recreatie en de mogelijkheid om te telefoner en. (als de telefoon niet kapot is, of bezet door een van de anderen die allemal even graag willen bellen). Meestal zitten we voor de tellevisie of doen een spelletje Rummicub of tafelvoetbal of tafeltennis.

Om kwart voor 9 kon ik nog even bellen: "Dag moeder, hoe gaat het met je?"

'Ik heb de wuille was hellemaal alleen aan de straat moeten zettem, de planten heb ik maar onder de dekens gestopt anders viezen ze dood met de nachtvorst":

'Moeder, ik bel morgen wel weer terug, ik moet mu achter de deur'.

Gelukkig heb ik begripvolle piw'ers, ik kan nog heel even naar mijn zus bellen. 'Nee, het gaat niet goed met moeder, ze is helemaal door de war. We zorgen wel voor haar, maak je niet druk, alles komt goed:"

Verdwaasd ga ik achter de deur, wat is er aan de hand? Er spookt van alles door mijn hoofd. Ze is altijd zo sterk geweest, nooit ziek. Ze is pas 70 jaar ...zal ik haar nog wel zien???

Vooral telefoneren van de ene gevangenis naar de andere, als daar een ander familielid zit, blijkt volgens de vrouwen veel problemen op te leveren. ${ }^{120}$

124 In: Ketellaars (1991) p. 11.

125 In: Ketelaars (1991) p. 13 .

126 In: Ketelaars (1991) p. 13-14.

$127 \mathrm{In}$; Ketelarars (1991) p. 13-14.

128 Uit: Dagboekfragment, Nemesis essays (1995) p. 94.

129 Ketelaars (1991) p. 13-14. 


\section{c. Partners}

Ten tijde van het onderzoek wan Brouwers en Sampiemon leefde ongeveer de helft van de vrouwen voor de detentie met een vaste partner. ${ }^{130}$ Uit later onderzoek van De Borst leid ik af dat driekwart officieel, volgens de registratie, alleenstaand is. ${ }^{\text {.3. }}$ Partnerrelaties zijn moeilijk in beeld te brengen. In ieder geval denkt een groot deel van de Nederlandse vrouwen dat de situatie na de detentie veranderd zal zijn, al hebben de meesten geen idee hoe dan. Sommigen willen ook niet terug naar hun oude situatie; ze willen ergens anders 'een nieuw leven beginnen'. ${ }^{132}$ De buitenlandse vrouwen verwachten well naar dezelfde situatie als voor hun detentie terug te zullen (moeten) keren.

\section{d. Mannelijke gedetineerden}

Veel gedetineerde vrouwen zoeken contact met gedetineerden van de mannenafdelingen als de gebouwelijke situatie dat toelaat. Dit contact bestaat uit seinen en zwaaien vanaf de luchtplaats. Soms bieden gezamenlijke activiteiten, zoals de kerkdienst, daartoe ook gelegenheid. Af en toe wordt er gecorrespondeerd.

"Het gebeurt waak dat wrouwen, zodra zij de mannentoren kunnen zien en kunnen seinen, totaal niet meer aanspreekbaar, noch te motiweren zijn iets te gaan doen: er bestaat dan niets anders meer voor hen. ${ }^{\text {mis }}$

Sommige vrouwen hebben het daar heel moeilijk mee. Zij zijn bijwoorbeeld mishandeld en willen niks meer met mannen te maken hebben. Anderen hebben een afkeer van seksistische opmerkingen.

"Ik spreek vitt ervaring. In het Pieter Baan Centrum werd ik als object bekcken en nict als mens. Ik yond het afschuwelijk. Als er bij hel sporten een stukje been bloot kwam dan krceg ik allerlei sexistische opmerkingen naar mijn hoofd geslingerd: ${ }^{\text {in }} 3$ :

Anderen missen mannen in hun omgeving of zijn op zoek naar een partner.

130 Brouwers en Sampiemon (1988) p. 31 .

131. De Borst (1991).

甘32 Dat geldt in bijzondere mate voor de vrowwen die een geweldsdelict tegen hun partner hebben gepleegd. Zie Fuldauer (1995) p. 84.

133 Brouwers en Sampiemon (1988) p. 33 ,

134 In: Ketelaars (1991) p. 28. 
"Nk vind het moeilijk om zo lang zonder man te zijn. $1 \mathrm{k}$ krijg geen liefde en daarom zou ik dolgraag contact met mannen willen." ${ }^{\text {ixi }}$

"Ik zou niets liever willen dan een goede man voor mijn kinderen. Als die man met iets illegaals bezig zou zijn, dan zou me dat niet storen. Je moet privé en zaken gescheiden weten te houden. Als het binnenshuis allemaal goed zou gaan, dan zou ik hem in zijn zaken ook steunen. Ik zou dan bereid zijn weer in de illegalitieit te gaan werken." ${ }^{\text {"136 }}$

De vrouwen vervreemden van mannen en dat willen ze niet. Als er nu mannen in de buurt van de vrouwen komen dan stellen zich aan als jonge meisjes. Ze lijken het niet meer gewend te zijn om gewoon met mannen om te gaan. ${ }^{137}$

\subsubsection{Seksualiteit/intimiteit}

Brouwers en Sampiemon stellen vast dat het gebrek aan privacy en de behoefte aan intimiteit twee spanningsvelden opleveren. De problematiek van intimiteiten in de inrichting lijkt uitdrukkelijk te spelen, maar niet goed bespreekbaar te zijn. ${ }^{1.8}$ Ook Zwering ziet dat er bij de vrouwen veel behoefte bestaat aan intimiteit, warmte en geborgenheid. Zij vindt dat er vanuit de inrichting op de behoefte aan troost en warmte nogal afwijzend wordt gereageerd. Veel bewakers reageren verkrampt op affectieve uitingen. ${ }^{130}$ Maar ook medegedetineerden hebben moeite met zichtbare onderlinge relaties.

"Je ziet veel zoenen en vrijen in het openbaar. Je leert hier veel slechte dingen, het is geen leven." ${ }^{140}$

Sommigen voelen zich zelfs belaagd. Daarom zouden zij ook nooit hun cel met iemand willen delen.

"Dat gaat nooit goed, ik heb al een aanzoek gehad." ${ }^{\text {"141 }}$

Veel vrouwen vertellen dat zij wel eens door een medegedetineerde benaderd zijn, maar dat een eenvoudig "nee" voldoendle was om met rust gelaten te worden en

135 In: Ketelaars (1991) p. 28.

$136 \mathrm{In}$ : Janssen (1994) p. 131.

137 Ketelaars (1991) p. 28.

138 Brouwers en Sampiemon (1988) p. 3.

139 Zwering (1988) p. 23.

140 Zie ook Janssen (1994).

141 In: Brouwers en Sampiemon (1988) p. 29. 
zij waren hier dan ook laconiek over. Anderen klagen over de beperkingen die hun opgelegd worden. ${ }^{\text {inz }}$

\subsubsection{Evaluatie op hoofdpunten}

De gedetineerde vrouwen hebben het meest te kampen met de zorg voor en on hun kinderen en overige (familie)relaties. Bij velen was dat woor de detentie ook all zo, maar de problemen lijken door de detentie te zijn verergerd. Ook problemen rond seksualiteit komen pregnant naar voren. Ze missen privacy en hebben behoefte aan intimiteit.

In de praktijk blijken gedetineerde moeders zich verstoken te voelen van de zorg over hun kinderen. Enerzijds moeten zij de dagelijkse zorg overlaten aan anderen: wie gaat er mee naar het consultatiebureau, wie verstelt en koopt de kleren, wie houdt rekening met het eten dat mijn kind verdraagt etcetera, maar ook: wie vertelt mijn kind wat er met mij aan de hand is en hoe wordt dat verteld? Niet alleen de praktisch organisatorische zorg is weggevallen, maar ook de emotioneel-affectieve zorg. Hoe percipieert het kind de situatie? Deze zorg om de zorg is knagend. De vrouwen noemen dit een dubbele bestraffing.

Daarbij vormen huwelijk en moederschap voor veel vrouwen een groot deel van de invulling van de eigen identiteit. Het leven buitenshuis wordt sterk bepaald door de relaties binnenshuis. Als 'partner en/of moeder van' treden veel vrouwen naar buiten, leggen contacten in de supermarkt, in het park, op het consultatiebureau, in de peuterspeelzaal, als vrijwilliger op school etcetera. Waar mannelijke gedetineerden vaker al een gescheiden leven buitenshuis en een leven binnenshuis hebben of in ieder geval in een dergelijke tweedeling gesocialiseerd zijn, hebben vrouwen het gevoel dat de detentie ook hun betekenis in het verdere leven bepaalt. Ook vrouwen die feitelijk geen moeder zijn stemmen de inrichting van hun leven vaak af op het potentiële huwelijk en moederschap. Ook zij definiëren zichzelf in rellatie tot anderen, wat onder andere invloed kan hebben op hun seksualiteitsbeleving. Sommige moeders die voor hun detentie al moeite hadden met hun rol, worden bovendien nog eens extra met hun 'falen' geconfronteerd, zonder dat zij bij machte zijn daar iets aan te doen.

\subsection{Theorievorming over gevangeniscultuur}

Theoretische inzichten omtrent de effecten van de detentie op emoties en gedrag van mensen zijn in Nederland vooral ontwikkeld ten aanzien van mannelijke gedetineerden. In het buitenland zijn er wel onderzoeken in en naar vrouwengevangenissen 
gedaan. Resultaten uit die bronnen zijn niet zomaar van toepassing op vrouwen in Nederlandse gevangenissen. Daarvoor verschillen de duur van de detentie en het gevangenisklimaat vaak te veel. ${ }^{143}$

De detentie is bovendien een fase in een heel leven van mensen. Het is een periode die niet geïsoleerd gezien kan worden van het leven voor en na die detentie, juist wanneer er geprobeerd wordt om een zinvolle invulling aan die executiefase te geven. In de executiefase kan gestreefd worden naar een humane tenuitvoerlegging of 'beperking van de detentieschade', maar dat zijn normatieve criteria, de mate van humaniteit of schade zal subjectief beoordeeld en beleefd worden.

De al of niet bedoelde effecten van de gevangenisstraf op de gedetineerden zijn ook interessant om iets te kunnen zeggen over het beoogde doel van de straf. Dat kunnen, naast de klasssieke doelen als vergelding en leedtoevoeging, toekomstgerichte doelen zijn zoals 'resocialisatie' of veel zwakker 'het voorkomen van recidive'. Het is een illusie om te veronderstellen dat deze op zichzelf gerechtvaardigde beleidsdoelen vanzelfsprekend in elkaars verlengde liggen. Het maatschappelijk draagvlak kan bovendien afwijken van het justitiële beleid, waardoor het leven na de detentie meebepalend is voor de uiteindelijk effecten. Uit een vergelijkend onderzoek tussen vrouwelijke gedetineerden uit $Z$ weden en Ierland bleek dat vrouwen in hun leven ná de detentie veel sterker uit het relatief repressieve bewind in Ierland kwamen dan uit het volledig op resocialisatie gerichte regiem in Zweden. ${ }^{\text {1.4 }}$ In Zweden bleek de stap tussen de voorzieningen in de gevangenissen en het ontbreken daarvan in de alledaagse werkelijkheid voor veel vrouwen te groot. De onderzoekster legt een verband met de sterkere familienetwerken in Ierland, die een relatief veilige basis vormen wanneer vrouwen terugkeren in de samenleving, terwijl de vrouwen in Zweden zich blijvend geïsoleerd en gestigmatiseerd voelen. Zolang een 'progressieve aanpak' in gevangenissen geen of onvoldoende draagvlak heeft in de samenleving zal dat probleem volgens de onderzoekster blijven bestaan. In Frankrijk wordt iets soortgelijks geconstateerd met betrekking tot gedetineerde moeders die tijdens gevangenschap hun baby's bij zich mogen houden en de vaak volstrekt onverwachte verwaarlozing van het kind, wanneer ze het in de vrije samenleving moeten rooien. ${ }^{145}$ Modelgevangenschap is dus geen garantie voor modelburgerschap.

Kelk meent dat niet alleen vanuit het resocialisatieperspectief, maar ook uit het oogpunt van humaniteit rekening met de toekomst moet worden gehouden: de nabije toekomst, dat wil zeggen het verloop tijdens de detentie, inclusief (o)verplaatsingen

1.43 Buitenlandse bezoekers zijn vaak verbaasd dat de gevangenen in Nederland geen uniformen dragen of dat bewaarders in vrouwengevangenissen ongewapend rondlopem. Gevangenisdirecteuren in Nederland spreken zich nogal eens uit over het werschil in sfeer en klimaat tussen marnen- en vrouweninrichtingen. Zie ook: Franke (1990), Fuldauer (1995) p. 113-114.

144 Lundström (1988).

145 Relais Enfants Parents (1993). 
en de maatschappelijke toekomst na de detentie. ${ }^{146}$ Onder mannen is in Nederland wel onderzoek gedaan naar effecten van verschillende regiems op het leven tijdens en na de detentie. ${ }^{\text {w7 }}$ Vanuit justitieel perspectief zijn bij mannen vooral recidivepatronen van belang, maar met name Van der Linden heeft ook gekeken naar persoonlijkheidsaspecten: de financiële situatie, de werksituatie, de sociale relaties, vrije tijdsbesteding, alcohol- en drugsgebruik en de attitude van de gedetineerde. Met betrekking tot het recidivegedrag onder mannen wordt in Nederland meer gekeken naar het belang van functionerende netwerken bij terugkeer in de samenleving. Onder wrouwen in Nederland is nooit een systematisch onderzoek gedaan naar het leven na de detentie. ${ }^{\text {by }}$ Het detentiebeleid lijkt vooral gebaseerd te worden op inventariserend onderzoek en niet op follow-up studies.

Ander relevant onderzoek plaatst de gevangenis als institutie in een maatschappelijke context: in hoeverre wordt in het gevangenisbeleid en de gevangeniscultuur het maatschappelijk beschavings- of controleproces weerspiegeld en welke rollen spelen de diverse betrokkenen daarin?

Net als in het criminologisch onderzoek zou er in het penologisch onderzoek een onderscheid gemaakt kunnen worden tussen:

- onderzoek naar psychosociale processen;

- onderzoek naar sociaalemancipatorische processen;

- onderzoek naar politisering en macht.

\subsubsection{Psychosociale processen}

Rooks onderscheidt in 1983 drie modellen die gehanteerd kunnen worden bij het inventariserend onderzoek naar de cultuur in gevangenissen ${ }^{149}$ :

1. het deprivatiemodel, waarbij gedrag verklaard wordt uit het feit dat de gedetineerde zich aanpast aan de positie in de inrichting;

2. het importmodel, waarbij gedragingen vooral verk]aard worden uit ervaringen die gedetineerden voorafgaand aan de detentie hebben opgedalan of uit andere invloeden van buitenaf;

3. het geïntegreerde model, waarbij een combinatie van detentie-invloeden en persoonlijke en sociale achtergronden van gedetineerden gezocht wordt.

Het gehanteerde model zal invloed hebben op conclusies en ook op mogelijk daaropvolgende beleidsinitiatieven en/of regelgeving. Vanuit de gekozen perceptie is ook de eerdergenoemde kritiek van Zwering en Verrijn Stuart op het WODC-inventarisa-

146 Kelk (1993-3).

$147 \mathrm{Vgl}$. Van der Linden (1981), Berghuis (1981).

148 In het buitenland gebeurt dat wel. Zie bijwoorbeeld. Carlen (1990-1), Eaton (1993).

149 Rooks (1983). 
tie-onderzoek te verklaren. ${ }^{150}$ In het WODC-onderzoek worden immers vooral de deprivatieverschijnselen bij vrouwen beschreven.

\subsubsection{Deprivatiemodel}

Goffman beschrijft in zijn boek over "Totale instituties" het deprivatiemodel: " In een totale institutie voltrekken alle facetten van het leven zich op dezelfde plats en onder hetzelfde gezag. Voorbeelden daarvan zijn, naast gevangenissen, dus ook een ziekenhuis, een schip, een kostschool en dergelijke. Kelk vindt de gevangenis een mengvorm van een totale institutie en en burocratische organisatie. ${ }^{152}$ Kenmerkend voor een totale institutie is een organisatie waarin slapen, werken en vrijetijdsbesteding in een en dezelfide leefsituatie plaatsvinden, onder dezelfde autoriteit, met niet zelf gekozen medegeïnstitutionaliseerden en waarin alle activiteiten door een strak van bovenaf geregeld tijdschema worden beheerst. Gevolgen zijn onder meer: regressie, geen adequate reacties op frustraties, identiteitsverlies, het ontwikkelen wan een overlevingsstrategie etcetera. Dit alles leidt tot 'detentieschade', de mate daarvan is afhankelijk van persoonlijke eigenschappen, detentieduur en detentieomstandigheden.

In zijn boek citeert Franke de beschrijving van Clemmer (1940) met betrekking tot de gevangenis: het proces waarbij gevangenen zich steeds meer gaan richten op de waarden, regels en eisen binnen de muren en daardoor steeds minder opgewassen raken tegen de eisen van het vrije leven. Het zijn subculturen met eigen gedragscodes, een eigen sociale hiërarchie en eigen vormen van sociale controle. De subculturen zouden een negatief effect op resocialisatie hebben. ${ }^{153}$

In het (Westerse) dagelijkse leven zijn veel mensen er inmiddels aan gewend dat er voor elke activiteit een aparte plaats is: werken, naar school gaan, eten, slapen etcetera. Het geindividualiseerde en gedifferentieerde leven behoort tot de privacy van mensen. In een totale institutie worden mensen losgeweekt van de buitenwereld en van de netwerken waarvan zij voorheen deel uitmaakten, zoals hun gezin en/of hun werkomgeving. Mensen missen dan zowel hun privacy als de vertrouwdheid van hun netwerken. $\mathrm{Zij}$ worden geconfronteerd met nieuwe sociale relaties en met onbekend personeel. Goffman vindt dat zij op die manier systematisch van hun persoonlijkheid beroofd worden. In een gevangenis komt dat verscherpt naar voren, omdat het in hoge mate onvrijwillig gebeurt. Gevolg van het verlies aan persoonlijk-

150 Zwering (1989), Verrijn Stuart (1992).

151 Goffman (1975).

152 Kelk (1993-1) p. 40.

153 Franke, Twee eeuwen gevangen (1990) p. 645. 


\section{Hoofdstuk 2}

heid is dat men gevoelig wordt voor de regels die men moet volgen, er worden 'overlevingsstrategieën' gezocht. ${ }^{154}$ Er zijn verschillende reacties mogelijk:

- regressief gedrag, het zich volledig terugtrekken;

- opstandig gedrag, de confrontatie aangaan;

- modelgedrag, het zich volledig conformeren aan de voorzieningen en de bij het gezag bestaande opvattingen. Via het verwerven van gunsten kunnen mensen zich immers nog een beetje onderscheiden van de rest, van de massa.

Er is -ook in het buitenland-weinig onderzoek gedaan naar de specifieke prisonatieverschijnselen bij vrouwelijke gedetineerden. ${ }^{155}$ Layton MacKenzie, Robinson en Campbell hebben geprobeerd verschillen in kaart te brengen tussen kortgestrafte en langgestrafte vrouwen. De groepen vrouwen verschilden qua demografische gegevens nauwelijks en ook niet wat eerdere ervaringen met justitie betreft. De enige belangrijke verschillen betroffen de lengte van de straf en het deel dat daarvan nog resteerde of al uitgezeten was. Uit eerder onderzoek was al afgeleid dat alle vrouwelijke gedetineerden het meest lijden aan het wrijwel ontbreken van relaties met de buitenwereld. Verder lijden, net als bij de mannen, de vrouwen die net gearriveerd zijn, maar nog een lang verblijf in het vooruitzicht hebben het meest. Hoewel er in het algemeen weinig verschillen lijken te zijn, blijken de kortgestrafte vrouwen en de vrouwen met lange straffen die net binnen zijn vooral bezorgd over hun eigen veiligheid. Verklaringen die de onderzoekers daarvoor geven zijn:

- ze hebben nog niet kunnen ervaren dat het er niet werkelijk gevaarlijk is;

- ze hebben de tijd nog niet gehad om gedrag te ontwikkelen waardoor ze het hoofd kunnen bieden aan hun nieuwe omgeving;

- de situatie is feitelijk gevaarlijker voor nieuwkomers omdat ze nog geen persoonlijk 'vrienden'netwerk hebben.

Nieuw binnengekomen vrouwen blijken ook eerder mee te doen in 'playfamilies', een soort surrogaat families, waarbinnen via lesbische contacten bijvoorbeeid een moeder-dochter relatie gekopieerd wordt of een man-vrouwrelatie. ${ }^{150} \mathrm{Ju}$ ist de nieuw-

154 Zie ook Kelk (1993-3) p. 74. De term "overlevingsstrategie" wordt ook gehanteerd in het kader van de wrouwenhulpwerlening. De machteloze positic van veel vrouwen zou een verkllaring woor hum passiviteit en conformerend gedrag zijn, zelfs in situaties waar zij sterk onder lijden. Medicijnalcohol- en drugsverslaving worden daar gezien als ongelukkige owerlevingssirategieën. Zie Egtberts (1992).

155 Vgl. Layton MacKenzie, Robinson en Campbell (1989) p. 223-238. Baanbrekend was wel het werk van Giallombardo (1966). Zij zocht naar de specifieke rolpatronen in yrouwengevangenissen om die te kunnen wergelijken met patronen in mannengevangenissen om zodoende meer te begrijpen van de maatschappelijke verhoudingen.

156 Zie cok Smaus (1992), p. 31. Smaus beschrijft de wijze waarop vrouwelijke gevangenen een gezinsleven proberen te creëren. "Eine besondere Rolle spielen hierbei die sexuellen Beziehungen die, $_{\text {, }}$ passend zu der kindlichen Rolle, in Gefängnis eigentlich nicht workommen sollten. Bezeichnend ist, dass in einem gleichgeschlechtlichen Milieu keineswegs nur lesbische Beziehungen eingegangen werden. Die Bezeichnung "lesbische Beziehung" bleibt denjenigen Frauen vorbehalten, die auch 
komer lijkt zich als lid van een familie zekerder te voelen. Bij langer verblijf neemt die behoefte af. De vrouwen die lang in de inrichting verblijven, krijgen het steeds moeilijker met alle beperkingen in de gevangenisomgeving. Hun wensen worden praktischer. Ze willen dichterbij hun familie zitten, ze missen mannen en een sociaal leven, ze willen meer doen, aan het werk, een interessante baan vinden en dergelijke. Wanneer dit gemis aan mogelijkheden tot een overstelpend gevoel van onmacht leidt, kunnen de vrouwen zich hierop volledig gaan concentreren. Ze worden bang gek te worden, krijgen suïcidale gedachten of vrezen het leven van een plant te leiden. Hoe de vrouwen hiermee om gaan hangt sterk af van de feitelijke situatie en van hun individuele geaardheid.

Vanuit het deprivatiemodel kan niet verklaard worden waarom er als reactie op de gevangenschap verschillende reacties en subculturen naast elkaar ontstaan.

\subsubsection{Importmodel}

Andere onderzoekers zijn daarom gaan kijken naar het effect van gedragspatronen buiten de inrichting op het gedrag binnen de gevangenis. ${ }^{15 \pi}$

De Werkgroep Vrouwen in detentie lijkt in zijn benadering heel nadrukkelijk voor het importmodel te kiezen en suggereert daarnaast in zijn algemeenheid ook dat de oorzaken voor het strafbare gedrag van gedetineerde vrouwen grotendeels uit het seksespecifiek gesocialiseerde leven voorafgaand aan de detentie te verklaren is. (de gedetineerde vrouw als het ultieme slachtoffer.) ${ }^{158} \mathrm{De}$ reactie van Staatssecretaris Kosto op de plannen van de werkgroep is in dit verband tekenend:

"Als u meent dat justitie tot taak heeft de sociaal economische posilie van die vrouwen te versterken, dan geeft $u$ een andere interpretatie aan artikel 26 dan justitie doet. Het kan nooit de taak van justitie zijn om de achterstand goed te maken die vrouwen in de vrije maatschappij opgellopen hebben." ${ }^{\text {"159 }}$

in der Freiheit Frauen bevorzugt haben. In anderen sexuellen Beziehungen bedienen sich Frauen zwar homosexueller Praktiken, folgen aber dem heteroseksuellen Vorbild. Folglich muss dabei eine Frau die männliche Rolle spielen. Diese Tatsache, dass die sozial definicrie Geschlechterrolle als stabile, nicht variable Einrichtung, das biologische Geschlecht dagegen als die Variable, auf die esgar nicht ankommt, erscheinen, könnte für die bissherige feminist ische Theor ie weit reichende Konsequenzen haben. Sie läuft nämlich auf die Erkenntnis hinaus, dass Geschlechtsrollen nicht wirklich geschlechts- sondern kontextabhängig sind."

$\mathrm{Zij}$ benadrukt de heel andere wijze waarop homoseksuele contacten in manneninrichtingen plaalsvinden, $n l$. veel meer als uitingen van geweld, wernedering en machtsvertoon. De comtacten zijn daar vaak eenzijdig geinitieerd, waarbij jongere psychisch zwakke gevangenen onvrijwillig de vrouwelijke rol moeten aannemen. De wrouwen proberen daarentegen een symbolische privésfeer te scheppen, waarin ze een duurzame wederzijdse loyaliteit vinden, dezelfde die 'buiten' idealiter in de farnilie woorkomt.

157 Irwin en Cressey, in: Janssen (1994) p. 28-29.

158 Rapport Werkgroep Vrouwen in detentie (1991).

159 In: Ketelaars en De Graaff (1992) p. 184. 


\section{Hoofdstuk 2}

Uit de invloed van hun seksespecifieke socialisatie op hun detentuebeleving zou in het allgemeen te verklaren zijn dat gedetineerde vrouwen relatief gezien met nog grotere problemen en identiteitscrises te maken hebben dan gedetineerde mannen. ${ }^{160}$ Wellicht speelt het feit dat de vruchtbare periode van vrouwen meer leeftijdsgebonden is dan die bij mannen en dat de detentie vaak in die levensfase plaatsvindt, ook een rol bij de identiteitsproblemen; weggegooide jaren in de periode dat je je als vrouw 'het meeste ward voelt'. Uiterlijk, fitness en missverkiezingen zijn niet voor niets ook in de bajes populair.

\subsubsection{Geintegreend model}

Vanuit een meer geïtegreerde benadering probeert Heidensohn al in 1969 op grond van de studies over de effecten van totale instituties, gevangenissen in het bijzonder, op mannen, een aantal vragen met betrekking tot vrouwen aan de orde te stellen. ${ }^{161}$ De meeste aandacht gaat uit naar het leed van de gevangenisstraf. Voor mannen is dat all eerder alls volgt omschreven:

1. het verlies van vrijheid;

2. het niet beschikbaar zijn van goederen en diensten;

3. het verstoken zijn van heteroseksuele contacten;

4. het verlies van zelfstandigheid;

5. het verlies van zekerheid.

Heidensohn onderzoekt in hoeverre dit leed ook door vrouwen gevoeld wordt en zoekt in haar verklaringen naar verbanden met de maatschappelijke positie van vrouwen.

- Het verlies van vrijheid, waaronder zowel de feitelijke opsluiting als de maatschappelijke uitstoting verstaan wordt, pakt voor vrouwen anders uit dan voor mannen: De vrouwelijke identiteit wordt vooral ontleend aan haar rol van vrouw en moeder. Zelfs als zij feitelijk die rollen niet vervilt, wordt zij toch van de mogelijkheid daartoe afgesneden. Als zij die maatschappelijke rol feitelijk al wel vervulde, vormt de scheiding een extra belasting en zorg voor vrouwen. Niet alleen door de scheiding, maar in het geval van kinderen ook door de zorg of er wel adequate vervanging is. Soms wordt er bij de straftoemeting rekening gehouden met zorgtaken. Als dat niet het geval is, lijdt de vrouw extra onder de stigmatisering een onverantwoordelijke moeder te zijn.

Mannelijke gevangenen kumnen zich door het werk in de gevangenis iets beter identificeren met een beroepsfunctie. Bovendien zijn zij bij voorbeeld door hun arbeidsverleden of de militaire dienst al enigszins gewend aan een gemeenschap van uitsluitend mannen. (bruut, autoritair, harde discipline) 
- In het algemeen schijnt het verlies van goederen en diensten het minst gevoeld te worden naarmate de levensstandaard lager was en de vooruitzichten geringer. Toch lijken vrouwen ook onder dit verlies relatief meer te lijden dan mannen. Gezien hun maatschappelijke rol zijn zij belangrijke consumenten, die de gezinsinkopen doen, graag winkelen en waarop de reclame zich vaak richt.

- De rol van de (hetero)seksualiteit voor vrouwen schijnt onderschat te worden. Hoewel seks bij vrouwen niet geassocieerd wordt met onmiddellijke seksuele bevrediging (zoals dat bij mannen vaak gebeurt) is seks voor vrouwen wel het belangrijkste middel tot contact met de maatschappelijke structuur. Een middel dat zij vaker op een affectieve dan een instrumentele manier gebruiken. Juist voor die affectieve relaties zoeken zij compensatie. ${ }^{162}$

- Onder het verlies van zelfstandigheid zouden vrouwen minder lijden omdat zij buiten de gevangenis ook vaak economisch en fysiek afhankelijk waren.

- Vrouwen schijnen zich wel vaak onzeker en onveilig te voelen tussen hun medegedetineerden. De daaruit voortvloeiende onrust is moeilijk te beheersen omdat die de vorm aanneemt van persoonlijke aanvallen of psychische terugslagen. Ook andere feministische onderzoekers zoeken, in navolging van Sykes, naar specifieke rolgebonden gevolgen van het verblijf in de gevangenis voor vrouwen ${ }^{163}$ rond de thema's: loss of liberty, loss of possessions, loss of autonomy. Steeds blijkt dat vrouwen lijden onder de tegengestelde eisen die aan hen gesteld worden. Volgens Carlen kan het regiem in vrouwengevangenissen samengevat worden met de woorden "Dïsciplineer, Infantiliseer, Feminiseer, Medicaliseer en Domesticeer" ${ }^{1.64}$ Er wordt

162 Over het hete hangijzer 'seksualiteit" en de verschillende beleving en interpretatie van de rol van seks, wordt soms een tipje van de sluier opgelicht door inrichtingswerkers die speciaal op dit thema gericht zijn (bijv. via daderbehandeling bij zedendelinquenten). Zie bijv. Welzen en Zomer (1989). Zij beschrijven hoe ook wat beleving en vormgeving van intimiteit en seksualiteilt betreft, verwachtingen, waarden en normen, rolopwattingen over man-zijn en vrouw-zijn, gedrag en taalgebruik uiteenlopen en botsen.

"Intimiteit bestaat in eerste instantie voor onze bewoners uit gebrek aan privacy en voor de staf uit een controlerende houding" (p. 54).

"Sinds er wat meer vrouwen in met name de sociotherapie werken, is de kwestic van intimiteit en seksualiteit meer aan de orde.... We zijn meestal geémancipeerder in ons denken dan in ons doen en woelen. Bewoners kunnen dan ook bij de staf primitieve man- en rouwbeelden actualiseren, die moeilijkheden kunnen veroorzaken." (p. 55).

"En dan de eventuele rivaliteit tussen collega's om een bewoner. Of soms ook rivaliteit tussen mannelijke stafleden en de bewoner om het vrouwelijk staflid." (p. 55).

"Over de angst voor het etiket "homo" omdat hij niet helemaal terugschrok woor homo-erotische gevoelens." (p. 56).

"Onze bewoners, die meestal weinig veiligheid, contact en respect hebben ervaren van hun omgeving, kunnen taal vaak niet beleven als expressiemiddel dat leidt tot contact of intimiteit. En met name in de taal komt het werschil in sociaal-culturele achtergrond naar voren." (p. 56).

163 Carlen and Worrall (1987), Genders en Player (1987).

164 Carlen (1987) p. 179. 


\section{Hoofdstuk 2}

well onderkend dat vrouwen anders zijn dan mannen, maar dit leidt tot tegenstrijdige verwachtingen. Terwijl ze tijdens hun gevangenschap getraind worden in huishoudelike en huiselijke vaardigheden, is het gevolg van hun detentie vaak dat er buiten de gevangenismuren helemaal geen huishouden meer is. Er ligt bijvoorbeeld een echtscheidingsverzoek, de huur is niet betaald en de kinderen zijn elders ondergebracht. De gevangene kan alleen maar om medicjinen vragen om tot rust te komen, terwijl ze weet dat de omstandigheden thuis (verder) verslechterd zijn als ze uit de bajes kont.

"Door medicijngebruik en de debiliserende effecten van de opsluiting zal ze dan nog minder in staal zijn om ze tot een oplossing te brengen. ${ }^{\text {"itas }}$

Janssen doet haar participatueonderzoek onder Latijns-Amerikaanse vrouwen in de Singel vanuit het geintegreerde import-en deprivatiemodel. ${ }^{16}$ Daarbij beschouwt zij 'gender' als een importvariabele. Het aardige is dat zij in haar onderzoek de verschillen in afkomst tussen gedetineerde vrouwen onderling sterk benadrukt. De sociaaleconomische en culturele omstandigheden waaruit de Latijns-Amerikaanse vrouwen komen, blijken veel invloed te hebben op hun gedrag tijdens de detentie. Zo valt de deprivatie mee, doordat de ruimtelijke omgeving veel humaner is dan het negatieve beeld dat zij daar, op grond van de situatie in hun eigen land, van hadden. Aan de andere kant zijn er veel misverstanden met het personeel, met name ook met de medische dienst, die te verklaren zijn vanuit een culturele context. Onder andere taal- en attitudebarrières leiden tot wederzijdse misverstanden. De LatijnsAmerikaanse vrouwen, vooral de oudere vrouwen, stellen zich over het algemeen voorzichtig op waardoor ze door het personeel als 'modelgevangenen' gezien worden. 'Het delict' blijkt over het algemeen een gemeenschappelijke importvariabele tussen de oudere en jongere Latijnsamerikaanse vrouwen te zijn, terwijl de geloofsovertuiging en de leeftijd nogal eens tot verschillen in waardeoordelen leiden als het gaat om verschijnselen die vooral pas tijdens de detentie tot uiting komen: homoseksualiteit en het gebruik van drugs.

Janssen heeft wel met de vrouwen over hun toekomstverwachtingen gesproken, maar ook in haar onderzoek is geen gelegenheid geweest een follow-up studie te doen.

\subsubsection{Sociaalemancipatorische processen}

Franke beschrijft, op basis van Elias' beschavingstheorie, het proces van veranderingen binnen de muren, de verschuiving van de machtsbalans tussen gedetineerden en gevangeniswezen. Het emancipatieproces wordt in zijn optiek niet zozeer bevorderd 
vanuit een emancipatiebeweging uit de gevangenen zelf, maar veel meer vanuilt geleerden en theoretici aan de zijlijn. Twee gedachten staan daarbij centraal: dat de gevangenisstraf ter voorkoming van recidive een opvoedend, later resocialiserend doel zou moeten hebben en dat de straf een sterker rechtvaardigingsdoel moet hebben naarmate het psychische en fysieke leed dat wordt toegebracht erger is, uiteindelijk resulterend in het streven detentieschade zoveel mogelijk te voorkomen. Het feit dat beide doelstellingen steeds maar niet gehaald werden en worlen, leidt ertoe dat de machtspositie van de gevangenen als het ware 'vanzelf' sterker wordt. Met name in de jaren zeventig en begin jaren tachtig wordt een hoogtepunt bereikt, vooral ook door de invoering van het beklagrecht. Bewaarders zijn in een onderhandelingspositie met de gedetineerden gekomen.

"Gevangenen, bewaarders en gevangenisfunctionarissen hebben elkaar nodlig voor een zo pretlig mogelijk leven en dat is een van de redenen waarom in Nederland gevangenisopstanden van ernstige omvang zich niet woordoen".

Voor een deel verklaart Franke dit emancipatieproces ook als passend binnen de algehele maatschappelijke ontwikkelingen, waarin alle mensen meer welvaart en macht kregen, maar hij benadrukt ook de eigen dynamiek van het proces binnen de muren. Overigens veronderstelt hij niet dat gevangenen het, naarmate hun emancipatieproces vorderde, ook prettiger zouden hebben.

"Dat is maar zeer de vraag, zoals het maar zeer de vraag is of vrouwenemancipatie vrouwen gelukkiger heeft gemaakt. $\mathrm{Zjj}$ hebben weliswaar meer rechten en vrijheden dan ooit, maar veel wijst er op dat het leven in onvrijheid voor veel gevangenen psychisch steeds moeilijker te dragen wall (......). In Nederland wordt het contact met de buitenwereld minder total afgesloten dan in buitenlandse gevangenissen. Dat voorkomt relationele schade en sociale wereldvreemdheid, maar het confronteert gevangenen wel steeds met de vrijheid die ze missen en het wrijft gevangenen wel voortdurend onder de neus wat ze met hun gevangenschap aanrichten in het leven van man, vrouw en kinderen."

Ook Kelk beschrijft de ontwikkeling van gunsten naar rechten als emanciperend. ${ }^{160}$ De gedetineerde is als rechtsburger erkend.

Franke verklaart de positie van de gedetineerde vrouwen gerelateerd aan die van mannelijke gedetineerden en niet vanuit een zelfstandige positie ten opzichte van gevangeniswezen. Hij meent dat de emancipatie van vrouwen "nog niet helemaal voltooid" is. ${ }^{\text {no }}$ Soetenhorst suggereert dat de versterking van de rechtspositie en het beklagrecht voor gevangenen in Nederland op mannen een meer emanciperend

167 Franke (1991) p. 353-354.

168 Franke (1991) p. 356-357.

169 Kelk (1993-2) p. 45-56.

170 Franke (1990) p. 704-712. 


\section{Hoofdotik 2}

effect zou hebben dan op vrouwen. ${ }^{17} \mathrm{Zij}$ laat daarbij in het midden of vrouwen nog een 'inhaalslag' moeten maken. Wel suggereert ze voor vrouwen een gedetineerdenvertrouwenspersoon aan te stellen. ${ }^{17 x}$

De Jonge geeft, op basis van Lestings normaliseringstheorie, aan dat het streven naar een zo groot mogelijke normalisering van het gevangeniswezen een bruikbare strategie voor gevangenishervorming is. ${ }^{13}$ Gevangenissstraf zal steeds minder afschrikwekkend worden, naarmate de levensomstandigheden daar beter zijn. Hij doet voorstellen tot normalisering van arbeidsverhoudingen. Normalisering bevestigt echter het dominante patroon in de samenleving. In het geval van vrouwen zou mijn inziens juist deze normalisering geproblematiseerd moeten worden, aangezien 'de normaliteit' vrouwen, maatschappelijk gezien, in veelal ongewenste patronen dringt.

Anderen zien in de verbetering van de condities in de gevangenissen het gevaar van 'netwidening'. Rechters zullen eerder geneigd zijn gevangenisstraffen op te leggen. ${ }^{174}$ Melk vindt echter dat het argument dat van een gevangenis, waarin positief aan het gedrag en de omstandigheden van de gedetineerden gewerkt wordt, een wervende kracht kan uitgaan door de feiten wordt weerlegd:

"Recente ontwikkelingen tonen aan dat de roep cm gevangenissen niet voortkomt uit de gunstige werking van de gevangenis, maar wit verhoogde en sterk verharde criminaliteit". ${ }^{\text {.75 }}$

Verwarrend is of het bij deze discussie gaat om de straftoemeting door justitie of om de publieke opinie en meningen van gekozen volkswertegenwoordigers. Daarbij kan de wisselwerking tussen die actoren ook nog een rol spelen.

Hoe dan ook lijken vrouwen zowel via emancipatie-als normaliseringsstrategieên in hun ambivalente afhankelijkheidsposities versterkt te worden.

In het buitenland zijn historiografische beschrijvingen aanleiding geweest tot analyses van het van 'op mannen georiënteerde gevangenissysteem' afgeleide bestaan van vrouwelijke gedetineerden. Hoewel er voor vrouwen aparte gevangenissen zijn, worden de hervormingsgerichte ideeën volgens een patriarchaal model ingevuld. Via activitei-

171 Soetenhorst (1987) p. 453-462.

172 Uit onderzoek kan niet echl afgeleid worden dat mannen in zijn algemeenheid eerder en meer beroep op hun rechten doen dan wrouwen. Ook machtsverschillen tussen mannen onderling binnen de gevangenishiërarchie zouden hier een rol kunnen spelen. Bovendien is het de vraag of juridisering van de verhoudingen in de bajes altijd het rooskleurige stempel van "beschaving" verdient. Voor zover beklagzaken van vrouwen de Beroepscommissie van de Centrale Raad voor Strafrechtstoepassing bereiken, lijkt het aantal klagers niet zozeer met sekse maar meer met locaties verbonden te zijn. De juridisering van de detentie komt in het volgende hooldstuk echter uitgebreider aan de orde.

173 De Jonge (1994) p. 250-252.

174 Wan Ransbeek (1992), Shaw (1996), Carlen en Tchaikowsky (1996).

175 Melk (1993) p. 785 
ten worden yrouwen in hun seksespecifieke rol gedrongen. Ze doen bijvoorbeeld de was voor de manneninrichtingen. ${ }^{176}$ De latere meer therapeutische benadering is ook gericht op aanpassing aan sociaal gewenst functioneren, waarbij het moedier. schap als overheersend ideologisch concept een grote rol speelt. ${ }^{27 t}$

\subsection{Politisering en macht}

Voor verschillende feministische onderzoekers is de geconstateerde seksestereotypering het sein geweest om de gevangenis als exponent en bekrachtiger van het patriarchale systeem en de dominante machtsverhoudingen te analyseren. Vamuit een wat. ambivalente houding zoeken zij aansluiting bij de theorie van Foucuult: ${ }^{\text {ro }}$

De maatschappelijke functie van straffen en gevangenissen staat in de theorie van Foucault centraal. ${ }^{170}$ Voortdurend wordt een scheiding in soorten wetsovertredingen aangebracht. De gevangenis isoleert en onderstreept bepaalde soorten wetsovertredingen en laat andere soorten, die men will of moet tolereren, in de schaduw. Daarmee kan de aandacht afgeleid worden van andersoortige criminaliteit van met name hogergeplaatsten.

Gevangenishervormingen zijn in deze visie alleen maar verfijningen wan de machtsuitoefening over lagere sociale klassen. De humanisering is in feite een vorm van overheersing en wordt ingegeven door eigenbelang van de machthebbers.

De kritiek op gevangenissen is vanuit dleze benadering al sinds jaar en dag dezelfde: de gevangenis wordt op grond van haar eigen doelstellingen gekritiseerd. Foucault onderscheidt daarbij zeven steeds in de kritiek terugkerende principes ${ }^{\text {soo: }}$

1. De gevangenis dient in de eerste plaats op verandering van het gedrag van individuen gericht te zijn. (beginsel van verbetering)

2. De gevangenis moet de gedetineerden verdelen op basis van de aard van het misdrijf, de leeftijd, het geslacht en dergelijke van de misdadiger. (beginsel van classificatie)

176 Vgl in Nederland de zwartboeken van de Solidariteitsgroep Vrouwelijke Gevangenen (1979, 1983). 177 O.a. Dobash, Dobash en Gutteridge (1986), Carlen and Worrall (1987), Carlen (1990), Eaton (1993), Bahavnani en Davis (1995), Carlen en Tchaikovsky (1996).

178 O.a. Dobash, Dobash and Gutteridge (1986.) Vgl. Howe (1990) p. 17:

"I will say here that a disdainful rejection of Foucault as simply phallocentric, would be counterproductive. And 1 say this despite the fact that he is, indisputely, "a profoundly androcentric wriler" (citaat. Morris) and also despite the fact that (and certainly not because) a male critic asserts that: "to write today about punishment and classification without Foucault is like talking about the unconscious without Freud (citaat Cohen)." This is not the place to create a usable Foucault for feminist historians. It suffices to say that he does provide a smorgasbord of possibilities."

179 Foucault (1979).

180 In: Lambrechts (1982) p. 141. 


\section{Hoofidstuk 2}

3. De gevangenisstraf moet variëren al naargellang het gedrag van de gedetineerde (beginsel van strafmodulatie).

4. Arbeid is in de gevangenis essentieel en mag niet worden gezien als verzwaring van de straf, maar veeleer als een ondersteuning van de gevangene en zijn gezin (beginsel van arbeid als plicht en recht)

5. De gevangenis moet de gevangene een opvoeding geven (beginsel van de opvoeding)

6. De gevangenis moet worden bewaakt door gespecialiseerd personeel (beginsel van technische controle)

7. De gevangenis moet door een aantal maatregelen op het vlak van de reclassering worden gevolgd (beginsel van gekoppelde instellingen)

Foucault denkt dat de mislukking van de gevangenis bewust gereproduceerd wordt, omdat de gevangenis er niet zozeer is om wetsovertredingen tegen te gaan, maar om soorten wetsovertredingen te onderscheiden, te verdelen en te gebruiken. De gevangenis creëert als het ware de criminaliteit in plaats van andersom.

Onder andere Smart en Cain hebben de disciplinerende werking van de vrouwengevangenis en de beelden van vrouwencriminaliteit gedeconstrueerd. ${ }^{\text {18" }}$

Vamuit een abolitionistisch perspectief bekritiseren. Bhavnani en Davis de huidige disciplineringstendensen binnen het gevangenissyssteem als exponenten van heersende maatschappelijk dominante opvattingen: ras als criminele factor, de waardering van voeding in combinatie met de cultus van het lichaam, de angst voor seks en de overwaardering van het biologisch moederschap als panacee voor alle maatschappelijke ellende. Zij benadrukken evenals Carlen dat vrouwen niet alleen maar als 'sociale slachtoffers' moeten worden afgeschilderd, waarvoor binnen de inrichting resocialisatieprogramma's moeten worden bedacht. ${ }^{13}$ De meeste vrouwen horen niet in gevangenissen thuis. De selectie via de strafeis en de straftoemeting moet bekritiseerd worden. Alleen de hele kleine groep die echt gevaarlijk is of een woor de samenleving zeer schokkende misdaad heeft begaan, moet gedetineerd worden. Aan het aantal detentieplaatsen moet een limiet worden gesteld omdat ongebreidelde uitbreiding van capaciteit en voorzieningen tot netwidening leidt. ${ }^{1 * 4}$

181 Smart (1990), Cain (1990).

182 Bhavnani en Davis (1995).

183 Carlen (1990,) Carlen en Tchailkowsky (1996).

184 Carlen en Tchaikovsky (1996). 


\subsection{Samenvatting}

Dit hoofdstuk handelt over de gevangeniscultuur. De jurist gaat uit van juridische feitenvaststellingen en dreigt daardoor de veelheid aan verschillen in verhalen die daaraan ten grondslag liggen weleens uit het oog te verliezen. In dit hoofdstuk is dan ook teruggegrepen op empirisch onderzoek dat niet vanuit juridisch perspectief verricht is. Allereerst is een impressie gegeven van de ervaringen van gedetineerde vrouwen in Nederland. Daarbij is aandacht besteed aan hun onderlinge verhoudingen, aan hun verhouding tot de mensen die met hen werken, aan hun dagbesteding, aan hun relaties buiten de inrichting, hun problemen rond seksualiteit, het gemis aan privacy en de behoefte aan intimiteit. Dit laatste en de zorg voor hun kinderen houdt de vrouwen het meeste bezig. Het valt op dat de problemen door de jaren heen dezelfde blijven, ook al zijn de diverse interviews op verschillende momenten en locaties gehouden. Dat maakt maar weer eens duidelijk hoe totaal de greep van de institutie is op de gedetineerde vrouwen, ondanks veranderingen en verbeteringen in het beleid, de rechtspositie en de accomodaties, waarover in de volgende hoofdstukken meer volgt.

De theoretische verklaringen omtrent het effect van een verblijf in een totale institutie leiden tot verschillende conclusies ten aanzien van specifieke effecten op vrouwen. Vanuit studies naar psychosociale processen wordt geconstateerd dat het overlevingsgedrag van vrouwen vooral op aanpassing is gericht en ook dat de seksuele contacten die vrouwen in detentie aangaan vooral met het 'naspelen van het gezin' te maken hebben. Verder lijken de vrouwen met nog grotere identiteitscrises dan mannen te maken hebben doordat zij gesocialiseerd zijn in een afgeleide identiteit (dochter van/ partner van/ moeder van). Ook vrouwen die niet aan een vaste leefsituatie gebonden waren voor hun detentie voelen zich afgesloten tot de mogelijkheid daartoe. Vooral seksualiteit is voor veel vrouwen het middel om zich een plek te verwerven in een bepaalde maatschappelijke structuur. Voor zover er in het detentiebeleid rekening wordt gehouden met de seksespecifieke rol van vrouwen staat die in wrang contrast met de maatschappelijke werkelijkheid, waar de oorspronkelijke basis, door de detentie, vaak zo goed als verdwenen is. De versterking van de rechtspositie van gedetineerden die vanuit de emancipatietheorie als tegenwicht tegen de effecten van de totale institutie naar voren wordt gebracht, lijkt op mannen een meer emanciperend effect te hebben dan op vrouwen. De gevangenis steeds meer te doen lijken op de 'normale samenleving', alls strategie tot gevangenishervorming, lijkt in het geval van vrouwen een paradox. De normaliteit kan immers veelal leiden tot ongewenste seksestereotypering. De gevangenis wordt dan de bekrachtiger van dominante systemen, waaronder het patriarchale. Het moederschap dient daarbij als ideologisch concept, terwijl de vrouwen verder als 'sociale slachtoffers' gestigmatiseerd worden. Uit de naar voren gehaalde thema's zoals de hiërarchie in de groep, het sluiten van vriendschappen, de seksualiteitsbeleving, de waardering van familierelaties, de ambiva- 
lenties ten opzichte van het moederschap en de financieeleconomische positie, blijkt echter dat in detentie een weerspiegeling van de maatschappelijke realiteit te zien is. Het lijkt niet alleen om problemen van gedetineerde vrouwen te gaan. Er zit een grote mate van gemeenschappelijkheid in wrouwenkwesties. Spreken over de seksualiteit of familiebanden van gedetineerde wrouwen zegt ook lets over de (contemporaine) identiteitsontwikkeling van vrouwen in het algemeen met alle onderlinge verschillen die er zijn. Zelfs in de overlevingsstrategieën (drugs/medicijnverslaving en psychiatrische problematiek) van gedetineerde vrouwen zouden parallellen met de soms verborgen leefwijze van veel 'vrije' vrouwen gezocht kunnen worden. De mate waarin er op al die terreinen verschillen optreden tussen vrouwen onderling, is veelal te verklaren uit culturele verschillen in achtergrond. De groep gedetineerde vrouwen is voor het doen van onderzoek een ideale groep omdat daar die culturele verschillen zo scherp zijn waar te nemen. Dat pleit voor een uitgebreid penologisch onderzoek onder vrouwen, waarbij niet alleen de ervaringen tijdens detentie onderzocht worden, maar ook de importvariabelen èn waarbij een follow-up studie gedaan wordt om het resocialisatieproces in kaart te brengen. 


\section{Detentiebeleid na WO II}

\section{Inleiding}

Uit de voorgaande hoofdstukken blijkt dat één van de kritiekpunten op het onderzoeks- en gevangenisbeleid is, dat het geënt is op de mannelijke maat. Doordat gedetineerde vrouwen een sterke minderheid vormen, wordt er aan hen weinig aandacht besteed. De vraag is nog of dat uitsluitend door de beperkte kwantiteit komt. Het kleine aantal zou immers juist een argument kunnen vormen om wel een gericht beleid te ontwikkelen. Het is meer waarschijnlijk dat deze vrouwen als groep geen factor van belang zijn in de maatschappelijke machtsverhoudingen, Ze zijn niet verstorend, bedreigend of bepalend voor de maatschappelijk orde. Ze wijken bovendien vaak negatief af van de vrouwelijke norm en roepen daardoor weinig solidariteit op.

Als de mannelijke maat echter leidt tot een humaan detentiebeleid is het de vraag of vrouwen er met een daarvan afgeleid beleid slecht vanaf komen. Vanuit een emancipatieperspectief lijkt dat mogelijk niet zo. Zoals in het vorige hoofdstuk aan de orde kwam, zouden vrouwen dan immers via een 'inhaalslag' op een gelijk niveau kunnen komen. Dit zou tot het geruststellende gevoel kunnen leiden dat het in Nederland, met zijn milde gevangenisklimaat, voor vrouwen nog zo slecht niet is. Om de juistheid van dat idee te onderzoeken wordt in dit hoofdstuk eerst een kort algemeen beeld geschetst van het gevangenisbeleid na de Tweede Wereldoorlog. Vervolgens wordt gekeken wat de implicaties van dat beleid zijn geweest voor vrouwelijke gedetineerden. Aan de hand van specifieke problemen die uit de eerdere hoofdstukken naar voren kwamen, worden beleidsinitiatieven aan de hand van enkele thema's nader uitgewerkt en becommentarieerd. 


\subsection{Kenmerken van het overheidsbeleid}

Voor mijn onderzoek acht ik in de beleidsworming vooral de naoorlogse periode interessant, met name omdat toen het centrale artikel $26 \mathrm{BGW}$ een rol ging spelen bij het bepalen van het doel en de invulling van de straf.' Dit artikel luidt:

"Met handhaving van het karakter van de straf of de maatregel wordt hun tenuitvoerlegging mede dienstbaar gemaakt aan de voorbereiding wan de terugkeer in het maatschappelijk leven".

Franke gaat uitgebreid in op de suggestie dat de inwoering van de Beginselenwet is terug te voeren op ervaringen van gevangenen onder het nazibewind in de Tweede Wereldoorlog. ${ }^{2}$ In die periode ervoeren sommige gezaghebbende mensen immers aan den lijve wat gevangenschap is. ${ }^{3} \mathrm{Zij}$ zouden, toen zij opnieuw maatschappelijk invloedrijke posities konden bekleden, gepleit hebben woor een humanere bejegening van gevangenen. Franke betoont zich kritisch tegenover een te romantisch beeld en meent dat de na-oorlogse hervormingen vooral stroomversnellingen zijn van ontwikkelingen die al voor de oorlog waren ingezet ${ }^{4}$ Hoe het ook zij, vlak na de oorlog kwam de commissie Fick met ingrijpende hervormingsvoorstellen: afschaffing van het cellulaire stelsel en differentiatie en selectie van gedetineerden binnen de inrichtingen. ${ }^{5}$

Kelk ziet in het ontstaan van de Beginselenwet en de gelijktijdig ingevoerde Gevangenismaatregel (1953) vooral de erkenning van de autonomie van de gevangene. Over de artt. 26 en 26 bis stelt hij":

"Zij tenderen beide naar de noodzaak van participatic van de gedelincerde in het recht, dus wan diens rechtsburgerschap, zij het wanuit verschillcnde optick: respectievelijk die van optimale rechtsgelijkheid van de burgers onderling, inhoudende cen zo gering mogelijke aantasting van hun integriteit alsook als rechtsgenoten (beginsel van minimale beperkingen) en die wan de maatschappelijkc positic van de burgers, inhoudende het behoud of het herstcl van matschappelijke functics, dus van hun sacialle medeburgerschap (resocialisaticheginsel)" ?

1 Zie voor de historie met name Franke (1990) en Spierenburg (1991), In 1935 verscheen een uitgebreid inventarisatierapport over inrichtingen voor vrouwen en meisjes van het Nederlandsch Genootschap tot zedelijke verbetering der gevangenen.

2 Franke (1990) p. 632-644.

3 Zie bijwoorbeeld De Graaff (1996) p. 88.

4 Zie ook De Haan (1995).

5 Commissie Fick (1947).

6 Art. 26bis BWG (voor onveroordeclden) luidt: "Zij dienen aan geen andere beperkingen onderworpen te worden dan die voor het doel hunner opsluiting of het belang der orde volst rekt noodzakelijk zijn".

7 Kelk (1993-1) p. 33-34. Kelk vindt dat de beginselen sterk naar clkaar toegrocien, hetgeen bevest igd wordt door het feit dat ze in het wetswoorstel PBW (TK 1994-1995, nr. 24263) in eén artikel voor 
In art. 26 BGW zijn zowel het veiligheidsaspect en de strafhandhaving als het resocialisatiedoel te onderscheiden. Schuyt spreekt over de fopspeenwerking van het artikel:

"de twee delen ontkrachten elkaar, zodat het niet verwonderlijk is dat iedereen het met zo' $n$ artikel eens is".8

Een terugblik in de geschiedenis vanaf 1947 , als het rapport van de Commissie. Fick verschijnt, tot nu laat zien dat in de loop der tijd accentverschuivingen plaatsvinden van het resocialisatiestreven via de decriminalisering naar de accentuering van het veiligheidsaspect van de gevangenissstraf.' In de jaren zestig staat, bijvoorbeeld in de Nota Scholten (1964), het resocialisatiebeginsel nog centraal. Leefeenheden, sociotherapie en de professionalisering van het maatschappelijk en later sociaalcultureel werk leiden tot hoge verwachtingen omtrent houdings- en gedragsveranderingen bij de gedetineerden. Maar ook de twijfel over de schadelijke effecten van het gevangenisverblijf en de zorgwekkende recidivecijfers blijven niet onopgemerkt. Studies over totale instituties en de schadelijke gevolgen van sociale isolatie worden bekend. In de Nota Zeevalking (1976) wordt de gevangenisstraf 'ultimum remedium'. Ten behoeve van de gedetineerden worden contacten met de gewone samenleving aangemoedigd via gespreksgroepen, sportieve evenementen en andere activiteiten. De Gevangenismaatregel wordt in 1977 herzien. Gedetineerden krijgen meer mogelijkheden tot contact met de buitenwereld, via bijvoorbeeld kranten, tijdschriften, radio en televisie, bezoek- en telefoonregelingen.$^{10}$ In de jaren tachtig worden de hoge verwachtingen ten aanzien van gedragsverandering en vermindering van recidive echter teruggeschroefd. In de Nota Taak en Toekomst van het Gevangeniswezen (1982) wordt gewaarschuwd voor een te ambitieuze invulling van het resocialisatiebeginsel:

"De gedachte dat de gedetineerde tot een beter mens moet worden gemaakt, lijkt niet erg realistisch". En vervolgens: "wel kan de detentie worden benut om de terugkeer van de gedetineerde in de samenleving beter woor te bereiden, zodat hij ook eerder in de samenleving geaccepteerd wordt en -wellichtzich zelf daarin beter weet te handhaven dan voordien het geval was"."

alle gedetineerden zijn ondergebracht (art. 2).

8 Schuyt (1991) p. 1.04.

9 Zie voor uitgebreide beschrijvingen Vegter (1989) p. 39-72 en Franke (1990) p. 636-755. Een overzicht van de ontwikkelingen gedurende de laatste tien jaar is te vinden in Van Swaaningen en De Jonge (1995),

10 In het rapport van de Commissie doelstelling en functie huis van bewaring (1977) wordt expliciet aandacht besteed aan de seksuele nood bij manmelijke gedetimeerden. Bezoek zonder toezicht. en pornografische afbeeldingen op de cel worden geintroduceerd.

11 Nota Taak en toekomst van het Nederlands Gevangenisweren (1981-1982) p. 21. 
In deze zelfde nota worden dan ook drie in elkaars verlengde liggende doelen geformuleerd:

1. humanisering van de detentie;

2. het voorkomen en/of beperken van schadelijke effecten;

3. de voorbereiding van de terugkeer in de samenleving.

In zijn inaugurele rede geeft Tulkens de begrenzingen van de gevangenisstraf weer:

"De gevangenisstraf impliceert dat het individu en dus zijn zelfherstel secundair zijn. Niett ondat de rechter dat bedoelt, maar omdat het in de 'natuur' van de gevangenis ligt. Zij maakt het uiterst moeilijk gedetineerdlen te overtuigen van de waarachtigheid van op zelfherstel gerichte bedoelingen. ${ }^{12} \mathrm{En}$ die natuur heeft hij eerder beschrewen: "Het zijn dwanginstituten. Degenen die er geplaatst worden, worden gedwongen er te blijven. Daartoe is verregaande reglementering, overzichtelijkheid, discipline en controlle nodig. Deze twee eigenschappen, bedrijfsmatigheid en beveiliging, versterken elkaar en maken de gevangenis tot een systeem, waarim speciaal preventieve doeleinden van zelfherstel niet of zeer beperkt zijn te realiseren."

Binnen de paradoxale context van de gevangenis wordt toch gezocht naar mogelijkheden om op de individuele capaciteiten van gedetineerden aan te sluiten. Zo ontwikkelt De Haas een model voor psychosociale gezondheid, toegespitst op de detentiesituatie. ${ }^{14}$ Het gaat daarbij om de wisselwerking tussen het individu aan de ene kant en de sociale situatie waarin hij of zij verkeert aan de andere. Dat betekent dat er informatie moet zijn over zowel de psychosociale vaardigheden van het individu als over de psychosociale kwaliteit van de situatie. Hij onderscheidt vier basale vaardigheden die zowel naar de negatieve als de positieve kant kunnen 'doorslaan'.

"Het gezonde individu is in staat zich open te stellen zonder overspoeld te raken, zich aan te passen zonder in een machteloos volgen verzeild te geraken. Het weet invloed uit te oefenen zonder op een negatieve manier te domineren en het kan zich afsluiten zonder in een isolement te geraken. De positieve mogelijkheden die de psychosociale vaardigheden in zich bergen: zich én voelen met, in harmonie zijn met, zichzelf als competent en zelfstandig beschouwen, hoeven, willen we onszelf psychosociaal gezond noemen bepaald niet dag in dag uit voor te komen. Aan de basis voor psychosociale gezondheid ligt naar onze mening wel de verwachting van het individu dat dergelijke positieve ervaringen niet uitgesloten zijn. ${ }^{\text {Hts }}$

Een bepaalde situatie, of het nu het gezin, het werk, de school, de buurt of de gevangenis betreft, is volgens De Haas van voldoende psychosociale kwaliteit als diegenen die deel uitmaken van die situatie in staat zijn zich open te stellen, zich aan te passen,

12 Tulkens (1988) p. 16.
13 Tulkens (1988) p. 15.
14 De Halas (1989) p. 12-28.
15 De Haas (1989) p. 23. 
invloed uit te oefenen en zich af te sluiten. ${ }^{16}$ Verrassend komt hij vervolgens tot de constatering dat de meest onvrijwillige situaties in onze cultuur die van het pasgeboren kind en die van de in een HvB of gevangenis opgesloten gedetineerde zijn. ${ }^{\text {? }}$ Betrokkenen hebben namelijk geen enkele mogelijkheid zich eraan te onttrekken. Beide situaties vereisen dan ook een optimale psychosociale kwaliteit. Niet om de gedetineerden te vertroetelen, maar om te zorgen dat hun aanwezige psychosociale gezondheid niet achteruitgaat en eventueel om hen in staat te stellen bepaalde vaardigheden te ontwikkelen. Op grond van zijn model pleit hij voor verdergaande differentiëring in de opvang van gedetineerden. Selectie en plaatsing zouden moeten plaatsvinden op basis van persoonlijkheidskenmerken, bijvoorbeeld introvert-versus extravertgeoriënteerden, met name bij langgestraften die veel langer de effecten van hun psychosociale omgeving ondergaan.

In de jaren tachtig en negentig verandert de gedetineerdenpopulatie. Niet alleen het aantal gedetineerden neemt toe, ook de probleemgevallen onder hen: ${ }^{18}$

Van Alem c.s. menen dat het toegenomen aantal verslaafden het stelsel van regiemsdifferentiatie en de verschuiving van resocialisatie, met het oog op de periode na detentie, naar een meer pragmatische aanpak gekenmerkt door hulpverlening tijdens detentie versneld heeft ${ }^{10}$ In de aard van de opvang wordt er naar gestreefd rekening te houden met persoons- en persoonlijkheidskenmerken, waardoor er steeds meer verschillende opvangmogelijkheden (regiems) worden gerealiseerd, bijvoorbeeld de drugsvrije afdelingen, het alcolholverkeersprogramma, extra beveiligde inrichtingen voor vluchtgevaarlijke gedetineerden, een forensische observatie- en begeleidingsafdeling etcetera. Ook de detentiefasering, geleidelijke reïntegratie via afnemende vrijheidsbeperking, wordt verder ingevuld via een uitgebreid verlofstelsel en dagdetentie. ${ }^{20}$ Het bestaande differentiatiestelsel komt door deze ontwikkelingen onder druk te staan. Er wordt een stuurgroep ingesteld door de Minister van Justitie om tot herziening van het differentiatiestelsel te komen, waarbij recente beleidsontwikkelin-

16 De Haas (1989) p. 25.

17 De vergelijking is aardig omdat hij de infantilisering verbecldt. Overigens denk ik in dit verband ook aan ernstig zieken en anderszins aan bed of huis gekluisterden. De lysieke alhankelijkheid blijft sowieso vaalk buiten beschouwing. Jvist in deze situaties zijn het zintuiglijke contact, de aanraking, blijken van affectie en aandacht voor ruimtelijke sfeer zo wezenlijk.

Zie ook de Nota Samenieving en Criminaliteit (1985), waarin de harde aanpak wan de drugscriminaliteit noopt tot meer cellenbouw. Hoewel er tegelijkertijd steeds meer alternatieve straffen (vermogenssancties, taakstraffen) gecreëerd worden, leidt dit uiteindelijk niet tot een alname van het aantal gevangenisstraffen. Met name de lengte van de straften neemt toe. Zic onder meer Verhagen (1989), Vegter (1993), Kester en Junger-Tas (1994) p. 69-71.

19 Van Alem, Erkeliens, Schippers, Breteler en Bekking (1989) p. 57.

20 In 1995 is het experiment met elektronisch huisarrest gestart. (TK 1994-1995, $23900 \mathrm{VI}$, nr. 29, NJB 1995, p. 1061). Zie voor cen kritische bespreking naar aanleiding van het rapport Schalken over dit onderwerp onder andere Van der Pijl-van Andel (1990) p. 291-294. 


\section{Hoofdstuk 3}

gen een wettelijke basis dienen te krijgen en waarin ruimte wordt gecreëerd voor toekomstige ontwikkelingen. De stuurgraep rapporteert in oktober 1991. IInmiddels is ook de beeldvorming rond criminelen en criminaliteit weranderd. Er treedt, met name in de publieke opinie en de politiek, een mentaliteitsverharding op. Die uit zich ook bij rechters in de vorm van langere en repressievere straffen. Gijzelingen en gewelddadige ontsnappingen zijn hiervan mogelijk een gevolg. ${ }^{2}$ De hardere aanpak van de (georganiseerde) criminaliteit doet de roep om beveiliging en vergelding. toenemen. Dit heeft zijn weerslag in de in 1994 verschenen beleidsnota "Werkzame detentie". De voorzleningen staan niet meer ongelimiteerd open woor alle gevangenen. Het regiem van beperkte gemeenschap wordt de uitgangspositie. Om voor voorzieningen, via een penitentiair programma, in aanmerking te komen, moeten gevangenen zich gemotiveerd tonen. 'Werk' staat centraal, individuele rechten moeten meer en meer 'verdiend' worden. In het in 1995 bij de Tweede Kamer ingediende wetsvoorstel Penitentiaire Beginselenwet krijgen zowel het differentiatiestelsel als de beveiliging en het penitentiaire programma een wettelijke basis. ${ }^{24}$ In de in 1996 gepresenteerde nota "In juiste verhouding" toont de minister zich bezorgd over de naar haar mening al te eendimensionale aanpak van criminaliteitsbestrijding door cellenbouw. Maar ook alternatieve straffen vormen naar haar idee slechts een beperkte oplossing.

"De conclusie dient daarom ook te zijn dat het gebruik van de vrijheidsstraf als hoeksteen van het veiligheidsbeleid ten gronde moet worden overwogen. ${ }^{.25}$

21 Rapport van de stuurgroep Herziening differentiatiestelsel (1991). De stuurgroep baseerde zijn advies op de rapporten van drie afzonderlijke werkgroepen:

- Interne en externe differentiatie,

- Vrouwen in detentie,

- Extramurale executiemadaliteiten.

22 Zie o.a. Van Ruller (1993). Overigens is er in de vrouweninrichtingen geen sprake van gijzelingen en ontsnappingen. Toch lijken zij wel medeslachtoffers te zijn geworden van die zogenaamde mentaliteitsverharding.

23 Nota Werkzame detentie, TK 1993 1994, 22 999, nrs. 10-11.

24 TK 1994-1995, nr. 24263.

25 Beleidsnota 'In juiste verhouding' (1996) p. 18.

$\mathrm{Zij}$ stelt voor een driesporembeleid te voeten, dat bestaat uit:

- toespitsing op criminaliteitspreventie, met name bij risicogroepen onder de jeugd;

- overleg met de PG over beheersing van vooral de langere vrijheidsstraf via het requireerbeleid; - vitbreiding van de capaciteit van justitiêle inrichtingen en reclassering, mede ten behoeve van het lokale veiligheidsbeleid, inclusief de verslavingszorg. 


\subsection{Kenmerken van het overheidsbeleid ten aanzien van vrouwen}

Als vrouwen gedetineerd worden, kun je je ten aanzien van de doelstellingen en beginselen van gevangenneming afvragen of er sprake zou moeten zijn van een specifieke invulling voor vrouwen. Het is intrigerend om te zien of veranderende emancipatieopvattingen in de naoorlogse periode hun weerslag hebben gekregen in de ontwikkeling van het beleid ten aanzien van vrouwen in penitentiaure inrichtingen. ${ }^{26}$ Leidt veranderende socialisatie ook tot specifieke resocialisatie? De Commissie Fick spreekt in 1947 vanuit stereotiepe rolpatronen over

"de specifiek vrouwelijke behoefte aan grotere huiselijkheid" en "gedifferentieerde arbeid die het gemoedsleven van vrouwen aanspreekt (men denke aan het vervaardigen van versieringen, speelgoed en kleertjes woor kindertehuizen etc. $)^{\mathrm{m} 27}$

Van Bemmelen houdt in 1954 een haast dromerig pleidooi voor een speciaal gesticht voor vrouwen. ${ }^{23}$

"Dat gesticht, ergens centraal in het land gelegen, moet zodanig zijn, dat het vrouwen de gelegenheid biedt zich meer dan thans vooral op huiswrouwelijke arbeid toe te leggen met daarnaast woldoende variaties in typisch vrouwelijke beroepen." ${ }^{\text {s }}$

In de Nota Scholten (1964) wordt een vrouwengesticht in het vooruitzicht gesteld. Gedetineerde vrouwen zijn, weliswaar gescheiden, ondergebracht in afdelingen van manneninrichtingen en dat maakt het volgens de nota

"niet goed uitvoerbaar recht te doen aan de eigen aard van de wrouw, noch op het gebied van materièlle verzorging noch op dat van de bejegening. Het te bouwen vrouwengesticht zall wat inrichting en aankleding betreft geheel op vrouwen kunnen worden afgestemd. Ook zal getracht worden de vereiste sfeer te scheppen, die voor vrouwen van zoveel belang is. Het spreekt vanzelf, dat zal worden getracht het programma van wederaanpassing geheel op de capaciteiten en interessen van de vrouw te richten al zal hierbij zeker nog een tijd van experimenteren nodig zijn. ${ }^{400}$

In 1965 doet Niekerk een uitgebreid inventarisatieonderzoek onder vrouwelijke gevangenen terwijl eenzelfde onderzoeksopzet bij mannelijke gevangenen wordt gehanteerd door Rijksen. Het laatste onderzoek leidt tot publicatie, het eerste niet. Waarom dat niet is gebeurd, is onduidelijk. Franke suggereert dat de openlijke en

26 Vgl. de vraagstelling van Rutenfrans (1989) ten aanzien wan de criminaliteitscijfers.

27 Commissie Fick (1947) p. 51.

28 Van Bemmelen (1954) p. 82-87.

29 Van Bemmelen (1954) p. 86.

30 Nota "Het Nederlands Gewangeniswezen" (1964) p. 32. 
uitgebreide aandacht die aan het thema seksualiteit en lesbische relaties gegeven werd, terughoudendheid bij de openbaarmaking in de hand heeft gewerkt. ${ }^{3}$ Nagel citeert overigens wel uit het rapport. ${ }^{32}$ De commissie "Huwelijksproblemen van gedetineerden" gaat in 1966 ook apart in op de positie van de gedetineerde vrouw. ${ }^{33}$ Zij geeft een aantal specifieke kenmerken weer:

- De vrouw zou zwaarder lijden onder de publieke opinie.

- Het achterlaten van het gezin is voor haar een zwaardere ingreep dan voor de man, ook gelet op de mogelijkheid dat haar plaats door een andere vrouw zal worden ingenomen en gelet op de vrees voor een officieel ingrijpen.

- De vrouw is door haar afhankelijke maatschappelijke rol vaak minder voorbereid om de consequenties van de detentie te weerstaan. Overigens merkt de commissie op dat een grote meerderheid van de vrouwen uit bevolkingslagen komt waar weinig sprake zal zijn van een beschut leven in afhankelijkheid.

- De accomodatie biedt onvoldoende mogelijkheden voor een verantwoorde selectie. Bovendien zitten onveroordeelde en veroordeelde vrouwen bij elkaar.

- Er is een zeer groot aantal min of meer geestelijk gestoorden. De commissie denkt dat daarom een meer open regiem niet haalbaar zou zijn.

"Tenslotte meent de conmissie dat, waar voor de detentic van de vrouwelijke gedetineerden de beperkingen vanuit de alleen al bouwkundige accommodatie well zeer pregnant blijken te zjjn, alle redenen bestaan om versneld uifwoering te geven aan de noodzakelijke bouwkundige woorzieningen voor de onderbrenging van gedetineerde vrouwen. ${ }^{3 i t}$

In de periode van grote teruggang in het aantal gedetineerde vrouwen wordt er op beleidsniveau niet veel aandacht meer aan de groep besteed. De nieuwbouw gaat ook niet meer door. ${ }^{35}$ Wel worden er kritische publicaties gewijd aan het benauwende regiem in de (toen enige) vrouweninrichting in Rotterdam. ${ }^{36}$ Dan verschijnt in 1977/1978 de Beleidsnotitie inzake het beleid van gedetineerde vrouwen van Staatssecretaris Haars. Zij geeft aan dat het beleid zich in beginsel niet onderscheidt van dat ten opzichte van mannelijke gedetineerden, maar

31 Franke (1990) p. 708.

32 Nagel (1977) p. 100 e.v. (citaat : Nickerk 1969, p. 114-119).

33 Commissie "Huwelijksproblemen wan gedetineerden' (1966) p. 38-39.

34. Commissie "Huwelijksproblemen van gedetineerden (1966) p. 39.

35 Quant-Worms (1972). Zie voor een uitgebreid verslag van de ontwikkelingen in de na-oorlogse periode: Franke (1990) p. 704-712. "In 1973, juist toen de situatie van mannelijke gevangenen in hoog tempo verbeterde, werd het plan woor nieuwbouw in Arnhem definitief opgegeven" (p. 707). Eerder geeft Franke aan hoe in de zeventiger jaren seks meer en meer werd beschouwd als iets waarop ook gevangenen recht hadden. Dit resulteerde onder andere in het "bezoek zonder toezicht" en het todaten van porno in de manneninuichtingen (0.a. p. 679).

36 Betlem (1978), Brinkhuizen (1978). De wakbond voor justitieklanten kreeg in de vrouwengevangenis de mogelijkheid tot het verlenen van individuele hulp binnen de bezoekregeling. 
"het feit dat dit geringe aantal bovendien aan nogal aanzienlijke schommelingen onderhevig blijkt, maakt bet voeren van cen verantwoond beleid tot cen geenszins eenwoudige aangelegenheid".

In de nieuwe inrichting in Amsterdam zal intern gedifferentieerd worden in functionele groepen volgens het paviljoensysteem. Door de opening van een paviljoen in Maastricht ontstaat de eerste mogelijkheid tot differentiatie. ${ }^{37}$ In moties wordt aangedrongen op

"gelijke behandeling als mannen, met name ter zake wan woorlopige hechtenis, proefverloven en beloning voor arbeid, en experimenten te deze, en dat zij gelijke behandeling krijgen bij het differentièren van de regiems van lang- en kortgestraften"

en het creëren van een half open en/of open inrichting voor vrouwen. ${ }^{38}$ In 1979 verschijnt, op de dag van de opening van de nieuwe vrouwentoren De Singel in Amsterdam, het eerste zwartboek van de Solidariteitsgroep Vrouwelijke Gevangenen. ${ }^{35}$ Die klaagt daarin de driedubbele discriminatie van vrouwen aan : als vrouw, als gedetineerde en als gevangene in een voor mannen bedacht systeem.

Rond de verhuizing naar De Singel is er tijdelijk veel aandacht voor de vrouwelijke gevangenen." Daarna lijkt het rustig te zijn. Er worden VOS en yoga-cursussen aangeboden. Er is een aanbod van vrouwelijke activiteiten, maar dat is wel stereotiep: vrouwen werken in de wasserij en schoonmaakdienst en kunnen kook-en naaicursussen volgen. ${ }^{4.42}$

Door de Solidariteitsgroep Vrouwelijke Gevangenen worden in 1983 concrete problemen en oplossingen aangegeven in een nieuw zwartboek. ${ }^{43}$ Daarin vergelijkt de

37 Beleidsnotitie inzake het beleid met betrekking tot gedetineerde vrouwen TK 1977/78 Begroting VI 14800, nr.22.

Verslag openbare commissievergadering over de nota Beleidsvraagstukken gevangeniswezen, 10 april 1978, 348 .

38 Motie kamerleden Wessel-Tuinstra en Zeevalking, TK $1977 / 78,14102$, nr 22.

Motic Haas-Berger, TK $1977 / 78,14102$, nr. 16.

39 Solidariteitsgroep Vrouwelijke Gevangenen (1979).

40 Vrouwenkrant Rotterdam (1978), De Boer (1978), Vrouwentongen (1978), Rooie Vrouwen in de PydA (1978), Soetenhorst (1978), Bijker (1978), Van H.(1979), Van Stegeren.(1979), Vrouwenkrant (1979), Besier (1979), Van Haaren (1979), Van H.(1980), Verrijn Stuart(1981).

41. Balans Themanummer (1981).

42 In 1982 wordt het Tussenfase huis in Amsterdam opgericht, een opwanghuis woor ex-gedetineerde wrouwen, gerund door vrijwilligers, die geen banden met Justitie hebben. In 1987 wordt het vijfjarig bestaan herdacht. (Tussenfasehuis: vijf jaar toevlucht voor ex-gedetineerde wrouwen, Kri, 1987, p. 12). In 1992 vindt er een symposium plaats met als doel het woortbestaan van het Tussenfasehuis veilig te stellen. Veertien jaar na oprichting functioncert het huis nog steeds. Er werken twee betaalde vrijwilligers, twee vaste wrijwilligers en zes oproepbare wrijwilligers. (Justitiekrant 1996/4, p. 7-8.).

43 Solidariteitsgroep Vrouwelijk Gevangenen (1983). 
groep tevens de verschillen in aanpak tussen Amsterdam, Maastricht en Groningen, waar inmiddels de poorten ook 'geopend" zijn voor vrouwen." Tevens wordt als feministisch ideaal uitgedragen: "creëer een kleinschalige leefgemeenschap voor vrouwen". In een interview met Opzij verklaart een justitievoorlichter in 1983 heel optimistisch dat hij verwacht dat de open vrouwengevangenis er binnen een half jaar zal zijn."

Het beleid blijkt echter uitsluitend gericht te zijn op uitbreiding van en differentiatie in de plaatsingsmogelijkheden voor vrouwen. Er komen in 1987 nieuwe locaties bij, waaronder naast gesloten plaatsen een 'echt' open deel in Utrecht en een halfopen inrichting in Sevenum. " Daarnaast trekt de komst van de nieuwe, mannelijke, directeur in De Singel aandacht. ${ }^{47}$

Intussen wordt er vanuit het WODC een inventarisatie-onderzoek verricht in de drie (dan bestaande) inrichtingen ${ }^{48}$ Het is een onderzoek dat zich tot alle vrouwen richt en daardoor een betrouwbaar beeld van de populatie geeft. Het onderzoek wordt scherp bekritiseerd door Zwering en in navolging van haar door Verrijn Stuart. ${ }^{\text {ty }}$ De onderzoeksters zouden zich teveel aan het inrichtingsgebeuren geconformeerd hebben, zich te weinig met de seksespecifieke achtergronden hebben beziggehouden en daardoor te weinig doorgevraagd hebben. Zwering zelf doet een, haars ondanks, weinig representatief onderzoek naar het leven in de Amsterdamse vrouwengevangenis en baseert zich met name op verhalen van (vijf) ex-gevangenen en op 'hear-say' van een aantal hulpverleners. Zij probeert haar bevindingen in een feministisch kader te plaatsen. ${ }^{50} \mathrm{De}$ bevindingen uit beide onderzoeken zijn in het vorige hoofdstuk inhoudelijk verwerkt. De vrouwen hebben het meest te kampen met de zorg over hun kinderen en overige (familie) relaties. Bij velen was dat voor hun detentie ook al zo, maar de problemen lijken te zijn verergerd. Verder komen de problemen rond seksualiteit naar voren. De vrouwen missen privacy en hebben behoefte aan intimiteit. Mede op grond van de inventarisatiestudies onder vrouwelijke gedetineerden komen er in het najaar van 1991 voor het eerst concreet uitgewerkte voorstellen voor een specifiek vrouwenbeleid vanuit een door het Ministerie van

44 Zie ook over Maastricht Blees (1984).

45 Nijman (1983).

46 Besier (1987), Besier en Van der Vlies (1987).

47 Geurts en De Haan (1986), Geurts (1987).

48 Brouwers en Sampiemon (1988).

49 Zwering (1989), Verrijn Stuart (1992).

50 Zwering (1988), Over haar moeilijkheden om de directie te overtuigen van haar onderzoeksmethode en onderzoeksvoorstel, zie p. 4-7. Een verkorte versie van haar onderzoeksresultaten is gepubliceerd in Nemesis (Zwering, 1989). 
Justitie ingestelde Werkgroep Vrouwen in detentie. ${ }^{\text {si }}$ Deze werkgroep is eén van de drie werkgroepen die onder de stuurgroep Herziening differentiatie Gevangeniswezen ressorteren. De opdracht aan de werkgroep is vooral de mogelijkheid tot gemengde detentie van mannen en vrouwen te onderzoeken. De werkgroep brengt echter een veel breder advies uit, waarin een samenhangend beleid ten aanzien van scholing, werk, zwangerschap, bevalling, bezoekregelingen en vrouwenhulpverlening wordt voorgesteld. Gemengde detentie wordt afgewezen, zij het dat bij wijze van experiment arbeid en scholing wel gezamenlijk kunnen plaatsvinden. Kinderen zouden tot hun vierde jaar bij de moeder moeten kunnen verblijven, mits de gebouwen daarvoor ook geschikt worden gemaakt. Voor kinderen die buiten de inrichting verblijven moeten de bezoekregelingen worden verruimd. De uitwerking van de aanbevelingen in dit rapport komt in de volgende meer specifieke paragrafen aan de orde.

Eind 1991 ontstaat er nog even beroering wanneer er plannen bestaan de vrouwen uit De Singel tijdelijk in andere locaties, mannengevangenissen in Hoogeveen en Alkmaar, onder te brengen. In 1995 zal dan de definitieve verhuizing naar vrouwengevangenissen in Alkmaar en Zwolle plaatsvinden. Personeel en vrouwen willen echter niet weg uit $\mathrm{De}$ Singel. Ze betuigen hun tevredenheid met het gevoerde beleid en willen de vertrouwde situatie handhaven en later en bloc verhuizen naar de nieuwbouw. Geïnterviewde gedetineerden zeggen nu niet geconfronteerd te willen worden met personeel dat geen ervaring heeft met vrouwelijke gedetineerden. ${ }^{52}$

In 1993 en 1994 verhuizen de vrouwen dan toch naar de nieuwbouw in respectievelijk Zwolle en Heerhugowaard. In 1993 komen in Utrecht gedetineerde vrouwen in opstand tegen de gevolgen van het zogenaamde 'masterplan' van gevangeniswezen. Dit plan moet leiden tot een eerlijker verdeling van bewaarders over alle inrichtingen, maar heeft tot gevolg dat de vrouwen in Utrecht minder recreatie-uren krijgen. Dat kost hun dagelijks drie uur recreatie. De sfeer wordt als 'zeer grimmig' beschreven. ${ }^{\text {s3 }}$ In 1994 wordt in Hoorn een experiment gestart met beperkte gemengde detentie. Ook in 1994 verschijnt de beleidsnota "Werkzame detentie". Het beveiligingsdenken en de inrichtingsarbeid staan centraal. ${ }^{s_{4}}$ Aan de vrouwen wordt één korte paragraaf besteed, waarin vakopleidingen voor vrouwen geïntroduceerd worden, met trajectbegeleiding, ook na de invrijheidsstelling. Verder zal er bijzondere opvang gerealiseerd

51. Rapport Werkgroep Vrouwen in detentie (1991). De werkgroep werd voorgezaten door de directeur van de vrowweninrichting De Singel en bestond verder uit zeven leden. Viff datarvan waren werkzaam op thet Ministerie van Justitie, Gén was directeur van de halfopen inrichting voor vrouwen en het enige buticnlid werkte bij het Clara Wichmann Instituni. Vrouwengevangenis in staking, NRC 19-12-1991, Vrouweljke gevangenen De Singel weren mannen regiem, Volkskrant 19-12-1991.

53 Volkskrant 7 oktober 1993. Werkzame detentie, Beleidsnota voor hel gevangeniswezen, TK 1993-1994, 22999, nrs. 10-11. 


\section{Hoofdstik 3}

worden voor drugswerslaafde en gestoorde vrouwen. ${ }^{55}$ Die drugsvrije afdeling (DVA) en individuele begeleidingafdeling (IBA) worden in 1994 gerealiseerd in de vrouweninrichting "Amerswiel" in Heerhugowaard ${ }^{\text {s6 }}$ Meer suggesties voor een specifiek vrouwenbeleid komen niet aan de orde. In het nader rapport op het advies van de Raad van State bij het ontwerp voor de nieuwe PBW wordt daar wel even kort op ingegaan:

"De Raad verzocht om bij de beschouwingen aangaande jeugdige gedetineerden expliciet in te gaan op de jeugdige wrouwelijke gedetineerden. Het vrouwelijk deel van de gedetineerdenpopulatie bedroeg zowel in 1992 als in 1993 slechts $4,4 \%$. Van die vrouwen waren er in 199375 jonger dan 25 jaar en in 1994 78. Gelet op deze bescheiden omwang van het aantal (jeugdige) vrouwelijke gedetineerden is het in de praktijk niet mogelijk deze groep te differentiëren in jeugdigen en volwassenen. Dit geldt te meer daar tevens wordt getracht ook voor de vrouwelijke gedetineerden enige regionalisering tot stand te brengen"."

Andere vormen van specifieke vrouwenzorg (bijvoorbeeld zwangerschaps-en bevallingsverlof) worden in het wetsontwerp onder "bijzondere opvang" gevat, waarbij de op de leeftijd, persoonlijkheid, lichamelijke of geestelijke gezondheidstoestand toegesneden detentie in dat geval een individueel karakter draagt.

Kortom, een specifiek vrouwenbeleid kan niet gerealiseerd worden, omdat de groep te klein is. De groep is te klein omdat er naar onderbrenging in de regio gestreefd wordt. De benodigde 'kritische massa' voor een vrouwengroep of een aparte vrouweninrichting wordt niet geëxpliciteerd.

\subsubsection{Locaties}

In het voorgaande is al ingegaan op de problemen die voortvloeien uit de geringe differentiatie in bestemmingen voor vrouweninrichtingen. Dat betreft de interne rechtspositie, bij voorbeeld de toepasselijke loonregeling, het ontbreken van aparte kortdurende psychiatrische (crisis-) opvang, de sterkere gebondenheid aan én bepaalde sfeer (bewoners en personeel), etcetera.

Ook de beperkte geografische spreiding schept problemen, vooral in het onderhouden van externe relaties. De Werkgroep Vrouwen in detentie stelt voor dit te verhelpen via aangepaste regionalisering, vooral ten tijde van de voorlopige bechtenis. $\mathrm{De}$ stuurgroep neemt deze aanbeveling niet over omdat die in strijd is met het wettelijk stelsel.

55 Nota Werkzame detentie, p. 24-25, Zie ook Van Ransbeek (1994).

56 Inmiddells wordt niet meer van DVA gesproken maar van VBA, Verslavings Begeleidings Afdeling (Productbeschrijvingen Gevangeniswezen, 1996).

57 TK 1994-1995, 24263, B. p. 5.

58 TK 1994-1995, 24263, nr. 3, p. 30.

59 Stuurgroep Herziening Differentiatiestelsel gevangeniswezen (1991), p. 21 . 
Ten aanzien van de detentiefasering doet de werkgroep geen concrete voorstellen, maar conformeert zich aan het bestaande beleid. De vraagtekens die hierbij gesteld kunnen worden ${ }^{80}$, zijn aanleiding voor de Centrale Raad om te adviseren tot versnelde detentiefasering bij vrouwen. Door de detentiefasering kan worden ingespeeld op de mindere noodzaak van beveiliging, op regionalisering en op de wenselijkheid de contacten met de samenleving, vooral de kinderen, zoveel mogelijk in stand te houden."

Wel vraagt de Werkgroep Vrouwen in detentie aandacht voor bijzondere groepen, met name

- de-al genoemde-vrouwen in voorlopige hechtenis. Afhankelijk wan het instellen van hoger beroep en de snelheid waarmee het rechterlijk apparaat werkt, kan de duur van de voorlopige hechtenis oplopen tot twee jaar. Van de vrouwen komt zestig procent voor de eerste keer in aanraking met justitie. Voor hen zijn de problemen van isolement, werwarring en onveiligheid, vaak het grootst. De werkgroep benadrukt daarbij de primaire zorg die veel vrouwen voor hun kinderen hebben. Zij stelt voor een apart regiem te voeren ten aanzien van vooriopig gehechte vrouwen, waarin tevens een voorlopig detentieplan wordt opgesteld. ${ }^{62}$

- de langgestrafte, buitenlandse vrouwen. Bijna de helft van de vrouwelijke gedetineerden is van buitenlandse afkomst. De geografische herkomst wordt sterk bepaald door de actuele drugshandel. Naast verbeteringen van de mogelijkheden tot contact stelt de werkgroep voor deze vrouwen te betrekken in vormen van detentiefasering. Voor plaatsing in een open of halfopen inrichting is nu immers nog een huisadres in Nederland vereist. ${ }^{6}$

- de gebruiksters van "alcohol, tabak, medicijnen en stoffen strafbarar gesteld onder de Opiumwet." (...) "De werkgroep heeft ervoor gekozen het drugsprobleem niet te verengen door het juridisch criterium 'illegaal' te hanteren. De basis voor een integraal drugsbeleid in inrichtingen dient zich te richten op alle stoffen waarvan het gebruik kan leiden tot schade voor de gedetineerde en bedreiging van de orde en rust in de inrichting" ${ }^{4}$ De werkgroep stelt voor een onderzoek onder de gedetineerde vrouwen in te stellen naar het gebruik van genoemde middelen en ook naar de aan drugsgebruik gerelateerde problemen. Met name het medicijngebruik onder vrouwen is opvallend. Pas als de resultaten van een dergelijk onderzoek bekend zijn, zou een besluit genomen kunnen worden over de wense-

60 Wolleswinkel (1992), Wurzer-Leenhouts (1992).

61 Centrale Raad voor Strafrechtstoepassing (1992) p. 2-3.

62. Rapport Werkgroep Vrouwen in detentie (1991) p. 34-35.

63 Rapport Werkgroep Vrouwen in detentie (1991) p. 35-36. Ook bij het m.m.k.project zujjn buitenlándse vrouwen en hun kinderen feitelijk buitengesloten! 
lijkheid van een drugsvrije afdeling voor vrouwen met mogelijk ook een specifiek op vrouwen gericht regiem.

- de vrouwen met psychische problemen. Voor vrouwen is geen FOBA-afdeling aanwezig. ${ }^{\text {ss }}$ De werkgroep stelt voor een afdeling in te richten voor vrouwen met ernstige psychische problemen, maar de capaciteit voorshands zeer beperkt te houden. Het lijkt met name om crisisopvang te gaan "omdat in bepaalde gevallen onmiddellijk ingrijpen is geïndiceerd." ${ }^{\text {"to }}$

Inmiddels zijn er in de in 1994 geopende vrouweninrichting "Amerswiel" in Heerhugowaard een drugsvrije afdeling en een individuele begeleidingsafdeling in gebruik genomen. De individuele begeleiding biedt een lichte vorm van psychosocialle hulp aan vrouwen die -tijdelijk- behoefte aan extra steun hebben. Echte psychiatrische opvang is daarmee nog niet gerealiseerd hoewel het Europees Comité ter Voorkoming van Foltering (CPT) daaraan wel speciale aandacht besteedt tijdens haar bezoek in september 1992. ${ }^{67}$

Het is ten aanzien van het laatste punt mijns inziens de vraag of er, nu het orn incidenten gaat, geen afspraken met crisisinterventieteams van de reguliere RIAGGS gemaakt kunnen worden. De psychische problematiek van de vrouwen zal wellicht meer verwantschap vertonen met die van vrouwen uit de gewone samenleving dan met die van mannelijke gedetineerden. Daardoor hoeven zij ook niet gebukt te gaan onder mogelijke onterechte stigmatisering door hulpverleners.

De Werkgroep Vrouwen in detentie sluit overigens aan bij de tendens tot individualisering in de bejegening van gedetineerden, via het maken van op het individu toegespitste detentieplannen. ${ }^{68}$

Interessant zijn in dit verband de kritische kanttekeningen die El Sadaawi maakt bij deze individualiseringstendens. ${ }^{\oplus}$ Via de benadering van het individu kan het management van de inrichting een verdeel-en-heers-politiek voeren. Degedetineerden kunnen zich immers moeilijker als groep met gemeenschappelijke belangen opstellen. Ik vraag me af of de -overwegend islamitische-vrouwen in bijvoorbeeld Egypte zich toch al meer een collectief voelen dan Westerse vrouwen, omdat zij vaak leven in een 'vrouwenwereld'. Westerse vrouwen stellen zich individualistischer op en defi-

dings Noordwijk, p. 212 , p. $68-69$

Nawal El Sadaawi spreekt vooral op grond van haar eigen ervaringen als politiek gevangene in Egypte (El Sadaawi, 1994). In de gewangenis ziet zij de microcosmos weerspiegeld: de gevolgen van patriarchaat, godsdienst, kolonialisme, klassenmaatschappij. Vanuit die analyse is het interessant de gemeenschappelijke belangen van vrouwen te benadrukken en ook de waarde van het je niet-conformeren aan de dominante maatschappelijke waarden. (waar het regiem juist op gericht is). 
nièren zichzelf vaak in relatie tot individuele mannen. Mannen in het westen worden wel meer gesocialiseerd in groepen. Stöckle-Niklas, die onderzoek in Duitse gevangenissen doet, ziet ook daar gedetineerde mannen meer als collectief opereren, terwijl vrouwen zich terugtrekken of met én of twee andere vrouw(en) intensiever contact hebben, maar dat is dan ook veel persoonlijker dan de contacten tussen mannen. Wellicht zou El Sadaawi's argument op dit moment in Nederland eerder weerklank vinden bij (belangenbehartigers van) mannelijke gedetineerden.

\subsubsection{Familierelaties}

Familierelaties zijn te onderscheiden naar kinderen, partners, ouders en overige familieleden. Allereerst iets over de kinderen.

\subsubsection{Kinderen}

De zorg van de overheid gaat tot nu toe vooral uil natar zwangere en pasbevallen vrouwen in detentie. Krachtens art. 31 Gevangenismaatregel (GM) mogen de vrouwen de baby's bij zich houden zolang die hun zorg niet kunnen ontberen. Dit wordt geacht zo te zijn voor een periode van negen maanden. De termijn is in de praktijk ontwikkeld en nooit vastgelegd in een circulaire. De directe aanleiding zou zijn geweest dat in de jaren zeventig een groep vrouwen zo lang borstvoeding gaf dat men hieraan paal en perk wilde stellen. De betreffende brief die daarover destijds vanuit het ministerie geschreven is, valt niet meer te achterhalen. Formeel kan er dus van de termijn worden afgeweken en in de praktijk gebeurt dat in individuele gevallen ook wel, met name wanneer het om buitenlandse moeders gaat die nog enkele maanden te gaan hebben en na hun vrijlating naar hun land terugkeren. Zij hebben hier veelal geen alternatieve opvangmogelijkheden, bijvoorbeeld bij familie.

Het is belangrijk om, bij de interpretatie 'zorg' in art. $31 \mathrm{GM}$, de verschillende fases in zorg te onderscheiden." Tijdens zwangerschap en in de zuigelingenfase is de fysieke zorg puur biologisch bepaald en aan de biologische moeder gebonden, te vergelijken met het reguliere zwangerschapsverlof en zoogrecht in arbeids- en andere situaties, waar de moeder bezigheden buitenshuis heeft. In de zuigelingenfase kan er al sprake zijn van gedeelde zorg, waarbij binding aan een beperkt aantal hechtings' figuren van belang kan zijn, te vergelijken met het reguliere ouderschapsverlof en babyopvang door gastouders en kindercentra. In de fase daarna wordt verbreding van de kinderwereld, juist ook in de omgang met andere kinderen, van groter belang. ${ }^{n}$

70 Stöckle-Niklas (1989).

71 Zie ook Monster (1995) p. 1-12.

72 Van den Broek en Broeshart (1989), In een later hoofdstuk komen ontwikkelingspsychologiische en pedagogische aspecten nog vitgebreid aan de orde. 
De Werkgroep Vrouwen in detentie brengt in haar aanbevelingen ook enig onderscheid aan door het voorstel te doen een zwangerschaps- en ouderschapsverlof in te voeren en aparte cellen voor zwangere vrouwen te creëren wanneer zij niet met verlof kunnen.

Wat de latere fase betreft komt de werkgroep tot de aanbeveling om kinderen tot vier jaar de gelegenheid te bieden bij hun moeder te blijven. ${ }^{73}$ Op dit voorstel en op de pedagogische en juridische onderbouwing ervan wordt kritisch gereageerd. ${ }^{74}$ Bij verschillende gelegenheden benadrukken leden van de werkgroep dat het in hun ogen alleen om uiterste gevallen zal gaan. ${ }^{75}$ Garanties daarvoor worden in het rapport echter niet gesteld. Ook de Centrale Raad voor Strafrechtstoepassing reageert in zijn advies naar aanleiding van het rapport van de werkgroep op dit punt uiterst terughoudend en zoekt 'oplossingen' veel meer in de sfeer van alternatieve sancties, versnelde detentiefasering en verruimde bezoekregelingen. ${ }^{76}$ Kinderen zouden sowieso niet in een gesloten setting opgenomen mogen worden. Maar ook anderszins moet in kwantitatieve zin terughoudendheid worden betracht met de aanpassing van gevangenissen voor vrouwen aan de behoeften van gedetineerde moeders met jonge kinderen. De Raad adviseert prioriteit te geven aan verruiming van de mogelijkheden voor bezoek boven permanente opvang. Voor de huidige incidentele gevallen stelt de Raad voor in plaats van de 'negen maanden grens' als beleidsgrens de leeftijd van anderhalf jaar te hanteren, "aangezien kinderen vanaf die leeftijd de ruimte moeten hebben te bewegen en zich bewust worden van hun omgeving"."

De Centrale Raad voor Strafrechtstoepassing stelt in zijn advies voor om in een daarvoor geschikte halfopen gevangenis een experiment te starten met opname van jonge kinderen van langgestrafte vrouwen die niet voor verantwoorde opvang buiten

73 Rapport Werkgroep Vrouwen in detentie (1991) p. 30.

74 Wolleswinkell (1992), Lissenberg (1992), De Jonge (1993) met naschrift van C.van Wamelen.

75 Verrijn Stuart (1992) p. 2 en 3, Verrijn Stuart (1992) p. 179 en 180, Wurzer-Leenhouts (1992).

76 Ook de werkgroep bepleit verruiming van verlof- bezoekregelingen "in het belang van het kind". (Rapport Werkgroep Vrouwen in detentie (1991) p. 31). Dit laatste wordt verder nict gedifferentieerd naar bijwoorbeeld leeftijd, bijzondere omstandigheden, zoals gehandicapte kinderen of de verbliffplaats van de vader. Vgl. Zweden waar gezinnen waarvan beide ouders gedetineerd zijn, de gelegenheid wordt geboden een weekendverlof in een vakantiecomplex door te brengen. (HuizerGerritsen, 1992).

77 Centrale Raad voor Strafrechtstoepassing (1992) p. 6-8.

Zie ook het advies van de Raad van State op het voorontwerp van de nicuwe PBW: "Mede gelet op het feit dat geen gedragswetenschappelijk onderzoek voorhanden is omtrent de effecten van langdurig verblijf van opgroeiende kinderen in een inrichting, acht de Raad cen meer voorzichtige. benadering van het probleem geboden. Hij wragt zich om die reden af of het niet de voorkeur verdient de thans in de praktijk gehanteerde leeftijdsgrens van 9 maanden als hoofdregel te handhaven en uitzonderingen mogelijk te maken voor bijzondere gevallen, met dien verstande dat het belang wan het kind dan als doorslaggevend criterium dient te gelden". (TK 1994-1995, 24263, B, p. 4). 
de inrichting kunnen zorgen. De objectieve criteria voor plaatsing zouden wat betreft het detentierestant kunnen worden verruimd. ${ }^{78}$ Dit resulteert in de in april 1993 in Ter Peel, Sevenum, geopende voorzlening voor moeders met kleine kinderen." Het gaat om een kleinschalig experiment van twee jaar waarin moeders tijdens hun detentie kinderen tot de leeftijd van maximaal vier jaar bij zich kunnen houden. Een aparte vleugel van de inrichting is verbouwd. Van de oorspronkelijke tien kamers is een leefeenheid/ voor moeders met kinderen gemaakt, de m.m.k.unit. Er is een gemeenschappelijke woon- en eetkamer met kitchenette. Daarnaast zijn er vier ruimtes die uit twee geschakelde kamers bestaan, ến voor de moeder en én voor het kind. Dan is er nog én kamer voor een moeder met kind, die alleen op vrijwillige basis gebruikt wordt als er meer animo is voor de m.m.k.unit dan ruimte. Ter Peel is van oorsprong een klooster. Het ligt afgelegen in een mooie omgeving. Er staan geen hoge muren om het terrein en het geheel ademt een boerderij-achtige sfeer. Dat lijkt voor kleine kinderen ideaal. Het biedt een veilige omgeving waarin veel buiten gespeeld kan worden. Voor de moeders, die vaak uit een stedelijk gebied komen, is het wennen. Ter Peel is niet met het openbaar vervoer te bereiken en de loopafstand naar het dichtstbijzijnde station is groot. Er zijn wel fietsen op het terrein beschikbaar, die soms gebruikt worden voor door de inrichtingsstaf georganiseerde gezamenlijke uitjes, bijwoorbeeld naar het zwembad. In Ter Peel komen "zelfmeldsters" en "detentiefaseersters"'. Zelfmeldsters zijn veroordeelde vrouwen die op afroep, vanuit de 'vrije' maatschappij, naar de inrichting komen. Detentiefaseersters komen vanuit een gesloten gevangenis om het restant van hun straf, maximaal achttien maanden, in dit regiem met meer vrijheden en verantwoordelijkheden door te brengen. Gedetineerden in een halfopen inrichting mogen een weekend per vier weken met verlof: $\mathrm{Zij}$ moeten dus een huisadres in Nederland hebben. Buitenlandse vrouwen worden daardoor veelal buitengesloten. Verder mogen de vrouwen niet verslaafd zijn. Sommige vrouwen kunnen de allerlaatste periode van hun detentie naar een open inrichting. Daar mogen ze buiten de inrichting werken en ieder weekend met verlof. Omdat vrouwen die normaal naar een open setting zouden gaan dit vanuit de m.m.k. unit niet kunnen, tenzij ze weer een andere oplossing voor de opvang van hun kind zouden zoeken, is de mogelijkheid gecreëerd om aan undividuele vrouwen in Sevenum de status van een gedetineerde in een open inrichting te verlenen.

78 Centrale Raad voor de Strafrechtstoepassing (1992) p. 8.

Circulaire 21 juni 1994, nr. $435839 / 94$ DJ-I, in Sancties $1994 / 5$, p. 298 . Voor de gevallen waarbij de moeder noodgedwongen zou moeten worden overgeplaatst matar een andere inrichting is er door de begeleidingscommissie een overplatsingsprotocol ten behoewe van het kind gemaakt. Zie Experiment moeders met kinderen (1995), bijlage 4 "De uitplaatsing van kinderen van gedeti neerde moeders . 
De m.m.k. unit heeft als begindoelstelling "door middel van het gezamenlijk verblijf van moeder en kind(eren) tijdens de detentie bewerkstelligen dat er zo weinig mogelijk afbreuk wordt gedaan aan de gezinssituatie tijdens de detentie en dat het hechte contact tussen moeder en kind(eren) gewaarborgd blijft". ${ }^{81}$ Het experiment wordt voorbereid door een ambtelijke werkgroep. Vervolgens neemt een interne werkgroep uit Ter Peel de praktische uitwerking ter hand. Eerst moet de verbouwing gerealiseerd worden. Uitgangspunt is dat moeders dezelfde dagactiviteiten als de overige gedetineerden hebben, dus wordt er voor de opvang van de kinderen een crèche op het terrein gerealiseerd. Een aantal penitentiair inrichtingwerkers (p.i.w.ers) krijgt een kortdurende opleiding tot crèchebegeleider via een Limburgse ondersteuningsorganisatie voor onder andere kinderopvang. Na verloop van één jaar worden de kinderen tijdens het experiment toch geplaatst in een regulier kinderdagverblijf in het dorp Sevenum. Verschillende signalen vanuit de inrichting vormen daartoe de aanleiding: uitval van het personeel, klachten van moeders over de continuïteit, zowel in de begeleiding als in de aamwezigheid van kinderen, soms te grote leeftijdsverschillen tussen de kinderen onderling, onvoldoende op de leeftijd afgestemd speelgoed etcetera. In alle opzichten blijkt de owergang naar de professionele kinderopvang geslaagd. Er is meer continuiteit in de opvang voor de kinderen. Er zijn altijd meer kinderen van dezelfde leeftijdsgroep aanwezig. Er is deskundige pedagogische begeleiding van moeder en kind. Er is uitdagend speelgoed dat aansluitend bij de ontwikkelingsfase van het kind wordt aangeboden. Moeder en kind zijn even onttrokken aan het alziend oog van justitie en de inbreng van buiten blijkt ook voor het gevangenispersoneel verfrissend en inspirerend te zijn. Daarnaast blijkt het uitbesteden van de kinderopvang ook nog goedkoper te zijn dan de poging alles intern te organiseren. Vanuit het kinderdagverbliff wordt gerapporteerd dat de kinderen uit Ter Peel qua ontwikkeling niet achterliggen bij andere kinderen. De kinderen wit Ter Peel vallen alleen op door hun vaak donkere huidskleur en doordat ze meer uren op de crèche zijn dan de meeste kinderen van buiten. De eerste drie weken hebben de kinderen wel nodig om te wennen. Met name ook het overwinnen van taalproblemen wordt genoemd. Na die drie weken handhaven de kinderen zich over het algemeen prima. In enkele gevallen maakt het kinderdagverblijf zich zorgen over de moeder-kindbinding. Het gaat daarbij om zeer jonge moeders waarvan de crècheleiding zegt dat het moederschap hun als het ware "overkomen" is. In samenspraak met de inrichting wordt een ondersteuningsaanbod gedaan en verder is er een protocol opvoedingsproblematiek gemaakt om problemen in een zeer vroeg stadium te signaleren. De belasting van de gedetineerde vrouwen lijkt wel een probleem. Naast een volledige werkweek de kinderen opvangen blijkt veel gevraagd. Er wordt een vrije middag gerealiseerd. Voor de invulling van zo'n middag wordt een speldeskundige benaderd. Uit rapportages vanuit de inrichting blijkt namelijk dat de moeders in hun vrije tijd vaak

81 Experiment moeders met kinderen in gevangenis Ter Peel (1995) p. 17. 
weinig ondernemen met hun kinderen. Er wordt veel televisie gekeken en rondgehangen. Het is moeilijk om zo'n rapportage te beoordelen. Net als de evaluaties wordt deze rapportage gedaan vanuit de inrichting, zodat zowel de wijze van observeren als van verslagleggen niet neutraal genoemd $k$ an worden. Misschien zijn de vrouwen wel passief door hun verblijf in de inrichting. Als de hele dag van uur tot uur voor je wordt ingevuld, is het lastig om plotseling initiatiefrijk en zelfbewust met je kind om te gaan. Voor ieder initiatief heb je ook weer toestemming nodig, bijvoorbeeld als je even een eindje wil fietsen, picknicken of zwemmen. Bovendien is het de vraag of de observaties, als ze kloppen, negatief beoordeeld moeten worden. Wellicht zijn ze gewoon een weerspiegeling van de manier waarop veel ouders met hun kinderen vrije tijd doorbrengen en is de gezellige spelletjesmoeder in het algemeen een cultureelbepaald burgerlijk ideaal. Of zo'n ingevulde spelmiddag verplicht zou moeten worden gesteld voor moeders die met hun kinderen naar Ter Peel komen, is dan ook de vraag.

Het is moeilijk om bij de beoordeling van het experiment kwantitatieve en kwalitatieve doelen uit elkaar te houden. Is het experiment "geslaagd" als er geen onderbezetting is en er veel vrouwen in willen participeren? Of is het geslaagd als een optimum aan pedagogische randvoorwaarden gerealiseerd kan worden?

In ieder geval valt op dat de doelgroep uitdijt. Ook al is het 'ultimum remedium' principe direct vastgelegd in een aantal selectiecriteria, in de praktijk lijkt daar nauwelijks rekening mee te worden gehouden. Via de detentiefaseersters is er ook een nieuwe doelgroep bij gekomen, namelijk de groep waarbij de band tussen moeder en kind opnieuw gevestigd moet worden, zelfs als dat kind in een rustige en veilige situatie verblijft. Die hereniging kost veel tijd en energie van alle betrokkenen en een goede nazorg is absolute voorwaarde om vol te houden dat die hereniging in de inrichting 'in het belang van het kind' plaatsvindt. Er zullen geoormerkte budgetten voor dit soort 'hulpverlening' moeten zijn. In het eindrapport van het experiment in Ter Peel is een beschrijving van zo'n plaatsingsprocedure opgenomen. ${ }^{\text {s }}$

Een ander aandachtspunt is dat het begrip continuïteit aanvankelijk zeer sterk vanuit het hechtingsgedrag en de fysieke binding van moeder en kind werd afgeleid. De vrije middag kon mede daardoor snel gerealiseerd worden. "Tijdens het experiment is gebleken dat continuîteit woor een kind ook te maken heeft met relaties met andere kinderen en volwassenen en met herkenbare afwisseling van ruimtelijke omgeving. Het blijft in dat opzicht de vraag of het verblijf in een totale institutie, zelfs als het een (half)open inrichting is, de kinderen toch niet te zeer inperkt. De kinderen uit Ter Peel gaan niet bij andere (crèche)kinderen spelen. Spontane uitjes kunnen niet gemaakt worden. Verjaardagen en contacten met familie (oma, opa) worden verschoven naar de verlofweekenden. Ze krijgen hun eten apart en dergelijke. Die structurele 
beperkingen moeten afgewogen worden tegen de mogelijke beperkingen van een alternatieve opvangsituatie van het kind.

Verder valt op dat het zo volmondig beleden uitgangspunt dat het belang van het kind woorop staat niet is los te maken van de context waarin dat kind ter wereld is gekomen. 'Het belang van het kind' is een cultureelbepaald begrip. Dat blijkt niet alleen uit de verschillende opvangmogelijkheden met bijbehorende legitimaties die in het buitenland bedacht zijn. Ook in Sevenum blijken cultureelbepaalde waardeoordelen te bestaan, bijwoorbeeld toen een groepje vrouwen uit voormalig Joegoslavie een van hen aanviel op het feit dat ze haar kind naar de crèche liet gaan. $\mathrm{Zij}$ hoorde het kind zo lang mogelijk in haar fysieke nabijheid te houden. ${ }^{\text {s }}$ Of de verwondering dat de moeders zo weinig met speelgoed en spelletjes doen, terwijl ook dat voor een deel cultureelbepaald is. Juist gezien de verschillende achtergronden wan de vrouwen is dit interessante discussiestof bij de continuering van het project.

Er zijn 38 kinderen tijdens het experiment in Ter Peel geweest. Evenveel meisjes als jongens. De leeftijd varieerde van enkele weken tot bijna vier jaar. De gemiddelde leeftijd was 1,4 jaar. De gemiddelde verblijfsduur 64,3 dagen. ${ }^{87}$ De meeste kinderen zijn dus maar gedurende korte tijd in Ter Peel. Voor hen is een opvangprobleem opgelost en de continuîteit in de relatie tussen moeder en kind is gehandhaafd. Er is aansluiting gezocht bij de 'thuissituatie' en geen 'tehuissituatie" voor de kinderen gecreëerd.

Verblijf in een gesloten inrichting zou veel verdergaande consequenties hebben. Hoe valak er behoefte is aan een voorziening voor permanent verblijf, blijkt overigens

84 In Frankrijk staat de driehoek wader-moeder-kind vanuit de psycho-analyse zeer centraal. Daar wordt 'de afwezige vader" als probleem benoemd en streeft men er ook na mishandelingssituaties nasar de gezinsbanden te helen. In Groot Brittannië is men niet op een therapeutische (ontwikkelingspsychollogische) aampak gericht, maar op activiteitenprogramma's. In Duitsland lijkt socialle aanpassing belangrijk. De moeder moeten onder andere leren budgetteren. Zij krijgen daartoe een vaste maandelijkse bijdrage, waarvan zij hun lasten moeten betalen. Als voorbeeld is genoend: hoe eerder zij haar kind zindelijk heeft, hoe eerder ze geld overhoudt (van de luiers) om andere dingen mee te doen. In hoofdstuk 8 wordt witgebreider verslag gedaan van ervaringen in het buitenlland.

85 Ook de periode waarin borstvoeding wordt gegeven, is valk cultureelbepaald. Zie het ontstaan van de negen-maanden termijn zoals dat eerder in deze paragraaf is beschreven.

86 Vgl. Van Lier (1994) p. 13. "Bij culturen waar de groepsnorm bepalend is, zijn sociale vaardighedem belangrijk. In het Westen, waar het individu voorop staat, ${ }_{\text {, }}$ hebben cognitieve vaardigheden meer aanzien. Nederlandse kinderen kinderen krijgen daarom al snel speelgoed in handen geduwd. Het vierkante blokje moet zo snel mogelijk in het vierkante gaatje ("Goed zo!"). In Turkse en Marokkaanse gezinnen ontbreken vaak speeltjes". Zie ook Van der Zwaard (1995), p. 25-26.

87 Experiment moeders met kinderen in Ter Peel (1995) p. 41. 
moeilijk in te schatten. Officièle instanties worden in ieder geval niet systematisch ten behoeve van deze kinderen ingeschakeld voor bemiddeling of het treffen van regelingen, zodat er ook geen registratie van 'het aantal en soort gevallen' bestaat." Welke mogelijke drama's zich bij de arrestatie en op het politiebureau voordoen, is helemaal moeilijk te achterhalen. Een enkel schrijnend en tegelijk humoristisch relaas, zoals in het Algemeen Politieblad over een vrouw die haar baby meenam in de politiecel, vormt wellicht een topje van een ijsberg. ${ }^{\circ}$ Het vermoeden bestat dat er nu tijdens de detentie veelal opvang in de omgeving door familie en buren wordt geboden." Het is goed mogelijk dat de behoefte aan opvang pas echt aan het licht komt als er daadwerkelijk voorzieningen getroffen zouden zijn. Ongeveer zestig procent van de gedetineerde vrouwen heeft immers kinderen. Volgens Brouwers en Sampiemon heeft een kwart van hen helemaal geen contact meer met de kinderen of alleen af en toe via de verzorgers. De rest belt, schrijft of krijgt bezoek." Vanuit Gevangeniswezen wordt nu ad hoc gereageerd. In alle inrichtingen zijn cellen voor verblijf van moeder en een zuigeling geschikt gemaakt, dat wil zeggen dat er gelegenheid is om het kind te verzorgen. Buiten Sevenum is van gekwalificeerde opvang van het kind, bijvoorbeeld via enkele dagdelen gastouderopvang, geen sprake. Van der Maas beschrijft in 1994 nog hoe de moeders en baby's in het HvB in Breda 24 uur per dag op elkaar aangewezen zijn. ${ }^{33}$ Dit is interessant in het licht van de opmerkingen die het CPT maakt over de situatie van moeders met kinderen in De Singel naar aanleiding van het bezoek in 1992.

"Although the De Singel Prison occasionally receives mothers with their babies, the CPT observed there were no special facilities for mothers and children. In this connection it should be ernphasised

88 Zie ook Van Kesteren (1996). Op recente kamervragen antwoordt de minister dat de praktijk laat zien dat zelden alle babykamers in gebruik zijn. Inmiddels maken babykamers en logeerkamers standaard deell uit van het programma van eisen bij nieuw te bouwen inrichtingen. (TK 1995-1996, Aanhangsel van de Handelingen, nr. 46, p. 91).

89 Bron: telefonische ronde langs de Raad voor de Kinderbescherming, kinderrechters, jaarverslagen reclassering, jeugdhulpwerlening. In het laatste hoofdstuk wordt uitgebreider op de ervaringen tijdens. het strafproces ingegaan.

90 Schaeffer en Koole (1991).

91 Brouwers en Sampiemon (1988) p. 32. Volgeins het rapport van de Werkgroep Vrouwen in detentie (1992, p. 13) in $65 \%$ van de gevallen door de familie en in $15 \%$ van de gevallen door de vader. Van Kesteren (1996, p. 13) merkt op dat in de meeste gevallen de moeder van de gedetineerde vrouw de verzorging wan het kind op zich neemt. Dat is overigens ook het nog steeds geval bij een meerderheid van werkende vrouwen! Vaak speelt daarbij het kostenaspect een rol. Dit komt in een volgend hoofdstuk nog aan de orde.

92 Brouwers en Sampicmon (1988) p. 32, Van Kesteren (1996) p. 15 noemt een percentage van 9\% dat geen contact zou hebben. Wellicht heeft dat te maken met de samenst elling van de onderzoeksgroep, met name de ondervertegenwoordiging yan buitenlandse vrouwen daarin. Van der Maas (1994) p. 52-53. 


\section{Hoofdstuk 3}

that mothers and children form a particullarly vulnerable group in prisons. They should be placed in conditions equivalent to those of a creche and be provided with specialised assistance (nursery, nurse, etc.). The CPT understands that there are plans to create such a unit in De Singel Prison, and wishes to receive information from the Dutch authorities about the progress being made in this respect.

In het antwoord wijst de regering vervolgens op de m.m.k.unit in Sevenum. Of er een soortgelijke unit zal komen in Zwolle, hangt af van de uitkomsten wan het experiment:

Op ambtelijk niveau is inmiddels vastgesteld dat een voorziening voor kinderen tot vier jaar in een geslloten inrichting geen aanbeveling verdient. Dit is nog eens bevestigd nu blijkt dat er een te verwaarlozen groep overblijft als de criteria van Ter Peel worden toegepast. ${ }^{*}$

Hoewel het onderwerp later in een breder kader terugkomt, wil ik hier alvast, op grond wan de studie van Hartz-Karp, in zijn algemeenheid een aantal gevaren aanstippen die kleven aan een specifick beleid voor gedetineerde moeders als dat met name gericht is op een permanent verblijf van kinderen bij hun moeders."

1. Het belangrijkste gevaar is dat moeders wellicht zwaarder gestraft worden of eerder een gewangenisstraf krijgen, nu een moeder niet van haar kind gescheiden hoeft te worden, terwijl er anders misschien actiever naar alternatieven was gezocht. $^{\text {g: }}$

2. Een gevaar is dat een kind niet dezelfde ontwikkelingsmogelijkheden krijgt als buiten de gevangenismuren. Er zou dus aan dezelfde condities voldaan moeten zijn als wanneer het kind in de vrije samenleving opgroeide.

3. Een probleem is dat er geen 'magische leeftijd' is waarop de moeder-kindbinding niet meer belangrijk of noodzakelijk zou zijn. Er zouden dus gezien de doeleinden van het verblijf van het kind bij de moeder (handhaven gezinsband, fysieke en geestelijke gezondheid van het kind en terugdringen van recidive) eigenlijk geen leeftijdsgrenzen vastgesteld kunnen worden.

4. Er ontbreekt vaak een goede nazorg waardoor de vrouwen met kinderen na de detentieperiode in een gat vallen: gebrek aan goede woonruimte, armoede, verbro-

$94 \mathrm{CPT} / \operatorname{Inf}(93) 15$, p. 42.

$95 \mathrm{CPT} / \operatorname{Inf}(93) 20$, p. 43.

96 Zie voor deze criteria de bij]lagen. Kwartaalbericht DJI 1996/3, p. 17. Van Dam, directeur van de p.iv. Amerswiel in Heerhugowaard en voorzitter van het' 'Categoraal overleg vrouswen in detentie, spreekt zich overigens expliciet uit voor een aparte moeder/kind unit met een eigen regiem, in cen centraal deel van Nederland. (Fuldauer (1995) p. 104-105).

97 Hartz-Karp (1989) p. 175-176.

98. Dit gevaar van "netwidening" zit in feite aan alle stappen die je zet ter verbetering en humanisering van de detentie. Zie ook Van Ransbeek (1992) p. 21, Shaw (1996). In het vorige hoofdstuk werd bepleit netwidening tegen te gaan door extra voorwaarden te verbinden aan de strafeis en de straftoemeting en door de beschikbare capaciteit aan een limiet te werbinden. Zie ook Carlen en Tchaikovsky (1996). 
ken relaties, werkloosheid en de dreiging alsnog van het kind gescheiden te worden als uiteindelijk gevolg van de sociaal-economische omstandigheden.

Veel zorgtaken hoeven ook niet met een permanent verblijf te worden ondervangen, maar zijn in te vullen met betere verlof-, bezoek- en overlegregelingen. Juist in het samen dingen doen wordt een band geschapen en gecontinueerd.

In de gesloten vrouweninrichtingen wordt de laatste jaren wel steeds meer beleid ontwikkeld dat ook gericht is op kinderen. Er zijn nieuwe bezoekfaciliteiten, met name kindermiddagen, voor kinderen tot twaalf jaar, in de inrichting zelf. ${ }^{\infty}$

In tegenstelling tot de algemene verwachting ervaren vrouwen de laatste fase in de open inrichting vaak als de zwaarste in hun bestaan, juist omdat ze dan geconfronteerd worden met hun gevoel van overbodigheid en de teleurstelling over wederzijds ontstane hoge verwachtingen. ${ }^{100}$ De normaliteit is er niet meer en kan ook maar moeizaam of niet meer hersteld, laat staan verbeterd worden. Juist door de grens tussen de straf en het familiebestaan vanaf het begin van de detentie flexibeler te maken, is er kans op enig gunstig effect op het bestaan na de detentie. Zelfs wanneer die familiebanden verre van ideaal zijn, kan de straf een mogelijkheid zijn om de negatieve kanten van de familiebeslotenheid en het isolement van individuele gezinsleden te doorbreken. ${ }^{101}$

\subsubsection{Parners}

Op partnerrelaties is door de Werkgroep Vrouwen in detentie niet ingegaan. Veel vrouwen hebben geen vaste partner, terwijl voor bijvoorbeeld het bezoek zonder toezicht voorwaarde is dat er een duurzame relatie bestaat. Als er wel bezoek zonder toezicht wordt toegestaan, komt dit in de plaats van het gewone bezoek. Kinderen en de vaste partner kunnen zo in een concurrerende positie ten opzichte van elkaar komen te staan. Overigens maken de vrouwen ook vaak gebruik van het bezoek zonder toezicht om rustig met (één van) de kinderen te praten.

Interessant in dit verband is het onderzoek van die Pösö waarin zij constateert dat 'familierelaties' door de autoriteiten vaak heel eng ingevuld worden. ${ }^{162}$ Het accent ligt op actuele relaties, die dan ook nog heel verschillend gewaardeerd worden. Een relatie op basis van een huwelijk wordt het meest gewaardeerd. Een heteroseksuele relatie meer dan een homoseksuele. Een relatie met een niet-crimineel meer dan met een medegedetineerde, etcetera. De context waarbinnen vrouwen hun familiere-

99 Van Dam (1996).

100 Beelen (1991) p. 56-59, zie ook Franke (1991) p. 356-357.

$101 \mathrm{Vlg}$. Holwerda (1995). Het betreft een mentorproject woor kinderen van liangdurig gedetineerde waders dat in hoofdstuk 8 aan de orde komt.

102 Pősö (1992) p. 104-108. 
laties plaatsen is echter een andere. Pösö schetst een caleidoscoop van wisselende impressies en gevoelens: ${ }^{\text {:os }}$

"Listening to the women prisoners in Finland or in any other country is listening about their male and femalle friends and partmers, about their children, about the people whom they intimately love or hate and for whom they care or they feel they ought to care. Even more, family relations are talked about in terms of wishes, dreams, fears, happiness, disappointment, humiliation and identities and aims for one"s life. These meanings outside the actual familylike relations are, however, neglected in scientific or professional-burocratic discourse about family relations in detention. ${ }^{\text {ilos }}$

Het familieleven krijgt volgens haar in detentie een andere, meer ideologische betekenis. De achterliggende norm bij verlof- en bezoekregelingen is dat het straks gemakkelijker wordt om terug te keren, dat de familiebanden meer zekerheid aan het bestaan geven. De verwachtingen ten aanzien van de inzet en inbreng van de familieleden is dan ook heel hoog. En die kunnen nog weleens tegenvallen: ingebakken in familierelaties zijn gevoelens van bezorgdheid, jaloezie, wrok, verdriet.

"Being bound to the social structure of family nature is complicated for any women as feminist researchers have shown. In detention this complication hardly gets any easier and it should not be expected to be so either." ${ }^{\text {105 }}$

Bovenstaande kanttekeningen gaan ook op voor de rol van ouders en andere familierelaties. Vaak blijken bijvoorbeeld meer leden van de familie gedetineerd te zitten. Ook culturele achtergronden geven aan de daadwerkelijke invulling van deze banden extra gewicht. Familie geeft je betekenis, maar zeker als kind heb je nooit voor die betekenis en lotsverbondenheid gekozen.

103 Zie ook Van Stolk en Wouters (1983), p. 173.

"Evelien, die tijdens het interview haar hele levenswerhal wat leek te romatiseren, liett ons later een tekening zien die een vriendin op de Bongerd voor haar had gemaakt:

"Kijk', zei ze 'dit is mijn leven, nog beter dan ik het jullie kon vertellen. De tekening was in twee helften verdeeld. Op de linkerhelft stond een ingewikkelde compositie van een wanhopige vrouwenkop met daarom heen een fles drank, omgevallen glazen, een asbak wol peuken en een omgevallen kinderwagen. Op de achtergrond waren, vaag, onprettige mannenkoppen te zien. De rechterhelft was leger; daar stond linksonder een stralende vrouw getekend die aan iedere hand een kind vasthield en rechtsboven een brede, knappe man. Er liep dwars over de tekening een pad wan de vrouw tot op de borst van de man, waar de gestalte van de wrouw, in het klein en zonder kinderen, nog eens was weergegeven.

'Zo was het en zo gaat het worden' zei Eveliem terwijl ze wan de linker-naar de rechterhelft van de tekening wees.

De tekening gaf niet alleen een voor haar emotioneel bevredigende symbolische weergave van haar leven, maar ook, onbedocld, een weergave van de standaardplot van de schriftromannetjes." 104 Pösö (1992) p. 105.

105 Pösồ (1992) p. 106. 
Pösó vindt dat de aandacht uit zou moeten gaan naar het ideologische concept van familierelaties, dat zo'n belangrijke roll speelt, waarbij het voor haar nog maar de vraag is welke beleidsconsequenties daaruit zouden moeten voortvloeien. Het is precies die vraag die ik ook in de volgende hoofdstukken wilt wil werken. Welke voorstellingen spelen een rol als er in beleidsworming en regelgeving gesproken wordt over familierelaties, moederschap en het belang van het kind?

\subsubsection{Gemengde detentie}

Ilustratief voor de ingewikkeldheid wan familierelaties is de discussie over gemengde detentie. Detentie van mannen met vrouwen samen, in welke vorm dan ook, is verschillende malen als mogelijkheid gesuggereerd. De Centrale Raad voor Strafrechtstoepassing brengt in 1989 advies uit. Na te hebben vastgesteld dat verdere regiemsdifferentiatie voor vrouwen wenselijk is en dat daarvoor niet altijd de differentiatie voor mannen model moet staan, zegt de Raad dat het niet uitgesloten is "dat in het gevangeniswezen regiems met gemengde populaties aanvaardbaar kunnen zijn". Wel raadt de Raad grote behoedzaamheid aan. ${ }^{07}$

Als staatssecretaris Kosto echter in 1990 met het plan komt om te onderzoeken of tot op zekere hoogte de strikte scheiding tussen mannen en vrouwen opgeheven kan worden en het gezamenlijk deelnemen aan bepaalde activiteiten toegestaan (onder verwijzing naar het voorbeeld van dagdetentie), roept dit heftige en zeer verschillende reacties op. ${ }^{108}$ De Vereniging Relaties van Gedetineerden reageert sterk afwijzend. De Nederlandse Federatie van Reclasseringsinstellingen staat er positief tegenover. De Coornhert Liga wil eerst een experiment. En het uitvoerende personeel lijkt verdeeld. De relaties van gedetineerden zijn bang voor het opbloeien van nieuwe relaties in zo'n gemengde setting met alle complicerende gevolgen voor het thuisfront. ${ }^{109}$ Ook kamerleden spreken hun vrees uit voor beheers- en zedenproblemen. ${ }^{10}$ De professionele betrokkenen reageren enerzijds vanuit het standpunt dat het gezien de matschappelijke omstandigheden volstrekt achterhaald is om in gevangenissen een strikte en kunstmatige scheiding tussen mannen en vrouwen te hanteren. Anderzijds bestaat het gevaar dat (ook beperkte) gemengde detentie uitsluitend gunstige effecten op het gedrag van mannen heeft. Gedetineerde vrouwen

106 Spronken en Wolleswinkel (1987) p. 350, Vegter (1989) p. 187, Van de Pol (1989) p. 123, Guise en Rutgers (1990), Van de Pol (1990) p. 15-17.

107 Centrale Raad voor Strafrechtstoepassing (1989) p. 13-14.

108 Tk. 1990-1991, nr. 21634 , 3, p. 2 en 3. De Jong (1990).

109 De Vereniging Relaties voor gedetineerden wordt overigens met name gevormd door vrouwelijke partners van gedetineerde mannen, die over het algemeen hun uiterste best doen om iets van 'thuis' te blijwen behouden voor hun gedetineerde partners. Zie Otten en King (1990) p. 11-15.

110 Handelingen UCV 1990/1991, nr. 33, Mevtoww Soutendijk-van Appeldoorn, p. 3 en de heer van den Berg, p. 11. 


\section{Hoofdstuk 3}

kunnen immers opnieuw in de afgeleide rol komen die ze privé en op het werk toch al zo valk hebben. Dienstbaar aan de man, gericht op sfeerverbetering etcetera." Later wordt daar nog een argument aan toegevoegd. Juist gedetineerde vrouwen zouden in hun verleden vaak slachtoffer zijn geweest van (seksueel) geweld door mannen in hun naaste omgeving. De detentie met uitsluitend vrouwen biedt rust en velligheid. ${ }^{\mathrm{n} 2}$

Guise en Rutgers hebben al eerder geprobeerd de verschillende argumenten zoals die door deskundigen in Nederland naar voren zijn gebracht, uit te diepen en te muanceren. ${ }^{1 \text { 13 }} \mathrm{Zij}$ komen tot de conclusie dat er ruimte gemaakt moet worden voor gemengde detentie.

"Gedetineerden moeten weer terugkeren in de samenleving en ons inziens is het goed om ze in de gewangenis voor te bereiden op die terugkeer. Daar hoort ook bij de omgang tussen mannen en wrouwen, mannen moeten leren dat vrouwen er niet alleen zijn om mee naar bed te gaan en vrouwen moeten leren om met lastige mannen on te gaan, over hun eigen wil te beschikken, want dat hebben ze buiten ook nodig.

Aan een experiment verbinden zij vier criteria:

- plaatsing op basis van vrijwilligheid;

- acceptabel evenwicht in de getalsverhoudingen;

- optimale invulling van relaties buiten de inrichting, dat wil zeggen gemengde detentie in een halfopen of open inrichting;

- voldoende privacy, dus de gedetineerden dienen te beschikken over een eigen kamer, die afgesloten kan worden.

De Staatssecretaris vraagt de Werkgroep Vrouwen in detentie een voorstel te ontwikkelen voor vormen van gemengde detentie. ${ }^{115}$ De werkgroep besluit niet alleen haar taakstelling uit te breiden, maar wijst ook het principe van gemengde detentie af. Zij will alleen én uitzondering maken, namelijk het op basis van vrijwilligheid gezamenlijk deelnemen aan bepaalde vormen van arbeid en opleiding, waarbij aan een aantal voorwaarden moet zijn voldaan:

- met deze vorm van gemengde detentie dient eerst op kleine schalal en in de vorm van een experiment ervaring te worden opgedaan;

- dit experiment dient zorgvuldig te worden woorbereid;

111 Zie ook Kersten (1989, p. 129-144), 1992, Anders: Stöckle-Niklas (1989), Zij toont juist aan hoe de rolspecifieke socialisatie van mannen en vrouwen wersterkt doorwerkt in gescheiden mannenen vrouweninrichtingen.

112 O.a. Verrijn Stuart (1992-3) p. 178.

113 Rapport Guise en Rutgers (1990).

114 Guise en Rutgers (1990) p. 45.

115 Rapport Werkgroep Vrouwen in detentie (1991) p. 16-18. 
- gemengde detentie dient uitsluitend te worden toegepast in inrichtingen die daarop gebouwelijk en regimair zijn ingericht;

- de nummerieke verhouding mannelijke en vrouwelijke gedetineerden dient verantwoord te zijn;

- de deelname door mannen en vrouwen aan gezamenlijke detentie dient uitsluitend op basis van vrijwilligheid te geschieden;

- een aantal praktische en organisatorische aanpassingen in de inrichting dienen te zijn gerealiseerd alvorens van gemengde detentie sprake zal kunnen zijn. ${ }^{116}$ De werkgroep komt onder meer tot dit gematigde voorstel op grond van reeds genoemde contra-argumenten en op grond van enkele ervaringen in Zweden. ${ }^{177} \mathrm{Het}$ gematigde voorstel is gemaakt naar het voorbeeld van een experiment in Duitsland. ${ }^{118}$

Ook een argument tegen gemengde detentie dat werkgroeplid Verrijn Stuart noemt, is dat uit het inventarisatie-onderzoek van het Clara Wichmann Instituut is gebleken dat de vrouwelijke gedetineerden op dit punt een "uitgesproken afwijzende stellingname" hebben. ${ }^{119}$ Nog afgezien van het feit dat het genoemde onderzoek onder slechts dertig vrouwen werd uitgevoerd, blijkt uit de resultaten dat zij bepaald geen eenduidige mening hebben. Uit de kwantitatieve gegevens wordt zelfs duidelijk dat van de geïnterviewde buitenlandse vrouwen meer dan de helft voor gemengde detentie is. En ook onder de Nederlandse vrouwen blijkt geen uitgesproken afwijzende instelling (zeven voor, tien tegen, drie twijfel). Het lijkt erop dat hier de interpretatie van de gegevens een bepalende rol speelt:

"Naar aanleiding van deze vraag kwam duidelijk naar voren dat een aantal vrouwen problemen heeft met de sexualiteit.(......) Voor deze problematiek is de gemengde detentie niet de juiste oplossing. Het probleem van de sexualiteit van wrouwen zal als een reëel probileen moeten worden bekeken zodat er naar oplossingen kan worden gezocht." ${ }^{120}$

116 Verrijn Stuart (1992-3, p. 177) lid van de werkgroep, noemt dit woorstel zelf's "Een concessie, maar dan wel een zeer kleine en voorzichtig geformuleierde".

117 Werkgroep Vrouwen in detentie (1991) p. 17, De brief van Eva Edstedt (wrouwiengevangenis Färingsö in Stemhara) is gepubliceerd in Nienhuis (1992) p. 66. Zie voor de beschrijving van de situatie in Zweden ook Leander (1995), p. 179. Ziji beschrijft daar een getalsverhouding van drie vrouwen op dertig mannen in kleine lokale gevangenissen.

118 De werkgroep baseert zich op Siekmann (1985) p. 11-15. Veel uitgebreider over de Duitse situatie is de dissertatie van Stöckle-Niklas (1989).

119 Verrijn Stuart (1992-3) p. 178.

120 Ketelaars (1991) p. 28. Zie ook Stöckle-Niklas (1989) 0.a. p. 261-262. Hier beschrijft zij dat er onder de vrouwen nog steeds onzekerheden bestaan over fysieke gevoligen van zellbevrediging. Maar ook morele problemen komen op bij het zoeken naar alternatieven voor seksuele bevrediging, bij wrouwen veelal zelfbevrediging en lesbische contacten, die leiden tot gevoelens van schuld, angst en walging. 


\section{Hoofolink 3}

Er wordt een eendimensionaal verband gelegd tussen ongewenste (seksestereotiepe) heteroseksualiteit en gemengde detentie. Dat andere interpretaties mogelijk zijn, zowel ten aanzien van de invulling van 'gemengde detentie' ais van '(hetero)seksualiteit'; wordt daardoor niet nader onderzocht. ${ }^{\text {12 }}$ Dit zou kunnen duiden op cultureelbepaalde vooronderstellingen in de benadering van de gedetineerde vrouwen. Het feit dat vooral buitenlandse vrouwen wel lets zien in gemengde detentie zou toch ook te maken kunnen hebben met de kans die zij dan hebben om landgenoten te treffen bij wie zij zich wellicht meer 'thuis' voelen. Blanke feministische onderzoekers afkomstig uit westerse burgerlijke milieus zullen vanuit de bij hen bekende kaders zaken onderzoeken. De rol en invulling van seksualiteit kan voor vrouwen zo verschillend zijn dat het te beperkend is om die zo eenduidig negatief in te vullen, zonder ook maar een begin van een oplossing voor het geconstateerde 'probleem' aan te geven. Is het trouwens niet veel vruchtbaarder om over wensen en behoeftes in plaats van over problemen te praten, juist wanneer het over seks gaat?

Eenzelfde vooringenomen stelling lijkt te schuilen achter een simpel zinnetje van de werkgroep:

"Ook het invulling geven aan kinderopvang en het voorzien in de hygienische behoeften van wrouwen kan eenvoudiger geschieden indien mannen en vrouwen gescheiden worden gedetineerd". ${ }^{22}$

Er wordt een vrouwendomein voorgesteld (zonder kwalitatieve invulling aan de kenmerken te geven) en daaraan wordt a priori de voorwaarde gekoppeld dat mannen buitengesloten moeten blijven omdat zij daarin 'de orde en rust' zouden verstoren. Wat wordt er bedoeld met het pragmatisch klinkende "eenvoudiger"? Ik kan me

121 Iets van de mogelijk verschillende invullingen komt boven tafel tijdens het international seminar on women in detention in Noordwijk. Over de gemengde detentie lijken de meningen het meest verdecld te zijn. In Denemarken bestaan al vijftien jaar vormen van gemengde detentie. Vrouwen kumnen kiezen of zij daarbinnen willen verblijwen. Ongeveer eenderde van de wrouwen kiest daarvoor. Het is wel belangrijk dat het aantal mannen en vrouwen niet disproportioneel is ten opxichte van elkaar. In Denemarken vindt men dat de maatschappelijke tendens om bepaalde eigenschappen en banen niet meer als typisch mannelijk of vrouwelijk te benoemen weerspiegeld moet worden in de gevangeniscultuur. De opmerking dat de seksualiteit binmen die instituten gecontroleerd en stereotiep ingevuld blijft (bijw. het aantal vriendjes dat een vrouw mag hebben wor dt gelimiteerd) wordt door de Deense partipant (de heer Trolberg) weersproken. Alleen in de familie-unit (waar ouders met kinderen verblijven) zijn beperkingen gesteld, in de andere units niet. Monika Plateik (Polen) vraagt zich af of er niet enorm veel jaloezie bestaat bij de famillie die buiten de in richting verblijft. Volgens de heer Trolberg zijn er nog nooit klachten van familie binnengekomen (Proceedings Noordwijk (1992) p. 212).

Feinman (1986, p. 65) heeft overigeas al eerder geschreven dat de totale integratie in de gevangenis van Ringe waarschijnlijk alleen mogelijk is in een land als Denemarken: "a small nation with a homogeneous population and a social value system that is accepting of sexual relations between unmarried people and of children born out of wedlock".

122 Werkgroep Vrouwen in detentie (1991) p. 17. 
voorstellen dat het een kwestie van tijd is, maar juist wanneer bijvoorbeeld zorgtaken een centralere plek zouden innemen in het beleid, is er, ook vanuit emancipatieoogpunt, veel voor te zeggen om ook zorgende vaders een plek in dat domein te geven. ${ }^{123}$ Dat het er kwantitatief wellicht weinig zullen zijn doet niets af aan het principe. Overigens zijn er in dit opzicht positieve ervaringen te melden in Duitsland, Denemarken en Zweden. ${ }^{24}$

Wat onder 'het voorzien in de hygiënische behoeften' van vrouwen wordt verstaan, is door de werkgroep niet uitgewerkt. Ik vermoed dat daarbij onder andere gedacht wordt aan het omgaan met de menstruatie. Smart heeft 'the management of menstruation' geproblematiseerd als weer een manier waarop vrouwen hun lichaam en hun lichamelijke functies verbergen, om maar serieus genomen te worden. $Z$ ij verwijst naar Martin, die het ontstaan van 'het menstruatieprobleem' in verband heeft gebracht met de actieve deelname van vrouwen aan het productieproces. Toen ontstond de noodzaak dat vrouwen zich 'als mannen' moesten gedragen en de consequenties van het verschil in lichamelijk functioneren gingen ontkennen. Overigens toont zij in haar empirisch onderzoek ook aan dat zwarte, working-class en middle-class vrouwen aan hun lichaam en hun lichamelijke functies, rond reproductie en menstruatie, verschillende betekenissen en interpretaties geven ${ }^{125}$

De keus van de werkgroep om uitsluitend op het gebied van arbeid en scholing tot een zeer voorzichtige integratie te komen, volgt overigens de maatschappelijke ontwikkelingen en er kan van de uitgebreide ervaringen in opleidingen en bedrijven, al of niet via positieve actieplannen, gebruik worden gemaakt bij het opzetten van dergelijke experimenten. In Het Keern in Hoorn is er inmiddels een vorm van gemengde detentie gerealiseerd. ${ }^{126}$ Niet alleen qua sekse maar ook qua bestemming

123 Feinman (1986, p. 64-72) geeft aan dat het belangrijk is het doel vast te stellen van waaruit naar gemengde detentie gestreefd wordt. Dat blijkt bepalend te zijn woor de organisatie en het beleïl. In de V.S. onderscheidt zij in de praktijk wier verschillende doelen om tot gemengde detentie over te gaan:

- om de kosten te beheersen, bijwoorbeeld door het vallen wan lege plaatsen;

- om de kosten voor vrouwenprogramma's terug te brengen en toch aan de eis vain gelijke behardeling te voldoen;

- om plaats te creëren voor mannen die de 'full minimum sceurity status' hebben;

- om een humane en meer normale omgeving te scheppen, waarin gericht naar een succeswollo re-integratie in de gemeenschap gewerkt wordt.

De positieve geluiden zijn wooral ontleend aan de laatste variant. Maar ook Feinman ziet veel mogelijke nadeien voor vrouwen, die echter vooral met de kleine aantallen te maken lijken te hebben. Het is met name belangrijk de staf te traïnen om alert te zijn op de schadelijke effecten van specifiek vrowwelijk rolgedrag.

124 Maelicke, Duitsland en Trolberg "Denemarken in Noordwijk (Proceedings (1992) p. 111-112).

Zie ook Huizer-Gerritsen (1992).

125 Smart (1991-2) p. 11-20.

126 Circulaire van 3 januari 1993, 418743/93/07. 


\section{Hoofdstuk 3}

gaat het om een gemengde vorm, namelijk een gecombineerde p.o.i. en dagdetentie. Er zijn vijf plaatsen voor vrouwen.

\subsubsection{Sekswaliteit}

Een belangrijk aspect bij de discussie over gemengde detentie is dus de seksualiteit. Ook de gedetineerde vrouwen spreken over hun seksualiteitsbeleving, maar in termen van hun behoefte aan intimiteit. Seksuele contacten kunnen plaatshebben tussen gedetineerden onderling en tussen leden van de staf en gedetineerden. ${ }^{127}$

De werkgroep gaat vrij uitvoerig in op de gewilde en ongewilde (seksuele) rellaties tussen gedetineerden en het personeel en tussen leden van de staf onderling: Zij stelt dat (seksuele) intimidatie inherent is en zal zijn aan de opzet en sfeer van het gevangeniswezen. Maar er kunnen maatregelen genomen worden om de kans daarop te verkleinen. Er zou een vertrouwensvrouw aangesteld kunnen worden en in het uiterste geval kan aangifte worden gedaan. ${ }^{129}$

Een gewilde relatie tussen een personeelslid en een gedetineerde kan in principe niet worden toegelaten, maar in voorkomende gevallen moet hierop "met beleid" worden gereageerd. De oplossing zal waarschijnlijk liggen in overplaatsing van én van beilde betrokkenen. Ook geeft de werkgroep aan dat er in de basisopleiding en op de afdelingen in de teambesprekingen regelmatig over het onderwerp gesproken moet worden. ${ }^{130}$

De werkgroep gaat niet in op gewilde en ongewilde (seksuele) relaties tussen gedetineerden onderling. Gelet op de voorgaande paragraaf, over gemengde detentie, zou het uiten van gevoelens en betekenissen rond seksualiteit en intimiteit ook tussen gedetineerden juist gestimuleerd moeten worden. In verband met de aidsvoorlichting wordt hier wel enige aandacht aan besteed. Hoewel dat op zichzelf belangrijk is, bestaat het gevaar dat seksualiteit uitsluitend in een negatieve context aan de orde wordt gesteld.

Eenzelfde discrepantie lijkt er in Zweden te bestaan, waar vanuit een feministisch/ hulpverleningsstandpunt negatief geoordeeld word t over gemengde detentie, maar waar uit een inventarisatieonderzoek onder gedetineerde vrouwen blijkt dat vrouwen juist samen met mannen gedetineerd willen worden. ${ }^{13 t}$

127 Noorman, m.m.v. B. de Wit (1983).

128 Rapport Werkgroep Vrouwen in detentie (1991) p. 40-43.

129 Krachtens art. 249 lid $2 \mathrm{Sr}$.

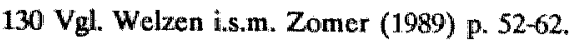

131 Brief van Eva Edstedt (vrouwengevangenis Färingsō in Stemhara) in Nienhuis (1992) p. 66, Fjarstedt en Bishop (1994) p. 15-22. 


\subsection{Activiteiten}

In alle inrichtingen heeft men vaste tijden voor het op cel in-en uitsluiten, maaltijden, luchten, arbeid, activiteiten en recreatie. Het dagelijkse programma verschilt per inrichting. Zo kan er soms hele en soms alleen maar halve dagen gewerkt worden. Gedetineerden in een $\mathrm{HvB}$ zijn niet verplicht aan de arbeid deel te nemen. Toch doen de meeste gedetineerde vrouwen dat wel. Hun motieven daarvoor zijn de tijd moeten doorkomen, van cel af zijn en geld verdienen. ${ }^{{ }^{332}}$ Men vindt over het algemeen dat men weinig verdient, ook al is het loon van langgestrafte vrouwen in het HvB inmiddels gelijkgetrokken met dat van langgestrafte mannen. Het werk dat verricht wordt, is vaak zwaar en "typisch vrouwelijk": wasserij, schoonmaakdienst en dergelijke.

Er worden over het algemeen veel activiteiten door het sociaalcultureel werk aangeboden in de recreatieve sfeer. Verder genieten sport en onderwijs veel belangstelling. Er zijn wel problemen bij het verkrijgen van structureel werk op de reguliere arbeidsmarkt. Vaak sluiten de cursussen of het arbeidsaanbod tijdens de detentie niet goed aan. Soms liggen de problemen bij de werkgevers. Het volgende voorbeeld wordt door een hoofd van het bureau Sociale Dienstverlening gegeven:

"Een vrouw verblijft in een open inrüchting en heeft een stageplaats in een bedrij؟. De stage verloopt zeer goed en er komt een vacature bij dit bedrijf. Het bedrijf vraagt de vrouw om te solliciteren wamt ze willen haar dolgraag houden. Ze solliciteert en wordt aangenomen maar ze moet eerst nog een bewijs van goed gedrag overleggen. Dit kan ze niet omdat ze een strafblad heefl. $\mathrm{Ze}$ word uiteindelijk niet aangenomen terwijl het bedrijf al tijdens de stage op de hoogte was wan het strafblad.

In twee inrichtingen voor vrouwen is nu een vakopleiding opgezet ter verbetering van de positie op de arbeidsmarkt. De trajectbegeleiding staat, ook na de invrijheids-

132 Brouwers en Sampiemon (1988) p. 21.

133 Ketellaars (1991) p. 32 . Het in de volksmond bekende 'bewijs van goed gedrag' is eigenlijk een 'verklaring omtrent het gedrag'. Het is een verklaring in negatieve zin. De burgemeester werklaart dat hem niets is gebleken vam bezwaren tegen een bepaalde persoon. Een absoluut vereiste daarbij is dat het gaat om een bepaald doel waarwoor de verklaring, wordt gevraagut (art. 19 lid 3 Wet justitiêle documentatie en de verklaring omtrent gedrag). Als de verklaring wordt gewraagd voor het vervullen van bepaalde werkzaamheden, dan moet de werkgever een verklaring overleggen waarin ook de aard van de werkzaamheden vermeld wordl (art. 21 lid 2 van de Wet JDVG). Volgens de Memorie van Toelichting "hoopte de regering hiermee te bereiken dat niet iedere werkgever voor letterlijk alle functies van alle mogelijke sollicitanten een v.o.h.g. zou eisem, maar dit alleen zou doen voor serieuze kandidaten en voor funkties waarvoor zo"n onderzoek ook werkelijk gerechtvaardigd zou zijn. De werkelijkheid is waarschijnlijk wat anders geworden dan de wetgewer zich heeft voorgesteld. Vele particuliere werkgevers eisen nimmer een v.o.h.g.. Daarlegenower staan overheidsdiensten die wel eens wat wer gaan met het eisen van een v.o.h.g.." (Singer-Dekker (1991) p. 46). 


\section{Hoofdstwh 3}

stelling, centraal. In het kader van een vanuit de EU gesubsidieerd projekt (New opportunities for women) worden ook in andere inrichtingen maatschappelijke integratieprogramma's opgezet met specialle trajectbegeleiding. Het gaat daarbij om cursussen banen- en beroepenoriëntatie, computeroriëntatie, een cursus Word Perfect en een catering opleiding. ${ }^{13 *}$

\subsubsection{Medische zorg}

Een groot deel van de medische klachten en de klachten over de behandeling daarvan vloeien rechtstreeks voort uit de detentiesituatie zelf: ${ }^{135}$ Het verblijf in een totale gesloten- institutie leidt nu eenmaal als natuurlijke reactie tot zuiver lichamellijke en psychosomatische klachten. Het gebrek aan frisse lucht, het actief en passief roken, het gemis aan privacy en aan gewenste intimiteit zijn inherent aan het verblijfi. Vrouwen hebben daarnaast in zijn algemeenheid vaker medische vragen en klachten dan mannen. Meestal is dat wanuit de biologische verschillen te verklaren, met name wanneer het gaat om menstratieproblemen, uitstrijkjes, anticonceptie, abortus, voortplanting en overgangsklachten. Maar ook het werschil in socialisatie tussen vrouwen en mannen lijkt de aard van de consulten mee te bepalen. Mannen zouden meer op curatieve behandeling gericht zijn, vrouwen ook preventief en informatiezoekend. $^{137}$

Gedetineerde vrouwen hebben bovendien vaak specifieke klachten die ook kunnen samenhangen met het leven dat zij leidden voordat ze in de inrichting terecht kwamen. Problemen als gevolg van incest, (seksueel) geweld en verbroken relaties komen relatief vaak aan de orde. ${ }^{138}$

Om teveel medicalisering en symptoombestrijding van problemen te voorkomen is het raadzaam om naar de oorzaak van de klachten te zoeken. De vrouwen zouden tot reële probleemverheldering moeten kunnen komen, en dus niet uitsluitend bevestigd dienen te worden in hun positie van slachtoffer van een onderdrukkend systeem. (of dat nu de gevangenis, de maatschappelijke context of allebei is). De werkgroep "Vrouwen in detentie" stelt voor om tot een worm van vrouwenhulpverlening te komen. ${ }^{130}$ Deze vorm van hulpverlening is volgens de werkgroep niet bevoogdend van aard en ondersteunt de vrouw in het verkrijgen van haar onafhankelijkheid. Als hulpverleners die vanuit dit perspectief werken, worden door de werkgroep 'deskundigen' genoemd die vervolgens met functies aangeduid worden (maatschappe-

134 Nota "Werkzame detentie", 1993-1994, p. 25. Zie ook Van der Maas (1994) p. 51.

135 Zie ook Kelk (1989-1) p. 11 .

136 Zie ook Brouwers en Sampiemon (1988) p. 35-38.

137 Onder meer Gijsbers van Wijk (1995) p. 231-239. Janssen (1994) heeft daarnaast de interculturcle verschillen tussen gedetineerde vrouwen in medische hulpvragen belicht.

138 Rapport Werkgroep Vrouwen in detentie (1991) p. 43-45.

139 Rapport Werkgroep Vrouwen in detentie (1991) p. 44-45. Zie ook Thooft (1991) p. 34. 
lijk werkers, psychiaters, psychologen, artsen, gynaecologen). Als voorwaarde is niet opgenomen dat vrouwelijke gevangenen het recht hebben desgewenst door vrouwen. onderzocht en behandeld te worden. De werkgroep volgt met haar advies het regeringsbeleid dat gericht is op integratie van vrouwerhulpverlening in bestaande instellingen. ${ }^{\text {14! }}$

De integratie van vrouwenhulpverlening in reguliere instellingen wordt door patiëntenorganisaties echter met argusogen gevolgd. ${ }^{142} \mathrm{Zij}$ vrezen dat de uitgangspunten van de vrouwenhulpverlening, zoals ervaringsdeskundigheid en gelijkwaardigheid, ondersneeuwen. Bovendien wordt door de integratie de angell wit de kritiek op het medisch-diagnostisch denken gehaald. Dit laatste lijkt enigszins bevestigd te worden in het verslag van de inventarisatie die in alle 43 algemene psychiatrische ziekenhuizen gehouden werd naar de vorderingen die de integratie van vrouwenhulpverlening maakt. ${ }^{143}$ Er wordt een verband gelegd met de hiërarchische structuur en de machtsverhoudingen binnen de instelling.

"Het draagvlak van de vrouwenhulpverlening binnen de medische cultuur in het psychiatrisch ziekenhuis blijkt beperkt. Daarnaast wordt vrouwenhulpverlening vaak beschouwd als een bedreiging van de (dominante) positie van mannelijke behandelaars. De hulpverleensters ervaren de ondervertcgenwoordiging van wrouwen in beleids- en managementfuncties als een belemmering voor de integratie van de vrouwenhulpwerlening

Wellicht kan een systematische beschrijving van het huidige werk van de medische en psychosociale hulpverleners (de aantallen hulpverleners naar rang, sekse, werktijdfactor, leeftijd, de vraag naar hulp, de aard van de klachten, het aanbod van hulp, het voorschrijfgedrag, de verwijzingen en dergelijke.) een optimale integratie van vrouwenhulpverlening in penitentiaire inrichtingen vergemakkelijken. Van der Maas heeft al een uitgebreid inventariserend onderzoek gedaan naar de medische zorg in de PIV te Breda. ${ }^{145}$ In haar conclusies wijst zij, naast de hierboven reeds genoemde seksespecifieke problemen, met name op:

- De overdrewen, op mannen gerichte, bewaking tijdens het transport naar het medisch consult, als dat buiten de poort plaatsvindt.

- De specifieke omstandigheden waarin vrouwen zich voor en na de detentie bevinden (druggebruik en prostitutie) die kanswergrotend werken op bemetting met seksueel overdraagbare aandoeningen, waaronder HIV.

$140 \mathrm{Vgl}$. de ontwerp resolutie van het Europees Parlement, waarin een dergelijke woorwaarde wel is opgenomen. (Publicatieblad, 26-6-1989, nr. C 158/512)

141 Zie Eindrapport Adviesgroep Vrouwenhulpverlening (1991).

142 Onder meer Tabak (1992) p. 1-2 en Nicolai (1992) p. 3-6.

143 Egtberts (1992).

144 Egtberts (1992) p. 21.

145 Van der Maas (1994). 
- Het recht op informatie omtrent vragen die samenhangen met de reproductieve functies in het algemeen en zwangerschap en moederschap in het bijzonder;

- De keuzevrijheid ten aanzien van anticonceptiemiddelen.

- De keuzevrijheid ten aanzien van abortus.

Ook Van der Maas vindt dat vrouwen recht hebben op seksespecifieke hulpverlening en zij baseert dit onder meer op art. 12 van het VN-Vrouwenverdrag. ${ }^{146}$ Hoewel het aantal uren verpleegkundige zorg voor vrouwen inmiddels is verhoogd ten opzichte van dat van mannen, is het van belang dat ook het kwalitatieve verschil in medische hulpvragen wordt vertaalld in specifieke hulpverlening. ${ }^{\text {iv }}$ Het blijft een vraag of vrouwenhulpverlening in een bajes echt te realiseren is of dat "hulp"initiatieven wooral van buiten moeten komen. In de nota "Zorg ingesloten" die in 1995 uitkomt, is over seksespecifieke zorg voor vrouwelijke gedetineerden niets terug te vinden ${ }^{148}$

\subsubsection{Penitentiair inrichtingswerk}

De penitentiaire inrichting is organisatiesociologisch gezien een mengvorm van een totale institutie en een burocratische organisatie. ${ }^{1}$ Vanuit het gezichtspunt van de gedetineerden domineert de totale institutie, vanuit dat van de functionarissen de burocratie. Er is sprake van een strakke hiërarchische gezagsstructuur. Ook de individuele bewaarders kunnen zich in het gareel gevangen voelen. De overlegstructuren kunnen per inrichting verschillen. Hoewel het beleid vanuit Den Haag steeds meer gedecentraliseerd wordt, kunnen de uitvoerende werkers, de p.i.w.ers, die het meest direct met de gedetineerden omgaan, zich ver verwijderd voelen van het management. Het management wordt gevormd door de algemeen directeur, bijgestaan door de unitdirecteuren. De vrouweninichting heeft een eigen unitdirecteur, die verantwoordelijk is woor het primaire proces. Onder haar werken de plaatsvervangende directeur, de afdelingshoofden en de p.i.w.ers en bewaarders. ${ }^{150}$ De Bureaus Sociale Dienstverlening en het Sociaal Cultureel Werk staan onder één unitdirecteur, maar de medewerkers werken verspreid over alle units van de inrichting. Het Hoofd Arbeid valt onder de speciale beheersunit, die is belast met Financiële en Facilitaire Zaken.

146 Van dier Maas (1994) p. 17-23. Zie voor art. 12 VN-Vrouwenverdrag Van den Brinkl en Hendriks (1994), Holtrust, Hendriks en Bauduin (1996).

147 Er is sinds 19911 arts op 300 gedetineerden en 1 verpleegkundige op 50 mannellijke of 35 vrouwelijke gedetineerden beschikbaar. (Zie ook CPT/inf. 93(15), p. 41).

148 Nota 'Zorg ingesloten' (1995).

149 Zie Kelk (1993-1) p. 27-28.

150 Zie voor het organogram van een grote inrichting De Graaff (1996), p. 175. De bewaarders hebben een eigen teamleider die hiërarchisch gezien ook onder de unitdirecteur valt. Zij vervullen taken die vooral met beveiliging te maken hebben, waaronder ook de portiersfunctie en de begeleiding bij transport. 
Tijdens het congres "Women in prison; perspectives for change" in 1992 in Noordwijk benadrukt Platek ook nog eens dat het belangrijk is om op een professionele manier naar bewaarsters te kijken. ${ }^{151}$ Met uitzondering van Nederland en de Scandinavische landen, meent zij, wordt er vaak met dezelfde minachting naar bewaarsters gekeken als naar gedetineerden. Vrouwen die in de gevangenis werken, missen vaak voldoening in hun werk en een soort professionele trots. Onderzoek in Finland wijst ook uit hoe karakteristiek stress is voor dit werk. Het is belangrijk om te erkennen dat bewaarster zijn

- een beroep is;

- een gelegitimeerd beroep is;

- en een beroep waarvan persoonlijke relaties een belangrijk deel uitmaken.

On een menswaardige relaties tussen gedetineerde en bewaarder mogelijk te maken, is voorwaarde dat de bewaarder zelf ook gerespecteerd wordt door de staf en door collega's. Ook benadrukt zij dat in gevangenissen met gemengd personeel een veel natuurlijker ("humane, relaxed, elegant and apt to general structures") klimaat bestaat. Met de beleidswijzigingen na de Tweede Wereldoorlog is in Nederland ook de taak van de bewaarder veranderd. Hij moet zich meer op de bejegening richten en ook de functiebenaming wordt daaraan aangepast: penitentiair inrichtingswerker. ${ }^{152}$ Door een gericht beleid van positieve actie worden meer vrouwelijke pii.w-ers aangesteld die ook in inrichtingen voor mannen werken. Ook mannen werken in vrouweninrichtingen. ${ }^{1.33} \mathrm{Er}$ worden zelden specifieke functie-eisen gesteld gerelateerd aan de bestemming van de inrichting. In Sevenum zijn de p.i.w.ers multifunctioneel inzetbaar. Zij volgen een landbouwopleiding van een aantal maanden en sommigen hebben de bijscholing kinderopvang gedaan.

Dat ook bij gevangeniswezen de implementatie van het beleid niet altijd vlekkeloos verloopt, blijkt onder andere uit het volgende bericht:

"De minister van Justitie heeft cen eenmalige schadevergoeding toegekend aan 18 penitentiair inrichtingswerksters die een verzoek bij de Commissie hadden ingediend. (Oordelen 334a-91-49t/m 334 r-91-66). Verzoeksters waren via een positiewe aktieproject voor herintredende vrouwen bij het ministerie in dienst getreden. Voor zij werden aangesteld moesten de deelneemsters aan het project zeven maanden stage lopen en een opleiding volgen. Deze voorwaarden golden niet voor kandidaten in de reguliere selectieprocedure. Het maken van onderscheid naar geslacht is toegestaan als het tot doel heeft vrouwen

151 Platek (1992).

152 Zie onder meer De Graaff(1996).

153 Zie circulaire 363988/93/DIl Positieve aktie (11 mei 1993).

In de circulaire wordt het beleid van de afdeling $D$. en J, ten aanzien van "Positieve aktie voor vrouwen" geformuleerd. Er zijn streefcijfers voor 1995 opgesteld. Voor de executieve dienst worden de streefcijfers $75 \%$ mannen t.0. $25 \%$ vrouwen; in de niet-executieve dienst $70 \%$ mannen t.o. $30 \%$ vrouwen. Voor inrichtingen met een wrouwelijke gedetineerdenpopulatie zijn de percentages mannen en vrouwen in beide diensten omgekeerd evenredig. Zie over het wervingsbeleid en de effecten daarwan (ook met betrekking tot allochtone p.i.w.ers): Van Huët (1988) p. 192-194. 


\section{Hoofdstuk 3}

in een bewoorrechte positie te platsen. Uit het onderzoek van de Commissie bleek echter, dat een aantal vernoeksters in gellijke mate aan de selectiecriteria woldeed als de regulier aangestelde kandidaten. De Commissie oordeelde hierdoor dat er sprake was van onderscheid naar geslacht in strijd met de Wet.

De minister heeft verzoeksters in een brief laten weten het oordeel van de Commissie in grote lijnen te volgen en erop te zullen toezien dat de selectie bij dergelijke projecten voortaan nog zorgvildiger zal gebeuren".

Binnen de Dienst Justitiële Inrichtingen worden vrouwelijke werknemers gestimuleerd deel te nemen aan de vrouwennetwerken die op functieniveau georganiseerd zijn. ${ }^{\text {1ss }}$

\subsection{Samenvatting}

In dit hoofdstuk is gekeken welke uitwerking het op de mannelijk maat geënte detentiebeleid heeft voor gedetineerde vrouwen. Er is geschetst hoe in het naoorlogse beleid het begrip resocialisatie centraal komt te staan en zelfs als doel van de gevangenisstraf samen met het beginsel van minimale beperkingen verankerd wordt in de wetgeving. Nadat aanvankelijk veel verwacht wordt van gedrags- en houdingsveranderingen bij gedetineerden via groeps-, maatschappelijk en sociaalculturee werk, wordt in de jaren zeventig steeds meer onderkend dat het verblijf in de totale institutie zelf tot schadelijke effecten leidt. Bovendien wordt de oorzaak van crimineel gedrag dan sterk in omgevingsfactoren gezocht. Dit leidt tot een decriminaliseringstendens. In de jaren tachtig slaat het optimisme om. Met name door de harde aanpak van de drugscriminaliteit en later de zogeheten zware georganiseerde misdaad treedt een mentaliteitsverharding op ten aanzien van veroordeelden. Vooral de straffen worden hoger. Maar ook wordt, tegelijk met de toename van het aantal gedetineerden, duidelijk dat er erg veel probleemgevallen in de gevangenis terecht komen. Dat leidt tot steeds meer specifiek beleid voor kwetsbare groepen, zoals drugsverslaafden, psychisch gestoorden, zedendelinquenten etcetera. De rechten van de groep gedetineerden lijken meer te veranderen in op het individu gerichte regelingen, waaronder het penitentiair programma. 'Werk' wordt leidend beginsel. Dit alles leidt tot steeds meer variaties in detentievormen (differentiatie) en een enorme uitbreiding van het aantal cellen, ondanks de gelijktijdig toegenomen aandacht voor detentiefasering en alternatieve vormen van vrijheidsbeneming.

De vrouwelijk gedetineerden zijn al die tijd relatief klein in aantal. Dat betekent onder meer dat zij tot eind jaren tachtig uitsluitend in afdelingen verblijven die zich binnen het complex van een manneninrichting bevinden en zijn onderworpen aan dezelfde regels en dezelfde beveiliging. De interne differentiatie is voor vrouwen

154 In: Nieuwsbrief Commissie Gelijke Behandleling m/v, sept. 1992, $3 \mathrm{e}$ jg., nr. 5. 155 Zie bijwoorbeeld circulaire 16 februari 1995/482362/95/DNI. 
echter veel minder groot. Het duurt tot in de jaren tachtig voordat er iets van gelijke behandeling met gedetineerde mannen gerealiseerd wordt zoals gelijke beloning, bezoek zonder toezicht, open en halfopen plaatsen. In de jaren negentig komt er een iets beter arbeids- en cursusaanbod. En er worden een individuele behandelafdeling en een drugsvrije afdeling geopend. Het gaat daarbij in feite nog steeds om het 'volgen' van het voorzieningenpakket voor mannen.

Er wordt tussen 1947 en 1990 wel af en toe gepleit voor een specifiek beleid voor vrouwen, maar op veel meer dan 'de eigen aard van de vrouw' zijn die pleidooien niet gebaseerd. Op verschillende momenten lijkt er nieuwbouw speciaal voor vrouwen te komen, maar ook dat wordt steeds weer afgeblazen. Voor zover er specifieke aandacht aan vrouwen wordt gegeven is het aan de vrouw als 'moeder van het jonge kind'. Blijkbaar appelleert dat aan een beeld waar de politici en beleidsmakers zich iets bij kunnen voorstellen. Ook het in 1991 door de Werkgroep Vrouwen in detentie gepresenteerde rapport, dat een samenhangend geheel aan emancipatoire aanbevelingen omvat, krijgt uiteindelijk vooral een vervolg waar het gaat om voorzieningen voor kinderen van gedetineerde moeders. Met name het project in de halfopen inrichting Ter Peel in Sevenum voor moeders met kleine kinderen is voortgekomen uit de voorstellen van de werkgroep. Het relatieve succes van het project heeft mijns inziens te maken met de korte gemiddelde verblijfsduur van moeder en kind en met de intensieve samenwerking met het professionele kinderdagverblijf buiten de inrichting. Belangwekkende bevindingen zijn vooral dat 'continuïteit' voor het kind niet automatisch de exclusieve hechting aan de moeder inhoudt en dat 'het belang van het kind' een cultureelbepaald begrip is. Bovendien blijkt dat de doelgroep uitdijt als een voorziening eenmaal bestaat.

Discussies omtrent de familierelaties van gedetineerden en het onderwerp 'gemengde detentie' laten zien dat een ideologisch bepaald concept van familierelaties een grote rol speelt bij het bepalen van het detentiebeleid. De eigen seksualiteitsbeleving van vrouwen, de ervaringen van de vrouwen met het gezin als bij uitstek onveilige en onderdrukkende omgeving, de ambivalenties rond de partner- en moederrol en de eigen aard van medische en psychische klachten en vragen worden of niet onderkend of op zo'n wijze geproblematiseerd dat de gedetineerde vrouwen gestigmatiseerd blijven in hun slachtofferrol. 


\section{De materiële rechtspositie}

\section{Inleiding}

In het vorige hoofdstuk is aan de orde gekomen hoe de humanisering van het gevangeniswezen na de Tweede Wereldoorlog politiek gestalte krijgt. De hervormingsvoorstellen worden juridisch vertaald in de Beginselenwet Gevangeniswezen (BWG) en de nieuwe Gevangenismaatregel (GM). ${ }^{.}$Volgens Kelk wordt er aanvankelijk nauwelijks gesproken over de rechten van gedetineerden in juridische zin. De zorg en de hulpverlening en ook de kwaliteit van het personeel en het informele toezicht staan voorop.

"In ieder geval kan worden gezegd, dat er nu iets van de broederschapsgedachte doorbrak: het ging om de bejegening van de gedetineerde in het perspectief van diens resocialisatie, of zoals de Utrechtse school het noemde: de 'ontmoeting" tussen gelijkwaardige mensen".

Het is van belang dat naast de materiële rechten van gedetineerden ook hun formele rechten gewaarborgd zijn. Via een duidelijke procesgang kunnen materiële rechten immers optimaal gerealiseerd worden en kan er bovendien toezicht worden uitgeoefend op de directie van de gevangenis, aan wie nu eenmaal veel discretionaire bevoegdheden zijn toegekend. De wet rechtspositie gedetineerden treedt echter pas in 1977 in werking. ${ }^{3}$ De gedetineerden hebben daarmee een klachtrecht, een procedure waarlangs zij procedurele en materiële rechten kunnen opeisen.

Kelk onderscheidt drie aspecten in de rechtspositie van de gedetineerdes:

1. de rechtspositie van de gedetineerde als gedetineerde in de detentiesituatie (interne rechtspositie);

2. de rechtspositie van de gedetineerde als burger (externe rechtspositie);

1 Stbl. 1951, 596, in werking getreden op 1-6-1953.

2 Kelk (1989-2) p. 578.

3 Kort daarwoor was in 1976 het beroepsrecht bij het Gerechtshof in Arnhem van kracht geworden voor veroordeelden aan wie voorwaardelijke invrijheidstelling geweigerd of te lat verleend werd. Inmiddels is de voorwaardelijke invrijheidsstelling vervangen door de vervroegde invrijheidsstelling (art. $15 \mathrm{Sr}$ ).

4 Kelk (1993-1) p. 58-59. 


\section{Hoofdstuk 4}

3. de rechtspositie van de gedetineerde als justitiabele in het straf(proces)rechtelijk kader (externe rechtspositie.)

In dit hoofdstuk komt vooral de interne materiële rechtspositie van de vrouwelijke gedetineerden aan de orde en dan nog beperkt tot de gebieden waarop mogelijk specifieke regelingen ten aanzien van vrouwen te verwachten zouden zijn. De regiemvoering is in het vorige hoofdstuk al besproken, maar toen vooral in de beleidssfeer. Hier staat het regiem in enge zin centraal, dat will zeggen de rechten en plichten zoals die naar geldend recht zijn. Het gaat daarbij in het kader van mijn onderzoek vooral om materiêle nomen die betrekking hebben op de continuering of hervatting van de contacten met de buitenwereld, met name die met familie en partners. De detentie begint op het politiebureau. De gedetineerde kan daar worden opgehouden jvoor verhoor, inverzekering zijn gesteld of er de bewaring of gevangenhouding gedeeltelijk moeten ondergaan. ${ }^{\text {s }}$ Ontrent de interne rechtspositie van de verdachte op het politiebureau is weinig geregeld.. ${ }^{6}$ Uitgangspunt is dat de beperkingen minimaal moeten zijn en dat naarmate beperkingen langer duren en ingrijpender zijn, de motivering tot het opleggen ervan aan strengere eisen moet voldoen. $\mathrm{Naar}$ aanleiding van het rapport van het Comitê ter Preventie van Foltering (CPT) dat in 1993 werd uitgebracht ${ }^{8}$, is in de Ambtsinstructie woor de politie de volgende bepaling opgenomen:

1.. "Voor zover het bij of krachtens het Wetboek wan Strafvordering bepaalde zich hiertegen niet verzet stelt de ambtenaar een familielid of een huisgenoot van een ingeslotene zo spoedig mogelijk op de

5 Zie ook Reijntjes (1994) p. 112-120.

6 Zie onder meer Fiselier (1991), Berkhout-Vann Poelgeest (1993), Wiewel (1994), Naeyé (1995) p. 292-296.

7 Art. $62 \mathrm{Sw}$. en $76 \mathrm{Sw}$ jo art. 222 en 225 Inwoeringswet Sv, Besluit inverzekeringstelling (KB 4 dec 1925, Stbl. 460).

Corstens hat in relatie tot het pressicverbod (art. 29 lid $1 \mathrm{~Sv}$ ) het volgende voorbeeld tain: "De verdachte is 's nachts thuis aangehouden en meegenomen naar het buread; hem wordt vervolgens gezegd dat hij pas na een bekennende werklaring terug naar huis mag; hij wordt in de waan gelaten dat de politie geen voorzieningen heeft getroffen woor zijn thuss achtergebleven kleine kinderen. Die situatie is voor de verdachte bedreigend. Indien hij verwolgens een bekennende verklaring aflegt, kan niet worden gezegd dat die in vrijheid is afgelegd" (Corstens (1995) p. 254).

$8 \mathrm{CPT} /$ Inf (93) 15, p. 21. Het CPT (bevoegd op grond van art. 17 e. $\psi_{.}$Verdrag tegen foltering en andere wrede, onmenselijke of onterende behandeling of bestraffing) baseert zich bij haar onderzoek met name op de VN-beginselen woor gedetineerden (AVVN 9 december 1988 A/43/889, in: Sancties 1990, p. 284-290) en de European Prison Rules (Aanbeveling R(97)3 van het comité van ministers van de Raad van Europa van 12 februari 1987.) Het CPT kijkt naar de situatie van alle categorieën gedetineerden. "Dat houdt in dat ook centra woor de tenuitvoerlegging var vreemdelingenbewaring, politiebureaus, ophoudcellen in gerechtsgebouwen en gesloten afdelingen van psychiatrische inrichtingen onder het bereik van zo*n commissie vallen" (De Jonge (1996) p. 95). 
hoogte van de insluiting. In geval de ingeslotene minderjarig is, doet hij dit uit eigen beweging, indien de ingeslotene meerderjarig is, doet hij dit slechts op verzoek wan de ingeslotene".

2. "Indien de omstandigheden de witwoering van het eerste lid niet toelaten bij een ingeslotene die geen ingezetene is, wordt de ambassade of het consulaat wan het land waarin de ingeslotene ingezetene is ${ }^{\prime}$ op de hoogte gesteld van de insluiting."

De korpsbeheerder stelt echter nadere regels met betrekking tot onder andere het telefoneren en het ontvangen van bezoek van de ingeslotene. ${ }^{10}$ Voor de interne rechtspositie van de verdachte maakt het dus veel uit of zij in het $\mathrm{HvB}$ of het politiebureau zit. Het HvB valt onder de BWG. ${ }^{1 i}$ De BWG en de GM zijn van toepassing op gedetineerden in HvB en gevangenissen. Ook het wetsontwerp Penitentaire Beginselenwet (w.o. PBW) beperkt zich daartoe. Dit wetsontwerp wordt waar nodig in dit hoofdstuk verwerkt. ${ }^{12}$ Aan het klachtrecht van gedetineerden en aan de doorwerking van grondrechten in het penitentaire recht wordt gezien het onderzoekskader slechts kort aandacht besteed. ${ }^{13}$ Het grondrecht dat in dat opzicht vooral van belang is, art. 8 EVRM, komt in een volgend hoofdstuk uitgebreider aan de orde, ook in relatie tot andere verdragsartikelen. In dat hoofdstuk zal namelijk het tweede door Kelk genoemde aspect van de rechtspositie, als burger, vanuit het familierecht belicht worden. In het laatste hoofdstuk worden de bevindingen uit eerdere hoofdstukken ook vertaald naar de rechtspositie van de gedetineerde ouder/moeder als justitiabele. Hoewel daar de rechtspositie vooral vanuit het derde perspectief wordt benaderd, komen uiteindelijk de drie verschillende op elkaar inwerkende aspecten aan de orde.

9 Art. 27 Ambtsinstructie voor de politie, de Koninklijke marechaussee en de buitengewoon opsporingsambtenaar (Besluit van 8 aprill 1994, Stbl. 275).

10 Art. 15 lid 4 Besluit beheer regionale politiekorpsen (Besluit van 28 maart 1994, Stbl. 224).

11 Art. 217bis Invoeringswet Sv.

12 TK 1994-1995, nr. 24 263. In het in 1995 bij de TK ingediende wetswoorstel FBW krigen het differentiatiestelsel, de beveiliging en het penitentiair programma (zie hoofdstuk 3) een wcttelijke basis.Hoewell de Vaste Commissie voor Justitie van de Tweede Kamer nog een extra hoorzitting over het wetsontwerp wil houden, gaat men er op het departement vanuit dat de PBW in het voorjaar van 1997 in werking zall treden (Kwartaalrapportage D.I 1996/3, p. 11.1).

13 Zie voor een algemene bespreking van de nieuwe Penitentiaire Beginselenwet in thet licht van de grondrechten Smaers (1996). Het walt op dat zij in haar toetsing met name leunt op de belejidsnota's, omdat de regelgeving in haar optiek is afgeleid van het geformuleerde beleid. Zij komt dan tot de conclusie (p. 511) dat "de in het EVRM neergelegde rechten niet langer als een minimum worden beschouwd, een fundering waarop de penitentiaire regelgeving verder bouwt, maar als een maar als een maatstaf voor wat maximaal van de overheid mag worden verwacht". 


\subsection{Het klachtrecht}

De gedetineerde heeft sinds 1977 een formeel klachtrecht bij de uit drie leden bestaande beklagcommissie van de Commissie van Toezicht. De leden zijn onafhankelijke burgers die 'representanten van de samenleving' heten te zijn. ${ }^{15}$ Deze beklagcom. missie kan in een aantal nader omschreven gevallen een bindende beslissing geven. Tegen zo"n beslissing staat voor de in het ongelijk gestelde partij de mogelijkheid open in beroep te gaan bij de Beroepscommissie $(\mathrm{BC})$ van de Centralle Raad voor Strafrechtstoepassing.

Het formele beklagrecht, zoals neergelegd in art. 51 Beginselenwet Gevangeniswezen, luidt:

"Een gedetineerde in een gevangenis, huis van bewaring of rijkswerkinrichting kan beklag doen over:

a. Een hem opgelegde disciplinaire straf;

b. Een weigering tot het uitreiken of verzenden van voor hem bestemde of door hem geschreven brieven en andere stukken, dan wel om wolgens de daarvoor in het gesticht geldende regeling bezoek van bepaalde personen te ontvangen;

c. Enige andere them door of vanwege de directeur opgelegde maatregel waarbij wordt afgeweken van de rechten die hij aan de in het gesticht geldende voorschriften kan ontlenen".

Met name de onder het laatste lid genoemde rechten kunnen zeer ruim opgevat worden. Het moet echter wel gaan om een beslissing genomen door of namens de directeur, wil de klacht ontvankelijk zijn. ${ }^{16}$ Andersoortige klachten kunnen eventueel onder de aandacht van de maandcommissaris van de Commissie van Toezicht worden gebracht. De beklagcommissie kan een beslissing van de directeur herzien als die in strijd met het recht genomen is of als onredelijk of onbillijk wordt beschouwd. Bij een beslissing waarvan de gevolgen niet meer ongedaan te maken zijn kan compensatie worden toegekend, bijwoorbeeld in de vorm van extra faciliteiten of in geld. In het w.o. PBW worden enige veranderingen in de klachtprocedure voorgesteld. ${ }^{17}$ Zo worden in zijn algemeenheid "beslissingen van de directeur" onderwerp van beklag, dus niet alle handelingen en gebeurtenissen die plaatsvinden onder verantwoordelijk-

15 De commissie van toezicht is breed samengesteld. De Minister streeft naar tenminste een rechter, een advocaat, een medicus en iemand uit de kring van het maatschappelijk werk (art. 9 lid 2 Gevangenismaatregel). Of zij naar etniciteit en sekse ook een weerspiegeling van de samenleving wormen, is mijn niet bekend (vgl. de ontwerp resolutie van het Europees Parlement onder d).

16 art. 12 lid 2 GM.

17 Artt. $60 \mathrm{t} / \mathrm{m} 71$ w.o. PBW. Zie ook Van de Pol (1996), p. 64-70. Zie voor commentaren op de nieuwe beklagregeling onder meer Jansen (1995), Kelk (1995) en Boonen (1995). 
heid van de directeur, tenzij de gedetineerde daarover een beslissing uitlokt. ${ }^{18}$ Een klacht moet volgens het wetsontwerp ook gemotiveerd worden. ${ }^{\text {p }}$ Verder wordt de mogelijkheid van bemiddeling, via een lid van de Beroepscommissie, geïntroduceerd en wordt de mogelijkheid van schorsing via de voorzitter van de beroepscommissie ingevoerd. Het beklagrecht is afgestemd op de individuele gedetineerde. Groepsacties, kwesties van algemene aard, zoals geschillen over het algemene beleid of regelgeving kunnen aan de Kort Geding rechter worden voorgelegd. ${ }^{\not \dagger}$ Ook strekt het klachtrecht zich niet uit tot klachten van derden, zoals familieleden. ${ }^{21}$

Door Kelk wordt een onderscheid gemaakt tussen de materiële en de procedurele rechten van de gedetineerde. ${ }^{22}$ Juist omdat in de detentiesituatie de materiële rechten zo moeilijk precies te benoemen zijn en de directeur via de aan hem of haar toegekende instructienormen zoveel macht heeft, is de formele positie van de gedetineerde van essentieel belang. Het zwaartepunt van het beklagrecht is dan ook gelegen in de procedurele rechtspositie, waarin rechtsbeginselen getoetst kunnen worden. Het individu moet als de zwakkere beschermd worden ten opzichte van de ordenende en controlerende overheid. Via de contradictoire procedure kan er dynamiek in de statische posities gebracht worden en kunnen in zekere zin, door het uitlokken van jurisprudentie, ook materiële rechten gecreëerd en ingevuld worden. ${ }^{23}$ Zoals in eerdere hoofdstukken te zien was, wordt aan de versterking van de rechtspositie in zijn algemeenheid ook een emanciperende functie toegekend of wordt het gezien als teken van emancipatie als een individu 'zijn recht gaat halen'. Wellicht past dat ook in het instrumentele idee dat in de zeventiger jaren overheerst, dat de machtspositie

$18 \mathrm{Nu}$ de bevoegdheid van de directeur tot het stellen van regels in de nieuwe wet wordt uitgebreid (art. 5 lid 1) zal een gedetineerde geen beklag kunnen indienen tegen een aanpassing van de huisregels, omdat het dan een algemene regeling betreft. Alleen wanneer de huisregel in strijd is met een hogere regeling en de directeur opgrond wan de huisregel een beslissing neemt, kan de gedetineerde stellen dat een recht van hogere orde is geschonden (zie ook MvT, TK 1994-1995, 24263; ni. 3, p. 73-74).

19 Zie Kelk (1995) p. 1038: "Maar men moet niet vergeten dat het overgrote deel van de populatie in penitentiaire inrichtingen miet de hoogste opvoeding en opleiding in verbale en schriftelijke uitdrukkingsvaardigheden heeft genoten en dat er zelfs analfabetisme onder hen woorkomt". MVT, TK 1994-1995, 24263, nr. 3, p. 75.

21. Vgl. De Jonge (1996) p. 101.

22 Kelk (1993-1) p. 45-46.

23 Zie ook: Habermas (1988) p. 51-89. Habermas theeft het over de legitimiteit wan de legaliteit die berust op een verstrengeling van juridische procedures met een morele argumentatie. Die wordt gebaseerd op de 'rationaliteit ' van het recht, nu er geen collectieve religieuze of metafysische zekerheden meer zijn. Het recht dient als compensatie voor de tekortkomingen wan een autonome moraal. Het recht staat tussen politiek en moraal. In het juridisch discours worden werbindingen gelegd tussen de toeprassingsargumenten van de wetsinterpretatie, argumenten over politieke doelstellingen en argumenten over morele rechtvaardiging. 
via collectieve actie verbeterd kan worden en waarbij verbetering van de rechtspositie als inherent verschijnsel wordt meegenomen. Nu er op alle fronten een verschuiving van het collectieve denken of van het denken vanuit collectieve belangen valt waar te nemen in de richting van het meer individualistische onderhandelingsdenken duikt opnieuw de vraag op welke functie de juridisering van zowel algemeen geldende als op het individu toegespitste afspraken daarin nu nog heeft. ${ }^{24}$

De juridiseringstendens van de detentiesituatie heeft aan Heijder de vraag ontlokt of een normatieve rechtsopvatting niet al te zeer het verband tussen de groei van bepaalde normen en de structuur van de situatie zelf miskent. ${ }^{25} \mathrm{Ik}$ denk dat deze vraag met name interessant is, nu de werking van macht steeds meer wordt gedifferentieerd en het instrumentele gebruik van het 'beschermende' recht niet meer vanzelfsprekend als onverdeeld gunstig voor de minder machtigen wordt gezien. ${ }^{26}$ Bimnen de doelgroep maken de meest machtigen en best geïnformeerden veelal gebruik van juridische procedures. ${ }^{27}$ Gedetineerde vrouwen voeren relatief gezien heel weinig beklagprocedures tot het eind. ${ }^{28}$ Beide verschijnselen rechtvaardigen de vraag of

24 Vgl. ook de opmerking van El Sadaawi (Proceedings, 1992, p. $68-69$ en 212) die waarschuwt voor een te individualistische benadering, omdat daardoor de kractst van het collectief gebroken kan worden.

Zie over de verschuiving van het denken em handelen vanuit het collectief naar de onderhandeling vanuit de individuele positie onder andere De Swaan (1989).

25 Heijder (1979) p. 467. Heijder bespreekt hier de dissertatie wan Kelk. Kelk heeft een rigide onderscheid gemaakt tussen "machtigen" en "onmachtigen" en verwacht veel van een instrumentele inzet van het recht. Heijder vindt dat Kelk de feiten een beetje naar zijn hand heeft gezet: " $Z$ ijn betoog zou crbij gewonnen hebben als hij feiten en normen niet zo definitief uit elkaar had gehaald en ze in hun onderlinge, historische, dus veranderende, ontwikkeling had laten zien". In de laatste druk van zijn "Kort begrip van het detentierecht" bespreekt Kelk wel de verwevenheid van feiten en normen die naar zijn mening alles te maken heeft met de verwevenheid wan machtsstructuur en juridische structurur in een penitentiaire inrichting. "In de penitentiaire inrïchting hebben normen vaak de schijn van feiten en feiten de schijn van normen" (Kelk (1993-1) p. 44.).

Onder andere Smart (1989), Pessers (1991), Goldschmidt en Holtmaat (1993) p. 505-517. Zie over de juridisering in de detentiesituatie De Jonge (1994), p. 258-272. Hij beschrijfif hoe een uitsluitend instrumentalistisch gebruik wan het recht zelfs een remmende inwloed kan hebben op penitentiaire ontwikkelingen.

27 Schuyt (1983) p. 4169.

28. Van der Berg (1986), Soetenhorst (1987) p. 461, Van Goudoever-Herbschleb (1994) p. 6. De laatste schrijft dat de inrichtingen woor vrouwen over het algemeen een lager aantal klaagschriften thebben dan het landelijk gemiddelde. Wel schijnen de klaagschriften van vrouwen vaak meerdere klachten te bevatten. Gezien de bestemmingswijzigingen en het feit dat de vrouweninrichtingen deel uitmaakten van grote manneninrichtingen heeft zij in haar onderzoek de vrouwenünichtingen miet apart kunnen onderzoeken. Op de najaarsvergadering van de Vereniging voor Penitentiair recht en Penologie werden alls mogelijke redenen voor de grote verschillen in aantal klachten tussen inrichtingen genoemul: de grootte van de (nieuwbouw)inrichtingen, de aanwezigheid van ervaren personeel, het psychosociale klimaat in een inrichting en de verstandhouding tussen de directeur en de commissie van toezicht (Wurzer-Leenhouts (1994) p. 43). 
de juridisering van de detentiesituatie uiteindelijk leidt tot versterking van mannelijke dominantie in het politieke en juridische denken over detentiesituaties. Vrouwen zouden ook daardoor relatief 'onzichtbaar' blijven. Dat hoeft niet per se ongunstig te zijn. Individuele vrouwen die cultuurhistorisch gezien, niet anders gewend zijn dan voortdurend in ongelijke posities te verkeren, zijn wellicht nog meer gesocialiseerd in het micro-onderhandelen, het verwerven van gunsten en extraatjes dan in het opeisen van rechten. ${ }^{\star} \mathrm{Zij}$ zullen in hun afhankelijkheidspositie, zowel thuis als daarbuiten, in de eerste plaats de harmonie willen bewaren. Er lijkt sprake te zijn van een soort van collectief bewustzijn dat openlijk de strijd aangaan juist bij vrouwen vaak leidt tot uitsluiting en positieverlies. Kelk stelt vast dat aan zijn beschouwingen in beginsel het beperkte mensbeeld van de 'mannelijke rechtsburger' ten grondslag ligt. ${ }^{30}$ Dat impliceert mogelijk een eendimensionale weergave van het zwakke individu ten opzichte van de ordenende en controlerende overheid. Het beeld van de vrouwelijke rechtsburger lijkt mij diffuser. Het zwakke individu dat in een permanente afhankelijkheidsrelatie tot (wisselende) anderen gedefinieerd wordt en ook zichzelf zo definieert. Zij wordt met een ambivalente rol van de overheid geconfronteerd, zowel een ordenende en controlerende als een beschermende. Ook het concept van de 'gedetineerde rechtsburger' lijkt zo genderspecifiek uitgelegd te kunnen worden. In oorsprong staat de man in een hiërarchische en de vrouw in een loyale relatie tot anderen, niet alleen binnen maar ook buiten de detentiesituatie. De vrouw lijkt vooral slachtoffer van haar strijdige loyaliteiten te zijn. Zij kent ook privé veelal geen autonome positie, maar geeft zichzelf betekenis in afgeleide identiteiten: de dochter, echtgenote, vriendin, moeder van.... De man kan buiten de detentiesituatie vaak op een (prive)leven terugvallen, waarover hij naar zijn idee de baas is. Het mensbeeld van de 'mannelijke rechtsburger' is overigens ook niet op alle mannen van toepassing. Binnen de mannen als groep moet net als bij vrouwen ook vanuit genderperspectief gedifferentieerd worden.

In de luwte van de onzichtbaarheid kunnen echter ook in relatieve stilte humaniseringsprocessen op gang gebracht worden die woor het collectief gunstig uitwerken. Bijvoorbeeld de in het vorige hoofdstuk geschetste kindermiddagen, kleinschalige kinderopvang en dergelijke. Omdat de kans op het ontstaan en het voortbestaan van dergelijke voorzieningen nu sterk afhankelijk is van persoonlijke initiatieven bij het management is het wel belangrijk om op enig moment iets vast te leggen. Creativiteit en continuïteit in de beleids- en bejegeningssfeer kunnen echter sterk beperkt worden als de beleidsvrije ruimte te vroeg wordt dichtgemetseld met regelge- 


\section{Hoofdstuk 4}

ving ${ }^{\text {aI }}$ Bovendien kunnen positieve ontwikkelingen in éen inrichting een hefboomwerking hebben in het op gang brengen van vernieuwende processen in de andere inrichtingen. Eventuele klachten van individuele gedetineerden kunnen vervolgens ook gemakkelijker, bijwoorbeeld op grond van het recht op gelijke behandeling, in positief geformuleerde eisen worden vertaald:

Al met al denk ik dat het klachtrecht wel een noodzakelijk en uiterst belangrijk deel van de rechtspositie wan de gedetineerde is. Bij vrouwen lijkt het nog meer dan bij mannen 'sluitstuk' van een onderhandelingsproces te zijn. In principe is de mogelijkheid van tussentijdse bemiddeling dan ook toe te juichen. ${ }^{32}$ Belangrijk lijkt het mij ook om de door Soetenhorst al lang geleden geïntroduceerde vertrouwenspersoon voor vrouwelijke gedetineerden nog eens serieus in overweging te nemen. ${ }^{33}$

\subsection{Grondrechten}

Voor eerbilediging van grondrechten en subjectieve rechten bestaat in de gevangenissituatie per definitie beperkt ruimte. Inherent aan de situatie zijn immers beperking van bijvoorbeeld de bewegingsvrijheid, de lichamelijke integriteit en de privacy. Aanvankelijk krachtens de leer van de 'inherent limitations' en later die van de 'legitimate limitations' kunnen de rechten van personen die zich ten opzichte van de overheid in een bijzondere rechtspositie bevinden, beperkter van omvang zijn dan van personen die buiten een dergelijke categorie vallen. ${ }^{34}$ Dit gellt dan met name voor verdragsartikelen waarin geen beperkingsclausules zijn opgenomen. (vgl. art. 3 en 6 EVRM). Dan zal van gevall tot geval bezien moeten worden welke beperkingen noodzakelijk en redelijk zijn. Bij toetsing van opgelegde beperkingen zullen alle relevante omstandigheden van het geval worden betrokken. Daar kan ook de "bijzondere rechtspositie" van de gedetineerde onder vallen. Als er in de verdragsbepaling uitdrukkelijk beperkingsvoorwaarden genoemd worden, moet aan én van die eisen voldaan zijn. De opsomming van dergelijke vereisten luidt in de verschillende artikelen wrijwel hetzelfde: de beperking moet bij wet zijn voorzien, in een democratische samenleving nodig zijn in het belang van 's lands veiligheid, de openbare veiligheid of het economisch welzijn van het land, de bescherming wan de openbare orde en het woorkomen van strafbare feiten, de bescherming van de gezondheid

31 Vgl. Werkgroep Vrouwen in detentie (1991) p. 47. Het is opwallend dat alle beleidsaanbevelingen, op ến na, van de Werkgroep Vrouwen in detentie onder de bestaande regelgeving gerealiseerd kunnen worden. Die ene, de oplveffing van de strikte scheiding tussen mannen en vrouwen, wordt overigens in art. 11 w.o. PBW ook herzien,

32 Zie ook Nijboer (1993).

33 Soetenhorst (1987) p. 461. Wellicht wervullen geestelijk werzorgers nu al vaak die roll, maar die zou dan toch meer onderscheiden en geformaliseerd moeten worden en een structurele basis krijgen.

34 Zie voor uitgebreide beschouwingen over de jurisprudentie van de Europese Comnisie en het Europese Hof in het kader van de detentie Smaers (1994). 
of de goede zeden of voor de bescherming van rechten en vrijheden van anderen. Zowel 'het voorzien bij wet' als de beperkingsdoeleinden kunnen bij verschillende rechtsprekende instanties tot interpretatieverschillen leiden. ${ }^{35}$ Het Europese Hof gaat uit van een materieel wetsbegrip, daaronder valt dus iedere algemene regel die een basis heeft in het nationale recht en die voldoende toegankelijk is en zo precies geformuleerd dat een burger de consequenties van zijn handelen redelijkerwijs kan voorzien. (legaliteitsbeginsel). Bij de toetsing van de beperkingsdoeleinden dienen vragen naar legitimiteit en proportionaliteit leidraad te zijn.

Een mogelijke beperking in de uitoefening van grondrechten van gedetineerden kan in Nederland ook gebaseerd worden op de algemene beperkingsgrond die te vinden is in art. 15 lid 4 van de Grondwet:

"Hij aan wie rechtmatig zijn wrijheid is ontnomen kan worden beperkt in de uitoefening van grondrechten voor zover deze zich miet met de vrijheidsbeneming verdraagt".

Volgens Kelk heeft dit artikell onmiskenbaar de bedoeling "gedetineerden te vrijwaren voor beperkingen in de uitoefening van hun grondrechten, die niet onverenigbaar zijn met de vrijheidsbeneming of daardoor feitelijk onmogelijk worden gemaakt". ${ }^{36}$ Binnen het penitentaire recht zijn in zijn algemeenheid beperkingen op grond van de orde en veiligheid in de inrichting gelegitimeerd. Zowel uit de jurisprudentie van de Beroepscommissie van de Centrale Raad voor Strafrechtstoepassing (voorheen Centrale Raad van Advies) en de Hoge Raad als uit de literatuur blijkt dat beperkingsclausules nogal casuïstisch worden toegepast en dat met name de algemene beheersbevoegdheid van de directeur bij de beslissingen een belangrijke toetssteen vormt. Het gaat daarbij vaak om een marginale toetsing. ${ }^{37}$ Hierbij kunnen de beginselen van proportionaliteit en subsidiariteit een rol spelen. Zo bepaalt de Beroepscommissie ten aanzien van onderzoek aan het lichaam door een personeelslid van de andere sekse dat dit, behoudens gevallen van dringende noodzaak, niet mag. (...) "dergelijke beperkingen behoren gedetineerden niet zwaarder te treffen dan door het doel van de vrijheidsbeneming en door een richtige tenuitvoerlegging daarvan is vereist" ${ }^{38}$

In de Memorie van Toelichting bij het wetsontwerp Penitentiaire Beginselenwet wordt overigens opgemerkt dat het vergeldend karakter van de vrijheidsstraf wordt

35 Viering (1988) p. 40-52, Smaers (1994) p. 64-101.

36 Kelk (1989-2) p. 579. Zie ook: Kellk (1986) p. 343, Boek (1991) p. 376-378, anders: Van Veen (1987) p. 195 e.v.

37 Viering (1988) p. 40-52, Kelk (1993) p. 13-14, Smaers (1996) p. 499.

38 Visitatie van mannelijke gedetineerden door vrouwelijk persaneel, BC 20 november 1987 , in : NJCM $14-1$, p. $36-42$, mel noot P. Vegter. De BC toetste overigens aan de beperkingsgrond van art. 8 lid 2 EVRM ten aanzien van het recht op privacy (art. 8 lid 1 EVRM). Onderzoek aan het lichaam wordt dus niet onder art. 3 EVRM geplaatst (verbad van vernederende behandeling). 
aangescherpt. Dit blijkt onder meer uit de toegenomen aandacht voor de beveiliging, waarbij als grond voor beperking van rechten van gedetineerden "een ongestoorde tenuitvoerlegging van de vrijheidsbeneming" aan de bestaande beperkingsdoeleinden (orde en velligheid in de inrichting) is toegevoegd. ${ }^{35}$ Die toegenomen beveiliging heeft feitelijk tot nu toe alleen betrekking op gedetineerde mannen, de algemene wettelijke regeling echter op mannen èn vrouwen. Het lijkt mij dat toetsing van zo beperkingsgrond aan de eis van legitimiteit en proportionaliteit (naar het doel en de noodzaak van de regeling) op grond van het beginsel van gelijke behandeling tot een genderspecifieke benadering zou moeten leiden.

In het kader wan de 'gelijke behandeling van mannen en vrouwen' is het interessant om te zien welke invulling de Beroepscommissie aan het gelijkheidsbeginsel geeft. De belangrijkste nationale uitspraak lijkt mij in dit verband die waarin de $B C$ stelde dat wanneer de vrouw op grond van feitelijke omstandigheden (beperkte differentiatie voor vrouwelijke gedetineerden) in een een ander paviljoen, met een ander regiem, is geplaatst dan waar zij eigenlijk thuis zou horen er ten opzichte van haar een extra criterium in het leven zou worden geroepen in vergelijking tot mannen met dezelfde detentiestatus, hetgeen in strijd is met de art. 14 EVRM en 26 IVBPR.+1 Dat zou dus een materiële invulling van het gelijkheidsbeginsel kunnen worden genoemd, omdat zowel de context als het effect van de regeling in de uitspraak betrokken worden. Kritische feministen zullen daarbij mogelijk aantekenen dat er toch sprake is van aanpassing aan de dominante norm, dat wil zeggen aan de heersende cultuur (regiems en differentiatiecriteria) die op de dominante, mannelijke, norm geènt is. De institutionele discriminatie van vrouwen blijft bestaan. ${ }^{42}$

In het detentierecht kunnen het EVRM en de rechtstreeks werkende verdragsbepalingen uit andere internationale verdragen, zoals het IVBPR, het VN-Vrouwenverdrag en het VN-Kinderverdrag dus een belangrijke rol spelen bij de invulling van materiële rechten in concrete situaties. ${ }^{43}$ Omdat de betreffende grondrechten in principe tegenover iedere rechter kunnen worden ingeroepen, is het interessant om te zien dat

39 TK 1994-1995, 24 263, nr. 3, p. 6-7. "Dit betekent dat ordemaatregelen niet alleen kunnen worden genomen, indien een gedetineerde de orde in de inrichting verstoort, maar ook indien zijn gedrag voor de vrije maatschappij ongewenste effecten heeft. Te denken valt bijvoorbeeld aan het lastigvallen van slachtoffers of het voortzetten van dubieuze zakelijk activiteiten vanuit de inrichting" (p. 7).

$40 \mathrm{Vgl}$. Holtmaat (1596) p. 4-17. Holtmaat houdt een pleidooi om ter bestrijding van de schijn vam gender-nentraliteit in het recht, nadruk te leggen op de discussie over thet doel van de -bestredenregeling.

41 BC 17 maart 1988, PI 1988, 57, Wolleswinkel (1988).

42 Vgl. Holtmaat, Nemesis (1996) p. 10-11..

43 Loenen meent dat de bepalingen uit het VN-Vrouwenverdrag ingelezen kunnen worden in art. 26 IVBPR en daardoor rechtstreekse werking krijgen (Loenen (1994) p. 10).

In penitentiaire casus hebben tot nu toe noch het VN-Kinderverdrag, noch het VN-Vrouwenverdrag een rol gespeeld. Relevante bepalingen uit beide verdragen komen in cen volgend hoofdstuk terug. 
van alle zaken die bij de Commissie in Straatsburg terecht komen (dus na uitputting van de nationale rechtsmiddelen) een groot deel afkomstig is van gedetineerden. ${ }^{*}$ Art. 8 EVRM dat met name van belang is om contacten met de buitenwereld te kunnen realiseren is herhaaldelijk door gedetineerden ingeroepen voor de Europese Commissie en het Europese Hof. Het betreft daarbij klachten van mannelijke gedetineerden. Met name in de zaken waarin het contact met een minderjarig kind aan de orde komt, wordt de klacht afgewezen met een beroep op het welzijn van het kind (art. 8 EVRM lid 2). ${ }^{45}$ In deze zaken lijkt het belang van het kind bovendien nauw gerelateerd te zijn aan dat van de moeder en daarmee dus ook voor een deel genderspecifiek bepaald. ${ }^{46}$ Mogelijke gevolgen voor eventuele aanspraken van gedetineerde primaire verzorgers (in casu meestal moeders) lijken me dan ook niet voorspelbaar op grond van de beschikbare jurisprudentie.

Interessant is nog het onderscheid dat in de Europese rechtspraak in het kader van art. 8 EVRM gemaakt wordt tussen het recht op privacy en het recht op family life in het contact met de buitenwereld via briefwisseling, bezoek en telefoon. Onder het recht op privacy valt, naast het contact met medegedetineerden ook dat met persoonlijke vrienden en kennissen. Het family life is beperkt tot de familie. ${ }^{\text {s7 }}$ Dit zou interessant kunnen zijn voor zowel vrouwelijke gedetineerden als hun kinderen, wanneer zij zouden willen ontsnappen aan een (levens-) bedreigende familiesituatie. Het negatieve sociale isolement waarin veel vrouwen en kinderen binnen gezinnen gevangen zitten, kan dan met een beroep op het eerbiediging van het recht op privacy doorbroken worden. ${ }^{48}$

44 Kelk (1993-1) p. 104-106, Smaers (1994) p. 19. Smaers constateert wel een afname van meer dan de helft van het totaal aantal klachten in de jaren zestig tot ongeveer 15\% in de jaren tachtig. Zij denkt dat dit mede te maken heeft mett het grote aantal niet-ontvankelijkverklaringen van de Commissie.

45 In: Smaers (1994) p. 259-260. In een yolgend hoofdstuk komt de hieraan verwante hor izontale belangenafweging binnen famillierechtelijke relaties op grond van art. 8 EVRM aan de orde.

47. Smaers (1994) p. 251-262.

48. In het mensenrechtendiscours zijn de begrippen private sphere, family sphere en het recht op privacy vaak als inwisselbare begrippen gehanteerd. Met name vanuit feministische hock is hierop kritiek geuit. Zie 0.a Eisler (1987) p. 287-308. "If we then look at the family as a social institution, the fundamental question is to what extent has society the right to interfere with the family in the interest of protecting individual rights, of which the right to privacy is one." En nadat ze heeft geconstateerd dat inmenging wel degelijk plaatswindt doordat ook de familiesfeer onder de wet valt en er ook opgetreden wordt wanneer bijwoorbeeld een man zijn broer vermoordt; stelt $z i j$ dat vooral autonomie van een speciale gezinsstructuur beschermd wordt: "a male headed, procreation-oriented patriarchal family in which women have few if any individual right $s^{\prime \prime}$ (p. 293). Volgens haar moet het verschil tussen het recht op privacy en het recht op non-interventie in het familieleven worden onderkend. $\mathrm{Zij}$ stelt dat het recht op privacy een individueel recht is, dat net als alle andere rechten bescherming verdient, binnen en buiten het gezin. 
Naast de direct werkende verdragsbepalingen zijn er ook normatieve regels, aanbevelingen aan lidstaten, die in beklagprocedures naar voren gebracht kunnen worden, met name de Standard Minimum Rules, VN 1977 en de European Prison Rules, Raad van Europa, 1987 en het VN-document 'Beginselen inzake de bescherming van alle categorieën gedetineerden en gevangenen, VN 1988. De Jonge en Verpalen noemen in dit verband ook de Code of Conduct for Law Enforcement Officials." Ook buiten beklagprocedures van gedetineerden om kan natuurlijk het detentiebeleid aan grondrechten en nader ingevulde gedragsregels getoetst worden. Zo kan er via landenrapportages en permanente commissies specifiek aandacht besteed worden aan de situatie van vrouwelijke gedetineerden en aan de effectuering van het recht op family life van gedetineerden en hun kinderen. ${ }^{\text {so }}$

Maar zelfs bij bestudering van grondrechten, kan vanuit cultuur- en genderrelativisme, de vraag opdoemen of deze niet zodanig geformuleerd zijn dat zij zelden een algemeen geldende waarde kunnen hebben. De scheiding tussen de publieke en de privêsfeer werkt immers, soms in alle subtiliteit, ook in internationale verdragen door. ${ }^{\text {sl }}$ In het Vluchtelingenverdrag is bij voorbeeld seksediscriminatie (en seksueel geweld) niet als criterium opgenomen en daarmee dus ook geen grond voor asielverlening. ${ }^{\text {sa }}$ Door codificatie en impliciete bevestiging van het dominante cultuurpatroon kan het onderscheid tussen legaal en illegaal gedrag juist van vrouwen heel diffuus worden, zoals in hoofdstuk 1 ook al aan de orde kwam.

Hoewel de rechtsposities wan vrouwen op nationaal niveau sterk zullen werschillen, is eerder al aan de orde gekomen hoe bijvoorbeeld in het strafrecht misdrijven die tegen of wellicht ook door vrouwen gepleegd worden (sekseverbonden criminaliteit) aan het zicht onttrokken zijn (vgl, vrouwenmishandeling en tot voor kort-verkrachting binnen het huwelijk).

In het kader van dit onderzoek is het interessant hoe het family life en private life zich in art. 8 EVRM tot elkaar werhouden en of bij de invulling daarvam bepalingen uit het VN-Kindlerverdrag en het VN-Vrouwenverdrag een rol kunnen spelen. Dit komt in de volgende hoofdstukken terug.

49 De Jonge en Verpallen (1992) p. 111.

50 Vgl. de werkzaamheden van het Comité ter Preventie van Foltering.

Om de rechten van kinderen van gedetineerde ouders te effectueren krachtens het VN-Kinderwerdrag worden nu de mogelijkheden onderzocht om het "European Action Research Committee for the children and their incarcerated parents" een permanente status te geven. Tot nu toe is dit een particulier initiatief van betrokkenen uit verschillende disciplines, die inhoudelijk zeer verschillende projecten en initiatieven bespreken en hierover publiceren (Vgl. Bouregba, 1996).

51 Onder andere Eisler (1987) p. 287-308, Brünott (1991) p. 27-30, Charlesworth, Chinkin en Wright (1991), Willems (1996).

52 Via art: 2 van het VN-Vrouwenverdrag zou bescherming tegen (potentielle) slachtoffers van selksueel geweld en seksediscriminatie well geboden moeten worden. Zie Van Walsum (1996). 


\subsection{Materiële rechten}

In de volgende paragrafen zal bekeken worden in hoeverre in het nationale penitentiaire recht rekening gehouden wordt met biologische en sociale functies van vrouwen of in de laatste functie - genderspecifiek-van verzorgende ouders..$^{53}$ In relatie tot het gezinsleven van gedetineerden komt allereerst het recht op briefwisseling, bezoek en telefoneren aan de orde. Rechten die onder de reikwijdte van art. 8 EVRM vallen en die ook in de nieuwe PBW gecodificeerd zijn onder de titel "Contact met de buitenwereld".s4 Het betreft dan de rechten van de gedetineerden en hun familie die worden witgeoefend binnen de poorten van de inrichting. Zoals uit voorgaande hoofdstukken blijkt zou met name voor verzorgende ouders ook gedacht moeten worden in een beweging van binnen naar buiten ter continuering van hun verzorgende taken, zowel in het kader van het recht op respect van het familieleven als in het licht van de (re)integratie van de gedetineerde in de maatschappij. ${ }^{\text {ss }}$ In dat kader zijn ook verlofregelingen, regionalisering en detentiefasering van groot belang. Het feit dat de beginselen van regionalisering en detentiefasering niet in de nieuwe PBW zijn opgenomen, is dan ook een inbreuk op art. $8 \mathrm{EVRM}^{5 \varsigma}$ In hoeverre in het positieve recht bij toekenning van verlof en bij plaatsingen en overplaatsingen rekening wordt gehouden met het familieleven van betrokkenen komt daarom in het vervolg van dit hoofdstuk ook aan de orde. $\mathrm{Nu}$ arbeid en scholing in de nota 'Werkzame detentie' en in de individuele trajectbegeleiding pijlers van het regiem zijn, is het interessant om te kijken of daar in de regelgeving op enige wijze rekening met zorgtaken en genderspecifieke reintegratie is gehouden. Tot slot kont de juridische veranke-

53 In het Nederlandse begrip "moederschap" kan niet het onderscheid gemaakt worden zoals bijv. in de Engelse taal bestaat tussen "maternity" (periode van zwangerschap en bevalling) en "motherhood". De biologgische aspekten wan de ouderrol betreffen per definitie vrouwen, de sociale aspecten van de ouderrol kunnen vrouwen en mamnen betreffen. In beide rollen is "moeder" een te beperkt begrip.

54 W.o. PBW, hoofdstuk VII.

Zie ook Smaers, p. 251, waaraan zij ook de titel geft: Art.8 EVRM en het recht op privacy en op contact met de buitenwereld via briefwisseling, bezoelk en tellefoon.

Zie voorgaande hoofdstukken waar het om specifieke regelingen voor vrouwen gaat.

Zie het resocialisatiebeginsel dat nu in art. $26 \mathrm{en}$ art. 26 bis van de Beginselenwet Gevangeniswezen is terug te vinden. In het w.o. PBW staat het beginsel in art. 2 lid 2 : "Met handhaving van het karakter wan de vrijheidsstraf of de vrijheidsbenemende maatregel wordt de tenuitwoerlegging zoveel mogelijk dienstbaar gemaakt aan de voorbereiding van de terugkeer van de betrokkene in cle maatschapij". Vgl. ook art 10 IVBPR. Zie ook Vrouwen in detentie (1991), Wolleswinkel (1992) Centrale Raad voor de Strafrechtstowepassing (1992).

56. Zie ook het commentaar van het NJCM (1996) p. 1-2. Uit de Memorie van Toelichting blijki dat de minister bang is dat vastleggen van het regionaliseringsbeginsel een snelle tenuitvoerlegging van de stral in de weg, zou kunnen staan (MvT, TK 1994-1995, 24263, nir. 3, p. 27). Zie ook Van de Pol (1996) p. 75. 


\section{Hoofdsturk' 4}

ring van de medische zorg aan bod. Daarin zou een sekse- en mogelijk ook een genderspecifieke regelgeving te verwachten zijn gezien het grote beroep dat vrouwen op de medische zorg blijken te doen."

\subsubsection{Correspondentie, bezoek en telefoon}

In het algemeen geldt dat het aantal brieven dat gedetineerden mogen schrijven en ontvangen onbeperkt is en dat zij ook met iedereen mogen corresponderen. De kosten zijn voor rekening van de gedetineerde. De briefwisseling kan gecontroleerd en soms zelfs geweigerd worden op inhoud. ${ }^{\text {. }}$ Controle van de briefwisseling met in art. 91 lid 2 GM nader beschreven personen en instanties, zoals de Koningin, justitiële autoriteiten, de Nationale Ombudsman etcetera, is niet toegestaan. Wel wordt in het w.o. PBW de mogelijkheid geschapen om die poststukken op de aanwezigheid van voorwerpen te controleren. Dit gebeurt dan in aanwezigheid van de gedetineerde, zodat die erop kan toezien dat er niet naar de inhoud gekeken wordt. Overigens is ook post van en aan de Raad woor de Kinderbescherming niet aan controle onderworpen. ${ }^{61}$ Voor brieven van advocaten geldt een bijzondere regel. De advocaat doet een brief aan de gedetineerde in een gesloten enveloppe, adresseert de brief aan de cliënt en doet die brief in een andere enveloppe, te adresseren aan de directeur met het verzoek de brief aan de gedetineerde te geven. ${ }^{\text {bz }}$ Dit alles om ongewenst hergebruik van enveloppen tegen te gaan.

De gedetineerde heeft er verder recht op om op eigen kosten abonnementen op kranten en tijdschriften te nemen.

57 Vgl. art. 12 VN-Vrouwenwerdrag. Zie ook Van den Brink en Hendriks, (1994), Gijsbers van Wijk (1995), Holtrust, Hendriks en Bauduin (1996). Zie voor de detentiesituatie Werkgroep Vrouwen in detentie (1991), Van der Maas (1994), Wolleswinkel (1995).

58 Art. $90 \mathrm{GM}$, art. 36 w.o PBW.

59 Art. 91 lid 2 GM en art. 36 lid 3 w.o. PBW (controle).

Art. 92 lid 5 GM en art. 36 lid 4 w.o. PBW (weigering). De criteria voor weigering zijn nu:

- het belang van de orde in de inrichting, of

- het belang van de voorkoming of opsporing van strafbare feiten, of

- het tegengaan van het gevaar voor vlucht, terwijl de directeur redelijkerwijs tot dit oordeel heeft moeten kunnen komen (art. 91 lid 5 GM).

In art. 36 lid 4 wo. PBW wordt gesproken over 'orde en veiligheid' en is het laatste criterium vervangen door:

- de bescherming van slachtoffers van of anderszins betrokkenen bij misdrijven.

60 Art. 36 lid 2 jo. art. 37 w.o. PBW.

61 BC 219/90, 4 januari 1991, Sancties 1991, 90.

62 Circulaire van 26 september 1985, nr. 791/385, PI 1986, nr. 3.

63 Art. 55 HHR HwB, art. 102 HHR Gevangenis. 
Zoveel mogelijk, maar minimaal éen uur per veertien dagen kan de gedetineerde bezoek van familieleden of andere personen ontvangen. ${ }^{\infty}$ In HvB hebben gedetineerden recht op minimaal een half uur bezoek per week, maar zij kunnen om meer bezoektijd vragen. In gevangenissen is de bezoekduur langer. In art. 38 w.o. PBW wordt gesproken over ten minste éen uur bezoek per week en wordt geen onderscheid meer gemaakt tussen HvB en gevangenis. ${ }^{65}$

Personen die op bezoek willen komen, moeten dit over het algemeen van te voren schriftelijk aanvragen. ${ }^{\circ}$ Het aantal bezoekers kan worden beperkt. Ook kan de directeur bezoekers weigeren. Hij kan dit bijvoorbeeld laten laten afhangen van de bereidheid van de bezoekers om zich te laten fouilleren bij binnenkomst in thet belang van de orde en veiligheid van de inrichting. Dat kan als er bij een eerder bezoek aan die gedetineerde bijwoorbeeld al eens verboden voorwerpen zijn binnengekomen. Weigering van bezoek geldt in de nieuw voorgestelde wet voor ten hoogste drie maanden. ${ }^{67}$ Dan kan er overigens wel opnieuw een weigering volgen.

Bezoekers moeten zich legitimeren en ze mogen geen toiletartikelen, voedsel of andere cadeautjes van buiten meenemen. Er is wel in iedere inrichting een winkeltje waar dergelijke artikelen aangeschaft of besteld kunnen worden. Vaak is de prijs echter beduidend hoger dan buiten de inrichting. Bij het bezoek kan toezicht aanwezig zijn $^{68}$ In gevangenissen voor langgestraften bestaat de mogelijkheid eenmaal per maand bezoek zonder toezicht te ontvangen. Ook partners die beiden gedetineerd zijn, mogen van het bezoek zonder toezicht gebruik maken. Criterium hiervoor is het bestaan van een "officiële duurzame relatie". ${ }^{\star}$ Voor een bezoek zonder toezicht moeten zowel de bezoeker als de ontvanger van het bezoek een verzoek bij de directeur indienen. In het HvB bestaat geen recht op bezoek zonder toezicht. Alleen onder bijzondere omstandigheden kan het toegestaan worden. ${ }^{7}$ Zo kreeg een langgestrafte vrouw, die in afwachting van de selectie, als passante in een $\mathrm{HvB}$ verbleef toch recht op bezoek zonder toezicht. ${ }^{71}$ In manneninrichtingen voor kortgestraften bestaat ook de mogelijkheid van bezoek zonder toezicht. Omdat kortgestrafte vrouwen zich op dezelfde locatie als preventief gehechten bevinden, geldt dit voor hen niet. Het is de vraag of dit ook niet tot ongelijke behandeling tussen mannen en vrouwen leidt. Het doel van veel vrouwen is overigens niet per se op geslachtsgemeenschap

64 Art. 92 lid $1 \mathrm{GM}$.

65 Art. 38 w.o. PBW.

66 Art. 92 lid 2 GM. In het w.0. PBW wordt dit in de huisregels nader vastgesteld.

67 Art. 38 lid 3 w.o.PBW.

68 Art. 92 lid 6 GM art. 38 lid 4 w.o. PBW.

69 BC 25 oktober $1985,14$.

70 Circulaire van 15 november 1990 , nr. 35241, DJ 90 . Vgl. BC 30 november 1990, Sancties 1991 , $31 \mathrm{~m} . \mathrm{n}$. H. van der Neut en BC 10 december 1990, Sancties 1991, 40.

71 BC 17 maart 1988, PI 1988, 57, Wolleswinkel (1988) p. 229. 


\section{Hoofdstuk 4}

gericht, maar meer op het ongestoord samenzijn. Zij gebruiken het bezoek zonder toezicht ook nogal eens om met hun kinderen samen te zijn.

In drie gesloten inrichtingen voor vrouwen zijn in 1995 bezoekmiddagen voor kinderen tot twaalf jaar geïntroduceerd. ${ }^{72}$ De frequentie en invulling van het kinderbezoelk verschilt erg per inrichting. In Zwolle is het kinderbezoek éen maal per drie maanden, in Breda én keer per maand op zaterdagochtend en in Heerhugowaard iedere twee weken anderhalf uur. In Heerhugowaard mogen de kinderen op de afdeling komen waar hun moeder verblijft. Zij zien dan ook de cel en kunnen zich daar eventueel terugtrekken. Het blijkt dat het zien van de omgeving waar hun moeder verblijt vaak geruststellend werkt; omdat kinderen soms van de werkelijkheid vervreemde fantasieän hebben over de gevangenis. Hoewell de verschillen in aanpak uit pragmatische motieven te verklaren zijn, is het de vraag in hoeverre deze ongelijkheid niet ook tot rechtsongelijkheid onder de gevangen vrouwen leidt.

In het w.o. PBW is de mogelijkheid van bezoek zonder toezicht overigens niet expliciet als een recht van de gedetineerde opgenomen.

Tussen gedetineerden onderling kan ook 'gewoon' bezoek plaatsvinden. Met name wanneer beiden in verschillende inrichtingen verblijwen, kunnen de bezoeken beperkt worden in verband met extra veiligheidseisen, transportvoorzieningen en dergelijke. In principe hebben advocaten, reclasseringsambtenaren, en ouders en voogden van minderjarigen vrije toegang tot gedetineerden. Zij zullen well rekening moeten houden met het dagprogramma al kunnen daarop uitzonderingen worden gemaakt. Daarbij worden weleens verschillende maatstaven gehanteerd. Behoort het luchten nu tot het dagprogramma van de gedetineerde en is het daarom een verplicht onderdeel of is het een recht en kan de gedetineerde bij voorbeeld in die tijd zijn advocaat ontvangen? ${ }^{73}$

Voor contacten van gedetineerden met de pers bestaat een bijzondere regeling. ${ }^{74}$ Zo'n onderhoud mag geen inbreuk maken op het karakter van de vrijheidsstraf van die gedetineerde in het bijzonder of in het algemeen. Het onderwerp van het onderhoud mag geen betrekking hebben op een nog lopende strafzaak. Ook schadelijke gevolgen voor anderen, waaronder medegedetineerden, kunnen een reden zijn voor weigering door de directeur van het contact met de pers. Op aanwijzing van de Minister moet het onderhoud worden geweigerd indien dit is vereist in het belang. van de openbare orde, de algemene veiligheid of de betrekkingen met andere landen.

In de huidige wet staat nog dat de directeur de gedetineerde kàn toestaan telefoongesprekken met personen buiten de inrichting te voeren. ${ }^{\text {In }}$ de de nieuwe PBW

72 Van Dam (1996).

73 Voorbeeld uit het jurisprudentie-overzicht in Sancties 1992/2, p. 109.

74 Circulaire van 19 april 1985 , nr, 1218/384, PI 1985, nr. 55 met nt. U. v.d. Pol.

75 Art. 92a GM. 
komt de gedetineerde een minimumrecht toe op tien minuten telefoneren per week. Nu moet in gesloten inrichtingen ook al minimaal geregeld zijn dat een gedetineerde eenmaal per week vijf minuten mag bellen. ${ }^{n}$ In de praktijk wordt dat vaak tien minuten. De kosten van deze telefoongesprekken komen voor rekening van de gedetineerde. Er kunnen problemen kunnen optreden wanneer een gedetineerde met een andere gedetineerde wil bellen, ook als dat een partner of familielid is. Er is dan wel geregeld dat iemand naar buiten mag bellen, maar niet dat de ander dat gesprek ook mag ontvangen. Sommige inrichtingen hebben een regeling voor binnenkomende telefoontjes. De meeste echter niet vanwege de extra werkdnuk die dat bij het personeel zou geven. In noodsituaties worden er dan wel afspraken gemaakt via het Bureau Sociale Dienstverlening. De Beroepscommissie acht het in een concrete casus onredelijk en onbillijk dat de algemene regel er toe leidt dat een gedetineerde vrouw geen enkel inkomend gesprek van haar partner mag ontvangen en oordeelt

"dat in dit speciale geval- te weten echtgenoten of waste partners die beiden gedetineerd zijn - eén of twee keer per maand een telefonisch contact moet kunnen wordlen geregeld". ${ }^{\text {. }}$

De directeur kan in gesloten inrichtingen ook regels stellen over het mee- en afluisteren. Met gesprekken met advocaten en reclasseringsambtenaren mag niet meegeluisterd worden. Wel kan, ter controle, de verbinding door een aan de inrichting verbonden medewerker tot stand gebracht worden. ${ }^{\text {* }}$

In de vrouweninrichtingen willen de gedetineerden vooral belregelingen om de contacten met thuis te onderhouden. Vaak is dat heel moeilijk, met name als de kinderen in tehuizen zitten of in het buitenland verblijven. In Heerhugowaard is een telefooncel op de gang waar de vrouwen in principe 'vrij' kunnen bellen met een telefoonkaart.

\subsubsection{Strafonderbreking en verlof}

In bijzondere gevallen kan de minister aan de gedetineerde toestemming geven de inrichting woor korte tijd te verlaten, bijvoorbeeld bij ernstige ziekte of sterfgevallen

76 Art. 39 w.o. PBW. Het recht kan ook weer ingeperkt worden (art. 39 lid 2 en 3 w.o. PBW).

77 Kelk (1993) p. 228.

78 BC 7 december 1995, A 95/373 II (Sancties, 1996, 27). Interessant is dat de directeur in zijn verwcer opmerkt dat de vrouw de mogelijkheid heeft om buiten de reguliere bezoekregeling haar kinderen te ontvangen en "derhalve" alle mogelijke medewerking vanuit de inrichting krijgt om contact met haar partner en kinderen te onderhouden. Hieruit blijkt weer dat partners en kinderen in concurrerende posities kunnen worden gedrongen. En ook dat open normen tot onderhandelingssituaties leiden zodat er een geïndividualiseerd gunstensysteem kan ontstaan (Vgl. Smaers (1996) p. 510-511).

79 Circulaire van 30 juni 1980, nr. 592/380, PI 1982, 86.

so Zie de huisregels onder "recreatie".. 


\section{Hoofdstuk 4}

in de naaste familie. ${ }^{\mathrm{g}} \mathrm{Na}$ zes maanden detentie kan hier ook het bezoek aan kinderen onder de vijftien jaar onder vallen. En ook het bezoek aan medegedetineerde familieleden, waarmee al zes maanden geen contact is geweest. Onderling bezoek van gedetineerde partners mag eenmaal in de zes weken plaatsvinden. Dat bezoek is ook niet gebonden aan een detentietijd van zes maanden. De betreffende bezoeken duren ongeveer anderhalf uur.

In open en halfopen inrichtingen maakt het verlof deel uit van de straftijd en wordt het dus meegeteld. In de open inrichtingen kan men in principe ieder weekend met verlof. In de halfopen inrichtingen eenmaal per vier weken. Daarnaast zijn er bijzondere verlofregelingen met de feestdagen.

In 1982 is de Algemene Verlofregeling gedetineerden (AVG) ingevoerd ${ }^{22}$, bestemd voor gedetineerden die in een penitentiaire inrichting zijn opgenomen waar de een of andere vorm van periodiek verlof niet als vast onderdeel in het regiem is opgenomen. Voorwaarden waaraan voldaan moet worden, zijn in ieder geval:

- dat de gedetineerde eenderde van de totale straf heeft ondergaan;

- dat het strafrestant tenminste drie maanden moet zijn en dat de ontslagdatum ten hoogste over een jaar valt.

Daarnaast zijn er nog uitgebreide procedurele eisen, die onder meer samenhangen met het delict en/of de maatschappelijke onrust die daaromtrent bestaat. De directeur heeft een grote beslissingsbevoegdheid bij het toekennen van verlof. Bij afwijzing staat beklag ex art. 51 BGW open.

In het w.o. PBW krijgt het regimaire en individuele verlof een wettelijke basis en wordt de beklagregeling tegen verlofbeslissingen uitgebreid. ${ }^{83}$ In de Memorie van Toelichting wordt opgemerkt dat het kenmerk van verlof is

"dat een vrijheid van beweging wordt toegestaan die past in de wettelijke opdracht van de voorbereiding van de terugkeer van de betrokkene in de maatschappij, zonder dat hiervoor direct een andere klemmende reden -familieomstandigheden- bestaat".4

De wetgever lijkt hier dus ruimte de bieden voor een specifiek beleid gekoppeld aan structurele maatschappelijke zorgtaken en familieomstandigheden die buiten incidenten om gaan. Bovendien zijn in het voorgestelde art. 26 w.o. PBW geen beperkingen meer opgenomen in die zin dat verlof pas kan worden verleend na het onder-

81 Op grond van de artt. $46 \mathrm{en} 47 \mathrm{BGW}$ en art. 95 e.v. GM.

82 Laatste wijziging: circulaire 20 december 1991, nr. 17214/91 DJ, Sancties 1992, 31, werlengd op 26 juli 1995, nr. 486817/95 DJI, Sancties 1995, 47. Op het ministerie wordt cen nieuwe regeling voorbereid. Er is een conceptregeling "incidenteel verlof en regimair verlof. Daarnaast komt er een regeling 'strafonderbreking”. Alle regelingen zullen uiteindelijk geintegreerd worden in een Ministeriële Regeling "Vrijhedenbeleid" (Kwartaalbericht DJI 1996/3, p. 13).

Art. 26 jo. 72 w.o. PBW.

84 MVT, TK 1994-1995, 24 263, nr. 3, p. 48. 
gaan van een bepaalde straftijd. ${ }^{85}$ Dat betekent dat ook de mogelijkheden van deten tiefasering gelijkmatiger over de straftijd verdeeld kunnen worden. ${ }^{\circ}$ Detentiefasering en regionalisering zijn dan well niet als beginselen in de voorgestelde wet opgenomen, maar ze liggen volgens de Memorie van Toelichting wel ten grondslag aan de beoogde differentiatie binnen de inrichtingen en de extramurale executiemodaliteiten die ertoe dienen de reïntegratie van de gedetineerde te bevorderen.

"Hierin verschuift het accent van de detentie van de -beperkte- beveiligingsdoelstelling en het vergeldingselement naar de algemene veiligheidsdoelstelling, de veiligheid op langere termijn door een succesvolle integratie van de gedetineerde in de samenleving". ${ }^{n 7}$

De extramurale executiemodaliteiten kunnen onderdeel zijn van het in het wetsvoorstel genoemde penitentiaire programma. ${ }^{28}$ De aard en omvang van dit penitentiaire programma roepen nog veel vragen op, zoals ook blijkt bij de behandeling in de Tweede Kamer. ${ }^{\text {D }}$ Opvallend is wel dat het programma ook tijdens de voorlopige hechtenis kan worden opgelegd. Van de Pol noemt als voorbeelden deelname aan een ontwenningsprogramma en het elektronisch toezicht op preventieven. ${ }^{90}$

\subsubsection{Overplaatsing}

Tegen plaatsing of overplaatsing in een gevangenis staat beroep open bij de Centrale Raad voor Strafrechtstoepassing. ${ }^{91}$ Omdat de differentiatie bij vrouwen zo gering is en verschillende detentiebestemmingen onder eenzelfde beheerstructuur kunnen vallen, kan er onduidelijkheid bestaan of er bij overplaatsing een klacht tegen een beslissing van de directeur moet worden ingediend (art. $51 \mathrm{BWG}$ ) of een beroep krachtens art. $123 \mathrm{GM}$ moet worden ingesteld. De laatste beroepsprocedure voldoet aan minder rechtswaarborgen. $\mathrm{Er}$ is slechts éen beroepsinstantie. De betrokkene wordt niet gehoord, de procedure verloopt schriftelijk en in rechtsbijstand is niet voorzien, hoewel op verzoek wel een advocaat wordt toegevoegd. ${ }^{92}$ Met name in

85 MvT, TK $1994-1995,24263$, nr.3, p. 28 .

86 Wolleswinkell (1992) p. 231-232. In het betreffende artikel worden ook andere alternatiewen voor wouwelijke gedetineerdem bepleit, die afwijken van de "gangbare" detentiefasering: enen geheel open of halfopen route voor vrouwen; kleinschalige open stedelijke voorzieningen zoals sociowoningen en halfweghuizen en extramurale execuriemodaliteiten als alternatief voor gevangenisstraf.

87 MVT, TK. 1994-1995, 24263, nr.3, p. 27.

88 Art. 4 lid 1 w.o. PBW.

89 TK 1994-1995, 24263, nr. 5, p. 10-14. De minister belooft in haar antwoord nadere regells in cen Penitentiaire Maatregel (PM), TK 1994-1995, 24263, nr. 6, p. 11-15.

90 Van de Pol (1996) p. 59.

91 Op grond van art. $23 \mathrm{GM}$.

92 Spronken en Wolleswinkel (1987) p. 348. 
De Singel in Amsterdam zijn een paar maal bestemmingswijzigingen doorgevoerd, waarmee de interne differentiatie een formeel karakter kreeg, om aan de bestaande onduidelijkheid een einde te maken. ${ }^{.3}$ Dat betekende onder andere dat bij overplaatsing binnen Singel II van het regiem met algemene gemeenschap naar het regiem met beperkte gemeenschap geen beklag meer openstond.* Wanneer een directeur van een gevangenis adviseert tot overplaatsing en de gedetineerde wordt in afwachting van herselectie in een Huis van Bewaring geplaatst, dan staat tegen dat advies beklag open. Tegen de eventueel daaropvolgende overplaatsing echter alleen beroep, dan is het immers een besluit van de minister na advies van de Selectie Advies Commissie." In de nieuwe PBW wil de minister een einde maken aan deze onduidelijke situatie.*

Bij de overplaatsing van vrouwen leidt het geringe aantal locaties voor langgestrafte vrouwen (Maastricht, Zwolle, Heerhugowaard) tot beperkte realisering van het streven naar regionalisering. Een vrouw die liever in Zwolle dan in Maastricht geplaatst wordt omdat dat met name voor de kinderen gemakkelijker te bereizen is, krijgt van de $\mathrm{BC}$ geen gelijk. ${ }^{\text {97 }} \mathrm{De}$ Beroepscommissie vindt "plaatsgebrek" voldoende argument voor de betreffende plaatsing omdat 'deze omstandigheid haar in dezelfde mate treft als andere langgestrafte vrouwen'. In hoeverre familie-omstandigheden ook bij andere overplaatsingen worden meegewogen en of daarin wellicht een argument voor ongelijke behandeling schuilt, wordt uit deze uitspraak niet duidelijk. De Beroepscommissie meent zelfs dat de reisafstand vanuit Nijmegen naar Maastricht voor het bezoek niet veel langer is dan wanneer zij in de gevangenis in Zwolle zou zijn geplaatst. Daarbij lijkt niet aan de orde te zijn geweest dat het bezoek (kinderen!) wellicht met het openbaar vervoer zal reizen. De treinreis naar Zwolle is immers een uur korter dan die naar Maastricht en bovendien zonder overstap.

Mijn inziens zou de wederzijdse bereikbaarheid in het kader van de familie-omstandigheden op grond van art. 8 EVRM een essentiële rol moeten spelen bij plaatsingen en overplaatsingen. ${ }^{98}$ Daarbij moet niet alleen aan zorgafhankelijke kinderen gedacht

93 Circulaire yan 4 januari 1988, PI 1988, 13, Circulaire van 12 april 1991, Sancties 1991, 34.

94 Vgl. Van Deutekom (1992) p. 113.

95 Boksem (1992) p. 107.

96 Art. 8 jo art. 15 en art. 72 w.o. PBW.

97 BC 1 juni 1994, RN 452, Nemesis 1995/1, Verzoek tot overplaatsing, reisafstand kinderen, met noot Ria Wolleswinkel, p. 4-6.

$98 \mathrm{Vgl}$. de ontwerp resolutie van het Europees Parlement, onder b, verzoekt de lidstaten ervoor te zorgen dat:

- er waarborgen zijn dat regelmatig bezock kan worden ontvangen en dat, indien de onnstandigheden dat toelaten, bezoekjes en langer verblijf thuis worden uitgebreid;

- de vrouwen het bezoek van hun familieleden mogen ontvangen en aan dezen, indien zij niet wonen in de plaats waar de gevangen vrouwen hun straf uitzitten, de reiskosten worden vergoed; aan de facto koppels bezoeken en reiswergoedingen worden toegestaan zonder discriminatie op grond van afkomst, ras of seksuele geaardheid. 
worden, maar ook aan oudere, zorgafhankelijke en zieke familieleden. Regionalisering in combinatie met regiemsdifferentiatie kan misschien alleen gerealiseerd worden via al dan niet beperkte vormen van gemengde detentie, zoals thans de dagdetentie en de gecombineerde p.o.i. met dagdetentie in Hoorn. ${ }^{99}$ Omdat de strenge beveiligingsdoelstelling ten aanzien van de meeste vrouwen niet gehanteerd hoeft te worden, zouden meer variaties in open detentievormen of alternatieve vormen van vrijheidsbeneming die ook openstaan voor daarvoor geschikte mannen gecreëerd kunnen worden. ${ }^{100}$ Overigens is het daarbij wel van belang dat een gezonde man-vrouw verhouding wordt nagestreefd, dus minimaal ongeveer eenderde van de "minderheidsgroep. ${ }^{\text {tol }}$ De maatschappelijke reïntegratie zou dan gericht kunnen zijn op zorgtaken, in combinatie met professionele kinderopvang en flexibele arbeidsrelaties.

\subsubsection{Venroegde invrijheidsstelling/gratie}

In 1987 is de vervroegde invrijheidsstelling ingevoerd. Deze houdt in dat de gedetineerde die veroordeeld is tot een gevangenisstraf van een jaar of meer, na tweederde van de straftijd in vrijheid wordt gesteld. Bij een straf tussen zes maanden en een jaar gaat de v.i. in op eenderde van het resterende tijdvak na zes maanden. Er is voor vi. geen toestemming van de minister nodig. Wel kan de Officier van Justitie bij de Penitentiaire Kamer van het Gerechtshof in Arnhem verzoeken v.i. uit te stellen of niet te verlenen. ${ }^{102}$

Ook kunnen gedetineerden een gratieverzoek sturen naar het Ministerie van Justitie (officieel de Koningin). Gratie kan worden verleend op grond van een omstandigheid waarmee de rechter op het tijdstip van zijn beslissing geen of onvoldoende rekening mee heeft gehouden of heeft kunnen houden en die, als die omstandigheid wel bekand was geweest, zou hebben geleid tot het opleggen van geen of een andere straf of maatregel. Een andere grond voor gratieverlening is dat

99 Circulaire van 3 januari 1994, nr. 418743/93/DJ. Zie ook TK 1994-1995, 24263, nr.6, p. 19.

100 Art. 11 lid 3 en 4 jo art. 14 w.o PBW.

101 Uit onderzoek van Kanter (1977) blijkt dat bij een verhouding van $20 \%$ tegenover $80 \%$ de minderheid een kans krijgt zich te profileren. Bij een verhouding wan $35 \%$ tegenover $65 \%$ "minority mentbers have potential allies among each other, can form coalitions, and can effect the culture of the group ... they begin to become individuals differentiated from each other as well as a type differentiated from majority" (p. 209). En balans is er bij een werhouding $40 \%-60 \%$. Dit onderzoek is binnen een bedrijf gedaan, maar zou algemene geldigheid hebben binnen alle situaties waarin én groep de minderheid vormt.

102 Art. 15a lid 2Sr. De gronden daarvoor zijn in art. 15a lid 1 Sr opgenomen. Vegter (1993, p. 195-204) denkt dat de steeds zwaardere straffen die rechters opleggen mede een gevolg kunnen zijn van de woorspellende waarde van de w.i. regeling. Rechters maken een bruto-netto berekening. 
"aannemelijk is geworden dat mel de tenuitvoerlegging, van de rechterlijke beslissing of de woortzetting darvan geen met do strafrechtstoepassing na te streven doel in redelijkbeid wordt gediend". ${ }^{103}$

In een gratieverzoek kan de gedetineerde eventueel zelf een alternatieve sanctie voorstellen, maar dat hoeft niet.

Van de Pol heeft in het verleden al eens voorgesteld om met name in het geval van buitenlandse vrouwen massaal tot vi. en gratieverlening over te gaan. ${ }^{104}$ Dat zou wellicht kunnen als compensatie voor het ontberen van verloffaciliteiten die andere gedetineerde vrouwen, met een verlofadres in Nederland, wel hebben. ${ }^{10 x}$ Een vergelijkend onderzoek naar vi.-en gratiebeleid tussen mannen en vrouwen is, woor zover mij bekend, niet gedaan. Zeker wanneer de detentiefasering meer gespreid wordt toegepast en er relatief veel open en halfopen detentielocaties met plaatsen voor vrouwen gerealiseerd worden, zou op dit punt actief beleid te verwachten zijn.

\subsubsection{Arbeid en scholing}

In een HvB kunnen gedetineerden op vrijwillige basis werken. In een gevangenis is deelname aan arbeid verplicht. ${ }^{106}$ Deze verplichting is niet in strijd met de wet. ${ }^{10 \%}$ Het loon in een HvB ligt lager dan dat in de gevangenis. In het laatste geval kunnen de toeslagen (op grond van toegekende punten) het loon aanmerkelijk verhogen. ${ }^{10 s}$ Wat de verdiensten betreft, heeft de beperkte differentiatie in de bestemmingen van de gebouwen bij vrouwen in het verleden ook een nadelige rol gespeeld. Zo wordt in KG in 1985 de loonregeling voor langgestraften niet van toepassing verklaard op een langgestrafte vrouw die in het HvB in Maastricht verblijft "mede in alanmerking genomen de mededeling van de staatssecretaris van Justitie (...) dat uitbreiding van de litigieuze loonregeling naar Maastricht om financiële redenen niet uitvoerbaar is en daarvoor voorts bezwaren van praktische aard gelden". ${ }^{109}$ De regeling is gekoppeld aan gebouwen en niet aan gedetineerden.

In een uitsprakk omtrent de uitkering tijdens zwangerschapsverlof besluit de $\mathrm{BC}$ dat woor het bepalen van de hoogte van de uitkering aansluiting gezocht moet worden bij de in de vrije maatschappij gangbare wetgeving. Volgens de BC zou dat $80 \%$

103 Art. 2 Gratiewet.

104 Van de Pol (1988) p. 157-159.

105 Wolleswinkel (1990) p. 98.

106 Art.14 Sr en art 32 BWG.

107 Toegestane uitzondering in ILO-verdragen, surs. 29 en 105, art. 4 lid 3a EVRM, art. 8 lid 3c(i) IVBPR.

108 Experimentele loonregeling 1977. Zie voor nadere uitwerking en berekeningen: Verpalen en De Jonge (1992) p. 54-62. De Jonge stelt in zijn dissertatie voor om, analoog aan de Wet Sociale Werkvoorziening, een Wet op de Penitentiaire Werkwoorziening in het leven te roepen (De Jonge 1994).

109 Hof Den Haag, 31 oktober 1985, PI 1986, nr.46. Zie Spronken (1987), Kelk (1993) p. 276. 
van het dagloon met toeslagen moeten zijn. Analoge toepassing van art. 29a van. de Ziektewet leidt mijns inziens zelfs tot $100 \%$ van het gebruikelijke loon gedurende ten minste zestien weken. ${ }^{\text {1. }}$

Vamuit een open inrichting wordt vaak arbeid buiten de muren verricht. Volgens een bepaalde verdeelsleutel krijgt de gedetineerde mar ongeveer $40 \%$ van het verdiende loon in handen. Volgens De Jonge is de ratio hierachter dat een bepaald deel van het loon van gedetineerden "in natura" (voeding, huisvesting, verzorging) wordt uitbetaald."

Krachtens art. 76, lid 2 GM kan voor studie tijdens arbeidsuren aan gedetineerden een beloning worden toegekend volgens door Onze Minister nader vast te stellen regels. Schriftelijke cursussen moeten geheel of gedeeltelijk door de gedetineerde zelf betaald worden. Verder wordt in de inrichting zelf een cursusaanbod gedaan. ${ }^{11 z}$ In het art. 4 w.o. PBW wordt het al genoemde penitentiaire programma geintroduceerd. Hierin worden de extramurale executiemodaliteiten (EEM) opgenomen. Het laatste deel van de vrijheidsstraf wordt daarbij buiten de inrichting doorgebracht met als doell de gedetineerde voor te bereiden op de terugkeer in de samenleving. Het programma kan bestaan uit arbeidsactiviteiten, vorming en scholing en uit combinaties van die drie. Daarbij kan gedacht worden aan de nu al bestaande vormen van dagdetentie, maar de minister laat een ruime experimenteermogelijkheid toe. ${ }^{113}$ Zij acht het vooral de taak van de reclassering om daartoe op lokaal niveau projecten te ontwikkelen. Het lijkt mij dat op dit gebied de uitdaging groot moet zijn om vrouwenprojecten op te zetten, met veel aandacht voor de combinatie van arbeid en zorg en met inschakeling van reeds bestaande knowhow op het gebied van vrouwenhulp- en dienstverlening.

\subsubsection{Medische zorg}

De directeur is verantwoordelijk voor de interne organisatie van de medische zorg." Hij heeft als intermediair een sterk faciliterende taak naar alle kanten. Naar de patiënt, de arts en naar externe medische instanties. Zijn zorgvuldig handelen wordt onder andere afgemeten aan de activiteiten die hij heeft ondernomen on de beoogde medische zorg van de patiènt en de beoordeling daarvan door terzakekundige medici op elkaar af stemmen. Hij moet daarbij de inhoudelijke interpretatie van de klacht

$110 \mathrm{BC} 24$ juni 1994, RN 451, Nemesis 1995/1, Hoogte zwangerschapsuilkering tijdens detentie, met noot Malva Driessen en Ria Wolleswinkel, p. 3-4.

111 De Jonge (1994) p. 75.

112 Zie woor het aanbod van arbeid en scholingsactiviteiten voor wrouwelijke gedetineerden onder andere Ketelaars (1991), bijlagen 5 en 6.

113 MVT, TK 1994-1995, 24263, nr. 3, p. $15-16$.

114 Op grond wan zijn beheerstaak art. 23 BGW. Zie ook art 42 w.o PBW. 
en de beoordeling of er noodzaak tot medische zorg is overlaten aan patiënt en arts. Dat bij de uitvoering vain die faciliterende taak algemene praktische regelingen soms behandeling van bijzondere individuele problemen moeilijk maken, lijkt voor de hand te liggen, zeker in een 'onnatuurlijke' situatie als detentie.

De zaak rond de invoer van cosmetica, c.q. noodzakelijke huidzalf is een voorbeeld van een warrige competentiestrijd. ${ }^{155}$ Het beoogde doel van de klaagster is haar eigen huidzalf in te voeren ondat dit het enige middel is dat helpt tegen haar huidaandoening. Op andere middelen reageert zij sterk allergisch. De directeur stelt dat cosmetica niet mag worden ingevoerd, wegens het gevaar van contrabande (drugs). Klaagster betoogt dat het niet om een cosmetisch produkt gaat maar om een zalf die zij nodig heeft voor haar gezondheid. Dan moet zij volgens de directeur maar om een recept van de arts vragen. Deze schrijft echter op zijn beurt niet de door haar gewenste zalf voor en hij gaat ook niet in op haar verzoek om verwijzing naar een huidspecialist. De Beroepscommissie kiest nu (in tegenstelling tot de directeur en de beklagcommissie) duidelijk voor de uitzondering op en relativering van de invoer-van-cosmetica-regel. Zo gaat de Commissie de discussie of er sprake is van een zuiver cosmetisch of medisch product uit de weg. De Commissie stelt dat er sprake is van een "voor haar geschikte crème" en geeft zelfs praktische tips om de controle op de invoer en het gebruik van de crème mogelijk te maken, daarmee de directeur op zijn autonome verantwoordelijkheid voor de (medische) zorg wijzend. De rol van de arts komt in de uitspraak verder niet aan de orde. Interessant is of deze zich mu als verlengstuk van 'justitie' heeft opgesteld of dat hij juist autonoom heeft gehandeld door een gezags- en ordeprobleem niet onnodig te medicaliseren. Ook wanneer algemene regels niet vanuit orde en veiligheid zijn gemaakt, maar juist met als doel optimale hygiëne en medische zorg te bieden, zou daar in individuele gevallen vanaf geweken moeten kunnen worden. Zo heeft de directeur naar aanleiding van de uitspraak over de medische zorg bij bevalling en kraamhulp afspraken met het regionale ziekenhuis gemaakt ten behoeve van toekomstige gevallen. ${ }^{110}$ Hij heeft daarmee dus aan zijn taak voldaan om tot eern goede aansluiting met externe voorzieningen te komen. Toch kunnen volgens mij de patiënt en de inrichtingsarts daar van afwijken indien zij samen een ander medisch beleid wenselijk achten. Vergelijk het "informed consent" in de Wet geneeskundige behandelingsovereenkomst (WGB). In de nota "Zorg ingesloten" wordt overigens gesteld dat in het geval van detentie de geneeskundige hulp niet op basis van een behandelingsovereenkomst

115 BC 16 aprill 1990, RN 284, Nemesis 1992/6, m.n. RW, p. 8-10.

116 Zie ook RVR 1992, nr, 208, m.n. RW. Afhankelijk van het vluchtrisico, worden gedetineerden voor kortdurende behandelingen veelal in een ziekenhuis in de regio behandeld. Gaat de opname langer duren, dan wordt er medische zorg geboden in het Penitentiair Ziekenhuis in"s-Gravenhage. Anders worden met name de personele kosten die gemoeid zijn met bewaking erg hoog. 
wordt verstrekt en dat de wet "dan slechts wan toepassing is voor zover de aard van de rechtsbetrekking zich daar niet tegen verzet ${ }^{*}$."

Gedetineerden in HvB hebben het recht op eigen kosten hun huisarts of specialist te raadplegen. ${ }^{118}$ Dit geldt zowel voor de preventief gehechten als de kortgestraften. Gedetineerden in gevangenissen hebben dit recht niet, al moet een verzoek daartoe wel zorgvuldig worden behandeld door de directeur. In de nieuwe PBW krijgen gedetineerden in alle soorten inrichtingen dit recht van consultatie. ${ }^{19}$ De inrichtingsarts blijft echter de behandelaar. In geval van conflict tussen beide artsen kan dit problematisch worden. Bij zorgvuldige afweging kan de directeur de knoop doorhakken en zal de commissie van toezicht hem daarin wellicht steunen. Omtrent de inhoudelijke medische gronden zou de Geneeskundige Inspectie bij het Ministerie van Justitie of het Medisch Tuchtcollege een oordeel moeten vellen. In dit laatste geval op grond van een klacht. Een echte vrije artsenkeuze heeft de gedetineerde dus niet. ${ }^{120}$ Een consequentie hiervan is ook dat de wens van een vrouwelijke gedetineerde om door een vrouwelijke arts behandeld te worden niet hoeft te worden gehonoreerd. Dit is overigens in strijd met de ontwerp resolutie van het Europees Parlement over vrouwen en kinderen in de gevangenis. ${ }^{121}$

Oordelen over het medisch handelen van de arts en dat van de onder zijn gezag staande verpleegkundigen behoort niet tot de competentie van de beklag- c.q. de beroepscommissie. Voor de patiënt die een klacht omtrent het medisch handelen wil indienen, is het niet altijd duidelijk zijn bij welke instantie dat zou moeten. ${ }^{\text {"z }}$ Wellicht is het praktisch voor de patiënt zijn als voor onduidelijke competentie- en conflictsituaties een gedetimeerdenvertrouwenspersoon, van buiten de inrichting, zou worden aangesteld, net als in de intramurale psychiatrie. Deze zou ter ondersteuning van de patiënt kunnen zoeken naar oplossingen in de communicatieve sfeer en deze eventueel kunnen begeleiden bij het formuleren en indienen van een klacht. $^{123}$

Moerings stelt voor om bij ingrijpende beslissingen, als het toedienen van dwangmedicatie, waarbij de grens tussen ordehandhaving en individuele patiëntenzorg soms moeilijk te trekken is, eerst tot een interne medische toetsing te komen, waarbij de arts verplicht wordt de zaak te bespreken met leden van de commissie van toezicht,

117 Nota 'Zorg ingesloten' (1995) p. 8.

118 Art. 32 HiHR HvB.

119 Art. 42 lid 2 w.o. PBW.

120 Zie ook: Sluiter (1993) p. 271-282.

121 "Gevangenen het recht hebben desgewenst door vrouwen onderzocht em behandeld te worden" (Publicatieblad 26-6-1989, nr. C 158/512).

122 Wolleswinkel (1995) p. 185-186.

123 Vgl. Soetenhorst (1987) p. 461. 


\section{Hoofdstuk 4}

die zelf arts zijn. Vervolgens zou er een klachtencommissie moeten zijn, naar analogie wan het klachtrecht onder de Wet Bijzondere Opneming Psychiatrische Ziekenhuizen. Mocht het gaan om zaken waarbij de arts feitelijk als 'ordehandhaver' optreedt, dan zou zijn beslissing vatbaar voor 'gewoon' beklag moeten zijn. ${ }^{125}$ Inmiddels is in de nota 'Zorg ingesloten' vastgesteld dat de Wet klachtrecht cliënten zorgsector noodzaakt to een regeling " ${ }^{126}$ De werkgroep stelt voor een onafhankelijke centrale commissie te formeren met ruime deskundigheild op medisch, juridisch en penitentiair terrein. Deze commissie moet dan oordelen over de gegrondheid van een klacht. Op de inhoudelijke kant van de medische zorg wordt in de nota nauwelijks ingegaan, op de seksespecifieke kenmerken daarvan helemaal niet. Zoals uit het voorgaande hoofdstuk blijkt, lijkt er bij vrouwen zowel in kwantitatieve als kwalitatieve zin een andere vraag naar medische zorg dan bij mannen te bestaan. Ook tussen vrouwen onderling lijken, afhankelijk van culturele achtergrond, verschillen op te treden. ${ }^{27}$ Op grond van art. 12 van het VN-Vrouwenverdrag bepleit Van der Maas positief discriminerende maatregelen, zoals de introductie van vrouwengezondheidszorg en integratie en bijscholing op dat gebied in penitentiaire inrichtingen voor vrouwen. ${ }^{128}$

Naast de arts en verpleegkundigen zijn er diverse andere hulpverleners, waaronder een tandlarts en een districtspsychiater en ook geestelijk verzorgers aan de inrichting verbonden. Met name het maatschappelijk werk kan een belangrijke taak vervullen bij het regelen en onderhouden van rechten en relaties buiten de inrichting, evenals het Bureau voor Rechtshulp dat meestal een vastgesteld spreekuur heeft. Afhankelijk van de organisatiestructuur vallen verschillende taken onder de verantwoordelijkheid van het Hoofd Sociale Dienstverlening.

124 Moerings (1993) p. 116-117. De commissie van toezicht meestal breed samengesteld en bestaat uit tenminste een rechter, een advocaat, een medicus en iemand uit de kring van het maatschappelijk werk (art. 9 lid 2 Gevangenismaatregel).

125 In de Memorie van Toelichting bij het w.O. PBW wordt gesuggereerd dat de directie bij de uitvoering van dwangmaatregelen politieartsen of aan de GGD verbonden artsen zou kunnen inschakelen. Die worden dan aangemerkt als een aan de inrichting verbonden arts krachtens thet nieuwe art. 42. (Tk 1994-1995, 24263, m. 3, p. 84)

126 Rapport "Zorg ingesloten", 1995, p. 35. De klachtprocedure aangaande het medisch handelen zal in de Penitentiaire Maatregel worden opgenomen (Kwartaalbericht DJI 1996/3 p. 12).

127 Janssen (1994).

128 Van der Maas (1994) p. 101. Zie voor art. 12 VN-Vrouwenverdrag Van den Brink en Hendriks (1994). 


\subsection{Speciale rechtspositie vrouwen}

In het hiervoor behandelde geldende recht wordt formeel geen onderscheid gemaakt tussen mannelijke en vrouwelijke gedetineerden. Of er daarmee ook sprake is van een gelijke behandeling is nog maar de vraag. Soms kan er door indirecte discriminatie toch strijd zijn met het gelijkheidsbeginsel. ${ }^{128}$ Ondanks gelijkheid voor de wet is er dan sprake van ongelijkheid door de wet, zonder dat dat gerechtvaardigd kan worden via een legitimiteits- en proportionaliteitstoets. Bij vrouwelijke gedetineerden is dat laatste enkele malen vastgesteld door de Beroepscommissie. Als strikte toepassing van de regel een zwaardere of extra eis ten aanzien van vrouwen in het leven roept, dan kan dat dus in strijd zijn met het beginsel van gelijke behandeling. ${ }^{130}$ Soms mag er wel onderscheid gemaakt worden tussen mannen en vrouwen, om achterstandssituaties op te heffen of ter bescherming van zwangerschap en moederschap. ${ }^{31}$ Tegelijkertijd roept het creëren van een direct onderscheid tussen mannen en vrouwen de vraag op of dat niet juist stereotypering van sekserollen in de hand werkt. ${ }^{132}$ Binnen vrouwenstudies rechten is er mede daarom voor gepleit om niet sekse, maar andere juridisch relevante differentiatiecriteria te zoeken, bijwoorbeeld 'zorg'. Dan hoeft de regeling zelf in ieder geval niet bij te dragen aan continuering van bestaande rolpatronen, terwijl de feitelijke omstandigheden wel meewegen in de juridische verankering. Het is een probleem dat nieuwe criteria vaak diffuus en (nog) weinig eensluidend zijn. Zo is het begrip 'zorg' nog voortdurend voorwerp van discussie.

In de volgende paragrafen wordt duidelijk hoe in de penitentiaire wetgeving tot nu toe met de specifieke positie van moeders van zuigelingen rekening is gehouden en hoe dat in toekomstige wetgeving wordt opgerekt naar meer open en sekseneutrale criteria.

In art. 14 van het w.o. PBW wordt overigens de mogelijkheid van "aparte opvang" gecreëerd. Dat kan ook ten behoeve van zwangere vrouwen. Gelet op het aantal zwangere vrouwen dat zich gelijktijdig in detentie bevindt, zal deze opvang volgens de Memorie van Toelichting een individueel karakter dragen. ${ }^{134}$ In feite staat er, buiten de seksespecifieke bestemmingen van de inrichtingen (art. 11 w.o. PBW), inhoudelijk in de nieuw voorgestelde wetgeving nergens meer specifieke regelgeving

129 Zie o.a. jurisprudentie op grond van art. 14 EVRM en art. 26 IVBPR.

130 BC 17 maart 1988, PI 1988, 57, Wolleswinkel (1988).

131 Vgl. art. 2 lid sub b en art. 5 AWGB, art. 4 VN.Vrouwenverdrag.

132 In het VN-Vrowwenverdrag wordi daar via de artt. 5 en 11 lid 3 wel tegen gewaakt.

133 Goldschmidt en Holtmaat (1993) p. 30-34.

134 Memorie van Toelichting, TK 1994-1995, 24263, nr. 3, p. 30. 
voor vrouwen. ${ }^{.35}$ Alleen in de nadere invulling van het beleid worden openingen geboden, maar dan heel minimaal, gericht op zwangerschap en ouderschap van jonge kinderen, dus nog steeds vooral selksegebonden. Meer gender- en rollgebonden regelingen worden niet aangereikt, noch in de wet noch in de Memorie wan Toelichting."

\subsubsection{Art. 31 Gevangenismaatregel}

$\mathrm{Er}$ is nu nog éen specifiek op vrouwen gerichte regel: art. $31 \mathrm{GM}$. De letterlijke tekst van dat artikel luidt:

"1. Indien de moeder wordt gedetineerd, kan het kind, dat miet van haar kan worden gescheiden, mede in het gesticht worden opgenomen.

2. Het verblijf van dit kind, alsook wan het kind dat in het gesticht wordt geboren, wordt beëindigd, zodra het de zorg van de moeder kan ontberen.

3. Voorzover de gedetineerde niet zelf in de behoeften van het met haat in het gesticht werblijvende kind kan voorzien, geschiedt zullks van rijkswege".

In feite gaat het hier om een heel oude regel, die in 1821 voor het eerst centraal is vastgelegd. ${ }^{137}$

In dit wetsartikel lijkt het uitsluitend te gaan om een permanent verblijf van het kind bij de moeder. Vooronderstelling is dat het kind de zorg van de moeder zou kunnen ontberen. In de praktijk wordt aan dit wetsartikel inhoud gegeven via een soepele toepassing van de zogenoemde 'negen maanden regel' voor moeders met zuigelingen. Deze regel is nooit bij circulaire vastgellegd, maar zou afgeleid zijn uit een briefwisseling ten tijde van de detentie in Amsterdam van een aantal gedetineerden, dat gedurende zeer lange tijd, twee à drie jaar, hun kinderen zoogden. In alle inrichtingen zijn inmiddels ruimtelijke voorzieningen gecreëerd, die gericht zijn op de directe verzorging van zuigelingen. In gekwalificeerde opvang van de baby's, bijvoorbeeld gedurende enkele dagdelen in een gastgezin, is niet voorzien. Alleen in Sevenum is nu een voorziening woor kinderen tot vier jaar, waarbij gebruik wordt gemaakt van professionele opvang in een kinderdagverblijf buiten de inrichting. Ook

135 De Raad van State is nog wel expliciet ingegaan op de positie van jeugdige vrouwelijke gedetineerden. De minister zegt echter dat het "gelet op deze bescheiden omvang" (in 199478 jonger dan 25 jaar) niet mogelijk is om verder te differentiëren. Ook het strewen naar regionalisering staat differentiatie in het beleid in de weg (TK 1994-1995, 24 263, B, Advies Raad van State en Nader Rapport, p. 5).

136 Dat had wel gekund, bijvoorbeeld in thet kader van bezoek, verlof, extramurale executiemodaliteiten, arbeid, kinderopvang, medische zorg, psychiatrische opvang, transport en dergelijke.

137 Art. 16 van het KB 4 november 1821, no. 16, in: De Jongh (1846) no. 84. 
wordt daar aan de moeders een cursusaanbod over opvoeding en verzorging gedaan, dat nitgevoerd wordt door gespecialiseerde krachten van het dagverblijf. $\mathrm{f}^{138}$

Het is opmerkelijk dat op het huidige art. 31 Gevangenismaatregel in het verleden alleen door een man een beroep is gedaan. ${ }^{139}$ Zijn verzoek werd afgewezen op grond van het feit dat het leefmilieu waarin hij verkeerde qua aard en karakter ongeschikt zou zijn voor het verblijf van zijn dochtertje. Tot een Kort Geding is het in deze zaak niet gekomen, omdat er een regeling werd getroffen, waarbij de man uitgebreid verlof kreeg om buiten de inrichting meer voor het kind te kunnen zorgen.(!) Uit het oogpunt van gelijke behandeling is bij toepassing van art. 31 Gevangenismaatregel naar mijn idee de sekseneutrale benadering via het begrip 'verzorgende ouder' juist. Zolang de feitelijke verhoudingen echter zo zijn dat de primaire zorg voor kinderen veelal bij vrouwen ligt, is het wetsartikel nog niet in strijd met de dagelijkse praktijk.

\subsubsection{Art. $12 \mathrm{PBW}$ (ontwerp)}

In het w.o. PBW wordt opnieuw een verblijfsmogelijkheid voor kinderen gecreẻerd. ${ }^{140}$ Het voorgestelde art. 12 PBW luidt:

1. Onze Minister wijst de inrichtingen of de afdelingen aan waarin kinderen tot een in de aanwijzing aangegeven leeftijd kunnen worden ondergebracht.

2. Indien een gedetineerde een kind in de inrichting of afdeling, bedoeld in het eerste lid, wil onderbrengen teneinde het aldaar te verzorgen en op te voeden behoeft hij de toestemming van de directeur. De directeur kan deze toestemming geven, voor zover dit verblijf zich verdraagt met de volgende belangen:

a. de bescherming van de persoonlijke veiligheid of de geestelijke of lichamelijke ontwikkeling van het kind;

b. de handhaving van de orde en veiligheid in de inrichting.

3. De directeur kan aan de toestemming voorwaarden werbinden met het oog op het belang als bedoeld in het tweedle lid.

4. De directeur kan over een door hem voorgenomen onderbrenging van een kind in de inrichting of afdeling het advies inwinnen van de Raad voor de Kinderbescherming.

5. De directeur kan de toestemming intrekken, indien dit noodzakelijk is met het oog op een belang als bedoeld in het derde lid of indien de gedetineerde een bepaalde voorwaarde niet nakomt. Indien de directeur een nader onderzoek nodig oordeelt, kan hij de medewerking van de Raad woor de Kinderbescherming inroepen.

6. De directeur is verplicht de toestemming in te trekken, indien de onderbrenging wan het kind in de inrichting in strijd komt met enige op het gezag over het kind betrekking hebbende beslissing.

138 Het is de vraag of hiermee in voldoende mate aan de kritiek van het CPT tegemoet is gekomen. Zie CPT/Inf(93)15, p. 42. en CPT/Inf(93)20, p. 53.

139 Vrij Nederland, mei 1987.

140 Art. 12 in het wetswoorstel PBW (TK 1994-1995, nr. 24263). 
7. In de huisregels worden nadere regels gesteld omtrent het verblijf van kinderen in de inrichting:

8. De kosten van de verzorging van het kind komen voor rekening van het Rijk, voor zover de gedet:neerde niet zelf in die kosten kan voorzien.

In een eerste ontwerp werd de mogelijkheid tot co-detentie niet verbonden aan leeftijdsgrenzen en niet meer gekoppeld aan "de behoefte van het kind", maar aan de "wil van de gedetineerde het kind in de inrichting onder te brengen teneinde het aldaar te verzorgen en op te voeden". Na het terughoudende advies van de Raad van State is in het bij de Tweede Kamer ingediende voorstel de afweging van belangen, die van het kind en die van de orde en veiligheid van de inrichting, nadrukkelijker naar voren gehaald. De leeftijdsgrens wordt in het voorstel per concrete situatie beoordeeld "waarbij de aard en de lengte van de detentie, de feitelijke detentiesituatie en het gedrag van de betrokken ouder een rol spelen".144

De juridische basis voor de voorziening wordt gevonden in art. 8 EVRM. In hoeverre een verblijf van een kind in een gesloten inrichting op gespannen voet staat met art. 5 EVRM wordt in de Memorie van Toelichting niet aan de orde gesteld. Hoewel het ouderlijk gezag in de jurisprudentie van het Europese Hof maatgevend is voor het recht op family life voor kinderen, zou naar mijn idee juist bij de vrijheidsberoving van het kind de materiële invulling van voorzieningen vanuit pedagogisch oogpunt weleens een bepalende rol kunnen gaan spelen ${ }^{142}$ Bovendien is inmiddels het $\mathrm{VN}$ Kinderverdrag geratificeerd en worden de zelfstandige rechten van kinderen steeds meer benadrukt. ${ }^{\text {tas }}$

Opvallend is het sekseneutrale rechtssubject in het wetsontwerp. In feite wordt seksestereotypering vermeden hetgeen mijns inziens op grond van art. 14 EVRM en art. $5 \mathrm{VN}-$ Vrouwenverdrag heel goed te verdedigen valt. ${ }^{144}$ Daarmee loopt het wetsvoorstel vooruit op alle internationale regelingen en aanbevelingen op dit terrein waarin voorzieningen steeds aan "moeders" gekoppeld zijn. ${ }^{145}$ Wel wordt in de MvT terecht een materiële invulling aan de sekseneutraal geformuleerde gedetineerde gegeven:

"Het zall woor de hand liggen dat een ouder die reeds voor de aanvang van het verblijf in de inrichting de verzorging op zich had genomen hiervoor eerder in aammerking komt dan een ouder die tot de aanvang van het verblijf hierbij niet of nauwelijks was betrokken". 140

141. MvT, TK 1994-1995, 24263, nr. 3, p. 85.

142 Vgll. EHRM 28 november 1988; Nielsen wersus Denemarken, NJ 1991, 541, m.n. EAA en de bespreking wan dezelfde zaak door Verheij (Verheij (1989) p. 611).

143 Zie voor kritische commentaren over het verblijf van kinderen in de gevangenis wanuit de rechtspositie van het kind: De Jonge (1993) met naschrift van Wan Wamelem, Krooi (1994).

144 Wolleswinkel (1992) p. 237.

145 Zie bijlagen.

146 MvT, TK 1994-1995, 24263, nr. 3, p. 85. 
Toch roepen het artikel en de implementatie ervan nog veel vragen op, waarvam ik de meeste hier kort aanstip om ze in de volgende hoofdstukken nader uit te werken.

Met name de vergelijking tussen het eerste lid van art. $31 \mathrm{GM}$ en het weede lid van art 12 w:o. PBW levert een aantal belangrijke verschillen op die in het huidige maatschappelijke discours over 'de zorg voor kinderen 'opmerkelijk zijn"

- De rechthebbende is vanuit een ander perspectief gekozen. In art. $31 \mathrm{GM}$ is de behoefte aan zorg van het kind, het belang van het kind uitgangspunt, terwijl in het midden wordt gelaten door wie en hoe dat vastgesteld wordt. In het nieuwe artikel is het recht op het geven van zorg en de will daartoe van de verzorger de ingang. In de toelichting wordt de grondslag voor een dergelijke voorziening voor de ouder gevonden in art. 8 EVRM lid 1 , terwijl een mogelijke inperking op grond van "de bescherming van de gezondheid of de rechten en vrijheden van het kind" onder art. 8 EVRM lid 2 gebracht wordt. ${ }^{147}$

- In art. 31 GM wordt gesproken over "de zorg van de moeder die het kind all dan niet kan ontberen", terwijl in het nieuwe artikel de "wil tot verzorging en opvoeding" van de ouder genoemd wordt. Dit lijkt een juridisering van begrip 'zorg' in de richting van 'ouderlijk gezag' te impliceren.

- De voorziening wordt in eerste instantie gecreëerd om de inbreuk op het family life van de gedetineerde teniet te doen. De wilsbeschikking van de verzorger impliceert echter in het nieuwe artikel niet het belang van het kind, want daarop moeten de directeur toezien. Via het toestemmingsvereiste van de directeur, eventueel na advies van de Raad voor de Kinderbescherming, is er dus sprake van inmenging van de staat in het gezinsleven. De overheid neemt bij co-detentie van kinderen een deel van de verantwoordelijkheid voor het individuele kind over. Waarom? Om een wettelijke basis aan het verblijf van het kind te geven? Art. 15 lid 2 Gr.w. en art. 5 EVRM vereisen immers een rechtsgrond voor de detentie. Het is opmerkelijk dat er juist vanuit de Raden voor de Kinderbescherming geageerd is tegen de in eerste instantie voorgestelde verplichte advisering. Zij zien de ouder als de primaire verantwoordelijke voor de keuze om het kind in detentie onder te brengen. ${ }^{\sharp 4}$ Ogenschijnlijk ${ }^{4 j \mathrm{kt}}$ er dus een uitbreiding van het recht van de gedetineerde verzorger te ontstaan, maar in feite wordt er een mogelijke belangentegenstelling tussen de gedetineerde verzorger en het kind

147 MvT, TK 1994-1995, 24263, nr.3, p. 85-86. "Het belang van een ouder bij het ter hand nemen dan wel voortzetten van de verzorging en de opvoeding van het kind kan op gespannen voet staan met het recht van een kind op een ontwikkeling en ontplooing in wrijheid en in wisselwerking met leeftijjdsgenoten" (p. 85).

148 MVT, TK 1994-1995, 24263, nr.3, p. 86. "Van een verplichte advisering is afgezien, ondat een dergelijke adviseringsverplichting niet behoort tot de kerntaken van de Raden woor de Kinderbescherming." Zie ook: Krooi (1994) p. 81-82. 
verondersteld, waardoor het de vraag is of er ubberhaupt een te effectueren recht gecreëerd wordt.

- De directeur moet naast het belang van het kind ook de orde en veiligheid in de inrichting bewaken. De volgorde van deze belangen is in de loop van het wetgevingstraject overigens omgedraaid, zonder dat toegelicht wordt of dat enig gevolg heeft voor prioritering van het ene belang boven het andere. De directeur kan de toestemming, krachtens lid 5, zelfs intrekken "als de gedetineerde een bepaalde voorwaarde niet nakomt". Die voorwaarde hoeft dus niets uit te staan te hebben met de opvangsituatie van het kind. De orde van de inrichting gaat dan in feite boven alles en het kind kan als het ware in een gijzelsituatie komen.

- De bevoegdheden van zowel de directeur, omtrent toestemming, intrekking toestemming, huisregels, en die van de Raad voor de Kinderbescherming, omtrent de wijze van advisering, in art 12 PBW en de afstemming op de procedures in art. 57 lid 1 jo art. 61 w.o.PBW roepen nadere vragen op, wat betreft de termijnen voor beklag en beroep en en de mogelijkheid tot het wragen van een second opinion. Op kamervragen verwijst de minister slechts naar het protocol "Uitplaatsing van kinderen" in Sevenum en meldt zij bovendien dat bij afzondering het kind bij de moeder op de cel verblijft. ${ }^{149}$

- De rechthebbende verzorger is in het nieuwe artikel sekseneutraal. In de Memorie van Toelichting wordt overigens alleen art. 8 EVRM in dit verband aangehaald. In de toelichting wordt vermeld: "Dat het voor de hand zal liggen dat een ouder die reeds voor de aanvang van het verblijf in de inrichting de verzorging op zich had genomen hiervoor eerder in aanmerking komt dan een ouder die hierbij tot de aanvang van de detentie niet of nauwelijks betrokken was". Hier zal ook de invulling van de vooronderstellingen de nodige problemen kunnen opleveren. Wat is "reeds voor de aanvang van het verblijf"? Telt de voorlopige hechtenis daarbij mee? De logische volgorde in het strafproces is niet per definitie "logisch" in de opvang voor kinderen.

- De begrippen "een gedetineerde" en "een kind" laten sowieso in het midden hoever het family life strekt. In de Memorie van Toelichting wordt we] over "ouder" en "zijn kind" gesproken. Gezien de diversiteit in opvoedingsgewoonten lijkt de ruime formulering zinvol. Hoever strekt het begrip "een gedetineerde"? Naar de letter van de wet zou ook een oma een beroep op dit toekomstig artikel 12 PBW kunnen doen, als zij de primair verzorgende was en als er geen strijd is met lid 6 van het artikel. De open formulering kan wel leiden tot vragen over de juridische verhouding tussen de gedetineerde en het kind en tussen de biologische ouder(s) en de feitelijke verzorger(s).

- Het pedagogisch doel van de voorziening wordt, citeerd. Dat gebeurt wel, weliswaar impliciet, bij de invulling van art. $31 \mathrm{GM}$ 
wel via de fysieke aanwezigheid moeder en de periode waarin borstvoeding gegeven mag worden. In de voorstellen van de werkgroep Vrouwen in detentie wordt expliciet de exclusieve hechtingsrelatie met moeder genoemd en een leeftijdscriterium van vier jaar gesteld. ${ }^{150}$ Wel worden in de Memorie van Toelichting bij het wetsontwerp bezwaarlijke kanten van co-detentie belicht. Het recht van een kind op een ontwikkeling en ontplooiing in vrijheid in wisselwerking met leeftijdsgenootjes. Het evenredig toenemen van noodzakelijke voorzieningen en veiligheidsrisico's met de groei van het kind en dergelijke. Het is mijns inziens de vraag of juist deze voorzichtige opstelling niet moet leiden tot een motiveringseis in de richting van de verzoekende gedetineerde. ${ }^{\text {isl }}$

- Over minimale pedagogische eisen waaraan een voorziening moet voldoen wordt nauwelijks gerept. In het derde en zevende lid krijgt de directeur de bevoegdheid om hiervoor nadere voorwaarden en regels te stellen. Het is echter de vraag of de directeur hiervoor, vanuit pedagogisch oogpunt, de meest geschikte functionaris is. Experimenten als die in de halfopen inrichting in Sevenum bieden inzicht in de complicaties die hierbij kunnen optreden.

- Omtrent de interne rechtspositie van het kind is niets geregeld. ${ }^{152} \mathrm{Er}$ zou een aparte, op de pedagogische opvang gerichte, klachtenregeling moeten komen. ${ }^{153}$ Ook kan gedacht worden aan de benoeming van een bijzondere curator buiten de inrichting die, ter ondersteuning van de gedetineerde, het belang van het kind bewaakt krachtens art 1:250 BW.

- Meer principieel is het de vraag of het kind niet een eigen rechtspositie zou moeten hebben, waarbij niet alleen in de basisbehoeften (ook in pedagogische zin) in een wettelijke regeling voorzien wordt. ${ }^{1.54}$, maar juist ook grondrechtelijke vrijheden gegarandeerd worden, bij voorbeeld het recht op lichamelijke integriteit (bijvoorbeeld in verband met fouilleren) en het recht op privacy en rust. (bijvoorbeeld geen intercorn.) Gezien het loslaten van een leeftijdscriterium zou het oudere kind daarbij een eigen rechtsingang moeten krijgen om formeel ook zaken aan de orde te kunnen stellen. Voor het jongere kind kan gedacht worden aan bovengenoernde mentor die niet in een afhankelijke relatie tot de directeur staat.

Zelfs wanneer niet de huidige differentiatie in de bestemming van de gebouwen als vaststaand gegeven zou dienen, maar er een aparte op verzorging van kinderen ingerichte voorziening zou komen met eventueel in de kinderopvang geschoold

150 Werkgroep Vrouwen in detentie (1991) p. 30.

151 Zie ook Krooi (1994) p. 81.

152 Vgl. De Jonge (1993) en Krooi (1994).

153 Klachtenregelingen uit de kinderopvangen de jeugdhulpverlening kunnen als voorbeelden gebruikt worden.

154 De MvT geeft de mogelijkheid dit in een huishoudelijk reglement te regelen. 


\section{Hoofdstuk 4}

personeel, blijft als principieel dilemma overeind staan dat het enerzijds een schande is om een kind in een strafinstituut op te nemen en anderzijds ook om een goed functionerende primair verzorgende ouder uit het gezin weg te halen. ${ }^{19 s}$

Ten aanzien vain de wenselijkheid van permanent verblijf van kinderen in de gevangenis kun je je afvragen of de overheid verzorgende ouders voor zo'n dilemma mag plaatsen in het kader van art. 8 EVRM. Als de ouder met gezag bekleed is (en de meeste al dan niet alleenstaande gedetineerde moeders zijn dat) rust op haar ook de verantwoordelijkheid het gezinsleven van het kind te beschermen tegen inbreuken van derden of de overheild. Zelfs als de ouder iets, in casu het strafbare gedrag, te verwijten is, zou het een plicht van de overheid moeten zijn om in het belang van het kind eerst alle alternatieve vormen van straf te onderzoeken ên aan te bieden om de continuïteit van de primaire zorg in het leven van het kind zoveel mogelijk veilig te stellen. Wanneer co-detentie van een kind dan toch overwogen wordt, dient vanuit 'het belang van het kind' een toetsing aan de beginselen van legitimiteit en proportionaliteit plaats te vinden. ${ }^{156}$.

Zoals gesteld is het bij co-detentie de vraag of het kind in beginsel, als rechtssubject, met instemming van de ouder, maar zonder zelfstandige wettelijke grondslag well gevangen gezet mag worden in het licht van art. $37 \mathrm{VN}-$ Kinderverdrag, art. 15 Grondwet en art. 5 EVRM. Zijn de primaire doelen van kinderverzorging en opvoeding te combineren met de primaire doelen van detentie? Moet er vanuit het kind een belangenafweging gemaakt worden tussen bijvoorbeeld slechte opvang buiten en iets betere opvang binnen?

In het nieuwe wetsartike] en de toelichting daarop komen niet de belangenafwegingen aan de orde in het familierecht spelen. Zijn er familierechtelijke betrekkingen in combinatie met feitelijke omstandigheden die het beroep op erkenning van het recht op family life van de ouder teri behoeve van een specifieke voorziening legitimeren? Bovendien wordt in de nieuwe PBW alleen iets geregeld over de verblijfplaats van het kind. Niet over een wederzijds recht op omgang en/of informatie, terwijl daar wellicht een groter gemeenschappelijk belang van gedetineerde verzorgers en hun kinderen ligt.

De antwoorden op bovenstaande vragen zijn nilet gemakkelijk te geven.Ik doe daar in het vervolg van dit onderzoek wel een poging toe. Eerst door op grond van de resultaten uit empirisch en theoretisch gedragswetenschappelijk onderzoek na te gaan wat nu eigenlijk dat, ook door juristen gehanteerde, begrip "het belang van het kind" inhoudt en hoe onlosmakelijk dat met het moederschap en/of familierelaties verbonden is.

155 Zie ook de algemene inleiding waarin dit dilemma breder geschetst wordt.

156 De fractie van Groen Links vind dat "de concrete situatie steeds dient te wordenafgewogen in het licht wan de aard en de lengtte wan de detentie, de feitelijke detentiesituatie, de mate van geslotenheid van de inrichting en het gedrag van de ouder" (TK 1994-1995, 24263, nr. 5, p. 34). 


\subsection{Samenvatting}

In de nationale regelgeving staat impliciet de mannelijke gedetineerde centraal. De formele en materiële rechten van vrouwelijke gedetineerden zijn gelijk aan die van mannen. Alleen op het punt van het verblijf in gevangenschap van zorgafhankelijke zuigelingen bestaat specifieke op moeders gerichte wetgeving. In de nieuwe Penitentiaire Beginselenwet is hetzelfde waar te nemen, zij het dat het recht op verblijf van kinderen bij de gedetineerde ouder wordt uitgebreid. Het blijft niet beperkt tot moeders en de criteria waaronder kinderen in gevangenschap worden toegelaten worden open gelaten.

In internationale normen blijkt een iets bredere invulling aan materiële voorzieningen voor vrouwen in detentie te worden gegeven, zij het dat het gevaar van seksestereotypering steeds dreigt. Het betreft bovendien regels die gelezen moeten worden als beleidsaanbevelingen, niet als direct werkende rechten.

In de jurisprudentie blijken op Europees niveau geen en op nationaal enkele uitspraken relevant voor vrouwen, met name die waar op grond van het gelijkheidsbeginsel indirecte discriminatie vastgesteld wordt omdat op grond van de feiten maatregelen zwaarder blijken uit te pakken voor de betreffende vrouwen dan 'normaal' het geval zou zijn geweest.

Wellicht moet er over de open normen in de nieuwe PBW niet worden getreurd en valt er in de beleidssfeer juist wel het een en ander te realiseren voor vrouwen dat na verloop van tijd alsnog gecodificeerd kan worden. Vrouwen blijken immers minder gauw hun recht te willen halen via regelgeving of daaraan gekoppelde juridische procedures. Vrouwen zijn door hun relatiegerichtheid geneigd zich gunsten te verwerven via onderhandelingen en modelgedrag. Door reflexief gedrag lijken zij bovendien eerder dan mannen geneigd hun behoeften in de behandelsfeer te uiten via bij voorbeeld medicalisering van onvrede.

Wat de materiële rechten in het licht van het respect op gezins- en familieleven betreft, is er in het ontwerp PBW een apart hoofdstuk "Contact met de buitenwereld" opgenomen. Dat bevat het recht op briefwisseling, bezoek en telefoneren en vormt een weergave van de, op grond van het nu geldende recht, gegroeide praktijk. Dit hoofdstuk valt onder de reikwijdte van art. 8 EVRM. Mijn inziens zouden het recht op respect van het gezins- en familieleven het streven naar reïntegratie van gedetineerden ook een genderspecieke benadering van verlofregelingen, detentiefasering en plaatsingsbeleid rechtvaardigen. In dat opzicht lijkt het een inbreuk op art. 8 EVRM te zijn dat regionalisering en detentiefasering niet als beginselen in de nieuwe wet zijn opgenomen. Ook in het kader van de individuele trajectbegelleiding zou bij regelingen van arbeid en scholing rekening met zorgtaken en genderspecifieke resocialisatie gehouden kunnen worden. Met betrekking tot de medische zorg is het de vraag of er, ook in regelgeving, een sekse-en genderspecifiek aanbod gedaan 
moet worden. Op al deze punten is er in het positieve recht nauwelijks aandacht voor de specifieke positie van vrouwen en/of gedetineerden die voor hun detentie primaire verzorgers waren of dat na hun detentie hoogstwaarschijnlijk zullen zijn. Het is boeiend dat het vrouwenbeleid dat wel in regelgeving (art. 31 GM) gestalte krijgt eenzijdig op de verzorging van kinderen gericht is, de klassieke moederrol. Biologisch/fysiologisch gezien worden echter niet alleen moeders, maar alle vrouwen met seksespecifieke reproductieve en seksuele functies geconfronteerd. De verzorging van kinderen is daarentegen genderspecifiek bepaald en hoeft dus niet per se aan vrouwen of zelfs moeders te worden toebedeeld. De sekseneutrale omschrijving in het voorgestelde wetsartikel (art. 12 w.o. PBW) met betrekking tot permanent verblijf van kinderen in detentie is derhalve een doorbraak te noemen. Het artikel is ook gebaseerd op art. 8 EVRM. Er lijken echter nog wel haken en ogen aan het voorgestelde wetsartikel te zitten, zowel wat de pedagogische als juridische uitwerking betreft. In de volgende hoofdstukken worden de maatschappelijke en juridische concepten die aan het betreffende art. 12 uit het w.o. PBW ten grondslag zouden kunnen liggen, nader bekeken. 


\section{Zorgen in het gezin}

\section{Inleiding}

Zoals uit de voorgaande hoofdstukken is gebleken, vormen de verstoorde familierelaties en de verwrongen seksualiteitsbeleving voor vrouwen in detentie de meest pregnante problemen. Deze lijken vooral op te treden als gevolg van het maatschappelijk isolement waarin zij verkeren. Het blijft de vraag of die problemen er voor en na de detentie ook niet waren of zullen zijn. Wellicht is het algemeen menselijk of misschien ook typisch westers om af en toe gefrustreerd te raken door (te) idealistische voorstellingen rond familierelaties en seksualiteit. ${ }^{1}$ In ieder geval is duidelijk dat frustraties en problemen in detentie verscherpt naar voren komen en moeilijker te hanteren lijken dan daarbuiten.

Ter verbetering van de familierelaties van gedetineerde vrouwen is er door de overheid inmiddels een aantal initiatieven genomen. Deze richten zich tot nu toe vooral op mogelijke co-detentie van kinderen bij hun moeder en op betere bezoekmogelijkheden voor kinderen van gedetineerden. Dus niet op een (geleidelijke) verplaatsing van de strafwaardige moeder naar buiten. Het meest in het oog springen de voorziening voor moeders met kinderen in de halfopen inrichting Ter Peel in Sevenum (de m.m.k. unit) en het voorstel tot vervanging van art. 31 Gevangenismaatregel door art. 12 in het wetsvoorstel voor de nieuwe Penitentiaire Beginselenwet. Zoals uit het vorige hoofdstuk blijkt, zijn er nogal wat vragen op te werpen rond dit wetsvoorstel. Wat wordt verstaan onder 'het belang van het kind'? Hoe sekse- of genderspecifiek zijn de praktijken en verwachtingen rond het ouderschap? Hoe ver reikt het family life etcetera.? Dit zijn vragen die niet alleen binnen de gevangenismuren, leven. In detentie dringen ze zich veel sterker op dan daarbuiten. Bovendien kan er van de overheid op grond van art. 8 EVRM een inspanning verwacht worden bij het formuleren van antwoorden op die vragen. ${ }^{2}$

Het 'zorgdebat' is in zijn algemeenheid net als het euthanasiedebat één van de meest publiek gevoerde discussies, die met veel emoties gepaard gaat. De terugtredende

1 Vgl. Pösö (1992).

2 De positieve verplichting die de overheid hiertoe mijns inziens juridisch gezien heeft op grond van art. \& EVRM wordt in het volgende hoofdstuk nog nader uitgewerkt. 


\section{Hoofdstuk 5}

overheid, de demografische ontwikkelingen en de niet meer vanzelfsprekende bereid. heid van vrouwen om onzichtbaar en onbetaald zorgtaken te vervullen noodzaken tot een brede discussie waarin politiekculturele waarden binnen een beperkte sociaal economische context herijkt worden. ${ }^{3}$ De kwaliteit van de relatie tussen moeder en kind is in het zorgdebat een heet hangijzer.

In netelige ethische kwesties lijkt het juridisch vertoog in brede maatschappelijke en wetenschappelijke kring nogal eens een overheersende rol te krijgen. Dit kan leiden tot overschatting van het inhoudelijk oplossend vermogen wan het recht. De aanvankelijk, na de Tweede Wereldoorlog, toegenomen overheidsbemoeienis met. het maatschappelijk leven heeft het bureaucratisch denken en het juridiseringsproces versterkt. Het ontwikkelen van procedures (en regelgeving op dat terrein) en het innemen van juridische stellingen zijn op zichzelf staande professionele waarden geworden. Daarnaast bestaat er een juridiseringstendens in het maatschappelijk debat die zich uit in het toenemend gebruik van juridisch jargon. ${ }^{5}$ De verschillen in betekenisgeving aan begrippen kunnen echter leiden tot mystificaties en schijnovereenstemming. En het juridische debat dreigt soms van het maatschappelijke te vervreemden, als het te ver verwijderd raakt van de materiële context.

Een dergelijke Babylonische spraakverwarring meen ik soms waar te nemen in het debat over de kwaliteit van de relatie tussen moeder en kind. Ouders en politici (met verschillende achtergronden), pedagogen, psychologen, medici en juristen geven vanuit hun persoonlijke en/of beroepsoptiek normatieve invullingen aan 'de functie van het gezin', 'het belang van het kind', 'het ouderlijk gezag' etcetera. Voorafgaand aan de juridïsche invulling van deze relevante concepten wordt in dit hoofdstuk geschetst op welke inhoudelijke, normatieve vooronderstellingen de huidige tamelijk impliciete juridische regels en afwegingen mogelijk gebaseerd zijn.

De belangrijkste aangevers van normatieve waarden over de ouder-kindrelatie zijn vooral de professionals, zij die daar uit hoofde van hun beroep iets over zeggen. Maas er zijn ook ervaringsdeskundigen, vooral moeders. Voor een deel overlappen die twee groepen elkaar."

3 Vgl. De Swaan (1989), De Bruijn (1994).

4 De eigen waarde van het recht zou zijn het ontwikkelen van rationele procedures die open staan voor morele argumentatic. (Zie Habermas $(1988$, p. 39.) De aan het recht verklonken procedurele rationaliteit houdt, in ieder geval buiten de casuïstiek, wellicht per definitie geen of te weinig rekening met persoonlijke levenskeuzes en situationeel gebonden beslissingen. Dat maakt het ook zo ingewikkeld om meer contextuele wijzen van moreel redeneren over te hevelen naar het recht. Vgl. Sevenhuijsen (1993-2), Tigchelaar (1993).

5 Vgl. De Vries (1992) over ethici die zich als amateurjuristen gedragen.

6 Vgl. Smart (1989).

7 Moller Okin (1989). Zij merkt op dat besluiten die diep ingrijpen in de zogenaamde privesfeer vaak door mannen op topposities (wetenschap, politiek, wetgeving) genomen worden, terwijl die personen geen of mauwelijks ervaringskennis hebben. In tegendeel, het opwoeden van je kinderen 
In dit hoofdstuk wordt eerst enige aandacht gegeven aan de rol die 'het geain' in onze maatschappij wordt toegedicht en aan de denkbeelden die professionals hadden en hebben over de plek van kinderen in gezin en/of samenleving. Daarbij maak ik onder andere gebruik van vrouwenstudiesonderzoek in andere disciplines dan het recht, omdat zij met oog voor de veranderende maatschappelijke posities van vrouwen (moeders) hun inventarisaties hebben gemaakt. ${ }^{8}$

Ook komt in dit hoofdstuk de doorwerking van moederschapsideologieën bij vrouwen zelf aan de orde. Omdat degelijk sociaalwetenschappelijk onderzoek op dit punt onder gedetineerde vrouwen ontbreekt", maak ik hierbij gebruik van resultaten uit meer algemeen vrouwenstudiesonderzoek. Vooralsnog ga ik er vanuit dat de doorwerking van voorbeelden, bijvoorbeeld uit damesbladen, voor een deel op dezelfde wijze bij gedetineerde vrouwen plaatsvindt als bij de groep vrouwen die onderzocht is. Die doorwerking zal bij hen, door hun over het algemeen, qua scholing en klasse, eenzijdige achtergrond misschien minder gedifferentieerd zijn. Anderzijds vormen zij qua culturele achtergrond mogelijk juist een gedifferentieerder beeld dan de groep vrouwen die voorwerp van onderzoek was.

Tot slot wordt op hoofdlijnen kort weergeven welke ontwikkelingspsychologische en pedagogische visies er zijn ontwikkeld met betrekking tot het belang van het kind in bepaalde opvoedingssituaties.

\section{$5.1 \quad$ Het gezin}

\subsubsection{De universele waarde van het gezin}

Naast ontwikkelingspsychologische en sociaalpsychologische studies over gevoelsrelaties en functionele relaties binnen het gezin, vindt onderzoek plaats naar rollen, taken en posities van het gezin in een bredere maatschappelijke context. Kan 'het gezin' afhankelijk van de historische, culturele en sociaaleconomische omstandigheden steeds een andere betekenis hebben of bestaat er wereldwijd zoiets als een 'kerngezin'? Onder historici, antropologen en sociologen bestaat geen eenstemmigheid over

overlaten aan anderen (vrouwen) is voorwaarde voor het bereiken van zo'n imvloedrijke positic. Zij formuleert idealistisch haar toekomstbeeld: "It would be a future in which men and women participated in more or less equal numbers in every sphere of life, from infant care to different kinds of paid work to high-level politics. Thus it would no longer be the case that having no experience of raising children would be the practical prerequisite for attaining positions of the greatest social influence." (p. 171)

Belangrijk empirisch materiaal is ook verzameld door de jurist Van Wamelen (1987) ten behoeve wan haar dissertatie-onderzoek. Zij stelde de perceptie van kinderen centraal.

9 Zie de - vooral methodologische - kritiek op de inventarisatiestudies onder gedetineerde vrouwen in hoofdstuk 1. 


\section{Hoofdsutuk 5}

de universele waarde van het gezin. ${ }^{10}$ In ieder geval blijkt uit cultuurantropologisch onderzoek dat aan het gezin in het Westen maar een beperkte invulling wordt gege-

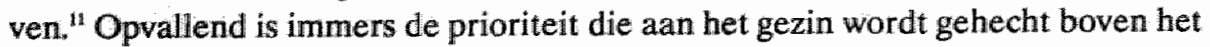
ruimere familieverband. Die lijkt nog steeds rechtstreeks voort te vloeien uit de betekenis die aan het huwelijk wordt toegekend. Daarnaast speelt in het Westen de individualisering een grote rol.

Toch is er in de historie in de diverse West-Europese samenlevingen een grote verscheidenheid te vinden in het familie-, huwelijks- en gezinsleven. ${ }^{12} \mathrm{Na}$ de Middeleeuwen en voor de industriële revolutie bestaan er in Westeuropa hoge sterfte- en geboortecijfers: ${ }^{\text {"n }}$ De huwelijksduur is gemiddeld kort en aan jonge kinderen wordt betrekkelijk weinig waarde gehecht. De samenleving is overwegend agrarisch-ambachtelijk. Er bestaan geen scherpe grenzen tussen woon- en werkplaats. De contrasten tussen de verschillende standen in de maatschappij zijn groot, maar ook de verschillen tussen arm en rijk, tussen seksen en generaties. De maatschappij is doortrokken van hiërarchische en autoritaire verhoudingen en van collectieve tradities. Voor individuele voorkeuren of variatie is weinig ruimte. Beschermings-en economische functies zijn voor gezinnen van groot belang. Het huwelijk is een werkgemeenschap. Gezondheid en werkkracht spelen een belangrijke rol bij de partnerkeus. Onder de adel, de grote boeren en de hogere stedelijke burgerij wordt rekening gehouden met het bezit van grond, geld en goederen. Ook de voortplantingsfunctie van de partners speelt een rol. De vrouwen krijgen gemiddeld vijf à zes kinderen, hetgeen belangrijk is vanwege de hoge kindersterfte en vanwege het nut van kinderen als arbeidskrachten en als oudedagvoorziening. Hoewel deze omstandigheden voor veel mensen tot ver in de negentiende eeuw nawwelijks veranderen, doen zich in de periode voor 1800 onder een deel van de bevolking al verschijnselen voor die wijzen op

10 Zie voor een resume Van Wamelen (1987) p. 35-54.

Als belangrijke samenhangende functies van het gezin worden genoumd: de seksuele, cconomische, voortplantings-en opvoedingsfunctie. Het unieke van het gezin als systeem zou in die samenhang zitten.(Murdock) Anderen bestrijden of de samenhang of het leit dat alle functies per se in het gezin thuis horen. Coser vindt dat de universaliteit niet verklaard word door de manifeste functies. Zijj noemt:"the institionalisation of social fatherhood, the establishment through marriage of alliances outside of bloodrelations, the imposition of social norms on the biological organism, and the bestow wing of social identity on its members". Met name de tweede door haar genoemde functie berust op het reciprociteitsbeginsel van Levi-Strauss. (incesttaboe en uitwisseling van seksuele partners)

11 Zie ook: Niehof (1994) p. 10-11. Zij geeft aan dat met name verschijnselen als polygamie en arbeidsmigratie de onbruikbaarheid van de op Westerse leest geschoeide definities aan het licht brengen. In Sub-Sahara Afrika zie je kerngroepen van vrouwen met kinderen die op verschillende manieren zijn geỉntegreerd in grolere huishoudelijke eenheden, waarin mannen wisselende posities innemen en waaraan ze ook een wisselende bijdrage leveren.

12 Zwaan (1994).

13 Dit had onder meer tot gevolg dat er waarschijnlijk ewenveel onvolledige, 'gebroken' en stiefgezinmen waren alls nu. Toen het resultaat van sterfte, nu van echtscheiding en alleenstaand moederschap. 
een meer emotionele invulling van familierelaties. Het ldeaal wan de romantische liefde tussen man en vrouw gaat een grotere rol bij de huwelijkssluiting spelen en de band tussen moeders en jonge kinderen wordt steeds meer geaccentueerd. Hoewel een huwelijk 'uit liefde' door de burgeriy nog lang als onwenselijk wordt gezien (gevoelens vormen een onzekere basis vergeleken bij zakelijke en materiele overwegingen), wordt liefde toch geleidelijk aan steeds meer als een voorwaarde voor een geslaagd huwelijk beschouwd en streeft men er op zijn minst naar dat de partners naar elkaar toe zullen groeien. Naast de moederliefde komt ook het ideaal van de ontplooiing van kinderen opzetten, onder meer door de groei van scholen. Aanvankelijk zijn deze vooral bestemd voor kinderen van de stedelijke burgerij. Hoewel er daardoor scherpere scheidslijnen komen tussen het gezin en de omringende samenleving is er ook binnen de gezinshuishoudingen sprake van een intensief sociaal verkeer. Met verwanten, die soms inwonen, met in-en uitwonend personeel en met vrienden en bekenden uit het plaatselijk circuit. 'Privacy' zoals we die nu kennen, ontbreekt. Gezinshistorici menen dat in het westen gezinsrelaties met sterke identificaties en een actief individualisme zijn ontstaan als gevolg van het marktkapitalisme. ${ }^{\text {" }}$ Productietaken vielen weg uit het gezin. Het wordt een burgerlijk ideaal dat vrouwen kunnen thüisblijven en zich volledig aan de opvoeding en het huishouden wijden. Het gezin wordt een veilige haven. Voor arbeidersvrouwen is dit ideaal niet weggelegd. Zij moeten mee de kost verdienen. Met de productietaken vallen ook de onderwijstaken weg. De kinderen gaan buitenshuis een vak leren. De opvoeding wordt een morele taak, het overbrengen van normen en waarden.

$\mathrm{Na}$ de Tweede Wereldoorlog wordt de affectieve relatie tussen moeder en kind benadrukt, hun binding is exclusief, de moeder moet het kind behoeden voor frustraties en opvoeding wordt iets emotioneels.

"In zekere zin zijn de ouders tegenwoordig de therapeuten van hun kinderen geworden. De moeder is werantwoordelijk voor het reguleren van de heftige en ambivalente emoties van haar kind." ${ }^{\text {"ts }}$

Politiek gezien is een van de gevolgen van de industrialisatie dat de nationale overheid zich meer gaat bemoeien met het gezinsleven van burgers. ${ }^{\text {t6 }}$ Wetten op het gebied van huisvesting, gezondheidszorg en armenzorg en wetten tegen de kinderarbeid en voor overheidsingrijpen bij verwaarlozing van kinderen, maar ook de regelingen binnen het familierecht en het erfrecht beïnvloeden de gezinsverhoudingen. Gezinnen gaan steeds meer op elkaar lijken door de toenemende verwevenheid tussen staat en gezin en door de gedeelde gezinsmoraal. Een tendens die zich tot ver na de Tweede Wereldoorlog voortzet. Sinds de jaren zeventig lijkt in ruime kring de 


\section{Hoofidstuk 5}

seksualiteit steeds meer losgekoppeld te worden van huwelijk en gezin, terwijl de relatie tussen huwelijk, gezin en voortplanting nog steeds aanwezig is." Er bestaat well meer diversiteit aan leefvormen, maar die lijken sterk op het 'kerngezin" " de opvoeding vindt nog voor een groot deel in die constellatie plaats. De grootste veranderingen in de laatste decennia hebben betrekking op de pasitie van vrouwen. Door de controle op de voortplanting en de grotere arbeidsparticipatie verwerven zij respectievelijk meer seksuele en economische wrijheid. ${ }^{19}$ Doordat deze veranderingen zich in een brede laag van de bevolking voltrekken; leidt dit tot een "vanzelfsprekendheid' in hel denken over gezinnen, waardoor soms verschillen tussen soorten gezinnen en in onderlinge verhoudingen bïnnen gezinnen niet worden opgemerkt. Ik denk daarbij aan de moeder-dochter relatie als spil in het arbeidershuishouden of de bredere familierelaties in adellijke en patriciërskringen en in boeren-en later allochtone families. Juist de gedetineerde vrouwen komen veelal niet uit doorsnee kerngezinnen. ${ }^{21}$ Hun families kenmerken zich mogelijk door andere praktijken en idealen dan de 'gemiddelde'.

\subsubsection{Functieverschuiving en individualisering}

De maatschappelijke functie van het gezin wordt gezien als het in standhouden van het subsysteem, het gezin, via de socialisatie van kinderen en het stabiliseren van de persoonlijkheden van alle gezinsleden. Daarmee wordt een bijdrage geleverd aan het voortbestaan van het grotere systeem, de maatschappelijke omgeving. ${ }^{2 z}$ Zwaan schrijft dat die (sub)systemen, door hem figuraties en netwerken genoemd, niet statisch zijn.

\footnotetext{
"Veranderingen en ontwikkelingen op het niveau van die grotere figuraties, bijvoorbeeld van de staat, de economie en de cultuur, bepalen mede de aard en het functioneren wan de tiguraties van familie en gezin." ${ }^{23}$
}

Verwantschapsnetwerken nemen volgens hem wel een heel bijzondere plaats in. Zowel het netwerk waarbinnen je geboren wordt als datgene dat je later mogelijk verwerft via een vaste partner en eigen kinderen. De bindingen zijn meervoudig

17 "In ruime kring", ondat dit langheen wel voorbehouden was aan geprivilegieerden: koninklijke, adellijke en wellicht ook patriciërsfamilies.

18 Zie ook Hoksbergen (1996) p. 20-22.

19 Zwaan (1994).

20 Zie ook Van der Zwaard (1995).

21 Zie o.m. De Borst (1991), Ketelaars (1991), Fuldauer (1995).

22 Parsons en Bales in: Van Wamelen (1987) p. 37.

23 Zwaan (1993-2) p. 341. 
en van relatief lange duur, ze vormen basuscomponenten van iemands persoonlijke identiteit en ze worden gekenmerkt door emotionele intensiteit.

In Nederland worden in de jaren zeventig vijf functies van het gezin onderscheiden: de seksuele, de procreatieve, de opvoedkundige, de economische en de koesterende. De laatste is de jongste loot. Daarnaast noemt Kooy als randfuncties: de godsdienstige, de statustoekennende, de beschermende en de recreatieve functie. Het feit dat in het gezin al deze functies vervuld worden, maakt volgens hem dat er zo"n "hoge graad van samenwerking, loyaliteit, solidariteit en affectiviteit in het gezin bestaat". In 't Veld-Langeveld heeft echter al eerder aangegeven dat het gezin een groot deel van deze functies niet meer of maar gedeeltelijk vervult:

"In een weinig geindustrialiseerde, sterk agrarische samenleving is het gezin een productieve eenheid. In een geindustrialiseerde samenleving valt deze productieve functie weg. Man, en eventueel vrouw en kinderen, werken in loondienst buitenshuis. De opvoeding van een jonge generatie, vroeger voornamelijk in handen van het gezin, werd ondergebracht in een gespecialiseerd instituut: de school. Vroeger had het gezin een taak in het bewaren en doorgeven van religieuze voorstellingen en gebruiken. De voortgaande ontkerkelijking maakte, dat het gezin aan deze praktijken, die hun betekenis verloren, niet meer de hand hield. De familie vervulde een beschermende functie ten opzichte van haar leden. Deze lag in beschutting tegen euvelen als : ziekte, armoede, ouderdomsgebreken en benadeling door buitenstaanders. Met de opkomst van het sociale verzekeringsstelsel, de groei van het maatschappelijk werk en de uitbreiding van de overheidszorg werden familie en gezin steeds meer van deze taak ontlast. Als onderdeel van de beschermende functie is de maatschappelijke positietoewijzing en het verienen van status te zien. Maatschappelijk telde het individu vroeger alleen als lid van een familie. Zijn familie verschafte hem in meer of mindere mate sociaal prestige onafhankellijk van zijn eigen gedragingen. Het gezin heeft zich echter losgemaakt uit zijn familie en de nadruk valt nu zo sterk op de persoonlijke prestatie in de maatschappij, dat het gezin geen functie meer zou hebben in de toekenning van status. Zijn ontspanning vond men vroeger in en met het gezin. Deze recreatieve functie zou het gezin zijn ontvallen met de opkomst van de vermaakindustrieën, die de mens uithuizig maken en hem onttrekken aan de vrijetijdsbesteding in gezinswerband. ${ }^{25}$

Volgens In't Veld-Langeveld is er niet zozeer sprake van functieverlies maar van functieverschuiving binnen het gezin, namelijk van productie-eenheid naar consumptieeenheid. Het gezin is bijvoorbeeld doelwit wan de reclame. Verder wordt vooral in de persoonlijkheidsworming en ontwikkeling van het (opgroeiende) individu een belangrijke rol aan het gezin toegedicht. ${ }^{2}$ Zo beschrijft $Z$ waan de verandering in de motieven die mensen hebben om kinderen te krijgen tussen vroeger en nu:

"De genoemde directe econom ische motieven zijn nagenoeg verdwenen: ouders eisen van hun kinderen geen economische bijdrage meer, kinderen zien de verzorging van hun oudgeworden ouders niet meer als vanzelfsprekende werplichting. De enorm gestegen welvaart, de mede daardoor voor zeer grote

24 Kooy (1977) in: Van Wamelen (1987) p. 38.

25 In 't Veld - Langeveld (1969), in : Van Wamelen (1987) p. 38-39.

26 Kooy en In't Veld-Langeveld in: Van Wamelen (1987) p. 40. Zie ook: T. Zwaan (1993-1). 
groepen sterk toegenomen bestaanszekerheid en de verwachting dat deze ook in de toekomst behouden zullen bllijven, hebben warschijjilijk ook de projectie van hoop op betere tijden in kinderen minder belangrijk gemalalkt. Het wergroten en van generatie op gemeratie doorgeven van familliebezit heeft door deze ontwikkelingen als drijfveer voor voortplanting wermoedelijk eveneens aam betekenis ingeboel. en familiebedrijwen zijn er wexnig meer. Voortzetting van geslacht en familienaam, in een bilateraal verwantschapssysteem wellicht altijd al van relatief minder belang, lijkt alls motief woor het krijgen wain kinderen nauwelijks meer relevant. Dat het besef van continuiteit tussen de geslachten binnen cen familie en thet belang dat daaraan gehecht wordt in recente tijd nog zijn verzwakt, kan misschien ook afgeleid worden uit de sterk veranderde gewoonten op het gebied van naamgeving (...) Naarmate in een geseculariseerde wereld meer wordt benadrukt dat elk kind van meet af aan een uniek individu is, wordt het moeilijker om in kinderen een voortzetting van het eigen ego en de eigen familie te zien. De motieven voor het krijgen van kinderen die dan resteren en die daardoor ook een sterker accent hebben gekregen, zijn moeilijk grijpbaar: diffuus verlangen, mogelijkheden voor het geven en ontvangen van affectie, geluk, bevestiging van de liefdesband tussen de ouders. En dat zijn ook inderdaad de motieven die uit modern onderzoek naar "ouderschapsmotivatie" naar voren komen. ${ }^{227}$

\subsubsection{Individualisering in het gezin}

Uit het functieverlies van het gezin wordt in de jaren zeventig door met name Amerikaanse wetenschappers het 'slechte functioneren' van de maatschappij verklaard. Twee oplossingen lijken mogelijk: restauratie van het gezin ${ }^{28}$ of juist de 'afschaffing' yan wat er nog resteert van het gezin. ${ }^{20}$

In Nederland komt de discussie over de effecten van maatschappelijke veranderingen op het functioneren van gezinsverbanden en vice versa later op gang. Raes legt een verband tussen de modernisering van de maatschappij op macronivo, gekenmerkt door differentiëring en fragmentering en de socialisatie op micronivo, waarbinnen individuen ook een veelheid aan interactiepatronen moeten aanleren. ${ }^{30}$ Ieder handelingsgebied eist een specifieke rol en lijkt een eigen moraal te kennen. Ieder individu lijkt een weelheid aan gedragspatronen te moeten ontwikkelen om zich in allerlei verschillende situaties te handhaven. De wilssoevereiniteit van het individu staat volgens Raes centraal. Ook in de mensenrechten. In zekere zin is het individu als 'rechtssubject' losgewrikt uit traditionele gemeenschapsverbanden."

27 Zwaan (1993-1) p. $285-286$.

28 Lasch (1980).

29 Laing en Esterson (1972). Zij beschrijven met name de relatie tussen schizofrenie en gezinsachtergronden. Schizofrenie is een overlevingsstrategie binnen de totalisatie van het gezin. Zij leggen daarbij een verband met het begrip "totale institutie" van Goffman. Zie hoofdstuk 2.

30 Raes (1994).

31 Hoewell ik daar hier niet op in wil gaan, zijn deze opvattingen mijns inziens zeer interessant in de discussie omtrent de cultuurrelativistische benadering van mensenrechten. Zie over dit debat Van Oord (1996). 
"Het individu wordt opgevat als autonome bron van waarde en kan niet eenvoudig worden gereduceerd tot diens plaats, functie of rol in een of ander gemeenschapsverband. De rechten van het individu primeren over de gemeenschapsrechten van weleer in die zin dat die laatste zich steeds als functie wan die eerste moeten weten te verantwoorden en niet omgekeerd. ${ }^{\text {t32 }}$

Ook gelijkheidsbenaderingen zoeken het ideaall van interindividuele gelijkheid en vinden hun legitimatie in de effecten op individuen. Privacy is heel belangrijk geworden en de openbare sfeer speelt nog slechts een rol voor zover er privédoelstellingen kunnen worden verwezenlijkt. In die zin is de economische logica van 'behoeftenbevrediging ${ }^{*}$ in alle facetten van het leven dominant geworden.

Raes constateert dat steeds meer eenoudergezinnen, maar ook steeds meer nucleaire tweepersoonsgezinnen als compensatie voor het wegvallen van de "grootfamilie" nieuwe sociale netwerken (vrienden-familienetwerken) zoeken. Netwerken waarbinnen men op vrijwillige basis relaties aangaat waarop een beroep kan worden gedaan wanneer er opvang nodig is of er problemen zijn. Kenmerken van deze spontane vorm van 'mantelzorg' zijn:

"1.dat men er zich voortdurend in moet blijven bewijzen en inspanningen moet doen om die gewilde relaties niet te verliezen;

2.dat zij doorgaans mono-cultureel, mono-generationeel en mono-levensbeschouwelijk zijn en meestal ook socio-economisch zijn samengesteld uit mensen van dezelfde klasse. In die zin zijn zij eenzijdig en dreigt het gevaar van apartheid tussen vrienden-familienetwerken;

3. dat er in een cultuur waarin 'gewilde" over 'ongewilde' relaties primeren steeds meer mensen zullen achterblijven 'die niet gewild worden'. Wie de wrije keuze in maatschappelijke verbanden laat primeren zal moeten erkennen dat de kans groot wordt dat talrijke indiwiduen niet gekozen zullen worden."

Zijn zorg is dat "the right to be left alone" te gemakkelijk verwordt tot een "right to leave alone" en dat de bekommernis om de medemens ook in familieverband vermindert in de hoop dat de gemeenschap daar wel voor zal zorgen. Met alleen een moralistisch appel houd je sociale netwerken echter niet in stand.

\subsubsection{Verdeling van functies binnen het gezin}

Binnen de functionalistische sociologie, waarin sociaalmateriële aspecten centralal staan, wordt de verdeling van gezinsfuncties tussen man en en vrouw aanvankelijk niet geproblematiseerd.

"Hoewel de weronderstelling is dat vader de kost verdient en moeder binnenshuis de zorg woor de kinderen heeft, heet 'echte' opvoeding een mannenzaak te zijn. De moeder komt pas in beeld alls de vanzelfsprekend aanwezige. Zij wordi niet gezien als opwoeder, maar wordt verwezen naar de sfeer 


\section{Hoofdistuk 5}

wan vooropwoeding, omgang, of pedagogische atmosfeer. De vooropvoeding betreft de periode tot ongeveer vier jaar en zou worden gekenmerkt door gewoontevorming en dressuur; er vindt dan nog geen opvoeding in de zin van persoonsworming plaats. Omgang en opwoeding verschillen in de mate waarin onwillekeurig dan wel opzettelijk aan de ontwikkeling van kinderen wordt gewerkt. Pedlagogische atmosfeer duidt op een vruchtbare emotionele inbedding voor "echte $e^{9}$ opvoeding. ${ }^{33}$

Pas in de jaren zeventig tonen wetenschappers interesse in de taakverdeling tussen ouders. Hun taken kunnen in tenminste vier componenten onderscheiden worden: fysieke verzorging, emotionele verzorging (koestering), overdracht van concrete en abstracte morele waarden (opvoeding), en vrijetijdsbesteding. De onderzoekers houden zich ook bezig met de vraag wellke betekenis de moeder- respectievelijk vaderactiviteiten voor het kind hebben. ${ }^{35}$ Zo wordt aan de ene kant verondersteld dat het fysieke zorgen voor kleine kinderen en het doen van huishoudelijk werk met dreutelende kinderen er om heen, de moederlijke activiteiten dus, nauwelijks bijdraagt aan de kwaliteit van de relatie met de kinderen en dat de speeltijd van vader met de kinderen, na werktijd, van veel meer betekenis zou zijn. Maar anderen menen dat vaders rol veel gewichtiger wordt woorgesteld dan hij feitelijk is en dat de kwaliteit van de ouder-kindrelatie niet alleen bepaald wordt door interacties waarin kinderen persoonlijke aandacht krijgen, maar ook door fysieke verzorgingsgerichte en moreelgerichte interacties en door indirecte effecten van fysieke aanwezigheid. Dezelfde discussie is meen ik terug te zien in de wederzijdse beoordeling van thuismoeders en werkende moeders, waarbij met name fulltime werkende moeders zich ook beroepen op hun 'kwaliteitsuurtjes'. .'

Overigens blijkt in 1987 uit het onderzoek van Van Wamelen dat er in de perceptie van kinderen al vee]. veranderd is in de rollen van ouders ten opzicht van de traditionele rolverdeling, hoewel er geen sprake is van algehele "role-sharing". ${ }^{37}$ Uit haar onderzoek, bij kinderen van tien tot dertien jaar, blijkt dat het verzorgend huishoudelijk werk well voormamelijk door moeder wordt gedaan. Maar het koesteren (meegaam naar ouderavonden, spelletjes doen, helpen met huiswerk, naar bed brengen) doen vaders en moeders in gelijke mate. Externe taken worden ook niet meer alleen door vader maar ook door moeder gedaan. (zestig procent tegenover veertig procent) Instrumenteel gedrag dat door kinderen aan vaders wordt toegeschreven is: vergaderen, dapper zijn, sterk zijn en geld verdienen. Instrumenteel gedrag dat zowel aan

Wegelin (1990) p. 22-23.

35 Zie o.a. Wegelin (1990) p. 21-29. Vgl. ook Singer (1989) p. 222-223, die beschrijft hoe veel thuisactiviteiten van moeders worden geromantiseierd, maar daarmee geïnantiliseerd. Allerlei huishoudelijke taken moeten "spelenderwijs" met de kinderen gedaan worden.

36 Morée (1992) p. 207.

37 Van Wamelen (1987) p. 70-76. Het begrip "role-sharing" wordt door Wegelin (1990) p. 23, gedefinieerd als "een gelijke feitelijke betrokkenheid wan moeder en vader bij de organisatie en uitvoering van genoemde gezinstaken." 
vaders en moeders wordt toegeschreven is : handig zijn, het druk hebben, zakgeld geven en erg veel weten.

\subsubsection{Ambivalenties ten aanzien van het gezin}

Het merendeel van de ouders met kinderen in Nederland lijkt het gezin nog steeds de meest ideale samenlevingsvorm te vinden, ondanks het feit dat een op de drie à vier huwelijken stukloopt. Meestal tussen het tweede en tiende huwelijksjaar, dus vaak in de fase dat er nog zeer jonge kinderen aanwezig zijin. Alleen de opvoedingsfunctie blijkt in veel gevallen dus een te smalle basis te zijn voor de instandhouding van het gezin. Veel gezinnen komen terecht in leefsituaties die niet meer passen in het traditionele gezinsmodel, maar zij kiezen ook niet bewust voor andere verzorgingsarrangementen. Ouders zoeken in opeenvolgende onderhandelingshuishoudens naar een optimale afstemming van taken en functies. Kinderen krijgen door de opeenvolgende leefvormen met meer opvoeders te maken, maar niet altijd in de collectieve communesfeer zoals die door sommigen in de jaren zestig en zeventig werd nagestreefd.

De gezinsideologie lijkt niet ter discussie te staan. Maar ideaal en werkelijkheid rond de invulling van gezin en moederschap zijn van elkaar verwijderd. Het blijkt moeilijk te zijn om de differentiatie die er is in beeld te brengen. Singer beschrijft hoe zowel in het overheidsbeleid als in de vaktijdschriften een ambivalente houding ten opzichte van het gezin en met name van moeders is te vinden. Enerzijds wordt vastgehouden aan het ideaal van het gezin alls beste opvoedingsomgeving. Anderzijds lijkt er weinig vertrouwen in de opvoedingskwaliteiten van moeders te bestaan.

\subsection{Moederschap}

Opvattingen over moederschap worden beïnvloed door maatschappelijke en culturele omstandigheden. ${ }^{3}$ In Nederland wordt na de Tweede Wereldoorlog het gezin met de moeder thuis en de vader als kostwinner sterk gepropageerd, in tegenstelling tot veel andere Westeuropese landen, waar vrouwen in het kader van de wederop-

38 Singer (1989) p. 21-45, Van der Zwaard (1995), p. 87-88.

39 Zie voor meer theoretische analyses van "het moederschap" De Beauvoir (1978) en

Badinter (1989) "Beiden vechten (De Beauvoir op grond van cultuurantropologische argumenten en Badinter vooral op historische) het bestaan wan een soort natuurlijk "moederinstinct" aan en maken duidelijk hoe de invulling van het moederschap bepaald wordt door maatschappelijk een culturele omstandigheden. Zie ook Vintgens (1992) p. 228," Niet het moederschap op zich maar een bepaalde maatschappelijke realisatie en voorstelling daarvan wordt in De tweede sckse bekritiseerd, en dit geldt eweneens voor het hwwelijk, voor economische afhankelijkheid enzovoort". Zie ook Poldervaart (1983). 


\section{Hoofdstiuk 5}

bouw mee moeten werken. ${ }^{40}$ Als bekend voorbeeld geldt nog altijd Zweden waar een verzorgingsstaat op geheel andere, arbeidspolitieke, leest wordt geschoeid dan in Nederland. Aanvankelijk komt er vooral wanuit feministische hoek kritiek op het vanzelfsprekende thuismoederschap. ${ }^{4 !}$ Vooral de vervelende uitputtende en geestdodende kanten van de moederrol worden benadrukt. ${ }^{42}$ Naarmate meer vrouwen de beschikking over voorbehoedmiddelen krijgen en abortus geliberaliseerd wordt, ontstaat er minder ongewenst moederschap. De feministische discussie verplaatst zich naar de patriarchale structuur van gezin en samenleving, waarin geen geld is voor adequate kinderopvang en waarin het combineren wan opvoeding en werk tot een zaak van vrouwen wordt teruggebracht. Geëist wordt een echte gelijke verdeling van betaalde en onbetaalde taken tussen vrouwen en mannen. Later wordt die discussie steeds meer verplaatst naar prive-onderhandelingen op microniveau. De macrodiscussie is toegespitst op emancipatie van vrouwen in de openbare sfeer, de arbeidsmarkt en publieke functies. Van feministische idealen is überhaupt weinig overgebleven. Misschien alleen het streven naar economische zelfstandigheid, hoewel dat door een heleboel vrouwen niet als prioriteit genoemd wordt. ${ }^{43}$ Van het eerlijk delen van met name huishoudelijke en verzorgende taken thwis komt weinig terecht. $\mathrm{Er}$ wordt gesproken over "een gestagneerde rewolutie"." Het feit dat veel werkende moeders zich overbelast voelen, wordt gezien alls hun persoonlijk falen. Onder invloed van Europese gelijke behandelingswetgeving, ontzuiling en demografische verschijnselen heeft er in het afgelopen decennium vanuit de overheid een vrij plotselinge en hevige verschuiving van perspectief ten aanzien van gezinnen en moeders plaatsgevonden. Afschaffing van kostwinnersvoordelen ten behoeve van traditionele gezinnen gaan gepaard met het streven naar individualisering van inkomens. Zonder deugdelijke overgangsregelingen, voldoende kinderopvang en arbeidsplaatsen worden met. name vrouwen geacht zich in vrij korte tijd om te vormen tot een ander bestaan en een andere moederrol dan die waarin velen van hen gesocialiseerd zijn. ${ }^{45}$

40 Zie Bussemaker (1993) p. 17-19, Schwegman en Withuis (1993) p. 570-583.

41. Als beginpunt van de tweede feministische golf wordt meestal het pamllet "Het onbehagen van de vrouw", wan Kool-Smit in 1967 genoend, Zie o.a. Holtrust (1993) p. 3 en Brinkgreve (1994) p. 13 .

42 Bij de uitgeverij De Bonte Was werschenen boekjes onder titels als: "Moederschap is monsterschap".

43 Moré (1992) p. 210.

44 Zie onder meer Visser (1994), Keuzenkamp (1995). De "dubbele belasting" van vrouwen wordt door Bekker (1995) genuanceend. Het leven van werkende moeders moet volgens haar in een nodeloos negatief daglicht worden gesteld. Specifieke omstandigheden, omvang en aard van het werk en de zorg en van de wisselwarking wan beide domeinen zijh bepalend. In het algemeen lijkt er volgens haar dan ook, wooral in althans in Nederland en de Verenigde Staten, eerder sprake van dubbele arbeidsvreugde dan van dubbele belasting.

45 Zie 0.a. Moree (1991) p. 101-113. Pelzer en Pot (1992), p. 141-153. 
Welke waarden, normen en verwachtingen moeders mede onder invloed van maatschappelijke discussies, thebben geïnternaliseerd is vanuit sociaalwetenschappelijke hoek onderzocht. Daarbij staat de subjectieve beleving van moeders centraal. Maar ook de invloed van met name vrouwentijdschriften in de naoorlogse periode komt aan bod. Knijn en Verheijen constateren een verschuiving in opvattingen over het moederschap die zij respectievelijk typeren als opoffering, opvoeding en ontplooiing. Uit de resultaten van hun onderzoek blijkt overigens dat moeders met traditionele opvattingen zich in het algemeen minder ontevreden voelen dan moeders met individualistische opvattingen. Bij traditionele moeders staat het moederschap nog steeds centraal in hun leven. Moeders met individualistische opvattingen vinden het moederschap slechts eén aspect van hun identiteit. Bij hen is de kloof tussen ideaal en werkelijkheid vaak groot. Onvrede bij traditionele moeders heeft vaak te maken met het sociaaleconomisch milieu, waarin zij verkeren. Materiële problemen en dagelijkse beslommeringen groeien hen boven het hoofd. Ze kunnen niet de moeder zijn die ze graag zouden willen zijn. Zij krijgen dan met name gezondheidsklachten. Moeders met individualistische opvattingen in lage sociaaleconomische milieus ervaren hun positie, gezien hun lage opleiding en het karige inkomen, het meest als "uitzichtloos".."7

Morée deed onderzoek onder verschillende generaties werkende moeders na de Tweede Wereldoorlog. Zij baseert zich in de uitleg van haar onderzoekskader op onder andere Schuyt en Komter. ${ }^{48} \mathrm{Zij}$ gaat er van uit dat er een relatie tussen formele rechten en plichten en macht bestaat. Machtsverschillen tussen mensen bepalen of accenten op rechten of plichten liggen. Voor minder machtigen zijn plichten vaker specifiek geformuleerd en rechten diffuus en algemeen dan bij meer machtigen. Hun rechten zijn nauw omschreven en hun plichten vager. Deze verschillen manifesteren zich vooral in de handhaving en effectiviteit van wetgeving. Het maatschappelijk toekennen van rechten en plichten heeft zijn weerslag op de subjectieve beleving van mensen. Minder machtigen maken met meer moeite aanspraak op rechten dan (relatief) machtigen. ${ }^{48}$ Het mechanisme dat minder machtigen structureel minder gebruik maken van hun rechten wordt aangeduid met het Mattheüseffect. ${ }^{50}$ Komter heeft dezelfde principes al eerder toegepast op machtsrelaties binnen huwelijken tussen mannen en vrouwen. Het gaat haar daarbij niet zozeer om formele rechten en plichten. Vrouwen blijken geneigd om zichzelf meer en meer gedetailleerde plich-

46 Knijn en Verheijen (1988), Knijn en Verheijen (1991), Moree (1992), Keuzenkamp (1995).

47 Knijn en Verheijen (1991) p. 80-92.

48 Morée (1992) p. 24-28.

49 In hoofdstuk 4 werd deze theorie ook al aangehaald als mogelijke verklaring voor het geringe aantal beklagzaken dat door gedetineerde vrouwen zou worden geëntameerd.

50 Ontleend aan Merton. Matth. 13 vers 12 luidt: "Want aan wie theeft zal gegeven worden en hij zal in overwloed hebben, maar wie niet heeft, zal ook ontnomen worden wat hij bezit". 


\section{Hoofdstuk 5}

ten toe te schrijven, bij voorbeeld over opvoeding, dan rechten. Dit leidt er onder meer toe dat mannen in staat zijn tot een meer witgesproken beleving van hun recht op vrije tijd, terwijl vrouwen hun specifieker beleefde verantwoordelijkheid voor de opvoeding en het welzijn van het kind boven hun eigen aanspraken op vrije tijd stellen. ${ }^{51}$ Hoewel vrouwen hun nauwer omschreven plichten en hun identificatie met de belangen van man en kinderen rechtvaardigen, kunnen ze tegelijkertijd een negatieve beleving van deze plichten hebben." Morée gebruikt vervolgens sociaalpsychologische theorieen om inzicht te krijgen in de manier waarop vrouwen omgaan met deze spanning. (coping-strategieên) ${ }^{53}$

In de volgende paragrafen wordt een chronologische weergave gegeven van hetgeen uit genoemd onderzoek is gebleken over de beleving van het moederschap. Daarna komt aan de orde wat de veronderstelde effecten van veranderend moederschap op de relatie met hun kinderen zijn en hoe de belangen van kinderen in het onderzoek daarnaar geproblematiseerd worden. Tot slot worden de ambivalenties en paradoxale verwachtingen rond het moederschap nog even op een rij gezet.

\subsubsection{Opoffering en moederplicht}

In de jaren vijftig bestaat er, ook onder deskundigen, overeenstemming over de plicht van de moeder tot voortdurend zorgende aanwezigheid. Vaders moeten zilch met name bij oudere kinderen wat meer betrokken tonen. Een maatschappelijk en juridisch recht op arbeid voor vrouwen met kinderen ontbreekt vrijwel. Vrouwelijke ambtenaren die trouwen krijgen ontslag. Terwijl de propaganda en de bescherming voor het gezin met een mannelijke kostwinner evident zijn, wordt er ook een geleide loompolitiek gevoerd, waardoor gehuwde vrouwen soms wel genoodzaakt zijn om bij te verdienen. ${ }^{54}$

In de jaren zestig ontstaat er een groeiende behoefte aan arbeidskrachten, ook in typisch vrouwelijk geachte dienstverlenende beroepen. De norm verandert. Moeders met schoolgaande kinderen worden "gedoogde werknemers". Maar kinderopvang of aangepaste werktijden worden zeer incidenteel en hooguit als gunst geregeld.

51 Opmerkelijk is dat dit mechanisme in het experiment "moeders met kinderen" in Sevenum zelfs al geformaliseerd was, door de moeders (aanwankelijk) uit te sluiten van sport en recreatie.

52 Vgl. Knijn en Verheijen (1991) p. 92.

"Aan de ene kant zijn zij er ten volle van overtuigd dat hun eigen identiteit en hun eigen ambities niet moeten worden bepaald door het moederschap. Aan de andere kant denken zij dat niemand zó betrokken kan zijn bij hun kinderen als zijzelf. Deze betrokkenheid winden zij noodzakelijk voor een optimale ontwikkeling van de kinderen. De oplossing van dit conflict wordt meestal gezocht in het opgeven van de eigen ambities, ondlanks de moeite die dit kost."

53 Moree (1992) p. 34.

54 Moré̃e (1992) p. 205. 
De vrouwen dienen zelf de nodige flexibiliteit op te brengen. Vervolgens worden zij dan wel weer tot minder betrokken werknemers bestempeld. Moeders met hele jonge kinderen die werken, overschrijden hun - maatschappelijk bepaalde-grenzen. In haar onderzoek constateert Morée dat deze moeders altruiistische verantwoordingsstrategieën gebruiken om zich te legitimeren. Hoewel ze in verschillende leefsituaties zitten en andere idealen en motieven hebben om te werken, leggen ze allemaal de nadruk op het vervullen van hun plichten, waarbij ze zich vergelijken met de thuismoeder. Hun 'te kort schieten' compenseren zij door de aandacht te vestigen op hun bewuste en intense aandacht voor de kinderen. ${ }^{35}$

"De nadruk op plichtsvervulling sloot overigens niet uit dat er op sommige punten aan de invulling van die plichten werd getornd. Door een karikatuur te schetsen van een altijd poetsende, overdreven zorgende of juist immer koffie drinkende thuismoeder, stelden buitenshuis werkende moeders hun alternatief van een minder zwaar opgevat huishoudem en een meer op zelfstandigheid wan het kind gestoelde opvoeding in een positief daglicht. ${ }^{\text {.56 }}$

De vrouwen benadrukken de allesoverheersende plaats die het moederschap in hun leven inneemt. Ze bestempelen zichzelf als anders dan de doorsneevrouw door zich bij voorbeeld te beroepen op een groot organisatietalent of het feit dat de kinderen nooit ziek zijn.

\subsubsection{Opvoeding en ontplooïng}

In de jaren zeventig en tachtig is er geen eenduidige maatschappelijke moraal meer ten aanzien van buitenshuis werkende moeders. Ieders recht op individuele ontplooiing en keuzevrijheid wordt ook naar vrouwen vertaald. Over de noodzaak tot voortdurende aanwezigheid van de moeder bestaat geen overeenstemming meer en ook niet over haar onvervangbaarheid als enige opvoedingsfigur. Langzamerhand wordt beroepsarbeid voor vrouwen een recht. In 1974 krijgt dat recht onder meer via het emancipatiebeleid van de overheid officieel inhoud. Staat aanvankelijk deeltijdwerk en kinderopvang (ten behoeve van moeders!) op de agenda, in de jaren tachtig wint het concept 'herverdeling van arbeid' terrein en worden naast kinderopvang ook

55 Morée (1992) p. 205 e.v..

Hun werkmotivatie verklaarden zij vaak ook met altruistische argumenten, door zich bij woorbeeld op een hoger belang te beroepen, zoals

- overmacht (financiële noodzaak);

- het recht van de samenleving op hun werkkracht;

- het belang van het gezin bij een hogere levensstandaard;

- hun onvervangbaarheid in de functie die zij uitoefenden.

56 Morée (1992) p. 207. 


\section{Hoofdstuk 5}

de organisatie van de arbeld, de algemene arbeidsduur en inkomensbeleid punten van discussie. Op grond wan voornamelijk economische motieven wordt een omslag in het denken over ouderschap en beroepsarbeid bereikt.

"De gedachte dat het recht op arbeid voor vrouwen ook verschuivingen in de rechten en plichten van mannen, werkgevers en de overheid met zich mee zou kunnea brengen, deed haar intrede in beleidsplan nen. $^{\text {*5T }}$

Toch blijft de moeder primair aansprakelijk voor de opvoeding van haar kind. De zorgplicht van de vader is vooral een theoretische mogelijkheid. Over schadelijke gevolgen van te weinig vaderlijke aandacht voor kinderen wordt nauwelijks gepraat: ${ }^{\text {ss }}$

"Het beeld wan het gezin met twee kinderen en een moeder die gedurende de eerste levensjaren wan haat kind thuisblijft om een hechte band met haar kind op te bouwen was het dominante ideaalbeeld. Kinderdagverblijven bleven in dit licht omstreden".

Vanaf 1985 komt in beleidsplannen het idee op meisjes voor te bereiden op het feit dat zij in de toekomst door arbeid in hun eigen onderhoud moeten voorzien, uiteindelijk resulterend in de 1990-maatregel. Op jongens wordt geen vergelijkbare druk uitgeoefend om zich voor te bereiden op zorgtaken, omdat dat geacht wordt een inmenging in de privésfeer te zijn.

Onder de vrouwen zelf is het in deze periode ook in toenemende mate geaccepteerd geraakt om buitenshuis te werken. $\mathrm{Zjj}$ willen dit weliswaar vanuit geheel verschillende motieven. Zowel ontplooiing in werk als zelfstandigheid en meer gelijkheid in de relatie met partner worden genoemd. Daarnaast willen ze allemaal ook een hechte band met kinderen. Gemeenschappelijk is een geloof in de planning van deze verschillende idealen en in de makbaarheid van een eigen levensloopbaan. Als legitimatie voor het buitenshuis werken, kiezen de vrouwen minder altruïstische argumenten dan voorheen. Vooral hogeropgeleide wrouwen richten zich meer op veranderingsstrategieên. Zij vergelijken zich niet meer uitsluitend met thuismoeders, maar ook met mannen, hun eilgen partner in het bijzonder. De veranderingsstrategieèn van de vrouwen zijn niet eenduidig. ${ }^{6}$ Wel lijken ze allemaal op zoek te zijn naar een nieuw evenwicht tussen de eigen en andermans rechten en plichten. In hun werk blijven ze zeer plichtsgetrouw. Ze komen voor het dilemma te staan tussen enerzijds aanpas-

57 Morke (1992) p. 208.

58 Dat is opmerkelijk, omdat kinderen van alleenstaande moeders vaak een geliefd object van onderzoek wormen en de "afwezige vader" dan al snel als verklaring voor eventuele problemen wordt opgevoerd.

59 Morke (1992) p. 209.

60 Vgl. Cuyvers (1996). 
sing aan de bestaande regels voor de goede werknemer en anderzijds een beroep doen op een uitzonderingspositie op basis van een ongelijke thuissituatie.

In de thuissituatie staan ze ambivalent ten opzichte van hun kinderen en partners. Ten aanzien van de kinderen is het moeilijk om de -deels door het werk bepaaldebegrenzing in tijd en aandacht te combineren met de eigen arbeidsintensieve opvoedingsidealen. Van de partners wordt aan de ene kant meer aandacht voor zorg verlangd, terwijl de vrouwen ook bang zijn om hun exclusieve positie en het daaraan gekoppelde overwicht in de opvoeding prijs te geven. ${ }^{61}$

Vrije tijd is voor de vrouwen een restpost, die ze het eerst inleveren uit angst voor voor strakke roosters en uit vrees voor verlies aan spontaniteit in hun privérelaties. Het verlangen naar economische zelfstandigheid blijkt volgens Morée bij de meeste vrouwen niet zo diep geworteld te zijn:

"alleen degenen die ervaring hadden met of zich zeer bewust waren wan de instabiliteìt van relaties beschouwden zichzelf als (mede)kostwinner".

Ondanks relativeringen blijft het moederschap centraal staan.

"Zowel thuis als op het werk gaan de buitenshuis werkende moeders van de jaren zeventig en tachtig echter de confrontatie met schuldgevoelens op een andere wijze aan dan hun voorgangsters, namelijk door er zeer uitgebreid en expliciet over te praten".

61 Zie ook het onderzoek van Doornebal (1996), waaruit naar voren komt dat de daadwerkelijk meeopvoedende partners inderdaad betere ouders lijken te zijn. $Z_{i j}$ treden adequater op, geven meer structuur aan kinderen, zijn duidelijker en dergelijke. Dat kan enerzijds genderspecifiek bepaald zijn (de voordelen van mannelijke socialisat ie), maar anderzijds moet niet veronachtzaamd worden dat er matuurlijk een woor hoede van gemotiveer de mannelijke opwoeders is geweest, de witte raven.

62 Morée (1992) p. 212. Dỉt is opmerkelijk omdat economische motieven, met name individualisering van inkomen en roldoorbreking, de leidraad woor het emancipatiebeleid van de overheid zijn geweest. Misschien kennen zoveel redelijk opgeleide wrouwen het genoegen van bemiddelde ouders en een goedwerdienende partner, dat zij hun eigen economische zelfstandigheid niet als reele of noodzakelijke bestaanswoonwaarde ervaren. Ik vraag me soms af of het, als reactie op emancipatie-ontwikkelingen, juist de vrouwen uit gegoede (bourgeois) milieus zijn die weer sterk de zorg gaan monopotiseren terwijl hun mannelijke partners de arbeidsproductie buitenshuis opvoeren door voortdurend meer en 'bij' te willen verdienen. Beide seksen klagen dat er geen vrije tijd meer overblijfl. De waarde van een bepaalde ordening van taken wordt dan feitelijk niet meer door de economische noodzaak bepaald. Zodra op macroniveau taken wel op grond van sociaaleconomische motieven maatschappelijk ge(her-)waardeerd dreigen te worden, zonder daar een morele of hogere bettekenis aan te geven, wordt er gereageend op grond van oude klassengebonden morele waarden.

63 Morée (1992) p. 212. 
Morée constateert dat er een verschuiving heeft plaatsgevonden van een zeer naww omschreven moederplicht en een vrijwel ontbrekend recht op arbeid naar een iets minder nauw omschreven moederplicht en een diffuus recht op arbeid. ${ }^{\text {st }}$

Gedetineerde moeders lijken misschien ver af te staan van de hiervoor beschreven wrouwen. Zij hebben veelal geen legaal werk en zijn in financieel opzicht afhankelijk van anderen of de overheid. Op de door hen gevoelde en vanuit de maatschappij werwachte moederplicht kan mogelijk wel vanuit dit onderzoek meer licht geworpen worden.

\subsubsection{Veranderend moederschap en het belang van het kind}

Veranderende opvattingen over de moederrol zullen hun doorwerking hebben in de definiëring van belangen en rechten van kinderen. Ook van kinderen van gedetineerde moeders. En de standaarduitdrukking is dan dat moeders van alles mogen, zolang het maar in het belang van het kind is. Maar wat is dat belang? Het valt op dat in onderzoeken in Nederland over het algemeen cognitieve aspecten centraal staan als de gevolgen van het buitenshuis werken van moeders worden onderzocht. $Z_{o}$ is er gedacht dat het buitenshuis werken van moeders de schoolprestaties van kinderen negatief zou beïnvloeden. Dronkers geeft echter aan dat de tegenstelling tussen buitenshuis werken of thuisblijven een valse is, als je zoekt naar eenduidige effecten op de schoolresultaten van kinderen. ${ }^{65}$ Afgaande op de onderwijskansen van kinderen, speelt vooral het niveau van de arbeid van de moeder een belangrijke rol.

"Het werken in arbeidstersberoepen heeft een negatief effect op de schoolloopbanen van de kinderen vergeleken bij het alleen huisvrouw zijn, terwijl het beroep van winkelierster, boerin of employee juist een positief effect heeft."

Het positieve effect op de schoolloopbanen van haar kinderen is bij middenstandsters en boerinnen krachtiger dan bij moeders die als lagere, middelbare of hogere employee werken. Dronkers concludeert:

"Blijkbaar zijn de beroepen van boerin en middenstandster een goede combinalie van een eigen actief en arbeidszaam leven van de vrouw en de mogelijkheden voor goede contacten met haar kinderen. ${ }^{\text {wor }}$

Hij schenkt daarmee geen aandacht aan mijns inziens veel wezenlijker en minder vrouwgebonden verklaringen, namelijk de zichtbaarheid van het werk van beide

64 Moré (1992) p. 213.

65 Dronkers (1992) p. 145-156.

66 Dronkers (1992) p. 145.

67 Dronkers (1992) p. 155. 
ouders voor de kinderen, de misschien ongelijke maar wel gelijkwaardige taakverdeling tussen de ouders, de verwevenheid van de publieke ( = werk) en privésfeer, voor zowel vader als moeder. Bovendien zijn veel taken in de privé- en bedrijfshuishouding sterk verwant en daardoor minder 'gendered'. Taken zoals schoonmaken, voorraden aanleggen, dienstverlening aan klanten en handelaren.

Dronkers geeft aan dat het beroep van de wrouw zeker een zelfstandige betekenis heeft voor de kansen in het leven, onder meer in het onderwijs, van de leden van haar gezin. Hij constateert echter ook dat "de betekenis van het beroep van de moeder nog lang niet zo groot is als die van de echtgenoot". ${ }^{\circledast}$ Deze conclusie wordt niet genuanceerd naar verschillen in milieus. Ik zou me namelijk kunnen voorstellen dat zowel bij arbeiders als employees het letterlijk buitenshuis, buiten het erf, het privéterritorium, werken wordt gecultiveerd door ouders. Door de scheiding publiekprivé te accentueren en het, onzichtbare, werk van vader veel status te geven wordt zijn werk de legitimatie voor allerlei arrangementen in het gezin, inclusief het binmens- en buitenshuis werken van moeder. Hoewel er bij boeren en middenstanders wel een markering tussen 'voor' en 'achter' is (en de vrouw vaak woor bezig is en de man achter), kennen hun kinderen beide werkterreinen en zullen het ene mogelijk niet per se van grotere betekenis achten dan het andere. Verschillen komen tot uitdrukking in relevante begrippen als geldbeheer, administratie, fysieke kracht, contacten met klanten en leveranciers en dergelijke.

Met name in burgerlijke gezinnen worden de privétaken van moeder binnenshuis bovendien tweeslachtig gewaardeerd. Enerzijds zijn zij ondergeschikt aan de statusgevoelíge en betaalde taken van vader. Anderzijds wordt de druk op moeder tot uiterlijke weerspiegeling van materiële welstand opgevoerd, ook onder invloed van modernisering en reclame. Iedereen loopt iedere dag in de frisse schone (merk)kleren, een onzichtbare witte tornado vliegt door het huis, een verantwoorde en het oog strelende

68 Dronkers (1992) p. 155

69 Dergelijke nuanceringen naar gezinsmilieu kunnen van belang zijn om bijwoorbeeld het effect wan het woorbeeldgedrag wan de moeder op de loopbaan van de dochter te onderzoeken. Het voert te ver om hier nader op de socialisatie van meisjes en jongens in te gaan in relatie tot de gezinshuishouding waaruit zij komen. Ik zou de hypothese dat kinderen, vooral meis.jes die uit "maatschapscomstructies" komen (boeren, middenstanders, zelfstandige kunstenaars, evt. vrije beroepsbeocfenaren) geneigd zijn een grotere autonomie na te streven graag onderzocht zien. Het zou de theorie dat in de Westerse wereld het ontstaan van een mannen- en vrouwendomein, met een superieure positie voor de mannen, verbonden is met industrialisatie (cen scheiding in domeinen die in alle hiërarchi" sche lagen van de fabriek en het kantoor is terug te vinden) toetsbaar maken, met name op de veronderstelde superioriteit-inferioriteit. Bij gezinshuishoudens wit niet-Westerse culturen kunnen weer andere patronen zichtbaar worden, bijwoorbeld via een sterk matriarchale structuur. 


\section{Hoofdowk 5}

maltijd verschijnt in een wip op tafel en als het kan, staat er een leuk tweede autotje voor de deur."

Dronkers besteedt apart aandacht aan allochtone ouders ${ }^{n}{ }^{n} \mathrm{Hij}$ vindt in zijn onderzoek steun voor de opvatting dat de onderwijsachterstand van etnische groepen voor een belangrijk deel herleid kan worden tot hun slechtere sociaaleconomische omstandigheden en hun geringe gebruik van de Nederlandse taal in gezinsverband.

Op het onderzoek naar de opwoedingsssituatie in éénoudergezinnen rust nog steeds een sterk morele lading, ${ }^{72}$ Als reactie op het onderzoek dat er van uitgaat dat de afwezigheid van een vader per definitie schadelijke effecten zal hebben op kinderen, verschijnt onderzoek dat mogelijke negatieve effecten direct aan maatschappelijke omstandigheden werbindt. ${ }^{73}$ Kinderen uit éënoudergezinnen bevinden zïch vaker in een lager sociaaleconomisch milieu dan tweeouderkinderen en dat kan op zichzelf verklarend zijn voor bijvoorbeeld meer crimineel gedrag bij jongeren. ${ }^{74}$ Ook bilijken eenouderkinderen vaker consument van gezondheids-en welzijnswoorzieningen te zijn, maar dat kan naast het vraaggedrag van moeders en vrouwen in het algemeen ook iets te maken hebben met de signalering, selectie en diagnosestelling door het hulpverlenersnetwerk. Van de alleenstaande ouders blijkt een groot aantal zich extra bekeken te voelen door buurtgenoten en familie. Wegelin merkt bovendien op dat veel empirisch onderzoek naar kinderen zonder (biologische) vader van geringe kwaliteit is, omdat mogelijke beïnvloedingsfactoren als de duur van de vaderlijke afwezigheid en de aanwezigheid van surrogaatmodellen niet zijn opgenomen. ${ }^{75}$

Zie Schwarz Conan (1983). Zij beschrijft hierin hoe met de modernisering van het huishouden (stofzuiger, wasmachine, diepvries, magnetron etc.) de normen mee veranderden: iedere dag stofzuigen in plaats van één keer per week (of maand?) de kleden kloppen, grote variatie in hett eten in plaats van de groenten van het seizoen, iedere dag schone kleren etc.. In Ned. o.a. Daru, m.m.v. Lakmaker (1993) p. 381-431. Misschien leidt het milieubesparend huishouden tot een herwaardering van huishoudelijke taken met een onwerwacht emancipatoir effect.

Dronkers (1992) p. 1153.

Zie ook Bosman (1994) p. 690 m 706 .

73 Wegelin (1993) p. 195-198.

74 De vraag waarom vooral vaderloze jongens en niet vaderloze meisjes crimineel gedrag vertonen, komt hier niet verder aan de orde. Mogelijke verklarende socialisatietheorieën zijn in hoofdstuk 1 aan de orde geweest. Junger-Tas (1996) maakt in haar onderzoek onderscheid tussen kindfactoren en gezinsfactoren die van belang kunnen zijn voor het verklarem van crimineel gedrag. Vooral het samenspel tussen verschillende factoren lijkt van belang te zijn. "Factoren die goede woorspellers zijn van criminaliteit, voorspellen eveneens psychologische en psychiatrische stoornissen in het gezin. Dit zün onder meer lage sociaal economische status, een groot gezin, huwelijksconflicten en geweld, criminaliteit van de vader, psychiatrische stoornis van de moeder en ingrijpen van de kinderbescherming." (p. 21.) 


\subsubsection{Ambivalenties ten aanzien van het moederschap}

In Nederland spitst de discussie zich vaak toe op werkende moeders en op alleenstaande moeders als het om 'goed moederschap' gaat. Maar er blijken, los van de overige bezigheden van moeders, zoveel tegenstrijdige en ambivalente normen over de taakvervulling van moeders te zijn, dat er altijd wel een reden gevonden kan worden om bezorgd te zijn over het opvoedingsniveau. Vooral vanuit de hulpverlening is ambivalent gereageerd op de veranderingen in gezin en moederschap. De hulpverlening blijkt trendgevoelig te zijn. Vergaande interventies in gezinnen en het optimisme over gedragsverandering bij ouders en kinderen hebben plaats gemaakt voor privacybescherming, bijsturing en schadebeperking bij opvoedings- en gezinsproblemen. Was aanvankelijk de middle-class-, ster'k op cognitieve aspecten gerichte, norm zelfs reden voor uithuisplaatsingen, inmiddels is er een uiterst grote voorzichtigheid voor bemoeienis met gezinnen. ${ }^{76}$

"De leefvormen zijn gemoderniseerd, geindividualiseerd en gedifferentieerd maar de samemleving heeft züch daar niet aan aangepast. Oude steun- en controlenetwerken zijn ver dwenen maar nieuwe vormen van steun en controle die zowel de nieuwe leefvormen respecteren als practische steun bieden, blijven achterwege. Juist door de zorg voor en de opvoeding van kinderen te beschonwen als een individuele aangelegenheid van ouders binnen de muren wan het gezin, is het doorbreken van het taboe op de eenheid van biologisch en sociaal ouderschap zo moeilijk bespreekbaar, is er geen circuit om morele opvoedingswaarden te bespreken, kunnen mishandeling en seksueel misbruik zolangverborgen blijven, neigen ouders die de opvoedingswerantwoordelijkheid te zwaar vinden, ertoe zich eraan te onttrekken en weten ouders die zorg en arbeid willen combineren zich in de steek gelaten door de samenleving."

Niet alleen de combinatie van zorg voor kinderen en arbeid kan problematisch zijn, maar met name ook de combinatie van zorg met werkloosheid en bijstandsafhankelijkheid. ${ }^{78}$ Het adequaat omgaan met interculturele aspecten blijkt daarnaast voor de hulpverlening uiterst moeilijk te zijp. Opvoedingsondersteuningsprojecten gaan uit van de achterstandsbenadering of van de cultuurverschilbenadering. Op beide komt kritiek. ${ }^{\text {}}$ In de eerste benadering worden de oplossingsstrategieën van de moeders zelf en hun eigen sociale netwerk niet benut. Bovendien zien de hulpverleners de grootmoeders vaak als concurrenten en niet als mede-opvoeders. In de tweede

76 Komen (1995) p. 22-42. Komen constateert in de geschiedenis van de kinderbescherming veranderende verhoudingen. Zo werd een kindwolgende opwodingsstij] in de jaren zestig cen vorm van verwennen genoemd. In de jaren tachtig moesten de werhoudingen tussen ouders en kinderen meer egalitair zijn. "Maar terwijl kinderbeschermers en ouders meer consideratie toonden met de jongeren, wees het gedrag van sommige pupillen erop dat zij juist minder rekening hielden met hun ouders en anderen". (p. 39)

77 Knijn (1992) p. 90-91.

78 Te Grotenhuis (1994) p. 707-719.

79 Zie Van der Zwaard (1995). 
benadering vinden vrouwen dat hun ambities niet aan bod komen. Ze vinden dat er niet alleen aandacht voor de moeder-kindrelatie moet zijn, maar vooral ook voor hun eigen ontwikkeling. Bovendien geven de moeders aan dat ze behoefte hebben aan ondersteuning bij de opvoeding van oudere kinderen.

Singer heeft onderzocht hoe door de overheid, in het voetspoor van ontwikkelingspsychologen en pedagogen, voortdurend een tegenstrijdig appèl wordt gedaan op moeders. Enerzijds zijn het gezin en de koesterende warmte van moeders een heilig huis waar niemand aan mag komen. Anderzijds wordt gesuggereerd dat moeders vreselijk veel tekort te komen om haar taak binnen dat gezin goed te vervullen.

"Zowel in het beleid als in het onderzoek naar de ontwikkeling van jonge kinderen wor d' voornamelijk uitgegaan van een traditioneel gezinsmodel. Op beide terreinen bestaat een sterke gerichtheid op problemen en preventie wan problemen in de gezinsopyoeding." ${ }^{\mathrm{m} z}$

Op de paradoxale situatie waarin moeders zich gesteld zien, reageren feministes ook tegenstrijdig. Terwijl zij als het ware met elkaar op de vuist gaan omtrent de beste zorg en opvang voor het kind, streven zij in feite eenzelfde doel na, namelijk maatschappelijke erkenning van de economische en culturele waarde van kinderopvoeding. Er zou geïnvesteerd moeten worden in kennis en ervaring op dat gebied. De vraag waar en hoe die investering zou moeten plaatsvinden, leidt tot verschil van mening. Er lijken twee opties te bestaan. Bescherming van de opvoeding thuis

80 Van der Zwaard (1995), p. 68. "Het is de klassieke angst en ongerustheid over de eigen beperkingen en de toekomst van de kinderen. Maar die angst krijgt in elke maatschappelijke context een andere betekenis."

81 Singer $(1989)$ p. $211-48$.

82 Singer (1989) p. 44-45. Overigens is wel interessant, zoals Singer ook opmerkt, o.a. op p. 263-265, dat juist vrouwen uit de midden- en hogere klasse zich actief in het wetenschappelijk onderzoek en de hulpverlening gemengd hebben: Nog altijd is driekwart van alle studenten in de pedagogische en andragogische wetenschappen wan thet vrouwe lijk geslacht. Over de ontwikkeling van de kennis merkt zij eem aantal fenomenen op:

- Opvoedingrdoelen worden steeds minder geformuleerd in concreet sociaal gedrag dat betekenis heeft voor de groep wartoe kinderen behoren. (vgl. helpen met de afwas, bedden opmaken, koeien melken, op jongere kinderen passen, boodschappen doen, sigaren maken etc.) Door observaties wan kinderen in aparte kinderruimtes gingen wetenschappers "de natuurlijke ontwikkeling" vastleggen en daarmee wat normaal en abnormaal was. Van alles werd gemeten en gewogen, vergeleken en beoordeeld alls normaal/gemiddeld en abnormaal/uitzondering. (Vgl. lichamelijke groei, dromen, denken, humor, probleemgedrag etc.) De sociale en persoonlijke betekenis van het gedrag verdween naar de achtergrond om plaats te maken voor scores op ontwikkelingsschalen.

- De eerste kinderpsychologen gebruikten ouders/moeders als informatiebron over het gedrag van kinderen. In een volgende lase werd die informatie wan ouders afgedaan als, "onwetenschappelijk" (lekenkennis). De kennis die wetenschappers van "het kind" verzamelen kreeg zo meer waarde dan de kennis van ouders over hun eigen kind. 
door herverdeling van taken te stimuleren of erkenning en uitbreiding van collectieve opvang, zoals peuterspeelzalen en verschillende vormen van kinderopvang. ${ }^{*}$ Opmerkelijk is dat peuterspeelzalen, hoewel oorspronkelijk opgezet door zich emanciperende moeders, ook door de overheid lang worden voorgesteld als kindgericht en aansluitend op de traditionele gezinssituatie thuis. Kinderdagverblijven worden daar dan tegenover gezet als moedergericht. De belangen van (werkende en studerende) moeders lijken zo tegengesteld te zijn aan die van hun kinderen. Bovendien wordt niet onderkend dat juist in de collectieve opvang betaald werk gecreëerd wordt, waarin specifieke kennis en ervaring op het gebied van verzorging en opvoeding vereist is."

Alleen in zorgelijke gezinssituaties wordt opvang in een kinderdagverblijf wel door hulpverlening en overheid gestimuleerd. Inmiddels is de scherpe tegenstelling tussen kinderopvangvoorzieningen aan het veranderen en lijkt er een differentiatie in voorzieningen te worden nagestreefd, waarbij behoeften van de arbeidsmarkt en van ouders richtinggevend lijken. Kinderopvang verschuift daarmee van de welzijnsector naar de marktsector. ${ }^{\text {as }}$ Welke plek de kinderopvang krijgt als een mogelijk nieuw netwerk voor moeders die door allerlei oorzaken in een maatschappelijk isolement zijn geraakt, is nog niet echt duidelijk. In het kader van sociale vernieuwing, armoedebestrijding en grote stedenbeleid wordt door de overheid wel over de noodzaak van kinderopvang gerept, maar bestaat ook sterk de neiging de regelingen hiervoor maar aan particuliere ouders en 'de markt' over te laten.*

De Raad voor het Jeudbeleid heeft zich, net voor zijn opheffing, vanuit pedagogisch perspectief sterk gemaakt voor een breed scala aan opvangvoorzieningen ${ }^{87}$ Kinderopvang is geen stalling van kinderen, ook geen substituut van gezinsopvoeding, maar complementair aan de opvoeding door eigen ouders thuis.

"Kinderen behoeven, naast opwoeding door hun eigen ouders, ook inspiratie van andere mensen en omgevingen. Woor het van nature nieuwsgierige kind valt er in de wereld oneindig veel meer te ontdekken

83 Zie Sevenhuijjsen en De Vries (1980) p. 165-166. Volgens hen waren kinderdagverblijven "onder de huidige verhoudingen patriarchale instellingen die de zeggenschap wan vrouwen over hun kinderen inperken en kinderen programmeren, disciplineren tot regelrecht politiek in doctrineren." Zie ook Pessers (1994) p. 62-65.

84 Het feit dat de functiewaardering van kinderverzorgers nog steeds tot te lage inschalingen leidt (in vergelijking tot bijwoorbeeld dierenverzorgers) laat ik hier nu maar even buiten beschouwing.

85 Bussemaker (1993) p. 197-236.

86 Zie ook Dierx (1996).

87 Raad voor het Jeugdbeleid (1996). In een reactie op de onder leiding van Bruyn-Hundt uitgebrachte nota "Onbetaalde zorg gelijk verdeeld" (1995) ondersteunt de Raad het zogenaamde combinatiescenario: zowel uitbreiding van de betaalde zorgarbeid, als verruiming van de mogelijkheden om betaald werk met (onbetaald zorgen) te kunnen combineren. 
dan een of twee ouders kunnen werzorgen. Bowendien vraagt de manier waarop onze samenleving is ingericht, ook steeds meer van het ontwilkkelingsniweau van mensen" "*

\subsection{Het 'normale' kind}

De sociaalpsychologische 'waarheden' omtrent de ontwikkeling van kinderen zijn niet waardevrij. Ze worden mede beïnvloed door sociaaleconomische en cullturele omstandigheden. Daardoor zijn ze vaak tijdgebonden en ook 'gendered'."

Tot in de achttiende eeuw is er geen fundamenteel verschil tussen volwassenen en kinderen vanaf ongeveer zeven jaar. Bij jonge kinderen bekommeren ouders zich om de materiële behoeftenbevrediging, de ordehandhaving en de lichamelijke verzorging. Intieme banden en individuele aandacht zijn niet aan de orde. In de achttiende eeuw ontstaat er een scheiding tussen de volwassen wereld en de kinderwereld. Kinderen worden uit de volwassenwereld geweerd. Vooral in de burgerlijke en adellijke kringen worden kinderen uit huis gedaan en door een min opgevoed of anders door het personeel. ${ }^{\text {*o }}$ In de lagere sociale klassen nemen kinderen al jong deel aan het arbeidsproces en worden zij voor het overige aan hun lot overgelaten.

Sinds de negentiende eeuw bestaat 'het gezin' zoals we dat nu kennen. Een zelfstandige eenheid, niet meer ingebed in het grote geheel van de familie, dat bestaat uit vader, moeder en kind(eren). Een van de functies van het gezin is het opvoeden van kinderen." Onder invloed van de Verlichting en het rationalisme veranderen in de negentiende eeuw de ideeën over opvoeding en wordt het de moeite waard aandacht aan kleine kinderen te besteden. Ook de kindersterfte daalt. Hoewel de oude ideeën over de slechtheid van kinderen, verbonden met enerzijds de erfzonde en anderzijds het dwaze in de mens, nog niet verdwenen zijn, ontstaat er een groter optimisme ten aanzien van het menselijk kunnen, de rede en het effect van opvoeding. Vooral in burgerkringen wordt in de tweede helft van de negentiende eeuw veel waarde gehecht aan de invloed van het gezinsleven op de geestelijke ontwikkeling van kinderen. Daarbij wordt het met de harde hand opvoeden echter steeds meer afgekeurd. Banden van warmte en genegenheid en een liefdevolle behandeling moeten gericht zijn op de 'gewetensvorming" van het kind. Daarin wordt speciaal een taak voor de moeder gezien. Dit idee, dat ouders en met name de moeder de kinderen

88 Raad voor het Jeugdbeleid (1996), p. 8-9.

89 Badinter (1989). In het boek beschrijft zij de status van het kind door de ceuwen heen. Zij gebruikt daarbij historische, filosofische en literaire bronnen. In het boek bestrijdt zij dat "moederliefde" een een matuurlijke aangeboren vrouwelijke eigenschap zou zijn. Singer (1989) p. 53 e.v., beschrijft met name de sociaal-olitieke achtergronden bij de opkomst van de bewaarscholen vanaf de negentiende eeuw.

90 Zie ook Badinter (1989) p. 104-128, Van Essen (1990).

91 Van Ooijen-Houben (1984) p. $68-69$. 
moeten koesteren breidt zich in de twintigste eeuw uit tot niet-burgerkningen. Singer beschrijft de gevolgen van de ontdlekking van "het kind" als object van onderzoek. Zij koppelt daaraan het ontstaan van de ontwikkelingspsychologie. Het kind wordt geobserveerd en die observaties leveren weer maatstaven ten behoeve van andere kinderen op. Zo ontstaan "het kind" en "de ontwikkelingspsychologie" als culturele fenomenen.

"Door de scheiding tussen gezin en de wereld van het werk werd de overdracht van kennis, vaardigheden en sociale regels die van belang zijn buiten het gezin problematisch. Het "pedagogisch handelen" werd een aparte categorie, los van andere bezigheden van de volwassenen. Er ontstonden aparte pedagogische raimtes voor kinderen met daarbij horende opvoedingsdeskundigen: wetenschappers, leidsters/onderwijzeressen en (kinder)therapeutem. Deze opvoedingsdeskundigen claimden over 'ware' kennis en betere opwoedingstechmieken te beschilkken dan ouders/moeders. Het kind zot een onbeschreven blad zijin, of het zou 'goed' en 'redelijke krachten' als een matuurlijke potentie in zich dragen. Als het kind op de juiste wijze "beschreven" zou worden of tot ontplooiing gebracht, zou de ideale samenleving dichterbij komen. De opvoeder werd geplaatst als schakel tussen het potentiële vermogen in het kind en de idealle samenleving:

Interessant is dat de ideeën over de maakbaarheid van het kind verschillen, afhankelijk van de levensovertuiging, hetgeen ook een veelheid aan opvoedingstheorieèn oplevert. Zo zou in de calvinistische overtuiging het kind helemaal niet onbeschreven zijn maar door de 'erfzonde' belast. Dat vereist per definitie een strenge aanpak. Wie zijn kind liefheeft, kastijdt het. ${ }^{\text {. }}$

Na de Tweede Wereldoorlog winnen de inzichten uit de gedragswetenschappen aan invloed in de samenleving. Mede door de secularisering, worden steeds meer zingevingsvraagstukken via (sociaal)psychologische theorievorming aan de orde gesteld. Mensen zoeken naar nieuwe 'zijns'wijzen en gaan in therapie. Veel problemen bij de volwassenwording worden verklaard vanuit de kindertijd. Die inzichten leiden soms tot algemeen verklarende theorieën. Sommige theorieën krijgen bijna de status van een geloof. Een aantal, min of meer, bekende inzichten over de persoonlijkheidsvorming passeren in de volgende paragrafen de revu.

\subsubsection{Hechting}

Over het algemeen ondersteunen pedagogische en psychologische onderzoeken de opvatting dat het opvoedingsmilieu in de eerste levensjaren van groot belang is voor de latere persoonlijkheidsontwikkeling.

92 Singer (1989) p. $5-8$ en p. $265-270$.

93 Singer (1989) p. 265-266.

94. Spreuken 13, vers 24 : "Wie de roede spaart houdt niet van zijn kind, want wie het liel heeft kastijdt het". Zie ook Baartman (1993).

95 In : Singer (1989) p. 182-183, Bowlby (1978). 


\section{Hoofdstuk 5}

Met name de attachmentheorie die Bowlby in thet begin wan de jaren zewentig introduceert, vindt veel weerklank. In zijn theorie staat de veilige gehechtheid van het kind aan de moeder centraal. Ieder pasgeboren kind komt ter wereld met de aangeboren neiging de nabijheid van mensen te zoeken. Volwassenen, met name moeders, hebben een aangeboren neiging bij het kind te blijven en het te beschermen. Een neiging van het kind is het exploratief gedrag in de buitenwereld. In hoeverre het kind een evenwicht tussen beide neigingen kan vinden, is afhankelijk van de moeder. Een altijd beschikbare, sensitieve en responsieve moeder is de beste garantie voor het "veilig hechten". Scheidingen woor het derde jaar zijn potentieel schadelijk, daarna heeft het kind zich een "working model" eigen gemaakt. Bowlby spreekt dan over een veilige thuisbasis, analoog aan het leger. De scheiding tussen het gezin, als veilige basis, en de wereld van het werk of de harde buitenwereld is volgens hem universeel en via de evolutie sterk in ons verankerd.

In later onderzoek komt de vraag aan de orde in hoeverre er significante verschillen bestaan tussen het hechtingsgedrag van kinderen gericht op de moeder en gericht op de vader." Vlak na de geboorte zou er, door het geven van borstvoeding, enige roldifferentiatie zijn tussen moeders en vaders, maar voor de periode daarna is gebleken dat vaders en moeders even sensitief kunnen zijn voor de signalen wan baby's. Bij oudere kinderen (twee jaar) wordt geen voorkeur voor de moeder gevonden, ook niet in stressvolle situaties. De sensitieve responsiviteit van ouders lijkt vooral verband te houden met de eigen (gehechtheids)ervaringen van de ouder. Bovendien blijkt uit dit meer recente onderzoek dat continue aanwezigheid niet

96 Bowlby had voorafgaand aan de attachment theorie al na WO II veel succes gehad met zijn "maternal deprivation" theorie. Hierbij ging hij uit van de schadelijke effecten van verstoorde relaties tussen moeders en kinderen. $\mathrm{Hij}$ onderzocht hoe het met kinderen was gegaan die door de oorlog van hun ouders gescheiden waren, thuislloos of wees waren.

Singer (1989) p. 184-191 geeft aan dat er verschillende verklaringen zijn te geven woor het succes van de maternal deprivation theory:

- de angst voor sociale chaos en dictatuur na wO II; de rouw maakt de mensen weer bewust van de rol van familiebanden;

- de politiek ten aanzien van (werkende) moeders in de tijd van wederopbouw;

- de opkomst van een nieuwe opvoedingsmoralal (fun morality), waarin veel ruimte is voor individuele verlangens en gevoellens. (consumptiemaatschappij)

97 O.a. Van IJzendoorn (1988).

98 De Raad voor het Jeugdbeleid (1996, p. 34) merkt in zijn advies dan ook op: "Ten tweede lijkt het erop dat de wijzen waarop vaders en moeders de ontwilkkeling beïnvloeden eerder gelijkenis vertonen dan verschillen; de invloeden zijn veeleer verbonden met ouderlijke karakteristieken dan met seksegebonden karakteristieken. Zo werd wat de invloed van de wader op de sekserolontwikkeling van jongens betreft verder gekonstateerd dat voor de vader kemmerkende karakteristieken (zoals masculiniteit) veel minder belangrijk waren dan de aard van de relatie, de warmte en de intimiteit van de vader; soortgelijke resultaten zijn gevonden voor de invloed van de vader op prestatiemotivatie en op psycho-sociaal aanpassingsvermogen. Dit wordt een belangrijke conclusie geacht omdat deze karakteristieken altijd als vrouwelijk zajn beschouwd". 
noodzakelijk is voor het tot stand komen van een veilige gehechtheidsrelatie. De kwaliteit van de relatie is daarvoor van veel groter belang. Voonwaarde daarvoor is naast de genoemde sensitieve responsiteit een regelmatige interactie. De noodzakelijke frequentie daarvan hangt vooral samen met de leeftijd van het kind. Hoe jongerhet kind, hoe belangrijker de aanwezigheid van eén of meer vaste verzorgers, maar dat hoeven niet per se de ouders te zijn. Rond het derde jaar heeft het kind de mogelijkheid tot "interne representatie" ontwikkeld. Bij afwezigheid van de gehechtheidspersonen kan het kind zich een beeld van hen vormen en er op vertrouwen dat er na de scheiding ook weer een terugzien en hereniging volgt.

\subsubsection{Het heteroseksuele ouderpaar: afstamming en identiteit}

In de psychoanalyse speelt het identificatieproces met de biologische ouders in de vroege jeugd een belangrijke rol. Anders dan Bowlby gaat de psychoanalyse uit van intrapsychische conflicten in ieder individu: tussen liefde en haat, tussen eén en gescheiden willen zijn, tussen het Ego en het Super-Ego. Bowlby stelt de behoefte van het kind gelijk aan het het recht op bevrediging. Psychoanalytici vinden dat volkomen psychische bevrediging door de innerlijke conflicten niet alleen onmogelijk is maar zelfs ongewenst. Door verdriet, teleurstellingen en conflicten wordt het kind zich ervan bewust een eigen persoon te zijn. Eriksson introduceert het begrip 'identiteit" in de psychologische literatuur. ${ }^{9}$ Volgens hem zullen moeders en vaders in alle samenlevingen hun rol in de beginfasen van het leven van het kind ieder op hun eigen, van elkaar verschillende, wijze voor hun kind vervullen. Vroegkinderlijke verschijningsvormen van identiteit veranderen dan ook niet of maar heel langzaam onder invloed van de omgeving. De eerste ontwikkelingsfasen van identiteit zullen er bij elke vorm van ouderschap ongeveer hetzelfde uitzien en worden in grote lijnen bij iedereen volgens een Freudiaans psychodynamisch model doorlopen. De rol van de biologische vader heeft daarbij een eigen functie:

- hij is van belang als positionele vader, die de symbiose tussen moeder en kind doorbreekt;

- hij is van belang als symbolische vader, die het maatschappelijk gezag representeert en zo de gewetensvorming stimuleert;

- hij is van belang als reële vader, die de mogelijkheid biedt tot imitatie en sekseidentificatie.

Als er geen vader aanwezig is, is het kind woor een goede identiteitsontwikkeling afhankelijk van andere mannen door wie die vaderfumcties worden vervuld.

99 Eriksson (1972) beschrijft in de laatste hoofdstukken als aparte categorieèn: de jeugd, de wrouw en 'ras' en identiteit in ruimere zin. Zie ook Van den Broek en Broeshart (1989) p. $80-86$ en Wegelin (1992) p. 22 e.v... 


\section{Hoofdsturk 5}

Pas vanaf de adolescentiefase krijgen sociale en culturele invloeden meer betekenis bij de identiteitsvorming.

Sommigen vinden echter juist in de adolescentieperiode de vader van specifiek belang voor zijn zoon, als figuur om zich tegen af te zetten bij het vinden van een eigen identiteit. Voor de identiteitsvorming van de dochter is de vader in deze ontwikkelingsfase belangrijk, omdat hij haar zelfvertrouwen als vrouw ten opzichte van mannen zou kunnen ondersteunen ${ }^{100}$ Gilligan benadrukt dat de ontwikkeling van de identiteit door Eriksson ontleend is aan een mannelijk model. ${ }^{101}$ Eriksson beschrijft de mannelijke identiteit immers als directe schakel met de wereld, de vrouwelijke als pas ontluikend in een intieme relatie.

Chodorow verklaart de zich herhalende sekseverschillen in de identiteitsvorming vooral vanuit de moeder-kindrelatie in de vroege kinderjaren. ${ }^{102}$ Juist omdat de belangrijkste verzorger in de eerste drie levensjaren vaak een vrouw is, zijn de interpersoonlijke drijfveren van jongens en,meisjes om een eigen identiteit te vinden anders. Jongens zullen zich afscheiden, hun egogrenzen zoeken, terwijl meisjes zich identificeren met het vrouwelijke en daarmee met juist de voortgezette verbinding en niet met individuatie. Voor Chodorow is het dan ook duidelijk dat een groot deel van de sekseverschillen kan ophouden te bestaan zodra mannen zich actief met de verzorging van zeer jonge kinderen bezighouden. ${ }^{103}$

100 Gerrilsma (1985), Kalter( 1987), Wegelin (1992) p. 25.

101 Gilligan (1985) p. 19 e.w..

102 Chodorow (1989).

103 Chodorow (1989) p. 269. "Kinderen zouden vamal het eerste begin afhankelijk kunnen zijn van personen wan beide seksen, en een geindividueerd ik-besef kunnen ontwikkelen in relatie tot beiden. Op deze manier behoeft mannelijkheid niel gekoppeld te worden aan de ontkenning van althankelijkheid en de devaluatie van vrouwen. De vrouwelijke persoonlijkheid zou minder gepreoccupeerd zijn met kwesties van individuatie, of kinderen zouden geen angsten ontwikkelen voor de almachi van de moeder, of werwachtingen koesteren omtrent unieke capaciteiten tot zelfopoffering van vrouwen. Mannen zouden minder aanleiding hebben tot het verdedigen van hum mannelijkheid en de macht over maatschappelijke en culturele terreinen waar vrouwen behandeld en gedefinieerd worden als tweederangs en machteloos; zij zouden wrouwen kunnen helpen de autonomie te ontwikkelen waaraan ze, doordat ze all te zeer in relaties opgaan, vaak niet zijn toegekomen. "In hoofdstuk 1 kwam reedls aan de orde dat Rutenfrans (1989, p. 131-158) in zijn verklaring van criminaliteit en sekse zear gecharmeerd blijkt te zijn van Chodorows theorie. 


\subsubsection{Loyaliteit}

In de contextuele benadering speelt de intergenerationele loyaliteit een belangrijke rol. ${ }^{104}$ De grondlegger Boszormenyi-Nagy vindt identificatie ook een centraal begrip. ${ }^{\text {ios }} \mathrm{Hij}$ hecht niet alleen grote waarde aan het gezin, maar ook aan de bredere context, dat wil zeggen de familie waaruit het gezin voortkomt. Nagy gaat uit van drie vooronderstellingen ${ }^{106}$ :

1. Loyaliteit is intergenerationeel. Loyaliteit speelt niet alleen in horizontale maar ook in verticale relaties tussen gezins- en familieleden. Bij gezinsconflicten moet daarom altijd gekeken worden naar de vorige generatie, waarin de ouders zelf kind waren om te begrijpen waar het gedrag vandaan komt. Als voorbeeld kan geweld in het gezin gezien worden.

2. Loyaliteit tussen gezinsleden is onlosmakelijk omdat zij gevestigd wordt door bloedverwantschap.

3. Loyaliteit is geen kwestie van voelen maar een kwestie van zijn. Het collectief systeem van gezinsloyaliteit drukt zijn stempel op het individu. Bij het stichten van een eigen gezin wordt die familiale loyaliteit uitgebreid naar partner en kinderen. Deze familiale loyaliteit is van nature dominant boven die jegens vrienden en vriendinnen.

Ook bij Miller speelt loyaliteit een grote rol, maar dan negatief. Het kind zit gevangen in de loyaliteit naar de ouders. Opvoeders, ouders en leraren zijn in wezen vijanden van het kind die hun waarden projecteren op het kind en via de socialisatie het kind wegdrijven van het ware zelf. Het kind voelt zich gedwongen aan de eisen en verwachtingen van de ouders tegemoet te komen. ${ }^{107}$

Hoe belangrijk de erkenning van het verschijnsel loyaliteit en met name in de vorm "generatie-overdracht" ook is, Nagy's visie op het begrip loyaliteit is volgens Wegelin te eendimensionaal:

De in onze cultuur bestaande ethiek van gezinsloyaliteit, de normen voor loyaliteit in het concrete gezin warbinnen men opgroeit en de individued gevoelde loyaliteit worden een. Zo sluit Nagy de mogelijkheid wan discrepantie tussen de verschillende niweaus van ethick uit" ${ }^{\text {tos }}$

104 Ook in detentiesituaties wordt soms wolgens die benadering gewerkt. Zie Proces (1996).

105 Boszormenyi-Nagy en Spark (1973), Bioszormenyi-Nagy en Krasner (1986), Van den Eerenbeemt en Van Heusden (1983), Onderwater (1986).

106 Zie ook: Wegelin (1991) p. 25 e.w..

107 Miller (1991). In een prévoorwoord (standpunt 1990) distantieert zij zich overigens nadrukkelijk van de psychoanalyse.

108 Wegelin (1991) p. 27. 


\section{Hoofidstuk 5}

De intergenerationele geweldscyclus blijkt in nader onderzoek niet bevestigd te worden. ${ }^{100}$ Slechte jeugdervaringen vormen niet de enige en wellicht niet de belangrijkste oorzaak van vormen van geweld.

"Een cultuur van mannelijke dominantie waarin sllaan of seksueel misbruik door mannen als normaal of onvermijdelijk wordt gezien; en stressfactoren zoals gebrek aan geld, slechte behuizing, ziekte van kinderen of moeder, en werkloosheid van de vader zijn voorbeelden wan oorzaken die tenminste even invloedrijk kunnen zijn", "10

De betekenis van de biologische band is onder andere onderzocht via het gedrag van adoptiekinderen. Slechts een kleine minderheid gaat op zoek naar de biologische wortels. Betekenisgeving aan het eigen bestaan lijkt daarbij van groter belang dan het werkelijk vormgeven van een band met biologische ouders. Degenen die echt contact zoeken, zijn het meest ontevreden over de relatie met de adoptiefouders, maar ook dan betonen zij hun loyaliteit jegens hun adoptiefouders. Wanneer men alleen met de biologische moeder contact zoekt, is het doel daarvan vooral een reëler beeld te krijgen van de omstandigheden waaronder men is opgegroeid. Als een kind opgroeit bij de biologische moeder en een sociale vader blijkt het feit of het kind al of niet last krijgt van identiteitsproblemen veelal samen te hangen met de vertrouwensrelatie die het met de moeder had. ${ }^{\text {III }}$ Ook de vaststaande loyaliteit, wordt in nader onderzoek niet bevestigd. Loyaliteit wordt mede bepaald door de concrete ervaringen met ouders. ${ }^{112}$ Op grond van de resultaten uit dit empirisch onderzoek concludeert Wegelin overigens dat ook de ideeën van Eriksson aangetast zijn. ${ }^{113}$ Zij pleit ervoor als uitgangspunt van opvoeding niet loyaliteit te nemen, maar autonomie en zelfbepaling van de minst machtigen in het gezin.

\footnotetext{
"'Autonomie' vormt de noodzakelijke tegenhanger van 'loyaliteit'. Beidle begrippen zijn minder ver van elkaar verwijderd dan vaak gedacht wordt, want iedere aanspraak op autonomie verwijst onmiddellij]k naar de vraag, hoe daarbij respect is op te brengen woor anderen." ${ }^{\text {"mit }}$
}

109 Zie ook Dijkstra (1995).

110 Wegelin (1991) p. 28.

111 Wegelin (1991) p. 31.

112 Wegelin (1991) p. 33 e.v.. De beoordeling achteraf ower je ouders lijkt mij nauw bepaald te worden door de levensfase waarin je zit. Het heden is in hoge mate bepalend voor de imterpretatie van het verleden. Onderzoek naar generationele banden met biologische ouders (en de effecten van echtscheiding, adoptie, en binnenkort i.v.f. met onbekende zaaddonor) vindt bijna altijd plaats onder adolescenten.

113 Wegelin (1993) p. 188-202.

114 Wegelin (1991) p. 36. 


\subsubsection{De continuitteit in de opvoeding: het verbrede opvoedingsmilieu}

Het belang van een veilige omgeving voor een kind wordt erkend, maar er onstaat discussie over de exclusieve rol van de moeder als belangrijkste hechtingsfiguur. De koesterfunctie van moeders wordt door sommige pedagogen ook gerelativeerd. ${ }^{\text {is }}$ Het romantisch idee van de altijd aanwezige moeder wordt immers nooit gerealiseerd. Niet alleen vanwege werkzaamheden buitenshuis, maar ook doordat het huishouden tijd vraagt en zij ook aandacht voor de andere kinderen moet hebben. Het gaat volgens hen dan ook om de kwalitatieve aandacht die kinderen krijgen. Zij introduceren en bepleiten het verbrede opvoedingsmilieu, waarin ook andere hechtingsfiguren een belangrijke rol spelen, zoals vader, de oppas, opa en oma. Door zo'n verbreed opvoedingsmilieu, kunnen kinderen bij ingrijpende gebeurtenissen op meer dan éen persoon terugvallen. In hun theorievorming gaat het daarbij vooral om het jonge. kind.

De overdracht van eigen waarden en normen binnen bepaalde (familie)tradities lijkt stabiliserende kanten te hebben. Dat kan positief uitpakken ${ }^{116}$, maar ook negatief.

"Kinderen van laagopgeleide, langdurig werkloze ouders ervaren een (zelf)uitsluitingsproces dat het behalen van diploma's, het vinden en behouden van werk en het gebruik maken van intermediairen sterk belemmert. Al op jonge leeftijd ervaren zij de maatschappelijke 'excommunicatie' die hun ouders vroeger ook hebben meegemaakt omdat zij eveneens niet langer voldeden aan de -steeds strengerenormen en eisen van de samenleving. Naarmate de uitsluiting langer duurt ontwikkelen de jongeren, net als hun ouders vroeger, gedragsreacties die de uitsluiting bestendigen. ${ }^{\text {m117 }}$

Juist de wens een eventuele negatieve spiraal in de cultuuroverdracht binnen het gezin of de familie te doorbreken, leidt ook tot pleidooien voor verbreding van het leefmilieu. ${ }^{118}$

115 Van IJzerendoorn, Tavecchio, Goossens en Vergeer (1985).

116 Vgl. Kousbroek (1992) p. 8. " Het is niet onmogelijk dat er al een generatie Nederlanders is opgegroeid zonder het bezit van dat wat het eigenlijke onderwerp is van dit boek: een over generaties langzaam opgebouwde cultuur, die nauw verweven is met dat woorlezen, en spelletjes doen, met dat aan het bedje van een ziek kind zitten, met die elliptische manier ('culture is a family joke') van iets aanduiden en die ironie - ... - een geërfde liefde, die ook weer op de volgende generatie moet worden overgebracht."

117 Te Grotenhuis (1994) p. 7118.

118 Singer (1989) p. 237-243 geeft aan dat verbreding van de opvang zowel binnen de thuissituatie kan plaatsvinden als door vervanging wan een deel van de zorg elders (bijvoorbeeld kinderdagverblij). 


\subsubsection{De eigen leefwereld}

Oudere kinderen hebben vanuit de optiek van het verbrede opvoedingsmilleu veel belang bij continuering van hun contacten buitenshuis: de school, hun vrienden, de buurt, werenigingen en dergelijke. Het onderzoek waaruit zou blijken dat de scheiding tussen ouders en kinderen desastreuze gevolgen heeft, is vaak eenzijdig gebaseerd op situaties waarin het kind uit de eigen leefomgeving wordt gehaald en er dus een totale scheiding plaatsvindt. ${ }^{\text {to }}$

In recent pedagogisch onderzoek wordt ook steeds vaker de waarde van een eigen leefwereld (buitenshuis) voor het hele jonge kind benadrukt. ${ }^{120}$ Ook in dit onderzoek speelt het begrip identiteitsworming een belangrijke rol, maar dan als psychosociale bezigheid. Volgens Taijfel verwerft een mens een identiteit door een plaats te vinden binnen de socialle groepen waartoe hij of zij behoort. Deze ontwikkeling voltrekt zich in drie stappen:

- Eerst leert men onderscheid maken tussen zichzelf en anderen aan de hand van bijwoorbeeld lengte, haarkleur, sekse, familieverband, slimheid en sportiviteit.

- Vervolgens leert men maa tschappeljjk betekenisvolle categorisaties maken naar bijvoorbeeld sekse, ras, leeftijd, sociale klasse, type school, type auto, lid vereniging en sportelub.

- Via de processen van onderscheiden en vergelijken plaatst men zichzelf, in wisselwerking met de omgeving, bimnen die categorieën. Iemands identiteit krijgt vorm via zijn 'status' die tijdelijk door bijvoorbeeld leeftijd, sociale klasse en sport of definitief, door bijwoorbeeld sekse en ras, wordt vastgelegd.

Zelfbeeld en identiteit vallen niet samen. Er is sprake van gelaagde identiteiten waarbij identiteit zowel een sociaalrelationeel begrip is als een persoonlijkheidskenmerk, herkenbaar door de uniciteit. In iedere sociale situatie en in iedere leeftijdsfase

$119 \mathrm{Vgl}$." The effect on a child of separation from its parents has proved to be one of the key issues in child psychiatry an developmental psychology. Some of the first systematic work in the area demonstrated dramatic short term effects following the admission of a child to hospital or a residential nursery (see Bowlby 1969). These findings still largely stand', aldus Stephen Wolkind and Michael Rutter in: Van Wijk (1992) p. 154, noot 35.

120 Dasberg (1988) p. 59: "Kinderen moeten het socialle leren ontplooien. En dat wordt wel eens veron-

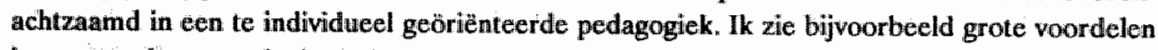
in grote gezinnen, ondanks de eventuele materiële nadelen ervan. Met de steeds kleiner wordende gezinnen denk ik dan ook dat het goed is als kinderen naar crèches gaan. Kinderen moeten leren om speelgoed te delen en ruzie te hebben."

Schröder (Volkskrant 7-1-1993): "Wat is er eigenlijk tegen kinderopvang als die van goede kwaliteit is? Wie heeft er bezwaar tegen een warme, veilige uitdagende omgeving woor jonge kinderen? Kijk alleen al eens met aandacht naar de interacties tussen baby"s en peuters onderling, zeker als zij elkaar kennen. Je kan niet anders dan constateren, dat dit ook voor heel veel jonge kinderen een verrijiking betekent."

Zie ook Singer (1989) p. 240-243, Taijfel en Fraser (1978). 
moet een kind een bestaansverhaal over zichzelf maken, zodat het zich steeds kan plaatsen binnen haar of zijn leefkaders. Niet alleen de persoonlijke identiteit en de sociale categorisering spelen een rol maar ook de meer omvattende culturele symbolisering. ${ }^{\text {t21 }}$ In (vrouwenstudies)onderzoek is bekeken hoe het individu via de identiteitslaag van "de geslachtsgebonden identiteit", en daaruit voortvloeiende gedragskeuzes, kan ontsnappen aan een eventueel cultureel en sociaal determinisme. ${ }^{122}$

De driehoeksverhouding moeder-vader-kind lijkt dus niet langer het enig fundament in de identiteitsontwikkeling, maar ook de dialoog met de omringende wereld. Door Lea Dasberg wordt de term "jeugdland" geïntroduceerd.

"Met jeugdland bedoelen we een gebied -een gebied in de tijd- waarin het kind kan rijpen aan een gemeenschap van leeftijdgenoten die zich in eenzelfde ontwikkelingsfase bevinden ${ }^{\text {in }}{ }^{123}$

De wederzijdse relatie tussen kind en ouder wordt steeds meer als een affectief gelijkwaardige ingevuld. De opvoeding vindt plaats in een dialoog, een wederzijdse beinvloeding van opvoeder en kind. Er wordt niet vanuit het ideaalbeeld van 'de gezonde volwassene' teruggeblikt op de behoeftes in de vroege jeugd, maar gezocht naar existentiële grondvormen die voor ieder individu belangrijk zijn.

De algemene grondvormen worden geconcretiseerd in aanraken, verzorgen, samen spelen, samen eten en drinken, samen feest vieren, samen erop uit trekken, samen werken, elkaar iets leren en samen praten. De grondvormen worden voor de beoordeling van opvoedingssituaties vertaald in vragen als:

- Weet de opvoeder hoe een kind op verschillende leeftijden moet worden aangeraakt (knuffelen, troosten, zoenen, stoeien, vasthouden)?

- Kent en beheerst de opvoeder de techniek van de verzorging van zichzelf, van kinderen (is het kind schoon en fris), dieren, planten en dingen? Hoe is de feitelij-

121. Wegelin (1993) p. 199-202.

122 Zie Wegelin (1990) p. 201-202, Hagemann-White (1989) p. 33-49. Dit is bijvoorbeeld interessant in relatie tot de voortplantingsfunctie van vrouwen. Bij "seksualiteit" hangt dat af de vraag of er zoiets is als "vrouwelijke seksualiteit, verbonden aan hormonale, c.q. biologisch-fysiologische factoren? De zorgfunctie lijkt per definitie cultureelbepaald. Via een langdurige zoogperiode proberen sommige wrouwen, ook in detentie, wel het determinisme te doorbreken.

123 Dasberg (1984) p. 24. De term "jeugdland" roept thans niet alleen positieve associaties meer op Zie Kruithof (1993) p. 338. "Er is voor kinderen in de loop der tijd ook veel meer een eigen wereld gekomen, met boeken, speelgoed, strips, televisie, computerspelletjes, sportverenigingen en wat dies meer zij. Maar daardoor is het, volgens sommigen, voor hen ook lastiger geworden on afscheid wan 'jeugdland" te nemen en streven ze er te krampachtig naar 'forever young' te blijven. Dit verschijnsel staat wel bekend als 'het Peter Pan-syndroom'. Daardoor zou het moeilijker voor hen zijn geworden zelf als ouders op te treden en zouden ze er minder in slagen hun kinderen het goede woorbeeld voor te leven." 
ke verzorging tot nu toe? Wie gaat er met het kind naar de dokter? Wie brengt het naar bed?

- Kan de opvoeder spelen? Spelen in de meest ruime zin van het woord: spelletjes, sport, knutselen, muziek spelen en er naar luisteren, zingen, dansen, met speelgoed en spelmateriaal omgaan, naar de bioscoop gaan voor kinderfilms en dergelijke?

- Geeft de opvoeder het kind regelmatig te eten en te drinken? (voorwaarden om zich fit te voelen)

- Kan de opvoeder een feestje organiseren? (bijvoorbeeld een kinderpartijtje)

- Weet de opvoeder er met de kinderen op uit te trekken? Op straat lopen of fietsen, met de bus gaan, een treinreis maken, winkelen, een bibliotheek, tentoonstelling of museum bezoeken, een avondje uit, een dagje uit, wandelen in het bos of op het strand, kamperen en met vakantie gaan. Krijgt het kind voldoende beweging?

- Weet de opvoeder hoe een gesprek te voeren, dat wil zeggen, neemt hij de tijd om te praten met het kind, naar hem te luisteren? Vertelt de opvoeder verhaaltjes en leest hij het kind voor (bijv. voor het slapen gaan)? Praat hij regelmatig met de school (leraar van het kind) over het kind? ${ }^{124}$

Vraag is dan well of ieder mens in intieme relaties in principe alle grondvormen moet (kunnen) realiseren of dat de opvoeder de eindverantwoordelijke is die ervoor moet waken dat het kind op alle terreinen aan zijn trekken komt en die dus juist kritisch naar de eigen (opvoedings-)kwaliteiten moet kijken. Vanuit de feministische discussie over de herverdeling van taken of de uitbesteding daarvan aan voorzieningen buitenshuis lijkt dat interessant. ${ }^{125}$ Is de moeder de uitvoerder en vader de uitbesteder? Zijn de ouders beiden uitbesteder aan de kinderopvang, de peuterspeelzaal, de muziekschool, de scouting? Of wordt de realisatie binnen de driehoek vadermoeder-kind of in ieder geval binen het kleine familieverband gezocht? Wat is 'in het belang van het kind'? Vervullen de ouders idealiter inwisselbare rollen? Of moet het kind seksestereotiepe activiteiten leren onderscheiden? ${ }^{126}$

Een apart punt lijkt mij nog in hoeverre het voor het kind van belang is zintuiglijk betrokken te zijn bij huishoudelijke en verzorgende activiteiten. Geuren bij de bereiding van het eten, een was die van de lijn wordt gehaald, gemaaid gras. Het spelen-

124 In: Van den Bergh (1986) p. 133-134.

125 Een discussic waarbij de meest voorkomende pragmatische oplossingen, in de sleer van verbreding van taken thuis door zwart en grijs onderbetaalde vrouwen of niet-betaalde oma's overigens veelal buiten beeld blijwen.

126 Bij de roldoorbreking past bij onder meer dat kinderen niet meer de seksespecifiek geladen woorden "mama" en "papa" gebruiken, maar hun ouders als gelijkwaardig met bijwoorbeeld hun voornaam aanspreken. In haar laatste boek bepleit Badinter (1993) juist wel een seksespecifieke socialisatie, waarbij woor jongens met name de positieve instrumentele mannelijke waarden (dapper zijn, naar buiten optreden, je verantwoordelijk voelen) essentieel zijn voor hun identiteitsvorming. 
derwijs betrokken zijn bij het koken, strijken, afwassen, schoonmaken, kleinonderhoud werrichten en gescheiden afval verzamelen. Ouders moeten zich niet alleen in het kind inleven en gericht zijn op cognitieve aspecten. Kinderen moeten ook gewoon dingen kunnen afkijken. Bovendien wordt continuïteit in het leven niet alleen bepaald door mensen, maar ook door een vertrouwde en veilige omgeving, terugkerende activiteiten, het ritme van de dag, sfeer, geuren, lichtinval etcetera.

\subsubsection{Opvoeding als sociale politiek: overheidsbemoeienis}

Bestaat er zoiets als 'nestwarmte'? Degenen die opvoeding als vorm van sociale politiek zien, menen, dat juist in het besloten gezin de kiem gelegd wordt voor maatschappelijke tegenstellingen later. In het gezin wordt immers bepaald wat 'normaal' is, worden bezits- en eigendomsverhoudingen vastgesteld en wordt in feite negatief discriminerend en bezitterig gedrag aangeleerd. Inmiddels is ook bekend dat het gezin voor zeer veel kinderen niet dat veilige nest is dat het naar buiten toe nog altijd lijkt. ${ }^{127}$ Dreigen met alle goede bedoelingen generatie op generatie ouders hun eigen ontploolingswensen en statusgevoeligheden niet op hun kinderen te projecteren? Via een naar buitengerichte open opvoeding kunnen klassenscheidingen doorbroken worden.

Feministen in de jaren zestig en zeventig zien in het traditionele burgerlijke gezin de bron van maatschappelijke ongelijkheid. ${ }^{28}$ Mannen en vrouwen moeten niet alleen gelijkwaardige partners op de arbeidsmarkt zijn, maar ook thuis.

"Feminisme' stond woor een revolutie op alle terreinen van het leven: werkende mannen en vrouweri levend in woongroepen, collectieve zorg voor de huishouding gemeenschappelijke verantwoordelijkheid voor de opvoeding en het doorbreken van de eenzijdige moeder/kindrelatie. De persoonlijke verzorging en opvoeding van kinderen mocht niet alleen op de schouders van vrouwen rusten.

\section{Singer en Miltenburg zeggen:}

"Dat samen opwoeden is van meet af aan binnen het feminisme een aandachispunt geweest. Het exclusieve moederschap en het gesloten gezin werden bekritiseerd (...) Maar het feminisme heeft wat betreft 'samen opvoeden' niet al haar beloften waargemaakt. In de eerste plaats impliceert kritick op het exclusieve moederschap ook kritiek op het alleenrecht en -heerschappij wan de moeders/ouders over het kind. In de tweede plaats hebben we ons tot nu toe voornamelijk beperkt tot het eisen van opvang

127 O.a. Willems (1990) p. 1243-1247.

128 Kool-Smit (1967), Diverse "Bonte Was boekjes", zoalls Moederschap is monsterschap etcetera. Ouders richtten in 1965 de eerste peuterspeelzaal op en er kwamen initiatieven als "het witte kinderenplan" en "anti-autoritaire kresjes". In 1970 organiseerden Man Vrouw Maatschappij, de Nederlandse Vrouwenbeweging en Dolle Mina grote crèchedemonstraties. Zie ook Holtrust (1993) p. 2-4.

129 Van Beckhoven en Meeuwig (1992) p. 14. 


\section{Hoofdstuk 5}

zonder inhoud te geven aan het begrip 'gedeelde opvoeding'. En dat laatste is zeer nodig binmen de context van een woorzieningensysteem dat gebaseerd is op het idee dat ouders of alle rechten/gezag en zorgplicht hebben, of nauwelijks iets te zeggen hebben in geval van de 'kinderbescherming-niet-moe$\operatorname{der}^{ \pm+1}+130$

In de meer feministische pedagogiek wordt nu gezocht naar mogelijkheden om het isolement van moeders, waaronder zowel alleenstaande moeders als moeders in traditionele gezinnen, te doorbreken zonder de verantwoordelijkheid voor de opvoeding van hen af te nemen..

"Het is van belang om de morele dilemma"s waar ouders mee geconfronteerd worden weer onderwerp wan gesprek te maken, in plaats van de verantwoordelijkheid hiervoor aan deskundigen over te dragen of ervan uit te gaan dat iedereen in moreel en praktisch opzicht zelf maar moet uitmaken hoe men met de kinderen denkt om te gaan. ${ }^{\text {ina }}$

Via sociale vernieuwing, bijwoorbeeld subsidiëring van peuterspeelzalen in ondenwijsvoorrangsgebieden, wordt een dergelijke visie soms ook politiek uitgedragen, al bestaat het gevaar dat begrippen als 'risico-gezinnen' en diagnostische termen uit de jeugdhulpwerlening een stigmatiserende werking hebben, die toch 'de illusie" van gezinsharmonie in stand houden en daarmee tevens, onder andere door het eenzijdig benadrukken van cultuurverschillen, klassediscriminatie nieuw leven inblazen. ${ }^{\text {|a }}$ De Raad voor het Jeugdbeleid heeft als aanvullend opvangarrangement het idee van een "tweede huis' naar buiten gebracht: "een ontmoetingsplaats voor kinderen waar van alles te beleven is, maar waar ze ook kunnen uitrusten of huiswerk maken". ${ }^{13 *}$

Uit de veelheid aan studies binnen de pedagogiek zou met een zeker optimisme geconcludeerd kunnen worden dat voor de identiteitsvorming van een mens noch de culturele normen, noch de sociale categorisering en ook niet alleen de persoonlijke identiteit voorgoed en deterministisch bepalen wie en hoe iemand is of zal worden. Het niveau van de feitelijke gedragingen verschaft eigenlijk iedere ouder (moeder) en ieder kind steeds weer de kans om te experimenteren. Maar er zal gezocht moeten worden naar omstandigheden en middelen om die experimenteerruimte te vergroten.

130 Singer en Miltenburg (1991) p. 98-99.

131 Singer (1989) p. 265 e.k., Singer (1991) p. $171-184$, Knijn (1992).

132 Singer (1991).

133 Minow (1990) p. 267: "Yet these public assistance and social work interventions too often in effect controlled and restricted those people and subjected them to governmental regulation without protection against power imbalances."

Zie ook Malmberg (1996), Junger-Tas (1996), Goudena (1996).

134 Raad voor het Jeugdbeleid (1996) p. 9 en 10. 


\section{$5.4 \quad$ Samenvatting}

In demografische en sociologische beschrijvingen van het gezin wordt bij de verklaringen voor de veranderingen na de Tweede Wereldoorlog de nadruk gelegd op de loskoppeling van huwelijk, seksualliteit en voortplanting, de toegenomen arbeidsparticipatie van vrouwen en de groei van het aantal echtscheidingen. Alleen de opvoedingsfunctie blijkt in veel gevallen een te smalle basis te zijn voor de instandhouding van het gezin. Het gezin wordt over het algemeen nog wel gezien als de ideale opvoedingsomgeving voor kinderen. $\mathrm{Er}$ is nog nauwelijks aandacht voor de invloeden van niet-Westerse culturen in onze samenleving. Door de vergrote mobiliteit en migratie lijkt dit wel een interessant item te zijn, ook in de ontwikkeling van een visie op een begrip als 'family life'.

Ten aanzien van het moederschap bestaan ambivalente verwachtingen. De plicht tot voortdurende aanwezigheid lijkt te veranderen in een ideaal van voortdurende responsiviteit en beschikbaarheid. De relatie tussen buitenshuis werkende moeders en alleenstaande moeders en hun kinderen wordt aanvankelijk geproblematiseerd, hetzij door een negatief effect op de schoolprestaties hetzij door afwijkend, crimineel gedrag van de kinderen te onderzoeken. De sociaaleconomische omstandigheden waarin het kind opgroeit, blijken echter voor beide effecten van veel groter belang dan de activiteiten of de leefvorm van de moeder. Vrouwen zelf zijn ook ambivalent over de moederrol. Traditioneel ingestelde moeders lijken het meest tevreden, behalve degenen die niet in de sociaaleconomische omstandigheden verkeren om hun moederschap waar te maken op de manier die ze zouden willen. Vrouwen die naast het moederschap nog andere ambities hebben om zich maatschappelijk te ontplooien buiten het gezin om, kampen soms met dubbele loyaliteiten, hetgeen nogal eens tot schuldgevoel en uitputting leidt. Dat lijkt nauw samen te hangen met het soort werk dat vrouwen hebben en met de activiteiten die ze doen. Vooral de meer individualistisch ingestelde vrouwen die wel ambities hebben, maar qua opleiding, geld, kinderopvang of anderszins niet de mogelijkheid hebben die te realiseren lijken zich het ongelukkigst te voelen. Vanuit de overheid is er aanvankelijk een op het kostwinnersmodel gerichte politiek gevoerd. Moeders werden geacht thuis te blijven en ontmoedigd om betaald te gaan werken. Mede door het emancipatiebeleid, dat een sterk economische invulling heeft gekregen, worden vrouwen nu sinds korte tijd gestimuleerd om zich een plek op de arbeidsmarkt te verwerven.

De hulpverlening krijgt vooral te maken met moeders die het moeder zijn met werkloosheid en bijstandsafhankelijkheid moeten combineren en met allochtone huishoudens. De ondersteuning die geboden wordt lijkt uit te gaan van blanke middle-class gezinsidealen en van ontwikkelingspsychologische beelden omtrent jonge kinderen. Vooral allochtone moeders geven aan dat zij meer ondersteuning bij de opvoeding van oudere kinderen wensen. Maar ook dat hun eigen ambities meer centraal zouden moeten staan, in plaats van de moeder-kind relatie. Bovendien moet er meer oog 


\section{Hoofdstuk 5}

zijn voor de cultuurgebonden sociale netwerken, waarin met name de grootmoeder een belangrijke rol vervult. In de theorievorming over de ontwikkeling van kinderen, zijn er grofweg twee stromingen te onderscheiden. De ene, ontwikkelingspsychologische, gaat sterk uit van het gezins- en familieverband. De driehoek vader-moeder-kind en de intergenerationele loyaliteit lijken belangrijke pijlers. De andere, meer pedagogische, richt zich op de autonome ontwikkeling van het kind, diens eigen leefwereld, waarin zowel de ouders als andere volwassenen en vooral leeftijdgenoten een plaats krijgen. Er lijkt een ander idee over identiteitsvorming aan de verschillen ten grondslag te liggen. Binnen beide stromingen wordt veel waarde gehecht aan een veilige omgeving voor het jonge kind. Omtrent de ontwikkelingen van oudere kinderen treedt veel meer verschil in opvattingen aan het licht. 


\section{'Het belang van het kind': de overheid en de privésfeer}

\section{Inleiding}

Met name vanuit de vrouwenbeweging is het onderscheid tussen de publieke en de privésfeer bekritiseerd. Enerzijds omdat productieve bijdragen uit de privésfeer niet als zodanig economisch en politiek gewaardeerd worden. Anderzijds omdat de privésfeer voor veel vrouwen en kinderen niet de machtsvrije en affectieve sfeer is, die aan het onderscheid ten grondslag ligt. Privê is er missschien geen sprake van overheidsbemoeienis, maar er spelen wel andere onderdrukkingsmechanismen. Waar in de beleving van mannen family life en privacy vaak in elkaars verlengde liggen, is het voor veel vrouwen en kinderen belangrijk die begrippen te onderscheiden. ${ }^{3}$ Het recht op privacy biedt hen de mogelijkheid om aan het isolement van gezin en familie ontsnappen. Het lot van moeders en kinderen is in de maatschappelijke werkelijkheid vaak nauw met elkaar verbonden. Een eigen netwerk aan relaties kan essentieel zijn bij het realiseren van andere grondrechten en in die zin lijkt de overheid een taak te hebben om de condities daarvoor te scheppen. In dit hoofdstuk komt dan ook de ambivalente houding van vrouwen (c.q. verzorgers) en kinderen ten opzichte van de overheid aan de orde. Enerzijds mag er geen overheidsbemoeienis zijn met het privê, gezins- en familieleven, anderzijds moet de overheid de voorwaarden scheppen om realisatie van een volwaardig privé- en familieleven voor alle participanten mogelijk te maken. In dit hoofdstuk ga ik eerst na op welke wijze in het recht inhoud aan het begrip "zorg voor kinderen" gegeven wordt. Als uitgangspunt neem ik daarbij een aantal verdragsbepalingen, waarin "the best interests of the child", "farmily life" en "private life" gegarandeerd worden. ${ }^{2}$ Vanzelfsprekend komen daarbij de ontwikkelingen in verband met de autonome rechten van het kind aan de orde. In eerste instantie gaat het hier echter vooral om de materiële invulling van begrippen. Gezien de ambivalenties omtrent impliciet en expliciet geformuleerde rechten en plichten van moeders in relatie tot het belang van hun kinderen, wordt ook inge-

1 Horizontale verhoudingen zijn veelal geen gelijkwaardige verhoudingen. Via het recht op privacy kunnen ook betrekkelijk machtelozen mogelijk een beroep op hun andere grondrechten doen. Niet alleen ten opzichte van de overheid, maar ook ten opzichte van ogenschijnlijk gelijkwaardige burgers. Zie 0.a. Eisler (1987) p. 292-296. Zie ook Goldschmidt en Holtmaal (1993) p. 150-151. 
gaan op daarop betrekking hebbende verdragsbepalingen. Verder wordt bekeken in hoeverre positieve verplichtingen voor de overheid voortvloeien uit de verdragsbepalingen. En in hoeverre vrijwaring van ongewenste overheidsinvloed in de privesfeer varn de burgers nog gewaarborgd wordt. De overheid heeft via beleid en regelgeving nu al grote invloed op de onderlinge verhoudingen in de familiesfeer. ${ }^{3}$ Voor ouders die expliciet afhankelijk zijn van de overheid, door bijwoorbeeld een witkeringssituatie, werkloosheid, armoede of detentie, geldt dit in versterkte mate. De legitimatie en begrenzing van overheidsbemoeienis in de privesfeer heeft voor een deel al ter discussie gestaan in het arbeidsrecht, het onderwijs en de gezondheidszorg. Wellicht zijn hier aanknopingspunten te vinden om gewenste overheidsbemoeienis in de privesfeer van gedetineerden en hun kinderen in te vullen.

\subsection{Autonome rechten van kind}

Naar aanleiding van het ontstaan van het VN-Kinderverdrag zijn er interessante discussies gevoerd over het nut en de noodzaak van het vaststellen van speciale rechten voor kinderen. Voor een deel overlappen die discussies over nut en noodzaak elkatr.

Bij het debat over het nut staat onder meer de effectiviteitsvraag centraal. Vanuit machtstheorieën is het de vraag wat kinderen aan rechten hebben die ze toch niet kunnen effectueren. Daartegenover staat 'the theory of interests', die in het formuleren van rechten niet zozeer de direct afdwingbare rechten ziet, maar veel meer een verwoording van de belangen en behoeften van kinderen, die vervolgens kunnen leiden tot verplichtingen van anderen. Na formulering van de rechten kunnen pas de condities worden benoemd waaronder anderen aan die verplichtingen kunnen voldoen. Binnen familieverhoudingen, zou de staat voorwaarden moeten scheppen waarbinnen ouders hun kinderen tot hun recht kunnen laten komen.

Omtrent de noodzaak van specifieke kinderrechten is de vraag interessant of kinderen, als 'mensen', niet gewoon onder de mensenrechtenverdragen vallen. Het antwoord hangt af van het perspectief waarin de rechten van kinderen gezet worden: dat van de volwassene, dat van het kind in zijn eigen leefwereld of dat van het kind met nog niet ingevulde ontwikkelingsmogelijkheden. In de 'gewone" mensenrechtenverdragen staat het perspectief van de volwassene centraal. De ontwikkeling tot 'een normale, gezonde volwassene' lijkt hoofddoel van leven. ${ }^{4}$ Daarmee wordt de suggestie gewekt dat alleen het leven als (potentiële) volwassene telt en het leven van het kind geen waarde op zichzelf heeft. Juist om het die waarde wel te geven kan ervoor

3 Zie ook Mulder (1995) p. 77, Van den Brink en Loenen (1996) p. 29-30.

4 Deze optie lijkt dezelfde als die van 'de mannelijke rechtsburger' waarover al eerder werd vastgesteld dat er een gendered en aan de verlichtingsfilosofie ontleend mensbeeld aan ten grondslag ligt. 
gepleit worden de existentie van het kind in zijn eigen leefwereld op een bepaald moment als centrale invalshoek te nemen. Om vervolgens het gevaar van teveel inperking (leveling down) te voorkomen is er nog een derde benadering ten aanzien van specifieke kinderrechten te onderscheiden, waarbij wel het ontwikkelingsperspectief wordt meegenomen, maar dan vanuit een 'vrije' positie van het kind. Een recht op ontwikkeling dus, maar waarbij niet vanuit een soort resultaatdenken een bepaalde 'normale' ontwikkeling deterministisch wordt vastgesteld.

Campbell pleit ervoor de verschillende invalshoeken te onderscheiden:

"In the case of children (that is, in law 'minors') it is helpful to distinguish between their interests as persons (which they have in common with all other persons), as children (which they have as immature and dependent persons), as juveniles (which they develop as they approach maturity) and as future adults (which relate to their future interests as adults). This analysis enables us to refine the principle that 'the best interests' of the child should determine how they are treated by parents, state, and others, and may lead us to give rather more emphasis to the rights of the child rather than those of the future adult:."

Hij vindt dat er niet in verschillende stadia van ontwikkeling met bijbehorende rechten verder gedacht moet worden, maar dat de belangen van kinderen in hun kindertijd een continu aspekt van het leven vormen die ook relevant zijn voor de adolescent en volwassene.

"Maybe we should attribute more moral and political weigt to "childishness" as an aspect of all stages of normal human life. ${ }^{47}$

Beide discussies, die omtrent de mogelijkheid voor kinderen om hun rechten zelf te effectueren en die omtrent de waarde van het creëren van eigen, ook materiële, rechten in zichzelf, komen in Nederland ook aan de orde. Onder andere in verband met de ratificatie van het $\mathrm{VN}$-Kinderverdrag. In de Memorie van Toelichting op

5 Campbell (1992) p. 1.

6 Waaronder ook de afhankelijkheid van een netwerk aan relaties. Zie $O$ 'Neill (1992) p. 24-42.

7 Campbell (1992) p. 21. Zie ook Eekelaar (1992) p. 234. "It would be logically possible to have framed the Convention on the Rights of the Child as a list of duties owed by adults to children. But that would have revealed a negative, suspicious, view of human nature; it would have seen people as servile, responding best to restraint and control. The strength of rights formulation is its recognition of humans as individuals worthy of development and fuliriment. This is not an appeal to narrow self interest. On the contrary, it recognizes the insight that people can contribute positively to oihers only when they are respected and fulfilled. And to recognize people as having rights from the moment of their birth continuously into adulthood could turn out, politically, to be the most radical step of all."

Vgl. de parallel met Wegelin over het samengaan van autonomie en loyaliteit. (hoofdstuk 5) 


\section{Hoofistuk 6}

de Goedkeuringswet van het Verdrag wordt ingegaan op het belang van een specifiek verdrag voor kinderen:

"Ten eerste worden in onderhavig verdrag de algemene rechten van de mens, zoals onder andere verwoord in de Universele Verkllaring van $1948 \mathrm{en}$ in beide verdragen van 1966, niet alleen opnieuw bevesigd maar ook toegespitst op de gewenste rechten van kinderen.

Ten tweede zijn andere rechten zoals adoptie, het onderwijs en het contact met ouders alleen op jongeren toepasselijk en op hen toegeschreven.

Ten derde zijn er ook nieuwe rechten, zoals een richtsnoer voor de verhouding grondrechten van kinderen en ouderlijk gezag en (internationale samenwerking op het gebied van) het gehandicaptenbelleid, in het verdrag opgenomen. Het is daarbij van belang om er op te wijzen dat het verdrag ook meer beoogt dan louter en alleen de bescherming van het kind ten opzichte van bepaalde daden of praktijken. Men heeft het kind ook het recht gegeven on te genieten van of toegang te krijgen tot bepaalde diensten. En nog meer heeft men het kind het recht gegeven te participeren door zijn of haar mening te uiten, wrij te vergaderen en zich te verenigen."

In Nederland is het VN-Kinderverdrag in 1995 geratificeerd."

\subsubsection{Relevante bepalingen}

Voor het onderwerp van mijn onderzoek zijn vooral de volgende artikelen uit het Kinderverdrag van belang:

- art. 9 lid 3 en 4 : het recht op contact met de ouders. ${ }^{10}$ In de Memorie van Toelichting wordt verwezen naar paragraaf 6 uit de preambule: Een kind dient voor de volledige en harmonieuze ontplooiing van zijn of haar persoonlijkheid op te groeien in een gezinsomgeving, in een sfeer van geluk, liefde en begrip." Volgens het derde lid van dit art. 9 dienen Staten die partij zijn het recht van een kind op contact met de ouders te eerbiedigen, tenzij dit strijdig zou zijn met het belang van het kind. Met 'scheiding' in het eerste lid van art. 9 worden dan ook die gevallen bedoeld waarin een kind door optreden van overheidswege uit zijn gezinssituatie wordt gehaald, omdat het niet in het belang van het kind zou zijin om daar nog langer te verblijven, In het vierde lid gaat het echter om gevallen waardoor anderszins een scheiding tussen ouder(s) en kind teweeg wordt gebracht zoals inhechtenisneming, gevangenneming, verbanning, deportatie. Dan rust op

8 TK 1992-1993, 22855 (R 1451), nr. 3, p. 7.

9 Trb., $1995,92$.

10 Vgl. art 23 lid 4 IVBPR en art. 8 EVRM.

11 In de vakliteratuur is een discussie ontstaan naar aanleiding van de restrictieve invulling die Crombag en Elzinga (1989) gewen aan "gezinsomgeving". Van Wijk (1992) p. 152. 
de staat de minimumverplichting om het kind te informeren over de verblijfplaats van de ouder."

In Groot Britannië is gelijktijdig met de officiële rapportage aan het VN-

Committee voor de Rechten van het Kind een rapport aangeboden door de Children's Rights Development Unit. Met betrekking tot kinderen van gedetineerden wordt daarin opgemerkt:

"Lack of money for visits, distress experienced during visits, the infrequency and unsatisfiactory nature of contact all add up to a picture of wery clear failure to acknowledge the rights of children whose parents are imprisoned. The current arrangements fail to take account of children's best interests (Article 3), of childiren's rights to maitain contact with both parents (Article 9) and of their right not to be discriminated against because of the status of a parent (Article 2) ${ }^{n}{ }^{n}$

Ook in Frankrijk worden rechten van kinderen van gedetineerden gebaseerd op onder andere deze bepaling. ${ }^{14}$

- art. 16: het recht op privacy. ${ }^{15}$ Zoals in de inleiding is gesteld kan het recht op privacy een ingang bieden tot realisering van andere grondrechten, bij voorbeeld via eigen contacten en netwerken met generatiegenoten.

- art. 30: het recht op beleving van de eigen cultuur, belijden van de eigen godsdienst en bediening van de eigen taal voor kinderen van minderheden. ${ }^{16}$ In de Memorie van Toelichting wordt opgemerkt: ${ }^{17}$

"Indien kinderen uit minderheidsgroepen ervaren dat hun voldoende ruimte en stimulans wordt geboden om hun eigen cultuur te beleven en hun eigen taal te spreken (...) bevordert dat hun socialle integratie in de maatschappij."

Juist door de oververtegenwoordiging van minderheidsgroepen in gevangenissen, kan dit artikel interessant zijn bij voorbeeld in verband met voedingsvoorschriften, de ontwikkeling van de eigen taal en dergelijke. Niet alleen met betrekking tot kinderen, maar ook in relatie tot eventuele gemengde detentie en daaruit voortvloeiende verzorgingsarrangementen. Zeker wanneer na de detentie geen integratie in de Nederlandse samenleving zal plaatsvinden, maar terugkeer naar de eigen cultuur. ${ }^{18}$

12 Zie art. 27 Ambtsinstructie voor de politie, de Koninklijke Marechaussee en de buitengewoon opsporingsambtenaar.

13 CRDU (1994) p. 39, in : Lloyd (1995) p. 13.

14 Bruel (1996).

15 Vgl. art. 17 IVBPR, art. 8 EVRM, art. 10 Grondwet.

$16 \mathrm{Vgl}$. art. 27 IVBPR.

17 MvT. p. 42.

18 Zie voor een analyse van art. 27 IVBPR: Mulder (1993) p. 179-185. 


\section{Hoofdstuk 6}

- art. 37: het recht op bescherming tegen foltering, wrede e.d. behandeling en bestraffing. 19 De Nederlandse overheid heeft zowel ten aanzien van art. 10 IVBPR als van dit artikel een voorbehoud gemaakt met betrekking tot het gescheiden detineren van kinderen en volwassenen. Dit overigens met het oog op de detentie van jeugdige daders. ${ }^{\infty}$

- art. 40 lid 2: het recht op een rechtvaardige behandeling in strafzaken."

Beide laatste artikelen zijn interessant, omdat er voor een deel een overlap zou kunnen zijn tussen de groep jeugdige daders en de groep kinderen van gedetineerden. $^{2}$

Van alle bovenstaande bepalingen kan, in ieder geval op grond van analoge bepalingen uit andere mensenrechtenverdragen, aangenomen worden dat rechtstreekse werking mogelijk is. ${ }^{2 s}$

Een andere (voor de kinderen van strafwaardige ouders) interessante bepaling uit het verdrag kan zijn:

- art. 31: het recht op rust en vrije tijd. In de Memorie van Toelichting wordt gewezen op art. 22 lid 3 Grondwet waarin wordt voorzien in een verplichting van de overheid tot het scheppen van voorwaarden voor maatschappelijke en culturele ontplooiing en vrijetijdsbesteding. Met name het beleid gericht op stimulering van speelmogelijkheden wordt genoemd. ${ }^{24}$

Er wordt binnen de Europese Unie momenteel gewerkt aan een Draft European Charter on the Rights of the Child, waarin aan de kinderen van gedetineerden specifiek aandacht wordt geschonken ${ }^{25}$ :

19 Artt. 7, 9, 10 lid 2 IVBPR, artt. 3 en 5 EVRM, Verdrag tegen Foltering en andere wrede onmenselijke of onterende behamdeling of bestraffing.

20 Vgl. art. $77 \mathrm{Sr}$ e.v. Zie over jeugdige delinquenten Koens en De Jonge (1995).

21 Vgl. artt. 9,14, 15 IVBPR, artt. 3,5 en 7 EVRM.

22 Als er al een verband aangetoond kan worden, lijkt dat seksegebonden te zijn. Jeugderiminaliteit is vooral jongenscriminaliteit en met name de criminaliteit van de vader wordt als ến van de mogelijke risicofactoren genoemd. Zie Kocns en De Jonge (1995) p. 11-7, Bouw (1995), Junger-Tas (1996) p. 21

23 TK 1992-1993, 22855 (R1451), nr. 3, p. 9. In een zaak over een ongangsrecht woor cen kind van een verwekker die dat niet wilde, is rechtstreeks beroep op art. 7 van het VN-Kinderverdrag toegestaan, zij het dat het verzoek niet werd gehonoreerd. (HR 22 december 1995, RvdW 1996, 10, zie ook NJCM-bulletin. 1996/3, m.n. van T. Loenen).

24 TK 1992-1993, 22855 (R 1451), nr. 3, p. 42.

25 Zie Resolutie van het Europees Parlement over de problemen wan kinderen in de gemeenschap. (A3-314/91, publ. EG nr. C 13/534) onder:

"2. verlangt cen bindend Europees Handvest voor de rechten van het kind; (...)

24. is van mening dat onderzoek moet worden werricht naar de situatie wan kinderen waarvan de moeder in hechtenis is genomen, respectievelijk naar de gevolgen op de lange termijn voor kinderen 
Any child who has one or both parents in prison must be allowed to maintain contact with them. Young children living with their mothers in prison must have the benefit of suitable facilities and care. The Member States shall guarantee that such children attend school outside prison. ${ }^{\text {a26 }}$

Of het kind zelf op grond van diverse verdragsbepalingen een zelfstandige rechtsingang heeft, is in veel gevallen nog onduidelijk.

- In verdragsbepalingen zelf zijn -soms- beperkingsvoorschriften opgenomen, zie bijvoorbeeld de bijzondere beperkingsgronden in de leden 2 van de artt. 8,9,10 en 11 EVRM. Deze moeten wel aan de volgende voorwaarden voldoen:

- bij de wet voorzien zijn;

- nodig zijn in een democratische samenleving;

- strekken ter bescherming van een uitdrukkelijk genoemd belang.

Via de leer van de "legitimate limitations" is door de Europese Commissie voor de Rechten van de Mens de beperking van grondrechten van personen in een bijzondere positie gerechtvaardigd, zoals van gedetineerden. ${ }^{27}$ Dit zijn impliciete beperkingsgronden. Het Hof heeft deze beperkingsgronden slechts aanvaard als er een klacht is over een bepaald verdragsartikel waarin geen expliciete beperkingsgronden zijn geformuleerd, dus niet voor de art. $8 \mathrm{t} / \mathrm{m} 11$ EVRM en art. 2 lid 4 Vierde Protocol. ${ }^{28}$ Het is de vraag of de minderjarige zich op grond van zijn leeftijd ook in zo'n bijzondere positie bevindt. ${ }^{*}$ Met betrekking tot het VNKinderverdrag wordt dat in de Memorie van Toelichting met zoveel woorden gezegd:

"Kinderen vallen onder het ouderlijk gezag. Bij de uitoefening van het ouderlijk gezag kunnen ouders de uitoefening van een grondrecht door een kind beperken."

en:

"De ouders en voogden wordt cen primaire rol toebedeeld bij het leiding geven aan en het begeleiden van kinderen; zij dienen daarbij echter rekening te houden met de toenemende capaciteiten van deze kinderen en dus navenant terug te treden. ${ }^{m 30}$

die een gestoord gezinsleven als gevolg van gevangenisstraf hebben gehad, of waarvan teen der ouders in de gevangenis heeft verbleven; is van mening dat tevens een grondig onderzoek moet worden verricht naar de situatie en leefwijze van kinderen in groepen of sekten woor wat betreft de naleving van de beginselen die zijn opgesomd in het VN-Verdrag over de rechten van het kind" .

27 Smaers (1994). Zie ook hoofdstuk 4.

28 EHRM 18 juni 1971, de Landloperij-zaken, Series A, vol. 12. EHRM 21 februari 1975, Golder, Series A, vol. 18, NI 1975, 462, m.n. EAA.

29 O.a. De Boer (1990) p. 20-21 en De Bruijn-Lückers (1994) p. 56-57.

30 TK 1992-1993, 22855 (R 1451), nr. 3, p. 11. 
- Ook kan er sprake zijn van samenloop of botsing van grondrechten van meer partijen. Bij samenloop hangt het van de in onderling verband te beschouwen omstandigheden van het geval af welk belang de doorslag hoort te geven. Bij botsing gaat het om de situatie waarin een legitieme uitoefening van een grondrecht door een persoon een inbreuk betekent op het grondrecht van een ander persoon. Juist in familiekwesties zal er meestal sprake zijn van samenloop en/of botsing van grondrechten, bijvoorbeeld op grond van de beide leden van art. 8 EVRM. Het belang van het kind zal dan mogelijk prevaleren. Bij kinderen van wie een verzorgende ouder gevangen zit, zal het de vraag zijn of er sprake is van samenloop of botsing tussen de belangen van die ouder en dat kind maar vooral of en zo ja, hoe de overheid daarover een onpartijdig oordeel zal kunnen vellen. De straffende overheid is immers verantwoordelijk voor de inbreuk op het grondrecht.

In feite is het lot van kinderen zeer sterk verbonden met dat van de ouders en daarmee ook hun rechtspositie. Pas wanneer het kind 'als rationele mens' mee gaat doen, krijgt het een zelfstandiger positie. Het Verdrag bevat echter geen voorzieningen waardoor het kind zelf zijn rechten kan effectueren. In principe treedt de wettelijk vertegenwoordiger op namens het kind. In de Memorie van Toelichting bij het Goedkeuringsverdrag wordt opgemerkt dat kinderen hun mening in procedures kenbaar mogen maken.

"Er mag namelijk van worden uitgegaan dat kinderen, zeker vanaf de leeftijd wan twaalf jaar, in staat zijn zich een mening over de eigen situatie te vormen en deze mening duidelijk onder woorden te brengen. ${ }^{331}$

Na verwijzing naar art. 1:162 a BW en art. 1:250 BW wordt vervolgens aangegeven dat het voornemen bestaat de bijzonder curator ook een taak te geven indien er een niet-vermogensrechtelijke belangentegenstelling tussen ouders en kinderen bestaat. Er wordt nog bezien welke functie een jeugdombudspersoon zou kunnen hebben. Verder wordt melding gemaakt van het klachtrecht in de jeugdhulpverlening, maar dat zal zich niet in eerste instantie tegen de ouders richten. Op het nagenoeg ontbreken van een eigen rechtsingang voor het kind, dus met name de formele positie, heeft het juridisch debat in Nederland zich toegespitst. ${ }^{32}$

Extra ingewikkeld is hier ook dat, met name bij zeer jonge kinderen, de zelfstandige rechten van het kind ten opzichte van de ouder veelal bepleit worden op advies of initiatief van dezelfde overheid, bijvoorbeeld via de Raad voor de Kinderbescherming,

31 TK 1992-1993, 22855 (R 1451), nr. 3, p. 12.

32 O.a. Van Emmerik (1992) p. 17, Rutten-Roos (1992), De Bruijn-Lückers (1990) p. 374, Von Brucken Fock (1990), De Langen (1990) p. 183, De Boer (1990) p. 21. Zie ook redactionele kanttekeningen. ((G.H.A.S.) in RM Thenis-8 (1993) p. 369-371. Zie ook het Europees. Kinderverdrag dat in januari 1996 door de Raad van Europa ter ondertekening is opengesteld (in: Jansen (1996) p. 137-138). 
die anderzijds vaak in de beklaagdenbank zit als degene die juist inbreuk maakt op het respect for family life, hetgeen de positie van het kind uiteindelijk niet sterk maakt. ${ }^{33}$

Ook Doek heeft nog eens benadrukt dat de regering een jeugdombudsman aan zou moeten stellen, waar minderjarigen hun klachten over schending van in het $\mathrm{VN}$ Kinderverdrag opgenomen rechten kunnen indienen. Eventueel zou de ombudsman ook in rechte namens het kind moeten kunnen optreden, maar de hoofdtaak zou zelfstandig onderzoek en bemiddeling moeten zijn. ${ }^{34}$

\subsubsection{Waartoe verplichten rechten?}

Volgens Van den Burg lijkt enige terughoudendheid geboden bij het bepleiten van kinderrechten in gezins- en opvoedingssituaties, met uitzondering van de elementaire behoeften zoals huisvesting, voeding en seksuele integriteit. ${ }^{35}$ De bezwaren tegen juridische erkenning van kinderrechten zijn vooral

- dat het moeilijk is om de rechten te effectueren;

- dat problemen in de ouder-kind relatie in een oppositionele sfeer worden getrokken;

- dat de contextgebonden zorgaspecten van de ouder-kindrelatie niet aan bod (kunnen) komen. Het recht omvat slechts een minimummoraal en de geformuleerde rechten zijn minimumrechten;

- dat in het rationele rechtenvertoog de essentiële ongelijkheid in opvoedingsrelaties niet aan bod komt. De emancipatoire functie van het recht is hier niet echt zinvol, omdat de opvoedingssituatie een inherente ongelijkheid kent.

"Door teweel te hameren op de beoogde gelijkheid waaryoor de oppositionele rechten een middel zijn, wordt een relatiemodel geintroduceerd dat vreemd is an de opvoedingssituatie". ${ }^{36}$

Van den Burg noemt wel "relatief anonieme instanties als de staat, de rechter, de school", waar oudere kinderen mee te maken hebben en tegen wie ze ook met behulp van kinderrechten voor zichzelf op zouden kunnen komen. ${ }^{37}$

Volgens Raes maakt de beweging voor de "kinderrechten" in het westen van de gelegenheid gebruik om een eigen interpretatie van kinderrechten door te drukken.

33 Vgl. Van Wijk (1992) p. 153. Zie ook: Damen (1992) p. 144-179.

34 Doek, (1995) p. 19. In Noorwegen bestaat het instituut van de jeugdombudsman overigens al.

35 Van den Burg (1993).

36. Van den Burg (1993) p. 72-73. Hij zet op grond van dit laatste argument overigens ook vraagtekens bij de vergaande juridiserïng van patiêntenrechten. Mijns inziens kunnen dezelfde kanttekeningen geplaatst worden binnen het penitentiaire recht (zie hoofdstuk 4).

37 Van den Burg (1993) p. 73. 
"Waar in de Conventie de nadruk ligt op een geheel aan sociale grondrechten voor het kind, wordt hier de nadruk gelegd op de nood aan erkenning van subjectieve rechtsclaims die kinderen tegenover

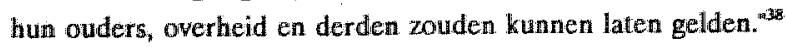

Hij plaatst deze beweging tegenover de anti-juridische kritiek uit de jaren zestig:

"De juridische noties/illusies van wilssoevereiniteit en formele gelijkheid, de primauteit van kontraktuele relaties en de vermeende rationaliteit wan het rechtssubjekt werden ontmaskerd als ideologische strukturanten om memsen in het keurslijf van kapitalistische marktverhoudingen te dwingen" ${ }^{39}$

\section{Nadat het}

"inzicht weld won dat a-juridische samenlevingsvormen en konfliktoplossingsstrategieèn evenmin de verhoopte emancipatie inkarneerden en niet zelden even of zelfs meer aliënerend en repressief zijn dan het afstandelijke rechit

is de opstelling gewijzigd. De individuele rechten moeten worden versterkt en de staatsbemoeienis teruggedrongen. Onverdeeld positief vindt Raes dit teruggrijpen naar de klassieke rechtsgronden niet:

"emancipatic en verrechtelijking kongrueren niet wanzelfsprekend en kinderrechten kunnen een alibi vormen om alternatieve en experimentele vormen van jeugdwerk af te bouwen, te bezuinigen". ${ }^{\circ}$

De erkenning van kinderrechten past wat Raes betreft well in een strategie waarin rollen van ouders, welzijnsinstellingen, rechters etcetera worden gezuiverd en hun bevoegdheden duidelijker worden omlijnd.

In haar openbaar college, gegeven in het kader van de Belle van Zuylen-leerstoel, wijst De Langen well op het belang van adequate voorzieningen op veel maatschappelijke terreinen, waardoor de overheid ouders moet ondersteunen in hun verzorgende en opwoedende functie. $\mathrm{Zij}$ noemt daarbij

"de jeugdgezondheidszorg, de kinderopvang, het onderwijs met name voor migrantenkinderen, huilswesting voor jonge gezinnen, opvang- en recreatiemogelijkheden voor jeugdigen"."!

38 Raes (1989) p. 324. Vgl. De Ruiter (1993) p. 187 e.v.. Hij stelt voor de betekenis van het werdrag niet aan de klassieke mensenrechtenindeling te toetsen (dan hebben volgens hem kinderen geen politieke rechten), maar aan de drie P's: provision, protection and participation. Vervolgens bekijkt hij dan weer in hoeverre het verdrag de participatie van de minderjarige regelt.

39 Raes (1989) p. 324.

40 Raes (1989) p. 326.

41. De Langen (1993) p. 17. 
Arbeidstijden en andere voorzieningen zouden het voor het ouders mogelijk moeten maken om beiden zowel buitenshuis te werken als voor hun kinderen te zorgen. En er moet een sociaalzekerheidssysteem bestaan waarbij het ook binnen cenoudergezinnen mogelijk is en blijft om kinderen te verzorgen en op te voeden.

Een dergelijke materiële invulling zou naar mijn idee ook voorstelbaar zijn in het belang van kinderen van strafwaardige primaire verzorgers, waarbij buiten en desnoods binnen de detentiesituatie noodzakelijke voorzieningen voor ouder en kind geschapen worden.

\subsubsection{Feministische visies}

De positie van vrouwen in het (kinder)rechtendiscours is ingewikkeld. Belangen van vrouwen en kinderen zijn over het algemeen nauw verweven. Als de condities voor kinderen goed zijn, zijn ze dat vaak ook voor vrouwen. In samenlevingen waar behoeften van kinderen genegeerd worden of waar kinderen misbruikt worden in het kader van bij voorbeeld arbeld of seksuele exploitatie, is de positie van vrouwen meestal ook slecht. Maar ook de rol van de vrouw als primair verzorgende ouder heeft vaak geleid tot economische afhankelijkheid, armoede en/of onderdrukking. Volgens Olsen zijn kinderen als gijzelaars gebruikt om vrouwen aan slechte huwelijken en thuissituaties te binden. ${ }^{42}$ In dat opzicht kan bescherming van kinderen gebruikt worden om levens van vrouwen te controleren.

In de feministische kritiek op het VN-Kinderverdrag komen de ambivalenties van vrouwen ook naar voren. Olsen onderscheidt vier feministisch-juridische benaderingswijzen: ${ }^{43}$

- de "Legal Reformist";

- de "Law as Patriarchy" (cultural feminists');

- de "Feminist Critical Legal Theory";

- de "Post Modern Feminism".

Aamhangers van de "Legal Reformist"benadering zijn het meest te vinden onder juristen. $\mathrm{Zij}$ proberen wia taalkundige ontleding en kritische analyses omissies in het recht bloot te leggen. Gebaseerd op het gelijkheidsbeginsel willen ze achterstandssituaties opheffen en via een materiële invulling van dat beginsel vrouwen (en andere achtergestelden) van dezelfde privileges als mannen laten genieten. Het eerste doel is vrouwen tot hun recht te laten komen binnen het bestaande rechtssysteem. Al zouden volgens sommigen in zijn algemeenheid grotere maatschappelijke veranderingen gewenst zijn. Positief aan het VN-Kinderverdrag is vanuit deze optiek dat de bepalingen genderneutraal geformuleerd zijn. Hoewel door de gebruikte taal de onzichtbare rolverdeling in zorgtaken als vanzelfsprekend bevestigd kan worden, 


\section{Hoofdrtuk 6}

is het gunstig dat de rechten positief geformuleerd zijn en daardoor juist een handvat bieden om de situatie van de machtelozen te verbeteren. Gevreesd wordt wel dat door de gelijke benadering van vaders en moeders, vaders rechten gaan claimen op grond van het verdrag. Claims die gehonoreerd kunnen worden als geen rekening zou worden gehouden met de ongelijke uitgangspositie en woorgeschiedenis tussen de ouders.

Aanhangers van de "Law as Patriarchy" benadering zijn juist bij het vaststellen van kinderrechten zeer actief. ${ }^{\text {s }}$ Zorgrelaties moeten ook in het recht (op)gewaardeerd worden. Het grootste maatschappelijke probleem is niet de achterstelling van vrouwen, maar het achterstellen van waarden, die met vrouwen geassocieerd worden. Deze stroming sluit aan bij de communitaristische kritiek op het atomistische karakter van rechten.$^{45}$ Rechten beschermen de individuele, persoonlijke autonomie, meer dan menselijke relaties of netwerken. In die optiek vormen de rechten van het kind enerzijds een doorbraak, als erkenning van "een recht op zorgrelaties", maar anderzijds is de transformering in "rechten" een verarming. De verplichtingen van ouders en andere volwassenen zouden meer benadrukt moeten worden, als voorwaarden waaronder relaties kunnen opbloeien.

Binnen de "Feminist Critical Legal Theory" wordt vooral het onderscheid tussen de publieke en de privésfeer aan de orde gesteld. Het VN-Kinderverdrag kan daarbij zowel gezien worden als de doorbreking van die dichotomie, maar ook als bevestiging van de conventionele plaats van het gezin als centrum van affectieve relaties. Dan zou het onderscheid tussen een productieve en een affectieve wereld blijven bestaan. Een ander terugkerend punt van kritiek is de presumptie van wilsvrijheid en de schijn van wilssoevereiniteit in het recht. Die is in het VN-Kinderverdrag gerelateerd aan de (wassende) leeftijd van het kind. Voor de rest vindt men dat er te weinig aandacht wordt besteed aan machtsverschillen en aan daarmee verbonden conflicten binnen bijvoorbeeld families.

De "Post-Modern Feminism"stroming stelt zich kritisch op ten aanzien van de universaliteit van rechten. Door te abstraheren van concrete situaties, bestaat het gevaar dat het VN-Verdrag in de praktijk vooral ten goede komt aan blanke, mannelijke, relatief geprivilegieerde kinderen.

Olsen zelf komt uiteindelijk tot een positieve waardering van het VN-Kinderverdrag. Ondanks alle haken en ogen die er aan kunnen zitten, is het beter dat het er wel is dan dat het er niet zou zijn. "Overall it may stand to improve the status and lives of children". 
Het kan zijn dat ongewild stereotiepe opvoedingspatronen via recht bestendigd worden. Hetzij door vrouwen in hun traditionele moederrol te bevestigen, hetzij door vrouwen die daarvan afwijken daarmee nog eens negatief te stigmatiseren. Sekseneutrale formuleringen leiden nu een maal niet vanzelf tot meer differentiatie in maatschappelijke verhoudingen. $\mathrm{Zij}$ zullen die eerder bestendigen en in het geval van verzorgende vaders zelfs extra voordeel op kunnen leveren voor een enkeling uit de dominante groep die zich niet stereotiep gedraagt. Zolang verzorgende functies niet zijn ingebed in andere maatschappelijke functies, werk, opleiding, sociale contacten, hobbies, vrije tijd, kan het 'huisvrouwensyndroom' zich opnieuw onder verzorgende ouders manifesteren. ${ }^{47}$ En dat gebeurt mogelijk in verscherpte mate wanneer zij in totale instituties verblijven. Tegelijkertijd moet het kind niet met het badwater worden weggegooid door zorgtaken uitsluitend negatief en als behorend bij een als vrouwelijk getypeerde "slavenmoraal" te kenschetsen. ${ }^{48}$

Daarom zijn zowel de nondiscriminatiebepalingen als de bepalingen met betrekking tot het moederschap in het VN-Vrouwenverdrag belangrijk. Enerzijds doen zij recht aan de noodzakelijke bescherming van het moederschap. Anderzijds benadrukken zij de plicht tot nonstereotypering. I $\mathrm{k}$ beperk mij tot de volgende bepalingen:

- art. 1: het discriminatiebegrip. Er wordt een zeer ruim discriminatiebegrip gehanteerd. Het bevat zowel directe als indirecte discriminatie. Er is voor de aangeklaagde wel ruimte (ook bij directe discriminatie!) om rechtvaardigingsgronden voor ongelijke behandeling aan te voeren, maar die zullen aan strikte eisen moeten voldoen. De regering heeft echter gesteld dat zij de norm vooral als een positieve verplichting wil uitleggen. In samenhang met aanbeveling 19 van de $\mathrm{CEDAW}^{\text {so }}$, kan het discriminatieverbod zich uitstrekken tot terreinen die niet expliciet in het verdrag zijn genoemd. Over de vraag of het discriminatieverbod alleen gericht is op formele gelijke behandeling of ook op materiële gelijkheid bestaat nog onduidelijkheid."

- art. 4: over voorkeursbehandeling en moederschap. Er mogen tijdelijke bijzondere maatregelen getroffen worden die gericht zijn op feitelijke gelijkstelling van mannen en vrouwen. Er bestaat uitsluitend op grond van deze bepaling geen positieve verplichting. Wellicht kan die er wel in gelezen worden in de context

47 Vgl de jaren zestig en zeventig toen de feminist ische reactie tegen het thuismoederschap opkwam (zie hoofdstuk 5).

48 Zie ook Sevenhuijsen (1993-1) p. 36.

49 TK 1986-1987, 18950 (R 1281), nr. 6, p. 21.

50 De CEDAW is het handhavingsorgaan bij het VN-Vrouwenverdrag, Staten brengen rapportages wit en het CEDAW doet ook algemene aanbevelinigen.

51 Zie o.a. Loenen (1994-1), Van Walsum (1996) p. 45-47. 
van art. 1. Maatregelen die zijn gericht op bescherming van het moederschap zijn niet discriminerend. Een aantal maatregelen wordt in het Verdrag voorgesteld, maar daartoe hoeft de regering zich niet te beperken. ${ }^{52}$ Heringa vindt het opvallend dat zwangerschap niet genoemd wordt. Bovendien lijkt de bepaling te zien op een relatief korte periode voor en na de bevalling. ${ }^{33}$ Het is mijns inziens de vraag of dit niet een kwestie van vertaling is. Het Engelse "maternity" impliceert zwangerschap en bevalling. Het Nederlandse moederschap sluit zwangerschap uit, maar impliceert veel meer dan alleen de periode voor en na de bevalling."

- art. 5: bestrijding van seksestereotypering en seksespecifieke socialisatie. Met name in het tweede lid komen twee zinsneden voor die direct raken aan hetgeen in dit hoofdstuk geproblematiseerd wordt. In het verdrag wordt gerept van "een juist begrip van het moederschap" en van de voorwaarde "dat het belang van de kinderen in alle gevallen voorop staat". In deze bepaling gaat het om het moederschap als sociale functie. ("maternity as a social function") Deze functie impliceert dat de maatschappij rekening moet houden met de biologische en sociale gevolgen van het krijgen van kinderen. Het moederschap is een rechtens relevant feit. ${ }^{5 s}$ Lijnzaad vraagt zich af of art. 5 ook verplicht tot het wegnemen van stereotypering in het recht, iets waar vanuit juridische vrouwenstudies al lang aandacht voor wordt gevraagd. . $^{\text {s }}$

- art. 11: bestrijding van discriminatie in het arbeidsproces. Omdat gedetineerde vrouwen over het algemeen niet aan het reguliere arbeidsproces deelnemen, ga ik er hier nu verder niet op in. In andere delen van dit onderzoek wordt, waar het gaat om arbeid, beloning en vrijetijdsbesteding in detentie wel gerefereerd aan ontwikkelingen in het arbeidsrecht.

- art. 12: bestrijding van discriminatie in de gezondheidszorg. Ook deze problematiek is in andere delen van dit onderzoek aan de orde geweest.

- art. 16: bestrijding van discriminatie inzake alle aangelegenheden betreffende huwelijk en familiebetrekkingen. Ook hier komt tweemaal de zinsnede: "in alle gevallen staat het belang van de kinderen voorop" terug. Forder betreurt dat in lid 1 van het artikel is gekozen voor non-discriminatie bepalingen." $\mathrm{Zij}$ geeft aan dat

54 Zie Monster (1995). Zie ook hoofdstuk 4.

55 Lijnzaad (1994) p. 48.

56 Lijnzaad (1994) p. 56. Vgl. de "Legal Reform" benadering bij Olsen (1992). Zie ook Veldiman (1996), p. 38. "Vruchtbaarder lijkt het daarom niet langer te praten over het feit dăt het recht stereotypeert, maar welke (sexe)stereotypen men, gezien tot wat voor rechtsgevolgen dat leidt, (nog) wenselijk vindt en welke niet meer."

57 Forder (1994) p. 239-253. 
"in hun rechten ten opzichte van kinderen, in beshissingen over conceptie en abortus, en ook in eigendomsrechten, vrowwen te kort worden gedaan als hun alleen dezelfde rechten als mannen wordt gegund".

Het tweede lid is verplichtender en dus positiever geformuleerd. Er wordt een materiële invulling aan het gelijkheidsbeginsel gegeven. Voor zwarte, migrantenen vluchtellingenvrouwen kan het artikel van groot belang zijn. ${ }^{\text {so }}$ In dit verband kan de volgende opmerking van Van Walsum niet over het hoofd gezien worden:

"Regells die vrouwen onder druk zetten een kind te nemen om zodoende onder de uitzonderingsbepalingen te vallen, ontnemen hen de vrijheid zelf te bepalen wanneer zij moeder worden. ${ }^{\text {"wo }}$

Dit is in strijd met art. 16 lid 1, sub e van het VN-Vrouwenverdrag. In hoeverre dit ook van toepassing zou kunnen zijn wanneer in het penitentiaire recht specifieke voorzieningen voor strafwaardige moeders worden voorgesteld is de vraag. Hoewel de betreffende bepaling toeziet op gelijke behandeling van mannen en vrouwen, kunnen vrouwen, die expliciet geen moeder willen zijn of worden, hier in samenhang met art. 5 van het Verdrag een legitimatie voor gelijke behandeling met moeders vinden.

Wat "het belang van de kinderen" betreft geeft Forder nog eens aan dat er belangrijke verschillen zijn tussen westerse en niet-westerse opvattingen van dat begrip. Zo zou het Bundesgerichtshof in Duitsland verschillende keren geweigerd hebben om Islamitisch recht toe te passen wegens strijd met de "ordre publique", in casu te geringe eerbiediging van het belang van het kind naar Islamitisch recht. ${ }^{61}$ Wellicht is de belangrijkste waarde van specifieke verdragen voor kinderen en vrouwen dat de aan hun feitelijke zorgrelaties recht doende bepalingen als het ware ingelezen kunnen worden in algemeen geformuleerde direct werkende bepalingen, zoals art. 26IVBPR en art. 8EVRM. Ook bij de interpretatie van nationale regelgeving kunnen verdragsbepalingen een aanscherpende functie vervullen. ${ }^{62}$

Daarnaast worden er ten aanzien van de deelnemende staten inspanningsverplichtingen geformuleerd, waarbij de gestelde normen als minimum gelden. Via geregelde rapportages aan het Comité voor de Rechten van het Kind en de CEDAW worden staten gedwongen voortgang te boeken. Schaduwrapportages van bij voorbeeld nongouvernementele organisaties voeren die druk op een zinvolle manier op. Voor beide

58 Forder (1994) p. 252.

59 Van der Linde en Van Walsum (1994) p. 273-286, Van Walsum (1996).

60 Van Walsum (1996), p. 51.

61 Forder (1994) p. 249-250.

62 Heringa, Hes en Lijnzaad (1994), In de bundel stellen schrijvers in verschillende artikelen de samenhang met andere verdragsbepalingen aan de orde. Zie ook Doek (1995) p. 10-21, Heringa (1995), De Groot (1995) p. 29-30, Van Waisum (1996) p. 39-48. 


\section{Hoofdostuk 6}

verdragen zijn overigens woorstellen gedaan om tot een individueel klachtrecht te komen. $^{\text {s. }}$

\subsection{Art. 8 EVRM en de zorgtaak van de overheid}

Naarmate het gezinsleven en de bevoegdheden van de ouders daarbinnen als maatschappelijke pijler geaccepteerd zijn, zal de overheid zich onthouden van al teveel bemoeienis met de privésfeer. Of zoals Bainham over het VN-Kinderverdrag concludeert:

"It would perhaps be unduly churlish to describe this as a 'parents' charter but it is certainly arguable that the concern for the independence of parents has resulted in a devaluation of the independent interests of children and the role of the state in protecting these. ${ }^{\text {nof }}$

De Jegitimatie voor overheidsbemoeienis 'in het belang van het kind' wordt tot nu toe veelal gevonden in art. 8 lid 2 EVRM. ${ }^{.5}$ Het bekendste voorbeeld in Nederland zijn natuurlijk civielrechtelijke jeugdbeschermingsmaatregelen. Alleen de positie van de kinderrechter als 'onafhankelijke en onpartijdige rechterlijke instantie " (art. 6 lid 1 EVRM) is door de cumullatie van diens functies ter discussie komen te staan. In de door Koens geformuleerde uitgangspunten voor een nieuw stelsel van maatregelen van jeugdbescherming is de centrale rol van de ouders ook terug te vinden. Ik citeer de eerste vier:

a) een toekomstig stelsel van maatregelen van jeugdbescherming moet uitgaan van het kind als rechtssubject;

b) ieder minderjarig kind heeft recht op een harmonische ontplooiing van zijn persoonlijkheid;

c) dit recht op harmonische ontplooiing valt in principe samen met het recht wan ouders om het kind naar eigen inzichten te verzorgen en op te voeden;

d) de overheid heeft als positieve werplichting de ouders in de gelegenheid te stellem hun opvoedingsen verzorgingsplicht naar behoren te vervullen; ....

63 Zie voor het VN-Kinderverdrag: Doek (1995) p. 19. Zie voor het VN-Vrouwenverdrag: Flinterman (1995) p. 5-11.

64 Bainham (1990) p. 221, Van Brucken Fock (1990).

65 Zie ook artikel 12 in het wetsontwerp PBW.

66 Ziw ook Van Emmerik (1992) p. 15-16, Van den Boogaard (1996).

67 Koens (1994) p. 37. Op blz. 39 merkt hij op dat in de wet nader moet worden omschreven dat onder "harmonische ontplooiing" wordt verstaan "een gezonde en evenwichtige ontwikkeling van het kind in lichamelijk, geestelijk, zedelijk en emotioneel opzicht". 


\subsubsection{Europese rechtspraak met betrekking tot "het belang van het kind"}

Tegen teveel of juist te weinig overheidsbemoeienis is op grond van art. 25 EVRM een aantal individuele klachten ingediend bij de Europese Commissie, waarbij de overheid 'in het belang van het kind' werd aangesproken op de positieve verplichting tot naleving van de bepalingen in het EVRM. Als een klacht ontvankelijk is verklaard toetst de Europese Commissie op basis van de haar bekende feiten of door nationale autoriteiten genomen besluiten in het licht van het EVRM en de omstandigheden van het geval redelijk zijn. ${ }^{*}$

- In de zaken rond lijfstraffen op Britse scholen is zowel door de moeders als de kinderen een klacht ingediend. ${ }^{\infty}$ De klachten van de moeders worden niet ontvankelijk verklaard aangezien zij ingestemd zouden hebben met de lijfstraffen door hun zonen naar scholen met een dergelijk regiem te sturen. De klachten van de kinderen zijn wel ontvankelijk.

Het gebruik van lichamelijk geweld is sinds 15 augustus 1987 verboden in het Verenigd Koninkrijk. Dit verbod geldt echter alleen voor openbare scholen. In de twee klachten die zijn ingediend, staat dan ook eerst de vraag centraal of de Engelse overheid verantwoordelijk is voor de praktijk van lijfstraffen op privéscholen. Ouders kunnen immers juist vanwege dit regiem zo'n school kiezen. Volgens de Commissie is de staat echter verplicht te verzekeren dat kinderen binnen hun jurisdictie niet onderworpen worden aan foltering, onmenselijke en vernederende behandeling in de zin van art. 3 EVRM.

Vervolgens wordt bekeken of een lijfstraf vernederend is in de zin van art. 3 EVRM. In dat geval zal de vernedering in kwestie een zekere graad van ernst moeten bereiken boven het gebruikelijke element van vernedering bij iedere straf("minimum treshold of severity"). In de twee zaken komt de Commissie hierover, aan de hand van de feiten, tot een verschillend oordeel. Opmerkelijk is de dissenting opinion van Schermers in de zaak waarin wel tot strijd met art. 3 EVRM wordt geconcludeerd. ${ }^{n}$ Hoewel hij lichamelijke bestraffing slecht vindt in opvoedkundige zin, vindt hij dat het recht van de ouders gerespecteerd moet worden om gematigde lijfstraffen te gebruiken en om hun kind naar een school te sturen die dergelijke straffen hanteert.

68 Buquichio (1988), Van Emmerik (1992).

69 Y tegen het Verenigd Koninkrijk (klacht nr. 14229/88) Pub ECHR, Series A, vol. 247-C. Jeremy Costello tegen het Verenigd Koninkrijk (klacht nr. 13134/87) Pub ECHR, Series A, wol. 247-A.

Zaak Y tegen het Verenigd Koninkrijk. (klacht nr. 14229/88). 
De Commissie vindt dat er, naast de toetsing aan art. 3 EVRM ook onderzocht moet worden of er sprake is van een inbreuk op het privéleven van het kind en of die inbreuk te rechtvaardigen is op grond van art. 8 lid 2 EVRM.

Uiteindelijk komt het in de ernstigste zaak tot een schikking en vindt er geen toetsing aan art. 8 EVRM plaats. In de tweede zaak oordeelt het Europese Hof dat in casu de nadelige effecten op de fysieke of morele integriteit onvoldoende waren om de behandeling onder art. 8 EVRM te brengen. ${ }^{n}$

- In het kader van co-detentie zijn vooral de zaken interessant waar een conflict over de verblijfplaats van het kind centraal staat. Dat was het geval inzake weggelopen kinderen waarbij de kinderen zich baseren op hun private life krachtens art. 8 EVRM $^{72}$ De bescherming van 'het belang van het kind' kan echter vorderen dat kinderen die van huis zijn weggelopen gedwongen worden naar hun ouders terug te keren, zelfs indien het kînd in kwestie dat juist als een inbreuk op zijn rechten ervaart. In het algemeen (uitzonderingen daargelaten) kan immers aangenomen worden dat de verplichting voor kinderen om met hun ouders samen te leven en zich aan een zekere controle te onderwerpen, nodig is voor de bescherming van de gezondheid en moraal van het kind.

Het kan ook zijn dat ouders in het belang van het kind een gescheiden verblijfplaats wensen, bij voorbeeld via een gedwongen psychiatrische opname. ${ }^{3}$ In de casus Nielsen tegen Denemarken is een jongen tegen zijn wil opgenomen in een psychiatrische kliniek. De jongen beroept zich op art. 5 EVRM, art. 2 Vierde Protocol en art. 8 EVRM. De jongen is in 1971 geboren uit een relatie tussen ongehuwde ouders die van 1968 tot 1973 duurde. Na 1973 blijft de jongen bij zijn moeder wonen, bij wie volgens de toen geldende Deense wet de ouderlijke macht berust. Na een wetswijziging die daartoe de mogelijkheid biedt, dient de vader een verzoek in orn de ouderlijke macht over zijn zoon te verkrijgen. Het verzoek wordt afgewezen. Vervolgens duikt de vader bijna vijf jaar met de zoon onder. Tijdens deze onderduikperiode wordt de jongen eenmaal door de politie ontdekt waarna zijn moeder hem laat

71 EHRM 25 oktober 1993, Y tegen het Verenigd Koninkrijk, Series A vol. 247-A, NJ 1995, 725, m.n. EAA, NJCM-bulletin (1993) p. 570-572, m.n. M.L. van Emmerik.

EHRM 25 maart 1993, Costello-Roberts tegen het Verenigde Koninkrijk, Series A, vol. 247C, NJ 1995, 247 m.n. JdB, NJCM bulletin 1993, p. 572-583, m.n. M.L. van Emmerik/

Zie ook De Boer (1994) p. 389-390 en p. 542. De Boer bepleit een verbod van lichamelijke bestraffing of andere vernederende behandeling van kinderen in boek $1 \mathrm{BW}$, zonder sanctie, maar om te voorkomen dat als norm blijft bestaan dat "een pedagogische tik" geoorloofd is. Een dergellijk verbod bestaat al in Zweden, Finland, Denemarken, Noorwegen en Oostenrijk. Zie ook Baartman (1993).

72 Zie De Langen (1990), p. 166-169.

73 EHRM 28 novembier 1988, Nielsen versus, Denemarken, Series A, vol. 144, NJ 1991, 541, m.n. EAA, NJCM bulletin 1989, p. 595-612m, m.n. L.F.M. Verhey, FJR 1990, p. 112-144, m.n. M.L.C.C. De Bruijn-Lückers. 
opnemen op een kinderpsychiatrische afdeling van een ziekenhuis in Kopenhagen. De jongen ontvlucht na twee maanden. Bijna vier jaar daarna, in september 1983, wordt de vader gearresteerd. Dit gebeurt direct na de hoorzitting bij de behandeling van een hernieuwd verzoek om overdracht van de ouderlijke macht. Het kind wordt op verzoek van de moeder op een gesloten psychiatrische afdeling van het ziekenhuis geplaatst. Voor opname is toestemming gegeven door een toezichthoudende welzijnscommissie en door het hoofd van de afdeling van het ziekenhuis. De jongen vlucht op het moment dat hij ontslagen is en naar zijn moeder gestuurd zal worden. Hij wordt door de politie gevonden en op verzoek van de moeder opnieuw opgenomen. Uiteindelijk wordt de jongen, na daar in totaal vijf en een halve maand te hebben doorgebracht, uit het ziekenhuis ontslagen. Zijn vader wordt bijna gelijktijdig tot negen maanden gevangenisstraf veroordeeld en, na aftrek van het voorarrest, meteen vrijgelaten. De Deense Hoge Raad beslist overigens later dat de ouderlijke macht bij de vader komt te liggen. In deze zaak spelen tenminste drie interessante aspecten een rol:

- De interpretatie van "vrijheidsberoving". In art. 5 EVRM wordt gesproken over "deprivation of liberty", in art. 2 Vierde Protocol over het lichtere " restriction of liberty". Het verschil tussen beide bepalingen wordt vooral gevormd door de intensiteit van de maatregel en is sterk afhankelijk van de concrete situatie waarin de klager zich bevindt zoals het type, de duur en de gevolgen van de maatregel en de wijze waarop die wordt uitgevoerd. In casu gaat het om een grensgeval waarbij Commissie en Hof tot een verschillend oordeel komen. De Commissie vindt het, gezien de voorzorgsmaatregelen die genomen zijn en omstandigheden in het ziekenhuis, een grensgeval. Maar de Commissie vindt wel dat er sprake is van vrijheidsberoving. De jongen is tegen zijn wil opgenomen, hij was geestelijk niet ziek en werd na een ontsnapping door de politie opgepakt en weer teruggebracht. Het Hof echter vergelijkt de situatie met een gewoon ziekenhuis en de beperkingen die daar aan kinderen gesteld worden. De jongen kon ook nog onder begeleiding naar de bibliotheek en musea gaan en ook de duur van het verblijf was niet abnormaal lang. De jongen was nog jong en er was geen sprake van kwade trouw bij de moeder. Het Hof komt al met al met een krappe meerderheid tot de conclusie dat er geen sprake van vrijheidsberoving in de zin van art. 5 EVRM was.

- De reikwijdte van de verantwoordelijkheid van de Deense overheid. De Commissie vindt dat de overheid een duidelijke inbreng heeft gehad bij de beslissing tot opname, met name via de "Chief Physician" van het ziekenhuis en acht daarom art. 5 lid 1 EVRM van toepassing. Het Hof komt aan de vraag eigenlijk niet toe, doordat hij de "deprivation of liberty" restrictief geïnterpreteerd heeft, maar hij stelt wel vast dat de opname van het kind het gevolg is van een beslissing van de moeder, genomen in het kader van de uitoefening van de ouderlijke macht. 


\section{Hoojdstuk 6}

- Als belangrijkste vraag speelt de grondrechtenkwestie tussen moeder en kind (en mogelijk vader). Uit het rapport van de Commissie blijkt dat de ouderlijke toestemming tot vrijheidsberoving deze niet 'au tomatisch' wrijwillig maakt. Aan het feilt dat de jongen tegen zijn wil was opgenomen wordt meer gewicht toegekend dan aan het feit dat dit met toestemming van zijn moeder gebeurd was. Het Hof is echter met een kleine meerderheid van mening dat het een verantwoorde uitoefening van de moeder van haar ouderlijk gezag in het belang van het kind betreft, beschermd door art. 8 EVRM, en dat daarmee art. 5 EVRM niet van toepassing is.

Het lijkt er op dat het Europese Hof in conflictsituaties het belang van het private life van een kind onderschat en er toe neigt het beroep op family life door de met gezag beklede ouder te honoreren. Dat laatste wordt dan tevens het door de overheid primair te beschermen belang.

Interessant is de visie van Verheij die opmerkt dat zelfs vrijwillige vrijheidsbeperking niet automatisch met zich brengt dat art. 5 niet is geschonden. ${ }^{74}$ De staat moet volgens hem voorwaarden creëren waaronder uitoefening van grondrechten ook in verhoudingen tussen burgers onderling effectief mogelijk is. ${ }^{75}$

In relatie tot co-detentie, met toestemming van de ouder, zal het steeds van de concrete situatie afhangen of er sprake is van vrijheidsberoving van het kind. Mij lijkt dat het referentiekader daarvoor gezocht zal moeten worden in de pedagogische randvoorwaarden van de voorziening in samenhang met de leeftijd van het kind, de duur van het verblijf en de in te schatten gevolgen ervan.

\subsection{De Nederlandse overheid en 'het belang van het kind"}

De rol van de overheid bij de bescherming van het gezinsleven en het privéleven van individuele burgers is een delicate, met name wanneer de bescherming van de een een inbreuk veroorzaakt op het recht van de ander. Vooral in Nederland, waar door het ontstaan van de verzorgingsstaat een tamelijk onomstreden compromis tussen een liberale, christelijke en socialistische opvatting over staatsbemoeienis met het privelleven leek te zijn ontstaan, was het beeld van de overheidsbemoeienis cen paradigma geworden. ${ }^{76}$ Enerzijds is de overheid verplicht voorzieningen en rand-

74 EHRM 28 november 1988, Nielsen tegen Denemarken, NJ 1991, 541, met noot E.A.A.. NJCMbulletin 14-5(1989), p. 595-612, met noot L.F.M. Verhey. Zie ook FJR 1990, p. 112-144, met noot M.L.C.C. de Bruijn- Luckers.

75 Verheij (1989) p. 611.

76 Ik bedoel daarmee dat na de oorlog via de ontzuiling een, politick gezien, tamelijk zakelijk bestuurbaar model van overheidsbeleid is gehanteerd. De ontpolitisering werd versterkt door de Europese eenwording. De stellingen waren tamelijk voorspelbaar en tastten het beeld nauwelijks aan. (Vgl. paradigma: als je op de ene manier kijkt zie je dit, op de andere manier dat, maar feitelijk hoeft 
voorwaarden te creëren waardoor een privéleven ook feitelijk invulling kan krijgen (gezondheidszorg, arbeid, inkomen, onderwijs $s_{x}$ etcetera.) terwijl zij anderzijds zodra het om individuele waarden gaat tot onthouding van inmenging en bescherming tegenover derden verplicht is. (lichamelijke integriteit, vrijheid van meningsuiting, godsdienst, etcetera.) Met de opkomst van het marktkapitalisme en de verzorgingsstaat zijn steeds meer taken en doelen uit de gezinssfeer verdwenen, met name op het gebied van arbeid en productie en op het gebied van onderwijs." In de verzorgingsstaat zijn artsen, hulpverleners en juristen in toenemende mate de verdelers van collectieve middelen geworden. Er onstaan processen van medicalisering en juridisering. ${ }^{7}$ Normen en waarden kunnen nog maar voor een deel via familie en gezin worden doorgegeven. Het is de vraag in hoeverre er nog een autonoom privéleven bestaat. Het gezin wordt nog wel 'veilige basis', 'publieksvrije ruimte' en 'een plek van liefde en affectie' genoemd.

Het optimum van de verzorgingsstaat lijkt inmiddels een gepasseerd station. $\mathrm{Er}$ worden nieuwe koersen uitgezet, aangepast aan economische golven van recessie en herstel en aan internationale afspraken. De overheid dereguleert en privatiseert. Het is daarbij nog niet duidelijk of dit ook een afname van overheidsbemoeienis met het privéleven en privébeslissingen van burgers tot gevolg heeft. Voor sommigen manifesteert de terugtredende overheid zich immers op alle fronten slechts als bezuiniger, waardoor juist de bescherming van de privésfeer wegvalt. Het traditionele onderscheid tussen "privê" en "publiek" lijkt te grof. De analyse van de wisselwerking tussen de privésfeer en de publieke sfeer kan bovendien, gezien de maatschappelijke verhoudingen, niet zonder gendertheorie gemaakt worden. In navolging van Habermas en Fraser maakt politicologe Bussemaker een vierdeling in maatschappelijke sferen: de individuele sfeer, de verzorgingsstaat, de markt en de politieke openbaarheid. Ze verheldert de impliciete opvattingen over sekse-identiteiten die ten grondslag liggen aan het onderscheid en de relaties tussen die sferen. ${ }^{70}$

het beeld niet te veranderen) Nu op grond van economische motieven verschuivingen in het type verzorgingsstaat optreden en de politieke machtsverhoudingen zijn veranderd, worden morele discussies over overheidsbemoeienis met het gezins- en privelewen weer op de agenda gezet.

77 Bussemaker (1993, p. 17/18) geeft aan dat er verschillende manieren zijn om de "verzorgingsstaal" vorm te geven. Zo stond in de Zweedse een actieve arbeidsmarktpolitiek centraal, terwijl in Nederland de aandacht heell lang uitging naar behoud van inkomen. Zij verklaart dat onder andere vanuit het grote vertrouwen in de gezinsideologie in Nederland. Vanaf de jaren zeventig is daar verandering in gekomen: naast de grotere arbeidsparticipatie van vrouwen en het toegenomen aantal echtscheidingen (en de daarvoor benodigde voorzieningen) staat een bezuinigende en deregulerende overheid.

78 De Swaan (1989), Zwaan (1993-1) p. 265-296, Zwaan (1993-2).

79 Bussemaker (1993) p. 22. Ook de Zweedse econome Agneta Stark doorbreekt de cenvoudige dichotomie betaalde versus onbetaalde arbeid om tot nieuw analyses te komen. Zij onderseheidt vier categorieën van werk aan de hand wan de financiering van dat werk:

1. de marktsector waar iemand een dienst of goederen betaalt vit eigen portemonnee. 
"De vrouwelijke identiteit is die van de consument, van werzorger (beide individuele levenssfeer) en van cliènt van overheidswoorzieningen (verzorgingsstaat), terwijl de mannelijke identitteit met name wordt gevormd door kostwinnerschap (markt) en burgerschap (politieke openbaarheid)."

Op microniveau worden de invulling van het ouderschap en opvoedingsidealen voor een groot deel bepaald door de sociaaleconomische positie van de ouders. De vraag in hoeverre de overheid zorg draagt voor de implementatie van de materiële rechten van het kind via collectieve voorzieningen is dan ook vooral een politieke vraag. Hoe gaat de overheid in dit tijdsgewricht om met "collectieve rechten' van burgers? Op het hoogtepunt van de verzorgingsstaat lagen veel bevoegdheden bij overheid: legitimatie, controle(inspectie) juridificatie en delegatie waren sleutelbegrippen. $\mathrm{Nu}$ zijn steeds terugkerende thema's privatisering, het afstoten van overheidstaken, de verantwoordelijkheid van het particulier initiatief, de heilzame werking van het marktmechanisme, falende overheidscontrole en afbraak van rechtsbeginselen. Het beeld van de calculerende burger lijkt een afsplegeling van de calculerende overheid te zijn. Economische principes overheersen die van rechtvaardigheid, moraal en deugd. Ook burgers claimen weer een private sfeer, behalve zij die de (financiële) middelen niet hebben om daar ook feitelijk iets van te maken.

Grofweg geschetst kunnen er twee politieke reacties zijn ${ }^{20}$ :

- een liberale, die overheidsbemoeienis altijd gevaarlijk vindt en de privésfeer een groot daartegen te beschermen goed. Het traditionele onderscheid tussen de

2. de publieke sector met werk waarbij de overheid in bredere zin de financierder en/of de werkgever is, zoals de gezondheidszorg en defensie.

3. het onbetaalde familiewerk dat uitgevoerd wordt op basis van menselijke relaties.

4. het gesubsidieerde familiewerk dat binnen de familie wordt uitgevoerd maar waarvoor de overheid betaalt. (bv. kinderbijslag)

Aan de hand van dit model kan zij duidelijk maken dat bij privatisering van de publieke sector veelal niet de beoogde verschuiving van werk wan de publieke naar de marktsector plaatsvindt, maar veel meer naar de onbetaalde familiesector (Stark 1993, p. 21).

80 Zie voor de verschillen in reacties ook: Bos en Isarin (1992) p. 4.

De politieke (vaak wertaald in juridische) reacties hebben alles te maken met de invulling van het "vrijheids" begrip. Gaat het om psychologische, sociale of potentiële vrijheid?

Loenen $(1994$, p. 212) noemt een aantal argumenten dat overheidsbemoeienis bepleit:

- geen overheidsbemoeienis is niet neutraal, zolang individuele mensen in zeer uiteenlopende situaties verkeren;

- de bescherming van rechten en belangen van anderen, met name van zwakkere en afhankelijke personen, maakt overheidsbemoeienis onontkoombaar en wenselijk;

- in de sociale rechtsstaat berust op de overheid de positieve verplichting om voor haar onderdanen de voorwaarden te scheppen om hun relaties naar eigen wens in te richten: "niet alleen "freedom from", maar ook "freedom to".

Beperkingen kunnen voortvloeien uit de bescherming van belangen en vrijheden van anderen of vanuit het algemeen belang.. Loenen noemt als voorbeelden " 's lands schatkist en overwegingen van solidariteit" Z Zie hierover ook: Raes (1992) p. 102-125. 
publieke en privésfeer wordt dus gehandhaafd en de privésfeer dient beschermd te worden tegen het almaar uitdijende publieke domein. In deze stroming blijft alle verantwoordelijkheid voor de zorg bij ouders. Er wordt vooral gesproken over affectie, verbeelding, humor en overdracht van culturele en affectieve waarden als bron voor de individuele ouder-kindrelatie. Pessers benadrukt het belang van het kind bij integratie in een verwantschapssysteem en generationele keten. ${ }^{81}$ Praten over 'de kost verdienen' in relatie tot het belang van het kind lijkt in deze benadering 'not done'. Praten over arbeid is praten over ontplooiing, niet in eerste instantie over het voorzien in je eigen onderhoud. "De markt" mag niet de bepaler van de tijd en ruimte zijn die voor het opvoeden nodig is. ${ }^{22}$

- een sociale, die veel meer nadruk legt op ongelijke ontwikkelingskansen van kinderen, omdat die sterk bepaald zijn door het nest waarin ze geboren worden. Er wordt een parallel getrokken met de al of niet beperkte ontwikkelingskansen voor moeders van die kinderen die uit dezelfde, veelal sociaaleconomisch bepaalde, omstandigheden voortvloeien..$^{89}$ Als vorm van sociale politiek wordt binnen deze stroming gepleit voor meer overheidsbemoeienis in de voorwaardenscheppende sfeer voor allle ouders en hun kinderen, juist om voortdurende klassen-, rassen- en sekseverschillen te doorbreken. De scheiding publiek-privé wordt ontmaskerd, door te laten zien dat de kiem voor (politieke) machtsverschillen

81 Pessers (1995) p. 1291-1297, Pessers (1996).

82 Vgl. Pessers (1994) p. 20. Het is mij niet duidelijk of zij aan hetzelfde begrip "markt" refereert als Bussemaker. Zie ook: Willems (1992) p. 8-23. Als ouders buiten het traditionele blanke gezinswerband leven kan dat gegeven bijwoorbeeld al een reden zijn voor toenemende zorg van dle overheid en wordt de zorg voor het kind in de publieke sfeer getrokken, vaak geformuleerd als preventieve taak in de jeugdhulpverlening. 


\section{Hoofdituk 6}

in het gezin gelegd wordt. Voor kinderen is het van belang nieuwe socialle netwerken te ontdekken.

Vanuit de verschillen in politieke invalshoek krijgen begrippen als 'het belang van het kind', 'family life' en 'private life' een andere invulling.

De liberale invalshoek sluit aan bij de klassiekjuridische benadering. Gericht op het individu, een ontwikkelingspsychologisch (psychoanalytisch) mensbeeld met de nadruk op generationele verbondenheid en een hiërarchische ontwikkelingslijn. ${ }^{. s}$

"Het zelfstandig worden van het kind, hetgeen gepaard gaat met steeds minder afhankelijkheid wan het kind ten opzichte van zijn ouder, doet de verhouding ouders-kind voortdurend wijzigen totdat de positie die zij ten opzichte van elkaar innemen in een aantal gevallen het niveau van gelijkwaardigheid bereikt $t^{\text {is }}$

De sociale invalshoek is betrekkelijk nieuw in het juridisch systeem. Die wordt ook veelal vam buiten aangevoerd door rechtssociologen en metajuristen. Als centrale elementen spelen het collectief, een pedagogisch (existentieel) mensbeeld en machtsconcepten een belangrijke rol.

Overheidsbemoeienis met de zorg voor kinderen kan zo op twee manieren gelegitimeerd worden of zoals Bainham stellt"

84 Vgl. Moller Okin Justice, Gender and the Family, p. 111. Zij geeft vier argumenten op grond waarvan ze concludeert dat "the public/domestic dichotomy is a mislcading construct (...):

- First, power -which has always been understood as paradigmatically political- is of centrall importance in family life.

- Second, the domestic sphere is itself created by political decisions, and the very notion that the state can choose whether or not to intervene in family life makes no sense.

- Third, the family is undeniably political because it is the place where we become our gendered selves.

- And fourth, the division of labor within the gender-structured family raises both practical an psychological barriers against women in all other spheres of life."'

In een bespreking van het boek van Moller Okin merkt Martha Nussbaum op dat de schrijfster onidanks de kritische toon ook teveel blijft uitgaan van het "kerngezin" : "If public policy determine: that the nuclear family in some form is an institution worthy of public support, this still leaves individuals with countless choices to make concerning whether or not to form families, and of what sort. And I suspect that a general theory of good human functioning might leave things more open-ended still, holding that there are a variety of different arrangements by which children may be raised with lowe and taught standards of justice, and that the capacities of childrem rather than the institution of the family itself, are what society is committed to supporting." (Nussbaum 1993 , p. 339.)

85 O.a. Thomassen (1993)

86 Memorie van Toelichting Goedkeuringswet VN-Kinderverdrag, p. 12. 
"Childrearing may be seen with equal justification as either a private matter, subject to state involvement only when public norms are transgressed, or as a public matter in the sense that the task of giving effect to the community's standards and expectations for child-rearing is delegated to parents. ${ }^{* 87}$

Op een aantal terreinen bestaat al actieve overheidsbemoeienis met het gezins- en priveleven. De wijze waarop de discussie daaromtrent gevoerd werd en wordt, biedt wellicht aanknopingspunten voor de zorgplicht van de overheid ten aanzien van gedetineerde ouders en hun zorgrelaties.

Een terrein waarop de overheid balanceert op de grens tussen beschermer en bepaler van het familylife is het arbeids- en socialezekerheidsrecht. Voorzieningen die de een een recht vindt, worden door de ander als plicht of te verplichtend ervaren. Met name de discussies over kinderopvang, maar ook eerder die over nachtarbeid voor vrouwen laten zien welke juridische paradigma's opdoemen.

Een terrein waarop de felste discussie lijkt te zijn uitgewoed is die wan het onderwijs, waarin er toch, via de leerplicht, sprake is van directe overheidsbemoeienis met opvoeding en overdracht van waarden en normen. Conflicten die zijn gerezen rond het dragen van hoofddoekjes tijdens schooltijd door Islamitische meisjes, kunnen overigens ten principale ook weer teruggevoerd worden op ongewenste (staats)bemoeienis met eigen (religieuze) waarden en normen.

In de gezondheidszorg staat het verplichtende karakter van schoolartsenonderzoek en inentingsprogramma's soms ter discussie. Het lijkt mij interessant om te kijken

87 Bainham (1990) p. 207. De juridische discussie over de rol van de owerheid bij de zorg voor kinderen gaat niet zozeer over de juridische eindverantwoordelijkheid voor de keuzes in de opvoeding op individueel niveau, maar over de 'delegatie' van bevoegdheden door de ouders aan de overheid op het niveau van de uitvoering. (waarbij de overheid vervolgens mett de haar ter beschikking staande middellen, vergunningen, kwaliteitseisen etc. taken weer naar instanties kan delegeren) De overheid kan optreden in verschillende rollen:

- als wet- en regelgever, beschermer van grondrechten en schepper van "publicksvrije ruimte" (beperking en legitimatie van bevoegdheden);

- als uitvoerder, bewaker van het collectief belang, belast met zorgplichten, op gebieden als welzijn, volksgezondheid, onderwijs, zeden en openbare orde; als schepper van condities, via subsidies en vergunningen. Deze uitvoerende taken worden steeds meer geprivatiseerd, waarbij de overheid zich dan bijwoorbeeld opstelt als vrager op de markt.

- als controleur (rechterlijke macht, inspecties, opsporing en vervolging strafbare feiten).

De taken vervloeien, vaak vallen bimnen de 'hoofdrol' ook andersoortige verantwoordelijkheden en bewoegdheden, bijna altijd vindt delegatie van uitvoerings- en controletaken plaats.

88 Goldschmidt en Holtmaat (1993) p. 357-364.

89 Vermogende ouders kunnen conflicten wellicht omzeilen via onderwijsdeelname van hun kinderen aan dure particuliere scholen. Overigens heeft de HR in een recente uitspraak (19 november 1996) nog eens bevestigd dat de leerplicht niet in strijd is met art. 9 EVRM "mede gelet op de in Nederland bestaande vrijheid van ouders hun kinderen de school van keuze te doen bezoeken dan wel een zelf opgerichte school waar volgens hun opvattingen les wordt gegeven, alsmede gelet op de mogelijkheid tot vrijstelling..." (o.w. 5.3) 


\section{Hoofdsituk 6}

of de juridische onderbouwing van bovengenoemde vormen van overheidsbemoeienis met het family en private life van zich 'normaal' ontwikkelende kinderen aanknopingspunten biedt voor oplossingen van knelpunten bij het onderhouden van gezinsrelaties waar door detentie van een ouder problemen optreden.

\subsubsection{Arbeid}

Mede als gevolg van de grotere arbeidsparticipatie van vrouwen wordt er steeds meer afgeweken van het tot voor kort in Nederland geldende "normale burgerlijke gezinsleven'. Aanvankelijk door vrouwen zelf bevochten, vanuit de emancipatoire eis tot economische verzelfstandiging en individualisering van inkomen, is deze arbeidsparticipatie vanuit demografische en economische ontwikkelingen nu ook in overheidsbeleid vertaald.

Zo zijn ook de door feministen aangezwengelde items over arbeidstijdverkorting, ouderschapsverlof en flexibele arbeid overgenomen in centraal overheidsbeleid en in de secundaîre arbeidsvoorwaarden binnen de arbeidsverhouding met als primair doel zoveel mogelijk optimaal inzetbare vrouwen op de arbeidsmarkt te krijgen. ${ }^{*}$ Het oorspronkelijke feministische doe] om daarnaast tot een herverdeling van zorg en huishoudelijke taken tussen mannen en vrouwen te komen wordt wel genoemd in het emancipatiebeleid van de overheid, maar is in de praktijk tot nu toe toch vooral als een zaak van privé-onderhandelingen beschouwd..$^{91} \mathrm{Nu}$ er inmiddels niet alleen voor mannen, maar ook voor vrouwen bijna een arbeidsplicht is ontstaan, zien de overheid en de sociale partners dat het noodzakelijk is voorwaarden te scheppen waardoor 'het gezinsleven' geen belemmering hoeft te zijn bij het toetreden en het behoud van vrouwelijke krachten op de arbeidsmarkt. Kenmerkend voor de overheidszorg lijkt dat zij zich conformeert aan de bestaande traditionele arbeidsen gezinsverhoudingen. Rekening houden met een optimaal management in de privésfeer is 'uitzondering op de regel', ook wanneer het alleenstaanden met verzorgende taken betreft.".2

Hoewel dus primair economische doelen en niet bescherming van 'het belang van het kind' of 'bescherming van het gezinsleven' motief zijn geweest, is er in het arbeidsrecht wel specifieke wetgeving met betrekking tot zorgtaken ten behoeve van kinderen te vinden." Te denken valt aan het zwangerschaps- en bevallingsverlof (formeel

90 Zie onder meer Goldschmidt en Holtmat (1993) p. 323-383.

91 Nota 'Met het oog op 1995'(1992), Nota 'Emancipatie in uitvoering' (1995), Beleidsbrief 1997 (1996).

92 Zie Hammerstein-Schoonderwoerd (1994) p. 14. "Ik vraag mij soms af of dit politieke scenario niet teveel geent is op de meest ideale situatie waarin beide ouders leuk werk hebben, goed verdienen, een zekere hexibiliteit in werkomstandigheden kennen en men minder oog heeft voor de veell meer voorkomende gevallen warin het werk minder boeiend is, het loon laag en de werkomstandigheden rigide." 
onder de Ziektewet), het ouderschapsverlof (art. 7A: 1638 oo lid $1 \mathrm{BW}$ ) en het in sommige rechtspositieregelingen en cao's opgenomen calamiteiten-en verzorgingsverlof. Wentholt laat zich kritisch uit over de motivering waarmee inhoudelijke grenzen en criteria aan de zorg worden gesteld.

"Ook de zorg voor kinderen is gevarieerd. Bekende leeftijdsgrenzen zijn vier jaar (ouderschapsverlof) en twaalf jaar ( belastingrecht en werkloosheidswet). Waarop zijn deze leeftijdsgrenzen gebaseerd, anders dan dat ze aansluiten bij de in het Nederlandse schoolsysteem geldende leeftijdsgrenzen? ${ }^{\text {nd }}$

Bij de parlementaire behandeling van de nieuwe werkloosheidswet werd een amendement om de periode waarin lichamelijk of geestelijk gehandicapte kinderen van twaalf tot achttien jaar verzorgd moesten worden, ook mee te tellen voor het verzorgingsforfait, verworpen.

"Hetgeen de vraag doet rijzen of de regeling van het verzorgingsforfait gebaseerd is op gegevens over de feitelijk aan kinderen te besteden zorg."

De nieuwe Algemene Nabestaandenwet en de wijziging van de Algemene Bijstandswet zonder adequate overgangsregelingen, deden de vraag rijzen in hoeverre de overheid in haar bezuinigingsdrift nog voldoende rekening weet te houden met opvoedingsidealen en emancipatiedoeleinden. Het negeren en niet waarderen van zorgtaken, zal sowieso niet leiden tot een herverdeling van die taken. ${ }^{\% 6}$

In opdracht van de regering heeft de commissie Bruyn-Hundt een aantal toekomstscenario's met betrekking tot de verdeling van (betaalde en onbetaalde) arbeid ontworpen." In het door haar bepleite combinatiescenario kan ook de Raad voor het Jeugdbeleid zich vinden. ${ }^{98}$ In de toekomst zal bovendien naast de zorg voor kinderen ook de maatschappelijke en privézorg voor ouderen een steeds grotere plaats moeten krijgen. ${ }^{9}$

94 Vgl. de woorstellen tot co-detentie uit het Rapport van de Werkgroep Vrouwen in detentie (1991) waar de pragmatische leeftijdsgrens wan vier jaar ook als het ware uit de llucht kwam vallen.

95 Wentholt (1991) p. 380 .

96 Zie o.a. Bussemaker (1995) p. 31-43, Westerveld (1995).

97 'Onbetaalde zorg gelijk verdeeld', 1995, 'Om de kwaliteit van arbeid en zorg; investeren in verlof, TK 1995-1996, 24332.

98 Raad voor het Jeugdbeleid (1996).

99 Zie ook Emancipatieraad (1996). 


\subsubsection{Kinderopvang}

De enkele bedrijven die vanuit sociaal personeelsbeleid eigen bedrifscrèches hadden, maken vanuit het oogpunt van "verstandige bedrijfswoering' steeds meer gebruik van reguliere, mede door de overheid gesubsidieerde kinderopvangvoorzieningen. ${ }^{\text {too }}$ Enerzijds kun je daarvan zeggen dat werkgevers zich blijkbaar steeds minder aantrekken van de bredlere zorgtaak die zij hebben voor hun werknemers ${ }^{101}$, anderzijds kun je betogen dat werknemers hiermee uit de alom klemmende greep van hun baas raken. In de laatste optie kan de verzelfstandiging van het privéleven van werknemers echter pas echt liets voorstellen wanneer de overheid in de subsidievoorwaarden bewaakt dat niet alleen werkgeversdoelen gediend worden, maar met name pedagogische doelen in alle diversiteit die ouders wensen. Voor kleinere werkgevers is overigens het inhuren van kinderopvangplaatsen bij particuliere initiatieven de enige mogelijkheid om op dit gebied iets aan sociaal personeelsbeleid te doen. ${ }^{102}$ De overheidsdoelstellingen op het gebied van de kinderopvang lijken de laatste jaren vooral in de verhoging van de kwantiteit te zijn gezocht. Bussemaker heeft de politieke discussies rond overheidsbemoeienis met kinderopvang geanalyseerd aan de hand van drie verschillende perspectieven: een moreel perspectief, een behoefteperspectief en een doelmatigheidsperpectief. ${ }^{103}$ Daarbij kan het zowel om een individuele moraal als een collectieve moraal gaan. In het behoefteperspectief staat de vraag centraal of een noodzakelijke individuele of collectieve behoefte (van kinderen en/of ouders) gerespecteerd moet worden. Het doelmatigheidsperspectief richt zich op het nut van de voorzieningen, bijvoorbeeld voor het aantrekken van de economie. Binnen én perspectief kunnen meer conflicterende visies bestaan, maar ook één bepaalde doelstelling kan vanuit meer perspectieven onderbouwd worden. Bussemaker heeft met name de rol van de overheid in dit kader geanalyseerd. Zo is de kinderopvang aanvankelijk door de overheid vanuit een moreel en behoefteperspectief gezien als een welzijnsvoorziening. Later wordt door de terugtredende, privatiserende en decentraliserende overheid het doelmatigheidsperspectief benadrukt. Kinderopvang wordt 'een product in de markt", waarbij de arbeidsmarkt de condities waaraan kinderopvang

100 Onder verstandige bedrijfswoering versta ik hier zowel het voeren van een sociaal personeelsbeleid als het afstotem van niet-primaire taken ten behoeve van het primaire produktieproces.

101 Waaraan vroeger bijvoorbeeld inhoud werd gegeven via de Philips Sport Vereniging, het Philips Gezondheidscentrum, de Hoogovens woningbouw, kortom een integratie van werk en prive, zoals die ooit tot veler geruststelling bestond.

$102 \mathrm{Vgl}$ het experiment met kinderen en hun gedetineerde moeders in Sevenum waarbij aanvankelij $\mathrm{k}$ een crèche op het terrein gerealiseerd was. $\mathrm{Na}$ bijna een jaar experimenteren vormden overwegingen van personele en pedagogische aard voldoende argument om de kinderopvang overdag buiten de inrichting in cen regulier kinderdagverblijf onder te brengen. Vgl. de ervaringen met moederbaby-units. in Groot Birttanniē, zoals beschreven door Catan. Zij benadrukt ook de grote voordelen voor het kind dat opgevangen wordt door gekwalificeerde krachten in de professionele kinderopvang (Catan 1992, p. 18-19).

103 Bussemaker (1993) p. 197-236. 
moet voldoen lijkt te gaan bepalen. Niet de pedagogische doelstellingen maar de inpassing in de arbeidscultuur worden leidraad in het kinderopvangbeleid van de overheid. $^{104}$

Overigens lijkt impliciet de vanzelfsprekende koppeling tussen vrouwen/ vrouwelijkheid en kinderopvang te blijven bestaan en niet ter discussie te worden gesteld. De werkgelegenheid die binnen de uitdijende kinderopvang is gecreëerd is dan ook wooral ten goede gekomen aan (herintredende) vrouwen.

Bussemaker stelt ten principale aan de orde in hoeverre de zorg voor kinderen een collectieve zaak is, waar dus ook een belang voor de overheid ligt of een privégebeuren, waarin de ouders de volle verantwoordelijkheid dienen te dragen en zij komt tot de volgende uitspraak:

"Kinderverzorging is een collectieve verantwoordelijkheid, voorzover het opvoeden van een nieuwe gemeratie een algemeen belang is. Maar het is ook een individuele verantwoordelijkheid, voorzower het krijgen wan kinderen niemand meer hoeft te overkomen en het om een beslissing gaat die men zelf neemt." ${ }^{\text {ns }}$

Er zit hier naar mijn mening een tegenstrijdigheid. Die 'individuele verantwoordelijkheid' is op zijn minst cultuurgebonden, afhankelijk van de emancipatiegraad en sociaaleconomische omstandigheden van vrouwen. In het (relatief geëmancipeerde) westen nemen vaak vrouwen uiteindelijk de feitelijke beslissing over de voortplanting en betrekken zij daarbij de implicaties voor de zorg. Impliciet gaan ook beleidsmakers daar meestal van uit. In de discussie over gemengde detentie bijvoorbeeld leggen beleidsmakers als vanzelfsprekend het 'voortplantingsrisico' exclusief bij vrouwen. Misschien dat mannen door met name het Aidsrisico iets meer doen aan 'veilig vrijen', maar dat heeft niet zo veel te maken met in een vroeg stadium de gevolgen overzien van de zorg voor een potentieel nageslacht. Holtrust stelt zelfs voor expliciet aan te nemen dat de zorgverantwoordelijk, na zwangerschap en baring, bij vrouwen ligt. Die van partners kan eventueel via een privaatrechtelijke overeenkomst vastgelegd en en gespecificeerd worden. ${ }^{100}$

Wellicht moet in Bussemakers visie een bepaald moreel oordeel worden gelezen over hoever de collectieve verantwoordelijkheid voor een volgende generatie zou moeten strekken. Ook intergenerationeel gedacht moet mijns inziens de collectieve verantwoordelijkheid in de zorg voor kinderen als een investering gezien worden in de collectieve zorg voor ouderen straks. Moreel gezien zijn bijvoorbeeld kortingen op de kinderbijslag met een beroep op de eigen verantwoordelijkheid van potentiële ouders kortzichtig. Wederkerigheid en solidariteit over generaties heen worden, in

104 Bussemaker (1993), Pessers (1994) p. 62-65.

105 Bussemaker (1993) p. 233. Zie ook: Zwaan (1993-2).

106 Holltust (1993) p. 323 . 
breder verband dan de familiekring, steeds belangrijker naarmate de samenleving multicultureler en mobieler wordt.

\subsubsection{Onderwijs}

Met de bescherming van het gezins- en privelleven komen we, omdat de twee elkaar niet overlappen maar wel nauw verbonden zijn, in de diffuse overgang tussen sociale en klassieke grondrechten. Met name wanneer het over opwoeding van kinderen gaat, lijkt het liberaal-christelijk gedachtengoed in Nederland zeer sterk verankerd te zijn en wordt enige inmenging wan derden of de overheid als bedreigend ervaren in de privesfeer. ${ }^{107}$ De enorme waarde die gehecht wordt aan de bescherming van de privésfeer zou volgens Hofstede typisch Nederlands zijn. ${ }^{108}$ Schooluniformen of warme maaltijden op scholen worden hier in algemene opvoedkundige zin niet aan de orde gesteld. ${ }^{109}$ Voorstellen tot praktische regelingen om de combinatie van verschillende taken voor ouders mogelijk te maken, zoals continuroosters op scholen en afstemming van sluitingstijden van scholen op de naschoolse opvang stuiten op verzet bij -vooral- besturen van bijzondere scholen. Dat leidt tot te veel overheidsbemoeienis in de privésfeer! De boterham moet tussen de middag bij moeder thuis gegeten worden. Het verschijnsel van rijen wachtende (of vanwege de verkeersdrukte brigadierende!) moeders tussen de middag is dan ook een typisch Nederlands verschijnsel.

De in Nederland opdoemende discussie over het dragen van hoofddoekjes tijdens schooluren door Islamitische meisjes, zal misschien duidelijk maken in hoeverre de tolerantie voor christelijke waarden en normen ook opgebracht wordt voor andere

107 Het is in dit verband ook opmerkelijk dat de Nederlander Schermers in de zaak Y tegen het Verenigd Koninkrijk (klacht nr. 14229/88) voor de Europese Commissie in zijn dissenting opinion De Britse regering niet aansprakelijk achtte voor de lijistraffen op privéscholen. "Naar zijn persoonlijke mening is lichamelijke bestraffing slecht in opwoedkundige zin: gebruik van geweld lokt geweld uit. Van de andere kant dient in zijn opinie het recht wan de ouders gerespekteerd te worden om gematigde lijistraffen te gebruiken tegen hun kinderen en om hun kinderen naar een schooll te sturen die een dergelijke straf gebruikt." (in: Van Emmerik 1992, p. 11.) Baartman beschrijft hoe hardhandigheid jegens kinderen ook in onze cultuur verankerd zit. "Overwicht, gezag, dwang en eventweel hardhandigheid werden door velle pedagogen en artsen gezien als moodzakelijke middelen om thet kind op het goede pad te brengen en te houden. Het kind werd gezien als een bundel driften die tijdig getemd moesten worden." (H. Baartman 1993, p. 44) In zijn opinie zijn fysieke kindermishandeling, lijfstraffen en corrigerende tikken onderdelem van een continuüm van gewelldadigheid. Zolang "de pedagogische tik" maatschappelijk aanwaardbaar wordt gevonden, zal de legitimatie om andere vormen van geweld af te wijzen ongeloofwaardig zijn. Zie hierover ook De Boer (1994) p. 389-390 en 542.

108 Hofstede, in: Doughty (1991) p. 176-177.

109 Een uitzondering vormen kleine groepen zeer welgestelden die via particuliere (kost)scholen hun kinderen in de mores van een bepaalde maatschappelijke bovenlaag willen inlijven. 
orthodoxe godsdiensten of dat de grenzen van het culturrelativisme bereikt zijn. Overigens is het bij dergelijke kwesties nog maar de vraag of er een conflitct speelt tussen de overheid en de ouders omtrent de reikwijdte van aan godsdienstvrijheid ontleende gedragingen of dat dit zich afspeelt tussen het bestuur en de ouders van de betreffende school. Dit maakt de vraag naar de primaire drager van het ondenwijsgrondrecht (bestuur of ouders) wel weer actueel, maar die vraag gaat het thema van mijn onderzoek te buiten. ${ }^{10}$

De argumentatie in de discussie over professionele kinderopvang vertoont echter een interessante gelijkenis met die over het onderwijs in de vorige eeuw. Een beroep op onder andere "overdracht van eigen humor en hoogstpersoonlijke waarden en normen ${ }^{m 11}$ lijkt op de houding van de bourgeoisie in de negentiende eeuw. Die wilde weliswaar de scholen voor minderbedeelden ondersteunen maar de eigen kinderen toch liever thuis opvangen, eventueel met gouvernantes. ${ }^{112} \mathrm{Het}$ is interessant om te zien welke afwegingen in de onderwijsdiscussie gemaakt zijn, zodat er niet alleen een sociaal recht op onderwijs is ontstaan maar zelfs een leerplicht. Er is inmiddels immers sprake van vergaande overheidsbemoeienis in de cultuuroverdracht. ${ }^{113}$ Coomans geeft een tweetal argumenten, dat ervoor pleit dat het recht op onderwijs te verenigen is met een leerplicht $t^{114}$ :

- Het onderwijs draagt bij aan de individuele ontplooiing en dus aan de uitoefening van andere rechten. Niemand kan het kind er van weerhouden onderwijs te volgen. De leerplicht dient ter bescherming tegen de nadelige invloed van ouders, het gezin of de staat op de belangen van het kind;

- De leerplicht beoogt gelijke kansen voor een ieder te scheppen in het onderwijs en in de maatschappij.

Ook Akkermans benadrukt de belangrijke rol van het onderwijs in het socialisatieproces en het belang van een gelijke behandeling voor ieder. ${ }^{.15}$

\subsubsection{Gezondheidszorg}

Binnen de gezondheidszorg wordt, met name in de preventieve sfeer, veel van de overheid verwacht. Maar er treedt discussie op bij een te verplichtende stellingname van de overheid, bijvoorbeeld bij de fluoridering van het drinkwater, de antipolioinenting en de antirokencampagne. Eigen waarden en normen van ouders die doorge-

110 Zie Bieurskens (1991) p. 99-107.

111 Pessers, Volkskrant, 5 januari 1993.

112 Singer (1989) p. 69 e.v., Van Essen (1990) p. $21-62$.

113 Ik wil overigens niet suggereren dat de discussic over de inhoudelijke bemoeienis met het onderwijs door de overheid niet meer gevoerd zou worden. Vgll. de Wet op de basisvorming en de dakarin geformuleerde kerndoelen. (O.a. Soetenhorst-de Savornin Lohman 1992, p. 5-12).

114 Coomans (1992) p. 269-270.

115 Akkermans (1980) p. 68-81. 
trokken worden naar het leven van de kinderen vormen een belangrijk argument tegen overheidsbemoeienis.

Met name ten aanzien van de preventieve gezondheidszorg ten behoeve van kinderen is de discussie nog gaande. Rond de poliovaccinatie duiken de verschillende standpunten na iedere epidemie opnieuw op ${ }^{116}$ Het is daarbij dan de vraag of de dreiging van lichamelijke ondergang voldoende concreet is om tot een tijdelijke ondertoezichtstelling over te gaan. Veldkamp en Bogers menen van wel en beroepen zich daarbij op de zelfstandige rechten van het kind. ${ }^{117}$ Art. 8 EVRM lid 2 biedt volgens hen de legitimatie om in te grijpen in het gezinsleven en het gezag van de ouders. Als andere juridische legitimaties voor een dergelijke inbreuk noemen zij de beperkingsgronden, met name het belang van de gezondheid en de bescherming van rechten en vrijheden van anderen. ${ }^{118}$ Art. 24 VN-Kinderverdrag ziet bovendien toe op alle kinderen zonder voorbehoud of beperking. ${ }^{119}$ Hermans toont zich zeer terughoudend ten aanzien van het hanteren van een kinderbeschermingsmaatregel in een individueel geval. ${ }^{120} \mathrm{Er}$ is vrijwel nooit sprake van een concreet en dreigend gevaar. Pas als eenmaal de diagnose is gesteld is er een bewijs, maar dan is het te laat. In navolging van Doek en Korteling; spreekt hij zich wèl uit voor een algemene absolute vaccinatieplicht. Hoewel er sprake kan zijn van beperking van een fundamenteel vrijheidsrecht (godsdienstvrijheid) wordt dit gerechtvaardigd op grond van een zwaarwegend belang, een beschermingsbelang. ${ }^{121}$

In het advies van de Nationale Raad voor de Volksgezondheid over het beleid inzake poliovaccinatie wordt handhaving van een vaccinatieplicht met gebruik van dwangmiddelen in de praktijk niet of nauwelijks mogelijk geacht. ${ }^{122}$ Dute merkt op dat de overheid aan haar grondwettelijke inspanningsverplichting en aan de beginselen van proportionaliteit en subsidiariteit heeft voldaan. De overheid geeft voorlichting, zorgt voor voldoende gelegenheid tot vaccinatie, bevordert dat elk kind wordt ingeënt en beoordeelt vervolgens of een vaccinatieplicht noodzakelijk is. Met de hoogste inentingsgraad tegen polio ter wereld $(95 \%)$ is een vaccinatieplicht niet noodzake-

116 Zie Nationale Raad voor de Volksgezondheid (1993). Vgl. ook Veldkamp en Bogers (1993) p. 1170-1173, met reacties en naschrift op p. 1626-1627.

$117 \mathrm{Zij}$ beroepen zich op art. 22 Grondwet, art. $11 \mathrm{ESH}$, art. 12 IVESCR en art. $24 \mathrm{VN}$-Kinderverdrag. 118 Zie in art. 6 lid 1 Grondwet, art. 9 lid 2 EVRM, art. 19 lid 3 IVBPR.

119 In het oude art. 1:245 lid 2 BW leggen zij de uilleg dat het gezag moet worden uitgeofend "met inachtneming van de rechten en bevoegdheden van kinderen".

120 Hermans (1990) p. 144-145.

121 Vgl. de jurisprudentie inzake de valhelmarresten. HR 22-6-1976, NJ 1977, 27 en HR 20-9-1976, NJ 1977. 28. De HR oordeelde dat bromfietsers "tegen door hen blijkhaar niet in volle omwang besefte gevolgen van hoofdletsel moeten worden beschermd" maar ook dat dit letsel niet alleen gevolgen heeft voor de betrokkenen zelf, maar ook voor de gemeenschap, gelet op de veelall langdurige, soms zelfs levenslange en kostbare verpleging in ziekenhuizen en inrichtingen.

122 Nationale Raad voor de Volksgezondheid (1993) p. 40. 
lijk: ${ }^{: 2}$ Met name in de preventieve sfeer is het lastig om welzijns- en gezondheidsrisico's concreet te vertalen naar individuele gevallen en dan voldoende legitimatie te vinden voor een actief overheidsingrijpen in de familiesfeer.

"Inbreuken op het recht van een kind op te groeien in een sfeer van geluk, liefde en begrip ajjn buitengewoon moeilijk vast te stellen, vanwege het principieel onmeetbare karakter wan geluk, liefide en begrip. Een gezin waarin de zwangere moeder rookt als een ketter en de aanstaande vader zwaar drinkt, kan gelukkiger zijn dan een gezin van akelige geheelonthouders. Zelfs wanneer er een statistisch verband zou zijn tussen roken en drinken enerzijds en een gebrek aan welbevinden anderzijds, dan nog mag niet worden aangenomen dat elke roker en drinker ongelukkig is. Een statistisch verband is namelijk geen causaal verband en geldt dus niet op individueel niveau. Hetzelfde geldt voor de relatie tussen het roken van de zwangere vrouw en de kans op een lager geboortegewicht van het kind."1z

Anders wordt het wanneer de overheid zich de preventie van risico's bij derden, zoals andere kinderen, ter harte neemt. Ik denk daarbij aan de discussie in het Reformatorisch Dagblad over een kinderdagverblijf dat een niet ingeënt kind de toegang weigert op grond van gemeentelijke verordening. Mag de gemeente zich daarmee bemoeien? Is dat een zaak voor het kinderdagverblijf en/of de betrokken ouders? Ik denk zelf dat de gemeente ten aanzien van deze risico's een zorgplicht heeft, net als bij (brand)veiligheid. Juist waar het om betrekkelijke subjectieve normen gaat, ook rond veiligheid in de privesfeer verschilt het gedrag van ouders, moet de overheid een redelijke norm vaststellen.

In het kader van de behandeling is eigenlijk al een oplossing gevonden in de gevallen waarin ouders, veelal op grond van hun godsdienstige overtuiging niet willen meewerken aan de behandeling van hun kind. Via de tijdelijke ondertoezichtstelling wordt de behandeling hier toch mogelijk gemaakt. ${ }^{125}$ Dit gebeurt bijvoorbeeld wanneer kinderen van Jehova's getuigen in een levensbedreigende situatie bloedtransfusie nodig hebben. ${ }^{120}$

In verband met de beoordeling van de rechtspositie van minderjarigen is binnen het gezondheidsrecht in concrete gevallen van vier criteria gebruik gemaakt ${ }^{127}$ :

- het recht op zelfbeschikking;

- het ouderlijk gezag en het oordeel des onderscheids ${ }^{128}$;

- het stellen van leeftijdsgrenzen ${ }^{12 x}$;

- het belang van het kind.

123 Dute (1993) p. 1626-1627 met naschrift van Veldkamp en Bogers.

124 Rutenfrans (1992) p. 26. Vgl, het gevaar van onkritisch diagnosticeren op grond van ontwikkelingsstatistieken bij individuele kinderen. (Singer (1989) p. 104-107.)

125 Artt. 7:645 lid 4 BW, 1:254, 1:257, 1:271 BW.

126 O.a. Hermans (1990) p. 143.

127 Hermans (1990) p. 34 e.v..

128 Vgl. art. 1: 234 lid $2 \mathrm{BW}$.

129 Zie de Wet geneeskundige behandelingsovereenkomst. Art. 7:450 BW. 


\section{Hoofdstuk 6}

In met name het criterium "het belang van het kind" en "het oordeel des onderscheids" komt het beschermingsidee tot uitdrukking. Hermans spreekt over het teleologisch karakter van dit criterium, gebaseerd op principes van weldoen of leed vermijden, in tegenstelling tot de andere criteria waaraan overwegend principes van autonomie en rechtvaardigheid, in de zin van gelijke behandeling, ten grondslag liggen. $\mathrm{Hij}$ probeert, in navolging van rechtstheoretische en ethische literatuur in de Verenigde Staten, invulling te geven aan de "best interests standard". Ervan uitgaande dat te weinig ingrijpen in het gezinsleven beter is dan teveel, bepleit hij ook een zogenaamde "differentiaal diagnose". Bij het omzetten van de diagnose in concrete maatregelen zou men zich op de noodzaak moeten richten de ouder-kindrelatie in stand te houden. Hermans pleit voor een specifieke wettelijke bepaling die het mogelijk maakt overheidsoptreden te rechtvaardigen:

"Overheidsoptreden ter bescherming van de gezond heid van minderjarigen is gerechtvaardigd, indien het niet verrichten van een medische handeling waarvoor toestemming wordt gevraagd wordt geweigend opgrond wan medische, et hische, sociale en psychologische prognoses vrijwel zeker tot blijvende schade van het kind en/of anderen zal leiden." ${ }^{.130}$

In de Wet geneeskundige behandelingsovereenkomst is de bescherming van de positie van de minderjarige, ook ten opzichte van de ouders duidelijk geregeld. ${ }^{131}$ Boven de zestien jaar beeft het kind geen toestemming van de ouders meer nodig. Tussen twaalf en zestien jaar kan een verrichting zonder toestemming van de ouders worden uitgevoerd

"indien zij kennelijk nodig is teneinde ernstig nadeel voor de patiênt te voorkomen, alsmede indien de patiënt ook na de weigering van de toestemming, de verrichting weloverwogen blijft wensen". ${ }^{132}$

Opmerkelijk is dat de beschermingsgedachte hier vooral gevoed wordt door een vrees voor ongebreideld medisch ingrijpen.

130 Hermans (1990) p. 145. Zie ook: De Bruijn-Lückers (1994)p. 161-165.

131 Zie ook De Brujun-Luickers (1994) p. 165-172, Jansen (1993), Koens (1994) p. 40-41, Leenen (1994) p. 146-149. Bij mijn weten is er nog geen gendergerelateerd onderzoek gedaan naar besluitvormingsprocessen rond de behandeling van kinderen, met name bij tegenstrijdige standpunten van ouders, In hoeverre komt de primaire verzorger, de met de feitelijke zorg belaste ouder, als zodanig uit de verf?

132 Art. 7: 450 lid 2. BW. Zie ook art. 7:447 BW. 


\subsection{Conclusie}

'Het belang van het kind' is in het VN-Kinderverdrag vertaald in positief geformuleerde rechten. Hoewel in Nederland de discussie over kinderrechten zich heeft toegespitst op de formele rechtspositie van het kind, zijn er in het verdrag vooral materiele rechten te vinden. De overheild moet de ouders steunen in hun verzorgende en opvoedende functie door adequate voorzieningen te creëren. De positie van kinderen is in de maatschappelijke werkelijkheid nauw verbonden met die van vrouwen. Zowel kinderen als vrouwen zijn gebaat bij het ontwikkelen van eigen sociale netwerken. Kinderrechten kunnen gebruikt worden om vrouwen in de traditionele moederrol te manipuleren. Daarom is ook de autonome positie van vrouwen van belang in relatie tot 'het belang van het kind'. In het $\mathrm{VN}$-Vrouwenverdrag worden de verschillende functies van 'moeders' beschermd. De potentieel biologische, die in principe alle vrouwen betreft, de feitelijk biologische, die zich beperkt tot zwangerschap, baring, zoging en ontzwangering en de sociale, die de feitelijke verzorging en opvoeding betreft. Wat het biologisch moederschap betreft is het van belang te onderkennen dat door in detentie vergaande privileges te creëren die verbonden zijn aan het feitelijk moederschap, vrouwen onder druk gezet kunnen worden om moeder te worden. Dan is er geen sprake van 'moederschap uit vrije wil' (vgl. art. 16 lid 1 sub e VN-Vrouwenverdrag) en kan er mijns inziens zelfs sprake zijn van ongelijke behandeling met vrouwen die geen moeder willen of kunnen worden.

Het moederschap als sociale functie betreft ook mannen. Het gaat hierbij om de verzorgende ouder. Het is wel belangrijk te onderkennen dat de invulling van sociaal ouderschap vaak genderspecifiek is. Daarom moet de feitelijke verzorging altijd beoordeeld worden naar de concrete omstandigheden. Een op de zorg voor kinderen ingesteld detentiebeleid zou toegankelijk moeten zijn voor vrouwen en mannen die op grond van hun sociale opvoedingsfunctie feitelijk verzorgende taken vervullen. Mede omdat beide verdragen nog betrekkelijk nieuw in onze rechtsorde zijn en de directe werking van diverse verdragsartikelen nog nader bepaald moet worden, is het van belang de relevante bepalingen in te lezen in verdragsartikelen die wel directe werking hebben, zoals art. 8 en 14 EVRM en art. 10 en 26 IVBPR. De overheid zou dus een beleid gericht op kinderen moeten ontwikkelen waarbij enerzijds het recht op family life gerespecteerd wordt en anderzijds het autonome recht op privacy van de verschillende gezinsleden gerealiseerd kan worden. In de Europese rechtspraak lijkt het erop dat in conflictsituaties het eigen recht op privacy van kinderen onderschat wordt en dat het beroep op family life door de met het gezag beklede ouder wordt gehonoreerd.

Wat een 'op de zorg voor kinderen ingesteld beleid' moet zijn, is vooral een politieke vraag. Analoog aan de ontwikkelingen in het arbeidsrecht, kan er in de voorwaardenscheppende sfeer gedacht worden aan zwangerschaps-, ouderschaps- calamiteitenen verzorgingsverlof. 
Met name in de voorbeelden uit de kinderopvang, het onderwijs en de gezondheidszorg, waar er veeleer sprake is van directe overheidsbemoeienis in de privésfeer staat de vraag centraal hoe het recht moet reageren op een botsing van het waardenstelsel van ouders dat haaks staat op het op gangbare overtuigingen gebaseerde overheidsbeleid. Overheidsbemoeienis op grond van art. 8 lid 2 EVRM joart. 14 EVRM mag geen discriminatie inhouden tenzij daarvoor een objectieve en redelijke rechtvaardiging bestaat, dat will zeggen dat met het onderscheid een legitiem doel wordt nagestreefd en dat de middelen om dat doel te bereiken proportioneel moeten zijn.

Een inbreuk op het family en private life van gedetineerde ouders en hun kinderen zou niet alleen legitiem moeten zijn (dat is het op grond van art. 15 Grondwet + de veroordeling krachtens het strafrecht) maar ook proportioneel. Vanuit het perspectief van zorgrelaties (vgl. het VN-kinderverdrag en het VN-Vrouwenverdrag) zal een nadere uitwerking aan de beginselen van subsidiariteit en proportionaliteit gegeven moeten worden. Concrete maatregelen zouden zich moeten richten op het in stand houden van de relatie tussen ouder en kind, tenzij dit tot schade voor het kind en/of anderen zal leiden. 


\section{'Het belang van het kind': privacy of family life?}

\section{Inleiding}

Wanneer er gedacht wordt over gedetineerden en de van hun zorg afhankelijke kinderen, lijkt er consensus te bestaan over het idee dat het creëren van voorzieningen om die relaties te optimaliseren in het belang van het kind moeten zijn. In een eerder hoofdstuk is al aangegeven dat 'het belang van het kind' geen eenduidig begrip is. Opvoedingstheorieën zijn tijd- en cultuurgebonden.

'Het belang van het kind' is ook een juridische constructie, die met name binnen het familierecht als beginsel wordt gehanteerd. Met verwijzing naar Pessers' noemt Franken dit een van de beschaafdste maar ook een van de meest hypocriete beginselen van het recht. Hij tracht te definiëren wat er met het beginsel wordt bedoeld:

"het welzijn van een al dan niet zozeer onmondige, maar wel zwakkere medemens. Een medemens, die nog niet zelf voor al zijn rechten kan opkomen. Daarom verdient hij bescherming en vereist hij zorg. Daarnaast geldt, dat het een medemens is, die naar gelang hij in staat is om acticf deel te nement aan maatschappelijke activiteiten ook kan worden aangesproken op eigen werantwoor delijkheden. $H_{\mathrm{ij}}$ krijgt plichten, maar ook rechten, die hem als iedere staatsburger toekomen." ${ }^{\text {"2 }}$

Kortom het kind kan worden gezien als voorwerp van bescherming en zorg en als drager van eigen rechten en plichten. ${ }^{3}$ De autonome positie van de minderjarige komt binnen wetgeving en rechtspraak vaak pas expliciet aan de orde als er sprake is van afwijkend gedrag van het'normale burgerlijke gezinsleven' of 'het traditionele gezin'. Veelal zal er sprake zijn van verstoorde gezagsverhoudingen of van een matschappelijk gezien negatief afwijkend gedrag van de jeugdige, wil er wettelijk expliciet jets geregeld zijn. In dit hoofdstuk gaat het echter om 'het belang van het kind",

1 Pessers (1987).

2 Franken (1988) p. 27.

3 Zie ook De Langen (1990).

4 Vgl. Van den Blink (Raad voor het Jeugdbeleid) op de NJV-vergadering, 1990, p. 55. "Het kind dat niet opgroeit in cen traditioneel gezin heeft volgens de Raad belang bij een duidelijk onderscheiden en consequente regeling van beide soorten ouderschap. Dit geeft het kind de beste mogelijkheid tot enerzijids hechting aan een of twee vaste opvoeders en anderzijds tot de ontwikkeling van een eigen identiteit door bewuste beleving wan zijn biologische oorsprong." 
dat door een externe verandering, zoals echtscheiding of detentie, gedefinieerd en veiliggesteld moet worden. ${ }^{5}$ Ik beperk me hier dan ook tot hetgeen er gebeurt met 'normale' kinderen, dat wil zeggen dat ik de zorg voor het afwijkende kind buiten beschouwing laat. Ik ga daarom ook niet in op de jeugdhulpverlening en het jeugdstrafrecht.

'Het belang van het kind' is voor vrouwen een ambigue beginsel. Enerzijds appelleert het aan de door vrouwen geînternaliseerde behoefte tot zorgen. Anderzijds kunnen wrouwen via een beroep op het belang van het kind in door hen niet gewenste en als onderdrukkend ervaren samenlevingsconstellaties worden gedwongen. ${ }^{6} \mathrm{Het}$ recht stelt de algemene norm maar moet ruimte bieden voor uitzonderingen juist ook om verschraling van relaties en machtsongelijkheid te voorkomen. Het is moeilijk om het belang van het kind in algemene zin te formuleren, net zoals dat het geval is met het belang van de vrouw. In hoeverre lopen belangen van vrouwen en kinderen parallel, wanneer kunnen ze strijdig zijn? Hoe kan het belang van het kind afgewogen worden tegen andere belangen, zoals die van de afzonderlijke ouders, andere kinderen of zoals in art. 12 w.o. PBW bijvoorbeeld 'het belang van de orde en veiligheid"? Gaat het collectieve belang, van 'het gezin' of 'de samenleving', boven het individuele? Hoe gaat het recht, met name het familierecht, om met die belangenafwegingen? Binnen de gewone kerngezinnen zijn de zorgtaken en de juridische machtsposities tussen mannen en vrouwen lange tijd ongelijk en seksespecifiek verdeeld geweest. ${ }^{7}$ Pas in 1905 kunnen moeders, na echtscheiding, de voogdij krijgen. Binnen het huwelijk behoudt de vader de ouderlijke macht tot 1947 . Vanaf dat jaar kunnen moeders mee de ouderlijke macht uitoefenen, maar alleen wat betreft de persoon van het kind. Het vermogen wordt beheerd door de vader, die ook het kind vertegenwoordigt in burgerlijke rechtshandelingen. ${ }^{8}$ Dit verandert in de jaren tachtig. Dan raakt de man ook de beslissende stem kwijt bij conflicten rond de verzorging en opvoeding.

5 In dit verband is het interessant dat het eerste concept van de nïeuwe BGW de Raad wan de Kinderbescherming werd teruggehaald in do "oude rol" die hij vroeger in echtscheidingsituaties had, namelljk advisering in alle situaties. Na de hierop vanuit de Raden genite kritiek, wordt nu in de Memorie van Toelichting wermeld: "Van een verplichte advisering is affezien, omdat eendergelijke adviseringsverplichting niet behoort tot de kerntaken wan de Raden voor de Kinderbescherming (TK 1994-1995, 24263, nir, 3, p. 86). Zie ook: Krooi (1994) p. 81-82.

6 Zie o.a. Diduck (1995) war zij waarschuwt tegen het gebruik van "the best interests of the child" als construerend begrip on het traditionele gezinswerband - opnieuw - lot superieure samenlewingsvorm te bestempelen.

7 Onder meer Badinter (1989), Sewenhuijsen (1987), Braun (1992), Hammerstein-Schoonderwoerd (1994).

8 Thomassen (1982) p. 155-156. In dit artikell toont zij aan de hand van feministisch-antropologisch onderzoek en marxistische theorievorning de sekse-onderdrukking in het familierecht (op dat moment) aan: arbeidsdeling naar sekse, heteroseksualiteit als norm is de basis, huwelijk als werbintenis tussen man en vrouw. "Ook is de inwloed van wrouwen op de produktieverhoudingen rond de voortbrenging van kinderen miet groot" (p. 155). 
Indien nodig grijpt nu de rechter in. Het is echter de vraag of de formele gelijkstelling tussen vaders en moeders altijd recht doet aan de feitelijke functieverdeling in het gezin. En welke rol 'het belang van het kind' daarbij als beginsel speelt.

Nu er steeds minder sprake is van continuïteit in 'normale' burgerlijke gezinnen met een stabiel heteroseksueel ouderpaar als vaste factor, is vooral binnen het familierecht het denken over de zelfstandige positie van de afzonderlijke familieleden binnen allerlei relatievormen in een stroomversnelling geraakt.

"De sterk op het huwelijk gerichte oriëntatie van het familierecht heeft plaatsgemaakt woor cen op het familie-en gezinsleven gerichte oriëntatie, zoals dat in de maatschappij feitelijk voorkomt. Delen vam het familierecht zijn dan ook niet langer uit de wet kenbaar. Het is daarvoor ook nodig de rechtspraak wan de Hoge Raad te kennen",

zo wordt gemeld in de Notitie Leefvormen van de Staatssecretaris van Justitie." Vooral de doorwerking van art. 8 EVRM heeft tot belangwekkende rechterlijke uitspraken geleid en tot grote activiteit op het gebied van wetgeving." Het nieuwe art. 12 w.o. PBW wordt in de toelichting ook gefundeerd op art. 8 EVRM. ${ }^{11}$ Voor zover relevant voor het onderzoeksthema wordt in dit hoofdstuk een beschrijving gegeven van actuele discussies in het familierecht, met name waar invulling aan 'het belang van het kind' wordt gegeven in relatie tot dat van de andere gezins- en familieleden. In hoeverre werken de verschillende in een eerder hoofdstuk beschreven pedagogische theorieën ook in het recht door? Staat de intergenerationele (bloed)band centraal, is er sprake van een genderspecifieke benadering van de ouder en in hoeverre wordt de leefwereld in ruime zin onderzocht? Welke rol spelen intragenerationele relaties, tussen kinderen onderling, binnen en buiten gezinsverband? Juist die relaties lijken immers van groot belang voor de verdere ontplooiing en identiteits-

9 Notitie 'Leefvormen in het Familierecht' (1995) p. 1.

10 "Terwijl woor de overheid juist op het terrein wan het familie- en jeugdrecht een zeer bescheiden taak is weggelegd, is haar de laatste jaren bij voortduring gevraagd om zich met dit familieleven te bemoeien en tot regulering van familierelaties over te gaan. Vele categorieën personen eisen hun veronderstelde rechten op, individueel bij de rechter en in meer algemene zin bij de wetgever, die zo hebben we kunnen constateren hier weïin terughoudend op gerexigeerd heeft. Met de pretentie dat alles ook geregeld kan worden, heeft men gemeend op vrijwel alle claims in te moeten gaan. Het lijkt dat noch de regering noch de Tweede Kamer er nog enig zicht op heeft, wat op dit terrein hun taak is, wat de zin is van werschillende wetsontwerpen en hoe zij eenmaal wet in de praktijk zullen werken. De discussies gaan voornamelijk over detailpunten en leiden eventueel tot incidentele wijzigingen, waardoor de grote lijnen uit het oog verloren raken en er weinig consistente en veel te gedetailleerde wetgeving tot stand komt" ' aldus een kritische De Langen (1993) p. 26.

11 TK 1994-1995, 24 263, nr. 3, p. 85-86. Zie hoofdstuk 4. 
vorming van het kind. Wordt het gepest, is het de leidersfiguur en welke rol spelen uiterlijke kenmerken, zoals lengte, gewicht, huids- en haarkleur etcetera. ${ }^{12}$ Het juridisch debat over de inmenging van de overheid in de privésfeer, de bescherming van de privacy en het family life is de afgelopen decennia, in navolging van de maatschappelijke ontwikkelingen, in alle hevigheid gevoerd. Juridische vrouwenstudies heeft enerzijds op een heel hoog abstractieniveau getracht het dominante juridische vertoog een 'vrouwelijke' stem te geven en anderzijds in haar reactie op diverse wetsvoorstellen en de rechtspraktijk geprobeerd om een aan de feiten rechtdoende invulling aan juridische concepten te geven. ${ }^{13}$ Op beide aspecten wordt in dit hoofdstuk vooraf kort ingegaan.

\subsection{Een vrouwelijke moraal?}

Binnen juridische vrouwenstudies wordt geprobeerd een manier te vinden om niet alleen de genderlading van het recht te openbaren en de dichotomie tussen de publieke en privésfeer te doorbreken, maar ook om het dominante vertoog te veranderen door 'het vrouwelijke' een stem te geven. ${ }^{14} \mathrm{Er}$ wordt gezocht naar een genderspecifieke, vrouwelijke manier van moreel redeneren en vervolgens naar een omzetting in het juridisch vertoog. Begrippen als zorg, het vrouwelijke, moederen en de relationele benadering zijn daarbij gebruikelijke concepten, hoewel deze niet persé op concrete taken betrekking hoeven te hebben. ${ }^{\text {is }}$

Hoewel zij zelf geen jurist is, heeft met name Gilligan vanuit het 'zorgperspectief' het denken binnen juridische vrouwenstudies beïnvloed. ${ }^{16}$ Gilligans onderzoek hoort thuis in de ontwikkelingspsychologie en gaat over de ontwikkeling van het volwassen vermogen om tot morele oordelen te komen. ${ }^{17} \mathrm{Zij}$ bekritiseert Kohlberg die zes stadia in de ontwikkeling van kinderen en adolescenten onderscheidt. Stadia die uiteindelijk leiden tot het vermogen morele beslissingen te nemen die in overeenstemming zijn met abstracte, generaliseerbare regels en normen van rechtvaardigheid. In het onderzoek van Kohlberg staat het moreel oordelen over testcases centraal en niet het moreel handelen. Hij hecht veel waarde aan cognitieve aspecten, met name het denkproces. ${ }^{18}$ Vrouwen lijken moeite te hebben de stap naar de laatste

12 Zie ook Lejiten (1993) p. vi. Zie ook "de gelaagde identiteitsvorming" en "het werbrede opvoedingsmilieu"' in hoofdstuk 5.

13 Zie Goldschmidt en Holtmaat (1993) p. 87-102.

14 Zie bij voorbeeld Gunning (1992) p. 455-461.

15 Een overzicht van de feministische rechtstheorieën is gegeven door Raes (1991).

18 Gilligan (1982). Krol en Sevenhuijsen (1992) over de doorwerking van Gilligans theorie in andere wetenschapsgebieden. Zie ook Tigchelaar (1993).

17 Zie Sevenhijsen (1988) p. 219 e.v..

18 Kohlberg (1986), Wegelin (1990) p. 58. 
twee stadia te nemen, hetgeen Kohlberg aanvankelijk afwijkend en niet volwassen vindt. Later constateert hij deze verschillen tussen mannen en vrouwen overigens niet meer, maar wel tussen plattelandskinderen en kinderen in verstedelijkte gebieden. ${ }^{20}$ Gilligan komt op grond van haar onderzoek tot de conclusie dat mannen morele problemen zien als een conflict van rechten of van algemene regels, die in een hiërarchische ordening geplaatst moeten worden om tot een beslissing te komen, terwijl vrouwen morele problemen in een concrete context plaatsen. In haar onderzoek bij vrouwen naar hun afwegingen om bij een ongewenste zwangerschap al dan niet tot abortus over te gaan, merkt zij dat vrouwen zich niet afvragen hoe zij hun rechten kunnen uitoefenen, zonder in conflict te komen met die van anderen, maar dat hun probleem is hoe zij hun gevoel verantwoordelijk te zijn voor anderen kunnen beperken zonder hun moreel besef geweld aan te doen.

"De vrouwelijke moraal is altijd bezig een evenwicht te vinden tussen werbondenheid en zelfgevoel. ${ }^{21}$

Dit type moraal wordt door Gillligan omschreven als een 'ethics of care' die zij plaatst tegenover de'ethics of rights".

Beide typen van moreel redeneren verschillen in de volgende opzichten:

1. In de zorgzaamheidsethiek gaat het om verantwoordelijkheid en relaties, in plaats van rechten en regels.

2. Deze ethiek is niet formeel en abstract, maar verbonden met concrete omstandigheden.

3. De moraal is geworteld in activiteit, alledaagse ervaringen en niet in abstracte universele regels.

Bij zowel Kohlberg als Gilligan is het verband dat zij leggen tussen individuele moraalbeleving en een algemeen geldende ethiek overigens niet erg duidelijk.

Inmiddels lijken echter de ontwikkelingspsychologische ideeën van Gilligan net als de psychoanalytische theorie over identificatie van Chodorow de status van een algemene sociologische theorie over het sekseverschil te hebben gekregen. ${ }^{22}$

In haar bespreking van Gilligans en andere theorieên over "moederlijk denken, de zorgzaamheidsethiek en een vrouwelijke stem" stelt Sevenhuijsen de drie onderliggende hypothesen ter discussie, te weten:

a. dat vrouwen een specifieke wijze hebben om morele dilemma's te construeren en te verwerken, dat er een vrouwelijke denktrant bestaat;

19 Zie ook Kraamwinkel (1993) p. 309-319.

20 Kohlberg (1986) p. 205-241. Zie ook. Wegelin (1990) p. 60.

21 Sevenhuijsen (1988) p. 220.

22. De theorie omtrent criminaliteit en sekse, zoals beschreven door Rutenfrans (1989), is ook gebasecrd op Chodlorow. (zie hoofdstuk 1) Chodorow gaat uit van het begrip 'identificatie' in de psychoanalyse, maar trekt vervolgens sociologische gevolgtrekkingen: als vrouwen en mannen maar anders gesocialiseerd worden dan... 


\section{Hoofdstuk 7}

b. dat deze vrouwelijke stem voortkomt uit de praktijk van het moederschap;

c. dat deze stem toegepast kan worden op morele dilemma's in de publieke sfeer en daar ook oplossingen kan bieden. ${ }^{2 a}$

Gilligan legt volgens haar een te sterke verbinding tussen sekse en moraal en problematiseert daardoor te weinig de gedifferentieerdheid van morele gevoelens van mannen en vrouwen die in de praktijk niet te verdelen zijn volgens een strikte dichotomie. ${ }^{24}$

Bovendien vreest Sevenhuijsen voor een intrinsiek conservatieve werking bij toepassing van de theorie in de publieke sfeer. Van de bescherming van het eigen gezin, de eigen cultuur, de eigen natie komen pleitbezorgsters van de zorgzaamheidsethiek steeds op toepassing op de grote vragen van de wereldpolitiek: milieu, bewapening etcetera. Hoe het ook zij, het debat is vruchtbaar gebleken, in die zin dat het een nieuwe aanzet heeft gegeven in het denken over zorg en ethiek.

\section{2 'Ethics of care' in het recht}

Ook in het recht wordt onderzocht of en hoe een zorgzaamheidsethiek naast of in plaats van een universalistische rechtvaardigheidsethiek gesteld kan worden. ${ }^{25} \mathrm{De}$ universalistische theorie is het meest bepalend voor het huidige rechtvaardigheidsdenken. Illustratief hiervoor is de theorie van Rawls. ${ }^{20}$ Rawls gaat uit van een "justice of fairness"," waarin twee principes een rol spelen. Het "liberal principle" en het "difference principle". Aan het slot van zijn boek bespreekt Rawls de individuele moraalontwikkeling. Hij komt, geïspireerd door het onderzoek van Kohlberg, tot een vorm van oplopende morele fasen. Essentieel is dat het individu in staat is tot perspectiefwisseling te komen met de (geabstraheerde) ander. Tegenover een algemeen geldend rechtvaardigheidsgevoel gebaseerd op een geabstraheerde relatie tussen het zelf en cle ander kan een contextgebonden rechtvaardigheidsgevoel gezet worden. Gilligan vertegenwoordigt deze stroming. Zij vindt het noodzakelijk om te kijken naar het concrete handelen op het moment dat het morele dilemma aan de orde is. "Egoilsme" en "verantwoordelijkheid" zijn bij haar terugkerende begrippen. Gilligan bepleit integratie van een principe van rechtvaardigheid en een principe van zorg en verantwoordelijkheid. ${ }^{27}$

23 Sevenhuijsen (1988) p. 222.

24 Zie ook Wegelin (1990) p. 67.

25 Onder andere Tigchelaar (1993) p. 287-307.

26 Rawls (1973).

27 Wegelin (1990) p. 61. 
In het (postmoderne) differentiedenken worden universalistische aanspraken vermeden en vormt 'het recht op anders zijn' de kern van de waarde van het rechtenvertoog. ${ }^{2 x}$ Doel is machtsongelijkheid boven tafel te krijgen, zorgrelaties te erkennen, en in de analyse vervolgens te zoeken naar objectieve grondslagen voor verschillen tussen vrouwen onderling.

Bower maakt overigens aan de hand van het 'differentiedenken' kanttekeningen bij het selectief lenen van concepten en begrippen uit andere wetenschappen om deze vervolgens in een discussie over rechten in te passen. ${ }^{2}$ In de West-Europese (met name Franse) feministische theorievorming wordt met het differentiedenken gestreefd naar het doorbreken van bestaande dichotomieën op abstract nivo. ${ }^{30}$ In de Amerikaanse staan concrete verschillen in uitgangsposities tussen vrouwen onderling, naar ras, klasse en culturele achtergrond centraal. ${ }^{31}$ Enerzijds is dus het gevaar van het te gemakkelijk gebruiken van concepten uit de ene wetenschap in de andere dat een concept een eigen leven gaat leiden, los van de oorspronkelijke context, anderzijds dat er een schijnovereenstemming op een heel abstract niveau lijkt te bestaan die feitelijk op drijfzand is gebouwd, omdat de onderliggende argumentaties volstrekt verschillen.

Of en zo ja, hoe de zorgzaamheidsethiek een plek moet krijgen binnen de universalistische gelijke rechtenbenadering is ook in Nederland nog niet uit bediscussieerd. Sevenhuijsen pleit voor een integratie van beide perpectieven in het algemeen en voor een afweging van de betekenis van beide perspectieven in concrete situaties. ${ }^{32}$ Volgens Soetenhorst is een universalistische rechtvaardigheidsethiek zelfs zorgethiek op discursief (redenerend) niveau. ${ }^{33}$

Juristen benadrukken veelal de reflexieve kant van het recht bij het behandelen van concrete casus. Essentie is het creëren van procedures voor het bereiken van overeenstemming op grond waarvan andere subsystemen zichzelf kunnen reguleren. ${ }^{34}$ Het reflexieve recht gaat echter uit van een gelijkwaardige positie van beide partijen. Probleem bij verandering van een normatief sturend recht naar een meer relationeel en reflexief recht is dan ook dat de ongelijkwaardigheid van partijen blijft bestaan. $\mathrm{Er}$ is immers geen machtsvrije ruimte. Vrouwen voelen zich niet langer buitengesloten maar ingesloten door het recht. Gunning en De Roos merken op, onder verwijzing naar Habermas, dat het concept van reflexief recht met name vanuit het privaatrecht en het ondernemingsrecht is ontwikkeld. De overheid zou de leefwereld kunnen

28 Minow (1990). Besproken door Loenen (1992-2).

29 Bower (1991). Zie ook Tigchelaar (1993).

30 Zie in Nederland Van den Oord (1994).

31 Zie Minow (1990).

32. Sevenhuijsen (1988) p. 222.

33 Soetenhorst- de Savornin Lohman (1990) p. 57 e.w. Zie ook Raes (1991) p. 10-11.

34 Gunning en de Roos (1992) p. 42. 


\section{Hoofdstuk 7}

bedreigen en "koloniseren' door woorheen communicatieve structuren te juridiseren. ${ }^{35}$ Lissenberg meent in navolging van onder andere Schuyt en Komter dat de begrippen "rechtvaardigheid" en "zorgzaamheid" allebei een sterk normatieve lading hebben. Hoewel het ene meer met met mannen en het andere meer met vrouwen verbonden zal worden, gaat het niet (alleen) om verschillen tussen mannen en vrouwen, maar vooral om verschillen in machtsposities en daarmee samenhangende ethische visies. Minder machtigen zullen altijd meer in de geest van "plichten" denken, zich noodgedwongen meer inleven in de positie van de ander. Machtigen kunnen zichzelf centraal stellen terwijl minder machtigen altijd een dubbele oriëntatie hebben. ${ }^{36}$ Naarmate machtsposities meer verschuiven, zullen rechten en plichten ook meer tijd- en plaatsgebonden begrippen zijn.

In het materiële recht wordt beoogd de norm, de algemene regel te stellen. In de concrete casus worden verfijningen en correcties aangebracht. Loenen laat zien hoe een spanningsveld tussen de algemene norm en de toepassing van de norm in concrete situaties tot zowel rechtsverfijning als open normen kan leiden. ${ }^{37} \mathrm{Zij}$ maakt daarbij een onderscheid tussen norm en begrip. "Het belang van het kind" noemt zij een open begrip, dat tot een meer of minder open norm kan leiden.

"Een regel echter die stelt dat de rechter bij echischeiding de voogdij toewijst overeenkomstig het belang van het kind, is een norm met een veel sterker open karakter dan een regel die zou stellen dat de rechter de voogdij doet toekomen aan de ouder bij wie het kind ten tijde van de echtscheiding zijn verblijfplaats heeft, tenzij daarmee het belang van het kind ernstig zou worden verwaarloosd. ${ }^{38}$

Loenen vraagt zich af of de toenemende ruimte die in ons recht aan de redelijkheid en billijkheid wordt geboden tot een feminisering van het recht zal leiden. De "ethics of care" doet haar sterk aan de notie van billijkheid denken ${ }^{39} \mathrm{Zij}$ vreest echter een verabsolutering van het individuele geval. Juist daarom moet er bij bij voorbeeld een inbreuk op een grondrecht een zorgvuldige afweging gemaakt worden tussen de ernst van de inbreuk aan de ene kant en het algemeen belang aan de andere kant. Ongebreideld streven naar individuele rechtvaardigheid kan het besef van betrokkenheid op de ander en noties van solidariteit aantasten. ${ }^{* 0}$ Misschien was de

35 Gumning en de Roos (1992) p. 42.

36 Lissenberg (1993) p. 103-119.

37 Loenen (1996) p. 123 -136.

38 Loenen (1996) p. 126.

39 Loenen (1996) p. 135.

40 Loenen (1996) p. 136. Ook Sevenhuijsen (1993) p. 37 waarschuwt woor de normatieve dimensies wan het indiwidualiseringsstreven. "Het liberale individualisme vult dit al gauw in als een streven naar negatieve vrijheid, dat wil zeggen het streven om vrij te zijn van extreme belemmeringen en verplichtingen. Het streven naar autonomie staat dan niet alleen voor het vermogen om eigen beslissingen te nemen, maar ook voor het vrij zijn of het vrij worden van menselijke verbondenheid en (morele) verplichtingen." 
'truc' die de Hoge Raad in de Aidstestzaak toepaste, door een grondrechtenconflict tussen partijen uit de weg te gaan via een belangenafweging op grond van de onrechtmatige daad, daarom wel zo intrigerend. Via die -open contextgebonden- benadering konden machtsverschillen in een concrete situatie immers toch meewegen. ${ }^{41}$ Een principieel juridisch kunststukje of een galante juridische, maar opportunistische oplossing?

In Nederland is in eerste instantie vooral via Rawlsiaanse verdelingsdenken getracht het principe van gelijke behandeling via 'positieve discriminatie' voor groepen in achterstandssituaties invulling te geven, de materiële invulling van het gelijkheidsbeginsel. ${ }^{42}$ Vooral vanuit emancipatiedoeleinden blijkt deze benadering zeer bruikbaar. Vervolgens rijst echter de vraag of en hoe voorkomen kan worden dat achterstandsgroepen zich geheel conformeren aan de dominante cultuur en het dominante vertoog. ${ }^{43}$ Gunning probeert de ongelijkheid tussen vrouwen en mannen niet in termen van achterstand, maar positief te formuleren. ${ }^{44}$ Dan komt de vraag aan de orde of er er wezenlijke verschillen bestaan tussen mannen en vrouwen die op de een af andere wijze tot uiting moeten komen? En of die verschillen het scheppen van 'speciale rechten' of een 'ander recht' rechtvaardigen?'s Als voorbeelden worden daarbij zwangerschap, bevalling en borstvoeding als typisch aan vrouwen gebonden condities benoemd. Maar er zijn ook sociaal geconstrueerde (gender)verschillen, waarbij het onderscheid niet in termen van 'achterstand' benoemd hoeft te worden, maar als niet eerder opgemerkte vanzelfsprekendheden. Er kan dan zowel gedacht worden aan het creëren van nieuwe rechten en concepten, zoals 'de verzorgende ouder'en de 'deeltijdwerker', als aan het geven van andere invullingen aan bestaande concepten, zoals de werknemer en de gedetineerde. Vervolgens kan de dichotomie tussen mannen en vrouwen doorbroken worden, door functies, taken en rollen inhoudelijk te benoemen en niet het sekseverschil te expliciteren. ${ }^{46}$ Ook Loenen bepleit een "meer materiële invulling van het recht", vanuit concrete relaties."

Er lijkt al met al consensus te bestaan om vooral vanuit feitelijke situaties en feitelijke taken een speciale behandeling, eventueel tijdelijk, te rechtvaardigen. Vaak worden daarbij begrippen als zorg, verantwoordelijkheid en zorgrelaties gebruikt. ${ }^{* 8}$ In veel

41 HR 18 juni 1993, NJ 1993, 347, m.n. van EAA en CHJB, NJCM bulletin 1993, p. 786-792, m.n.

L.F.M. Verhey. Zie ook Goldschmidt (1993-3).

Zie onder andere Goldschmidt (1989), Sloot (1989).

Mulder (1993), Schuyt (1995).

44 Gunning (1985).

45 Holtmaat (1988-1) p. 3-13 en (1988-2) p. 60-66.

46 Wentholt (1990).

47 Loenen (1990) p. 92-99, Loenen (1992) p. 260-265.

48 De titels van diverse juridische proefschriften spreken voor zich: Wentholt: Arbeid en zorg (1990), Holtmaat: Met zorg een recht (1992), Holtrust: Aan moeders knie (1993). 
gevallen zal het daarbij toch concreet gaan om zorg voor kinderen of andere zorgafhankelijke familieleden.

\section{3 'Ethics of care' in het familierecht?}

Gilligan heeft met name aanzetten gegeven voor toepassing van haar zorgzaamheidsethiek op gebieden die in direct verband staan met seksepolitiek, zoals abortuswetgeving, antipornostrijd en ouderlijke macht. Ook Sevenhuijsen lijkt daarom voor toepassing in het familierecht wel te voelen. Zij vindt dat zorg niet gelijkgesteld mag worden met zelfopoffering.

"Het waak gehoorde (zelf)werwijit dat vrouwen bijna per definitie zouden lijden aan een 'slavenmoraal', geeft blijk van een ernstige mate van onderschatting van de positieve mogelijkheden van een ethiek van zorg"

Anderen zijn minder optimistisch. Zij vrezen dat een zorgzaamheidsethiek in het familierecht juist rolbevestigend werkt.

"The traditional view of the family has always embodied ideals of unselfishness and nurturing, ideals that many feminists now argue should be utilized in other areas of the law. It may seem contradictory for someone like myself who supports the goal of an "ethic of care" to criticize an attempt to reinstitute this ethic in family law- an area where it may seem to belong naturally. This seeming contradiction can be explained by Fran Olsen's observation that our historical experience with the liberalization of the family makes us assume- often without realizing it- that the only alternatives are patriarchy on one hand and atomistic individualism on the other. ${ }^{\text {m50 }}$

Vrouwen hebben de afgelopen decennia steeds meer afstand genomen van het patriarchale gezinsverband. Financiële, emotionele en intellectuele afhankelijk van de partner is niet meer vanzelfsprekend. Maar de losmaking uit families en gezinnen en het - al dan niet gedwongen- kiezen voor eigen relaties en levensbronnen maakt vrouwen ook onzeker, brengt hen uit evenwicht. Ze verliezen het family life als vrouwelijk domein. Niet alleen hun privacy is vergroot, ook die van hun afzonderlijke gezinsleden. Wat betekent dat voor de relatie tussen vrouwen en hun kinderen? En wat wordt als 'het belang van het kind" geformuleerd?

49 Sevenhuijsen (1993) p. 36.

50 Lacey (1992). Ook Oisen (1983), Cain (1990), Pösö (1992). 


\subsection{Afstamming: de wortels van het bestaan?}

Met name in de adviezen en commentaren op de achtereenvolgende wetsontwerpen omtrent het afstammingsrecht, komen verschillende visies met betrekking tot "het belang van het kind' naar voren. Is het kind nu vooral gebaat bij een 'warm nest' of biedt een genealogisch verantwoord familieverband een veilige bedding voor de identiteitsvorming van het kind $?^{{ }^{51}}$ Hoe belangrijk is het voor het identiteitsbesef van het kind om zijn of haar biologisch/genetische oorsprong te weten? In feite is de afweging tussen het funderen van familierechtelijke betrekkingen op grond van sociaal (feitelijk) ouderschap en/of van het biologisch ouderschap voortdurend in de discussies terug te vinden..$^{22}$

In 1985 wordt door de Emancipatieraad onderzocht welke rol 'het belang van het kind' speelt in de afstammingsdiscussie. ${ }^{33}$ Volgens de androcentrische benadering hebben kinderen behoefte aan een vader en een moeder, willen zij weten wie hun (biologische) vader is en is het belangrijk dat zij voor de wet twee ouders van verschillend geslacht hebben. De Raad stelt daar de gynocentrische benadering tegenover. De concrete dagelijkse verzorging en opvoeding van kinderen is een belangrijke reden voor het creëren van rechten. Vrouwen en mannen zijn alleen gelijk wat het leveren van genetisch materiaal betreft. Biologisch zijn vrouwen door negen maanden zwangerschap, baring en zoging veel meer aan het kind gebonden. ${ }^{34}$ Bovendien is de waarheid omtrent het moederschap nog altijd veel zekerder dan die omtrent het vaderschap. Overigens blijkt uit een onderzoek van Holtrust dat er onder ongehuwde moeders een zeer grote openheid ten aanzien van hun kinderen bestaat omtrent de bekendmaking van de identiteit van hun verwekker. ${ }^{\text {ss }}$ Holtrust wijst ook op het grote aantal kinderen dat in buitenechtelijke relaties verwekt wordt, zonder dat de echtgenoot of het kind daar achter komt. Welk belang heeft het kind bij 'de waarheid'? De biologisch/genetische informatie lijkt aanvankelijk niet zozeer uit psycholo-

51 Door Pessers (1995, p. 1293) gedefinieerd als: "het verschaffen van legitimiteit aan het kind door toewijzing van twee werantwoordelijke ouders van verschillend geslacht en door integratie van het kind in een generationele keten die langs twee verwantschapslijnen loopt."

52 Zie voor een overzicht onder andere Holtrust (1993) p. 17-25.

53 Emancipatieraad (1985) p. 37-49.

54 Zie ook: Thomassen (1982) p. 161. "Het biologische uitgangspunt verdoezelt dat op het moment van de geboorte van een kind moederschap en vaderschap twee totaal versehillende dingen zijn". Holtrust (1993) p. 22. Zie ook : Liberale abortuswetgeving niet in strijd met het EVRM, ECRM, 19 mei 1992, De zaak Hercz tegen Noorwegen, in: NJCM-bulletin 18-1(1993) met noot van T. Loenen. In deze zaak kwam ook de verhouding tussen de biologische moeder en de biologische vader (verwekker) aan de orde. De Commissie stelde het belang van de vrouw voorop: er was geen "civil right" van de vader in het geding en ook het discriminatieverbod gold niet omdat beide ouders zich niet in "analogous siltuations" bevinden, gezien de implicaties die een zwangerschap voor vrouwen heeft.

Emancipatieraad (1985) p. 41, Holtrust (1985) p. 207. 
gisch opzicht van belang voor het kind te worden geacht, maar vooral in verband met gezondheidsrisico's en dergelijke. ${ }^{36}$ De rol van de biologische vader is later vanuit het zoeken naar de 'wortels', als identificatieproces, benadrukt. ${ }^{57}$ Maar ook het creëren van een breder financieel en emotioneel draagvlak wordt als argument genoemd. In brede zin zelfs, als het uitbreiden van een verwantschapsnetwerk, al lijkt dat dan weer minder aan het waarheidsgehaite omtrent de oorsprong verbonden te worden." In het kielzog van de psychologische trends, worden nu dus ook in het recht steeds vaker de kennis van de biologisch/genetische oorsprong en het intergenerationele familieverband tot existentiële belangen van het kind verklaard. Vanaf 1981 tot nu is er in de gang van voorontwerp naar wetsvoorstel een ontwikkeling te zien van de aanvaarding wan familierechtelijke betrekkingen als een rechtshandeling, naar het doen ontstaan van die betrekkingen op grond van het waarheidsbeginsel. De Langen, die zich al Janger voorstandster betoont van het waarheidsbeginsel (waarin familierechtelijke betrekkingen voor beide ouders op grond van biologische afstamming gevestigd worden) pleit in haar preadvies voor de Nederlandse Juristen Vereniging voor een beperking van de rechtsgevolgen van het ontstaan van deze betrekkingen. ${ }^{\circ}$

"Familierechtelijke betrekkingen dienen in deze visie niet anders dan wederzijdse onderhouds- en erfrechtelijke aanspraken ten gevolge te hebben, onafhankelijk van de vraag of de totstandkoming van deze familierechtelijke betrekkingen met of zonder toestemming van de moeder of vader is geschicd ${ }^{\text {th }}$ Aan afstamming op zich andere gevolgen verbinden ligt niet voor de hand, daar het maar al te waar is dat biologische betrekkingen nog geen wederzijdse zorg, genegenheid en begrip voor elkaar "nodig voor een goede relatie tussen ouder en kind, garanderen. Dit betekent dat familierechtelijke betrekkingen zonder meer geen basis kunnen vormen voor een wederzijds omgangsrecht, noch woor een gezagsregeling. Naast erkenning van de biologische afstamming, die leidt tot familierechtelijke betrekkingen, zullen andere bevoegdheden alleen op grond van feitelijk gezinsleven en het aanvaarden van ouderschap verkregen kunnen worden. ${ }^{62}$

57 Zie ook Forder (1995) p. 127: "By the 1980s, not only most areas of family law, but also the concept of identity, had undergone a metamorphosis, being focused upon the establishment of biological origins. Variaties in the concept of identity can occur, not only within the same culture in different periods of time, but -even so more- between cultures." Van den Blink (1990): "beleving van zijn biologische oorsprong", Van Wamelen (1996).

58 Pessers (1995).

59 Van den Blink (1990), Pessers (1995), Van Wamelen (1996).

60 De Langen (1990) p. 104-105. Zie ook Hammerstein-Schoonderwoerd (1988).

61 Ik vraag me af of het "wederzijds" betrekking heeft op de kinderen jegens hun biologische ouders (zie art.1: 392 BW.) Dan zouden kinderen die geen enkele historie (los van geslachtsdaad en bij moeders eventueel zwangerschap en bevalling) met hun ouders hebben toch onderhoudsplichting zijn wanneer zij in behoeftige omstandigheden komen..... 
De Raad voor het Jeugdbeleid komt in zijn rapporten tot de conclusie dat een goede

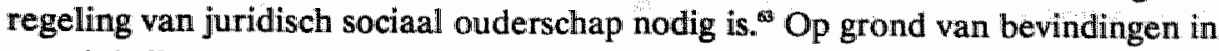
ontwikkelingspsychologisch, orthopedagogisch en sociaalpsychologisch onderzoek zegt de Raad:

" Er zijn geen gerechtvaardigde gronden ora het juridisch onderscheid dat op grond van de huidige wetgeving bestaat tussen de verschillende vormen van ouderschap te handhaven.

- Bij iedere vorm van ouderschap bestaan risico's dat een evenwichtige ontwikkeling van kinderen wordt belemmerd; die risico's dienen zoveel mogelijk te worden gereduceerd.

- Stigmatisering van nieuwe vormen van ouderschap dient te worden bestreden.

- Büj iedere vorm van ouderschap is het wenselijk dat meerdere personen/verzorgers van beide seksen bij de opvoeding worden betrokken en is het meer dan wenselijk dat de opvoeding niet in een sociaal isolement plaatsvindt. Bij de opvoeding betrokken zijn betekent in dit verband niet zozeer het uitoefenen van de opwoedersrol, als wel het regelmatig deel uitmaken van de feitelijke leefwereld van het kind.

Voor een vernieuwing van de wettelijke regeling zou het bovenstaande volgens de Raad betekenen dat er zo jong mogelijk, liefst bij de geboorte een juridische afstammingsrelatie met minimaal een en maximaal twee ouders vastgelegd moet worden. Uit die juridische afstammingsrelatie vloeien rechten en plichten voort. Wanneer een ouder of ouders die plichten niet kan/kunnen of wil/willen vervullen, heeft het kind recht op sociale ouders die de dagelijkse opvoedingsverantwoordelijkheid op zich nemen. Daaraan dienen voor de sociale ouders rechten en plichten te worden verbonden (vergelijkbaar met de gezags- en onderhoudsrelatie), zonder dat de, reeds bestaande, juridische afstammingsrelatie zelf wordt gewijzigd. De juridische regeling van het sociaal ouderschap moet losgekoppeld zijn van het regelen van de juridische afstammingsrelatie. Eventuele wijzigingen in juridische relaties worden uitgesproken via de rechter, waarbij de jongere een eigen rechtsingang heeft. Omtrent de rechtsgevolgen en de overlappingen daarin tussen juridische en sociale ouders blijft de Raad nogal algemeen. Wel lijkt er een soort chronologie in de soorten relaties aangebracht te worden.

Van Wamelen bepleit ook een verdergaande loskoppeling van juridisch en sociaal ouderschap. Zij vindt dat sociale ouders die het gezag witoefenen (gebonden aan de woonplek van het kind) onderhoudsplichtig jegens hun kind moeten worden.

"Waar een sociale ouder mede onderhoudsplichtig wordt, wordt de onderhoudsplicht van de niet-woonouder, opgeschort. Niets belet hem echter, in goed overleg met de woonouders, voor zijn kind te blijven

63 Raad voor het Jeugdbeleid (1988), Raad voor het Jeugdbeleid (1990). Zie voor een samenvalting: De Wild (1992) p. 104-106.

64 De Wild (1992) p. 105-106. 
betallen. En ma beëindiging van het woonouderschap van de sociale ouder en daarmee van zijn gezag en onderhoudsplicht- herleeft de onderhoudsplicht van de juridische niet-woonouder. ${ }^{\text {"ts }}$

Het is niet mijn bedoeling hier het hele afstammingsrecht te behandelen. Wel is duidelijk dat 'het belang van het kind' niet los gezien wordt van zijn biologische oorsprong, maar dat ook de feitelijke relaties, het warme nest en het verwantschapsnetwerk een rol spelen in de discussies.

\subsection{Art. 8 EVRM en het belang van het kind}

Sinds 1980 speelt het begrip "family life" een belangrijke rol in de familierechtspraak. Het is ontleend aan art. 8 EVRM en omvat zowel afstammingsrelaties, gezag als omgang. Wat is family life en wanneer bestaat er een recht op family life krachtens art. 8 EVRM? In hoeverre spelen biologische relaties of feitelijke zorgrelaties een rol? Kern van het family life is "the mutual enjoyment by parent and child of each others company"s6 of zoals De Langen zegt: "het wederzijds genieten van elkaar" "67 Van Wamelen beschrijft hoe in het Nederlandse recht het family life verengd dreigt te worden tot gezinsleven, terwijl in oorsprong meer het deel uitmaken van een groter sociaal (familie) verband centraal stond. In de laatste Nederlandse vertaling van art. 8 EVRM is 'gezinsleven' overigens vervangen door 'familie- en gezinsleven'. Family life kan zich in de zin van nauwe persoonlijke banden in drie vormen voordoen:

"a. De nauwe persoonlijke banden, onderhouden tijdens het samenleven in een primair leefverband" de samenlevingsverbanden.

b. De nauwe persoonlijke banden die, na beëindiging van het samenleven in eem primair leefverband, tussen de ex-leden van dit leefverband voortbestaan: de post-samenlevingswerbanden.

c. De nauwe persoonlijke banden die voortwloeien uitt bepaalde verwantschapsrelaties. ${ }^{\text {w9 }}$

De vraag of er op grond van bloedverwantschap sprake is van een familierechtelijke relatie komt aan de orde in het Marckxarrest. ${ }^{\text {70 }}$ In deze zaak wil een ongehuwde Belgische moeder de juridische afstammingsrelatie van haar kind vastgesteld zien

65 Van Wamelen (1992) p. 115. Het omgangsrecht koppelt zij vervolgens los van onderhoud, zodat het recht op omgang van het kind niet afhankelijk wordt van het al of niet betalen (c.q. ontvangen) van 'kijkgeld'.

66 EHRM 22-6-1989, Eriksson Zweden, Series A, vol 156, NJ 1992, 705, m.n. EAA, FJR 1990, p. 83-88, m.n. M.J.C. Koens.

67 De Langen (1990).

68 NJB (1990) p. 1502-1506. Zie ook: Holtrust (1993) p. 221 en Von Brucken Fock (1996-1) p. 147.

69 Van Wamelen (1987) p. 279.

70 EHRM 13 juni 1979, Marckx v. België, Series A, vol. 32, NJ 1980, 462, m.n.. EAA. 
om met name erfrechtelijke en andere juridische achterstelling van haar (onwettige) kind op te heffen. "De rode draad in het Marckxarrest is, dat het een fundamenteel juridisch recht is om met iemand in familierechtelijke betrekkingen te komen en in beginsel te blijven, indien er een bloedband tussen beiden bestaat. ${ }^{171}$ Het Hof schenkt daarbij ook aandacht aan het feit dat de moeder 'continuously' voor haar dochter heeft gezorgd. In het Marckxarrest staat 'het belang van het kind' centraal. Bovendien wordt door een ongehuwde (Belgische) moeder een beroep op respect van het family life met en van haar dochter gedaan ten opzichte van de staat. Zowel in de Straatsburgse als Hoge Raad jurisprudentie wordt in latere uitspraken op grond van art. 8 EVRM gelaveerd tussen honorering van aanspraken krachtens het recht op privacy en het recht op family life. ${ }^{n}$ Aan de hand van de feiten van de casus wordt vastgesteld of er, naast een familierechtelijke relatie, ook sprake is van 'family life de facto'. ${ }^{73}$ Het is vooral uit uitspraken die volgen op het Marckxarrest duidelijk dat art. 8 EVRM niet slechts tot bescherming van het gezinsleven de iure dient maar van dat de facto. Zowel de uitspraken van de Europese Commissie en het Europese Hof als de doorwerking van art. 8 EVRM in de rechtspraak van de Hoge Raad sinds het Marckx-arrest zijn elders uitgebreid geanalyseerd. ${ }^{74}$

71 De Langen (1990) p. 96.

72 * EHRM 28-12-1984, Rasmussen v. Denemarken, NI 1986, 4, m.n. EAA en EAAL. (Gehuwde vader met twee kinderen. Heeft tweede kind miet verwekt. Na echtscheiding en n.a.v. onderhoudsclaim wil vader af van het juridisch vaderschap van dat kind. Hof: art. 8 van toepassing maar dit valt onder 'private life')

* EHRM 18-12-1986, Johnston v. Ierland, J 1989, 11 (977), m.n. EAA.

(Gehuwde man woont al jaren samen met ongehuwde vrouw. Er is een kind verwekt. Hof: kind heeft "legally and socially" recht op dezelfde status als een binnen huwelijk geboren kind. Argumentatie berust op gelijkstelling tussen wettige en omwettige kinderen, niet op biologische afstamming).

73. Zie onder andere:

* EHRM 21-6-1988, Berrehab w. Nederland, Series A, vol. 138, N.J 1988, 746, m.n. EAA, NJCM bulletin 1988/ , p. 579-586, m.n. H. Steenbergen, FJR 1988, p. 193-196, m.n. J.E. Doek, R VR 1992, 183 , m.n. SwW. (Een kind dat uit een wettig en/of oprecht huwelijk is geboren heeft ipso jure een als family life aan te merken relatie met beide ouders vanaf het moment dat het is geboren. Latere gebeurtenissen kunnen die relatie ongedaan maken. Hier niet, ook na cchtscheiding zag de vader de dochter vier keer per week, droeg hij bij aan de kosten voor levensonderhoud en was toeziend voogd.)

* EHRM 27 oktober 1994, Kroon e.a. w. Nederland, Series S, vol 297C, NJ 1995, 248, m.n. JdB, NJCM-bulletin $1995 / 1$, p. 45-53, m.n. C. Forder. (Voor vaststelling family life kijkt het Hof of er sprake is van samenwoning of van andere factoren die de duurzaamheid van de relatie tussen de ouders kan aantonen. De moeder moet het vaderschap van haar echitgenoot kunnen ontkennen en dăarna haar toestemming geven tot erkenning door de biologische vader. Forder merkt in haar annotatie op dat slechts éen van de rechters "het belang van het kind" als invalshoek voor zijn (dissenting) opinion heeft genomen.)

74 Holtrust (1993) p. 221-272, De Bruijn-Lückers (1994), Forder (1995), Von Brucken Fock (1996) p. 147-169. Zie ook Van Dijk (1994) in het kader van het vreemdelingenrecht. 


\section{Hoofdsouk 7}

Wanneer vooral gescheiden en ongehuwde vaders eisen hun recht op family life opeisen, komt ook de horizontale werking van art. 8 EVRM aan de orde, vaak in combinatie met art. 14 EVRM. ${ }^{75}$ Soms worden zij ontvankelijk verklaard en vervolgens moet de rechter dan een afweging maken of hun recht ingeperkt kan worden op grond van het tweede lid van art. 8 EVRM, meestal het belang van moeder en het bij haar verblijvende kind. Begrippen als "gelijke behandeling" en "het belang van het kind" spelen in die afweging soms een impliciete rol. ${ }^{76}$ In hoeverre de belangen van kinderen werkelijk aan bod kunnen komen in conflictsituaties tussen ruziënde ouders is natuurlijk nog maar zeer de vraag. "Volgens Van Wamelen strekt het recht op bescherming van het family life overigens tot bescherming van een collectieve

75 In Nederland is de biologische moeder via de 'mater semper certa est" regel ook de juridische. Holtrust stelt overigens vast dat het Marckx-arrest in Nederland hooguit versterkend gewerkt in de toch al op gang gekomen stroom van (omgangs-)rechteneisende niet (meer) gehuwde vaders. (Holtrust 1993, p. 244-248)

76 Zie 0.a.:

* EHRM 26 mei 1994, Keegan v. Ierland, Series A, vol 290, NJ 1995, 247, m.n. JdB, NJCM-bulletin $1995 / 1$, p. $37-44$, m.n. M. de Bruijn-Lü̈ckers.(In casu bestaat er volgens het Hor familly life tussen de biologische vader en het kind, gezien de aard van de retatie tussen wader en moeder en hum wens die relatie duurzaam te bestendigen en samen een kind te verwekken, ook al is de relatie met moeder al voor de geboorte verbroken. Bloedband lijkt belangrijker dan nauwe feitelijke band. Doordat het kind mede door het tijdsverloop inmiddels geworteld was in een pleeggezin, kon de vader uiteindelijk de adoptie niet meer ongedaan maken.)

- HR 8 april 1988, NJ 1989, 170, m.n. EAAL, RVR 1992,3, m.n. NH/IdH (later: zie NJCM bull. $1995 / 1$, p. 50). Of het belang wan het kind benaderd moet worden als liggend in het verlengde van dat van de moeder (art. 8 lid 2 EVRM) of als een autonoom recht op cen biologische vader. (art. 8 juncto art. 14 EVRM) is in Nederland vooral aan de orde gekomen naar aanleiding van de weigering van toestemming door de moeder tot erkenning door de vader. De belangrijkste uitspraak die de HR in dit verband (art.1:224 lid 1 BW) deed is dat er naast het biologisch vaderschap ook een feitelijk gezinslewen in de zin van art. 8 EVRM moet zijn woor het bestaan van familierechtelijke betrekkingen. (HR 8 april 1988, NJ 1989, 170) Maar ook :' Een redelijke, met art. 8 EVRM rekening houdende uitleg van het huidige recht brengt daarom mede dat, (..) wanneer de weigering van de moeder om toestemming tot erkenning te verlenen slechts kan worden opgevat. als misbruik wan de bevoegdheid die in art. 224 lid 1 aanhef en onder d besloten ligt' er langs de weg van rechterlijke uitspraak toch een rechtsgeldige erkenning tot stand kan komen." Dit betekent dat er geen absoluuut vetorecht van de moeder meer is. De HR creëerde met deze uitspraak ümmers een voor rechterlijke toetsing vatbaar vetorecht van de moeder. (belangenafweging en evenredigheidsvereiste). Maar de invulling van die toetsing en nadere regelgeving daaromtrent liet hij vervolgens aan de wetgever over. Criteria voor het bestaan van een feitelijk gezinsleven in de zin van art. 8 EVRM zijn daarmee dus nog niet gegeven.

In recentere uitspraken van de Hoge Raad komt het perspectief van het kind vaker expliciet aan de orde. Vgl. de "Jeroen-zalak" (HR 22 december 1995, NJ 1996,419) en HR 23 juni 1995, NJ 1996, 17, m.n. JdB. Zie ook Forder (1996) p. 1347 en Von Brucken Fock (1996).

77 Zie 0.a. Van Wijk (1992), Dijkers (1991, 1991a). 
zaak. $^{\text {7a }}$ Zodra de leden van het collectief hun belangen als tegenstrijdig ervaren of verschillend interpreteren houdt de bescherming op. Als ze geen leefeenheid meer vormen, kan een beroep gedaan worden op eerbiediging van hun "by mutual consent intended" family life. En dan resteert tot slot de mogelijkheid een beroep te doen op het recht op eerbiediging van de privacy. $\mathrm{Zij}$ meent dan ook dat de rechten die men kan ontlenen aan het beschermde family life niet kunnen leiden tot plichten van de anderen. Het is de vraag of zij met haar stellingname in feite horizontale werking van een deel van art. 8 EVRM tot onmogelijkheid verklaart, of dat zij een belangenafweging bepleit van alle betrokkenen (ook het kind) waarbij vanuit ieders recht op privacy ook ieders behoeften aan bod komen. ${ }^{\text {}}$ Dat komt dicht bij de zorgethiek op het terrein van het familierecht zoals Gunning die lijkt te bepleiten: "een volwaardige behandeling van het kind als een ander". ${ }^{80}$ Gunning zoekt vervolgens in het familierechtelijk verband naar een zorgethiek die gericht is op de (verzorgings)behoeften van kinderen en bevoordeelt daarmee niet automatisch de vrouwelijke sekse. ${ }^{81}$

Tot nu toe zijn het in Nederland vooral gescheiden en ongehuwde vaders geweest die een beroep op art. 8 EVRM hebben gedaan. Gedetineerden vormen gezien in relatie tot hun kinderen een gevarieerde groep. Gedetineerde verzorgers verkeren over het algemeen in een andere positie dan gescheiden vaders: De moeders onder hen staan in Nederland via de "mater semper certa est" regel al in een familierechtelijke verhouding tot hun kind. ${ }^{2}$ Doordat zij in detentie veelal wel gedwongen zijn gescheiden van hun kind te leven, zouden zij mogelijkheden tot continuering van hun family life kunnen eisen in de richting van de staat en/of van de verzorgers van haar kind. Concrete afwegingen in scheidingscasus kunnen mogelijk aanknopingspunten bieden om de belangen van de feitelijk van elkaar gescheiden verzorgende ouders en kinderen vast te stellen. Voor een beroep op "family life" ga ik er daarbij vanuit dat er sprake is van een gemeenschappelijk belang. Het is immers nog de

79 Zie ook: De Bruijn-Lückers (1994) p. 113-114, Van Langen (1990) p. 91, Goldschmidt en Holtmaat (1993), p. 150-152.

Zie de Hoge Raad in de "Jeroen-zaak" (HR 22 december 1995, NJ1996,419), onder o.w. 3.3.: "dat de eisen die aan het bestaan van "family life" gesteld moeten worden, aflhankelijk zijn van de. context waarin op art. 8 EVRM een beroep wordt gedaan, dat daarbij mede van belang is wic het beroep doet, en dat, indien een kind de bescherming van artikel inroept temeinde enige vorm van contact met zijn biologische wader te realiseren, niet dezelfde voorwaarden behoeven te worden gesteld als wanneer de biologische vader op enige vorm van contact met een door hem verwekt maar niet erkend kind aanspraak maakt".

Gunning (1994) p. 22. Zij zegt daarbij dat een formele rechtsingang voor het kind daarbij een instrument zou kunnen zijn. Opde materiële weging van behoeften (met name van jonge kinderen) gaat zij helaas niet in.

81 Gunning (1994) p. 17-23 zie ook Wegelin (1990) p. 71.

Zie art. 1:253b BW. 
vraag of het uitgaande van het kind als rechtssubject (en niet uitsluitend als object van ouderlijke zorg) überhaupt mogelijk is om binnen relationele betrekkingen wederzijdse rechten en plichten te ontlenen aan het door art. 8 beschermde family life. ${ }^{\text {s. }}$

\subsection{Feitelijke zorg}

Wat is een 'family life de facto' en wat moet de feitelijke zorg zijn om dat vast te stellen? Thomassen pleit er in 1982 al voor om concreet na te gaan wat zorgen voor kinderen eigenlijk inhoudt. ${ }^{2}$ Dan kan bediscussieerd worden welke verplichtingen, verantwoordelijkheden echt des moeders of des ouders zijn, welke een deel van maatschappelijke zorg, als algemene voorzieningen, zijn en welke verplichtingen wellicht op morele, ethische of misschien zelfs juridische gronden, het recht op privacy en op rust van het kind, afgestoten kunnen worden.

Eekellaar onderscheidt de claims die kinderen kunnen hebben in

- "basic interests" (to physical, emotional and intellectual care) ${ }^{\text {ss }}$;

- "developmental interests" (that their potential should be developed so that they enter adulthood as far as possible without disadvantage);

- "autonomy interests" (the freedom to choose a lifestyle of their own) Hij geeft daarbij aan dat de invulling van deze belangen in de empirie ontstaat en dat die ook steeds voorwerp van discussie zal blijven. Maar hij zegt ook:

"But the pllausibility of the claim that children would wish to be provided with equall life-chances has the potential for considerable social impact.".to

Er is de laatste jaren een aantal empirische studies in Nederland verschenen waarin de concrete invulling van de primaire zorg wordt beschreven. ${ }^{87}$ Bij de verzorging van kinderen is die zorg met name gerelateerd aan hun "basic interests". De Emancipatieraad doet pogingen deze concrete gegevens in juridische concepten te vertalen. Niet alleen via de introductie van het begrip "verzorgende ouder ${ }^{\text {nasis }}$, maar ook door aard en inhoud van informele zorg te beschrijven:

83 Vgl. HR 15 april 1994, NJ 1994, 608, m.n. H-S., NJCM bulletin,1994/6, p. 652-666, m.n. L.F.M. Verhey (Valkenhorst).

HR 22 december 1995, NJ 1996, 416, NJCM bull. 1996/3, p. 423-427, m.n. T. Loenen ("Jeroen-zatak").

Thomassen (1982).

85 Singer en Miltenburg (1991) noemen bed, bad en brood "the basics", die voor alles gaan.

86 Eekelaar (1992) p. 230-231.

87 Zie Knijn (1993), Emancipatieraad (1993), Mozes- Philips en Westers (1993).

88 Emancipatieraad (1992) p. 5. 
- algemeen buishoudelijke handelingen als schoonmaken, boodschappen doen, maalijden verzorgen, reparatie- en kluswerkzaamheden;

lichamelijke verzorging, waaronder ook verpleging;

social-emotionele ondersteuning en begeleïding, bevorderen van sociale contacten;

coördinerende en administratieve taken. ${ }^{\text {was }}$

Met dit laatste wordt vooral het thuismanagement bedoeld, de zorg om de zorg: oppas regelen, afspraken maken met de kapper of de tandarts, het organiseren van verjaardagsfeestjes en dergelijke. Juist in die categorie taken vloeit veel tijd weg. Taken zijn versnipperd in de tijd, afhankelijk van openings-en beschikbaarheidstijden van anderen en bestaan veelall uit wachten en aanwezig zijn. Dit element van zorg wordt het beschikbaarheidscriterium genoemd. ${ }^{\infty}$

Wanneer vaders actief bij de opvoeding betrokken zijn, blijken zij vooral tijd te besteden aan klussen, spelen met de kinderen en soms boodschappen te doen en te koken. Vrouwen doen (noodgedwongen?) meer activiteiten met een routinematig, solitair karakter: opruimen, poetsen, stofzuigen, wassen, strijken, tuinonderhoud en dergelijke. ". Wat de directe zorg voor kinderen betreft lijkt het mij belangrijk om naast het spelen en verzorgen van de kinderen met name te letten op de organisatorische kant van kinderverzorging, temeer daar blijkt dat ook gedetineerde vrouwen bang zijn daarop het zicht te verliezen. Juist vrouwen die maatschappelijk gezien in een, vaak door armoede, migratie of verslaving bepaald, isolement verkeren kunnen taken die voortvloeien uit routine en beschikbaarheid niet delen of delegeren. Leefvorm en sociaaleconomische status zijn bepalend voor grote onderlinge verschillen tussen vrouwen en hun kinderen in het kunnen terugvallen op een al dan niet gekozen verwantschapsnetwerk. Het ontbreken van een netwerk maakt het gevaar van uitsluiting groter en daarmee ook de achterstand van kinderen bij het realiseren van "developmental and autonomy interests".

De "developmental interests" van kinderen lijken nauw samen te hangen met optimaliseren van sociale grondrechten waarbij in het geval van met name arme families een inspanning van de overheid noodzakelijk is. Op dit terrein worden de grootste verschillen in (materiële) levenskansen tussen kinderen zichtbaar, zeker naarmate de samenleving consumentgerichter wordt en status en capaciteiten aan de hand van uiterlijke kenmerken en cognitieve kennis bepaald worden. Hier speelt ook het verbrede opvoedingsmilieu en de gelaagde identiteitsvorming van kinderen binnen de eigen leeftijdsgroep een grote rol.

89 Emancipatieraad (1993).

90 Emancipatieraad (1993) p. 24 e.v..

91 Dit is owerigens niet uniek in Nederland. Uit een rapport van de Internationale Arbeidsorganisatie van de Verenigde Naties blijkt dat deze werschillen in investering tussen mannen en vrouwen (blijven) bestaan, ook in landen waar via wetgeving geprobeerd is hier enige verandering in te bewerkstelligen. (Volkskrant 9-8-1992) 
De "autonomy interests" staan in nauwe relatie tot de zelfstandige (rechts) positie van kinderen, ook ten opzichte van hun ouders. ${ }^{22} \mathrm{Zij}$ hebben te maken met het recht op privacy, het recht om met rust gelaten te worden, het recht op eigen contacten met volwassenen en kinderen.

Vooral de positie van het zeer jonge kind dat in alles zeer afhankelijk is van de volwassenen om hem heen, is kwetsbaar. ${ }^{93}$ Bij het ontwerpen van juridische concepten rond zorg, moederschap en 'het belang van het kind' moet er genderspecifiek naar de invulling van de feitelijke zorg gekeken worden.

\subsection{Ouderlijk gezag en het belang van het kind}

Volgens de wet omvat het ouderlijk gezag

"de plicht en het recht van de ouder om zijn minderjarige kind te verzorgen en op te voeden. Onder verzorging en opvoeding wordt mede verstaan de zorg en de verantwoordelijkheid woor het geestelijk en lichamelijk welzijn van het kind en het bevorderen van de ontwikkeling van zijn persoonlijkheid.."t

In het Nederlandse recht wordt aan ouders die in familierechtelijke betrekking tot hun kind staan voorrang gegeven om met gezag bekleed te worden. ${ }^{95} \mathrm{Zij}$ krijgen daarmee bevoegdheden waardoor zij de verplichting om hun kinderen te verzorgen en op te voeden, kunnen waarmaken. Volgens De Langen dient ouderlijk gezag er onder meer toe om de positie van kinderen te beschermen tegen derden en de overheid. .6

92 Zie cok Guning (1992) p. 456: "Het gat er nu om een mensbeeld te ontwikkelen dat ten grondslag wordt gelegd aan de verdere villeg wan het wrijheids-en gelijkheidsbeginsel, waarin wordt erkend dat elk mens, man of vrouw, kind of bejaarde, homo of hetero, autochtoon of allochtoon, hetzelfde recht heeft werkelijk mondig te worden en owereenkomstig zijn of hatar individuele positieve identiteilt: te leven. Dat wil zeggen dat ieder mens op elk gebied wan het leven de heerschappij ower zichzelf heeft in een betrokkenheid met anderen en met behoud van zijn of haar sekstualiteit".

93 Guning en De Roos (1992), blz 41 bepleiten een verandering van het kindbeeld: "We moeten kinderen niet zo klewn houden dat ze klein blijven. Noch moeten we het kind gelijk aan volwassenen behandelen. Een kind zou recht moeten krijgen groot te worden en klein te zijn." Hoe dit nader geconcretiseerd kan worden, kunnen zij vooralsnog ook niet duidelijk maken. Zells het versterkem wan de procestechtelijke postie van de minderjarige (art. 6 EVRM) kan er inhoudelijk toe leiden dat het kind wordt neegezogen in een claim- en procedurecultuur, waarin conflicterende ouders xich nu al vaak begeven.

94 Art. 1: 247 BW.

95 De wettelifke regeling werd ingrijpend veranderd in 1995.

96 De Langen (1990) p. 122 .

In de regerimgsnota "Inzake leefvormen en de betrekkingen met kinderen" (TK 22700) wordt gesteld : "het ouderlijk gezag maakt wolwassenen verantwoordelijk voor hem en geeft hem aldus gelegentheid om kind te zijn, het beschermt zijn gezinsleven tegen imbreuken van derden." Het is dan de wraag 
Relevante wetsartikelen, waarin het ouderlijk gezag geregeld wordt, zijn:

- art. 1: 251 lid $1 \mathrm{BW}$, waarin geregeld is dat binnen huwelijk ouders van rechtswege het gezag over hun kinderen krijgen;

- art. 1: 251 lid $2 \mathrm{BW}$, waarin ouders na echtscheiding op eensluidend verzoek het gezamenlijk gezag kunnen blijven uitoefenen. De rechtbank wijst dit verzoek af indien gegronde vrees bestaat dat bij inwilliging de belangen van het kind zouden worden verwaarloosd;

- art. 1: 251 lid $3 \mathrm{BW}$, waarin, bij ontbreken of afwijzing van een verzoek tot gezamenlijk ouderlijk gezag, én van de ouders het gezag over ieder van de kinderen toekomt;

- art. 1: 252 BW waarin ouders buiten buwelijk gezamenlijk ouderlijk gezag kunnen uitoefenen, "zulks op beider verzoek";

- art. 1: $253 \mathrm{~b}$ lid 1 en $2 \mathrm{BW}$, waarin staat dat buiten huwelijk of gezamenlijke gezagsuitoefening moeder het gezag krijgt;

- art. 1: $253 \mathrm{ha}$, waarin de minderjarige moeder die als degene die het gezag heeft, haar kind wenst te verzorgen en op te voeden, als zij zestien wordt, de rechter kan verzoeken haar meerderjarig te verklaren;

- Een kleine inbreuk op dit wettelijk systeem is gemaakt ten gunste van de pleegouders. Wanneer er een conflict ontstaat tussen ouders en pleegouders over de wijziging van de verblijfplaats van het kind en de ouders een verzoek om toestemming bij de rechter moeten indienen (art. 1: 253s lid 1 en 2, art. 336a lid $2 \mathrm{BW}$ ), kan op grond van die beslissing door de pleegouders een verzoek om ontheffing uit het ouderlijk gezag van de ouders gedaan worden. ${ }^{97}$ Bovendien kunnen pleegouders, na een kind een jaar verzorgd en opgevoed te hebben, een verzoek indienen om met gezag bekleed te worden, als de voogdij tenminste bij een derde berustte. (art. 1: $299 \mathrm{BW}$ )

- art.1:269 BW regelt de ontzetting uit het ouderlijke gezag onder andere op grond van onherroepelijke veroordeling:

1. wegens opzettelijke deelneming aan enig misdrijf met een onder zijn gezag staande minderjarige;

2. wegens het plegen tegen een minderjarige van een van de misdrijven omschreven in de titels XIII-XV en XVIII-XX in het Wetboek van Strafrecht;

3. tot een vrijheidsstraf van twee jaar of langer.

In die gevallen kàn de rechter, in het belang van de kinderen, tot ontzetting overgaan.

thegen welke inbreuken de gedetineerde ouder haar kind moct beschermen.

97 Zie De Bruijn-Lückers (1994) p. 45-47. Zij beschrijft dat het blokkaderecht van pleegouders in de meeste andere landen onbekend is. Het leid dan ook wel eens tot onaangename cultuurgebonden confrontaties. 
Met spijt constateert Van Wamelen dat in Nederland het ouderschap nog steeds in de context van rechten en bevoegdheden van ouders staat. ${ }^{\text {98 }} \mathrm{Al}$ in 1975 proberen zeven jeugdrechtspecialisten tot een concretisering van het begrip 'ouderlijke macht' te komen, waarin de verantwoordelijkheid van ouders voor de verzorging en opwoeding centraal staat en de ouderlijke macht slechts een middel is om dat doel waar te maken." Ouderlijk gezag is doelgezag. ${ }^{100}$ Ouderlijk gezag brengt dus voor ouders geen zeggenschap zonder meer met zich. Ze dienen de uit het gezag voortkomende bevoegdheden aan te wenden in het kader van hun zorgopdracht. Daarbij wordt onderscheid gemaakt tussen gezag wat betreft de persoon en gezag wat betreft het vermogen..$^{\text {10i }}$

In de Recommendation on parental responsibilities van de Raad van Europa uit 1984, wordt in plaats van 'parental authority' het begrip 'parental responsibility' gebruikt.

98 Van Wamelen (1992) p. 113-116.

997 Jeugdrechtspecialisten, Rechten van jeugdigen en gezag van ouders, NJB 25 januari 1975 , afl. 4, p. 97-104.

100 Zie ook De Bruijgn-Lückers (1994) p. 97.

101 De zeven jeugdrechtspecialistem zoeken voor de juridische invulling van de rechtsverhouding tussen ouders en kinderen aansluiting bij het arbeidsrecht. Ook wordt wel aansluiting bij het bestuursrecht gezocht voor de toetsing van de ouderlijke gezagsuitoefening. Zie De Ruiter (1974). De Ruiter legt een verband met andere rechtsgebieden. Hij stelt onder verwijzing naar respectievelijk het beschermingselement en het mondigheidselement, dat de ouderlijke gezagsuitoefening moet voldoen aan de beginselen van een behoorlijke verzorging en opvoeding en thij vergelijkt deze met overeenkomsten die te goeder trouw moeten worden uitgevoerd en met de algemene beginselen van behoorlijk bestuur waardoor de overheid zich moet laten leiden.

Zie ook Van Gerven (1983) p. 6. Hij spreekt daarin ook over toetsing van de ouderlijke macht aaxn algemene beginselen wan behoorlijk bestuwr. "Deze bij wet erkende positie van bovengeschiktheid is aan de ouders verleend in het belang van thet betrokken kind of van het gezin. Welnu, dezelfde beginselen wan behoorlijik bestuur die de overheid in acht moet nemen, binden evenzeer de ouders. Om er maar enkelle te noemen: het is de ouders niet toegestaan hun bevoegdheid woor een ander doel aan te wenden dan het belang van ter behartiging waarvan zij werd verleend (zuiverheid van oogmerk); het komt de ouders niet toe kinderen kennelijk ongelijk te behandelen, behoudens bijzzondere omstandigheden (bijv. gehandicapt kind) in welk geval zij tot een gedifferenticerde behandeling in gelijke mate van de ongelijkheid (gelijkheidsbeginsel) gehouden zijin; een kennelijk onredelijke uitoefening van de ouderlijke macht bij afweging vam alle in aanmerking komende belangen is ongeoorloofd (evenwichtigheidsprincipe). In beide gevallen betreft het evenwel een rechtmatigheidscontrole: aan de ouders zoals aan de overheild komt een ruime Ermessensfreiheit toe aangaande de opportuniteit van een of andere beslissing in de beoordeling waarvan de rechter niet mag treden." 
In order to do so they exercise powers to carry out duties in the interests of the child and not because of an authority which is conferred on them in their own interests". ${ }^{102}$

Van Wamelen legt uit dat het hebben van ouderlijke verantwoordellikheden onderscheiden moet worden van het uitoefenen daarvan. ${ }^{103}$ Elke ouder heeft ouderlijke verantwoordelijkheden welke uitdrukkelijk strekken tot de zorg voor het geestelijk en lichamelijk welzijn van het kind. ${ }^{104}$ Ouderlijke verantwoordelijkheden, zoals daaraan invulling wordt gegeven in de Recommendation, kunnen in drie categorieèn onderscheiden worden:

1. Verantwoordelijkheden die inherent zijn aan ouderschap: de onderhoudsplicht, het onderhouden van persoonlijke betrekkingen met het kind en het recht te worden geïnformeerd over belangrijke aangelegenheden betreffende het kind, welk recht voor de andere ouder de plicht meebrengt dergelijke informatie te verstrekken.

2. De verantwoordelijkheid voor de zorg voor de persoon van het kind, met als juridische component de ouderlijke macht wat de persoon van het kind betreft.

3. De verantwoordelijkheid voor het bewind over het vermogen van het kind en de vertegenwoordiging van het kind in burgerlijke handelingen, met als juridische component de ouderlijke macht wat het vermogen van het kind betreft. Het hebben van ouderlijke verantwoordelijkheden betekent niet automatisch dat men deze ook uitoefent. De Recommendation bepleit wetgeving volgens welke beide ouders in beginsel gezamenlijk hun zorgopdracht kunnen nakomen.

102 In: Van Wamelen (1987) p. 113. Het is interessant om in relatie tot 'het belang van het kind' de inaugurele rede van Van Gunsteren te lezen: "Verantwoordelijkheid overdragen is niet het overdragen van een ding, maar het veranderen vam relaties tussen mensen." Van Gunsteren (1974) p. 22. Hij concludeert dat er twee contrasterende ver antwoordelijkheidsconcepties geformuleerd kunnen worden, een verticale en een horizontale:"'De verticale conceptie wordt gekenmerkt door de wolgende termen : controle, ongelijkheid, zekerheid, algemene regels en wetten, quasi-automatische toepassing van wetten en theorieên, anonimiteit, gegeven normsystemen een wetgeving. De horizontale conceptie van verantwoordelijkheid wordt gekenmerkt door de termen: respect, gelijkheild, onzekerheid, contextualiteit, verhaal, geschicdenis, aanwezigheid van het zell, transformatieproces en forum. .... De horizontale conceptie is primair en werticale verantwoordelijkheid kan alleen gedijen in de. levende aarde van horizontale verantwoordingsprocessen." Van Gunsteren (1974) p. 24-25.

103 Van Wamelen (1987) p. 329-336.

104 Damen (1985) vindt dat er pas over 'verantwoordelijkheid' kan worden gesproken als duidelijk. is tegenover welk forum die geldt. Als er geen forum is, werkt het begrip versiluierend en kan werantwoordelijkheid ontdoken worden. En passant merkt hij op dat de verantwoordelijkheid van de ouders voor de opvoeding van hun kinderen en de plichten die daaruit voortvloeien uiteindelijk ter beoordeling van de (kinder)rechter staan die daarmee het forum vormt. Zie Damen (1992) p. 144-179. Hij betoogt dat de kinderrechter nog teveel binnen het privaatrecht geplaatst wordt en te weinig in het bestuursrecht. Zie over het - nieuwe - toetsingskader van de kinderrechter bij ondertoezichtstelling Van den Boogaard (1996). 
Van Wamelen trekt in 1992 de conclusie dat uit de opsomming van feitelijke taken, behorend bij de zorgopdracht van ouders, blijkt dat het gezag de juridische component is voor de verantwoordelijkheid voor de feitelijke verzorging en opvoeding, dus van woonouderschap. ${ }^{105} L$ Later introduceert $z i j$ "het recht op eerbiediging van een zorgrelatie" als een door art. 8 EVRM beschermo recht. ${ }^{100} \mathrm{Zij}$ beschrijft de zorgrelatie als:

"de relatie tussen een volwassene en een kind, die zich kenmerkt door duurzame zorg voor het kind, mel wie de volwassene samenwoont; deze zorg omvat de verzorging, de opvoeding, bescherming, emotionele zorg, beschikbaarheid, verantwoordelijkheid voor en organisatie van de zorg alsmede financiele zorgen

Zij vindt met name het zèlf zorgen belangrijk. Het uitbesteden van zorg staat in haar optiek op gespannen voet met art. 7 van het VN-Kinderverdrag. Als voorbeeld van uitbesteding noemt zij het pleeggezin. In hoeverre zij onder uitbesteding ook vormen van dagopwang laat vallen, is onduidelijk. In haar optiek lijken de gezamenlijke verblijfplaats en de beschikbaarheid van de ouder een cruciale rol te spelen. De ontwikkelde optie is interessant omdat zij mogelijk aansluit bij de vraag welke consequenties het inwoeren wan een zorgethiek in het familierecht heeft. De discussie is dan vooral of bij het vaststellen van de "zorgrelatie" genderverschillen een rol mogen en/of moeten spelen. In hoeverre ze dat doen in de huidige rechtspraktijk en welke effecten dat heeft, wordt hierna besproken.

\subsubsection{Eén-ouder gezag na echtscheiding}

In het gros van de gevallen is echtscheiding de oorzaak van het beëindigen van het gezamenlijk gezag van de ouders. Dat betekent dat er een inbreuk gemaakt wordt op het gezinsleven als bedoeld in art. 8 EVRM, maar dat mag krachtens lid 2 van dat artikel: 'zij is bij wet voorzien en in het algemeen, in verband met de tussen ouders bij de ontwrichting van hun huwelijk te verwachten spanningen, is zij gerechtvaardigd door de belangen van het kind, op bescherming waarvan het recht heeft ${ }^{x}$.as De wet geeft geen inhoudelijke criteria aan de hand waarvan de rechter kan beslissen aan wie het kind wordt toevertrouwd. Wel is bekend dat 'het belang van het kind" leidraad is. In de (rechts)praktijk wordt aan dit beginsel wel inhoud gegeven. Dat 'het belang van het kind' een aan verandering onderhevig begrip is, schetst Van den Bergh in verband met de ontwikkelingen in de voogdijregeling na echtscheiding. Hij laat daarbij ook de samenhang tussen pedagogische theorievorming en juridische

105 Van Wamelen (1992) p. 114.

106 Van Wamelen (1996) p. 76-82.

107 Van Wamelen (1996) p. 77.

108 HR 4 mei 1984, NJ 1985, 510. 
besluitvorming zien. ${ }^{109}$ Aanvankelijk, vanaf het begin van de eeuw tot ver na de Tweede Wereldoorlog, is het kind voorwerp van bescherming en wordt aan de biologische ouders een onvoorwaardelijke instinctieve band toegeschreven. Later, vooral in de jaren zeventig, komt ook de continuitteit van de eigen leefwereld van het kind in beeld ${ }^{110}$ De 'ervaringsregel' dat de verzorging en de opvoeding in handen van de moeder 'als daartoe de door de natuur meest aangewezene en geroepene' ${ }^{\text {"II }}$ wordt in de jaren zeventig nog van toepassing geacht voor 'zeer jonge kinderen'. Soms worden de kwaliteiten van de vader pas gewaardeerd als de moeder ongeschikt is bevonden. Dan wordt de identificatie met beide biologische ouders als doorslaggevend argument opgevoerd.

In 1988 publiceert Bönnekamp gegevens uit een observatieonderzoek bij twee rechtbanken, in Haarlem en Utrecht, naar de besluitvorming in conflictueuze advieszaken omtrent de voogdij. ${ }^{112}$ Aanleiding is onder meer het toenemend aantal gevallen waarin vaders de voogdij toegewezen krijgen, zonder dat geheel duidelijk is op welke gronden dat gebeurt. Een belangrijke rol in deze zaken speelt de Raad voor de Kinderbescherming, die veelal een adviserende taak heeft. Belangrijke conclusies uit het onderzoek zijn ${ }^{113}$ :

- De argumenten in de beschikking, zijn 'harde' argumenten, dat wil zeggen gericht op houdbaarheid bij een eventueel hoger beroep. Dat betekent dat de beschikking zelden alle doorslaggevende argumenten voor de beslissing weergeeft. Soms ontbreken zelfs de argumenten die in de besluitvorming een grote rol hebben gespeeld.

- Het overheersende patroon bij de voogdijtoewijzing wordt gevormd door de 'wet' van de status quo. De kinderen blijven bij de ouder bij wie ze op het moment van de aanvang van de procedure zijn. De rechtvaardiging is de overweging dat gezien de stabiele situatie en het welbevinden van het kind daarbij, geen aanleiding bestaat in de verblijfplaats van het kind verandering te brengen. Daarbij wordt het begrip continuïteit gehanteerd. Het gaat dan echter over een korte termijn, zelfs als de kinderen bij de moeder zjn wordt naar deze korte termijn verwezen (" De kinderen worden al 5 maanden door de moeder verzorgd en het gaat uitstekend met ze"), ook al zorgt ze al vanaf hun geboorte voor hen.

109 Van den Bergh (1986) p. 131-138.

110 Van Wijk (1992) p. 149 spreekt ower "een blokkaderecht avant la lettre" wanneer zij op de wetswijziging van art. 1:269 lid 1e BW (1947) ingaat. De oorspronkelijke rechtsgrond (woor het overlaten van de feitelijke zorg aan anderen) was "bij gegronde vrees voor verwaarlozing van het kind" en werd " bij gegronde vrees voor verwaarlozing van de belangen van het kind", waardoor niet alleen mogelijke toekomstige verwaarlozing als rechtsgrond was geaccepteerd, maar ook : schade door doorbreking van de continuiteit van het verwangend milieu.

111 Rb Amsterdam, 20 februari 1933, NJ 1933, p. 75.

112 Bönmekamp (1988).

113 Bönnekamp (1988) p. 49-53. 


\section{Hoofdstuk 7}

Maar als de moeder uit huis is gegaan, met de bedoeling dat het tijdelijk zou zijn, wordt de continuilteit geacht door de vader geboden te worden. Als het gedrag van de vader of zijn gebrek aan pedagogisch inzicht daartoe aanleiding geven, worden kinderen wel bij de moeder teruggeplaatst.

- De Raad wil sekseneutraal opereren en vaders gelijke kansen geven. Vaak vormen zijn klachten ook de ingang van het onderzoek. Bijvoorbeeld de klacht dat de moeder de kinderen niet persoonlijk verzorgt en opvoedt omdat zij werkt en het problematiseren van haar beroepsarbeid en de door haar georganiseerde kinderopvang. De adviezen ten gunste van vaders blijken tijdens het onderzoek echter steeds vaders te betreffen die voltijds werken en met behulp van een nieuwe partner of gezinshulp de kinderen verzorgen. De Raad behandelt hier mannen en vrouwen dus niet gelijk. Hijj weegt niet zorg en kwaliteit van beide ouders tegen elkaar af, maar betrekt de nieuwe partner van de vader in zijn oordeel.

- Als een van de ouders voor het proces (tijdelijk) vertrokken is, wordt dit bij vaders benoemd als "het verlaten van de echtelijke woning", terwijl van moeders wordt gezegd dat zij "hun kinderen hebben verlaten". De stigmatisering in negatieve zin ('breuk met de kinderen') vindt eenzijdig richting moeders plaats.

- Aan een nieuwe partnerrelatie van vader wordt een andere betekenis gehecht dan aan die van moeder. De partnerrelatie van moeder wordt vaker geacht niet stabiel of duurzaam en vooral seksueel gericht te zijn. Bij vaders wordt eerder verondersteld dat er iemand in huis is om voor de kinderen te zorgen en stabiliteit in de situatie te brengen.

Interessant is in dit verband een Britse studie waaraan Carol Smart refereert, waaruit blijkt dat ook ouders zelf genderspecifieke verschillen tussen "care for" en "care about" niet onderkennen. Zo zijn vrouwen tijdens het proces soms geneigd hun eigen alledaagse dagelijkse zorg te negeren en dus niet te waarderen, terwijl ze hoog opgeven over de bemoeienis van hun (ex)echtgenoot met de kinderen. Feitelijk bestaat die dan vaak niet uit meer dan af en toe 's avonds een verhaaltje voorlezen of in het weekend met het kind gaan zwemmen. ${ }^{1 / 4}$

Waarschijnlijk is de seksespecifieke socialisatie, waarin vrouwen veel meer op aanwezigheid en dienstbaarheid binnenshuis gericht zijn en mannen op waarneembare activiteiten ook in de uitoefening van verzorgingstaken terug te vinden. Ook hier is de 'mannelijke zorg' meer zichtbaar en benoembaar dan de vrouwelijke die ten onder gaat in vanzelfsprekendheid. ${ }^{115}$

114 Smart (1991-1). Zie ook stelling 1 bij het proefschrift van Morée (1992) "Buitenshuis werkende moeders lijden nog in groten getale aan een 'witte raven complex': zolang vaders die substantieel bijdragen aan de zorg voor kinderen zo zeldzaam zijn, geeft elke vaderlijke zorg die uitstijgt boven de middelmaat de betrokken vrouw het gevoel een geluksvogel te zijn."

115 Zie ook Emancipatieraad (1993). 
Wegelin onderzoekt de verschillende manieren waarop aan het begrip 'gelijkheid' betekenis wordt verleend bij de verdeling van het ouderschap na echtscheiding in verschillende circuits: de wetenschap, rechters, de deskundigen (raden van kinderbescherming, psychosociale hulpverleners als bemiddelaars) en de gescheiden ouders zelf. ${ }^{116}$ Op alle niveaus wordt ook het gescheiden ouderschap primair benoemd als een gevoelsrelatie tussen ouder en kind. In het algemeen wordt de verhouding tussen gescheiden moeder en kind en gescheiden vader en kind symmetrisch voorgesteld. Op wetenschappelijk niveau worden de meeste differentiaties in gelijkheid aangebracht. Gelijkheid in de principiële mogelijkheden van moeders en vaders om te voorzien in de gevoelsbehoeften van het kind, gelijkheid in de mate waarin beiden onmisbaar geacht worden voor het kind, gelijkheid in de mate waarin ouderschap te leren valt en gelijkheid in de feitelijke taakvervulling. Alleen de psycho-analyse veronderstelt een principieel verschil in de betekenis van beide seksen voor de ontwikkeling van een kind. In de uitspraken van deskundigen ontbreken dergelijke differentiaties. Gelijkheid wordt door hen vooral ingevuld als symmetrie in potentiële betrokkenheid. Tot eind 1989 wordt door de Hoge Raad bovendien de biologische verwantschap essentieel gevonden voor het bestaan van "family life". Zo wordt ook een symmetrie tot stand gebracht tussen de onmisbaarheid van de biologische moeder en de biologische vader. In de uitspraken van de deskundigen wordt vervolgens symmetrie gecreëerd via het concept "gezamenlijke verantwoordelijkheid". Hierin komt een aantal vormen van gelijkheid samen en wordt een aspect van (mede) zeggenschap toegevoegd. Door rechters wordt vooral verwezen naar een gelijkheid tot zeggenschap door goed overleg of via gezamenlijke ouderlijke macht. Door bemid-

116 Wegelin (1990). Wegelin onderzoekt vanuit een ideologie-theoretisch perspectief ook de wisselwerking die tussen de verschillende niveaus van betekenisgeving bestaat. "Onsamenhangende betekenissen die circuleren op het niveau wan het dagelijks leven worden via een proces van "condensatie" verdichting-opgenomen in coherente ketens van betekenisgeving op institutionele niveaus. Omgekeerd wordt de betekenisgeving die groepen en individuen verlenen aan hun dagelijks leven gestuurd door een proces van 'interpellatie' -aanspreking-vanuit de coherente ideologieën die geproduceerd worden op institutionele niveaus." (p. 202)

Wegelin veronderstelde bij de aanvang van haar onderzoek dat er een hiërarchie van betekenisbeînvibeding zou bestaan. In tegenstelling tot haar verwachting bleken daarin niet de wettenschappelijke teksten, maar die van de deskundigen( = beroepsgroepen) de meeste coherentie te vertonen. $\mathrm{Zij}$ verklaart dit onder meer vanuit de maatschappelijke autonomie die rechters en hulpverleners hebben verworven, maar ook vanuit hun professionaliseringsstrategieẽn om met macht om te gaan, zoals het streven naar kennisoverwicht, het streven naar moreel overwicht, het zelf vaststellen van succescriteria (bijwoorbeeld het bereiken van formele afspraken in plaats van gerealiseerde regelingen), het reguleren van de cliëntenstroom (bij de RvdK bijv. op grond van de succeskans bij bemiddeling), de actieve interactie met cliënten, waarbij de deskundige onder meer procedureregels, plaats, ruimte en tijdsinvestering vaststelt en beleidsmatig door te streven naar cen centrale plaats in besluitwormingsprocessen. (p. 215-216) 


\section{Hoofdstik 7}

delaars wordt een gelijk verantwoordelijkheidsgevoel van beide ouders voor het continueren van beider gevoelsrelatie met het kind bedoeld.

Volgens Wegelin vindt de door deskundigen gepostuleerde gelijkheid als "gezameniljke verantwoordelijkheid" bij ouders geen enkele weerklank.

"Veel overleg over de plaats van beide ouders in relatie tot de kinderen is er niet meer en voor zower dit er wel is wordt dit gekenmerkt door een uitgesproken sekse-bias. De ouders gaan veelal wel uit wan een blijvende vorm van bemoeienis of zeggenschap ten gunste van de $m a n$, maar niet ten gunste wan de wrouw wanneer deze de kinderen achterlaat. ${ }^{\text {sil }}$

Een minderheid van de ouders zegt bovendien geen bemoeienis van de ex-partner te accepteren, wanneer deze niet (meer) bijdraagt aan de feitelijke zorg voor de kinderen. Wegelin signaleert

"een spanningsverhouding tussen gelijke ouderlijke aanspraken op een affectiewe relatie met de kinderen en de ongelijkheid die gewoonlijk bestaat in de feitelijke verdeling van zorg en in de zeggenschap die ieder van de seksen wordt toegestaan. ${ }^{\text {mils }}$

Op wetenschappelijk niveau is er in de jaren tachtig aandacht gekomen voor de zorgrelatie tussen ouder en kind, het sociaalmaterieel ouderschap. Op deskundigenniveau is die aandacht volgens Wegelin nagenoeg afwezig. ${ }^{119}$

De Emancipatieraad levert in het rapport "Ouderlijke macht en voogdij" kritiek op de rechtspraktijk inzake de regeling van de voogdij na echtscheiding omdat thans geen rekening wordt gehouden met de geïnvesteerde zorg in kinderen en huishoudelijke taken. Vanuit een materiële invulling van het gelijkheidsbeginsel stelt de Raad voor het concept 'verzorgende ouder' te gebruiken ${ }^{120}$

Wegelin merkt op dat uit het gezorgd hebben voor kinderen niet automatisch een relationele betrokkenheid voortvloeit die rechtvaardigt dat de rechter kinderen automatisch aan deze ouder zou moeten toewijzen. Rechten, wensen of mogelijkheden van de kinderen zelf moeten niet ondersneeuwen doordat de vraag naar rechten van vaders en moeders dominant blijft. ${ }^{121}$

Dijkers geeft een impressie hoe hij als rechter omgaat met voogdijtoewijzingen. ${ }^{12}$

"Waar geschreven wordt over het belang van het kind (...) valt te lezen dat nagegaan moet worden in hoeverre de ouders kinderen in hun ontwikkeling ruimte geven, begeleiden en stimuleren, alsmede dat kinderen gebaat zijn bij een stabiele en continue opvoeding en verzorging en de mogelijkheid zich

117 Wegelin (1990) p. 204.

118 Wegelin $(1990)$ p. 205.

119 Wegellin (1990) p. 205-206.

120 Emancipatieraad (1992) p. 5.

121 Wegelin (1990) p. 71.

122 Dijkers (1991) p. 281-286. 
te hechten. Nader uitgewerkt leüdt een en ander tot overwegingen dat werhuizingen van de ene ouder naar de ander en schoolwisselingen zoveel mogelijk vermeden dienen te worden, dat kinderen uit een gezin bij elkaar moeten blijven, dat een kind recht heeft op een relatie met beide ouders, dat ouders hun kinderen niet moeten belasten met hun onderlinge conflicten enz. ${ }^{\text {"t23 }}$ Verder merkt hij op dat "bedacht dient te worden dat hetgeen als belang van het kind wordi aangemerkt, in de tijd niet onveranderlijk is en mede wisselt naar gelang de (sub)culturele context."

Dijkers pleit ervoor het subjectieve oordeel van de rechter zoveel mogelijk te objectiveren door te zoeken naar een objectief criterium in het feitelijk gedrag van de ouders tot het moment dat het mis ging in hun relatie.

"Als de ouders tijdens het huwelijk een rolverdeling hadden dat de een (meestal de moeder) feitelijk het leeuwedeel had van de dagelijkse zorg voor de kinderen, hebben zij kennelijk zelf die ouder als opvoeder het meest geschikt/bekwaam gevonden. In ieder geval is die ouder het meest ervaren en heeft die ouder de voorafgaande tijd getoond zich ook daadwerkelijk te willen/kunnen wijden aan de zware taak van het verzorgen en opvoeden (wat van de andere ouder nog maar afgewacht moet worden, alle ten overstaan van de rechter betoonde goede voornemens ten spijt.) ${ }^{\text {n124 }}$

Via feitelijke vragen probeert hij te achterhalen wie het grootste deel van de zorg op zich nam.

"Wie bracht de kinderen naar school, welke ouder onderhield de contacten met de leerkrachten, wie begeleidde het kind bij het bezoek aan de dokter, wie bracht de kinderen naar bed? etc."125

Maar hij geeft ook aan dat je soms, in uiterste gevallen, moet afwijken van de tot dusver bestaande rolverdeling, bijvoorbeeld wanneer die ouder een hele andere ongunstige levenswijze is gaan volgen en/of onderdak heeft gevonden op een plek die voor de kinderen beslist ongeschikt is. Ook kan het zijn dat de kinderen al geruime tijd bij de andere ouder wonen en dan zou het met name bij zeer jonge kinderen een nadeel zijn om die continuïteit te doorbreken. ${ }^{126}$ In de gevallen, waarbij de niet-verzorgende ouder aanvoert dat de ex-partner het tijdens het huwelijk al niet goed deed, denkt Dijkers aan, eventueel gedwongen, hulpverlening in het gezin van de bekritiseerde partner. Hij ziet reden tot twijfel aan de opvoedingskwaliteiten van de partner die nu kritiek heeft. Deze heeft immers zelf nooit ingegrepen. ${ }^{27}$ Het is de vraag of hij hierbij niet te gemakkelijk aan de uiterst ingewikkelde relatiekluwens en machtsconstellaties binnen een gezinssysteem voorbij gaat. Waarom zou

123 Dijkers (1991) p. 282 .

124 Dijkers (1991) p. 282 .

125 Dijkers (1991) p. 282.

$126 \mathrm{Juist}$ in deze situaties kunnen de resultaten van Bönnekamps onderzoek omtrent het verschil in beoordeling van nieuwe leefsituaties tussen moeders en vaders ter harte worden genomen.

127 Dijkers, (1991) p. 283. 
er bijvoorbeeld geen hulp moeten zijn voor de tijdens het echtscheidingsproces 'afgegleden' ouder? Bovendien zijn er nogal eens seksespecifieke verwachtingen ten aanzien van de zogenaamd 'toekijkende' (medeplichtige) ouder en de verkeerde inschattingen die de hulpwerlening daarbij maakt. ${ }^{123}$

\subsubsection{Gezamenlijk gezag na echtscheiding en buiten huwelijk}

Sinds 1995 is de mogelijkheid tot gezamenlijke voortzetting van het ouderlijk gezag na echtscheiding in de wet opgenomen. ${ }^{12}$ In 1984 spreekt de Hoge Raad zich woor het eerst op grond van art. 8 EVRM uit over continuering van de ouderlijke macht na echtscheiding. ${ }^{130}$ De ouderlijke macht (die beide ouders tijdens het huwelijk hadden) kan in sommige gevallen 'in het belang van het kind' na echtscheiding doorgaan. Als "woormelde belangen van het kind" worden beschreven:

"indien de ouders zich in staat achten het kind in goede onderlinge verstandhouding te blijwen verzorgen en opvoeden en zij op die grond verzoeken om gezamenlijk met het gexag over het kind belast te blijwen."

Na deze uitspraak komt de vraag op of de ouderlijke macht hiermee zo los was komen te staan van het huwelijk dat deze op grond van de artt. 14 en 8 EVRM ook toegekend kan worden aan ouders die niet gehuwd(geweest) zijn. De HR overweegt daarop

"dat onder de huidige maatschappelijke omstandigheden en opvattingen de vooronderstelling die ten
grondslag heeft gelegen aan de wet van 1901, dat er uitsluitend binnen een huwelijk tussen ouders
een zodanige goede verstandhouding bestaat dat zij beiden in staat zijn hun invloed te doen gelden,
onderling overleg te plegen en elkaar te controleren, niet meer opgaat". ${ }^{3 \|}$

Een verzoek van niet gehuwde ouders kan volgens de HR worden toegewezen indien:

a. beide ouders tot het kind in familierechtelijke betrekking staan en tot uitoefening van het gezag over dit kind bevoegd zijn;

b. blijkt dat beide ouders wensen met de ouderlijke macht te worden bekleed;

c. aannemelijk is dat tussen de ouders de goede onderlinge verstandhouding bestaat die vereist is voor gezamenlijke uitoefening van het gezag, alsmede voor het in onderling overleg voorzien in de kosten van verzorging en opvoeding van het kind;

d. het belang van het kind zich niet daartegen verzet.

Uitwerking van dit laatste criterium wordt door de HR niet gegeven.

128 Vgl. Jonker-de Putter (1991).

129 Art. 1: 251 lid 2 BW.

130 HR 4 mei 1984, NJ 1985, 510, m.n. EAA en EAAL.

131 HR 21 maart 1986, NJ 1986, 585, m.n. EAA en EAAL. 
Ook deze vorm van gezamenlijk gezag is inmiddels in de wet verankerd ${ }^{132}$, overigens zonder toewijzingscriteria.

Het feit dat de HR ouderlijk gezag aan juridisch ouderschap en dus aan een heteroseksuele relatie tussen ouders, blijft koppelen, roept kritiek op. ${ }^{133}$

Juridisch ouderschap is een juridische constructie. Dit ouderschap blijkt - anders dan sociaal en biolo* gisch ouderschap- niet uit de feiten, maar uit de wettelijke regelingen inzake juridisering van bepaalde feiten. Art. 8 EVRM strekt echter niet tot bescherming van juridische banden maar van feitelijke banden. ${ }^{.134}$

In de nieuwe wet is de eis van de familierechtelijke betrekkingen echter een onneembare hindernis gebleven om juridisch gezag over het kind te verkrijgen. ${ }^{135}$

\subsection{Verblijfplaats}

Een belangrijk gevolg van ouderlijk gezag is dat de ouder mag bepalen wat de verblijfplaats van het kind is. Wanneer er door ingrijpen van de overheid inbreuk wordt gemaakt op dit recht en/of dus (in)direct op de uitoefening van het ouderlijk gezag, is het de vraag hoe actief de overheid zich moet opstellen om het family life van de betreffende ouder en het kind te beschermen. Als het idee van 'woonouderschap' en/of "zorgrelatie" van Van Wamelen ingang zou vinden, is die vraag nog nijpender, omdat in haar optiek het hebben van een gezamenlijke verblijfplaats voorwaarde is voor continuering van het juridische gezag. Het is de vraag of de door Van Wamelen genoemde criteria de primair zorgende gedetineerde niet in een fuik drijven. Effectuering van het ene recht via gezamenlijk verblijf zou moeten leiden tot codetentie. Maar co-detentie leidt tot aantasting van andere grondrechten van het kind, met name de bewegingsvrijheid, het recht op privacy en lichamelijke integriteit. De dilemma's rond (mede) vrijheidsberoving zijn niet alleen van belang bij detentie van verzorgende ouders, maar komen ook in het kader van het Vreemdelingenrecht naar woren. Bij minderjarige asielzoekers is al aan de orde gesteld of zij samen met

132 Art. 1: 252 BW.

133 Zie ook Emancipatieraad (1992) p. 5. "Het bestaan van een effektief gezinsleven kan aannemelijk worden geacht indien het een gezamenlijk verzoek betreft van (sociale) ouders binnen wier relatic het kind is geboren, of indien het een gezamenlijk verzoek betreflt wan (sociale) ouders die het kind tenminste een jaar in thun gezin hebben verzorgd en opgevoed. Hieruit vloeit voort dat aath de niet-juridische ouder, die aan deze woorwaarde voldoet, het recht op ouderlijke macht toekomt" Zie ook Van Vliet $(1987,1992)$, Loenen (1990) p. 219-227.

134 Van Wamelen (1987) p. 319.

135 Zie ook Hammerstein-Schoonderwoerd (1993) p. 133-137. 
hun ouders gedetineerd mogen en/of moeten worden. ${ }^{136}$ Het Hoge Commissariaat voor de Vluchtelingen vindt dat het beginsel van eenheid van familie geen rechtvaardigingsgrond kan zijn voor het detineren van minderjarige asielzoekers samen met de ouders. ${ }^{137}$ De Vreemdelingen circulaire (A 7 bewaring) bepaalt dat kinderen beneden de twaalf jaar niet in een huis van bewaring of politiecel in bewaring worden gesteld, tenzij de tevens in bewaring gestelde ouder(s) van de vreemdeling erop staat de kinderen bij zich te houden. De Raad voor het Jeugdbeleid vindt dat het vreemdelingenrecht zich niet bij voorbaat dient te richten naar de toestemming van de ouders, maar juist het kader zou moeten scheppen, waarbinnen vervolgens de regels van familierecht betreffende de gezagsrelatie tussen ouders en kinderen werkzaam kunnen zijn. In aansluiting op het jeugdstrafprocesrecht zou geen bewaring mogelijk moeten zijn, ook niet met instemming van de ouders, maar hoogstens 15 uur (inclusief de nacht) verblijf voor verhoor op het politiebureau. ${ }^{138}$

Voor de Hoge Raad komt de kwestie aan de orde of de Nederlandse staat een (Surinaamse) moeder, door haar met uitzetting te bedreigen, voor een keuze plaatst waarin zij altijd een rechtens beschermd belang van haar kind zou schaden. ${ }^{139}$ Als het kind in Nederland zou achterblijven, zou het zonder zijn moeder-voogd moeten opgroeien. Door het mee te nemen zou zij hem de mogelijkheid ontnemen in zijn eigen land op te groeien. ${ }^{\text {lat }}$ Of het onrechtmatig is de moeder voor zo'n keus te stellen, komt hier niet aan de orde. In zijn noot bij het arrest gaat Boeles daar wel op in, onder andere op de samenhang tussen de artt. 5,9 en 10 van het VN-Kinderverdrag, waaruit blijkt dat een kind niet tegen hun wil wan zijn ouders mag worden gescheiden. ${ }^{\text {tal }}$

136 Zie hoofdstuk 6. Zie De Ruijter (1992) p. 123-127.

137 UNHCR, Guidelines on Refugee Children (aug. 1989) p. 9, in : De Ruijter (1992) p. 124.

138 Raad woor het Jeugdbeleid, nr. 36, p. 30, in : De Ruijter (1992) p. 124. Vgl. het voorbehoud dat Nederland bij art. 37 van het VN Kinderverdrag gemaakt heeft. Zie art. $61 \mathrm{~Sv}$, art $487 \mathrm{~Sv}$, Koens en De Jonge (1995) p. 97.

139 HR 8 mei 1992, met noot van P. Boeles, NJCM-bulletin 17-7 (1992) p. 759-765.

140 Art. 8 EVRM en art. 3 Vierde Protocol. Holterman (1996, p. 39-40, en 112-113) beschrijf hoe de argumentatie van de HR met betrekking tot het belang van het kind lijnrecht staat tegenover die in een soortgelijke casus van de Adf. rchtspraak waarin wervolgens hem van 'verhapte uitzetting" sprake is. Zelfs de verschillende kamers binnen het Hof in Den Haag komen tot tgengestelde uitspraken.

141 Dat bij conflicterende belangen tussen ouder en kind het ouderlijk gezag prioriteit krijgt boven het privacybelang wan het kind kwam in hoofdstuk 6 aan de orde bij de bespreking van de zaak Nielsen versus Denemarken. (EHRM 28 november 1988, Series A, vol. 144, NJ 1991, 541, m.n. EAA) 


\subsection{Omgangs- en informatie- en consultatierecht}

De niet met gezag beklede ouder heeft in de nieuwe wetgeving een aantal rechten gekregen. In afnemende graad van betrokkenheid zijn dit het omgangsrecht, het informatierecht en het consultatierecht. ${ }^{142}$

Ook het recht op omgang tussen het kind en anderen dan de niet met gezag belaste ouder is bij wet geregeld. ${ }^{143}$ Daarbij moet het gaan om personen die in een nauwe persoonlijke betrekking tot het kind staan, zoals grootouders, broers en zusters, vroegere pleegouders en de verwekker van het kind. De rechter moet per geval beslissen of er sprake van zo'n betrekking is. Het verzoek kan worden afgewezen, als het belang van het kind zich tegen toewijzing verzet of als het kind van twaalf jaar of ouder zich tegen een omgangsregeling verzet.

Het kind en de niet met gezag beklede ouder zijn zonder meer ontvankelijk in hun verzoek tot omgang met elkaar, maar er zijn wel ontzeggingsgronden limitatief opgesomd in art. 1:377a lid 3BW. ${ }^{144}$

In een bespreking van het wetsontwerp merkt Gunning op:

"Vanuit een relationele benadering is het in de wet vastleggen van een recht op omgang van de ouder hoogst problematisch, ondat daarmee onwoldoende tot uitdrukking wordt gebracht dat daartegenover het recht staat van het kind op de eerbiediging van zijn privacy."ths

\section{Of zoals Van Langen al eerder zei:}

"Los van deze kritische opmerkingen kan men zich afvragen of dit gehele wetsontwerp wat het omgangsrecht betreft niet te zeer tegemoet komt aan aanspraken van een ieder die zich ouder noemt op een omgangsregeling met kinderen met wie hij of zij een bepaalde relatic heeft. Bovendien zal een dergelijke door anderen dan ouders opgelegde ongangsregeling tegen de wens van de ouder of ouders, die de dagelijkse zorg voor het kind hebben, zeer moeilijk gerealiseerd kunnen worden. Dit lijkt op cen te wengaande overheidsbemocienis met familierelaties, waarbij en ongerechtwaardigde overheidsinterventie mogelijk wordt gemalkt in het feitelijk gezinsleven, in het bijzonder van de betreffende kinderen, en

142 Art. 1: 377 a $t / m$ h BW.

143 Art. 1:377 f BW.

144 De rechter ontzegt het recht op omgang slechts, indien:

a. omgang ernstig nadeel zou opleveren voor de geestelijke of lichamelijke ontwikkeling van het kind, of

b. de ouder kennelijk ongeschikt of kennelijk niet in staat moet worden geacht tot omgang, of

c. het kind dat twaalf jaren of ouder is, bij zijn werhoor van ernstige bezwaren tegen omgang met zijn ouder heeft doen blijken, of

d. omgang anderszins in strijd is met zwaarwegende belangen van het kind.

145 Gunning (1994) p. 21. 
cen inbreuik op hun recht op eerbiediging van thun privelleven, dat in de eerste plaats door art. 8 van het Europees Verdrag voor de Rechten van de Mens beschermd dient te worden." ${ }^{\text {at6 }}$

Naar aanleiding wan de uitspraak wan het Europese Hof in de Hokkanen-zaak kan inmiddels vastgesteld worden dat er volgens het Europese Hof zelfs uitdrukkelïk een inspanningsverplichting woor de autoriteiten ligt om contacten tussen vader en kind te realiseren. ${ }^{167}$ Von Brucken Fock vindt dan ook dat in Nederland de noodzaaik van een wettelijke regeling die voorziet in bemiddeling tussen ouders en/of kind zal moeten worden bestudeerd. ${ }^{143}$

\subsection{Verhouding tot derden/ pleegouders}

Ook wanneer een biologische moeder het gezag over het kind opeist nadat het jaren door pleegouders is verzorgd en opgevoed, zullen beide partijen een aanspraak op bescherming van hun family life krachtens art. 8 EVRM kunnen doen. ${ }^{195}$ De een op grond van bloedverwantschap, de ander op grond van sociaal ouderschap. Het recht van het kind kan op beide gezinslevens betrekking hebben en de vraag is welk zou moeten prevaleren. Uit de Straatsburgse jurisprudentie en die van de Hoge Raad kan dus worden opgemaakt, dat de term family life niet alleen betrekking heeft op juridische familiebetrekkingen maar ook op de feitelijke situatie van hen die een gezin vormen. ${ }^{150}$ Op grond daarvan zullen pleegouders wel toegang tot de rechter hebben, maar in feitelijke geschillen is hun positie soms zwak en wordt hun recht op eerbiediging van hun gezinsleven niet gehonoreerd. ${ }^{151}$

146 De Langen (1993) p. 8.

147 EHRM 23 september 1994, Hokkamen w. Finland, Series A, vol. 299A, NJCM bullecin (1996/1) p. $100-105$.

De vader had, na de dood van zijn vrouw, zujn kind wrijwillig ondergebractht bij de ouders wan zija vrouw Een goede ongangsregeling kon steeds maar niet geeffectueerd worden doordat de grootouders en de vader onderling een zeer slechte werhouding hadden. De bevoegde autoriteiten wonden dat het in het belang wan het kind was om contact met de vader te hebben, dat de vader voogd moest worden en dat het kind beter met hem kon samenleven. Het Hof oordeelde dat de nietafdwinging door de autoriteiten van dit recht wan de vader op contacten met het kind een schending. van art. 8 EVRM opleverde.

148 Von Brucken Fock (1996) p. 166.

149 Veel pleegzorg vindt op vrijwillige basis plaats en wordt ook niet als zodanig aangemeld. Zie ook Scholten en Frijling (1994).

150 De Langen (1990) p. 138 e.v., De Boer (1990), De Brujin-Lückers (1994) p. 45-47, Von Brucken Fock $(1996)$ p. $151-152$.

$151 \mathrm{Vgl}$. HR 10 maart 1989, NJ 1990,24 (pleegouders). HR 23 maart 1990, NJ 1991, 149 (opvangouders) HR 23 marart 1990, NJ 1991, 150, m.n. EAAL (grootouders). 
In dit verband is met name de uitspraak van het Europese Hof in de zaak Eriksson interessant. ${ }^{152}$ Het gaat om een meisje dat in 1978 (een maand oud) op grond van een jeugdbeschermingsmaatregel in een pleeggezin wordt geplaatst. Haar moeder is dan veroordeeld tot een gevangenisstraf van veertien maanden wegens heling en bezit van verdovende middelen. In 1979 trouwt de moeder met de vader van het meisje en uit dat huwelijk wordt in 1981 een zoon geboren. In 1986 scheiden de ouders en krijgt de moeder het gezag over de kinderen. Vanaf 1980 stelt de moeder alles in het werk om met haar kind herenigd te worden of in ieder geval omgang met haar dochter te krijgen met als doel die hereniging. Er lopen verschillende procedures en daarbij behorende onderzoeken naar de opvoedingskwaliteiten van de moeder, die feitelijk tot gevolg hebben dat de scheiding tussen moeder en kind blijft voortduren.

In deze zaak is belangrijk dat het Hof zegt:

a. dat het feit dat het verbod om het kind uit het pleeggezin te hallen gebaseerd is op een wettelijke bepaling, nog niet betekent dat de inbreuk 'in accordance with the law" is als bedoeld in art 8 lid 2 EVRM. Dit vereiste houdt namelijk in dat die wettelijke bepaling voldoende concreet en derhalve niet te waag mag zijn. $^{159}$

b. Verder onderzoekt het Hof of de gemaakte inbreuk evenredig is a an het doel dat daarmee beoogd wordt: de bescherming van de gezondheid en de rechten van het kind.

"In gevallen zoals dit houdt art. 8 EVRM-aldus het Hof- voor de moeder in een recht op het treffen van maatregelen met het oog op hereniging met haar kind. Dit is niet zozeer een werplichting van negatieve aard (om zich als overheid te onthouden van een bepaalde handeling of gedraging) maar een verplichting van positieve aard (een handeling of gedraging die juist verricht moet worden door de overbeid om schending te voorkomen). Deze verplichting van positieve aard is er voor de overheid in gevallen waarin aan de overheidsingreep in het gezag van de ouder een einde is gekomen en er geen twijfels zijn ten aanzien van de geschiktheid van de desbetreffende ouder tot opwoeding en werzorging van het kind of de omstandigheden in het ouderlijk gezin". ${ }^{154}$

Bij de uiteindelijke belangenafweging komen moeder en kind er slecht af. Juist het feit dat de moeder geen zinvolle relatie met het kind heeft kunnen opbouwen laat het Hof zwaar wegen. Moeder en kind krijgen schadevergoedingen voor de imma-

152 EHRM 22 juni 1989, Eriksson v. Zweden, Series A, vol. 156, NJ 1992, p. 705, m.n. EAA.

153 De HR interpreteerde zelfs bij een bestaande concrete bepaling extensief, bijv. HR bij ouderlijk gezag na echtscheiding. (HR 4 mei 1984, NJ 1985, 510) De rechter kon volgens de HR aan art. 94 Grondwet de bevoegdheid ontlenen om art. 1:161. lid $\mathbb{1}$ BW (oud) buiten toepassing te laten, als die bepaling niet verenigbaar is met art. 8 EVRM.

154 Koens (1990) p. 87 en 88. 
terielle schade. De lengte van de procedures in drie instanties in Zweden zelf (twintig maanden) werd niet buitensporig geacht. (art. 6 EVRM)

Ook in de Keegan case warr een vader de adoptie door de pleegouders wilde blokkeren, kreeg de man zijn juridisch gelijk, maar leeft het kind, op grond van het tijdsverloop toch bij de pleegouders.

Horizontale belangentegenstellingen lijken, buiten de echtscheidingsconflicten, vaak vooral te maken te hebben met het isolement waarin mensen ten opzichte van elkaar zijn komen te verkeren en de tijd die daarmee verstreken is. Juist in het belang van het kind zouden de voorheen verzorgende en de actuele verzorgers in dialoog met elkaar moeten kunnen blijven. 'Het belang van het kind' kan een bindend in plaats van een scheidend element zijn. Zeker wanneer de overheid primair verantwoordelijk is voor het verschuiven van samenwoningsconstellaties, vloeit daar direct de verplichting uit voort om waar mogelijk "in het belang van het kind" het oorspronkelijke contact zoveel mogelijk te continueren. ${ }^{156}$

\subsection{Samenvatting en conclusies}

In dit hoofdstuk wordt de discussie over een zorgzaamheidsethiek in het recht geïntroduceerd. De van de concrete casus geabstraheerde rechtvaardigheidsethiek lijkt onder meer tot genderverschillen in het recht te leiden. Dat kan gecorrigeerd worden door een contextgerichte benadering. De belangenafwegingen zouden meer in relatie tot het concrete handelen moeten staan. Of dat in het familierecht vruchten afwerpt is de vraag. Sommigen vrezen dat ongewenste familieverhoudingen bestendigd worden. Anderen menen dat door de feitelijke zorgrelaties tot uitgangspunt te nemen een materiële invulling van gelijkheid mogelijk is. Machtsverschillen in privé-verhoudingen zullen zo juist aan het licht komen.

Aan het gezin wordt in het positieve recht hoe dan ook grote waarde gehecht. Het bestaan van een gezinsleven in de zin van art. 8 EVRM wordt veelal afhankelijk gemaakt van juridische (afstammings-) relaties en van feitelijke omstandigheden, die op het eerste oog sekseneutraal worden vastgesteld. Aanspraken die ontleend worden aan het in art. 8 EVRM beschermde family life worden beoordeeld aan de hand van feitelijke banden. Autonomie en zelfbepaling van kinderen zijn ondergeschikt aan het ouderlijk gezag. 'Het belang van het kind' geldt met name in conflictsituaties als leidend principe maar krijgt in wetgeving en rechtspraak vaak geen nadere invulling. Degene die het ouderlijk gezag heeft, is vrij de verblijfplaats van het kind

155 EHRM 26 mei 1994, Keegan v. Ierland, Series A, vol. 290, NJ 1995, 247 m.n. JdeB, RN 1995, 469. De adoptieprocedure in Ierlland was niet verenigbaar met art. 8 EVRM, omdat in casu de ongehuwde biologische vader, niet was geïnformeerd en dus ook geen toestemming had gegeven. 156 Zie hoofdstuk 6. Zie ook Forder (1992) p. 611-637, Von Brucken Fock (1996) p. 153-155. 
te kiezen en kan de verzorgende en opvoedende taken door anderen laten uitoefenen. Wanneer ouder en kind gescheiden van elkaar leven, wordt bij de beoordeling van verzoeken om een omgangsregeling of wijziging van de verbliffplaats het belang van het kind sterk gekoppeld aan de stabiliteit en de continuiteit van de omgeving waar het op dat moment verblijft. In andere conflictsituaties dan echtscheidingen, blijkt het isolement waarin de ouder en het kind door het tijdsverloop ten opzichte van elkaar zijn komen te verkeren veelal van doorslaggevend belang bij het al dan niet effectueren van bestaande rechten. Uit uitspraken van het Europese Hof valt af te leiden dat er een verplichting bij de autoriteiten ligt om er alles aan te doen om continuering van bestaande familierelaties mogelijk te maken

De niet met gezag beklede ouder heeft in het onlangs gewijzigde familierecht een recht op omgang, informatie en consultatie. De kring van omgangsgerechtigden is bovendien uitgebreid tot personen die in nauwe betrekking staan tot het kind, zoals grootouders, broers en zussen.

Hoewel zorgen niet typisch vrouwelijk is, blijkt in de meeste concrete situaties de zorg voor kinderen aan vrouwen gekoppeld te zijn. Er bestaan wel grote verschillen tussen vrouwen onderling bij de invulling van die zorg, afhankelijk van klasse, opleiding, etniciteit, godsdienst etcetera. In feite bestaat er in verzorgingsrelaties een spiegelbeeldige situatie aan bijvoorbeeld de arbeldsmarkt. Zolang daar nog een beperkte beroepensegregatie wan vrouwen is zal er een weelheid aan juridische constellaties zijn die betrekking heeft op de diversiteit aan beroepen en arbeidsverhoudingen van de mannelijke beroepsbevolking. In het private domein treden nog betrekkelijk weinig mannen op. Om recht te doen aan een zo groot mogelijk scala van "verzorgingsrellaties tussen ouders en kinderen' zal de focus in eerste instantie op moeders gericht zijn. Juist om te vermijden dat een ideaaltypische en beperkte invulling van 'family life' gehanteerd wordt, moet in eerste instantie aan de diversiteit recht worden gedaan.

Gedetineerde en/of veroordeelde moeders zijn vaak alleenstaand. In dat geval hebben zij] in het algemeen alleen het gezag. Na echtscheiding zullen zij ook veelal alleen met het gezag bekleed zijn. Tijdens de detentie verblijven de kinderen vaak via. informele regelingen bij (vrouwelijke) familieleden en kennissen. In principe kumnen gedetineerde vrouwen de zorg voor hun kinderen uitbesteden. De vraag is of ze dat willen en of er alternatieven zijn waardoor zij de zorgtaken bijwoorbeeld intensiever zouden kunnen delen met anderen. De moeders stellen zich vaak terughoudend en afhankelijk van familie en instanties op uit vrees het gezag te zullen kwijtraken. Wanneer als enig alternatief een permanent verblijf van het kind bij de moeder in detentie wordt geboden, kan de moeder voor een onoplosbaar grondrechtenconflict. met betrekking tot haar haar kind gesteld worden.

In de nieuwe PBW wordt alleen iets geregeld over de verblijfplaats van het kind, niet over een recht op omgang en/of informatie. Daar ligt wellicht juist een gemeenschappelijk belang van, al dan niet met gezag beklede, verzorgers, hun kinderen 


\section{Hoofdstuk 7}

en andere familieleden. Gezien de positieve verplichting die op de overheid rust, zou materièle steun geboden moeten worden, zoals reisgeld, bemiddeling, vakantieopvang, bezoek- en logeermogelijkheden en spelfaciliteiten.

Centrale vraag zou in individuele gevallen, analoog aan het familierecht, kunnen zijn: Zijn er feitelijke omstandigheden in de relatie tussen de gedetineerde en een kind die het beroep op specifieke contextgerichte materiële regelingen legitimeren? Voor de meeste gedetineerde vrouwen bieden de huidige concepten van 'family life' nog weinig aanknopingspunten. Dat pleit voor een benadering waarbij rekening gehouden wordt met de verschillen tussen de gedetineerden onderling, ook in het verzorger- c.q. moederschap. Rekening houden met variëteiten in verzorgingsrelaties in de casuístiek in het penitentiaire recht hoeft niet negatief noch positief discriminerend te zijn. Verschillen in feitelijke zorg en opvoedingsstijlen kunnen via een contextuele benadering in individuele gevallen zichtbaar worden. Daar kunnen consequenties aan verbonden worden. Dat zou mijns inziens overigens moeten gebeuren tijdens alle fasen van het strafproces. Vanaf de arrestatie tot en met de eventuele tenuitvoerlegging van een vrijheidsstraf. Met name bij de straftoemeting zou in de strafmodaliteiten proportioneel rekening gehouden moeten worden met de feitelijke zorgrelatie met kinderen. Naarmate de rechter een modaliteit kiest die relatief gezien een grotere inbreuk op het "family life" veroorzaakt, dient de rechtvaardiging daarvan aan strengere motiveringseisen te volldoen. Een gedifferentieerde benadering kan er dan ook toe leiden dat de rechtspositie van sommige gedetineerde vrouwen bijvoorbeeld dicht bij die van het stereotype van 'de gescheiden man' komt. 


\section{Detentie en family life}

\section{Inleiding}

Uit de voorgaande hoofdstukken is gebleken dat 'de overheid' zich in de publieke en private sfeer in verschillende rollen manifesteert. Op welke wijze de strafwaardige ouder daarmee wordt geconfronteerd, komt in dit hoofdstuk aan de orde. Het gaat hierbij om de verschillende rollen van de overheid waar verdachte en/of veroordeelde ouders tijdens het strafproces in chronologische volgorde mee te maken kunnen krijgen, toegespitst op de verantwoordelijkheid voor en het belang van hun kinderen. Uit voorgaande hoofdstukken is al naar voren gekomen dat vooral de gedetineerde moeders te kampen hebben met problemen:

- zij zijn over het algemeen -voor de detentie- de primaire verzorgers van hun kinderen;

- zij hebben over het algemeen niet de (financiële) middelen om 'de ideale op hun kind toegesneden zorg' in hun privéleven te realiseren;

- zij hebben veelal geen keus uit adequate door de overheid gegarandeerde voorzieningen;

- zij worden wel geconfronteerd met overheidsbemoeienis vanwege de 'afwijkende situatie'. Zij zijn veroordeeld of worden verdacht van het plegen van een strafbaar feit. Bovendien zijn ze vaak alleenstaand, hebben veelal een donkere huidskleur en voorzien niet zelf of via verboden gedragingen in hun onderhoud;

- detentie leidt voor hen persoonlijk tot vergroting van hun wellicht all bestaande maatschappelijk isolement.

Het negeren van hun situatie en het afwijzen van overheidsbemoeienis door een abstract-feministisch beroep te doen op hun eigen verantwoordelijkheid en privacybescherming, lijkt mij inadequaat en onrechtvaardig. Juist vrouwen in extreme afhankelijkheidssituaties kunnen baat hebben bij een actief optredende, voorwaardenscheppende overheid, mits die overheid een duidelijke afbakening in taken en bevoegdheden van haar eigen organen aanbrengt.

Ook het argument dat het noodzakelijk is voorrang te geven aan een brede maatschappelijke aanpak in de economische en politieke waardering van verzorgende taken en de herverdeling van die taken, lijkt me ondeugdelijk als het gebruikt wordt 
om de minst geprivilegieerden niet te laten profiteren wan de kleine emancipatoire vooruitgang die geboekt wordt.

Ik ben het dan ook niet eens met het standpunt dat de vroegere staatssecretaris Kosto innam over de versterking van de sociaaleconomische positie van gedetineerde vrouwen:

"Als u meent dat justitie tot taak heeft de sociaal economische positie van de vrouwen te versterken, dan geeft $u$ een andere interpretatie aan artikel 26 dan justitie doet. Het kan nooit de taak van justitie zijin on de achterstand goed te maken die wrouwen in de wrije maatschappij opgelopen hebben.

Er kunnen wel degelijk voorstellen ontwikkeld worden om het recht op een ongestoord family en private life van gedetineerden en hun kinderen te verbeteren, mits die in beginsel aansluiten op continuering van de leefwereld van het kind en negatieve seksestereotypering doorbreken. Optimale verzorgingsrelaties zijn ook basiscondities voor emancipatie in brede betekenis. Het is dan misschien niet de taak van de overheid om een achterstand goed te maken, wel om een perspectief te scheppen. De art. 26 en 26 bis Beginselenwet dienen in het perspectief van grondrechten gelezen te worden. ${ }^{2}$

De juridische fundering voor deze specifieke aandacht voor verdachten en veroordeelden met zorgverplichtingen ligt volgens mij in art. 8 EVRM, juncto art. 2, 3 en 9 VN-Kinderverdrag en de art. 4 en 5 VN-Vrouwenverdrag. Uit art. 8 EVRM en de daarop gebaseerde rechtspraak kan het bestaan worden afgeleid van een positieve verplichting van de overheid om een door haar veroorzaakte breuk in het aantoonbare 'family life' tot een minimum terug te brengen en die maatregelen te treffen die leiden tot herstel van die band dan wel hereniging met de verzorger. ${ }^{3}$

De overheid dient het family en private life van ouders en kinderen te respecteren, ook als die ouder een strafbaar feit heeft begaan. Beginselen van proportionaliteit en subsidiariteit moeten een rol spelen in iedere fase van het strafproces, bij het nemen van beslissingen die ingrijpende gevolgen voor het gezinsleven impliceren. Daarbij spelen enerzijds de inhoud van de feitelijke zorg en het belang van het kind een rol, anderzijds de ernst van het delict en de veiligheid van de samenleving. Gezien de neerwaartse spiraal van stigmatisering door de 'buitenwereld', waarin verdachte en veroordeelde burgers zich bevinden, zou er juist vanuit rechtspolitiek perspectief reden zijn om het (rechts)burgerschap van deze groep bij voorrang te optimaliseren. Vanuit een 'ethiek van zorgzaamheid' kan dat niet zonder het leefsys-

1 In: Ketellaars en De Graaff (1992) p. 184.

2 Zic ook art. 10 lid 3 IVBPR. In art. 2 w.o. PBW zijn het beginsel van minimale beperkingen en het resocialisatiebeginsel uit de art. 26 en 26 bis $B G W$ weer te vinden.

3 Zie onder meer de zaak Eriksson, EHRM 22-6-1989, Series A, vol. 156, NJ 1992, 705, m.n. EAA, FJR $1990 / 4$, p. 83-88, m.n. M.J.C. Koens. Zie verder hoofdstuk 6 en 7.

4 In dat licht zou art. 9 VN Kinderverdrag lid 3 en 4 ook gelezen moeten worden, waarbij lid 3 de Staat verplicht tot een maximum inzet en lid 4 afhankelijk van de context, een minimum garandeert. 
teem van die gedetineerden daarbij te betrekken. Het strafprocesrecht en het penitentiaire recht richten zich met name op de individuele burger. In het familierecht kunnen wel noties van een contextuele benadering gevonden worden die analoog in de andere rechtsgebieden toegepast kunnen worden. Nu juist de privésfeer van werdachten en veroordeelden door hun gevangenneming tot een minimum is beperkt, zal er door de overheid en nongouvernementele organisaties veel actiever dan buiten de detentiesituatie gewerkt moeten worden aan condities om het contact met de leefwereld te optimaliseren. Dit alles onder het voorbehoud dat de veiligheid van personen en de openbare orde geen onnodig gevaar mogen lopen. In dit kader zullen doel en middelen hoe dan ook in een redelijke verhouding tot elkaar moeten staan. Voor zover pragmatische argumenten van personele en financiële aard een rol spelen om terughoudend te zijn ten aanzien van individuele arrangementen voor gedetineerden, zou er ten aanzien van collectieve regiemverandering voorrang kunnen worden gegeven aan instellingen met vrouwelijke gevangenen. Aan het belang van orde en veiligheid kunnen geen argumenten worden ontleend om dat niet te doen. Het feit dat de aard van de delicten en de recidivecijfers onder vrouwen substantieel verschillen van die van de mannelijke gedetineerden en dat hun bestraffing relatief zwaarder doorwerkt in het privé- en familieleven rechtvaardigen een voorrangsbeleid. Ten aanzien van de meest ingrijpende en ogenschijnlijk simpele ingreep, waar in de weten regelgeving de meeste aandacht naar uitgaat, het gezamenlijk detineren van ouders en hun kinderen, is het de vraag of een staat een ouder überhaupt voor zo'n keus mag stellen of dat de ouder daarmee voor een onaanvaardbaar dilemma geplaatst wordt. ${ }^{6}$ De Ruijter meent met betrekking tot de detentie van minderjarige asielzoekers in het Grenshospitum dat er sprake is van strijd met nationale en internationaalrechtelijke normen. Zij verwijst daarbij naar het Hoge Commissariaat voor de vluchtelingen dat heeft gezegd dat het beginsel van eenheid van familie geen rechtvaardigingsgrond kan zijn voor het detineren van minderjarige asielzoekers samen met hun ouders, zelfs wanneer het om een illegale binnenkomst zou gaan. ${ }^{7}$ Inmiddels is het in het vreemdelingenrecht zo dat kinderen beneden de twaalf jaar niet in een huis van bewaring of politiecel worden gezet tenzij de tevens in bewaring gestelde ouder van het kind erop staat het kind bij zich te houden. De Raad voor het JeugdbeJeid vindt daarentegen dat het vreemdelingenrecht zich niet bij voorbaat dient te richten naar de toestemming van de ouders maar juist eerst het kader moet scheppen waarbinnen vervolgens de regels van het familierecht die de gezagsrelatie tussen

5 De uitspraken inzake de bescherming van de privacy en het family life in de (T)EBI's stemmen wat dat betreft niet optimistisch.

6 Zie Boeles (1992) p. 764. Zie ook ECRM 5 oktober 1987, Appl. 12139/86, X-Nederland, RV 1987, 93. Het ging in deze casus om de in het Nederlands beleid aan een polygaam gehuwde vader opgelegde keuze tussen de kinderen wan de ene of de andere vrouw. De Commissie overwoog dat "this rule could give rise to some problems in relation to minor children born by another wife".

7 De Ruijter (1992). 
ouders en kinderen betreffen ook kunnen werken. ${ }^{8}$ Analoge toepassing van deze visie op het penitentiaire recht zou betekenen dat ook hier eerst een kader geschapen moet worden dat een reële 'keuze' van (primair verzorgende) ouders mogelijk maakt." Het is zelfs de vraag of de co-detentie van het kind met toestemming van de ouder een voldoende wettelijke basis kent. ${ }^{10} \mathrm{Er}$ kan sprake zijn van vrijheidsberoving van het kind op grond van art. 5 EVRM, met name wanneer het kind in een gesloten inrichting zou moeten verblijven, zelfs al zijn de motieven nog zo legitiem en ter bescherming van het belang van het kind, bijvoorbeeld het krijgen van borstvoeding en de handhaving van de band tussen kind en verzorger. De vrijheidsberoving wordt immers beoordeeld aan de hand van de feitelijke situatie waarin het gedetineerde kind verblijft. De motieven voor of doeleinden van de co-detentie zijn niet relevant voor het vaststellen van het vrijheidsberovend karakter ervan. Afhankelijk van de duur van het verblijf en de leeftijd, ontwikkeling en mobiliteit van het kind zal er mijns inziens zeker in een gesloten setting al snel sprake kunnen zijn van vrijheidsberoving. Wanneer bovendien de directeur van de gevangenis een bepalende rol krijgt bij de toelating van het kind en bij het bepalen van de randvoorwaarden waaronder het verblijf plaatsvindt, is de verantwoordelijkheid van de staat bij het geheel aangetoond en zal de vrijheidsberoving mogelijk ook minder restrictief geïnterpreteerd worden dan wanneer het uitsluitend om een besluit en handelen van de ouder (op grond van het ouderlijk gezag) zou gaan. Ook Verheij meent dat de staat een verantwoordelijkheid kan hebben bij de invulling van grondrechten in horizontale verhoudingen:

"de staat moet de voorwaarden creëren waaronder uitoefening van grondrechten ook in verhoudingen tussen burgers onderling effectief mogelijk is. Het is aannemelijk dat de rol van de staat dan een ander karakter draagt dan in de 'normalle' verticale verhouding tussen overheid en burger. Deze notie moet tot uitdrukking komen in de wijze waarop grondrechtenbepalingen worden geïnterpreteerd." ${ }^{\text {mII }}$

8 Raad woor het Jeugdbeleid, nr. 36, p. 30 .

9 Een inspanningsverplichting voor de staat om materiele voorzieningen te treffen. Zie art. 4 in het VN-Kinderverdrag: "alle passende (...) maatregelen nemen".

10 Art, 15 Grondwet.

11 EHRM 28 november 1988, Nielsen versus Denemarken, Series A, wol. 144, NJ 1991, 541, m.n. EAA. Zie ook Verheij (1989), p. 611. Verheij gaat in zijn commentaar met name in op het gesloten. karakter van de voorziening en op de toepassing van art. 5 EVRM in horizontale dan well verticale relaties.

Zie ook De Bruijn-Litckers (1994), p. 219. Zij is wan mening dat het Hof zich teveel heeft laten leiden door het ouderlijk gezag en de motieven wan de moeder: "De goede trouw en de bedoeling van de moeder ontnemen aan de opname in het ziekenhuis niet het vrijheidberovend karakter." Zie verder jurisprudentie inzake art. 5 EVRM ower "het gesloten karakter" van een voorziening (het gaat hier steeds om volwassenen!) bijvoorbeeld

- EHRM 8-6-1976, Engel, Series A, Vol. 22, NJ 1978, 223. (Over de duur van de maatregel.)

- EHRM 6-11-1980, Guzzardi, Series A, Vol. 39. (Over het kleine ggebied en het strikte toezicht.) 
In relatie tot co-detentie, met toestemming van de ouder, zall het steeds van de concrete situatie afhangen of er sprake is van vrijheidsberoving van het kind. Mij lijkt dat het referentiekader daarvoor gezocht moet worden in de pedagogische randvoorwaarden van de voorziening in samenhang met de leeftijd van het kind, de duur van het verblijf en de in te schatten gevolgen ervan.

Voordat detentie van de verzorgende ouder en eventueel co-detentie, c.q. vrijheidsberoving van kinderen, aan de orde komt, moeten andere mogelijkheden tot vrijheidsbeneming van de ouder geprobeerd of overwogen zijn. In beginsel maakt het daarbij niet uit of de vrijheidsbeneming ten behoeve van het onderzoek of als bestraffing geschiedt. In beide gevallen is een (leef)systeemgerichte manier van denken vereist in het straf-en penitentiaire proces, waarbij met name de inbreuk op het leven van direct aan de verdachte, c.q. veroordeelde burger gelieerde betrokkenen een plaats in het rechtsgeding moet krijgen, terwijl er toch een eerlijk proces moet plaatsvinden. In zo'n leefsysteemgerichte benadering moet het overheidsingrijpen getoetst worden aan het bestaande family life, aan het belang van het kind en aan de bescherming van het moederschap, c.q. verzorgerschap zonder dat dit tot negatieve seksestereotypering leidt.

In de chronologische volgorde van het strafproces worden in dit hoofdstuk voorstellen tot een leefsysteemgerichte benadering gedaan. Daaraan voorafgaand wordt een beeld geschetst van het 'leefsysteem van gedetineerden' voor zover daar in Nederland gegevens over bekend zijn. In de tekst wordt ter illustratie geregeld informatie uit het buitenland verwerkt. Deels is die ontleend aan grijze literatur, deels ook aan mondelinge overdracht. Vanaf 1993 zijn er, op initiatief van de Franse organisatie Relais Enfants Parents en de Bernard van Leer Foundation, workshops georganiseerd waarin deskundigen uit verschillende landen ervaringen uitwisselen over het werken met kinderen van gedetineerden. Deelnemers komen uit België, Groot Brittannië, Duitsland, Frankrijk, Portugal, Spanje, Italië en Nederland. De professionele achtergrond varieert van gevangenisdirecteuren en stafleden, medewerkers van ministeries van Justitie, psychologen, psychotherapeuten, maatschappelijk werkers en juristen tot onderzoekers en leden van nongouvernementele en vrijwilligersorganisaties. De vaste kern blijft vrij constant, maar doordat de workshops in verschillende landen georganiseerd worden, kunnen lokale geïnteresseerden worden uitgenodigd. Ter plekke worden er ook gevangenissen bezocht. Al met al ontstaat er niet alleen een goed beeld van de gemeenschappelijke problemen, maar juist ook van de cultuurgebonden variaties in problemen en oplossingen. Het werk heeft geresulteerd in de oprichting van het European Action Research Committee on Children of Imprisoned Parents in 1995. De leden van het Committee initiëren lokale initiatieven en studieda-

EHRM 28-5-1985, Ashingdane, Series A, Vol. 114. (Over de gesloten afdeling van een ziekenhuis, het op regelmatige tijdstippen met toestemming verlaten van het ziekenhwis was niet van overwegende betekenis.) 
gen en hebben bijgedragen aan een inventarisatierapport dat in januari 1997 in Brussel aan het Europees Parlement is aangeboden. ${ }^{12}$ Door mijn actieve betrokkenheid bij dit netwerk vanaf de eerste workshop in september 1993 in Brussel, ontleen ik nogal wat informatie aan deze uitwisselingen. Voor zover mogelijk verwijs ik daarbij naar -inmiddels gevonden of verschenen- geschreven bronnen. ${ }^{13}$

\subsection{Het leefsysteem}

\subsubsection{Family life}

Bij een leefsysteemgerichte benadering moet duidelijk zijn binnen welk verwantschapssysteem een gedetineerde leeft en welke personen daarin direct van zijn of haar zorg afhankelijk zijn. Dat hoeft geen doorsnee kerngezin te zijn. Juist verschillen tussen soorten gezinnen en in onderlinge verhoudingen binnen gezinnen moeten worden opgemerkt. Ik denk daarbij aan de moeder-dochter relatie als spil in arbeidershuishoudens en/of bredere en vaak matriarchale familieverbanden in allochtone families. Juist gedetineerde vrouwen komen veellal niet uit doorsnee kerngezinnen. Hun families kenmerken zich mogelijk door andere praktijken en idealen dan die welke achter theoretische gezinsconcepten schuil gaan. Naarmate de samenleving mobieler wordt en de migratie toeneemt, vallen mensen overigens minder op hun directe familie terug, maar zoeken zij nieuwe sociale netwerken. Netwerken waarbinnen men op vrijwillige basis relaties aangaat en waarop ook een beroep kan worden gedaan wanneer er opvang nodig is of er problemen zijn. De 'vrije keuze' maakt de kans groter dat sommige individuen niet gekozen zullen worden en dat the right to be left alone" in een "right to leave alone" verandert. Ook vanuit het familieverband vermindert de zorg om de medemens en het appèl op collectieve voorzieningen neemt dan ook toe. ${ }^{14}$ Die tendens betekent niet dat de in oorsprong via socialisatie in gezinnen en families doorgegeven verschillen in klasse, etniciteit, godsdienst, sekse en dergelijke, doorbroken zijn of worden. Nog steeds lijken sociaaleconomische, financiele en uiterlijk waarneembare kenmerken als sekse en ras discriminerend te werken. Van de gedetineerde vrouwen leidde een substantieel deel een maatschappelijk geisoleerd bestaan voor de detentie. Het vormen van een (nieuw) sociaal netwerk lijkt voor hen een belangrijke zorg tijdens de detentie, naast het in stand houden van het bestaande. Art. 8 EVRM legt de overheid zowel een negatieve als een positie-

12 European Action Research Committee on children of imprisoned parents (1966). Zie voor de studiedag in Nederland Proces (1996). Zie ook Nieuwsbrief "Gedetineerde ouders en hun kinderen" (dlecember 1996):

13 Zie met name Lloyd (1995), Bouregba (1996), Ayre (1996).

14 Raes (1994) p. 241. 
ve verplichting op als het gaat om de voortzetting van het family life de facto. Bij een op grond van art. 8 lid 2 EVRM gelegitimeerd overheidsingrijpen in de gezinssfeer moeten er concrete maatregelen genomen worden om de verzorger-kindrelatie in stand te houden. Kinderen vormen een deel van het netwerk van de gedetineerde, maar zij kunnen ook belang hebben bij een eigen verwantschapsnetwerk waar ze op kunnen terugvallen, met andere volwassenen en generatiegenoten. Dat betekent dat de belangen van gedetineerde verzorgers en hun kinderen niet altijd parallel hoeven te lopen. Juist bij gedwongen scheidingen kan er zowel sprake zijn van samenloop en/of botsing van grondrechten, bijvoorbeeld op grond van de beide leden van art. 8 EVRM. Het belang van het kind zal dan prevaleren. ${ }^{15}$ Rechten, wensen of mogelijkheden van de kinderen zelf moeten niet ondersneeuwen doordat de aanspraken van vaders en moeders dominant blijven. ${ }^{16} \mathrm{Bij}$ kinderen van wie een verzorgende ouder gevangen zit, zal het de vraag zijn of er sprake is van samenloop of botsing tussen de belangen van die ouder en dat kind en vooral of en zo ja, hoe de overheid daarover een oordeel kan vellen. De straffende overheid is immers verantwoordelijk voor de inbreuk op het grondrecht.

\subsubsection{Belang van het kind}

Het lijkt voor kinderen van groot belang te zijn dat ze opgroeien in een stabiele, veilige omgeving, waarin de continuïteit in relaties, ruimtelijke omgeving, structuur van de dag en dergelijke zoveel mogelijk gewaarborgd is.

Uit studies binnen de pedagogiek zou met een zeker optimisme geconcludeerd kunnen worden dat voor de identiteitsvorming van een mens noch de culturele normen, noch de sociale categorisering en ook niet alleen de persoonlijke identiteit voorgoed en deterministisch bepalen wie en hoe iemand is of zal worden. Het niveau van de feitelijke gedragingen verschaft eigenlijk iedere verzorger en ieder kind steeds weer de kans om te experimenteren. Maar er zal gezocht moeten worden naar omstandigheden en middelen om die experimenteerruimte te optimaliseren.

De kwaliteit van de relaties is daarvoor van groot belang. Voorwaarde is dat er sprake is van sensitieve responsiviteit en een regelmatige interactie. De noodzakelijke frequentie in het contact hangt vooral samen met de leeftijd van het kind. Hoe jonger het kind, hoe belangrijker de aanwezigheid van ến of meer vaste verzorgers, maar dat hoeven niet per se de ouders te zijn. Of zoals de Raad voor het Jeugdbeleid zegt:

15 Vgll. art. 3 VN-Kinderverdrag; art. 5 VN-Vrowwenverdrag. Zie ook HR 22 december 1995 , NJ 1996, 419, o.w 3.3. (Jeroen-zaak).

Wegelin (1990), p. 71 . 
"Kinderen behoeven, naast opvoeding door hun eigen ouders, ook inspiratie van andere mensen en omgevingen. Voor het van nature nieuwsgierige kind valt er in de wereld oneindig weel meer te ontdekken dan én of twee ouders kunnen werzorgen. Bovendien vraagt de manier waarop onze samenleving is ingericht, ook steeds meer van het ontwikkelingsniveau van mensen".47

Ontwikkelingsbelangen van kinderen lijken nauw samen te hangen met het optimaliseren van sociale grondrechten waarbij in het geval van met name arme families een inspanning van de overheid noodzakelijk is. ${ }^{*}$ Hier worden de grootste verschillen in (materiêle) levenskansen tussen kinderen zichtbaar, zeker naarmate de samenleving consumentgerichter wordt en status en capaciteiten aan de hand van uiterlijke kenmerken en cognitieve kennis worden bepaald. Het verbrede opwoedingsmilieu en de gelaagde identiteitsvorming van kinderen binnen de eigen leeftijdsgroep kunnen daarbij een belangrijke rol spelen.

Autonome belangen van kinderen staan in nawwe relatie tot de zelfstandige (rechts) positie van kinderen, ook ten opzichte van hun ouders. $\mathrm{Zij}$ hebben te maken met het recht op privacy, het recht om met rust gelaten te worden en het recht op eigen contacten met volwassenen en kinderen.

\subsubsection{Vermijden van seksestereotypering}

In art. 5 van het VN-Vrouwenverdrag wordt gerept van "een juist begrip van het moederschap" en van de voorwaarde "dat het belang van de kinderen in alle gevallen voorop staat". In deze bepaling gaat het om het moederschap als sociale functie. ("maternity as a social function") Deze functie impliceert dat de maatschappij rekening moet houden met de biologische en sociale gevolgen van het krijgen van kinderen. Het moederschap is daarmee een rechtens relevant feit. ${ }^{19}$

Wat het biologisch moederschap betreft is het van belang te onderkennen dat vrouwen niet onder druk gezet mogen worden om moeder te worden. Dan is er geen sprake van 'moederschap uit vrije wil'.

"Regels die vrouwen onder druk zetten een kind te nemen om zodoende onder de uitzonderingsbepalingen te wallen, ontnemen then de vijheid zelf te bepalen wanneer zij moeder worden. ${ }^{\text {wat }}$

In hoeverre dit ook van toepassing zou kumnen zijn wanneer in het penitentiaire recht specifieke voorzieningen voor strafwaardige moeders worden voorgesteld, is de vraag. Hoewel de betreffende bepaling toeziet op gelijke behandeling van manmen

17 Raad voor het Jeugdbeleid (1996), p. 8-9.

18 Eekelaar (1992), p. 230-231. "But the plausibility of the claim that children would wish to be provided with equal life-chances has the potential for considerable social impact."

19 Lijnzaad (1994) p. 48 . Zie ook art. 4 VN-Vrouwenverdrag.

20 Vgl. Van Walsum (1996)p: 51, art. 16 lid 1 sub e VN-Vrouwenverdrag. 
en vrouwen, kunnen vrouwen, die expliciet geen moeder willen zijn of worden, hier in samenhang met art. 5 van het Verdrag wellicht een legitimatie voor gelijke behandeling met moeders vinden. Art. 5 is immers gericht tegen seksestereotypering en seksespecifieke socialisatie.

Seksestereotypering kan bij alle vrouwen in feite leiden tot 'gevangenhouding in moederschap". Moederschap is te onderscheiden in verschillende functies: die van potentieell moeder, die van feitelijk biologisch moeder en die van feitelijk sociaal moeder. Die functies kunnen samenvallen, maar hoeven dat niet.

Met potentieel moederschap hebben alle vrouwen te maken voor zover het hun lichaam betreft. Ook vrouwen die geen moeder willen of kunnen worden, hebben een lichaam dat op voortplanting is ingesteld. Zij worden geconfronteerd met een maandelijkse cyclus, al dan niet verhoogde kansen op baarmoeder(hals)- en borstkanker en de overgang.

In hoeverre de aanwezigheid van bepaalde hormonen tot duidelijke seksespecifieke verschillen in gedrag leidt, is nog de vraag. Wel lijkt het erop dat alle vrouwen min of meer in hun sekserol gesocialiseerd worden en daardoor ook bijwoorbeeld de vraag naar specifieke gezondheidszorg bepalen. ${ }^{21}$ Ook vrouwen die geen voorbehoedmiddelen gebruiken, of andere dan de pil, komen met op preventie gerichte vragen bij de dokter, bijvoorbeeld voor uitstrijkjes. En natuurlijk ook voor seksespecifieke behandelingen zoals abortus, curettage, borstkanker etcetera.

Voortplanting en seksualiteit zijn echter niet onlosmakelijk met elkaar verbonden. Voor sommige vrouwen is dat van nature nilet zo, anderen gebruiken daartoe voorbehoedmiddelen. Het vrouwenlichaam en seksualiteit moeten daarom los gezien worden van feitelijk moederschap en alles wat met de lichaams- en/of seksualiteitsbeleving te maken heeft, hoeft niet in het licht van de socialisatie tot het moederschap betekenis te krijgen. Dat betekent dat er, ook in de detentiesituatie, veel meer aandacht zou moeten zijn voor de socialisatie en levenscyclus van vrouwen zonder eenzijdige gerichtheid op voortplanting.

Met feitelijk moederschap worden vrouwen geconfronteerd die gewild of ongewild zwanger worden en zijn, gewild of ongewild een abortus krijgen, gewild of ongewild een kind krijgen, die ontzwangeren en zogen. Sommigen hebben een vaste relatie met een man, anderen met een vrouw, weer anderen met geen wan beiden. Sommigen leiden een monogaam seksleven, anderen hebben meer partners. Sommigen raken in verwachting na een ongelukje, anderen na een verkrachting. De ontstaansgeschiedenis van zwangerschappen is divers. Moederschap is niet onlosmakelijk verbonden met een duurzame heteroseksuele relatie en met een gewenste ouderrol. Het traditio-

21 Vrouwen lijken de neiging te hebben om lichaams- en seksualiteitsbelewing te problematiseren en in gezondheidsklachten te vertalem. Zie in relatie tot gedetineerde vrouwen onder meer Janssem (1994) en Van der Maas (1994). 
nele westerse gezinsverband kan vrouwen isoleren, vooral wanneer zij geen eigen sociaal netwerk opbouwen en hun financieeleconomische situatie slecht is: Seksestereotypering leidt tot ontkenning van gedwongen moederschap, tot stigmatisering van alleenstaand moederschap en tot idealisering van een abstracte moederrol. Het feitelijk moederschap zou in alle diversiteit herkend en waar nodig, zowell in fysileke als sociaaleconomische zin, ondersteund moeten worden. ${ }^{2}$ Het gaat daarbij om praktische opvoedingsondersteuning via geld, scholing, werk " eigen ontwikkelingskansen en concrete hulp bij de opvang en opvoeding van de kinderen. Vooral kwetsbare moeders, zoals drugs-medicijn-en allcoholverslaafden, moeten in relatie tot hun kinderen apart en gericht aandacht krijgen in hulpwerleningsprogramma's. In detentie betekent dat onder andere dat het isolement van moeders doorbroken moet worden. Opvoedingsondersteuning en eventuele co-detentie moeten niet leiden tot idealisering van het moederschap. Het ouder-zijn kan niet los gezien worden van het maatschappelijk bestaan-in-brede-zin. Alternatieve vormen voor vrijheidsbeneming als huisarrest zouden niet gestimuleerd moeten worden ats zij leiden tot isolering in de thuissituatie. ${ }^{23}$ Juist vrouwen die maatschappelijk gezien in een, vaak door armoede, migratie of verslaving bepaald, isolement verkeren kunnen opvoedende, verzorgende en huishoudelijke taken die voortvloeien uit routine en beschikbaarheid niet delen of delegeren. Leefvorm en sociaaleconomische status zijn bepalend voor grote onderlinge verschillen tussen vrouwen en hun kinderen in het kunnen terugvallen op een al dan niet gekozen verwantschapsnetwerk.

Sociaal moederschap is niet per se aan vrouwen verbonden. Seksestereotypering leidt tot het ideaal van thuismoederschap, iemand die steeds beschikbaar en responsief is voor de kinderen en vaak ook nog voor de partner. Een moeder die haar agenda voortdurend aanpast aan school-, werk- en openingstijden van anderen. Zolang de feitelijke omstandigheden zo zijn dat moeders er, al dan niet door de omstandigheden gedwongen, voor kiezen om die sociale functie te vervullen, moeten zij daarin maatschappelijk gezien wel tegemoet gekomen worden. Het sociale moederschap kan echter anders verdeeld worden, met partners, binnen sociale netwerken en via collectieve opvang voor kinderen. Binnen detentie betekent dat, dat vrouwen aangemoedigd worden om hun eigen sociale netwerken te vormen en gebruilk te maken van collectieve opvang. Vrouwen kunnen leren mannen als gelijkwaardig te benaderen waar het gaat om de invulling van de ouderrol. In detentie kan dat laatste mede versterkt worden door het openen van detentievoorzieningen voor een gemengde populatie van verzorgende ouders. Er zou daarbinnen dan wel een evenredige verdeling naar sekse moeten zijn en vooraf moet onderkend worden dat de

22 Opvoeding van kinderen is een collectieve zaak. Naarmate de migratie toeneemt en de samenleving multicultureler wordt, zullen wederkerigheid en solidariteit ook meer in collectief en intergenerationeel verband invulling moeten krijgen.

Wolleswinkel (1995) p. 128-129. 
invulling van sociaal ouderschap vaak sekse-en genderspecifiek is. Wegelin signaleert bijwoorbeeld

"een spanningswerhouding tussen gelijke ouderlijke aanspraken op een affectieve relatie met de kinderen en de ongelijkheid die gewoonlijk bestaat in de feitelijke verdeling van zorg en in de zeggenschap die jeder van de seksen wordt toegestaan."

Daarom moet het feitelijk verzorgerschap altijd beoordeeld worden naar de concrete omstandigheden. Een op de zorg voor kinderen ingesteld detentiebeleid zou in eerste instantie toegankelijk moeten zijn voor vrouwen en mannen die op grond van hun sociale opvoedingsfunctie feitelijk een substantieel deel van de verzorgende taken vervullen of willen gaan vervullen.

Als een verzorger gedetineerd is, moeten, juist in het belang van het kind, de voorheen verzorgende en de actuele verzorgers in dialoog met elkaar kunnen blijven. 'Het belang van het kind' kan een bindend in plaats van een scheidend element zijn. Misverstanden en uit elkaar gegroeide verhoudingen blijken vaak voort te komen uit het isolement waarin men ten opzichte van elkaar is komen te verkeren en de lange duur daarvan. Zeker wanneer de overheid primair verantwoordelijk is voor het verschuiven van samenwoningsconstellaties, vloeit daar direct de verplichting uit voort om waar mogelijk 'in het belang van het kind' het oorspronkelijke contact zoveel mogelijk te continueren..$^{25} \mathrm{De}$ uitbreiding van de kring van omgangsgerechtigden in het familierecht biedt in de detentiesituatie ook perspectief voor een brede kring verwanten van het kind. Bij omgangs- en bezoekregelingen zullen degenen die de dagelijkse zorg voor het kind hebben, betrokken moeten zijn en bijvoorbeeld financieel tegemoet moeten worden gekomen.

\subsection{Het leefsysteem van gedetineerden}

\subsubsection{Kinderen en partners}

Ouders die met het strafrecht geconfronteerd worden in de rol van verdachte kiezen hier over het algemeen niet voor. Soms is het risico ingecalculeerd, soms is het verdrongen, vaak wordt men overvallen in de rol van verdachte. Dat is niet alleen voor de betrokkene een schok, maar ook voor diens naaste omgeving, die vaak nog meer verrast is door de vermeende activiteiten van hun dierbare. Met name voor

24 Wegelin (1990) p. 205.

25 Zie hoofdstuk 6. Zie cok Forder (1992) p. 611-637 en Von Brucken Fock (1996) p. 153-155. De niet met gezag beklede ouder heeft in het onlangs gewijzigde familierecht een recht op omgang, informatie en consultatie. Analoge toepassing in de detentiesituatie voor gedetineerde verzorgers verdient aanbeveling. 
kinderen is het confronterend dat 'hun gezag' nu door het overheidsgezag ter verantwoording wordt geroepen voor iets dat blijkbaar niet deugt. Voor de betrokken kinderen maakt het veel uit:

- op welke plek de ouder wordt aangehouden;

- of dat in hun aanwezigheid gebeurt en hoe;

- om welk delict het gaat;

- of het om moeder en/of vader gaat;

- of de primaire verzorger wegvalt;

- of er een verzorger thuisblijft;

- hoe de omgeving (familie, buurt, school) reageert.

Na de eerste schok wordt duidelijk of de detentie ten behoeve van het strafrechtelijk onderzoek langer gaat duren en of de verdachte mogelijk tot een gevangenisstraf veroordeeld wordt en er dus sprake zal zijn van een langdurige scheiding, met vaak ook verderstrekkende gevolgen op sociaal en financieel gebied.

Voor een deel lijkt zo'n crisissituatie op een (onverhoedse) echtscheiding of een (plotselinge) ziekenhuisopname, voor een deel ook niet omdat in de persoonlijke beleving van de gezinsleden de 'eigen schuld' een belangrijke rol kan spelen, soms bevestigd door de reacties van de omgeving. ${ }^{*}$ Dat kan leiden tot uitsluiting en stigmatisering. De buurt kan echter ook sterk meeleven wanneer ze de verdachte en het gezin als 'slachtoffer van de situatie' zien. In sommige buurten is het überhaupt

26 Zie Richards (1992) p. 3-12. Omdat er nog zo weinig bekend is over de gevolgen bij kinderen van detentie van (een) van hun ouders heeft Richard gekeken naar onderzoek in andere scheidingssituaties. Hoewel ook hij het voorbehoud makt dat veel factoren een rol spelen bij het welbevinden van kinderen (met name sociaal-economische omstandigheden!) is opmerkelijk dat op de langere termijn kinderen de dood van een ouder beter verwerken dan het vertrek door echtscheiding. Bij echtscheiding wordt het kind verlaten, het voelt zich afgewezen, terwijl de dood hen allen "overvalt" (een oorzaak van buiten) Bovendien reageert de (naaste) omgeving heel anders. De dode wordt gekoesterd, soms vereerd, de achtergebleven partner ontmoet meer respect en meeleven dan de gescheiden partner. Het verdriet dat in huis heerst om het verlies, is gemeenschappelijk. Er is begrip. De achtergebleven ouder is vaak extra gemotiveerd de zorg voor de kinderen ter hand te nemen. $\mathrm{Na}$ een echtscheiding blijft er vaak een sfeer wan ruzie en wrok ten aanzien van de wertrokken ouder. De belangen wan de kinderen komen voor de achtergebleven partmer soms op het tweede plan te staan. Bovendien wordt er na echtscheiding vaak sneller hertrouwd (eem nieuwe partner is vaak de directe oorzaak van de scheiding) dan na ontbinding van het huwelijk door de dood. De aanpassing van de kinderen aan de nieuwe leefvormen kan heel werschillend. verlopen, maar soms roepen de nieuwe situaties zeer gemengde gevoelens bij hen op.

Richards besteedt ook aandacht aan de vader die voor zijn werk veel of langdurig afwezig is. Hier schijnt vooral het enthousiasme wan het thuisfront voor de aard wan het werk van belang te zijn. in de beleving van kinderen. Vooral opgroeiende jongens schijnen vaak juist trots te zijn op hun vader en het beroep dat hij heeft, terwijl meisjes, naarmate zij ouder worden meer lijden onder de afwezige vader, die zij bij hun identiteitsvorming juist dan nodig hebben. (vgll. pedagogische theorievorming in hoofdstuk 5)

Parallellen trekkend naar gedetineerde ouders lijken er niet veel positieve indicaties te zijn. 
geen schande om op deze manier met de overheid in aanraking te komen. ${ }^{27}$ Zonder hier nader op in te gaan, kan ik wel stellen dat het voor de kinderen hoe dan ook een lot is waar ze door getroffen worden en waar ze mee zullen moeten leven. Hoewel er niet veel onderzoek is gedaan onder kinderen van gedetineerde ouders zijn er wel aanwijzingen dat kinderen van gedetineerde ouders om uiteenlopende redenen in de problemen kunnen raken. ${ }^{28}$ Onder andere de bovengenoemde factoren spelen een rol in de betekenis die de kinderen persoonlijk aan het gebeuren geven. Hoe dat gebeurt, verschilt per kind, afhankelijk van de leeftijd, de aard, intelligentie en de omgeving. Met name de plaats van het kind binnen het gezin schijnt ook een belangrijke rol te spelen. Zo zijn oudste kinderen vaak het best op de hoogte van wat er speelt en nemen zij de rol over van de afwezige ouder (parentificatie). Tegenover jongere broertjes en zusjes wordt soms gezwegen, om hen niet met nare informatie te belasten. Detentie van een ouder hoeft niet altijd negatief uit te werken. Soms is er juist een einde gekomen aan een uiterst gespannen situatie of aan veel echtelijke ruzies. Problemen die bij de psychologische verwerking kunnen optreden, worden door Nijnatten ondergebracht in de categorieën:

- Verdedigingsmechanismen, dit is het vervormen van de oorspronkelijke gevoelens bij een psychisch als direct bedreigend ervaren situatie, bijvoorbeeld haat die wordt omgezet in liefde. Ook kan er objectverschuiving optreden waardoor het kind bijvoorbeeld de agressie niet uit tegen de gedetineerde ouder, maar tegen een familielid of de politie.

- Schuldgevoelens, doordat het kind zich direct verantwoordelijk voelt voor het delict (bijvoorbeeld bij seksueel geweld) of doordat het bang is het zijn of haar ouder, die toch al zo'n pech heeft, nog moeilijker te maken door bijwoorbeeld slechte schoolprestaties.

- Loyaliteitsconflicten, omdat de loyaliteiten ten opzichte van voor het kind belangrijke personen als strijdig worden ervaren. Ze hebben het gevoel te moeten kiezen. Dit is helemaal moeilijk als bijvoorbeeld de partner van de gedetineerde of een broer of zus het slachtoffer van het delict is.

- Verstoring in de gezinsrelaties. Door het wegvallen van een ouder worden de onderlinge relaties in het gezin beïnvloed. Er komt een andere hiërarchie en er worden nieuwe bondgenootschappen gesloten.

Het onderzoek waarop Nijnatten zijn bevindingen baseert, vond plaats onder kinderen van gedetineerde mannen. Ook het mentorproject dat uit dit onderzoek is voort

27 Vgl. Shaw (1992) over de kinderen van gevangenen in Noord-Ierland.

Tijdens de conferentie in Brussel van het European Action Research Committee vertelde Bouregba hoe in sommige voorsteden van Parijs het aantal malen dat iemand gedetineerd is geweest via tatoeages op de arm geregistreerd wordt. De vergelijking met strepen op het uniform bij partijen aan de andere kant (politie, leger) dringt zich onmiddellijk op.

Van Nijnatten, Van der Leer en Ausems (1990) p. 77-92. Vam Nijnatten (1996). 
gekomen, is tot nu toe gericht op kinderen van langdurig gedetineerde vaders." De doelgroep van het mentorproject in Nederland wordt gevormd door kinderen van acht tot zestien jaar. Het mentorproject is geînspireerd op ervaringen in Israël, waar maatschappelijk werkers en vrijwilligers met kinderen de gevangenis bezoeken. Door de week trekken studenten, van dezelfde sekse als het kind, als een soort grote broer of zus met de kinderen afzonderlijk op. In Nederland krijgen de kinderen een mentor (leeftijd 20 tot 26 jaar) die probeert maatjes met het kind te worden. De mentor begeleidt het kind onder andere bij het gevangenisbezoek en reist samen van en naar huis. Er worden ook gezamenlijke activiteiten met meer kinderen en hun vaders in één inrichting georganiseerd. Het samen eten maakt daarvan een substantieel onderdeel uit. De mentoren worden voornamelijk geworven bij hogescholen..$^{30}$

Overigens zijn de vragen om aandacht voor de problemen van kinderen niet zozeer vanuit de gedetineerde mannen naar voren gekomen, maar vanuit hun achtergebleven gezinsleden. Juist de vrouwen van gedetineerde mannen hebben zich verenigd in een belangengroep. Zij zijn ook degenen die meestal in deze moeilijke situatie invulling aan de feitelijke zorg voor hun kinderen moeten geven. ${ }^{31}$

Het is belangrijk om binnen de groep gedetineerde ouders onderscheid te maken tussen primaire verzorgers, zij die de feitelijke zorg hebben, en andere ouders/verzorgers. Uit de vraaggesprekken die Ketelaars met gedetineerde vrouwen voerde, kwam naar voren dat meer dan driekwart van de moeders zelf voor de kinderen zorgde voordat ze gedetineerd werden. ${ }^{32}$

"Uit de interviews blijkt dat de moeder vaak de bindende en stimulerende factor binnen het gezin is. $\mathrm{Zij}$ zorgt ervoor dat bijwoorbeeld het eindexamen van een kind een feestelijk tintje krijgt, dat de eerste communie een mooie dag voor het kind wordt, dat een kind zijig studie afmaakt, dat het thuis gezellig is enz. ${ }^{\text {mas? }}$

Een groot deel van deze vrouwen had, op het moment dat het interview gehouden werd, een partner, maar sommigen hadden die pas leren kennen tijdens de detentie. Van eenderde deel van de moeders zou de partner theoretisch de zorg voor de kinderen overgenomen kunnen hebben. Toch had maar ruim tien procent dat gedaan. De meeste kinderen werden door familieleden, (schoon)-moeder of (schoon-) zuster,

29 Holwerda (1995).

30 De opmerkelïke erwaring in Israël dat studenten uit de niet softe studierichting waak betere mentoren zijn, is bij de selectie blijkbaar meegenomen. ("omdat mensen afkonstig uit die hoek (sociale akademies, RW) teveel op de hulpverleningstoer zouden kunnen gaan", Gerian Holwerda in Vrij Spraak (1996) p. 9).

31 Otten en King (1990) p. 11-15. Zie ook Smit (1990).

32. Ketelaars (1991) p. 15 .

33 Ketelaars (1991) p. 17. 
verzorgd. Bij één vrouw was de zorg voor het kind door een goede vriendin overgenomen. Kinderverzorging blijft ook hier dus in het leven van alledag over het algemeen aan vrouwen gekoppeld.

Woodrow beschrijft een vergelijkbare situatie in Groot Britannie.. Kinderen van gedletineerde vrouwen raken 'ouderloos'. Als er al een partner was, neemt die de zorg niet over. Soms wordt de partner ook gedetineerd, soms is er sprake van partnerdoding door de moeder, vaak vertrekt de partner als de vrouw is opgepakt. Nog vaker was de vrouw al alleenstaand moeder. Oudere kinderen nemen in het gezin nogal eens de rol van moeder over. De zorg komt echter meestal op vrouwen in de familie neer, grootmoeders en tantes, of op vriendinnen van de moeder. Kinderen komen vaak terecht bij vrouwen van middelbare leeftijd die op den duur uitgeput lijken te raken, sowieso een verschijnsel dat Woodrow bij de opvangadressen waarneemt. De kinderen verkassen dan ook veel en worden vaak gesplitst ondergebracht. Zowel de vrouwen die de kinderen opvangen als de moeders durven niet goed over deze zaken te spreken, omdat ze bang zijn dat de kinderen dan 'afgepakt' zullen worden en in instituten geplaatst.

\subsubsection{Primaire verzorgers}

Voor zover er beleid is ontwikkeld in Nederland richt dat zich wel op primaire verzorgers, maar dan die van het heel jonge kind.5. Zowel in onderzoek als in beleid komt tot nu toe dus maar een beperkte groep kinderen aan bod.

Voor alle kinderen tot de meerderjarige leeftijd zou er denk ik op grond van art. 8 EVRM en de art. 2, 3 en 9 van het VN-kinderverdrag enige vorm van opvang moeten zijn, aangepast aan de leeftijd en bijzondere (familie-)omstandigheden. Die opvang hoeft niet per se door de overheid geboden te worden, maar er zou wel getoetst moeten worden of er aan gedacht is. Onder "opvang" moet in brede zin worden verstaan de dagelijkse zorg, de informatieoverdracht, het onderhouden van de contacten met de gedetineerde ouder en de mogelijkheid tot verwerking in de eigen omgeving.

Hoeveel kinderen in Nederland geconfronteerd worden met detentie van ouders is onduidelijk. Zowel in de voorfase van het strafproces als tijdens de executie van een gevangenisstraf worden gegevens omtrent de gezinssituatie, op grond van privacy-

34 Zie Woodrow (1990) p. 29-40.

35 Voorzover er cijfers over het aantal minderjarige kinderem van gedetineerde vrouwen beschikbaar zijn, blijkt hieruit dat kinderen tot 4 jaar ongeveer $9 \%$ uitmaken. De grootste groepen lijken zich te bevinden tussen de 5 en 12 jaar (32\%) en 13 en 18 jaar (20\%) De allergrootste groep is al ouder dan 18 (34\%) maar valt buiten mijn aandachtsgebied. (Ketelaars (1991), gebaseerd op De Borst (1991), tabel 7). 
overwegingen, niet systematisch geregistreerd. ${ }^{36}$ Uit andere studies (straftoemetingsonderzoek, inventarisatiestudies, evaluaties) zijn wel wat gegevens te herleiden. ${ }^{37}$ Ten behoeve van het inventarisatierapport van het European Action Research Committee zijn door de afdeling Beleidsinformatie van het Ministerie van Justitie onder voorbehoud schattingen gegeven. ${ }^{38}$ Er zouden in Nederland op jaarbasis 11.350 kinderen gescheiden van hun gedetineerde vaders leven en 525 van hun gedetineerde moeders. In hoeverre de kinderen voorafgaand aan de detentie ook al gescheiden van éen wan hun ouders leefden, is niet te achterhalen. De cijfers van het Ministerie lijken op het eerste oog niet erg betrouwbaar. Bovendien is het vreemd om de kinderen van buitenlandse moeders uit de berekening weg te laten. Wanneer de gemiddelde verblijfsduur in detentie 150 dagen is, er rond de 460 cellen voor vrouwen zijn (HvB en gevangenissen) en minstens zestig procent van de vrouwen de zorg voor gemiddeld twee kinderen had, komt een eenvoudige rekensom dichter bij 1500 kinderen van verzorgende moeders op jaarbasis.

Voor het creëren van sommige voorzieningen zijn kwantitatieve gegevens noodzakelijk, voor andere niet per se. Zo zou een draaiboek/checklist woor de eerste fase van het strafproces al te maken zijn. Alleen de invulling van personele inzet zou meer onderbouwing vergen. Al doende kan men echter ook achter een bepaalde

36 Zie art. 10 Grondwet, art. 8 EVRM en de Wet Persoonsregistraties (WPR).

De wet verstaat onder persoonsregistratie een samenhangende verzameling van op verschillende personen betrekking hebbende gegevens die langs geautomatiseerde weg wordt gevoerd of systematisch is aangelegd: Personen die in het registratiesysteem worden opgenomen moeten daarvan in kennis worden gesteld en de informatie mag alleen worden gebruikt voor het doel dat met persoonsregistratie verenigbaar is. Verstrekking van gegevens aan derden mag alleen voor zover het voortvioeit uit het doel wan de registratie of op basis van een wettelijk voorschrift of met toestemming van de persoon op wie de gegevens betrekking hebben.

Gegevensregistratie met als doel al in een vroeg stadium van de detentie de gedetineerde te resocialiseren en het kontakt met het thuisfront te continueren, mede in het belang van het kind, lijkt mij verenigbaar met de WPR. Wel zal steeds toestemming van de afzonderlijke familieleden vereist. zjjn. Het is goed voorstelbaar dat de achterblijwers, ook kinderen, miet geassocieerd en geregistreerd willen worden met de gedetineerde. Kinderen boven de 12 jaar zouden, analoog aan het burgerlijk recht, zelf gehoord moeten worden. Het gebruik van deze persoonsgegevens voor wetenschappelijk onderzoek en beleidsworming, zal op zichzelf getoetst moeten worden aan doel/procedure en toestemmingsvereisten.

37 Zie hoofdstuk 3, Kannegieter (1994), p. 235. Kannegieter merki bij zijn onderzoek onder mannelijke verdachten (351 diefstal, 146 mishandeling) op dat persoonlijke bindingen van de verdachte in zowel de dassiers als op de zittingen sterk onderbelicht blijven. In zijn onderzoek was van 59 mannen bekend dat zij kinderen hebben.(p. 226) De arbeidspositie speelt bij mannen echter een grote rol in de straftoemeting: vooral bij first offenders kan het hebben van werk wan de verdachte reden zijn om af te zien van een geïndiceerde onwoorwaardelijke vrijheidsstraf. Anderzijds leidt het niet hebben wan een baan juist eerder tot gevangenisstraf, waarvoor dan argumenten worden gevonden in de draagkracht of de recidiveprognose.

38 European Action Research Committee on Children of Imprisoned Parents (1996), p. 8. 
behoefte komen, zoals uit reeds genoemde experimenten als het mentorproject en de m.m.k-unit in Sevenum ook is gebleken. Ik denk overigens niet dat er een nieuwe doelgroep voor de hulpverlening gecreëerd moet worden. In eerste instantie zou er door politie en justitie meer verwezen naar en/of samengewerkt kunnen worden met andere instanties met als eerste doel het leefsysteem zoveel mogelijk in stand te houden. Mogelijk wordt er nu te snel doorverwezen waardoor kinderen uit het zicht van justitie en de door haar gevangen gehouden ouder verdwijnen. Een telefonische vragenronde langs verschillende politiebureaus leert dat vooral overwegingen van financiële aard een rol spelen bij doorverwijzing. Ook de politie werkt volgens het management-nieuwe-stijl en moet aan het primaire 'product' denken. Door de bezuinigingen en reorganisaties bij politie, jeugdhulpverlening en kinderbescherming is het dus de vraag hoe een begeleidingstraject voor kinderen van gedetineerde ouders eventueel gefinancieerd moet worden. Op zich lijken de scenarioteams die door samenwerkende hulpverleners en politie op enkele plekken in het land vorm krijgen ook voor deze problematiek wel een ingang te bieden. ${ }^{30}$ Zolang dergelijke teams structureel overwerken en vooral uit persoonlijke betrokkenheid tot creatieve samenwerking komen, is het moeilijk van hen nòg een extra inspanning te vragen.

Wat uit de van de bezettingscijfers afgeleide gegevens naar voren komt, is dat er bij de vrouwen, veelal dus primaire verzorgers, twee pieken zijn in de detentie, wat betreft hun groeiende en verstikkende bezorgdheid over de kinderen. Allereerst tijdens de preventieve fase en later bij de langgestraften. Voor de opvang van kinderen en voor de continuering van het contact lijken in beide situaties heel andere eisen gesteld te moeten worden. Als tijdens de preventieve fase de zorg voor het leefsysteem extra aandacht krijgt, zou dat in eventuele fases later in het proces echter wel gunstig kunnen doorwerken. Overigens denk ik hierbij wel in eerste instantie aan kinderen die in Nederland verblijven.

\subsubsection{Buitenlandse vrouwen}

De (geografisch gezien) buitenlandse gedetineerde vrouwen van wie de kinderen in het thuisland verblijven, vormen een apart verhaal. Toch maken zij ongeveer $50 \%$ uit van de totale vrouwelijke gedetineerdenpopulatie. (Surinaamse en Antilliaanse vrouwen meegeteld). ${ }^{\text {su }}$ Hoewel er geen systematisch onderzoek beschikbaar is blijkt uit de onderzoeken van Ketelaars en Janssen dat de meesten gemiddeld twee kinderen hebben. De leeftijdscategorieën zijn niet goed te traceren."

39 Zie bijwoorbeeld Kruuk en Verhoeven (1995).

40 De Borst (1991). Bij mannen 27\% op de totale mannelijke gedetineerdenpopulatic. Van Swaaningen en De Jonge (1995, p. 25) maken een onderscheid naar etniciteit. Van de Nederlandse gevangenen zou $52 \%$ blank zijin.

41 Ketelaars (1991) p. 14, Janssen (1994) p. 60. 


\section{Hoofdsiuk 8}

Buitenlandse vrouwen zijn qua status onder te verdelen in verschillende categorieentit

1. Vrouwen die nog niet in Nederland zijn toegelaten;

2. Vrouwen die op doorreis naar een ander land gepakt worden (in transito);

3. Vrouwen die als toerist zijn toegelaten in Nederland.

4. Vrouwen die, als vluchteling in Nederland verblijven. ${ }^{44}$

De laatste categorie heeft hun kinderen vaak meegenomen naar Nederland Voor de andere categorieen geldt dat niet. Via de "vroeghulp" van de reclassering wordt meestal direct na de arrestatie bijstand geboden en de situatie thuis, zoals familie en werk, in kaart gebracht. Het is over het algemeen moeilijk om contacten met de thuissituatie te leggen. Er is vaak geen telefonische verbinding en ook briefverkeer verloopt niet moeiteloos. . $^{4}$

Deze vrouwen dachten meestal na een paar dagen, hooguit een week, weer thuis te zijn. Opvang voor hun kinderen is er dan ook maar voor een korte tijd. Wat er daarna moet gebeuren, weten ze niet en ze kunnen vanuit hun detentie ook niets regelen. Meestal nemen familieleden de zorg voor de kinderen op zich. ${ }^{*}$ Op partners kunnen de vrouwen over het algemeen niet terugvallen.

"In de meeste Latijnsamerikaanse samenlevingen beschikken de burgers over meer keuzemogelijkheden wat betreft een relatievorm. Het komt vaak voor dat man en vouw min of meer 'als getrouwd' samenwonen en ook kinderen hebben zonder ooit naar het altaar te zijn gestapt. Mannen komen en gaan in veel Latijnsamerikaanse huishoudens. Dit brengt met zich mee dat vrouwen verantwoor delijk zijn voor het gezinsinkomen" ${ }^{* 47}$

Janssen veronderstelt ook een directe relatie tussen de slechte economische omstandigheden waarin de vrouwen verkeren en het feit dat ze als drugskoerier in de criminaliteit gaan werken. Daarbij maakt ze wel onderscheid tussen 'professionals' en 'echte mulas', "vrouwen die voor het eerst op pad gaan en geen enkel idee hebben van wat er op hen af komt". ${ }^{48}$ Hoewel er nu, op aandringen van de Rechtbank Haarlem, van al deze vrouwen door de reclassering een voorlichtingsrapportage wordt gemaakt, blijkt dat bij de straftoemeting de hoeveelheid en aard (hard of soft) van de drugs en de plaats van de verdachte binnen de criminele organisatie een grotere rol spelen dan de sociaaleconomische omstandigheden. ${ }^{49}$ Onlangs heeft minister

42 Janssen (1994) p. 125-126.

43 Bijvoorbeeld vrouwen die bij de douanecontrole betrapt worden op het vervoer van drugs.

44 Fuldauer (1995, p. 105) spreekt over 13 'illegale vrouwen' in 1995.

45 Janssen (1994) p. 95-96.

46 Ketelaars (1991) p. 16.

47 Janssen (1994) p. 59.

48 Janssen (1994) p. 64.

49 Janssen (1994) p. 65. "Volgens Paul Kerkhoff kan met behulp van dit rapport de straf met hooguit een half jaar of een jaar verminderd worden." (wat mij toch niet gering lijkt bij gemiddelde straffen van anderhalf tot drie jaar, $R W$ ). 
Sorgdrager wel ingestemd met het besluit van de PG om lagere straffen te eisen woor drugskoeriers die in zeer slechte sociale omstandigheden verkeren en voor een eenmalige verleiding bezweken zijn. ${ }^{\text {so }}$

De vrouwen staan ambivalent tegenover de mogelijkheid hun straf in eigen land uit te zitten (via gebruikmaking van de Wet Overdracht Tenuitvoerlegging Strafvonnissen), met name omdat de omstandigheden in de gevangenissen daar zoveel slechter zijn dan in Nederland. Het enige voordeel zou zijn dat ze daar meer contact met hun kinderen kunnen hebben. Als vrouwen dit wel zouden willen, kan het problematisch worden wanneer er door Nederland geen verdrag is gesloten met hun land wan herkomst. ${ }^{5.1}$

Bij ontslag worden vrouwen uit de twee eerstgenoemde categorieën via de Vreemdelingenpolitie 'teruggeleid' naar het land van herkomst. De luchtvaartmaatschappij betaalt in principe de kosten. Als een vrouw naar een ander Jand toe wil, betaalt zij de kosten zelf. In het identiteitsbewijs komt een stempel waaruit afgeleid kan worden dat die persoon de toegang tot Nederland is geweigerd. Ook moet een verklaring ondertekend worden waarop de reden en wijze van teruggeleiding staan vermeld..$^{52} \mathrm{Na}$ een gevangenisstraf van meer dan zes maanden mag de betrokkene niet meer op Nederlands grondgebied komen.

Bij de derde categorie volgt na ontslag uit de gevangenis een uitzettingsprocedure. Hier draait de staat op voor de vervoerskosten. Deze gedetineerden krijgen een verklaring mee omtrent de reden van verwijdering. ${ }^{3 x}$ In de genoemde gevallen wachten de ex-gedetineerden in het passantenverblijf van de politie in Hoofddorp op hun terugreis. Gedetineerden kunnen overigens een asielverzoek indienen. De kans dat dit geweigerd wordt, is echter groot. Bij toewijzing zou er vervolgens wel een mogelijkheid tot gezinshereniging zijn.

In Groot Britannië bekommert een vrijwilligersorganisatie zich speciaal om het lot van Nigeriaanse vrouwen. Er worden bezoeken aan de familie van gedetineerde vrouwen in Nigeria gebracht. Ook wordt er voorlichting gegeven aan vrijwilligers, zoals Save the Children en NACRO, die in de Britse gevangenissen werken, omtrent culturele verschillen, zoals voedingsgebruiken." Zoals alle vrijwilligersorganisaties is ook deze voortdurend bezig financiële middelen woor het werk te zoeken. Dankzij de steun van een zeer machtige en rijke Nigeriaanse politicus is hun werk van de grond gekomen. Het is niet altijd mogelijk de zuiverheid van dergelijke bronnen te garanderen. De kans is aanwezig dat de gelden gefourneerd worden uit de inkomsten van de georganiseerde criminaliteit, waarvan de gedetineerde vrouwen als klein

Nolkskrant, 22-8-1996.

51 Ketelaars (1991) p. 26-27.

52 Beschikking krachtens art. 21 Vreemdelingenwet.

53 Zie hoofdstuk III Vreemdelingenwet.

54 The African Family Advisory Service of Save the Children. Zie Save the Children (1991). 


\section{Hoofidstuk 8}

radertje onderdeel uitmaakten. ${ }^{\text {ss }}$ Zo bouwden de drugsbaronnen in Colombia en de maffia in Italie immers ook een eigen 'verzorgingsstaat' in hun land op, met ziekenhuizen, scholen en andere voorzieningen. Gezien de toegenomen migratie en grensoverschrijdende criminaliteit zou juist ten aanzien van buitenlandse gedetineerden, een gedifferentieerd resocialisatiebeleid gevoerd moeten worden. ${ }^{56}$ Ook in relatie tot hun family life. Binnen Europa zou er via regelgeving en fondsverwerving veel gedaan kunnen worden aan afstemming van gevangenisregiems op elkaar, zodat op de langere termijn regionalisering van strafexecutie binnen Europa mogelijk wordt. Op korte termijn valt er te denken aan bezoekregelingen, verstrekking van telefoonkaarten en alle mogelijkkeden van moderne telecommunicatie. Met uitbreiding van telecommunicatiemiddelen, ook in hun thuisland, zouden ook gedetineerden die afkomstig zijn uit landen buiten Europa tegemoet gekomen kunnen worden.

\subsection{Preventieve fase}

De eerste fase in het strafproces is veelal bepalend voor de verzorgingsarrangementen, zoals die ook bij voortduring van de detentie hun vorm krijgen. Een adequate opvang van verzorgingsbehoeftigen zou met name bij de primaire verzorgers tot besparing van leed leiden, maar ook de achterblijvers zouden enigszins opgevangen kunnen worden in hun ontreddering. Doel van ondersteuning zou steeds moeten zijn rust te brengen in de situatie en voor zover de situatie voor de kinderen stabiel was, die stabiliteit zoveel mogelijk te waarborgen. De continuïteit van de leefwereld van kinderen bestaat niet alleen uit het contact met de verzorger, maar ook uit contacten. met andere volwassenen (zoals de andere ouder, familie, onderwijzer, buurvrouw, sportleider), met generatiegenoten, de ruimtelijke omgeving (bed, kamer, huis, buurt, school, crèche, peuterspeelzaal etcetera), het ritme van de dag (rituelen rond eten, naar en van school gaan, rituelen rond naar bed gaan) en soms uit dingen, die zintuiglijk aangename prikkels geven. (de 'traumabeertjes', de geur van eten en dergelijke) Afhankelijk van de leeftijd, de aard en het karakter van het kind kan, waar mogelijk met hulp van de gedetineerde gepaste opvang gezocht worden die zoveel mogelijk stabiliteit aan het kind geeft. Een eerste taak lijkt hier voor de politie en de reclassering te liggen.

In situaties die bedreigend zijn voor het kind, is hulpverlening geindiceerd. Ik denk daarbij aan het kind dat getuige was van het misdrijf, bijwoorbeeld in het geval van partnerdoding, of het kind dat zelf slachtoffer was of dreigde te worden. Op die

55 Mondelinge informatie via het European Action Research Committee.

56 Dit zou interdepartementaal aangepakt kumnen worden, bij voorbeeld in een samenwerkingsverband tussen de ministeries van Justitie, Buitenlandse Zaken en Ontwikkelingshulp. 
siltuaties zijn de reeds genoemde scenarioteams over het algemeen al redelijk ingespeeld. ${ }^{\pi}$

\subsubsection{Aanhouding}

"Douanerecherche en politie hebben woensdag vier kilo heroîme gevonden bij een inval in cen woning in het plaatsje Oude Tonge op Goeree-Overflakkee. Twee wrouwen van 25 en 30 jaar, zijn gearresteerd. De sociale dienst heeft erop toegezien dat een tweejarig kind van een van de arrestantes wordt opgevan*

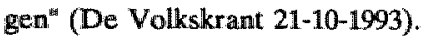

Bijgaand krantenbericht roept de vraag op hoe er bij een crisissituatie als aanhouding gehandeld wordt. ${ }^{\text {ss }}$ Een telefonische rondgang langs regionale politiebureaus leert dat er op de meeste plaatsen in overleg met de moeder ad hoc besloten wordt waar de kinderen naar toe moeten. In het gros van de gevallen is dat naar een familielid. Als vooraf bekend is dat iemand bijvoorbeeld van haar bed gelicht zal worden, wordt veelal van te voren een plan gemaakt en is er ook iemand bij die op de kinderen let. Als er geen adres beschikbaar is, wordt er in sommige regio's contact gezocht met een kindertehuis in de buurt. In de regio Eindhoven bestaat een vast contact met een tehuis dat voor dit soort situaties 'crisisbedden' heeft. In de regio Amsterdam/Amstelland bemiddelt een crisisteam dat zich speciaal met de opvang van kinderen bezighoudt. Dit hanteert ook een soort draaiboek dat afgehandeld wordt. Het gaat hierbij om de allereerste opvang. Er wordt 'op maat' gewerkt. Soms is het nodig om RIAGG-interventie in te roepen. In de andere regio's lijkt men meer te improviseren, vooral omdat dit soort situaties naar hun zeggen nauwelijks voorkomt. De vraag zet hen echter wel aan het denken: "Tsja.., wat doen we dan?" De belangrijkste zorg van de politie lijkt vervolgens het vinden van een plek ("We laten zo'n kind heus niet alleen hoor!"). De plaatsing van een kind zal in voorkomende gevallen worden overgelaten aan het maatschappelijk werk en/of de Raad voor de Kinderbescherming. De beperkte bereikbaarheid van het maatschappelijk werk, niet buiten kantooruren en in het weekend, speelt hierbij een rol.

Als een kind bij een familielid zit, wordt er verder niet meer door justitie en/of hulpverlening naar gekeken. Gedurende het verblijf op het politiebureau heeft de ouder, c.q. moeder geen contact met haar kind(eren). Het is onduidelijk wie het kind op de hoogte stelt van het wel en wee van de ouder en vice cersa.

In deze fase van het strafproces zou er dus al met de aanwezigheid van kinderen rekening moeten worden gehouden. hulpverleningsteams gewormd worden, die ook rgelmatig (moeten) rapporteren in het scenarioteam. (zie A.1.5 -A.1.8) 


\section{Hogfdstuk :}

Er kan worden geprobeerd te vermijden dat kinderen getuige zijn van fysiek geweld of het in de boelen doen van zijn ouder(s) Een persoon krijgt bijvoorbeeld als speciale taak de directe opvang en bescherming van aanwezige kinderen.

Voor heterdaadsituaties kan een draaiboek gemaakt worden. Bij voorkeur moet een kind uit een crisissituatie worden gehaald. Ook als er paniek optreedt, moet er een crisisopvangadres achter de hand zijn. Daarnaast kan er een standaardchecklist worden gemaakt die thuis of op het bureau met de ouder wordt doorgelopen en waarbij de stabiliteit en continuïteit van de eigen leefwereld van het kind centraal staat. De grootste categorie minderjarige kinderen wan gedetineerde vrouwen zit in de leeftijd van vijf tot en met twaalf jaar en van twaalf tot en met achttien jaar. Dat betekent dat er in de meeste gevallen op de korte termijn een opvangadres geregeld moet zijn. Afhankelijk van de woonplaats van het kind bij voorkeur binnen de familie- of kennissenkring. De afspraken van het kind moeten worden gecontroleerd en eventueel afgezegd. En de bijzonderheden van het kind moeten bekend zijn. Niet alleen gegevens over medicatie, allergie, bedplassen en dergelijke, maar ook de knuffel en het lievelingsboekje, speelgoed of cassettebandje.

Als het verblijf van de ouder langer gaat duren moet de checklist bijgewerkt worden. Er moet een vertrouwenspersoon zijn die een informatieve rol heeft naar kind en ouder en vice versa. ${ }^{61}$ Dit kan iemand wit de omgeving van het kind zijn, maar vooral als het langer gaat duren, kan het beter zijn dit door een professionele hulpverlener te laten doen. Wellicht moet er ook een nieuw opvangadres gezocht worden. Misschien is het kind even snel bij buren, een vriendje of oma gebracht en gaat het er nu pas naar uitzien dat het een wat langere logeerpartij wordt. De vertrouwenspersoon moet ook zorgen dat er afspraken gemaakt worden met degenen die het kind opvangen over de kosten, kleding en dergelijke. En de contacten met broertjes en zusjes moeten niet verwaarloosd worden.

In het rapport dat de Committee for the Prevention of Torture in juli 1993 uitbracht over Nederland wordt ook aandacht besteed aan het recht op het informeren van familieleden over de detentie. ${ }^{62}$ Dit recht moet volgens de commissie wettelijk worden erkend, waarbij uitzonderingen duidelijk moeten worden omschreven en zo kort mogelijk mogen duren. Ze moeten bovendien op schrift gesteld worden en goedge-

59 Ketelaars (1991) en Van Kesteren (1996).

60 Inverzekeringstelling duurt maximaal zes dagen. (art. 57 e.v. Sv). Inbewaringstelling duurt maximaal tien dagen (art. 63 e.v. Sv).

$61 \mathrm{Vgl}$ art. 9 lid $4 \mathrm{VN}-$ Kinderverdrag en art. 280 lid $3 \mathrm{Sr}$.

62. CPT/Inf (93) 20 Report to the Dutch Government, p. 20-21. De CPT richt zich bij haar onderzoeken naar het Europees Anti Folterverdrag, het VN verdrag tegen foltering en andere wrede onmenselijke of vernederende behandeling of bestraffing, art. 3 EVRM, art. 7 IVBPR, de VN beginselen inzake de bescherming van alle categorieën gedetineerden en gevangenen van 9 december 1988 en de European Prison Rules. Zie ook art. 9 lid 4 VN-Kinderverdrag, art. 27 Ambtsbesluit voor de Politie (1994). Zie voor een overzicht Berkhout- van. Poclgeest (1993), p. 123-142. 
keurd door de OvJ of een hoge politieambtenaar. Berkhout pleit ervoor dat er een functionele scheiding wordt aangebracht tussen de functie van degenen die zich op het politiebureau met het onderzoek bezighouden en zij die verantwoordelijk zijn voor de gang van zaken bij de detentie. ${ }^{63}$ Dit zou ook het mogelijk, via de kinderen, onder druk zetten en intimideren van verdachte ouders in het vooronderzoek kunnen voorkomen.

\subsubsection{Voorlopige hechtenis}

Voorlopige hechtenis is een dwangmiddel dat kan worden toegepast op grond van vluchtgevaar, het belang van het onderzoek, het gevaar voor herhaling en de geschokte rechtsorde. ${ }^{\Delta t}$ Het verdient aanbeveling om, rekeninghoudend met de grond waarop voorlopige hechtenis bevolen wordt, de minst vergaande maatregelen te nemen met het oog op de mogelijke verstoring van het gezinsleven. Er zijn ruime mogelijkheden voor schorsing van de voorlopige hechtenis, waarbij de rechter vrij is de vorm van de voorwaarden te bepalen. Alleen de twee voorwaarden, het zich niet zullen onttrekken aan de tenuitvoerlegging van de voorlopige hechtenis bij opheffing van de schorsing respectievelijk van de straf bij veroordeling, staan vast. Uit Beijerse en Van Swaaningen zijn teleurgesteld over de geringe inbreng en creativiteit van advocaten en de reclassering op dit punt, temeer daar empirisch kan worden aangetoond dat het verblijf in voorlopige hechtenis een sterk bepalende factor is' bij het opleggen van een gevangenisstraf. Als iemand maanden in voorarrest heeft gezeten, zal er niet zo snel een geldboete of andere alternatieve straf opgelegd worden. ${ }^{65}$

"Een alternatieve afdoening moet standaard zijn, toepassing van de gevangenisstraf uiltzondering. Naar een dergelijke afdoening moet worden gezocht zodra duidelijk is dat er anders vrijheidsbeneming zal plaatsvinden, meestal bij de beslissing tot voorlopige hechtenis. Het karakter van het alternatief dient aan te sluiten bij de grond van vrijheidsbeneming.

De Jonge stelt woor bepalingen die gaan over schorsing van de preventieve hechtenis aan te vullen ten aanzien van zwangere vrouwen en ten aanzien van met de ouderlijk gezag beklede personen, van wie de kinderen direct van hun feitelijke zorg afhankelijk zijn." Ook valt te denken aan het "bij voorrang" behandelen van zaken, waarbij de maatschappelijke schade van toepassing van het dwangmiddel relatief groot is. Afhankelijk van de grond waarop iemand voorlopig in hechtenis wordt gehouden, is de preventieve fase in het strafproces wellicht de moeilijkste periode om rekening

64 Art. 67a Sv.

65 Uit Bejjerse en Van Swaaningen (1994) p. 41-43.

66 Uit Beijerse en Van Swaaningen (1994) p. 46.

67 De Jonge (1993) p. 101. Zie ook art. 9 lid 2 VN Kinderverdrag. 


\section{Hoofdotuk 8}

te houden met de belangen van kinderen. De verdachte is in principe onschuldig, dus het is uiterst ingewikkeld om de kinderen neutraal te informeren over wat er gebeurt. ("We hebben je vader/moeder heel hard nodig om een misdaad op te lossen..") Wanneer het doel van de gevangenhouding vanuit justitieel oogpunt de bewijsgaring is, bestaat het gevaar dat een al te grote vertrouwensrelatie tussen een justitieel ambtenaar en een kind leidt tot het verzamelen van extra bewijsmiddelen. Wat doe je als het kind spontaan vertelt wie er thuis zoal over de vloer kwamen? Is er dan sprake van onrechtmatig verkregen bewijs omdat het kind van het verschoningsrecht op de hoogte gesteld had moeten worden, is er sprake van een onbetrouwbare verkllaring omdat die is afgegeven onder dubieuze omstandigheden? Ook in dit licht verdient het aanbeveling de uitvoering van de opvang te bieden vanuit een ander circuit dan het onderzoeksteam, bijvoorbeeld via het algemeen maatschappelijk werk. Misschien zou er gedacht kunnen worden aan de reclassering of een andere afdeling bij de politie, hoewel rolvermenging daar al snel kan optreden. In feite zou een vertrouwenspersoon een eigen beroepscode en verschoningsrecht moeten hebben. Krachtens art. $272 \mathrm{Sr}$ zou de vertrouwenspersoon gebonden zijn aan het beroepsgeheim en kan hij zich ook op het verschoningsrecht (art. $218 \mathrm{~Sv}$ ) beroepen. Slechts noodtoestand kan hem of haar ontslaan van het beroepsgeheim.

Mocht er aanleiding zijn het kind in het kader van het vooronderzoek te verhoren, dan kan dat alleen met toestemming van de ouder, tenzij het om een delict gaat dat direct binnen de familie heeft plaatsgevonden. Eventueel kan een met waarborgen omkleed getuigeverhoor van het kind plaatsvinden in een speciale verhoorstudio. Het is wel van belang te weten dat het kind een verschoningsrecht heeft. ${ }^{\infty}$ Bonarius waarschuwt voor het langetermijneffect van het getuigeverhoor wanneer het kind zich ervan bewust wordt dat de ouder mede door zijn of haar toedoen is veroordeeld. ${ }^{x}$ Mols pleit voor een eigen advocaat die het kind-als-getuige bijstaat. ${ }^{71}$ Voor de gedetineerde ouder is het belangrijk op de hoogte te zijn van de toestand thuis. De ouder die tot de detentie de feitelijke zorg had, moet in de gelegenheid gesteld worden tussentijdse regelingen te treffen. Nu 'voorlopig' in het kader van de hechtenis, net als in het civiele recht, veelal de juridische betekenis van 'vooruitlopend op' de gevangenisstraf krijgt, zouden analoog aan het echtscheidingsproces 'voorlopige voorzieningen' getroffen moeten worden. Met de vertrouwenspersoon kunnen de afspraken en een checklist steeds geactualiseerd worden. Te denken valt aan

- het inschakelen van de andere ouder, naaste familie, vrienden, buren bij alle lopende zaken, waaronder het bezoek aan het HvB;

69 Art. $217 \mathrm{~Sv}$.

70 Bonarius (1994) p. 1167-1174.

71 Mols (1993) p. 21. 
- het inlichten van de school, de crèche, de peuterspeelzaal;

- het controleren van lopende afspraken: arts, tandarts, consultatiebureau, logopedist, zwembad, sportclubs etcetera;

- het treffen van financiële regelingen.

De Jong stelt voor om een tussenhuis te creëren tussen huis van bewaring en gevangenis, met name voor gedetineerden die, bijvoorbeeld doordat zij in appà zijn gegaan, de hele detentieperiode in het HvB doorbrengen. In zo'n tussenhuis zouden dan ook de ruimere bezoek- en verlofregelingen en de mogelijkheid tot detentiefasering kunnen gelden. ${ }^{\text {. }}$

Het opstellen van een detentieplan mede met het oog op de latere resocialisatie, dus met de terugkeer in de samenleving, werd onder meer bepleit door de werkgroep Vrouwen in detentie. ${ }^{3}$ In dit plan zou al een relatie gelegd kunnen worden met de te verwachten latere straf.

Het probleem dat het strijdig zou kunnen zijn met de presumptie van onschuld om al in deze fase van het proces rekening te houden met een eventueel uit een veroordeling voortvloeiend strafdoel kan opgelost worden door de wil van de verdachte daartoe tot uitgangspunt te nemen. De presumptie van onschuld geeft rechten en legt geen plichten op. ${ }^{74}$ Een detentieplan in de fase van voorarrest kan zo'n recht zijn, mits het wordt gemaakt op basis van vrijwilligheid.

\subsection{Terechtzitting: straftoemeting}

In het Nederlandse straftoemetingsstelsel wordt uitgegaan van bijzondere per delict bepaalde strafmaxima en algemene hele lage strafminima. De rechter kan daardoor bij de strafoplegging met alle omstandigheden en factoren die de concrete casus betreffen, rekening houden. De rechter moet wel ingaan op strafmaatverweren en de voorgestelde strafmaat motiveren. ${ }^{75}$ Als hij een vrijheidsbenemende sanctie oplegt moet hij in het bijzonder motiveren waarom niet met een andersoortige sanctie kan worden volstaan. ${ }^{76}$ Vaak wordt een standaardformule gebruikt waarin gerefereerd wordt aan "de ernst van het feit en de persoon van de dader". Bij de straftoemeting zouden eerst chronologisch alle niet-vrijheidsbenemende alternatieve straffen overwogen moeten zijn, voordat tot het opleggen van een gevangenisstraf wordt overgegaan.

72 De Jong (1994) p. 96.

73 Rapport Werkgroep (1991) p. 35, Rapport Stuurgroep (1991) p. 25.

74 Zie Reijntjes (1994) p. 120-121.

75 Art. 358 lid $3 \mathrm{~Sv}$, resp. art. 359 lid $5 \mathrm{~Sv}$.

76 Art. 359 lid $6 \mathrm{~Sv}$. 


\section{Hoofdotuk 8}

Met het oog op de primaire verzorging van kinderen zou deze motiveringseis aangescherpt kunnen worden."

Kelk stelt voor materiële normen vast te leggen die profiel geven aan verschillende (nu in specifieke gevallen soms al gehanteerde) strafverminderingsgronden. ${ }^{78} \mathrm{Hij}$ noemt daarbij in zijn algemeenheid de groep vrouwelijke gedetineerden als een voorbeeld van een categorie justitiabelen

"die tijjdens de detentie reeds is of nog zal worden geplaatst in een regiem, dat vergeleken bij andere regiems als extra zwaar en belastend moet worden aangemerkt $t^{\mathrm{a}}$.

Een andere ingang is wellicht het verzoek om een compensatieregeling voor het zogenaamd zwaarder straffen van primaire verzorgers, in casu moeders door langdurige scheiding van hun kinderen..$^{\infty}$ Op grond van art. 14 EVRM zou beargumenteerd kunnen worden dat er sprake is van indirecte discriminatie door feitelijk ongelijke behandeling wanneer er geen rekening wordt gehouden met feitelijke zorgtaken. Dit onderscheid kan nog aangescherpt worden in de vergelijking tussen in Nederland woonachtige vrouwen en buitenlandse vrouwen. Voor buitenlandse vrouwen is de straf relatief immers nog zwaarder. Zij missen sowieso al de voordelen van bezoeken verlofregelingen en detentiefasering, hetgeen zou moeten kunnen leiden tot vervroegde invrijheidstelling of gratiëring.

Kelk noemt een aantal zorgsituaties waaruit strafvermindering zou moeten kunnen voortvloeien. De argumenten daarvoor staan dus los van het delict en de gevolgde procedure, zoals

"- een naaste van de verdachte is volledig op hem/haar aangewezen wegens een ernstige ziekte;

- de verdachte is, bij voorbeeld wegens dood van zijn partner, verplicht om voor de kinderen te zorgen (het is trowwens de vraag of niet in alle gevallen van een verzorgingsverplichting voor kinderen daarmee rekening gehouden zou moeten worden; men denke aan de Zuidamerikaanse drugskoeriersters) ${ }^{\text {hra }}$

\section{De Jonge suggereert:}

"Een andere mogelijkheid zou zijn om het vijfde boek van het Wetboek van Strafvordering (Tenuitvoerlegging en kosten) wit te breiden met een bepaling die inhoudt, dat de tenuitvoerlegging van vrijheidsbenemende straffen wordt opgeschort ten aanzien van zwangere vrouwen en ten aanzien van met de ouderlijke macht beklede personen, wier kinderen direct van hun feitelijke zorg afhankelijk zijn. Dan

77 Wolleswinkel (1992) p. 230, Lissenberg (1992) p. 270-271.

78 Kelk (1994) p. 51-70.

79 Kelk (1994) p. 60.

80 Wolleswinkel (1990) p. 97.

81 Zie Van de Pol (1988) p. 157-159.

82 Kelk (1994) p. 63. Zie ook Janse de Jonge (1991) p. 172. 
kunnen de kinderen van 'zorgende' vaders ók van zo'n regeling profiteren. Vindt er tijdens zo'n schorsing recidive plaats, dan kan de straf alsnog ten witvoer worden gellegd. Gaat alles goed, dan is dat een argument om gratie te verlenen, al dan niet onder voorwaarde van dienstwerlening " ${ }^{\text {kg }}$

Een dergelijke verplichting zou ook afgeleid kunnen worden uit art. 3 lid 1 van het VN-Kinderverdrag. De bepaling heeft betrekking op "alle maatregelen betreffende kinderen", waaronder ook een strafprocedure tegen een verzorgende ouder kan vallen. Wanneer het concept van de 'feitelijk verzorgende ouder' als uitgangspunt genomen wordt, is het belangrijk daaraan wel in de concrete casus invulling te geven. Hier zouden rechter, advocaat en reclassering een rol kunnen vervullen. Binnen het familierecht is gebleken hoe feitelijke zorgactiviteiten waak genderspecifiek vastgesteld worden en hoe problematisch het is om daadwerkelijk te bepalen welke zorg in het belang van het kind gecontinueerd moet worden. Wellicht zou er nog een aparte controle, en de mogelijkheid van een second opinion daarop, door een deskundigge, moeten zijn.

Janse de Jonge gaat in op het mogelijke dilemma dat het meewegen van persoonlijke factoren bij de straftoemeting met zich kan brengen. Vanuit het oogpunt van rechtsgelijkheid en rechtszekerheid valt te vrezen dat mensen die toch al in de marge van

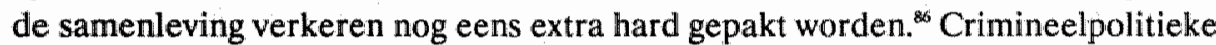
overwegingen zouden volgens hem dan ook nooit een rol mogen spelen. Ze zouden bovendien haaks staan op ander overheidsbeleid dat juist probeert maatschappelijke achterstellingen op te heffen. Hij vindt dat die persoonlijke factoren in het licht wan de strafbekwaamheid van het individuele geval een rol moeten spelen. Juist dan wordt er een zekere gelijkwaardigheid bereikt tussen de ernst van het feit en de

83 De Jonge, a.w., p. 101.

84 Zie ook Vogler (1992), p. 101-113. Art. 3 lid 1 VN-Kinderverdrag luidt:

"Bij alle maatregelen betreffende kinderen, ongeacht of deze worden genomen door opembare of particuliere instellingen woor maatschappelijk welzijn of door rechterlijke instantics, bestuurlijke autoriteiten of wetgevende lichamen, wormen de belangen van het kind de eerste overweging." Loenen (1994), p. 207-227. Op p. 225 : "in het recht ontbreekt namelijk vooral de erkenning van de betekenis van het bestaan van een feitelijke zorgrelatie als constitutief element woor de juridische erkenning van een ouderrol $\mathrm{m}^{\mathrm{m} .}$..."Op die manier ontstaat ruimte voor de juridische erkentuing van 'afwijkende vormen' van feitelijk ouderschap." Hoewel zij thierbij niet deze groep voor ogen heeft en ook de discussie binnen het familierecht gericht is op het scheppen van gezagsrelaties binnen andere leefvormen dan het huwelijk, is de redenering bruikbaar voor gedetineerde verzorgers bij het creëren van materiële voorzieningen om hun gezagsrelatie optimaal inhoud te geven. De waarschuwing tegen teveel overheidsbemoejenis in de privésfeer verandert hier in een verplichting van de overheid voorzieningen te scheppen om de privesfeer te beschermen.

86 De actuele discussies over de straftoemeting gingen overigens net over de ongelijk heid in straf mat tussen diverse arrondissementen. Zie onder meer het themanummer "Gelijkheid van straffen, Trema (1992). Kelk (1992, p. 117) in dat nummer: "De ware kunst, de ars aequi, richt zich niet in de eerste plaats op de vraag wat de gelijkheid in deze betekent, maar weeleer op het problematische en bijzondere karakter van het geval". 
straf die de betreffende dader moet ondergaan. De straftoemeter is er dan steeds van doordrongen wat de straf voor de veroordeelde aan leed betekent ${ }^{87}$ Ik vrees dat Janse de Jonge hier iets te gemakkelijk heenstapt over structurele effecten die zo' $n$ in haar aard goedbedoeld en geïndividualiseerd straftoemetingsbeleid toch kan hebben. Juist in dat opzicht zijn de (Groningse) criminologische onderzoeken onthullend.

Ook de ideeën die Tulkens in zijn oratie ontwouwde, teneinde de vrijheidsstraf te ontdekken "om de gevangenisstraf te overwinnen", lijken perspectieven te bieden. Hij bepleit een verandering van het sanctiestelsel, een meer verfijnd proces, waarin het toekomstig gedrag van de gestrafte ook een rol speelt.

"De vrijheidsstraf zou in deze visie kunnen worden geformuleerd als het door de rechter platisen van een weroordeelde gedirende een bepaalde tijd onder het gezag wan cen daartoe aangewezen instantix voor het vervullen van op te leggen werplichtingen, waarvan de aard wordt bepaald door de mogelijkheid van zeltherstel en de medewerking wan de veroordeelde en door het maatschappelik belang, op daartoe aan te wijzen platsen, zo nodig in detentic."

Tulkens laat zich verder niet uit over welke instantie dat zou moeten zijn. Ook de motivering van de straf zal aan bepaalde criteria moeten voldoen, wil de rechtszekerheid van de delinquent niet in het geding komen.

87 Janse de Jonge, a.w., p. 190-191. De vraag is hoe er een expliciete relatie met het doel van de straf gelegd moet worden. Doel van straf is de leedtoevoeging en -in het geval varn gewangenisstrafmogelijk ook de vrees woor herhaling, beveiliging van de samenteving dus. Beide strafdoelen worden gerealiseerd door rekening te houden met de ermst van het feit en de persoon van de dader. Bij de leedtowoeging is de genderbias interessant. Werktt iemands 'maatschappelijke verantwoordelijkheid" strafverlichiend of juist verzwarend? Vgl. de werkgever met meer dan honderd werknemers en de alleenstaande moeder met een gezin. Is het plegen wan het strafbaar feit voor iemand in die positive extra moreel verwerpelijk of dient de spoedige terugkeer in de matsehappelijke rol een groter moreel belang? Wat staft in het beveiligingsdenken centraal: de crimineel die gevaarlijk is of de omgeving die de persoon tot criminaliteit 'werleid"? Vanuit het beweiligingsdenken zou de wolgende genderconstructie te winden kunnen zijn. Bij wrouwen is er vrijwel altijd samenhang met omgevingsfactoren, hetzij de armoede in combinatie met primaire zorgverantwoordelijkheid, hetzij de aanpassing/aantuankelijkheid aan een criminele partmer(s). Bij mannen zou veel eerder gezocht worden nar intrapsychische afwijkingen, gestoorde agressieregulering en daarmee matar biopsychologische en neurologische affwijkingen.

88 Zie onder andere het onderzoek van Kannegieter (1994) naar de factor arbeid.

Het niet hebben van een baan blijkt bjj de door hem onderzochte mannen uiteindeljk de belangrijkste indicator woor het opleggen wan gevangenisstraf, zelfs al worden argumenten als 'draagleracht' en 'recidiveprognose" genoemd.

89 Tulkens (1988).

90 Tulkens (1988) p. 18. 
De voorstellen voor een executierechter ontlenen hun legitimatie eveneens aan de noodzaak tot een grotere controle op het effect en de doelmatigheid van de straf en op de mogelijkheid van heroverweging op grond van het detentieverloop. ${ }^{\text {9h }}$ Tijdens de detentie lijken selectiemechanismen te werken, waarvan nu de vraag is of ze voorzien of beoogd zijn door de rechter. Deels gebeurt dit vanuit pragmatische motieven zoals het voorkomen van onderbezetting, maar deels ook op inhoudelijke gronden. Ten aanzien van vrouwen noem ik de volgende voorbeelden:

- In onderzoek over partnerdoding wordt geconstateerd dat vrouwelijke partnerdoders niet in de straftoemetingsfase in het psychiatrische circuit terechtkomen, maar wel in de executiefase via artt. 47 en $120 \mathrm{GM}^{92}$

- Opmerkelijk is ook dat via de procesevaluatie van de m.m.k.unit -bij toeval-bleek dat bij de voor Sevenum geselecteerde vrouwen, vooral zelfmeldsters, de moeders met kinderen in de basisschoolleeftijd ontbreken. De helft van de moeders blijkt grote kinderen te hebben, pubers en adolescenten en een iets kleinere helft hele jonge kinderen. Dit is intrigerend nu uit inventarisaties in gesloten inrichtingen blijkt dat daar meer moeders zitten van kinderen in de basisschoolleeftijd dan uit andere leeftijdsgroepen. ${ }^{.3}$

Het is de vraag of ook een mogelijk toekomstig verzorgerschap mee zou kunnen wegen in een tussentijdse heroverweging. Het gevaar van netwidening van het gevangeniswezen door humanisering tijdens het detentieverloop moet niet onderschat worden. Zo is steeds weer te zien hoe een bepaald voorzieningenpakket een eigen behoefte creëert. Ook in de m.m.k. unit in Sevenum is het 'ultimum remedium' standpunt bij de opvang van kinderen verlaten doordat er gaandeweg een hulpaanbod is gekomen voor detentiefaseersters. Er wordt dan niet meer gecheckt of dit echt de laatste oplossing qua opvang is die verzorger en kind geboden kan worden. Het gevaar van deze ontwikkeling zou kunnen zijn dat er een nieuwe voorziening gecreëerd wordt die eigenlijk niet binnen het straf- en detentieklimaat thuishoort. Rechters zullen dan op grond van de feitelijke omstandigheden van een veroordeelde misschien juist eerder tot gevangenisstraf in plaats van een alternatief besluiten. Zoals ander wegbezuinigd en weggereorganiseerd hulpverleningsaanbod ook al binnen justitie vervangen wordt via drugsvrije afdelingen en intensieve behandelafdelingen voor psychische gestoorde gedetineerden, zou ook op dit terrein een hulpverleningstaak oneigenlijk binnen het justitieapparaat terecht kunnen komen. Die tendens. leidt immers mede tot de voortdurende groei wan het aantal cellen.

91. Verpalen (1994) p. 71-84.

92 De Boer (1990) p. 110.

93 Zie Borst/Ketelaars (1991): 32\% van de kinderen zou tussen de 5 en 12 jaar zijn. Zie ook Van Kesteren (1996). Zij maakt helaas geen onderscheid in leeftijdscategorieën van de kinderen, maar merkt wel op dat slechts éenvijfde onder de vier jaar is (p. 24) en dat ongeveer $15 \%$ van de kinderen na de detentie van de moeder zelfstandig woont en woor het grootste deel ouder dan achttien jaar is (p. 13). Daaruit kan afgeleid worden dat $65 \%$ van de kinderen tussen de 4 en 18 jaar is. 


\section{Hoofdrtuk 8}

Alleen wanneer de humanisering gericht is op vervroegd ontslag, op de richting van de gedetineerde naar buiten, op resocialisatie en reïntegratie, zouden de genoemde overwegingen naar mijn idee een rol mogen spelen.

\subsection{Tenuitvoerlegging}

Het $\mathrm{OM}$ is nu formeel verantwoordelijk voor de executie van de opgelegde straffen. Noch het openbaar ministerie, noch de rechter hebben veel belangstelling voor de executie, zo werd vastgesteld op de najaarsvergadering van de Vereniging voor Penitentiair Recht en Penologie in 1994.

"Van de Pol vindt het gewenst dat het openbaar ministerie stelselmatig meedenkt over het executiebeleid. Hij heeft het openbaar ministerie (het landelijk executieoverleg) en de Centrale Raad woor Strafrechtstoepassing als twee volstrekt uit elkaar gegroeide werelden ervaren, het geen hij een zorgelijke ontwikkeling vindt.

Zoals in een eerder hoofdstuk bleek wordt het opleggen van gevangenisstraffen als "ultimum remedium" beschouwd. ${ }^{97}$ Het is duur, het leidt niet tot minder recidive en de detentieschade bij de individuele gedetineerde is over het algemeen groot hetgeen kan leiden tot rancuneus en dus vaak opnieuw tot strafbaar gedrag. Ook uit het oogpunt van generale preventie $ل$ lijken gevangenisstraffen weinig effect te sorteren. Er wordt mogelijk well aan een primaire wraak- en vergeldingsbehoefte in de publieke opinie beantwoord. ${ }^{96}$ Helaas heeft de introductie van alternatieve vrijheidsbenemende straffen nog niet tot een vermindering van het aantal cellen geleid. Naast de alternatieve straffen werden hogere, dus langere gevangenisstraffen opgelegd. ${ }^{90}$ Dit heeft mede geleid tot een enorme groei aan cellencapaciteit. ${ }^{100}$

\subsubsection{Alternatieve vrijheidsbeneming}

De alternatieve sancties begonnen met de zogenaamde dienstverleningsprojecten: "het verrichten van arbeid ten algemenen nutte". In 1.991 adviseerde de Overlegen Adviescommissie alternatieve sancties (OCAS) de dienstverlening uit te breiden tot "de straf van vrijheidsbeperking", waarbij van de delinquent een inspanningsver-

94 Art. 4 R.O, art. 553 Sv., art., 107 GM.

95 Wurzer-Leenhouts (1994) p. 45. Zie hierwoor al eerder Vegter (1989) p. 84-97.

96 Wurzer-Leenhouts (1994) p. 45.

97 Zie hoofdstuk 4.

98 De uitbreiding van het aantal cellen ten behoeve van prewentief gehechten lijkt wel een werhoging van het "gevoel van veiligheid" te (moeten) bewerkstelligen.

99 Zie ook Nota 'In juiste verhouding' (1996).

100 Nota 'In juiste verhouding' (1996), Begroting Ministerie van Justitie (1996), zie NJB 1996, p. 1389. 
plichting wordt gevraagd, die wordt uitgevoerd in de samenleving en die ten dienste staat van een toekomstig beter maatschappelijk functioneren van de betrokkene. ${ }^{101}$ Hierbij kwam zowel de resocialisatie (ter voorkoming van recidive) als de behoefte aan normbevestiging en leedtoevoeging aan de orde. Inmiddels is de term alternatieve sanctie vervangen door "taakstraf" ${ }^{102}$ Binnen het arsenaal van alternatieve sancties vallen ook behandelprogramma's voor seksuele delinquenten, arbeidstrainingsprogramma's, vaardigheidstrainingen en zogenaamde leerstraffen, waarin een gedragstherapeutische aanpak centraal staat, bijvoorbeeld de Alcohol Verkeers Cursus, de cursus Gokpreventie, Kijk op Slachtoffers en dergelijke. ${ }^{103}$ De reclassering is verantwoordelijk voor de uitvoering van de projecten bij volwassenen, de Raad woor de Kinderbescherming bij jeugdigen.

Ook het huisarrest (al of niet met dienstverlening) zou een alternatief voor de gevangenisstraf kunnen zijn. In Nederland is in 1995 in Noord-Oost Nederland een experiment gestart met elektronisch toezicht. Dit vindt plaats in de laatste detentiefase als aanvulling op een taakstraf en ter vervanging van een middellange vrijheidsstraf. Bij welslagen van het experiment zal het elektronisch toezicht vanaf 1997 geleidelijk landelijk ingevoerd worden. ${ }^{104}$ Zorgende ouders worden nergens expliciet als mogelijke doelgroep van elektronisch toezicht en/of huisarrest genoemd. ${ }^{105}$ In Italië is het aantal gedetineerde vrouwen dat samen met kinderen in detentie verblijft enorm afgenomen, sinds een wet van kracht is dat voor zwangere vrouwen en moeders met kinderen tot drie jaar huisarrest geïndiceerd is. ${ }^{100}$ Voor de continuïteit in de leefwereld van het kind lijkt dat een goede oplossing. Voor de moeder zou ook deze vorm van vrijheidsbeneming gelegitimeerd en aan een strafdoel gekoppeld moeten worden, wil ze niet tot ongewilde seksestereotypering leiden. ${ }^{107}$ Bij veroordeelde vrouwen kan haar gedrag immers vaak mede worden verklaard door te sterke afhankelijkheidsrelaties, armoede en maatschappelijk isolement. Voor moeder en kind zou het daarom, juist ook bij huisarrest, belangrijk zijn dat isolement en de symbiose te doorbreken. Met name de reclassering kan een taak hebben bij het zoeken naar scholings-en werkmogelijkheden en goede kinderopvang.

101 OCAS-rapport (1991).

102 Beleidsnota Taakstraffen (1996). In de nota wordt wel onderscheid aangebracht tussen jeugdigen en volwassenen, maar binnen beide categorieèn niet tussen vrouwen en mannen.

103 Uit Bejjerse en Van Swaaningen (1994) p. 32-34.

104 Nota Taakstraffen (1996) p. 32. Zie ook: Baas (1995), Van Hattum, (1995) p. 318-336.

105 Eind 1996 hebben er in totaal zes vrouwen aan het experiment meegedaan. (bron: Ministerie van Justitie)

106 European Action Research Committee (1997)

107 Wolleswinkel (1995) p. 128-129. 


\subsubsection{Gevangenisstraf}

In feite zijn in Nederland voor de invulling van het family life van veroordeelden de meest concrete voorstellen gedaan met het oog op daadwerkelijke gevangenhouding van ouders, zoals het mentorproject voor kinderen van gedetineerde ouders en de m.m.k. unit in Sevenum. Voorbeelden van voorzieningen in het buitenland worden, ook door de media via documentaires en films, gretig aangehaald met de suggestie dat dergelijke voorzieningen navolging verdienen in Nederland. Soms wordt dan vergeten dat het strafklimaat in die landen, zoals de Verenigde Staten, Groot Brittannië en in mindere mate Duitsland, nog altijd harder is dan in Nederland. En over het algemeen is de rechtspositie van gedetineerden er ook vaak slechter dan hier. Vanuit dat zware strafklimaat worden initiatieven ten aanzien van het verblijf van kinderen in de gevangenis soms zelfs gelegitimeerd. De directeur van de Bedford Hills gevangenis in New York zegt ook dat de zomerse logeerpartijen van kinderen een gunstig effect op de sfeer in de gevangenis hebben. Hierdoor lijken de vrouwen hun detentie beter verdragen. ${ }^{108}$ Wat daar mooie voorzieningen zijn, zou in Nederland echter relatief gezien minder bijdragen aan een beter klimaat voor gedetineerden en hun kinderen. ${ }^{100}$

Mijns inziens zou 'de verbetering van het klimaat' in principe nooit het doel van voorzieningen in detentie voor kinderen mogen zijn. Alleen de continuitteit en stabiliteit voor het kind en het resocialiserend effect op de gedetineerde legitimeren voorzieningen. Daarom juist vormen de familierelaties van gedetineerden naast tal van andere relevante argumenten een extra reden om te zoeken naar alternatieve straffen. ${ }^{110}$

Mocht er, na de schuldigverklaring, geen alternatieve straf opgelegd kunnen worden, dan dient alsnog bekeken te worden of de zwaarte van het delict een gevangenisstraf rechtvaardigt dat wil zeggen dat het bestaan van voorzieningen voor kinderen niet

108 Documentaire H. Kennedy, Women behind bars, New York. Toelichting in de VPRO-gids (14-31994): De statat New York kent geen vergiffenis: het stempel 'crimineel' raken de wrouwen er nooit meer kwijt. Strafvermindering bestaat er niet. Een straf van vijftien jaar, blijft een straf van vijftien jaar. En de gevangenis gaat ook niet erg mee met $z$ 'n tijd. In een aantal jaren is het aantal vrouwen in de cellen verdubbeld, maar de faciliteiten zijn daar niet op aangepast. Deze harde realiteit maakt het er voor moeders niet makkelijker op om na een weekje weer afscheidt te nemen van hun kinderen."

$109 \mathrm{Er}$ is een parallel te trekken met het in hoofdstuk 1 bij de straftoemeting beschreven "battered woman syndrome", dat ook is komen overwaaien uit de VS, maar dat daar als (enige) wapen gebruikt kan worden tegen extreem lange gevangenisstraffen (en ter voorkoming van de doodstraf). In Nederland is er wanuit de bestaiande strafuitsluitingsgronden mogelijk een betere verdediging op te bouwen, waardoor hier de vrouwen wellicht niet onnodig gepsychiatriseerd hoeven te worden.

$110 \mathrm{Vgl}$. Hounslow, Stephenson, Stewart and Crancher (1982), Maher (1988), Carlen (1990), Maelicke (1993), Von den Driesch en Kawamura (1995). 
drempelverlagend mag werken bij het opleggen van vrijheidsbenemende straffen." Daartoe dient een specifieke motiveringseis in het wetboek te worden opgenomen." Mochten er dan nog zwaarwegende motieven zijn om tot detentie over te gaan dan zou daarbinnen gekeken moeten worden naar mogelijkheden tot versneide detentiefasering, andere differentiatiemodaliteiten en meer toezicht en sturing in de executiefase. ${ }^{\text {113 }}$

Mocht een feitelijke verzorger niet bij het kind kunnen, willen of mogen blijven, dan dienen er bezoek- en verlofregelingen vice versa vastgesteld of andere contactmogelijkheden gecreëerd te worden.

Parallel aan andere scheidingssituaties in het familierecht, zou er bijvoorbeeld aan een omgangsregeling gedacht kunnen worden, de vaststelling van een minimum aantal fysieke ontmoetingen of een vorm van wederzijds schriftelijk contact met het kind en/of de dagelijkse verzorgers, al naar gelang de toestand van het kind.

Mocht hierin niet voorzien kunnen worden door oorzaken die niet bij de gedetineerde gelegen zijn, bijvoorbeeld geografische afstanden, dan zouden mogelijkheden tot bijvoorbeeld vervroegde invrijheidsstelling uitgebreid moeten worden.

Familierelaties moeten naar mijn idee steeds op hun feitelijke invulling gewaardeerd worden. In die zin is het zorgwekkend dat op een studiedag in Nederland over kinderen van gedetineerden door werkers in gevangenisinrichtingen zo gemakkelijk over de feitelijke zorgrelaties van moeders met kinderen is heengestapt en prioriteit werd gegeven aan de belangen van gedetineerde vaders. ${ }^{114}$

De argumenten klinken emancipatoir, maar berusten in feite op tamelijk ongefundeerde vooronderstellingen:

- Voor moeders wordt al veel gedaan (met verwijzing naar Sevenum en de bezoekmiddagen in Heerhugowaard);

- Vaders moeten geschoold worden in hun vaderrol. Dat helpt tegen machogedrag;

- Het kind heeft de relatie met de vader nodig.

De voorstellen die vervolgens ontwikkeld zijn, lijken van seksegelijkheid tussen gedetineerde ouders uit te gaan. Zowel de gedetineerde als de thuis achtergebleven moeders dreigen daardoor als vanzelfsprekende reeds functionerende verzorgers in de onzichtbaarheid te worden gedreven. ${ }^{115} \mathrm{Ik}$ denk dat de verwantschap tussen gedetineerde moeders en de vrouwen van gedetineerde mannen veel groter is dan die tussen gedetineerde vrouwen en mannen. Ook al leiden sommige ontwikkelingspsychologi-

111 Zie ook Centrale Raad woor de Strafrechtstoepassing (1992) p. 7.

112 Wolleswinkel (1992) p. 230, Lissenberg (1992) p. 271.

113 Zie Verpalen (1994), De Jong (1994).

114 Themanummer Proces (1996) p. 112-113. Vgl. Wegelin (1991) die in haar onderzoek naar voogdijbeslissingen in echtscheidingszaken ook vaststelde dat met name de deskundigen meer gericht zijn op 'potentiële gelijkheid in het bieden van zorg' dan op de feitelijk bestaande zorgrelaties.

115 Zie ook Smit (1990). 
sche theoriëen tot de ideale driehoeksverhouding vader-moeder-kind, de realiteit is $s$, ook voor kinderen, dat de moeder de primaire verzorger is in het kinderleven van alledag. Stabillisering en continuering van de leefsituatie voor het kind is vooral gebaat bij normalisering van de voor het kind vertrouwde situatie. Die kan, door culturele, klassen- of gendergebonden situaties ver afliggen van theoretische gezinsen vaderschapsidealen. Vrouwen hebben belang bij ondersteuning in de feitelijke opvoedingssituatie en bij doorbreking van seksestereotypering. Dat is allebei ook in het belang van hun kinderen. Bij gedetineerde mannen is dat vooralsnog zeer onduidelijk. Over het algemeen zijn ze (nog) niet intrinsiek gemotiveerd voor hun vaderrol. Wellicht zijn ze binnen de detentiesituatie nog wel te porren tot enige activiteit. Daarbuiten is de kans echter groot dat zij, zoals zowele andere vaders, geen prioriteit aan de opvoeding en verzorging van hun kinderen zullen geven. De positie van de gedetineerde vader lijkt nog het meest op die van de (stereotiepe) gescheiden vader. Met bezoek en activiteitenprogramma's kan daarom al relatief snel in een behoefte van vaders en kinderen voorzien worden.

De positie van de gedetineerde moeder is veel ingewikkelder. Deze kan per vrouw zeer sterk verschillen en in haar geval zal er dus steeds in de concrete situatie een plan gemaakt moeten worden, rekening houdend met de bestaande opvoedingsen verzorgingstaken en gericht op het woorkomen van negatieve seksestereotypering, zoals het onnodig problematiseren van alleenstaand moederschap.

\subsubsection{Voorzieningen tijdens detentie}

De achterliggende ideeën over hoe de band tussen de gedetineerde ouders en hun kinderen het best gesmeed of gehandhaafd kan worden, kunnen sterk verschillen. Zo blijkt tijdens conferenties van het European Committee over dit onderwerp dat ook in dit kader onder 'interest of the child' ieder wat anders verstaat. Dat is veelal cultureelbepaald. De Fransen benaderen de driehoek vader, moeder, kind psychoanalytisch. ${ }^{116}$ Hechting en traditionele identificatie zijn uitgangspunt bij interventies. Sommige gezinsleden gaan individueel in analyse en daarna volgt soms gezinstherapie. Er wordt veel aandacht gegeven aan families waarin incest en seksueel misbruik heeft plaatsgevonden, omdat meer dan veertig procent van de incestplegers zelf periodes van hun leven gescheiden van hun families heeft doorgebracht, vaak als gevolg van gezinsproblemen. Juist incestplegers doen vaak een beroep op counselling door professionals van Relais Enfants Parents. ${ }^{17}$ Het is opmerkelijk dat naast de

\section{Ayre (1996).}

117 Ayre (1996), p. 48-51. De theoreische verklaring die Bouregba geeft voor incest door vaders en de mogelijke medeplichtigheid daaraan van moeders luidt (in de Engelse vertaling):

"Unconsciously, the father is looking for proof of a biological link to the child. He wants to proof that he is linked sensually to his child. He becomes an auxiliary mother to a certain extent. The man ceases to exist in his role as a father. Why is the man the father? The child is linked to him by language, by law. In the eyes of the law, one is not a father because one is the genitor, but 
Fransen vooral Belgische deelnemers in deze specifieke problematiek van (kinderen van) gedetineerden gespecialiseerd zijn. ${ }^{118}$ Deelnemers uit andere لlanden lijken, ook vanuit het belang van het kind, meer afstand te nemen tot deze specifieke groep. Al met al lijkt in Frankrijk niet de primaire verzorging de start van een begeleidingstrajekt te zijn, maar vooral 'de rol van de vader' in de psychosociale ontwikkeling van het kind. Zowell in het geval van gedetineerde vaders als in de situatie van de met haar kind gedetineerde moeder wordt door de Fransen de vraag naar voren gebracht: Wat zijn de gevolgen van de afwezigheid van vader? ${ }^{119}$

De Britten willen juist principieel niet uitgaan van de 'afwijkende gezinssituatie' en daarop toegepaste hulpverlening. Zij benadrukken de privacy van de afzonderlijke gezinsleden en proberen tijd, ruimte en sociale condities te creëren waarin ouders hun eigen invulling aan activiteiten kunnen geven. Dat kan zwemmen zijn, maar ook koken, samen bijpraten en knuffelen. ${ }^{120}$ Hoewel er ook projecten met gedetineerde vaders gestart zijn, was men in eerste instantie gericht op de vrouwengevangenissen. En verder staat de belangenbehartiging voor de kinderen erg centraal. Zij worden gestimuleerd hun krachten te bundelen en onderling ervaringen uit te wisselen. Het mentorproject in Nederland lijkt qua uitgangspunten een tussenpositie in te nemen. Enerzijds is het theoretisch gestoeld op psychoanalytische inzichten en in eerste instantie gericht op gedetineerde vaders, maar aan de andere kant ligt er veel nadruk op de opvang van het kind in de eigen omgeving en op ondersteuning van het thuisfront. In Nederland en Duitsland is de betrokkenheid van selfhelpgroepen ook relatief groot, zoals de Vereniging Relaties van gedetineerden, die voornamelijk uit vrouwelijke partners van gedetineerde mannen bestaat.

Aan welke voorzieningen kan nu concreet worden gedacht als het gaat over het handhaven van de band tussen het kind en de gedetineerde ouder? ${ }^{12}$

because one has legally recognised the child as yours. Law, society and language create the bond af fatherhood.

If the father does not feel satisfied with this social bond, he may want to reinforce a sensual bond (a latent desire in all fathers).

No matter what the cost, he takes the risk of eliminating the bond being merely social. By abusing the child, he ceases to be the father. As the stops being the father, he reinforces the mother in her rolle, who is often unconsciously satisfied: she becomes an accomplice to the act. She derives secondary benefits from it; she is elevated in her role as mother.'

118 Zie onder meer Lampo (1996), Igodt (1996) en Vandenbroucke (1996).

119 Zie ook Ter Heine (1995). Op de sludiedag in Nederland werd door de inleiders ook sterk de noodzakelijke band met de vader benadrukt, onder meer vanuit de intergenerationele therapie. De meer praktische beschouwingen over projecten in Sevenum en de vrouwengevangenis gingen over gedetineerde moeders en hun kunderen. (Proces, 1996)

120 Lloyd (1992).

121 Zie ook Proces (1996). 
1. Versnelde detentiefasering en andere differentiatiemogelijkheden

In hoofdstuk drie en vier is de mogelijkheid om het criterium van de verblijfsduur (het strafrestant) bij de detentiefasering los te laten al aan de orde geweest. Ook zou vanaf de aanvang van de detentie een detentieplan per gedetineerde opgesteld moeten worden, waarbij ook aandacht besteed wordt aan diens sociale netwerk, inclusief familierelaties. In Duitsland bestaat al ruim tien jaar de "Frauenfreigang", waarbij vrouwen met schoolgaande kinderen overdag hun taak als moeder en huisvrouw oppakken, als een vorm van "werk" buiten de (halfopen) inrichting. Zij verlaten de inrichting om zes uur's morgens en komen rond negen uur 's avonds weer terug. 's Nachts moet er dan wel oppas gezocht worden. De vrouwen ontvangen een salaris en krijgen de reiskosten vergoed. Er doen ongeveer vijftien vrouwen mee aan dit programma.:22

Ter eerbiediging van het recht op family life zouden de mogelijkheden tot vervroegde invrijheidsstelling en gratiëring benut kunnen worden. ${ }^{12}$

Verder zou de gevangenhouding in de nabijheid van de familie van belang kunnen zijn. Regionalisering en tenuitvoerlegging van het vonnis in het land van herkomst kunnen in dat kader beleidsdoelen zijn.

Ook kan gedacht worden aan vormen van gemengde detentie in samenhang met regionalisering en (half)open detentie. ${ }^{124}$ In Denemarken kunnen gedetineerden het laatste deel van hun straf in het bijzijn van hun familie doorbrengen in een halfweghuis. ${ }^{125}$ De thans bestaande vormen van dagdetentie in Nederland worden ook aan een gemengde populatie aangeboden. Bij het creëren van echte woonvoorzieningen zou wel het feitelijke gezinsleven leidraad moeten zijn. Wellicht zouden dan ook meer kleinschalige 'woon'voorzieningen met eigen budgetten in aanmerking komen. Een goede aansluiting op het openbaar vervoer is in al deze voorzieningen uitermate belangrijk.

2. Aangepaste verlofregelingen

- In het wettelijk regiem kan aansluiting gevonden worden bij het arbeidsrecht, zowel wat de biologische als de sociale ouderrechten betreft. ${ }^{126} \mathrm{Z}$ wangerschaps-en

122 Schmitz-Rossner (1996) p. 174. Zie voor de discussie omtrent het rolbevestigend karakter van deze voorziening Harjes (1985) p. 284-286.

123 Art. 15 Sr. en art. 2 Gratiewet.

124 Zie boofdstuk 3. Zie ook De Jong (1994).

125 Roose (1996) p. 8-9. Er zijn zeven halfweghuizen met ongeveer 25 plaatsen. De wachtlijsten zijn groot.

126 Te denken valt aan: calamiteitenverlof, zorg/verpleegverlof, loopbaanonderbreking, zwangerschapsen bevallingsverlof, kraamveriof, ouderschapsverlof, adoptieverlof. (Zie Ariachne, Verlofregelingen: een tussenbalans, nowember 1996.) 
ouderschapsverlof met (analoog) doorbetaling van loon, gelegenheid tot het geven van borstvoeding, mogelijkheid tot deeltijdwerk etcetera.

- Ook de mogelijkheden voor bijzonder verlof zouden ten aanzien van primaire verzorgers uitgebreid kunnen worden, door bijvoorbeeld niet alleen calamiteiten-, maar ook verzorgingsverlof toe te staan. Wat kinderen betreft, valt daarbij te denken aan verjaardagen, geboorte van (klein)kinderen, ziekte, communie, examen, eerste schooldag, eindfeest groep acht en dergelijke. ${ }^{127}$

- Wellicht zouden gedetineerden ook verlofdagen 'vrij', dat wil zeggen niet gelabe]d, moeten kunnen opnemen, vergelijkbaar met de arbeidssituatie. Voor kinderen is het belangrijk in hun gewone thuissituatie dingen samen met de ouder te doen. Niet naar een sporttoernooi kunnen gaan, omdat er een bezoek aan de gevangenis gebracht moet worden, is bezwaarlijker voor het kind, dan wanneer de ouder de mogelijkheid krijgt het sporttoernooi te bezoeken. In dat opzicht zou aan verloffaciliteiten naar buiten voorrang gegeven moeten worden boven bezoekfaciliteiten binnen de inrichting.

- Ook kan gedacht worden aan het creëren van situaties, waarbij verzorgers en kinderen een dag of een weekend samen kunnen doorbrengen, met name wanneer de reistijden voor familieleden lang zijn. ${ }^{128}$ Kinderen uit een familie die door de detentie van een verzorger gescheiden van elkaar leven, kunnen elkaar zo ook ontmoeten.

- Er kunnen voorzieningen gecreëerd worden voor kinderen waarvan beide ouders gedetineerd zijn. In Zweden heeft men een soort vacantiedorp (Gruvberget) mede voor deze doelgroep ${ }^{12 x}$. Dankzij de natuurlijke omgeving met eindeloze bossen is het ontsnappingsrisico daar vrijwel nihil. Maar er kan in Nederland in eerste instantie ook gedacht worden aan het starten met gezinsmiddagen op een wat gezellige locatie.

3. Expliciete ouderrechten voor gedetineerde ouders.

Het lijkt me mogelijk een aantal 'ouderrechten' expliciet te formuleren en die te koppelen aan eerder voorgestelde 'voorlopige voorzieningen' tijdens de voorlopige hechtenis. Verplichtingen die aan de zorg voor kinderen verbonden zijn kunnen, bij bepaalde handelingen wan of ten behoeve van het kind tot een toestemmingsvereiste van de gedetineerde ouder leiden. Het is van belang in het oog te houden of de betreffende ouder al dan niet met het ouderlijk gezag is bekleed. ${ }^{130}$ Ook de niet

127 Shaw (1992) p. 10.

128 Vgl. Zweden, Fjarstedt en Bishop (1994) p. 20.

129 Huizer-Gerritsen (1992).

130 Buiten de situaties waarin het kind feitelijk doelwit of slachtoffer van het delict was, komt het ouderlijk gezag van gedetineerden in Nederland tot nu toe niet echt in gevaar. Dat is anders in 
met gezag beklede ouder heeft in het onlangs gewijzigde familierecht een aantal rechten gekregen. ${ }^{134}$ Die zouden minimaal gegarandeerd moeten zijn. Te denken valt aan het informatie- en consulttatierecht betreffende:

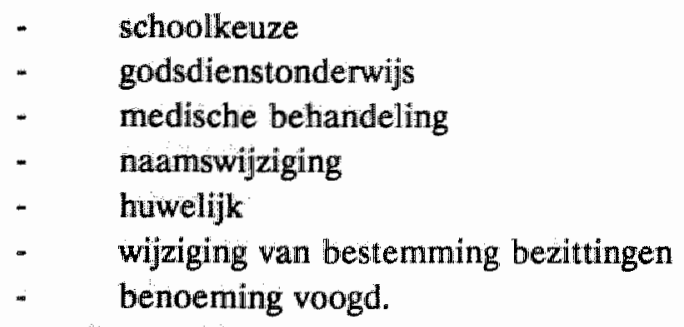

Het recht op omgang voor een uitgebreide kring van personen die in een nauwe betrekking tot het kind staan, kan ook in detentie geeffectueerd worden. ${ }^{132}$ Ik denk met name aan gedetineerde oma's, maar ook aan 'verwantschaps'middagen, die zijn afgestemd op voor voorheen bestaande verzorgingsarrangementen van het kind die door de detentie verstoord zijn.

\section{Aangepaste bezoekregelingen}

- Voor veel kinderen is alleen reizen een probleem. Kinderen zouden begeleid moeten kunnen worden bij hun bezoeken aan de inrichting. Nu wordt er vaak een beroep op familie gedaan, maar de investering in tijd en geld kan zwaar drukken. De mogelijkheid vergoeding van reiskosten aan te vragen de Sociale Dienst, via de bijzondere bijstand, moet aangereikt worden.

- Bezoek zonder toezicht zou niet moeten concurreren met het reguliere bezoek. Bovendien zou het bezoek zonder toezicht niet voorbehouden moeten zijn aan (heteroseksuele) partners. Dat moet ook tot uiting komen in de inrichting van de bezoekkamer. Kinderen willen ook weleens zonder pottenkijkers in de buurt met hun ouder optrekken.

- Bezoekruimtes moeten aangepast zijn aan kinderen, waardoor het ook een beetje leuk wordt om te komen. Wellicht zou er ook enige vorm van kinderopvang

bijvoorbeeld de VS. Zie onder meer Haley (1977), Jackson (1979), Downing (1989), Beckerman (1989).

Gedetineerde ouders in Nederland zijm wel vaak bang het gezag te zullen verliezen. Daardoor zijn zij ook geneigd selectief te rapporteren over problemen van of met hun kind. Zeker als die de relatie tot de vervangende verzorgers zou kunnen schaden. Zie meer in thet algemeen hierover Singer (1991).

$131 \mathrm{Zie}$ art. $1: 377 \mathrm{a} \mathrm{t} / \mathrm{m} \mathrm{h}$ BW.

132 Zie art.1:377r BW.

133 Zie de folder van Save the Children:

"For a súccesful visitor's centre:

* Make sure the Centre is warm and welcoming. 
gerealiseerd kunnen worden, waardoor het bezoek van volwassenen en dat van de kinderen niet hoeven te concurreren.

- Het mentorproject voor kinderen van gedetineerde ouders zou uitgebreid moeten worden en een structurele basis moeten krijgen. ${ }^{134}$

- Er zouden logeermogelijkheden voor kinderen tijdens de vacanties in de omgeving van de inrichting gezocht kunnen worden, met de mogelijkheid om overdag, al dan niet georganiseerd, gezamenlijke activiteiten te ondernemen. ${ }^{1.55}$

- Have a smile and a word for people as they enter the building.

* Provide comfortable tables and chairs.

* Carry information that may be relevant and useful to families on matters such as travel, parcels, assisted visits, visiting hours, wellfare rights and cheap accommodation.

* Be clear about your services-what you offer and when. Mast inportantly, don't raise false expectations by suggesting you can deliver a service which you cannot.

* Offer your services to all small communities likely to want to use them. This may mean, at the least, supplying information in languages other than English and catering for different dietary needsbut there may be other more specific needs you can anticipate.

* Follow proper fire and safety precautions, including drills, regular equipment checks and clear notices in different languages.

* Have a well-equipped first aid box and people who can use it.

* Make sure the building (and the toilets) are accessible to people with disabilities. Consider having an induction loop system and advice from disabled people about their needs.

* Have a canteen or cafetaria offering nourishing and inexpensive food. Be sure that you comply with food hygiene regulations

- Use good quality hard-wearing fittings and furnishings but not in institutional styles or colours. Cutting costs is false economy as cheap materials won't last. And if it feels like a prison, people wil not come to visit.

* Ensure that there are adequate supplies of toilet rolls, soap and other necessaries. Fit a sanitary towel dispenser. Have facilities to prepare food and heat bottles.

* When planning your play provision make sure you meet the requirements of The Children Act. Your local sociall services department will be able to offer advice..

* Make the play area fun, well-equipped and generously supplied with materials like paper, pens, scissors and glue. Cater for a broad range of children and have a worker who can supervise and stimulate."'

In andere landen wordt aandacht besteed aan 'green area's' en speelwoorzieningen buiten. Zie onder andere European Action Research Committee (1996).

134 Holwerda (1994), Schutte (1994) p. 8-9.

135 Vgl. V.S. Zie Briggs (1988) en Rickard (1990). In Tarrengower Prison (Maldon, Australiê) is bij de vrouwengevangenis een apart Family Visit Centre gebouwd, the Bunkhouse. Bij het huis is een kinderboerderij. Tweeëndertig vrouwen leven in acht units en hebben elk een eigen kamer. De units liggen verspreid rond een binnenplaats en zijn gebouwd in de stijl van de landelijke omgeving. De beveiliging is minimaal, het is een open gevangenis. In the Bunkhouse kunnen kinderen tot achtien jaar maximaal drie dagen logeren. Andere familieleden mogen meekomen, maar die moeten dan well een aantoonbare sterke en duurzame band met het kind hebben. De directeur beslist uiteindelijk op de aanvragen die gedaan worden, over de duur, de frequentie en de deelmemers aan de logeerpartij. Ook worden er sinds 1990 wacantieprogramma"s op Tarrengower georganiseerd. 
5. Het detentieverblijf van de verzorger, met name de arbeid en de recreatietijd, kan zinvol gemaakt worden ten behoeve van thuis. De buitenlandse vrouwen sparen vaak al. Er kan ook gedacht worden aan direct op de kinderen gerichte activiteiten zoals brieven schrijven, truien breien, kleren/speelgoed maken, groente/fruit inmaken, Sinterklaas/Kerstsurprises verzorgen. In Frankrijk vervult Relais Enfants Parents ook in dit opzicht een belangrijke rol. ${ }^{136}$ Met de moeders worden workshops georganiseerd, waar al knutselend veel wordt afgepraat en moeders ook ondersteund worden in hun moederrol. Vaders krijgen wel materiaal, maar maken daar vaak, ieder voor zich, iets van in hun cel. Mannen vinden het in de gevangenisssituatie moeilijk om zich 'als vader' te manifesteren. ${ }^{137}$ Medewerkers van Relais noemen het opvallend dat moeders steeds praten over de behoefte van het kind aan hun zorg en bemoeienis, terwijl bij vaders de eigen behoefte aan liefde van hun kinderen centraal staat. Moeders zijn bang hun kind in de steek te laten, vaders om rechten te verliezen, verstoten te worden. In beide gevallen is het goed terug te grijpen op het alledaagse bestaan van het kind en te kijken of je daarin iets kunt betekenen. Met name vaders moeten daarop worden getraind: Van welke boeken houdt je kind, naar welke televisieprogramma's kijkt het, heeft het een lievelingskleur of speelgoed etcetera? Zo leren ze over hun kind te praten en niet steeds over zichzelf.

\subsubsection{Verblijf van kinderen bij hun ouder in detentie}

Op grond van art. 31 Gevangenismaatregel, jo art. 8 EVRM zouden tijdens de vrijheidsbeneming voorzieningen getroffen kunnen worden voor een eventueel permanent verblijf van jonge kinderen. De vraag of dat ook in gesloten inrichtingen zou moeten kunnen, blijft ook in het nieuwe art. 12 w.o. PBW actueel.

Er is in de halfopen gevangenis voor vrouwen Ter Peel in Sevenum een moeder-metkind-unit voor kinderen tot vier jaar. ${ }^{138}$ Versterking van het sociale netwerk van moeder, via scholing, werk, vrouwenhulpverlening komt in het beleid nog niet echt tot uiting. De kinderen gaan wel naar een crèche buiten de inrichting, maar hun leven wordt verder door de regels van het instituut bepaald. Ze kunnen niet naar verjaardagsfeestjes, ze krijgen eten van de centrale keuken en moeders met kinderen kunnen niet zomaar even gaan fietsen, picknicken, winkelen of naar het zwembad gaan. Voor een deel lijkt dit laatste 'opgelost' te worden door de verlofmogelijkheden van moeder en kind in de halfopen inrichting. Bovendien kan er een aan de gedetineerde gekoppelde p.o.i.status verleend worden. De doelgroep leek aanvankelijk

Zo kunnen familiebanden gecontinueerd worden, zonder dat de stabiele leefomgeving van het kind verstoord wordt. Bovendien hebben de verwangende verzorgers dan even vrijal.

136 Zie Ayre (1996) p. 29-38.

137 Alleen Relais Enfants Parents in Haute-Normandie heeft een workshop voor vaders kunnen organiseren.

138 Zie hoofdstuk 3. 
vooral te zullen bestaan uit vrouwen die hun kind in de inrichting hadden gebaard of die direct vanuit hun dagelijkse zorg opgenomen werden, zonder dat zij in staat waren betrouwbare opvang voor hun kind te regelen, zoals sommige preventief gehechten en zelfmeldsters. Nu deze voorziening er is, lijkt er een hulpverleningsaanbod in te sluipen ten behoeve van de reïntegratie van moeder en kind.

Vooruitlopend op de resultaten van het experiment in Sevenum is in de ontwerpPenitentiaire Beginselenwet reeds voorgesteld een artikel op te nemen, waarin de minister inrichtingen kan aanwijzen waar verzorgers hun kind kunnen meenemen in de inrichting. ${ }^{39}$ De directeur moet toestemming verlenen en daarbij oog hebben voor de orde, rust en veiligheid in de inrichting en voor het belang van het kind. Ten behoeve van die laatste taak kan hij advies vragen aan de Raad voor de Kinderbescherming, zo luidt het wetsvoorstel. Dit alles betekent ook dat, vergeleken bij de huidige wetstekst niet meer de behoefte van het kind de eerste ingang tot de voorziening is, maar de wens van de (sekseneutrale) verzorger. Bovendien is het betreffende artikel vrijwel gelijkluidend in de nieuwe wetgeving voor t.b.s. en jeugdinrichtingen terecht gekomen. ${ }^{140}$ De ontwikkeling van de ouderrol lijkt mij in de genoemde sectoren heel specifiek en nogal verschillen van die van de 'normale' gedetineerde ouder. ${ }^{141}$ De invulling van 'het belang van het kind' geheel aan het oordeel van de directeur overlaten lijkt mij tegelijkertijd riskant en tè vrijblijvend. ${ }^{142}$ Enerzijds omdat de meeste directeuren geen specifieke knowhow op pedagogisch gebied zullen hebben, anderzijds omdat een directeur ook andere managementbelangen heeft, zoals een het zorgen voor een goede 'bezetting.' ${ }^{13}$

Co-detentie is niet onomstreden. ${ }^{144}$ Met name in de Scandinavische landen met een hoge emancipatiegraad van de vrouwelijke bevolking heeft men de neiging het kind niet mee te laten lijden onder de straf van de moeders. ${ }^{145}$ Daar is het maatschappelijk niveau van materiële en opvangvoorzieningen voor kinderen hoog, omdat veel kinderen sowieso buitenshuis opgevangen worden. Dat past bij het normale leefsysteem, waarin vrouwen veelal buitenshuis werken. Wel wordt in bijvoorbeeld Zweden heel veel aandacht gegeven aan bezoekregelingen en vakantiemogelijkheden. In andere, vooral zuidelijke, landen is het verblijf van het jonge kind in de fysieke

139 Zie hoofdstuk 4.

140 TK 1993-1994, 23.445, art. 46, woorontwerp Beginselenwet jeugdinrichtingen, art. 14 (6 maart 1996).

141 Zie voor kritisch commentaar op dit onderdeel in het w.o. t.b.s. Krooi (1994).

142. In Zweden is de indicatiestelling voor co-detentie niet in handen van de Prison Administration, maar in die van een "local social welfare committee" (Fjarstedt en Bishop (1994) p. 19). Zie ook Richard (1990), p. 12.

143 Er moet ook in het gevangeniswezen steeds bedrijfsmatiger gewerkt worden. Dat betekent onder andere dat er gestreefd wordt naar een bezettingspercentage van $103 \%$

144 Zie onder meer Maelicke (1983) p. 144-147, Pépic (1986), Birtsch en Rosenkranz (1988), Dillner (1992) p. 933, White (1989) p. 106-109, Catan (1992), Maelicke (1993), p. 226-230.

145 Zie ook Huizer-Gerritsen (1992). 
nabijheid van de moeder meer vanzelfsprekend, al blijken de aantallen betrokken kinderen in de participerende landen sterk uiteen te lopen. ${ }^{146}$ De gevangenisregels zijn per land vaak wel centraal tot stand gekomen. Maar de creativiteit van de mensen ter plekke lijkt bepalend te zijn bij het doorbreken van het centralisme binnen het gevangeniswezen. Zo hebben de moeder-kind units in éénzelfde land toch vaak een andere invulling gekregen ${ }^{\mathrm{i}}{ }^{17}$ In zijn algemeenheid blijkt de gevangeniscultuur tussen de landen onderling moeilijk te vergelijken te zijn.

Argumenten voor co-detentie worden veelal gebaseerd op de ontwikkelingspsychologie:

- een plotselinge scheiding van moeder en kind moet vermeden worden;

- een uithuispiaatsing naar een tehuis of vreemden kan slechter zijn dan co-detentie;

- er kan in de inrichting een positieve moeder-kindbinding worden ontwikkeld;

- de moeder kan opvoedingsondersteuning krijgen;

- een goede verzorging van het kind is gedurende detentie gegarandeerd;

- tijdens de detentie kan al gewerkt worden aan de nazorg, zoals huisvesting, financiën, kinderopvang, werk.

Argumenten daartegen berusten vaak op sociologische en sociaalpsychologische inzichten:

- het gesloten karakter van de inrichting beperkt het kind onnodig in zijn of haar bewegingsvrijheid en spontaniteit;

- vaak kan een moeder niet alle kinderen meenemen en wordt een kind gescheiden van broertjes en zusjes;

- de contacten met de familieleden buiten de inrichting zijn sterk beperkt.

- de gevangenis als leefomgeving kan naar het kind meestal niet verklaard worden;

- het kind ervaart de onmacht en afhankelijkheid van de moeder, vooral door het 'sleutel- en opsluitingsgeweld';

- er kunnen ontwikkelingsstoornissen bij het kind ontstaan;

- voor alle betrokkenen treedt stress op. Vaak worden de negatieve kanten van het samenwonen van een groep moeders en kinderen onderschat;

- het personeel is niet ingesteld op het werken met kinderen;

- zowel personeel als moeders verwachten teveel van kinderen in de zin van 'klimaatverbetering'. Zij houden geen rekening met stressfaktoren bij kinderen, zowel vanuit de natuurlijke groei als in hun reactie op de omgeving.

- in de gevangenis vindt een sterk'vrouwelijke' socialisatie plaats. Het mannelijke element ontbreekt nagenoeg geheel.

- de vrouwen die bewust of ongewild geen moeder zijn, kunnen zich benadeeld en gestereotypeerd voelen.

146 Ondermeer Alliance NGO's (1987), European Action Research Committee (1996).

147 Zie bijvoorbeeld Maelicke (1995). 
Ondanks de per land zeer uiteenlopende aanpak blijkt een aantal zorgen en aandachtspunten gemeenschappelijk te zijn ${ }^{148}$ :

- Met name de schuld- en schaamtegevoelens van de moeder ten opzichte van haar kind worden genoemd. De moeder vertoont vaak een ambivalente houding. Enerzijds is zij geneigd tot 'samensmelting', anderzijds juist tot afwijzing. Vaak blijken de schadelijke gevolgen van deze ambivalentie voor het kind pas na de detentie op te treden.

- Voor het kind is het belangrijk dat het zoveel mogelijk normaal socialiseert, dat wil zeggen dat het overdag met andere kinderen optrekt, dat moeder en kind geen gijzelaar worden van elkaar of van het systeem, dat het recht van moeder en kind op een privéleven erkend wordt, dat het kind niet meer dan normaal aan de vrijheid onttrokken wordt. De behoeften van het kind gaan voor de gevangenisregels. In Duitsland fouilleert men de kinderen bijvoorbeeld ook niet meer. Dat wordt een aanvaardbaar en noodzakelijk te nemen risico geacht.

- Er moeten financiële middelen zijn om aan de voorwaarden op medisch, pedagogisch, sociaal en hygiënisch gebied te voldoen. Voeding verdient speciale aandacht.

- $\mathrm{Er}$ is geen volkomen systeem; in feite moet co-detentie voorkomen worden.

- Belangrijk is ook dat het verblijf bij de moeder niet mag leiden tot verbreking van het family life met anderen, bijvoorbeeld met broertjes, zusjes, de vader of grootouders.

Over het algemeen zijn schadelijke effecten van co-detentie voor kinderen (nog) niet aangetoond in onderzoek. ${ }^{149}$ Effecten hangen niet alleen af van externe condities, maar ook van de leeftijd waarop het kind meegedetineerd wordt en van de duur van de detentie. De theoretische inzichten daarover verschillen sterk. ${ }^{150} \mathrm{Het}$

148 Maher (1988). Zie ook: Relais Enfant Parents (1993), Rickard (1990). Problemen die in Tarrengower Prison (Australië) gesignaleerd worden, zijn met name:

- kleinzielige jaloezie tussen gedetineerde ouders onderling;

- niet-acceptatie door andere gedetineerden. Sommigen willen geen kind in hun unit;

- onvrede over geconstateerde privileges;

- gezagsproblemen bij de moeder, door de verschillende invloeden van allerlei volwassenen. op het kind":

- de moeite die moeders hebben met het aanleren van ruwe taal door hun kind.

Toch noemt hij het resultaat bemoedigend. Het is wel zo dat men er in Australiè de woorkeur aan geeft de bestaande verzorgingsarrangementen van het kind te handhaven of te zoeken naar levensvatbare alternatieven. De gedetineerde moet het verzoek indienen en motiveren walarom alternatieven voor haar kind niet geschikt zijn. Voor de platsing van ieder kind worden 'community agencies' en de vervangende verzorgers geconsulteerd en worden de juridische stat us, het toexicht en de omgangsregelingen vastgesteld. Overdag gaan de kinderen naar een 'buitencreche".

149 Birtsch, Riemann und Rosenkranz (1983), Catan (1989, 1992), Biondi (1996).

150 Ter illustratie wan de verschillen in leeftijden zie Baulon (jaar onbekend), Alliance of NGO's (1987), European Action Research Committee (1996). In Spanje is per 1 januari 1996 de Jeeftijdgrens voor co-detentie omlaag gebracht van 6 naar 3 jaar. (Relais Enfants Parents, 1996). 


\section{Hoofdrow 8}

is ook moeilijk een controlegroep ten behoeve van onderzoek te vinden die kan dienen ter vergelijking. In Italie was geen controlegroep, in Duitsland bestond de controlegroep uit kinderen die in een tehuis waren geplaatst en en Engeland uit kinderen van gedetineerde vrouwen die bij familie of pleegouders waren geplaatst. Deze beide groepen werden weer vergeleken met baby's die een universiteitscrèche bezochten. ${ }^{\text {sI }}$ Toch zijn ook de onderzoekers niet voor co-detentie. Het lijkt slechts een noodzakelijk kwaad om andere, slechtere oplossingen te vermijden. In feite geven ook de moeders aan dat zij ter verbetering van de familierelaties niet in eerste instantie aan co-detentie denken. $Z_{i j}$ willen meer betrokken zijn bij het gewone leven van het kind buiten de inrichting. ${ }^{152}$ Ook Marie-France Blanco van Relais Enfants Parents vertelt hoe de inrichting, die al bezig was met de voorbereiding van een kinderunit, plotseling op het verkeerde been stond toen de uitslag van een enquête onder moeders binnenkwam:

"The women's greatest need was to be listened to and assisted in seeing their children again. We quickly had to treorient the project. Mothers had endless questions, and their questions were nearly identical to the children's- everything revolved around daily life."153

\subsubsection{Co-detentie in het buitenland}

Juist in het belang van het kind moeten eerst alternatieve vormen van straf voor de verzorgende ouder worden overwogen. Is detentie, bijvoorbeeld gezien de aard van het delict en de recidivekansen onontkoombaar, dan zullen verzorgingsarrangementen gecreëerd moeten worden waarbij het kind buiten de gevangenismuren socialiseert en waarbij het handhaven van het contact tussen ouder en kind prioriteit heeft. ${ }^{154}$ Hoewel ik co-detentie dus niet bepleit en slechts in een beperkt aantal

151 Catan (1989) p. 9-12, Catan (1992).

152 Zie ook Van Kesteren (1996).

153 Ayre (1996) p. 23

$154 \mathrm{Vgl}$. Maher (1988) p. 32. Niet de vraag 'should children be allowed to stay with their mothers in prison?' moet centraal staan, matr. "How do we keep a child with her/his mother without sending them to prison?" In 1987 is door de United Nations Alliance of Non-Governemental Organisations (NGO's) on Crime Prevention an Criminal Justice een wereldwijde studie verricht naar vormen wan co-detemtie. (zeventig landen, niet in Nederland.) Er werd een enorme variëteit in omstandigheden gevonden waaronder co-detentie plaatswond. Op sommige plaatsen voelde men zich overigens veiliger in de gevangenis dan daarbuitem. De aanbevelingen luiden "in decreasing order of suitability.

1. Alternatives to imprisonment. These includes practices as house arrest, community service and restitution. Whenever possible, a suspended or conditional sentence or one which would allow the women to continue to live at home should be the first alternative for a mother with young children.

(Throughout this report, reference is made only to children being with their mothers. While this is the situation in almost all of the reported countries, there were instances of a son with his father 
gevallen onontkoombaar en aanvaardbaar acht, geef $i k$ hier een paar woorbeelden van vormen van co-detentie in het buitenland, om de diversiteit in opvangvormen te illustreren.

Allereerst Frankfurt-Preungesheim in Hessen, Duitsland. ${ }^{4 s 5}$ De moeder-kind unit begon in de gesloten inrichting in 1975. Nu is het een open afdeling, buiten het gevangenisterrein. $\mathrm{Er}$ is plaats voor achttien vrouwen met kinderen tot de leeftijd van zes jaar. Frankfurt is zeer "forschrittlich" vergeleken bij de andere plekken in Duitsland waar moeders met kinderen gedetineerd worden. ${ }^{150}$ Alleen hier is sprake van een separaat open huis. Werken is voor de vrouwen verplicht. Er wordt buitenshuis geld verdiend. Het geld wordt gebruikt om "Haftkosten" te betalen en eventueel

(India) and with an older sister (Peru). For the safety of a child, allowing it to be with its father in prison in not recommended. However, all of the alternative sentences for mothers with children apply equally to fathers with child-caring responsibilities. For the purpose of these recommendations, 'mother' includes the natural mother or any other person with primary responsibility for the child.) A sentence in which the mother remains at home permits young children to be with their mother without suffering any of the negative consequences of being in prison. It also solves the problem that exists in many countries of older children who, if not claimed by family or friends, become street children. (In addition, the woman does not add to the overcrowding plaguing most prisons while saving the State money.)

2. Community centres. Community-based residences should be the next alternative for those mothers (and fathers) who require more superwision than can be afforded in the home setting. The facility can be designed for women with children, with special programming for the children and childrearing instruction for the mothers. The child has the advantage of a setting more closely approximating the real world, opportunity to leave the facility and play and go to nursery school with other children.

3. Seperate unit. If the determination is made that the safety of society requires that the mothers be confined in prison, it is still possible to avoid imprisoning the children. A seperate unit can be provided outside the security of the prison but part of or adjacent to it. The children would reside in this unit, with free aceess to the outside world for play and school. Mothers would reside within the security of prison and be with their children after their work is finished. Seperation from one's child is not to be used as a punishment.

4. In prison. Actually placing children in a prison, subject to all of its confinement, should only be used if there are no other arrangements that can be made for its care in the outside world. Until there is a special unit described above, there are ways to lessen negative effects of imprisonment. Mothers with children should be housed in seperate rooms or in a separate dormitory. If that is not possible and there are several children, they should sleep together in a seperate area. If there is only one child and it is sleeping with its mother, seperate bedding should be provicled. 5. Community activities. Whatever arrangements are provided, frequent opportunities should be provided for the children to leave the institutions to go to school in the community, to visit family and friends or to play with other children. The children should be allowed to leave the institutions on a daily basis, at least to run and play." (Alliance of NGO's on Crime Prevention and Criminal Justice (1987), p. 11)

155 Zie onder meer Bieback-Diel en Maelicke (1985), Bernhard (1988) p. 51-54.

$156 \mathrm{Er}$ is één keer een - Nederlandse - man met een kind in huis geweest. Dat ging prima. Maelicke (1992), Schmitz (1996). 
voor schuldsanering. Daarnaast wordt overbruggingsgeld gespaard voor na het ontslag. In het huis beschikken de vrouwen over een eigen budget. $\mathrm{Zij}$ doen de inkopen en koken ook zelf. Zo leren de vrouwen te budgetteren en gezonde maaltijden samen te stellen. De vrouwen krijgen apart "Erziehungsgeld". Daarvoor kunnen zij bijvoorbeeld luiers kopen. Men denkt dat bijvoorbeeld de zindelijkheidstraining meer kans van slagen heeft door de moeder in haar portemonnee te laten voelen dat zij ruimere bestedingsmogelijkheden ten behoeve van het kind heeft als ze geen dure luiers meer hoeft te kopen. In het huis werkt gespecialiseerd personeel. Het tijdstip waarop de kinderen geplaatst worden is niet meer afhankelijk van het restant van de straftijd van de moeder. Doel is de kinderen zo snel mogelijk in een open inrichting te plaatsen. Het kind kan tot drie jaar 'binnen' opgevangen worden. Daarna wordt zeker gestreefd naar een plaats in een crèche buiten de inrichting. Men vindt het beter wanneer het kind al eerder, met tien tot twaalf maanden, naar buiten treedt. Het is goed als het dan andere mensen en dingen ziet. Problemen treden bij de kinderen vooral op als zij de omgeving gaan ontdekken, rond de leeftijd van een jaar. De moeders hebben het idee dat zij hun kinderen dan niet langer tevreden kunnen stellen. Ze willen met hen de stad in, fietsen, naar dieren kijken. Preungesheim wordt vaak als "paradepaardje" gepresenteerd, hoewel de directie zelf wat sceptisch is over de uiterlijke schijn..$^{157}$

In de gesloten inrichting is nog een apart huis gecreëerd met vijf plaatsen, die bestemd zijn voor moeders met kinderen, waarvan het vooronderzoek nog loopt. Er wordt bij toelating van een moeder met kind een grens aan de eventueel te eisen maximum straf van negen jaar(!) gesteld, zodat de feitelijke strafduur nooit het langst mogelijke verblijf kan overstijgen. Tijdens het voorarrest krijgen de vrouwen de eerste week de mogelijkheid om allerlei zaken te regelen. Op de gesloten afdeling hebben de moeders een sleutel van de eigen kamer. Het aantal plaatsen wordt bewust klein gehouden om doorschuiven naar het open deel te bespoedigen. In de inrichting werkt een vrouwelijke inrichtingsarts. Eventuele verwijzingen naar artsen buiten de gevangenis worden onder begeleiding gerealiseerd. Eenmaal per week komt een kinderarts langs. De vrouwen maken zelf het eten klaar. De ingrediënten worden aangevoerd. De kinderen kunnen overdag -met een busje- naar de crèche gaan.

Een aparte probleemcategorie vormen de Zuid-Amerikaanse vrouwen en gedetineerde paren. De rechter beslist wat er tijdens het voorarrest geregeld wordt met betrekking tot het bezoek. Ten aanzien van vreemdelingen wordt samen met de daarmee belaste autoriteiten beslist of er sprake kan zijn van plaatsing in een open regiem.

157 De directie vindt dat de voorziening te groot is geworden. Er is een omslagpunt bereikt. Men wil nu alleen nog maar reageren op een duidelijk verzoek van de ouder en men vindt dat er bij voorkeur naar een andere oplossing gezocht moet worden voor het kind. Als er geen andere oplossing is, zou er bij opname in de inrichting eventueell vooraf geselecteerd moeten worden. 
In Frankrijk verblijven vijfenvijftig à achtenzestig kinderen onder de achttien maanden bij hun moeder. Zij zijn verdeeld over drieëntwintig afdelingen van leder een tot vijf plaatsen. De gevangenissen kunnen zelf het beleid invullen. Zeven afdelingen, waaronder Marseille en Lyon, hebben kinderopvang buiten de inrichting gezocht. Alleen in Fleury-Mérogis is een babystation voor kleine kinderen. Hier kunnen vijftien moeders en zestien kinderen, als er een tweeling bij is, verblijven. Na achttien maanden gaan de kinderen naar pleeggezinnen.

Er komen zelden kinderen van buiten in de gevangenis wonen. De meeste moeders waren zwanger toen zij gedetineerd werden. $\mathrm{Zij}$ zitten in eenpersoonscellen, maar de leefruimte is tamelijk klein. Overdag gaan de kinderen naar de crèche, waar een kinderverzorgster, een gespecialiseerde kracht en een opvoedkundige werken. De moeders kunnen overdag werken, maar hoeven dat niet. Er is ook een officieel zwangerschapsverlof van acht weken. Als de moeder niet werkt, kan haar kind toch naar de crèche. In feite brengen de moeders met hun kind zestien uur op hun cel door, waarvan de deur dan vaak open staat. Het babystation beschikt over een klein busje, waarmee ze met de kinderen naar buiten gaan, bijvoorbeeld naar de markt. De kinderen eten samen. De moeders eten apart op hun cel. 's Nachts worden de cellen afgesloten. De moeder heeft geen sleutel. Bij onrust klopt zij op de deur, de bewaker beoordeelt de situatie en waarschuwt indien nodig de chef-bewaker die een sleutel heeft.

De psychologe die in het Fleury-Mérogis werkt, zegt dat

- de moeders altijd een negatief zelfbeeld hebben. Ze hebben dubbele schuldgevoelens, over het delict en over het feit dat ze zichzelf een slechte moeder vinden. Het maakt daarbij eigenlijk niet uit of het kind binnen of buiten de inrichting verblijft;

- andere gedetineerden denken dat de moeders worden voorgetrokken. Zij hebben eenpersoonscellen en douches en zij worden minder snel gestraft en/of geïsoleerd. Moeders zijn zich hiervan bewust, maar durven daardoor hun moeilijkheden niet meer aan de orde te stellen;

- het systeem de vrouwen infantiliseert. Hun eerste status is die van gevangene, niet die van moeder. Eventuele moeilijkheden worden altijd uitgelegd in termen van 'weerstand bieden, lastig zijn'. De infantilisering blijkt ook uit het feit dat alles wordt aangeleverd, zoals het eten en de kleren. De zelfzorg is minimaal;

- er veel intriges binnen de afdeling zijn, bijvoorbeeld rond moeders die niet werken;

- de geïnfantiliseerde moeder geen verantwoordelijke moeder wordt. Zij verkeert in een gijzelingssituatie. De moeders worden erg afhankelijk van het personeel. Zo kunnen bewakers de moeder bang maken. ("We nemen je kind weg") Anderzijds maken moeders ook gebruik van hun kind, ze nemen het graag mee naar de onderzoeksrechter; 


\section{Hoofdstuk 8}

- de moeders teveel verwachten van hun kind en van hun status als jonge moeder. Dat het kind huilt, tandjes krijgt en zeurt zijn enorme tegenvallers. De moeder denkt dat het kind haar straft, dat zij geen normaal kind heeft kunnen baren.

- de kinderen dikker en ronder zijn dan gemiddeld. Zij krijgen meer dan waar ze werkelijk behoefte aan hebben;

- de kinderen hinder hebben van het systeem, zoals de fouillering en voortdurende controles (licht aan, raampje open).

Bij co-detentie, als ultimum remedium, zal vanuit 'het belang van het kind' altijd naar de pedagogische randvoorwaarden van de voorziening moeten worden gekeken, gerelateerd aan de leeftijd en de aard van het kind en de duur van het verblijf. Contact met leeftijdgenoten en 'de buitenwereld', ook in ruimtelijke zin, zijn daarbij belangrijke criteria. Het is niet voldoende om binnen de gevangenismuren een 'kinderwereld' te creëren. Veel opvoedkund ige activiteiten ontstaan, min of meer toevallig, in relatie tot de omgeving waar de verzorger zich ophoudt. Dingen die je overkomen bij het boodschappen doen, het 'geld uit de muur halen', het reizen met tram of bus, het oude brood aan de eenden voeren of een brief posten, zoals de straatmuzikant, het praatje met de buurvrouw, de geur van versgebakken brood, een onverwachte onweersbui of de eerste krokussen die je in het voorjaar ziet.

\subsection{Tot slot}

Voor de meeste gedetineerde mannen, niet primaire verzorgers, zal ten behoeve van het contact met hun kinderen, aansluiting gezocht kunnen worden bij de ontwikkelingen in het familierecht, vergelijkbaar met de positie van gescheiden vaders. Voor gedetineerde vrouwen bieden de huidige concepten van 'family life' weinig aanknopingspunten. Dat pleit voor een genderspecifieke benadering waarbij rekening gehouden wordt met de feitelijke zorgtaken die iemand voordat zij werd opgepakt had. Het onderscheid tussen de gedetineerde vrouwen onderling, ook in het moederschap, is daarbij in het algemeen veel relevanter om te onderzoeken dan het onderscheid tussen hen en gedetineerde mannen.

In de zorg voor hun kinderen treden cultureelbepaalde verschillen op, waarmee rekening gehouden moet worden. Daarom zal één voorziening waar ieder gelijkelijk gebruik van kan maken, niet voldoen. Juist de verschillen in feitelijke zorg en opvoedingsstijlen moeten via een contextuele, leefsysteemgerichte benadering in individuele gevallen zichtbaar worden. Pas dan kunnen er consequenties aan verbonden worden. Dat zou moeten gebeuren tijdens alle fasen van het strafproces: vanaf de arrestatie, de preventieve fase tot en met het eventueel uitvoeren van een vrijheidsstraf. Met name bij de straftoemeting zou in de strafmodaliteiten proportioneel rekening gehouden moeten worden met de feitelijke zorg voor kinderen. 
De eigen wensen en behoeften van kinderen en de leeftijdsfase waarin ze zitten zouden bij de afwegingen betrokken moeten worden. Naarmate de rechter een modaliteit kiest die relatief gezien een grotere inbreuk op het 'family life veroorzaakt, dient de rechtvaardiging daarvan aan strengere motiveringseisen te voldoen. Een gedifferentieerde benadering kan er dan echter ook toe leiden dat de rechtsposïtie van bepaalde gedetineerde vrouwen bijvoorbeeld dicht bij die van de gescheiden man komt.

Ook in het collectieve regiem dienen negatieve gevolgen van seksestereotypering vermeden te worden. Dat betekent dat in een regiem waarin het leefsysteem veel aandacht krijgt en waarin bij het creëren van voorzieningen van binnen naar buiten gewerkt wordt, ook vrouwen die niet primair op verzorging gericht (willen) zijn, onder dat regiem kunnen vallen. Niet alleen kinderopvang, maar ook vrouwengezondheidszorg, vrouwenvakscholen, politieke, sociale en basisvormende activiteiten, veelal met aandacht voor culturele identiteit zouden juist in de 'publieke sfeer' buiten de inrichting gezocht moeten worden, zodat vrouwen ook na de detentie niet per se in hun privé-isolement terugvallen. Binnen een dergelijk 'normaliserend' regiem zou, afhankelijk van het resocialisatiedoel, ook gemengde opvang van mannen en vrouwen, met eventuele differentiatie naar culturele achtergrond, tot de mogelijkheden kunnen behoren. 


\section{Samenvatting}

In dit onderzoek staat de (rechts)positie van gedetineerde moeders centraal en met name de vraag in hoeverre zij aan hun positie van feitelijk verzorgende ouder rechten kunnen ontlenen ten aanzien van de overheid of derden.

In de hoofdstukken een tot en met vier worden de gedetineerde moeders als 'criminele vrouwen' beschreven. In de hoofdstukken vijf tot en met zeven gaat het in het algemeen om 'het moederschap in relatie tot het belang van het kind' en de betekenis van het in verdragsartikelen beschermde family life en private life. In het laatste hoofdstuk worden de inzichten uit de voorgaande hoofdstukken met elkaar verbonden, waarbij ook vanuit een genderspecifieke benadering suggesties worden gedaan voor beleid en regelgeving.

In hoofdstuk een is onderzocht welke verklaringen er te vinden zijn voor het feit dat $z o$ weinig vrouwen in vergelijking tot mannen strafbare feiten plegen. Tot het midden van de negentiende eeuw kwamen er relatief veel meer vrouwen dan nu in aanraking met het justitiële apparaat. Sinds de industriële revolutie en de opkomst van de medische en in het kielzog daarvan criminologische wetenschap lijkt het aandeel van vrouwen in de criminaliteit zeer gering. Dat kan te maken hebben met de soort delicten die strafbaar gesteld zijn of met de wijze van registreren en interpreteren. Sommigen zoeken echter ook naar meer fundamentele verklaringen, zoals biologische en psychologische verschillen tussen mannen en vrouwen. Anderen richten zich op sociaalpsychologische en sociologische verklaringen. Met name sociale controlemechanismen worden onderkend als belangrijke bepalers van crimineel gedrag. De vraag komt op waarom vrouwen dan zo gevoelig zijn voor sociale controle. Het antwoord wordt met name gezocht in socialisatietheorieën. De rolverwachting ten aanzien van vrouwen is anders dan die bij mannen. Vrouwen worden met relatiedoeleinden opgevoed, gericht op voortplanting, moederschap en zorg voor anderen. Mannen worden met statusdoeleinden opgevoed, gericht op kostwinnerschap en hiërarchische relaties. Criminaliteit van vrouwen wordt deels verklaard uit onaangepastheid en deels uit verzet tegen de voorbestemde rollen. De moederschapsideologie speelt in de diverse verklaringstheorieën een belangrijke rol. Enerzijds om op grond van de persoonlijkheids- en socialisatieleer het aangepaste, niet criminele gedrag van vrouwen te verklaren. Anderzijds om de deviantie gepsychiatriseerd als 'ontsporing' of gepolitiseerd als 'verzet' te benoemen. Nu seksualiteit en moederschap, 


\section{Samenvatting}

dankzij de beschikbare woorbehoedsmiddelen en de legalisering van abortus, niet

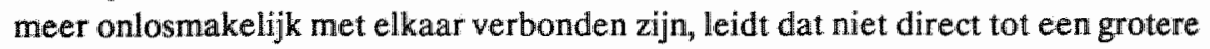
vrijheid van vrouwen, die ook wordt weerspiegeld in criminaliteitscijfers. In het laatste decennium komt er een hausse aan onthullingen rond seksueel misbruik en mishandeling van vrouwen en kinderen boven tafel. Juist ook criminele vrouwen blijken daarvan slachtoffer te zijn of te zijn geweest. De dichotomie tussen dader en slachtoffer wordt doorbroken. Feministische criminologen tonen aan dat criminaliteit en ook de criminologie niet sekse-en genderneutraal zijn. In feite worden mannen en uitwassen van mannelijk gedrag bestudeerd. De strafbaar gestelde delicten, de criminaliteitsregistraties en de interpretatie van beide leiden tot veel 'blinde vlekken'. Niet alleen onderscheid naar sekse en leeftijd, maar ook naar klasse en etnische afkomst wordt nog onvoldoende en zeker niet geintegreerd onderkend. De ontwikkeling van heit genderbegrip heeft wel duidelijk gemaakt dat er een veelheid aan dominante cultuurbepaalde constructies is die de beschrijving en bestudering van de criminaliteit beinviloeden.

Het tweede hoofdstuk gaat over de gevangeniscultuur. Aan de hand van ervaringen van gedetineerde vrouwen wordt aandacht besteed aan hun onderlinge verhoudingen; hun verhouding tot de mensen die met hen werken, aan hun dagbesteding, hun relaties buiten de inrichting, hun seksualiteitsbeleving, het gemis aan privacy en de behoefte aan intimiteit. Er zijn verschillende studies gedaan naar het effect van een verblijf in totale instituties op (vrouwen)levens. Vanuit onderzoek naar psychosociale processen wordt geconstateerd dat het overlevingsgedrag van vrouwen vooral op aanpassing is gericht. De seksuele contacten die vrouwen in detentie aangaan lijken met het 'naspelen van het gezin' te maken te hebben. Vrouwen zouden in gevangenschap met grotere identiteitscrises dan mannen te maken krijgen doordat zij gesocialiseerd zijn in afgeleide identiteiten. (als dochter van, partner van, moeder van...) Vooral seksualiteit is voor veel vrouwen het middel om zich een plek te verwerven in een bepaalde maatschappelijke structuur. Ook vrouwen die niet aan een vaste leefsituatie gebonden waren voor hun detentie, voelen zich afgesloten tot de mogelijkheid daartoe. Als er in het detentiebeleid rekening wordt gehouden met de seksespecifieke rol van vrouwen, dan staat die in wrang contrast met de maatschappelijke werkelijkheid, waar de oorspronkelijke basis door de detentie vaak zo goed als verdwenen is. Vanuit de emancipatietheorie wordt de versterking wan de rechtspositie van gedetineerden als tegenwilcht tegen de effecten van de totale institutie naar voren gebracht. Die lijkt op mannen een meer emanciperend effect te hebben dan op vrouwen. De gevangenis steeds meer te doen lijken op de 'normale samenleving', als strategie tot gevangenishervorming, lijkt in het geval van vrouwen een paradox. De normaliteit kan immers leiden tot ongewenste seksestereotypering. De gevangenis wordt dan de bekrachtiger van dominante systemen, waaronder het patriarchale.. Het moederschap dient daarbij als ideologisch concept, terwijl de vrouwen verder als 'sociale slachtoffers' gestigmatiseerd worden. In de problemen van gedetineerde 
vrouwen is een scherpe weerspiegeling van de maatschappelijke realiteit te zien. De seksualiteitsbeleving en de ambivalenties rond familiebanden en het moederschap wan gedetineerde vrouwen, maken ook iets duidelijk over de (contemporaine) identteitsontwikkeling van vrouwen in het algemeen met alle onderlinge verschillen die er zijn. Zelfs in de overlevingsstrategieèn (drugs-medicijnverslaving en psychiatrische problematiek) van gedetineerde vrouwen zouden parallellen met de soms verborgen leefwijze van veel 'vrije' vrouwen gezocht kunnen worden. De mate waarin er op al die terreinen verschillen optreden tussen vrouwen onderling, is veelal te verklaren wit verschillen in culturele achtergrond, bijvoorbeeld naar klasse en etnische afkomst. Er wordt gepleit voor een uitgebreid penologisch onderzoek onder vrouwen, waarbij niet alleen de ervaringen tijdens detentie onderzocht worden, maar ook de importvariabelen èn waarbij een follow-up studie wordt gedaan om het resocialisatieproces in kaart te brengen.

In hoofdstuk drie is bestudeerd welke uitwerking het op de mannelijke maat geënte detentiebeleid in Nederland heeft voor de gedetineerde vrouwen. In het naoorlogse beleid staat het begrip resocialisatie centraal. Het wordt als doel van de gevangenisstraf, samen met het beginsel van minimalle beperkingen, verankerd in de wetgeving. Nadat aanvankellijk veel verwacht wordt van gedrags- en houdingsveranderingen bij gedetineerden via groeps-, maatschappelijk en sociaalcultureel werk, wordt in de jaren zeventig steeds meer onderkend dat het verblijf in de totale institutie op zichzelf tot schadelijke effecten leidt. Een decriminaliseringstendens volgt. In de jaren tachtig slaat het optimisme om. Met name door de harde aanpak van de drugscriminaliteit en later de zogehe ten zware misdaad treedt een mentaliteitsverharding op ten aanzien van veroordeelden. Maar ook wordt, tegelijk met de toename van het aantal gedetineerden, duidelijk dat er erg veel probleemgevallen in de gevangenis terecht komen. Dat leidt tot meer specifiek beleid voor kwetsbare groepen. De rechten van de groep gedetineerden lijken te veranderen in op het individu gerichte regelingen, waaronder het penitentiair programma. 'Werk' wordt leidend beginsel. Dit alles leidt tot steeds meer variaties in detentievormen (differentiatie) en een enorme uitbreiding van het aantal cellen, ondanks de gelijktijdig toegenomen aandacht voor detentiefasering en alternatieve vormen van vrijheidsbeneming. De vrouwelijke gedetineerden zijn al die tijd relatief klein in aantal. Dat betekent onder meer dat zij tot eind jaren tachtig uitsluitend in afdelingen verblijven die zich binnen het complex van een manneninrichting bevinden en dat zij zijn onderworpen aan dezelfde regels en dezelfde beveiliging. De interne differentiatie is voor vrouwen echter veel minder groot. Het duurt tot in de jaren tachtig voordat er iets van gelijke behandeling met gedetineerde mannen wordt gerealiseerd, zoals gelijke beloning, bezoek zonder toezicht, open en halfopen plaatsen. In de jaren negentig komt er een iets beter arbeids- en cursusaanbod. Er worden een individuele begeleidingsafdeling, voor vrouwen met een lichte psychosociale problematiek, en een verslavingsbegeleidingsafdeling geopend. In de beleidsnota's die tussen 1947 en 1990 verschijnen wordt af 
en toe wel gepleit voor een specifiek beleid voor vrouwen, maar op veel meer dan 'de eigen aard van de vrouw' zijn die pleidooien niet gebaseerd. Dat is anders in het rapport van de werkgroep Vrouwen in detentie dat in 1991 wordt gepresenteerd. Het bevat een samenhangend geheel aan emancipatoire aanbevelingen. Het krijgt uiteindelijk vooral een vervolg waar het gaat om voorzieningen voor kinderen van gedetineerde moeders. Met name de moeder-met-kind unit in de halfopen gevangenis in Sevenum komt voort uit de voorstellen van de werkgroep. Het project wordt in dit hoofdstuk beschreven. Het relatieve succes ervan wordt toegeschreven aan de gemiddeld korte verblijfsduur en aan de intensieve samenwerking met het professionele kinderdagwerblijf buiten de inrichting. Belangwekkende bevindingen zjjn wooral dat 'continuiteit' voor het kind niet automatisch de exclusieve hechting aan de moeder inhoudt en dat 'het belang van het kind' een cultureelbepaald begrip is. Daarnaast wordt geconstateerd dat de doelgroep van een voorziening uitdijt als die voorziening er eenmaal is.

Discussies rond het thema 'gemengde detentie' en de familierelaties van gedetineerden laten zien dat een ideologisch bepaald concept van familierelaties een grote rol speelt bij het bepalen van het detentiebeleid. De eigen seksualiteitsbeleving van. vrouwen, de ervaringen van vrouwen met het gezin als bij uitstek onveilige en onderdrukkende omgeving, de ambivalenties rond de partner-en moederrol en de eigen aard van medische en psychische klachten worden of niet onderkend of op zo'n wijze geproblematiseerd dat de gedetineerde vrouwen gestigmatiseerd blijven in hun sllachtofferrol.

Hoofdstuk vier handelt over de rechtspositie van gedetineerde vrouwen. Mannelijke en vrouwelijke gedetineerden hebben in het nationale recht dezelfde formele en materiële rechten. Alleen op het punt van het verblijf in gevangenschap van zorgafhankelijke zuigelingen bestaat specifiek op moeders gerichte wetgeving. In internationale normen blijkt een iets bredere invulling aan materiële voorzieningen voor vrouwen in detentie te worden gegeven, zij het dat het gevaar van seksestereotypering steeds dreigt. Het betreft bovendien regels die moeten worden gelezen als beleidsaanbevelingen, niet als direct werkende rechten. In de jurisprudentie blijken op Europees niveau geen en op nationaal niveau enkele uitspraken relevant voor vrouwen, met name die waar op grond van het gelijkheidsbeginsel indirecte discriminatie wordt vastgesteld omdat in casu maatregelen zwaarder blijken uit te pakken voor de betreffende vrouwen dan 'normaal' het geval zou zijn geweest. In dit hoofdstuk wordt ook aandacht besteed aan het wetsvoorstel voor een nieuwe Penitentiaire Beginselenwet. Onder andere het recht op briefwisseling, bezoek en telefoneren valt onder de reikwijdte van art. 8 EVRM. Het recht op respect van het familie- en gezinsleven en het streven naar reintegratie zouden echter ook een genderspecifieke benadering rechtvaardigen van verlofregelingen, detentiefasering en het plaatsingsbeleid. In het kader van individuele trajectbegeleiding kan bij regelingen van arbeid en scholing ook rekening worden gehouden met zorgtaken en een genderspecifieke resocialisatie. 
In het kader van de medische zorg is het ook de vraag of er een sekse- en genderspecifiek aanbod moet worden gedaan. De sekseneutrale omschrijving van de gedetineerde ouder in het voorgestelde wetsartikel over permanent verblijf van kinderen in co-detentie (art. 12 w.o. PBW) wordt vanuit genderperspectief een doorbraak genoemd. Het artikel is gebaseerd op art. 8 EVRM. Er lijken echter zowel met betrekking tot de pedagogische als de juridische uitwerking nogal wat haken en ogen aan het voorgestelde wetsartikel te zitten.

In hoofdstuk vijf komen de maatschappelijke ontwikkelingen in het denken over gezin, moederschap en het belang van het van het kind, aan de orde. De loskoppeling van huwelijk, seksualiteit en voortplanting, de groei vam het aantal echtscheidingen en de toegenomen arbeidsparticipatie van vrouwen hebben grote invloed gehad op het functioneren van het gezin. Hoewel de opvoedingsfunctie alleen in veel gevallen een te smalle basis voor de instandhouding van het gezin blijkt te zijn, wordt het gezin over het algemeen nog wel gezien als de ideale opvoedingsomgeving voor het kind. In onderzoek is er nog erg weinig aandacht voor de invloeden van niet-Westerse culturen in onze samenleving. De vergrote mobiliteit en migratie lijken echter wel van invloed te zijn op het bestaande 'family life'. Ten aanzien van het moederschap bestaan ambivalente verwachtingen. De plicht tot voortdurende aanwezigheid is veranderd in een ideaal van responsiviteit en beschikbaarheid. Aanvankelijk werd de relatie tussen alleenstaande en/of buitenshuis werkende moeders en hun kinderen geproblematiseerd, door effecten als slechte schoolprestaties en crimineel gedrag bij hun kinderen te onderzoeken. De sociaaleconomische omstandigheden waaronder kinderen opgroeien lijken hiervoor echter bepalender dan de leefvorm of activiteiten van de moeders. Vrouwen zelf lijken ook ambivalent te staan ten opzichte van de moederrol. De sociaaleconomische omstandigheden, het soort werk en de activiteiten waar vrouwen zich mee bezighouden, lijken in relatie tot hun eigen idealen bepalend te zijn voor onderlinge verschillen tussen moeders. Vanuit de overheid is er aanvankelijk een op het kostwinnersmodel gerichte politiek gevoerd. Moeders werden geacht thuis te blijven en werden ook ontmoedigd om betaald te gaan werken. Mede door het emancipatiebeleid, dat een sterk economische invulling heeft gekregen, worden vrouwen nu sinds korte tijd gestimuleerd zich een plek op de arbeidsmarkt te verwerven. Een stimulans die veelal de vorm van verplichting krijgt. De hulpverlening komt vooral in aanraking met moeders die het (alleenstaand) moederschap met werkloosheid en bijstandsafhankelijkheid moeten combineren en met allochtone huishoudens. De ondersteuning die geboden wordt lijkt nog vaak uit te gaan van klassieke middleclass gezinsidealen en van ontwikkelingspsychologische ideeën omtrent jonge kinderen. Vooral allochtone moeders geven aan dat zij meer (praktische) ondersteuning wensen bij de opvoeding van oudere kinderen. Maar ook dat hun eigen ambities meer centraal zouden moeten staan, niet alleen de moeder-kind-relatie. Bovendien moet er meer oog zijn voor cultuurgebonden sociale netwerken, waarin met name de grootmoeder een belangrijke rol vervult. In de theorievorming over de ontwikkeling van 
kinderen zijn grofweg twee stromingen te onderscheiden. De ene, ontwikkelingspsychologische, gaat sterk uit van het gezins- en familieverband. De driehoek vadermoeder-kind en de intergenerationele loyaliteit lijken belangrijke pijlers. De andere, meer pedagogische, richt zich op de autonome ontwikkeling van het kind, diens eigen leefwereld, waarin zowel ouders als andere volwassenen en vooral leeftijdgenoten een plaats krijgen. Er lijkt een ander idee over identiteitsvorming aan ten grondslag te liggen. Binnen beide stromingen wordt veel waarde gehecht aan een veilige omgeving voor het jonge kind. Omtrent de ontwikkeling van oudere kinderen treedt veel meer verschil in opvattingen aan het licht.

In hoofdstuk zes worden het belang van het kind en de bescherming van het moederschap in het licht van de Rechten van de Mens bekeken. In verschillende verdragsbepalingen wordt het family life en het private life van burgers beschermd.(Vgl. art. 8 EVRM.) Het VN-Kinderverdrag verplicht de overheid ouders te steunen in hun verzorgende en opvoedende taak door adequate voorzieningen te scheppen. De positie van kinderen is in de maatschappelijke werkelijkheid nauw verbonden met die van vrouwen. Zowel kinderen als vrouwen hebben baat bij eigen sociale netwerken. Kinderrechten kunnen echter gebruikt worden om vrouwen in de traditionele moederrol te manipuleren. Daarom is ook de autonome positie van vrouwen van belang in relatie tot 'het belang van het kind'. In het VN-Vrouwenverdrag worden de verschillende functies van 'moeders' beschermd. De potentieel biologische, die in principe alle vrouwen betreft, de feitelijke biologische, die zich beperkt tot zwangerschap, baring, zoging en ontzwangering en de sociale, die de feitelijke verzorging en opvoeding betreft. De sociale is genderspecifiek en kan dus ook betrekking hebben op mannen, als zij feitelijke zorgtaken vervullen. Die feitelijke verzorging moet beoordeeld worden naar de concrete omstandigheden. Hoever de overheidsbemoeienis mag gaan bij het ontwikkelen van een 'op de zorg voor kinderen ingesteld beleid' is vooral een politieke vraag. In dit hoofdstuk worden ontwikkelingen in het arbeidsrecht; de kinderopvang, het onderwijs en de gezondheidszorg weergegeven, om mogelijke aanknopingspunten voor het detentiebeleid te vinden.

In hoeverre ouders en kinderen zich rechtstreeks op verdragsbepalingen kunnen beroepen, is nog niet geheel duidelijk.

Verdragsartikelen die directe werking hebben, zoals art. 8 EVRM en art. 10 en 26 van het IVBPR kunnen aangescherpt worden door bepalingen uit het VN-Kinderverdrag en het VN-Vrouwenverdrag. Wanneer de overheid een inbreuk maakt op het gezins- en familieleven van een burger op grond van art. 8 EVRM lid 2, moet dat legitiem zijn en proportioneel. Het strafrechtelijk optreden tegen een ouder zal in de regel legitiem zijn, maar aan de beginselen van proportionaliteit en subsidiariteit zal vanuit het perspectief van bestaande zorgrelaties uitwerking moeten worden gegeven. Concrete maatregelen zouden erop gericht moeten zijn de bestaande relatie tussen kind en ouder in stand te houden, tenzij dit tot schade van het kind of anderen zou leiden. 
In hoofdstuk zeven gaat het om de relaties tussen gezinsleden. Hier wordt de discussie ower een zorgzaamheidsethiek in het recht geïntroduceerd. De van concrete casus geabstraheerde rechtvaardigheidsethiek lijkt onder meer tot genderverschillen in het recht te leiden. Dat kan gecorrigeerd worden door een contextgerichte benadering. De belangenafwegingen zouden meer in relatie tot het concrete handelen moeten staan. Of dat in het familierecht vruchten afwerpt is de vraag. Sommigen vrezen dat ongewenste familieverhoudingen bestendigd worden. Anderen menen dat door de feitelijke zorgrelaties tot uitgangspunt te nemen een materiële invulling van gelijkheid mogelijk is. Machtsverschillen in privéverhoudingen kunnen dan juist aan het licht komen. In het familierecht wordt het bestaan van een family life in de zin van art. 8 EVRM veelal afhankelijk gesteld van juridische (afstammings-) relaties en van feitelijke omstandigheden, die op het eerste oog sekseneutraal worden vastgesteld. 'Het belang van het kind' geldt met name in conflictsituaties als leidend beginsel, maar krijgt in wetgeving en rechtspraak vaak geen nadere invulling. Degene die het ouderlijk gezag heeft, is vrij de verblijfplaats van het kind te kiezen en kan de verzorgende en opvoedende taken door anderen laten uitoefenen. Wanneer een ouder en kind gescheiden van elkaar leven, wordt bij de beoordeling van verzoeken om een omgangsregeling of wijziging van de verblijfplaats het belang van het kind sterk gekoppeld aan de stabiliteit en de continuilteit van de omgeving waar het op dat moment verblijft. In andere conflictsituaties dan echtscheidingen, blijkt het isolement waarin de ouder en het kind door het tijdsverloop ten opzichte van elkaar zijn komen te verkeren veelal van doorslaggevend belang bij het al dan niet kunnen effectueren van bestaande rechten. Uit uitspraken van het Europese Hof valt af te leiden dat er een verplichting bij de autoriteiten ligt om er alles aan te doen om continuering van bestaande familierelaties mogelijk te maken. In het familierecht kunnen noties van een contextuele benadering gevonden worden die analoog in andere rechtsgebieden toegepast kunnen worden.

In hoofdstuk acht volgt een pleidooi voor een leefsysteemgerichte benadering in het straf- en penitentiaire recht. De overheid dient het family life en het private life van ouders en kinderen te respecteren ook als die ouder een strafbaar feit heeft begaan. Beginselen van proportionaliteit en subsidiariteit moeten een rol spelen in iedere fase van het strafproces, wanneer beslissingen worden genomen die ingrijpende gevolgen voor het gezinsleven impliceren. Daarbij spelen enerzijds de inhoud van de feitelijke zorg en het belang van het kind een rol, anderzijds de ernst van het delict en de veiligheid van de samenleving. In een leefsysteemgerichte benadering moet het overheidsingrijpen getoetst worden aan het bestaande family life, aan het belang van het kind en aan de bescherming van het moederschap, c.q. verzorgerschap zonder dat dit tot negatieve seksestereotypering leidt. Daarnaast rust op de overheid de verplichting verzorgingsrelaties te optimaliseren. Optimale verzorgingsrelaties zijn basiscondities voor emancipatie in bredere maatschappelijke betekenis. De art. 26 en 26 bis Beginselenwet Gevangeniswezen dienen dan ook in het perspectief van 
grondrechten gelezen te worden. Om recht te doen aan een zo groot mogelijk scala aan verzorgingsrelaties zal de focus in eerste instantie op vrouwen gericht zijn. Zij zijn veelal de primaire verzorgers. Om te vermijden dat een ideaaltypische en beperkte invulling van 'family life" wordt gehanteerd, moet met name aan de diversiteit in opvoedingsrelaties recht worden gedaan. Uit de ervaringen van gedetineerde moeders blijkt dat er twee pieken zijn in de detentiefase, wat betreft hun verstikkende en groeiende bezorgdheid om hun kinderen. Eerst aan het begin van de detentie, tijdens het voorarrest, en later bij de langgestraften. Voor de opvang van de kinderen en voor de continuering van het contact lijkt in beide situaties aan heel verschillende voorzieningen gedacht te moeten worden. Als de zorg voor het leefsysteem tijdens de preventieve fase van het strafproces extra aandacht krijgt, kan dat echter wel gunstig doorwerken in eventuele latere fases. Die eerste fase is immers vaak bepalend voor de verzorgingsarrangementen zoals die bij voortduring van de detentie hun vorm krijgen. In dit hoofdstuk worden voorstellen gedaan voor een leefsysteemgerichte benadering vanaf het voorarrest en de straftoemeting tot en met de tenuitvoerlegging van de detentie. Voortdurend wordt benadrukt dat detentie voorkomen moet worden. Ten aanzien van co-detentie van kinderen wordt een uiterst gereserveerd standpunt ingenomen. Het is de vraag of een staat de ouder überhaupt voor zo'n dilemma mag stellen. Mocht er na afweging van alle mogelijke alternatieven geen andere oplossing zijn, dan dient in het belang van het kind op grond van art. 5 EVRM een proportionaliteitstoets plaats te vinden naar de pedagogische randvoonwaarden waaronder het kind gedetineerd wordt. Hierbij spelen de duur van het verblijf, de aard, leeftijd, ontwikkeling en mobiliteit van het kind en de mogelijkheid tot contact met leeftijdgenoten en de buitenwereld, ook in ruimtelijke zin, een belangrijke rol. De buitenlandse vrouwen, die ongeveer vijftig procent uitmaken van de populatie van vrouwelijke gedetineerden, zouden, voor zover zij geen baat hebben bij een leefsysteemgerichte benadering, gecompenseerd kunnen worden via strafvermindering en gratiëring.

Voor zover pragmatische argumenten van personele en financiële aard een rol spelen om terughoudend te zijn met individuele arrangementen voor gedetineerden, zou er ten aanzien van collectieve regimeverandering voorrang kunnen worden gegeven aan instellingen met vrouwelijke gevangenen. Aan het belang van orde en veiligheid kunnen geen argumenten worden ontleend om dat niet te doen. Het feit dat de aard van de delicten en de recidivecijfers onder vrouwen substantieel verschillen van die van mannelijke gedetineerden en dat hun bestraffing relatief zwaarder doorwerkt in het privê- en familieleven rechtvaardigen een voorrangsbeleid. In zo'n regiem zou er bij het creëren van voorzieningen van binnen naar buiten gedacht moeten worden. Niet alleen kinderopvang, maar ook vrouwengezondheidszorg, vrouwervakscholen, politieke, sociale en basisvormende activiteiten, veelal met aandacht voor culturele identiteit, zouden buiten de inrichting gezocht moeten worden, zodat vrouwen ook na de detentie niet in hun privé-isolement terugvallen. Binnen een dergelijk 
"normaliserend' regiem, zou, afhankelijk van het resocialisatiedoel, ook gemengde opvang van vrouwen en mannen tot de mogelijkheden kunnen behoren. 


\section{Summary}

The central issue of this study is the legal status of women detainees, in particular the extent to which they can derive rights from their position as child-caring parent in relation to the authorities or third parties.

In Chapters 1 through 4, detained mothers are described as "delinquent" women. The general theme of Chapters 5 through 7 is "motherhood" in relation to the "interest of the child" and the meaning of "family life" and "private life" as safeguarded by the treaty provisions. The final chapter synthesizes the insights gained in the preceding chapters and policy and legislative recommendations are made from a gender-specific perspective.

Chapter 1 studies the explanations which can be found for the fact that, in comparison with men, so few women commit criminal offenses. Until the middle of the nineteenth century, relatively speaking, the number of women who fell afoul of the law was substantially greater than today. Since the industrial revolution and the emergence of medical science, and subsequently of criminology, the number of delinquent women has been very low. This may have to do with the type of acts that are punishable or with the methods of keeping record and interpretation. Some scholars, however, are seeking more fundamental explanations, such as biological and psychological differences between the sexes. Others focus on sociopsychological and sociological explanations. Social control mechanisms in particular are acknowledged as major determinants of criminal behaviour. The question then arises as to why women are so sensitive to social control. The answer must be sought in the socialization theories. Expectations of women are different from those of men. Women are raised with relationship objectives, such as procreation, motherhood, and care duties. Men are raised on the basis of status focusing on providing and hierarchical relations. Delinquency in women can be explained in part by social maladjustment and in part by rebellion against pre-established roles. The ideology of motherhood plays an important role in the various interpretation theories: in explaining the adjusted, nondelinquent behaviour of women on the basis of personality and socialization theories, on the one hand, and in qualifying deviant behaviour as "derailment" and psychiatrizing it, or as "rebellion' and politicizing it, on the other. Although thanks to the availability of contraceptives and the legalization of abortion, sexuality and motherhood are no longer inextricably linked, no greater freedom for women has 
resulted. This is reflected in the statistics on delinquency. In the course of the past decade, a stream of sexual and physical abuse cases has surfaced. It has turned out that delinquent women in particular had suffered or were suffering from such abuse. The dichotomy between offender and victim has disappeared. Feminist criminologists demonstrated that delinquency and criminology were gender-specific. In reality, men and aberrant male behaviour had been the objects of study. The nature of punishable acts, the recording of delinquency and the interpretation of both have led to many "blind spots." Apart from differentiation according to gender and age, social and ethnic origin are also still not fully acknowledged, and where they have been, they are not integrated into a total view. The development of the gender concept has made it plain, however, that an array of dominant culture-specific interpretations influences the description and study of delinquency.

Chapter 2 deals with prison culture. Using the experience of women detainees as a source, the author pays attention to the relationships between the women themselves; their relationships with the people who work with them; their daily activities; their relations outside the prison; the way in which they experience sexuality; their lack of privacy; and their need for intimacy. Several studies have been conducted into the effect on a woman's life of having to serve time inside institutions. Research into psychosocial processes reveals that women's survival behaviour is oriented towards adaptation. The sexual contacts made by women in detention seem to be designed to re-enact the family drama. It is alleged that women in prison are faced with greater identity crises than men who find themselves in the same situation, because women have been socialized through derived identities, i.e. someone's daughter, partner, mother and so on. Sexuality, in particular, is the means through which women attempt to win a place in a particular social structure. Even women who were not part of a settled relationship prior to their detention, felt excluded from the possibility. Although the gender-specific role of women may have been taken into account in detention policy, this is in sharp contrast with reality, where they virtually have lost their original basis because of the detention. Emancipation theorists advocate strengthening the legal status of detainees as a counterweight against the effects of being fully institutionalized. This seems to have more of an emancipating effect on men than on women: in the case of women, making prison look more and more like "ordinary society" as a prison reform strategy seems a paradox. Normality may after all result in undesirable sexual stereotyping. Prisons in such cases reenforce dominant systems like the patriarchal system. For this purpose, motherhood serves as an ideological concept, further stigmatizing women as "victims of society." The problems of women detainees sharply reflect social reality. The way in which they experience sexuality, the ambivalences with respect to family ties and the motherhood of women detainees also reveal something of the (contemporary) development of female identity in general, irrespective of the differences existing between them. Even in the survival strategies of detained women 
(narcotic or medical drug addiction and psychiatric problems) parallels may be found with the, frequently secret, lives of many "free" women. The extent of the differences between women can often be explained by their different cultural backgrounds, for instance, a different social or ethnic background. Extensive penological research among women is advocated. Such research should not only investigate their experiences as a result of their confinement, but also their different backgrounds. In addition, a follow-up study should be conducted to chart the resocialization process. In Chapter 3, the effect on women detainees of Dutch detention policy, which has been modeled on men, is studied. Resocialization has been the central theme of Dutch postwar policy. It has been enshrined in our legislation as the objective of detention, together with the principle of minimum restrictions. Initially, there were great expectations that through cooperative work, social work or socio-cultural work detainees' behaviour and attitude could be changed. In the seventies, however, the realization grew that being totally institutionalized may have adverse affects. The result was a tendency towards decriminalization. In the eighties, the initial optimism faded. Tougher measures against narcotics crimes and subsequently against serious crime were a manifestation of a change in mentality which was less lenient towards convicted criminals. However, it also became clear that with the increase in the number of detainees, a great many problem cases landed in jail. This resulted in a special policy for vulnerable groups. The rights of detainees seemed to change from collective rights to arrangements geared to the individual, such as the extramural programme at the end of the detention. "Work" became the leading principle. These developments resulted in differentiation, i.e. more variation in the forms of detention, and a great increase in the number of cells, in spite of an increased focus on phased detention and alternative forms of freedom deprivation. The number of women detainees in this period of time was relatively small. This implied that, until the eighties, these women were detained exclusively in separate wards of men's prisons and that they were subjected to the same regime and the same security. For women, however, there was far less internal differentiation than for men. Only in the eighties women started receiving some equal treatment, in the form of equal pay, unsupervised visits, open and semi-open prisons. In the nineties, the supply of courses and labour was somewhat improved. A ward where individuall counselling was possible for women suffering from non-severe psycho-social disorders and a special ward for addicted women were opened. In the policy statements appearing between 1947 and 1990 on occasion it was advocated that there should be a special policy for women, but these pleas were based on little more than the "proper nature of women." Not so in the report ' $T$ rouwen in detentie' (Women detainees) that was published by a working party of the same name in 1991. This report contains a coherent set of emancipatory recommendations. The arrangements made in respect of the children of detained mothers was the main result of this report. In particular, the mother-and-child unit in the semi-open prison in Sevenum (NI) was the result of the proposals made by 
the working party. A description of the project is given in this chapter. Its relative success is ascribed to the average short stay in the institution and to the intense cooperation with the professional child care centre outside the institution. Remarkable findings are in particular that "continuity" for the child does not automatically imply exclusive bonding with its mother and that the "interest of the child" is a culturespecific concept. The author concludes that the target group of a particular facility or arrangement will grow once the facility has been established.

The debate on the topics "mixed detention" and "relatives of detainees" show that "family relations" as an ideology-specific concept plays a major role in detention policy.

Sexual experiences of women and their experience with the family as a pre-eminently unsafe and oppressive environment, the ambivalences relating to their roles as mother and partner and the specific nature of physical and mental complaints are either not acknowledged or are problematized to such an extent that women detainees continue to be stigmatized as victims.

Chapter 4 discusses the legal status of women detainees. In Dutch law, male and fermale detainees enjoy the same rights under criminal law. Only with respect to the intramural presence of care-dependant infants are there special rules for mothers. Under international standards, the material facilities for women detainees are somewhat broader defined, although the danger of sexual stereotyping is always present. Furthermore, the rules in question must be construed as policy recommendations, not as rights which may be directly invoked in domestic courts. No European case law exists on the subject and there are only a few national decided cases that are relevant for women, in particular the one in which indirect discrimination was established on the grounds of the principle of equality, because in that case the measures proved to have a much tougher effect on the women in question than they ordinarily would have had. In this chapter, attention is also paid to the Bill for a new Prisons Act (Penitentiaire Beginselenwet). The rights to correspondence, to visits and to make telephone calls fall within the scope of article 8 European Convention on Human Rights (ECHR). The right to respect of "family life" and the efforts in relation to reintegration warrant, however, a gender-specific approach to leave arrangements, phased detention and placement policy. Within the framework of individual guidance the arrangements for work and training must take into account care tasks and gender-specific rehabilitation. The question also arises as to whether there should be a differentiation on the grounds of gender in relation to medical care. From a gender perspective, the neutral definition of "detained parent" in the article governing the co-detention of children (art. 12 of the Prisons Bill) can be seen as a breakthrough. The article is modeled on article 8 ECHR. However, there are quite a few problems as to the legal and educational application of the bill. 
Social developments in relation to the views on family, motherhood and the interest of the child form the subject of Chapter 5. The disunion of marriage, sexuality and procreation, the growing number of divorces and the increased participation of women in the labour market have had a major impact on the family. Although in many cases the childbearing function proves to be too small a basis for the preservation of a family, in general, the family is still seen as the ideal environment for raising a child. There has been very little attention in research for the impact of non-Western cultures on our society. Increased mobility and migration, however, do appear to influence our present "family life." With regard to motherhood, the expectations are ambivalent. The duty of having to be permanently present has been replaced by the ideal of responsiveness and availability. Initially, the relation between single and/or working mothers and their children was problematized by studying bad grades in school and the delinquent behaviour of these children. The socioeconomic circumstances under which children grow up seem more determinant, however, than the mothers' living conditions or activities. Women themselves seem to suffer from ambivalence where their role as mothers is concerned. In relation to their own ideals, the socioeconomic circumstances, the type of work and activities that women undertake seemed to be the decisive factors in the differences between women. The government initially pursued a policy based on the breadwinner model. Mothers were supposed to stay at home and were discouraged from working outside the house. Recently, partly because of emancipatory policy, which was given a strong economic accent, women have been encouraged to find a place on the labour market. An incentive which often comes in the form of an obligation. Organizations assisting young persons are mainly confronted with mothers who are forced to combine (single) parenthood, unemployment and welfare dependency and with immigrant families. The assistance offered seems still to be based on the classic middle-class family ideals and on the developmental psychology of young children. Young mothers from an immigrant background, in particular, make it clear that they would like more (practical) support in raising the older children. They feel that, apart from the mother/child relation, their own ambitions should be given a more prominent place. Also, more attention should be paid to culture-specific social networks, in which the grandmother in particular plays an important role. Roughly, two movements can be distinguished in the theorization of child development: the first is developmental psychology, which departs from a family perspective which heavily leans on the nuclear family and intergenerational loyalty. The other, a more pedagogic, approach centres on the autonomous development of the child, its own world, in which both parents and other adults, and especially peers, receive a place. This approach seems to depart from a different view on identity formation. In both movements, much value is attached to a safe environment for the young child. Where the development of older children is concerned the approaches show more dissimilarities. 
In Chapter 6 , the interest of the child and the protection of motherhood is discussed from a human rights perspective. In several treaty provisions, the "family life" and the "private life" of citizens are protected (cf. art. 8 ECHR). The UN Convention on the Rights of the Child obligates governments to support parents in the caring for and raising of their children by making adequate provisions. In social reality, the position of children is narrowly linked with that of women. Both children and women benefit from their own social networks. Children"s rights can be used, however, to coerce women into taking up the traditional mother role. For this reason, the autonomous position of women in relation to "the interest of the child" is important. The UN Convention on the Elimination of all Forms of Discrimination against Women (CEDAW) protects the various functions of "mothers": the potential biological function, which, in principle, pertains to all women, the actual biological function, which is limited to pregnancy, confinement, breast-feeding and recovering from the effects of pregnancy, and the social function, relating to actually caring for and rearing children. The social function also relates to men, where they undertake care tasks. The actual care must be assessed on the basis of real circumstances. The issue of the extent of government interference in developing a policy geared to child care is of a predominantly political nature. In this chapter, developments in labour law, professional child-care, education and health care are described in order to find possible relevant factors for detention policies.

As yet is it not clear whether and to what extent parents and children may directly invoke treaty provisions before the national courts. Treaty provisions that have direct effect, such as article $8 \mathrm{ECHR}$ and articles 10 and 26 of the International Covenant on Civil and Political Rights, may be tightened with the aid of provisions in the UN Convention on the Rights of the Child and in CEDAW. If the government interferes in a citizen's right to respect of "family life" on the grounds of article 8, par. 2, ECHR, such interference must be in the pursuit of a legitimate aim and proportional to that aim. As a rule, action against a parent by the authorities under the criminal law will be legitimate, but the principles of proportionality and subsidiarity need to be developed from a perspective of the existing care relations. Concrete measures should be aimed at preserving the relation between child and parent, unless this would result in harm to the child or others.

In Chapter 7, relations between family members are examined. The author introduces the debate on the desirability of care ethics in law. The ethics of rights which have been abstracted from real-life cases seem to result in, among other things, differentiation as to gender under the law. This may be remedied by a contextual approach. The weighing of the interests involved should be related more to concrete acts. It is debatable whether this is to have a beneficial effect on family law. Some fear that undesirable family relations will thus be preserved. Others argue that by taking the actual care relations as the point of departure it is possible to define 
equality in a concrete way. Power discrepancies in private relations may thus be exposed.

In family law, the existence of family life within the meaning of article 8 ECHR is often made contingent on legal parentage and on actual circumstances, which, at first sight, seem to be established in a gender-neutral way. "The interest of the child $^{\text {n }}$ is the guiding principle especially in situations of discord, but is not further defined by legislation and decided cases. The person who is vested with parental authority is entitled to choose the child's place of residence or abode and may charge others with the caring for and raising of the child. If the parent and the child live separately, in the event of a petition for (mutual) visiting rights or a change of abode, the interest of the child is related to the stability and continuity of the environment in which it remains at that time. In conflict situations other than divorce, the isolation of the parent from the child and vice versa caused by the lapse of time turns out to be the decisive factor in the attempt to enforce existing rights. From the case law of the European Court of Human Rights it can be inferred that there is a duty for the authorities to do everything possible to ensure that existing family relations continue. In family law, notions of a contextual approach may be found which could find analogous application in other areas of law.

Chapter 8 contains a plea for a contextual approach in criminal and prison law. The authorities must respect the family and private life of parents and children even if a parent has committed a criminal offense. Principles of proportionality and subsidiarity must play a role in any stage of the criminal process each time decisions need to be taken with great implications for family life. Other relevant factors, apart from the contents of the actual care and the interest of the child, are the gravity of the offense and the general safety of society. In a contextual approach, government interference must be tested against the existing family life, against the interest of the child and the protection of motherhood, or as the case may be, the role of care provider, without this resulting in negative sexual stereotyping. In addition, the authorities have a duty to optimize the care relations. Optimum care relations are a prerequisite for emancipation in a broader, social sense. The provisions of articles 26 and 26 bis of the present Dutch Prisons Act must be seen as principles within the framework of fundamental rights. To do justice to a maximum number of different care relations, the focus should be first and foremost on women. They are often the primary providers of care. To prevent the use of a standard and restricted definition of "family life" "the diversity of the child-rearing relations must be given a proper place. The experience of detained mothers teaches us that there are two peaks in the detention stage, in which they are stifled and increasingly concerned about their children. The first peak is at the beginning of the detention, in the preliminary detention stage, and the second happens to women detainees who are serving long sentences. Both situations seem to require very different solutions as regards child-care facilities and ensuring continuing contact between mother and 
child. The extrat attention given to a system of cohabitation in the preliminary detention stage may have a positive effect in later stages, since this first stage often determines the care facilities in case of continued detention. In this chapter, the author proposes a contextual approach from the pre-trial, trial and sentencing stage up to and including the implementation of the detention. The author stresses at every occasion that detention must be prevented. She has her reservations about the codetention of children and questions whether a government should confront a parent with such a dilemma. If after assessing all possible alternatives, there is no other solution, then in the interest of the child, pursuant to article 5 ECHR the proportionality of the pedagogic conditions under which the child is detained must be assessed. In such cases, the length of the stay at the detention centre, the personality, age, development and mobility of the child and the possibility of contacts with peers and the world on the outside, also in a spacial sense, are the relevant factors. Foreign women, who make up some fifty per cent of all women detainees, should be compensated through remission and pardon, if they do not benefit from a contextual approach.

Where pragmatic reasons of a personal or financial nature prescribe restraint in making individual arrangements for detainees, in the event of a collective change of regime preference could be given to special institutions for women detainees. No arguments may be derived warranting other measures in the interest of order and security. The fact that the nature of the offenses committed by women and the statistics for female recidivists differ substantially from those relating to male detainees and the fact that their punishment has a relatively greater impact on their private and family lives justify such a policy of preferential treatment. In such a regime, the facilities created should be outward-looking. Not just child care, but also health care for women, vocational schools for women, political, social and skillsenhancing activities, in many cases focusing on cultural identity, should be sought on the outside, so that women do not regress into their private isolation upon being released. Under such a "normalizing" regime also mixed accommodation of women and men might be possible, depending on the resocialization objective.

Translated by Louise Rayar 


\section{Résumé}

Cette étude porte sur la situation des mères détenues, notamment au plan juridique : elle examine en particulier si leur qualité de parent assurant l'entretien d'un enfant au quotidien leur confère quelque droit vis-à-vis des autorités ou de tiers.

Les chapitres un à quatre présentent les mères détenues en tant que « délinquantes ». Les chapitres cinq à sept traitent dans les grandes lignes la « maternité par rapport à l'intérêt de l'enfant $w$ et le sens des notions de vie familiale et de vie privée, protégées par des dispositions conventionnelles. Le dernier chapitre établit un lien entre les idées exposées dans les chapitres précédents et fait des suggestions de régime pénitentiaire et de réglementation répondant à une approche spécifique à la problématique du genre. Le chapitre premier examine les explications possibles au fait que si peu de femmes, en comparaison des hommes, commettent des délits. Pourtant, jusqu'au milieu du XIX ${ }^{\circ}$ siècle, le nombre de femmes ayant affaire à l'appareil judiciaire était relativement beaucoup plus élevé que maintenant. Depuis la révolution industrielle, le développement de la médecine et, dans son sillage, de la criminologie, la part des femmes dans la criminalité semble très faible. Ce phénomène peut s'expliquer par la nature des délits qui sont punissables ou par la manière de les enregistrer et de les interpréter. Toutefois, certains recherchent des explications plus fondamentales, ayant trait par exemple à des différences biologiques ou psychologiques entre les hommes et les femmes. D'autres s'orientent vers des explications psychosociologiques ou sociologiques. On a identifié notamment des mécanismes du contrôle social qui sont des facteurs importants du comportement de délinquance. On se demande alors pourquoi les femmes sont si sensibles au contrôle social. Les théories sur la socialisation peuvent apporter une réponse à cette question. Le rôle imparti aux femmes est différent de celui qui revient aux hommes. En effet, les femmes sont élevées dans une perspective relationnelle centrée sur la reproduction, la maternité et l'entretien d'autrui ; tandis que les hommes sont élevés dans une perspective de statut social, axée sur le soutien financier de la famille et les relations hiérarchiques. La criminalité chez les femmes s'explique en partie par l'inadaptation et en partie par l'opposition aux rôles prédestinés. Dans un cas comme dans l'autre, l'idéologie relative à la maternité joue un rôle important dans les diverses théories explicatives. D'une part, pour élucider le comportement adapté, non délinquant, des femmes sur la base de la psychologie de la personnalité et de la socialisation. 
D'autre part, pour qualifier la déviance psychiatrisée d' « égarement » et la déviance politisée d'« opposition ». Maintenant que la sexualité et la maternité ne sont plus indissociables, grầce aux moyens de contraception actuels et à la légalisation de l'avortement, il s'ensuit indirectement une plus grande liberté des femmes qui se reflète aussi dans les statistiques de la délinquance. La dernière décennie a vu une augmentation du nombre des révélations concernant les abus sexuels et les voies de fait envers les femmes et les enfants. Or il apparaît précisément que les femmes criminelles en sont ou en ont été, elles aussi, les victimes. La dichotomie entre l'auteur des actes et la victime s'efface. Les criminologues féministes démontrent que la délinquance et la criminologie ne sont neutres ni au plan du sexe ni au plan du genre. En fait, on étudie les hommes et les excès du comportement masculin. Les délits déclarés punissables, l'enregistrement des actes criminels et l'interprétation des uns et des autres mènent à de nombreuses zones d'ombre. On accorde encore une attention insuffisante non seulement au sexe et à l'âge, mais aussi à l'origine sociale et ethnique et au lien entre ces différents facteurs. Le développement de la notion de genre a montré qu'il existe un certain nombre de schémas de domination, déterminés par la culture, qui influencent la description et l'étude de la criminalité. Le chapitre 2 aborde la question de la culture carcérale. Sur la base d'expériences de femmes détenues, l'étude analyse leurs relations mutuelles, leurs relations avec les personnes qui travaillent avec elles, l'occupation des journées, les contacts en dehors de l'établissement pénitentiaire, leur sexualitế, le manque de respect de la vie privée et le besoin d'intimité. Différentes recherches ont étudié les effets d'un séjour dans des établissements en milieu fermé sur la vie des détenus, hommes ou femmes. Une étude psychosociale a permis de constater que le comportement de survie des femmes repose surtout sur l'adaptation. Les contacts sexuels que les femmes établissent en détention semblent relever d'une « reproduction du schéma familial ». Les femmes incarcérêes souffriraient davantage que les hommes d'une crise d'identité parce qu'elles ont été socialisées avec des personnalités dérivées (fille de, femme de, mère de...). La sexualité surtout est pour de nombreuses femmes le moyen de se forger une place dans une structure sociale déterminée. Même les femmes qui, avant leur détention, n'étaient pas liées à un cadre de vie fixe, se sentent exclues de la possibilité d'établir une telle situation. Si le régime de la détention tient compte du rôle sexuellement spécifique des femmes, ce dernier se trouve alors en âpre contraste avec la réalité sociale dont la détention, bien souvent, a pratiquement fait disparaître la base originelle. Selon la théorie de l'émancipation, le renforcement de la position juridique des détenus sert de contrepoids aux effets de la vie en milieu fermé. Ce renforcement semble avoir un effet émancipateur plus important sur les hommes que sur les femmes. Dans le cas des femmes, ill parâtt paradoxal d'adopter une stratégie de réforme des prisons visant à ce que le centre de détention ressemble de plus en plus à une « société normale ». La normalité peut en effet conduire à l'apparition de stéréotypes sexuels qui ne sont pas souhaitables. La prison devient 
alors un agent de validation de structures de domination, dont le patriarcat. Dans ce contexte, la maternitế sert de concept idéologique, et les femmes sont stigmatisées en tant que « victimes sociales ». Les difficultés vécues par les femmes détenues reflètent crument la réalité sociale. La vie sexuelle et les ambivalences concernant les liens familiaux et la maternité des femmes détenues sont significatives de l"évolution (contemporaine) de l'identité des femmes dans l'ensemble, malgré toutes les différences qui existent entre elles. Mềme dans les stratégies de survie des femmes détenues (dépendance de drogues ou de médicaments et troubles psychiques), on pourrait chercher des parallèles avec la manière de vivre parfois cachee de nombreuses femmes « libres $"$. Les différences qui surgíssent dans tous ces domaines entre les femmes elles-mêmes s'expliquent souvent par la variêté̉ de leur contexte culturel, en fonction, par exemple, de leur origine sociale ou ethnique. Certains plaident en faveur d'une êtude détaillée relevant de la pénologie, effectuée parmi les femmes, qui examinerait non seulement les expériences pendant la détention, mais aussi les variables apportées, et quil assurerait un suivi du processus de resocialisation.

Le chapitre 3 analyse l'effet sur les femmes détenues du régime pénitentiaỉre néerlandais, greffé sur le modèle masculin. Le régime de l'après-guerre est axé sur la notion de resocialisation. But de la peine carcérale, cette notion est ancrée dans la législation, de même que le principe des restrictions minimales. Après de grandes attentes initiales en termes de changements de comportement et d'attitude chez les détenus grâce a des activités sociales et socioculturelles de groupe, on constate de plus en plus clairement dans les années soixante-dix qu'un séjour en milieu fermé a, en soi, un impact nocif. Apparaît alors une tendance à la decriminalisation. Pendant les années quatre-vingt, l'optimisme tombe. La lutte féroce engagée contre les délits en matière de stupéfiants et, plus tard, contre les crimes les plus graves contribue a durcir les mentalités à l'égard des condamnés. Mais, avec l'augmentation du nombre des détenus, on s'aperçoit rapidement que la prison accueille un très grand nombre de cas difficiles. Il en résultera un régime spécifique pour les groupes sensibles. Les droits du groupe de détenus semblent fä̈re place aux règles axées sur l'individu, y compris dans le programme penitentiaire. Le travail devient un principe directeur. Tout ceci conduit à des formes de plus en plus variées de détention (différenciation) et à une augmentation énorme du nombre des cellules, malgré l'attention acerue que l'on porte en même temps au régime progressif de la détention et aux formes nouvelles de privation de liberté. Pendant toute cette période, les femmes détenues représentent un nombre relativement restreint. Cela signifie en particulier que, jusqu'a la fin des annees quatre-vingt, elles sejjournent uniquement dans des sections qui se trouvent dans un complexe pénitentiaire pour hommes, où elles sont soumises au même régime et aux mềmes règles de sécurité. Cependant, la différenciation interne est beaucoup moins marquée pour les femmes. Il faudra attendre les années quatre-vingt pour voir appliquer un traitement à peu près êgal à celui des hommes sous la forme de rếmunération égale, de visites sans surveillant, de placement en 


\section{Resume}

milleu ouvert et semi-ouvert. Les possibilitês de travailler et de suivre des cours s'améliorent légèrement pendant les années quatre-vingt-dix. On crée une section: offrant un accompagnement individuel aux femmes confrontées a des difficultés légères d'ordre psychosocial, et une section d'accompagnement pour droguées. Certes, les rapports gouvernementaux publiês entre 1947 et 1990 plaident parfois en faveur d'un régime spécifique pour les femmes, mais ces plaidoyers vont rarement au-dela du * caractere propre de la femme . Il en va autrement dans le rapport Vrouwen in detentie (Femmes en détention) qui est présenté en 1991. Ce rapport contient un ensemble cohérent de recommandations émancipatrices. II y est donné suite surtout en ce qui concerne les dispositions pour les enfants de femmes détenues. L'unité mère-enfant de la prison de Sevenum, par exemple, où sont détenues des fermmes bênéficiant d'un régime en millieu semi-ouvert résulte des propositions du groupe de travail. Le projet est décrit dans ce chapitre. Il doit son succès relatif a la courte durée moyenne de séjour et a la coopération intensive avec la crếche qui se trouve en dehors de la prison. Il a principalement permis de constater que la continuitê pour l'enfant n'implique pas forcément un lien exclusif avec la mère, et que l'intérêt de l'enfant est une notion qui varie en fonction de la culture. Par ailleurs, on constate que le groupe cible d'une structure gonfle une fois que cette structure a êté mise en place.

Des débats sur le thème de la dêtention mixte et des relations familiales des détenus montrent qu'une notion idéologique des relations familiales joue un rôle important dans le choix du régime de détention. Le vécu sexuel des femmes, les expériences des femmes dont la famille constitue un environnement d'insécurité et d'oppression par excellence, les ambivalences relatives au rôle d'épouse ou de compagne et de mère, et la nature spécifique des symptômes médicaux et psychiques sont soit ignorés, soit dramatisés d'une manière telle que les femmes détenues continuent de porter les stigmates de la victime.

Le chapitre 4 traite de la situation juridique des femmes détenues. Qu'ils soient hommes ou femmes, les détenus ont selon le droit national les mêmes droits tant sur le fond que sur la forme. Il existe une législation spécifique pour les femmes uniquement en ce qui concerne le sejour en prison de nourrissons. Il apparaît que les normes internationales donnent une interprétation un peu plus large aux disspositions de fond pour les femmes en détention, même si le danger de voír surgir les stéréotypes sexuels menace toujours. Il s'agit en outre de règles qu'il faut lire comme des recommandations de régime et non comme des droits à effet direct. La jurisprudence ne contient aucune décision prise au niveau européen qui soít pertinente pour les femmes, et n'en comporte que quellques-unes prises à l'échelon national, en particulier dans des cas où, en vertu du principe d'égalitê, on constate une discrination indirecte du fait que, en l"espèce, des mesures ont des effets plus profonds pour les femmes en cause que cela ne serait le cas « normalement ". Ce chapitre aborde également le nouveau projet de loi sur les principes de 
l'administration pénitentiaire (loi PBW). Le droit au respect de la correspondance, aux visites et à l'usage du téléphone, notamment, tombent sous le coup de l'artícle 8 de la Convention européenne de sauvegarde des droits de l'homme et des libertés fondamentales. Toutefois, le droit au respect de la vie familiale et les efforts de réintégration justifieraient aussi une approche tenant compte de la problématique du genre, en ce qui concerne les règles régissant les permissions de sortir, le régime progressif de la détention et la politique de placement. Dans le cadre de l'accompagnement individuel, les règlements relatifs au travail et a la formation peuvent egalement tenir compte de l'entretien d'autrui et d'une resocialisation spécifique relevant du genre. Il convient de se demander s'il faut faire également prendre en compte les aspects du sexe et du genre pour les soins médicaux. La description asexuée du parent détemu, contenue dans l'article du projet de loi portant sur le séjour permanent d'enfants en codétention (article 12 du projet de loi PBW), est une nouveauté importante du point de vue de la problématique du genre. Fondé sur l'article 8 de la Convention européenne, il semble toutefois poser encore quelques difficultés d'ordre pédagogique et juridique au niveau de son élaboration.

Le chapitre 5 analyse les évolutions de la société relatives à la conception de la famille, de la maternité et de l'intérêt de l'enfant. La dissociation du mariage, de la sexualité et de la procréation, l'augmentation du nombre des divorces et la participation croissante des femmes au processus du travail ont eu une influence considérable sur le fonctionnement de la famille. Bien que, dans de nombreux cas, la fonction éducatrice seule soit un fondement insuffisant pour le maintien de la famille, le cercle familial est en général considéré comme le cadre idéal pour l'éducation de l'enfant. Peu de chercheurs se sont penchés sur l'influence des cultures non occidentales dans notre société. Cependant, la mobilité et la migration accrues semblent bel et bien exercer une influence sur la vie familiale actuelle. À l'égard de la maternité, on constate des attentes ambivalentes. Le devoir des femmes d'être constamment présentes s'est transformé en un idéal de disponibilité mentale et physique. Au dểbut, on dramatisait la relation entre les femmes qui travaillaient en dehors de la maison, mères célibataires ou non, et leurs enfants en étudiant les effets sur leurs enfants, tels que l'échec scolaire et la délinquance. Sur ces points, pourtant, la situation socioéconomique dans laquelle les enfants grandissent semble plus déterminante que le mode de vie ou les activités de la mère. Les femmes elles-mêmes montrent une certaine ambivalence à l'égard de leur rôle de mère. Les conditions socio-économiques, la nature de leur travail et leurs activités semblent déterminer les différences entre les mères par rapport à leurs propres idéaux. Les pouvoirs publics ont d'abord mené une politique tournée vers le modèle du soutien de famille. Les mères étaient censées rester au foyer et rien ne les encourageait à aller travailler. Grâce notamment à la politique d'émancipation, qui revêt un aspect économique important, les femmes sont depuis peu incitées à conquérir une place sur le marché du travail. Cette incitation prend souvent la forme d'une obligation. Les services sociaux ont des contacts 


\section{Resumé}

principalement, d'une part, avec des femmes qui doivent combiner le rôle de parent (isole) avec le chômage et une allocation socialle minimum et, d'autre part, avec des ménages allochtones. L'assistance qui leur est offerte relève encore souvent des idếaux familiaux traditionnels de la classe moyenne et de principes de la psychologie du développement concernant les enfants. Les mères allochtones surtout font savoir qu'elles souhaitent recevoir un soutien (pratique) intensifié pour l'ếducation des enfants plus ágés. Mais aussi que le soutien devrait être davantage axẻ sur leurs propres ambitions, et non pas simplement sur la relation mère-enfant. Il convient, en outre, d'accorder une plus grande attention aux réseaux sociaux liés à la culture, dans lesquels la grand-mère notamment joue un rôle important. Les théories sur le développement de l'enfant sont fondées sur deux courants principaux. L'un, relevant de la psychologie du développement, repose en majeure partie sur les liens familianx. Le triangle père-mère-enfant et la loyauté intergénérationnelle en sont les principaux piliers. L'autre, plus pédagogique, vise le développement autonome de l'enfant, son propre enviromnement, dans lequel les parents aussi bien que d'autres adultes et surtout des enfants de son áge trouvent une place. Ce courant s'appuie sur une autre notion de la formation de la personnalité. Les deux courants attachent une grande valeur à la sécurité de l'environnement dans lequel vit l'enfant en bas âge. Les conceptions concernant le développement des enfants plus ägés comportent des différences nettement plus marquées.

Le chapitre 6 étudie l'intérêt de l'enfant et la protection de la maternité dans la perspective des droits de l'homme. Différentes dispositions de la Convention européenne protègent la vie familiale et la vie privée des citoyens (voir article 8 de la Convention européenne). La Convention des Nations unies relative aux droits de l'enfant oblige les pouvoirs publics à soutenir les parents dans l'entretìen et l'éducation de leurs enfants en créant les structures adéquates. Dans la réalité sociale, la situation des enfants est étroitement liée à celle de la mère. Les enfants ont tout autant à gagner que les femmes à avoir leurs propres réseaux sociaux. On peut toutefois utiliser les droits de l'enfant pour pousser les femmes dans leur rôle traditionnel de mère . C'est pourquoi il est également inportant dans la perspective de "l'intêrêt de l'enfant * que la mère soit autonome. La Convention des Nations unies sur l'élimination de toutes les formes de discrimination a l'égard des femmes protège les differentes fonctions des a mères $\%$. La fonction biologique potentielle, qui conceme en principe toutes les femmes, la fonction biologique effective, qui se limite a la grossesse, a l'accouchement, a l'allaitenent et a la récupération physique postnatale, et la fonction sociale, qui recouvre l'entretien et l'éducation. La fonction sociale relève du genre et peut donc incomber an homme, s'il s'occupe effectivement de l'enfant au quotidien. II faut examiner dans chaque cas concret la manière dont se déroule la pratique quotidienne. Le degré d'ingérence des autorités dans le développement d"un « régime tourné vers l'entretien des enfiants » est avant tout un choix politique. Le present chapitre indique les evolutions du droit du travail, des structures 
d'accueil pour les enfants, de l'enseignement et de la santé publique, afin de trouver d'éventuels points de rattachement pour le régime pénitentiaire. On ne peut pas encore dire clairement dans quelle mesure les parents et les enfants peuvent recourir directement à des dispositions conventionnelles.

Les articles conventionnels qui ont un effet direct, tels l'article 8 de la Convention européenne et les articles 10 et 26 du Pacte international relatif aux droits civils et politiques, peuvent être renforcés par les dispositions de la Convention des Nations unies relative aux droits de l'enfant et de la Convention des Nations unies sur l'élimination de toutes les formes de discrimination à l'égard des femmes. La violation de la vie familiale d'un citoyen par les autorités en vertu de l'article 8, paragraphe 2 , de la Convention européenne doit être légitime et proportionnelle. Une intervention pénale à l'égard d'un parent sera en général légitime, mais il faudra préciser les principes de proportionnalité et de subsidiarité dans la perspective des relations existant dans le cadre de l'entretien de l'enfant. Des mesures concrètes devraient viser à maintenir les relations établies entre l'enfant et le parent, sauf au cas où cela devait être préjudiciable à l'enfant ou à d'autres personnes.

Le chapitre 7 a trait aux relations entre les membres de la famille. Il introduit le débat sur une éthique de l'entretien d'autrui dans le droit. Il s'avère que l'éthique de la justice, isolée de cas concrets, conduit à des différences dans le droit relevant notamment de la problématique du genre. On peut y remédier en considérant le contexte. La prise en compte des intérêts devrait être davantage liée aux agissements concrets. Reste à savoir si cela aurait des incidences sur le droit de la famille. Certains craignent que des relations familiales indésirables s'en trouvent renforcées. D'autres pensent qu'en se basant sur la situation effective de l'entretien, on peut parvenir à une interprétation matérielle de l'égalité et faire apparaître les rapports de pouvoir dans les relations privées. En droit de la famille, l'existence d'une vie familiale au sens de l'article 8 de la Convention européenne dépend souvent des liens juridiques (de filiation) et de la situation de fait, qui, à première vue, sont établies indépendamment du sexe. «L'intérêt de l'enfant » sert de principe directeur dans les situations de conflit, mais, en règle générale, ni la législation ni la jurisprudence ne précisent l'interprétation à lui donner. La personne qui exerce l'autorité parentale est libre de choisir le lieu de résidence de l'enfant et peut confier l'entretien et l'éducation de celui-ci à des tiers. Lorsqu'un parent et un enfant vivent séparês l'un de l'autre, l'intérêt de l'enfant, pris en compte pour examiner les demandes de droit de visite ou de changement de lieu de résidence, est défini surtout en fonction de la stabilité et de la continuité de l'environnement qui est sien à ce moment-là. Dans des situations conflictuelles autres que le divorce, il apparaît que l'isolement dans lequel le parent et l'enfant se trouvent l'un par rapport à l'autre du fait de l'écoulement du temps, est souvent déterminant pour l'exercice ou le non-exercice de droits existants. On peut déduire de décisions de la Cour européenne de justice que les autorités sont tenues d'oeuvrer en vue de permettre le maintien des relations de famille existan- 


\section{Resume}

tes. Le droit de la famille contient des notions d'approche contextuelle qui peuvent s'appliquer par analogie d'autres domaines.

Le chapitre 8 présente un plaidoyer en faveur d'une approche tenant compte du mode de vie dans le droit pếnal et le droit pénitentiaire. Les autorités doivent respecter la vie familiale et la vile privée des parents et des enfants, même lorsqu'un des parents a commis un acte punissable. Les principes de proportionnalité et de subsidiarité doivent être respectés dans chaque phase de la procédure pénale, lorsque se prennent des décisions qui impliquent des conséquences profondes pour la vie familiale. A cet egard, il faut tenír compte, d'une part, de la pratique de l'entretien de l'enfant au quotidien et de l'intérêt de l'enfant et, d'autre part, du degré de gravitê du délit et de la protection de la société. Dans une approche centrée sur le mode de vie, il importe de contrôler les interventions des autorités par rapport à la vie familiale établie, à l'intérêt de l'enfant et à la protection du lien avec la mère ou avec la personne quil assure l'entretien de l'enfant, sans tomber pour autant dans des stéréotypes vicieux. Par ailleurs, les autorités sont tenues d'optimaliser les relations avec la personne assurant l'entretien de l'enfant. Cette optimalisation est indispensable pour que ce réalise l"émancipation dans un sens social large. Les articles 26 et 26 bis de la Loi sur les principes de l'administration pénitentiaire (loi BGW) doivent aussil s'interpréter à la lumière des droits fondamentaux. Pour tenir compte d'un éventail le plus large possible de relations en matière d'entretien, on centrera l'attention principalement sur les femmes. Ce sont généralement elles qui prennent soin en premier lieu des enfants. Pour éviter de donner à la notion de « vie familiale w une interprétation restrictive et correspondant certains idéaux, on prendra en compte la diversité des relations en matière d'éducation. Il ressort des expériences des mères détenues que la phase de détention connaît deux périodes pendant lesquelles l'inquiétude oppressante qu'elles ressentent pour leurs enfants atteint un point culminant. D'abord, au début de l'incarcération, pendant la détention provisoire, puis dans une phase ultërieure, pour les femmes condamnées à de longues peines. Pour l'accueil des enfants et le maintien du contact, les deux situations nécessitent des structures très differentes. Si l'on a accordé une attention particulière au mode de vie pendant la phase préventive de la procédure pénale, les phases ultêrieures éventuelles peuvent s'en trouver facillitees. En effet, cette première phase est souvent déterminante pour les arrangements concernant les enfants qui sont fixés en cas de prolongement de la détention. Ce chapitre contient des propositions d'approche centrée sur le mode de vie, applicable à partir de la mise en détention provisoire et la fixation de la peine jusqu'à la fin de la détention. Ces propositions insistent constamment sur la nécessité d'éviter la détention. Le point de vue adopté à l'égard de la codétention des enfants est extrêmement réservé. On peut d’ailleurs se demander si un Etat est en droit de mettre le parent devant un tel dilemme. Au cas où un examen de toutes les options possibles n'apporte pas d'autre solution, il faut, dans l'intérêt de l'enfant, procéder à un contrôle de la proportionnalité, en vertu 
de l'article 5 de la Convention européenne, portant sur les conditions pédagogiques dans lesquelles l'enfant est détenu. À cette fin, on retiendra les facteurs suivants : la durée du séjour, le caractère, l'âge, le degré de développement et de mobilité de l'enfant et la possibilité d'entretenir des contacts avec d'autres enfants de son âge et le monde extérieur, y compris dans le sens spatial. Les femmes étrangères, qui représentent environ la moitié de la population carcérale féminine, pourraient avoir une compensation sous la forme d'une réduction de peine ou d'une grâce, dans la mesure où une approche centrée sur le mode de vie ne présente aucun intérêt pour elles.

Dans la mesure où des arguments pragmatiques - personnel ou moyens financiers disponibles - incitent à être réticent en ce qui concerne des arrangements individuels pour les détenus, on pourrait, dans le cadre d"une modification du régime collectif, accorder une priorité aux établissements pénitentiaires accueillant des femmes. Aucun argument touchant à l'ordre et à la sécurité ne peut justifier de ne pas agir dans ce sens. Le fait que la nature des délits et le pourcentage de récidive parmi les femmes diffèrent grandement de ceux que l'on constate parmi les détenus hommes, et que la peine subie ait un impact relativement plus lourd sur la vie privée et familiale des femmes justifie un régime prioritaire. Un tel régime impliquerait la création en milieu ouvert de structures prévues actuellement en milieu fermé. Il faudrait chercher à l'extérieur de l'établissement pénitentiaire non seulement des crèches et des garderies, mais aussi les soins médicaux pour les femmes, des écoles professionnelles pour femmes, des activités politiques, sociales, une formationgènérale élémentaire, en tenant compte autant que possible de l'identité culturelle. Ces activités en milieu ouvert permettraient aussi d'éviter qu'après la détention, les femmes ne retombent dans l'isolement. Dans une perspective de resocialisation, un tel régime de « normalisation " pourrait également prévoir des lieux d'accueil mixtes pour hommes et femmes.

Traduit par Catherine Miginiac 


\section{Literatuur}

- Adler, F., Sisters in crime, The rise of the new female criminal, MoGraw Hill, New York, 1975.

- Akkermans, P.W.C., Onderwijs als constitutioneel probleem, Samson, Alphen aan de Rijn, Brussel 1980.

- Alem, V.C.M. wan, L.H. Erkelens, G.M. Schippers, M.H.M. Breteler en J.M. Bekking, Verslavingsproblematiek in de penitentiaire inrichtingen, JV 1989/2, p. 39-61.

- Allen, H., Justice Unbalanced: Gender, Psychiatry and Judicial Decisions, M. Keynes Open University Press, 1987.

- Alliance of NGO's on Crime Prevention and Criminal Wussice, Children in prison with their mothers, New York, 1987.

- Ammons, L.L., Battered Woman Syndrome. Afrikaans-Amerikaanse wrouwen en geweld binnen het gezin, Nemesis 1996/6, p. 183-192.

- Andriessen, M.F. interview mett Dorie Klein, "We moeten de realiteit van vrouwenlevens leren begrijpen', TwCr, 1982/3, p. 131-144.

- Ayre, $E$, Theywon't take no for an answer: the Relais Enfants-Parents, Early Childhood Development: Practice and Reflections, number 11, Bernard van Leer Foundation, 's*Gravenhage, 1996.

- Baantman, H., Wie zijn kind liefheeft.....Over slaag, geweld en mishandeling, in: A. Groen en A. van Montfoort (red), Kinderen beschermen en jeugd hulp verlenen, Gouda Quint, Arnhem, 1993, p. 37-58.

- Baas, N.J., Elektronisch toezicht in een aantal landen, Ministerie van Justitie, WODC, 1995.

- Badinter, E., De mythe van de moederliefde, Rainbow Pocket, Amsterdam, 1989.

- Badinter, E., XY. Over de manneljke identiteit, Contact, Amsterdam/Antwerpen, 1993.

- Bainham, A., The Privatisation of the Public Interest in Children, The Modern Law Review, March 1990 , p. $206-222$.

- Balans, Themanummer, Over vrouwen, 1981,6/7.

- Baulon, M-A. e.a., Tableau comperatif de la legislation et des pratiques dans 65 Etats, Auditeurs de Justice. Ecole Nationale de la magistrature, Bordeaux (jaar onbeikend).

- Beauvoir S. de, De wweede sekse, Feiten, mythen en geleelde werkelijkheid, "Erven Bijleveld", Gitrecht 1978 (6e druk).

- Beckemam, A, lncarcerated Mothers and Their Children in Foster Care. The Dilemma of Visitation, Children and Youth Services Review, 1989/11, p. 175-183.

Beckhoveri, A. vant en M. Meenwig, Mama komt je straks weer halen. Gezinsopwoeding en kinderopvang, Aramith uitgevers, Bloemendaal, 1992.

- Beelen, P., Opgesloten in een inrichting, De Penitentiaire Open Irrichting voor Vrouwen, doctoralscriptie Rijksuniversiteit Utrecht, 1991.

- Beijerse, J. wit, en R. van Swaaningen, De zachte krachten zullen zeker winnen op 't eind, in: M.J.M. Verpalen (red), Druk en tegendruk Willem Pompe Instituut, Gouda Quint, Arnhem, 1994, p. 23-50. 


\section{Literatuur}

- Beleddsbrief 1997, Ministerie van Sociale Zaken en Werkgelegenheid, TK 1996-1997, 25006, nr. $\mathbb{1}_{\text {. }}$

- Beleidsnota, Met het oog op 1995, Beleidsprogramma Emancipatie, Ministerie vam Sociale Zaken en Werkgelegenheid TK 1992-1993, 22913, nrs. 1 en 2.

- Beleidsnota Emancipatie in uitvoering, koersbepaling van het emancipatiebeleid na 1995, Ministerie wan Sociale Zaken en Werkgelegenheid, TK 1995-1996, 24406, nr.4.

- Beleidsnota Taakstraffen, 'Voor strafleren werken', Ministerie van Justitie, 's-Gravenhage, 1996.

- Beleidsinota 'In juiste verhouding". Beleidvoornemens met betrekking tot rechtshandhaving en veiligheid, Ministerie van Justitie, "s-Gravenhage, 1996.

- Bekker, M., Werk en kinderen: dubbele belasting of een gezonde combinatie?, TVV 1995, p. 397-412.

- Bemmelen, J.M. van, Gedenkt der gevangenen. Opstellen over hervorming van het strafrecht en gevangeniswezen, Martinus Nijhoff, 's-Gravenhage, 1954.

- Berg W. van der, Naar een gedifferentieerde klachtprocedure woor gedetineerden, Trema 1986, p. 241-249.

- Bergh, P. van de, In het belang van thet kind, FJR 1986/4, p. 131-138.

- Benghuis, A.C., De Sprang, evaluatie van een bijzonder regiem in een jeugdhuis van bewaring, WODC, 's Gravenhage, 1981.

- Berkhout-yan Poelgeest, S., Detentie van verdachten op politiebureaus, in: J.A. Janse de Jonge, M. Moerings en A. van Vliet (red.) Binnen de steen van dit bestaan, Willem Pompe Instituut, Gouda Quint, Arnhem, 1993, p. 123-142.

- Bemhard, C., Mutter und kind im Strafvollzug, Fachhochschule Wiesbaden, 1988.

- Besier, E.J., De penitentiaire inrichting voor vrouwen, Balans 1979/2, p. 27-31.

- Besier, EJ., Open penitentiaire inrichtingen voor vrouwen 'Het Spoor', Balans 1987/7, p. 12-14.

- Besier, EJ. en P. van der Kies, Ter Peel, nu zelfmeldinrichting voor wrouwen, Balans 1987, p. 23-24.

- Bettem, $T$., 'Ze kunnen de muren wel met goud behangen, maar als de bejegening niet verandert, verandilert er niks, Kri-Katern, april 1978.

- Beurskens, WJJ.J., Sociaal recht en het bijzonder onderwijs, KLluwer, Deventer, 1991.

- Bhavnani, $K-K$ and $A$. Dawis, Incarcerated Women: Transformative Strategies, in: Gevangen yrouwen. Over criminaliteit en detentie, Nemesis-essays 1995/2, p. 142-158.

- Bieback-Diel, L. en B. Maelicke, Mütter und Kinder in Gefängnissen. Endbericht der Planungsberatung des Mutter-Kind-Heimes der Frauenstrafanstalt Frankfurt/M.-Preangesheim, I.S.S., Arbeitshefte 14, 1985.

- Bijker, B., Vrouwen zijn niel veroordeeld tot vorming, Proces 1978, p. 23-26.

- Biondi, $G$., Le jeune enfant vivant auprés de sa mère incarcerée, in: A. Bouregba (red.), Colloque Europeen. Liens familiaux \& déttention, Transitions nr. 39, Parijs, 1996, p. 179-182.

- Birsch, $V_{y}, I$. Riemann, en J. Rosenkranz, Die Entwicklung won Kindern, die mit ihren Mutter in Mutter-Kind Einrichtungen von Frauenstrafanstalten untergebracht sind, Institut für Sozialarbeil und Sozialpedagogik, Frankfurt, 1983.

- Bisschop, F, Experiment moeders met kinderen in cen halfopen inrichting, Proces $1996 / 5$, p. 108110.

- Blees M., Gevangenisstraf is hetzelfde als handen afhakken, Hervormd Nederland, 21-1-1984, p. 26-29.

- Boek, J., Gebruik van geweld binnen penitentiaire inrichtingen, Sancties 1991/6, p. 372-381.

- Boeles, $P$., Verblijfsvergunning voor buitenlandse moeder van kind met Nederlandse nationaliteit, NJCM-bulletin 1992/7, p. $759-765$.

- Boer, A.P. de, Partnerdoding, Gouda Quint, Arnhem, 1990.

- Boer, J. de, De pedagogische tik, NJB 1994, p. $389-390$ en p. 542. 
Boer, J. de, Artikel 8 EVRM. Algemeen 1, Pré-advies Nederlandse Juristen Vereniging, 1990, p. 1.64.

- Boer, W. de, Vrouwelijke gevangenen, Nieuwsbrief Nederlandse Vrouwenraad, 1978/2, p. 3-5.

- Boksem, J., Rechtspraak belklag ex art. 51 Beginselenwet Gevangeniswezen, Sancties 1992/2, p. 107-112.

- Bonarius, J.CJ., Het horen van kinderen als getuige bij incest: het verschoningsrecht, NJB 1994, p. 11167-1174.

- Bonger, W., Criminality and economic conditions (1916), herdruk onder redaktie van A.T.T. Turk, Indiana University Press, Bloomington, London, 1969.

- Bönnekamp, DA., De rechterlijke besluitworming inzake voogdij na echtscheiding, IWV, Vakgroep Rechtstheorie/encyclopedie, Rijksuniversiteit Utrecht, 1988.

- Bontekoe, E.H.M. Criminaliteit en geslacht, TvCr, 1984/1, p. 18-31.

- Boogaard, M.M.Al. van den, De kinderrechter en de (bestuurs)rechterlijke toets, FJR 1996/11, p. 199-201.

- Boonen, $K$, De nieuwe Penitentiaire Beginselenwet: Teloorgang van een aantal (rechts)waarborgen, Rechtshulp 1995/12, p. 2-14.

- Borst $t_{n}$ EJ. de, Women in detention, facts and figures about the Dutch penal system, Ministerie van Justitie, afdeling Beleidsinformatie D. en J., 's-Gravenhage, 1991.

- Bos, A., De zelfdefiniëring van vrouwen in detentie, scriptie Universiteit van Amsterdam, 1996.

- Bos, A.M., en J. Isarin, Kinderen, moeders, wrouwen, Nemesis $1992 / 3$, p. 4.

- Bosman, R.,'Je moet lief en streng zijn', Opvoeden in moedergezinnen, Jeugd en samenleving, $1994 / 12$, p. $690-706$.

- Boszormenyi-Nagy I., en G. Spark, Invisible Loyalties. Reciprocity in Intergenerational Family Therapy, Harper and Row; New York, 1973.

- Boszomenyi-Nagy en B. Krasner, Between Give and Take, Bruner-Mazel, New York, 1986.

- Boumans, T. en W. Kayzer, De zaak Annie E., Bert Bakker, Amsterdlam, 1979.

- Bouregba, A., Le parent terrible. Réflexions sur quelques cas des parents incestueux, Dialogue, $1992 / 3$, p. $62-70$.

- Bouregba A., Liens ou chaines? L'enfant victime d'un parent dangereux , Dialogue 1993/1, p. 35-42.

- Bouregba, A.(red.), Colloque Europeén. Liens familiaux \& détention; Transitions nr. 39, Parijs, 1996.

- Boutellier, H., Solidariteit en slachtofferschap: De morele betekenis van criminaliteit in een postmoderne cultuur, SUN, Nijmegen, 1993.

Bouw, C., Misdadige meisjes, TVC 1995/2, p. 124-137.

Bower, L., "Mother" in Law: Conceptions of Mother and the Maternal in Feminism and Feminist Legal Theory, Differences, A journal of Feminist Cultural Studies, 1991/1, p. 20-38.

Bowwlby, J., Attachment and Loss, vol. 1 en 2, Penguin, Hammondswordth, London, 1978.

- Box, S., Deviance, reality and society, Holt, Rinehart and Winston, London, 1981 (2d ed.)

- Braun, $M$, De prijs van de liefde: de eerste feministische golf, het huwelijksrecht en de vaderlandse geschiedenis, Hel Spinhuis, Amsterdam, 1992.

- Briggs, S., Women in prisons: a new age, The Bridge, 1988/7, p. 10-11.

- Brink, M. van den en A.C. Hendriks, Vrouwen en de gezondheidszorg, in: A.W. Heringa, J. Hes en L. Lijnzaad (red.), Het Vrouwenwerdrag een beeld van een verdrag....., METRO/Maklu, Antwerpen, Apelidoorn, 1994, p. 163-184.

- Brink, $M$. van den, en T. Loenen, Publiek/privé revisited: internationaal recht en vrouwen, in: Vechten om grenzen.. Beschouwingen bij het Joegoslavië Tribunaal, Nemesis-essays 3, 1996, p. 22-39. 


\section{Lineratuur}

- Brinkgneve, $C$, De belasting van de bevrijding, in: C. Brinkgreve, De vrouw en thet badwater, ower de lusten en lasten van het moderne (vrouwen)leven, Meulenhof, Amster dam, 1994, 4e dr. p. 9-26.

- Brinkhuizen, C., Vrouwengevangenis biedt ruimte voor BWO-hulp, Kri-Kallern, december 1976.

- Broek, M.C. van den en C.M. Broeshart, Vrouwen met kinderen in een penitentiaire inrichting: JV $1989 / 2$, p. 77-95.

- Brouwers M. en M. Sampiemon, Vrouwen in detentie, Ministerie van Justitie, WODC-rapport nr. 83, "s-Grawenhage, 1988.

- Brucken Fock, E.P. von, Ondertoezichtstelling en EVRM, JV 1990/2, p. 67-100.

- Bnucken Fock, E.P. von, Familicleven en familierecht, NJCM-bulletin 1996/1, p. 147-169. (1)

- Bnucken Fock, E.P. von , De Hoge Raad laat Jeroen in de kou staan, FJR, 1996/3, p. 62-65. (2)

- Bnuel, $M$, Le jeune enfant vivant auprès de sa mère incarcerée. Les parents terribles: jusqu'où le maintien des liens?, In: A. Bouregba (red.), Colloque Européen. Liens familiaux \& détention, Transitions nr. 39, Parijs, 1996, p. 137-147.

- Bnuijn-Lückers, M.L.C.C. de, Een rechtspositie voor minderjarigen?, NJB 1990, p. 373-376.

- Bruijn-Lückers, M.L.C.C. de, EVRM, minderjarigheid en ouderlijk gezag 'A whole code of juwenile law?; Tjeenk Willink, Zwolle, 1994. (1)

- Bnuijn-Lackers, M.L.C.C. de, Het familierecht wan vreemdelingen, NJCM-bulletin 1994/1, p. 34-47. (2)

- Bruijn, J. de, 'Het Nationaal Zorg Plan', witgebracht ter gelegenheid van de 8 maart lezing van Opzij, 1994.

- Bruinsma, G.J.N., C.I. Dessaur en R.W.J.V. wan Hezewijk, Female criminality in the Netherlands, in: F. Adler (ed.), The incidence of female criminality in the contemporary world, New York University Press, New York, 1981, p. 35-50.

- Brinsma, G.J.N., Criminaliteit als sociaal leerproces: een toetsing van de differentiële associatietheorie in de versie van K-D., Gouda Quint, Arnhem, 1985.

- Bninsma, G.J.N. en E. Lissenberg, Vrouwen als daders, in: G. Bruinsma e.a. (red.), Vrouwen en criminaliteit, Boom, Meppel, Amsterdam, 1987, p. 11-25.

- Brïnot, L., Mensenrechten als vrouwemrechten, Nemesis 1991/2, p. 27-30.

- Buquicchio-de Boer M., Children and the European convention on Human Rights, A survey of case-law of the European Commission and Court of Human Rights, in: F. Matscher en H. Petzold (ed.), Protecting Human Rights: the European Dimension (opstellen aangeboden aan G.J. Wharda), Köln, 1988, p. 73-89.

- Buruma, Y., Victimalisering van het strafrecht, in: M. Moerings (red.), Hoe punitief is Nederland?, Willem Pompe Instituut, Gouda Quint, Arnhem, 1994, p. 211-233.

- Bung, W. van den, Rechtem van kinderen: enkele filosofische kanttekeningen, in: $C$. van Nijnatten (red.), Kinderrechten in discussie, Boom, Ansterdam, 1993, p. 64-80.

- Bussemaker, $J$., Betwiste zellistandigheid, individualisering, sekse en verzorgingsstaat, SUA, Amsterdam, 1993.

- Bussemaker, $J$., Individualisering als paradox: Zelfstandigheid en persoonlijke levenssfeer naar aanleiding van de Algemene Bijstandswet, ir: Publiek geheim. Deprivatisering van het vrouwenleven, Nemesis-essays 1,1995 , p. 31-43.

- CTP/Inf (93) IS, Report to the Dutch Government on the visit to the Netherlands carried out by the European Committee for the Prevention of Torture and Inhuman or Degrading Treatment or Punishment (CPT) from 30 August to 8 September 1992, Straatsburg, 1993.

- CTP/Inf (93)20, Report of the Netherlands Government to the Report of the European Conmittee for the Prevention of Torture and Inhuman or Degrading Treatment and Pumishment (CPT) on its visit to the Netherlands from 30 August to 8 September 1992, Straatsburg, 1994. 
- Cain, M., Towards Transgression: New Directions in Feminist Criminology, International Journal of the Sociology of Law 1990/18, p. 1-18.

- Compbell, TD., The rights of the minor: as person, as child, as juvenile, as future adult, International Journal of Law and the Familly $1992 / 6$, p. 1-23.

- Carlen, P., Criminele vrouwen. Autobiografische verhalen, BZZTOH, 's-Grawenhage, 1987.

- Carlen, $\boldsymbol{P}$., Alternatives to Women's Imprisonment, Milton Keynes, Open University Press, 1990.

- Carlen, P., Women, Crime, Feminism, and Realism, Social Justice, 1990/4, p. 106-123.

- Carlen, P. en C. Tchaikovsky, Women's Imprisonment in England and Wales at the End of the Twentieth Century: Legitimacy, Realities and Utopias, in: R. Matthews and P. Francis, Prisons 2000. An international perpective on the current state and future of imprisonment, Mac Millan Press Londion, St. Martin"s Press New York, 1996, p. 201-218.

- Carlen, P. en A. Worrall (ed.), Gender, crime and justice, Milton Keynes, Open University Press, Philadelphia, 1987.

- Catan, $L$, The development of young children in prison mother and baby units, Research Bulletin $1989 / 26$, p. 9-12.

- Catan, $L_{n}$, Infants with mothers in prison, in: R. Shaw, Prisoner"s children. What are the issues?, Routledge, London N.Y., 1992, p. 13-28.

- Centrale Raad voor Strafrechtstoepassing, Differentiatie- en selectiestelsel gevangeniswezen, 8 juni 1989.

- Centrale Raad voor Strafrechtstoepassing, Vrouwen in detentie, 27 mei 1992.

- Charlesworth, H., C. Chinkin en S. Wright, Feminist approaches to internationall law, The American Journal of International Law, 1991, p. 613-645.

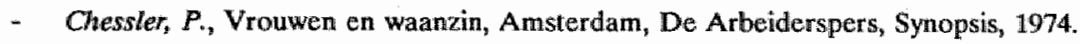

- Chodorow, N., Waarom vrouwen moederen, Psycho-analyse en de maatschappelijke verschillen tussen mannen en vrouwen, Van Nijgh en Ditmar, Amsterdam, 1989. (5e druk)

- Cleiren, C.P.M., Strafrecht als object van werlangen, in: E.A. Alkema en A.Ph.C.M. Jaspers, Lof der verscheidenheid. Rechtsgeleerden over vrouwen en recht, Tjeenk Willink, Zwolle, 1993, p. 41-48.

- Cloninger, R.C., and S.B. Guze, Psychiatric Illnesss and Female Criminality: The Role of Sociopathy and Hysteria in the Antisocial Woman, The American Journal of Psychiatry, september 1970, p. 79-97.

- Cohen, M.J., Over het denken van juristen, Nieuwenhoflezing V, Maastricht, Kluwer, Deventer, 1992.

- Commissie Fick, Rapport van de commissie tot verdere uitbouw van het gevangeniswezen, Ministerie van Justitie, 's-Gravenhage, 1947.

- Commissie "Huwelijksproblemen van gedefineerden", Ministeric van Justitie, "s-Gravenhage, 1966.

- Coomans, F, De internationale bescherming yan het recht op onderwijs, Stichting NJCM Boekerij nr. 20, Leiden 1992.

- Corstens, GJ.M, Het Nederlandse strafprocesrecht, Gouda Quint, Arnhem, 1995. (2e druk)

- Crambag H.F.M., en W. Elzinga, Niet waar de kinderen bij zijn, in: K. Blankman en L.C.M. Stegman (red.), Het recht of het belang van het kind, Van Gorcum, Assen/Maastricht, 1989, p. 2-13.

- Crambag H.F.M. P.J. van Koppen en W.A. Wagenaar, Dubiewze zaken, de psychologie van strafrechtelijk bewijs, Contact, Antwerpen/Amsterdam, 1992.

- Crombag H.F.M. en H.L.G.J. Merkelbach, Herwonden herinneringen en andere misverstanden, Contact, Amsterdam/Antwerpen, 1996.

- Cuyvers, P.F., Uitstel wan kinderen. Een kwestie van carrière of modernisering van de levensloop?, JV $1996 / 8$, p. $9-19$. 
- Dalebout, $L$, De vrouwengevangenis, Niewwe Revu, 16-23 augustus 1990.

- Daly, $K_{\text {, }}$ Rethinking judicial paternalism: Gender, Work, Family Relations and Sentencing, Gender and Society, 1989/1, p. 9-36.

- Dam, B. van, Kindermiddagen en andere bezoekmogelijkheden in gevangenissen, Proces, $1996 / 5_{\text {, }}$ p. 110-111.

- Damen, $L$., Versluierend gebruik van het begrip 'verantwoordelijkheid', Recht en Kritiek, 1985, p. 94104:

- Damen, $L$, De kinderrechter: bestuursorgaan of rechter?, Recht en Kritiek 1992/2, p. 144-179.

- Daru, M., m.m.v. H. Lakmaker, Een verborgen eiland in het verborgen continent. Een historiografische verkenning van de geschiedenis van de huishoudelijke arbeid, Tijdschrift voor Sociale Geschiedenis, november 1993, p. 381-431.

- Dasberg $L_{\text {., }}$ Grootbrengen door kleinhouden als historisch verschijnsel, Amsterdam/Meppel, 1984.

- Dasberg, L., Opvoeden in een weerbarstige samenleving, gesprelk met J.C.J. Boutellier, JV 1988/8, p. 52-57.

- Delden, P. van, Misdaad en straf in Nederland, Van Gorcum, Assen/Maastricht, 1987.

- Dessaur, C.I, Criminologie zonder masculisme, TVCr, 1979/5, p. 203-210.

- Deutekom, F.A.P.M. van, Rechtspraak beroep ex art. 123 Gevangenismaatregel, Sancties $1992 / 2$, p. 112-116.

- Diduck, A., The Unnodified Family: The Child Support Act and the Construction of Legal Subjects, Journal of Law and Society, 1995/4, p. 527-548.

- Diex, J., Marktgedrag in de kinderopwang. Privatisering wan de kinderopvarig en het VN-Vrouwenverdrag, Nemesis $1996 / 5$, p. 133-135.

- Dijk, G. vam, en A. de Wr, Vrouwe Justitia of Vrouwe Hysterica. Een artikel over psychiatrisering van vrouwenkriminaliteit, Proces $1982 / 7$, p. 188-197.

- Dijk JIJ.M. van, H.I. Saget-Grande en L.G. Toomwliet, Actuele criminologie, Koninklijke Vermande, Lelystad 1996. (2e herziene druk)

- Dijk, $P$. van, Toelating en verblijf van vreemdelingen in Nederland; eerbiediging van het familieen gezinsleven op grond van artikel 8 EVRM, NJCM-bulletin 1994/1, p. 6-33.

- Dijkers, $W$., Toewijzing van kinderen. De rechterlijke beslissing inzake de voorlopige en definitieve gezagswoorziening. Beslissingsproces en criteria, NJB 1991, p. 281-286.

- Dijkers, W., Is dat wat we willen?, NJB 1991, p. 583-584.

- Dijkstra, $S$., Perpetuum mobile? De overdracht van geweld betwist, TvCr. 1994/4, p. 348-359.

- Dobash, R.P., R.E. Dobashts en S. Gutteridge, The Imprisonment of Women, Basil Blackwell, Oxford and New York, 1986.

- Doek, $J_{\text {, }}$ De ratificatie van het Verdrag woor de rechten van het kind. Enige beschouwingen over de mogelijke gevolgen voor de Nederlandse rechtspraktijk, NJCM-bulletin 1995/1, p. 10-21.

- Doome-Fituiskens, J.A, van, Betaalde en onbetaalde arbeid: over oude spanningen en nieuwe uitdagingen, Christine de Pissanreeks nr. 5, Erasmus Universiteit Rotterdam, 1992.

- Doughty, J., Een kwestie van cultuur? De aanpak van kindermishandeling in Nederland en de Verenigde Staten vergeleken, in: E. Singer en M. Wegelin, De familieband verbroken, Van Arkel, Utrecht, 1991 , p. 176-179.

- Downing, D.S., The Incarcerated Mother's Rights with Respect to her Children, Columbia Human Rughts Law Review, 1989/20, p. 75-93.

- Driesch, $D$, von den, en $G$. Kawamura, Straffällige Frauen-Lebenslagen und Hilfeangebote, Neue Kriminalpolitik, 1995/1, p. 33-36.

- Dronkers, J., De betekenis van het beroep van werkende moeders voor de ongelijkheid in de samenleving, Tijdschrift voor Arbeidsvraagstukken, 1992/2, p. 145-156. 
- Dute, J.CJ., De vaccinatieplicht als schijnoplossing, NJB 1993, p. 1626-1627 met naschrift van Veldkamp en Bogers.

- Eaton M., Justice for women? Family, Court and Social Controll, St. Mary's College, Strawberry Hill, 1986, p. 87-98.

- Eaton, M., Women after prison, Buckingham, Open University Press, 1993.

- Edwands, A.R., Sex/Gender, Sexism and Criminal Justice: Some Theoretical Considerations, International Journal of the Sociology of Law 1989/17, p. 165-184.

- Edwards, S.S.M., Women on trial. A study of the female suspect, defendant and offender in the criminal law and criminal justice system, Manchester University Press, 1984.

- Edwards, S., Battered women who kill, New Law Journal, october 1990, p. 1380-1392.

- Eekelaar, J., The importance of thinking that children have rights, International Journal of Law and the Family, 1992/6, p. 221-235.

- Eerenbeemi, Ev van den en A. van Heusden, Balans in beweging. Ivan Boszormenyi-Nagy en zij̄n visie op individuele en gezinstherapie, De Toorts, Haarlem, 1983.

- Egtberts, J. e.a., De lange mars door de instituties, TGP, januari 1992, p. $20-22$.

- Eindrapport Adviesgroep Vrouwenhulpverlening. Zorgvernieuwing op het lijf geschreven, kwaliteitsverbetering door ontwikkeling en integratie van vrouwenhulpverlening, Rijswijk 1991.

- Eisler, R., Human Rights: Toward an Integrated Theory for Action, Human Rights Quarterly 1987/9, p. 287-308.

- El Sadaawi N., Vrouwengevangenis, Rainbowpocket nr. 166, Muntinga, Amsterdam, 1994.

- Elzinga en Naber, Meisjes en de kinderbescherming: justitiële controle op de sexualiteit, TvCr $1984 / 4$, p. $209-224$.

- Emancipatieraad, Het afstammingsrecht en zijn rechtsgevolgen. Achtergrondstudie over afstammingsrecht, ouderlijk gezag en omgangsrecht, "s-Gravenhage, 1985.

- Emancipatieraad, Oudlerlijke macht en voogdij. Een advies over de oudlerlijke macht en over enkele aspecten met betrekking tot de voogdij na (echt)scheiding), 's-Gravenhage, 1992.

- Emancipatieraad, Advies Vrouwenmantel en mannentrouw in de thuiszorg, 's-Gravenhage, 1993.

- Emancipatieraad, Met recht een emancipatoire zorg. Een beschrijving van het onderzoek naar zorg, mede met het oog op de juridische toepasbaarheid ervan, "s-Gravenhage, 1993.

- Emancipatieraad, Met zorg naar nieuwe zekerheid. Advies over een geëmancipeerd inkomensen sociale zekerheidsbeleid, "s-Gravenhage, 1996.

- Emmerik, M. van, Klachten van kinderen bij de. Europese Commissie voor de Rechten van de Mens te Straatsburg, Rechtshulp 1992/6, p. 9-18.

- Eriksson, E.H., Identiteit, jeugd en crisis, Spectrum, Utrecht, 1972, $2 \mathrm{e}$ dr..

- Essen ${ }_{0}$. van, Opvoeden met een dubbel doel, Twee eeuwen meisjesonderwijis in Nederland; SUA, Amsterdam, 1990.

- European Action Research Comntittee an children of imprisoned parents, Children of imprisoned parents. Family ties and separation. Report on the situation in eight European Union countries, Paris, 1996.

- Ewing C.P., Psychological Self-Defense, A Proposed Justification for Battered Women who kill, Law and Human Behavior, 1990/6, p. 579-594.

- Experiment moeders met kinderen in gevangenis Ter Peel, Ministerie van Justitie, afd. DJI, juni 1995.

- Feeley, M.M. en D.L. Little, The vanishing femalle: the decline of women in the criminal process, 1687-1912, Law and Society Review, 1991/4, p. 719-757.

- Feinman, C., Women in the criminal justice system, Praeger, New York, 1986, (2e ed.).

- Fiselier, J.P.S., De kwaliteit wan het verblijf in de politiecel, Sancties 1991/4, p. 205-210. 
- Fiseller, J.P.S., The State of the Prisons: geen reden tot juichen, Sancties 1993/5, p. $268-271$.

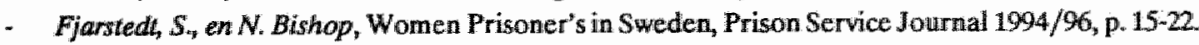

- Ftinteman, C. Het recht tot klagen. Totstandkoming van een Facultatief Protocol bij het Vrourwen* verdrag, Nemesis $1995 / 1$, p. 5-11.

- Forder, C. en R. Wolleswinkel, The trutth about women's bodies, interfacultaire vrouwenstudiesdag, Maastricht, 1991.

- Forder, CJ., Positieve verplichtingen in het kader van het Europees Verdrag tot bescherming van de Rechten van de Mens en haar fundamentele vrijheden, NJCM-bulletin 1992/6, p. 611-637.

- Forder, $C_{n, *}$ In het gezinslewen: 'Different but equal ${ }_{j}$ in: A.W. Heringa, J. Hes en L. Lijnzaad, Het Vrouwenwerdrag een beeld wan een werdrag...., MAKLU, Antwerpen/Apelldoorn, 1994, p. 239-253.

- Forder, $C$. Legal Establishment of the Parent-Child Relationship: Constitutional Principlles, Maastricht, 1995.

- Forder, CJ., Kroniek wan het personen- en familierecht, NJB 1996, p. 1344-1347.

- Foucaul, M., Discipline and punish. The birth of the prison, Vintage Books Ed., Random House, New York, 1979.

- Franke H.J., De golfslag van het gevangeniswezen, Sancties 1991/6, p. 345-357.

- Franke HJ., Twee ceuwen gevangen. Misdaad en straf in Nederland, Aula paperback, Het Spectrum, Utrecht, 1990.

- Franken, H, Het belang van het kind voor wetgeving en bestuur, in: Met het oog op het belang van het kind. Afscheidsbundel M. Rood-de Boer, Kluwer, Dewenter, 1988, p. 27-42.

- Fuldauer, A., Fatale liefde. Mannen en vrouwen die hun partner doodden, off daartoe een poging deden, De Arbeiderspers, Amsterdam, 1994.

- Fuldauer, A., Vrouwenvleugel. Gesprekken met gedetineerde vrouwen (1), in: Gewangen wrouwen. Over criminaliteit en detentie, Nemesis-essays 1995/2, p. 76-91.

- Fuldauer, A., Rondom zeven, gesprekken met gedetimeerde vrouwen(2), in: Gevangen vrouwen. Over criminaliteit en detentie, Nemesis-essays, 1995/2, p. 103-114.

- Genders E. en E. Player, Women in Prison: The Treatment, the Control and the Experience, in : P. Carlen en A. Worrall (ed.), Gender, Crime and Justice, Open University Press, Milton Keynes, Philadelphia, 1987, p. 161-175.

- Gerritsma, H., in: A. Ladan, P.G.J., Mettrop, W.G.H. Wolters (red), De betekenis van de vader: psycho-analytische visies op het vaderschap, Boom, Meppel, 1985.

- Geuris, R. en W. de Haan, Moeders wil is wet in de vrouwentoren, Kri, juni 1986, p. 5-6.

- Geurts, R., Direkteur Jan Piek viert de teugels in "De Singel", Kri, december 1987, p. 15-16.

- Genwen, W. van, Beginselen wan behoorlijk handelen, Tjeenk Willink, Zwolle, 1983.

- Giallombardo, R., Society of women: a study of a women's prison, John Wiley \& Sons Nc, New York, London, Sydney, 1966.

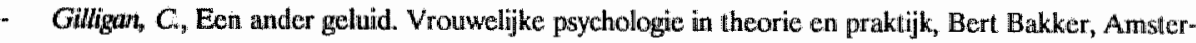
dam, 1985.

- Gijsbers van Wijk, C.M.T., Sex differences in symptom perception. A cognitive-psychological approach to health differences between men and women, Thesis, Universiteit van Amsterdam, 1995.

- Goethals, J., E. Maes en P. Klinckhamers, Vrouwen en strafrechtsbedeling. Is er sprake van een geslachtsspecifiek selectieproces?, Panopticon 1995/5, p. 420-450.

- Goffman E., Totale instituties, Universitaire Pers Rotterdam, 1975.

- Goldschmidl, J.E, Staats- en bestuursrechtelijke aspecten van positieve actie, Pré-advies Nederlandse Juristen Vereniging, Tjeenk Willink Zwolle, 1989, p. 57-117.

- Goldschmidt, J.E. en R. Holtmaat, Vrouw en Recht, DCE/STEO-trendrapport, 's-Gravenhage, 1993. 
Goldschmidt, J.E, Een ander werhaal in het recht, in: J.E. Goldschmid, We need different stories, Tjeenk Willink Zwolle, 1993 , p. 1-30. (1)

- Goldschmidt, J.E, Verhalen van verschil, in: J.E. Goldschmidt, We need different stories, Tjeenk Willink Zwolle, 1993, p. 33-68. (2)

- Goldschmidt, J.E., De aidstest: doorwerking of beperking van macht?, NJB 1993, p. 1539-1543. (3)

- Goldschmidt, J.E., Mensenrechten; vrouwenrechten?, Nieuwenhoflezing VII, Maasiricht, Kluwwer, Deventer, 1995.

- Goudal-Bourdy, M.C., 1983-199310 ans d'accompagnement des mères incarcérees avec leur bébe, (13 p., ongepubliceerd).

- Goudena, P.P., Pedagogische preventie; mogelijkheden en preventie, IV $1996 / 6$, p. 38-49.

- Goudoever-Herbschleb, M.D. van, Klachten van gedetincerden. Een analyse van ingediende klachten in het kader van de beklagregeling gedetineerden, Ministerie van Justitie, afd. DJI, 's-Gravenhage, april 1994.

- Graaff, $K$. de, Praktijkboek voor de penitentiair inrïhtingswerker, Samson/Tjeenk Willink, Alphen aan de Rijin, 1996.

- Groenhujisen, M., Audiowisuele registratie van verhoren van jeugdige getuigen, DD 1992/1, p. 1-7.

- Groot, G.R. de, Op weg naar een Europees personen- en familierecht, AAe, 1995, p. 29-33.

- Grotenhuis, H. te, Opgroeien aan de rand van de verzorgingsstaat, Jeugd en samenleving, 1994/12, p. $707-719$.

- Guise, A. en H. Rutgers, Gemengde detentie: dat zit wel goed!, scriptie Rijksuniversiteit Utrecht, 1990.

- Guming $M$., Liever gemarmerd, Recht en Kritiek 1985/11, p. 12-32.

- Gunning, $M$., Vrouwen, vrijheid en gelijkheid: De rechtsfilosofische ontdekküng van de privésfeer, in: Rode draad: Op naar eem gefeminiseerd recht, AAe 1992, p. 455-461.

- Gunning $M$., Communitarisme en onrechtvaardigheid in het gezin. Een pleidooi voor het primaat van een hartstochtelijke recht. Pré-advies van de vereniging voor wijsbegecrte wan het recht, $R$. en R. 1993/11, p. 7-35.

- Gunning M., Onvolwassen recht. Erkenning van het kind als de ander, Nemesis 1994/1, p. 17-23.

- Gunuing M. en T. de Roos, Het recht om groot te worden en klein te zijn. Reflecties op het kindbeeld in het (omgangs) recht, in: De kant van het kind, Liber Amicorum voor M. de Langen, Gouda Quint, Arnhem, 1992 , p. $35-50$.

- Gunsteren, H.R. van, Denken ower politieke werantwoordelijkheid, Samson, Alphen aan de Rijn, 1974.

- $\quad H$, E. van, Brief uit de vrouwenbunker van de Bijlmerbajes, "Dit onmenselijke gebouw, waar je je soms net een kasplantje voelt", De Nieuwe Linie, 3-10-1979, p. 8-10.

- $\quad H$., $E$ war, Tweede brief uit de vrouwenbunker van de Bijlmerbajes. Eenzame opsluiling wegens het weigeren van dwangarbeid, De Nieuwe Linie, 30-1-1980, p. 8-10.

- Haan, $F$, de, "Niet langer cellulair nog steeds Elizabeth Fry', in: Gevangen wrouwen. Over criminaliteit en detentie, Nemesis-essays, 1995/2, p. 58-75.

- Haaren, wan, De vrouwentorem van de Bijlmerbajes, Proces 1979, p. 107-111.

- Haas, O.P. de, Naar een model voor psychosociale gezondheid, toegespitst op de detentiesituatie, in: "Psycho-sociale kwaliteit van de detentie", Ministerie van Justitie, afd. D. en J., "s-Gravenhage 1989, p. 12-28.

- Habemas, J., Recht en moraal, Twee voordrachten, ingeleid door W. van den Burg en W. van Reijen, uitg. Kok Agora, Kampen, 1988.

- Hagemann=White, C., 'Geslacht en gedrag', Soc.Fem. Teksten, 1989/11, p. 33-49. 


\section{Literanum}

- Holly, K, Mothers Behind Bars: A Look at the Parental Rights of Incarcerated Women, New England Journal on Prison Law, 1977/4, p. 141-155.

- Hammerstein-Schoondenwoerd, $W_{4}$, Samen door het leven..., Nieuwenhoflezing VI, Maastricht, Kluwer, Deventer, 1994.

- Hammenteim-Schoandenwoend, W.C.E., Ouderschap, anders geregeld, Tjeenk Willink, Zwolle, 1988

- Hammerstein-Schoondenwoerd, W.C.E., Kroniek van het Personen- en Familierecht, NJB 1993, p. 133-137.

- Harjes, $U$, "Frauenfreigang" zur Versorgung der Kinder und des Haushaltes. Vorschlag einer Verwaltungsworschrift zu par. 11 StVollzG, ZIStVo, 1985, p. 284-286.

- Hant, A.C. "t, 't Recht als schild van Perseus; voordrachten ower strafrechtstheorie, Gouda Quint BV/KIuwer Arnhem-Antwerpen, 1991.

- Hart, A.C.'t, Totale instituties en het totalitaire, Gouda Quint, Arnhem, 1993.

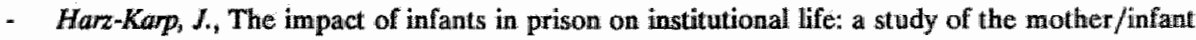
prison programme in Western Australia, Australian/New Zealand Journal of Criminology, 1983/16, p. $172-189$.

- Hatum, WF. van, Van insluiten naar elektronisch aanlijnen. Het experiment met elektronisch toezicht, Sancties 1995/6, p. 318-336.

- Heidensohm, F., Prison for women, The Howard journal of penology and crime prevention, d1.12, nr. 4,1969 , p. $281-287$.

- Heidensohn, F., Women and Crime, MacMillan Education Lid, London, herdruk 1986.

- Heijden, T. van der, Sekse en criminaliteit, in. G. Bruinsma (red.), Vrouw en criminaliteit, Boom, Meppel/Amsterdam, 1987, p. 30-34.

- Heijder, A., Recht voor gedetineerden, DD 1979/9, p. 460-469.

- Heine, B.G.T.J. ter, Gewelddadigheid in huwelijk en gezin. Een forensisch psychologische bijdrage, DD $1995 / 9$, p. $943-955$.

- Heringa, A.W., Voorkeursbehandeling en moederschap, in: A.W. Heringa, J. Hes en L. Lijnzaad (red.), Het Vrouwenverdrag: een beeld van een verdrag...., MAKLU, Antwerpen/Apeldoorn, 1994, p. 31-42.

- Heringa, A.W., Botsende systemen....., Algemene wet gelijke behandeling en Vrouwenverdrag, Nemesis $1995 / 1$, p. 16-18.

- Hemans, $H$., Gezondheidsrecht en minderjarigen, Kluwer, Deventer, 1990.

- Hezewijk, R. van, en G. Bnuinsma, Vrouwencriminaliteit, de achilleshiel wan de criminologie, TWCr 1979/5, p. 223-224.

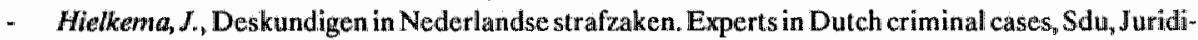
sche en Fiscale Uitgeverij, Den Haag, 1996.

- Hoksbengen, R.A.C. Belangen van kinderen in niet-traditionele gezinnen, JV1996/8, p. 20-35.

- Holternan, Th., Vreemdelingenrecht, toelating en verblijf van vreemdelingen in Nederland, Tjeenk Willink, Zwolle, 1996. (4e geheel herziene druk)

- Holtmaat, $R$, Naar een ander recht $I_{*}$ De macht van juridische begrippen. Oniwikkeling van een feministische rechtsthearie. Nemesis $1988 / 1$, p. 3-13.

- Holtruat, R, Naar een ander recht II, Ferninistische theorie en feministische rechtstheorie. Aanzetten tot een methode. Nemesis, 1988/2 p. 60-66.

- Holtwaat, $R$, De macht van het recht. Carol Smart en de sirenenzang van het recht, Nemesis 1990/6m p. 275-282.

- Holtomaat $R_{\text {, }}$ Met zorg een recht? Een analyse van het politick-juridisch vertoog over bijstandsrecht, Tjeenk Willink, Zwolle, 1992.

- Holtmaat, R., Deeltijdwerk, gelïk heid en gender, Nemesis 1996/1, p. 4-17. 
- Hollowi, N., A.C. Hendiks en D.M.I. Bouduin (red.), De betekenis van art. 12 Vrouwenverdrag voor Nederland: gezondheid als recht, VUGA, Amsterdam, 1996.

- Holtnust, N. en I. de Hondt: Gelijke behandeling in het familierecht, Nemesis 1987/5, p. 324-328.

- Holtrust, N., Moederzorg en vaderrecht, NJB 1985, p. $201-207$.

- Hollnust, $N_{\text {ty }}$ Aan moeders knie. De juridische afstammingsrelatie tussen moeder en kind, Ars Aequi Libri, Nijmegen, 1993.

- Holwenda, $G_{n,}$, Nog honderd nachtjes slapen. Evaluatieverslag van het Mentorproject woor kinderen van gedetineerden. Verslag naar het onderzoek naar de psychosociale situatie wan kinderen met een gedetineerde ouder en interventiemogelijkheden, Reclassering Nederland, "s-Hertogenbosch, 1995.

- Hooghiemstra B.TJ. en M. Niphuis-Nell, Sociale atlas van de vrouw, Sociaal en Cultureel Planbureau, Rijswijk, 1993.

- Hounslow, B., A. Stephentson, J. Stewart and J. Crancher, Children of imprisoned parents, Ministry of Youth and Community Services of New South Wales, Sydney, 1982.

- Howe, A., Prologue to a History of Women's Imprisonment: In Search of a Feminist Perspective, Social Justice, Voll. 17, $1990 / 2$, p. 5-22.

- Hudig J.C., De criminaliteit der vrouw, Dekker en Van de Veght, Nijnegen, 1940.

- Huët J.F. wan, De gedetineerde van allochtone afkomst in de penitentiaire inrichting, Migrantenrecht: $1988 / 7$, p. 192-194.

- Huizer-Gerritsen, $J$, Mothers in detention: fact or fiction?, Verslag van een studiereis gesubsidicerd door een Social Fellowship grant wan de Council of Europe, 1992.

- Igodt, M., Le parent terrible, maltraitant ou abuseur, in: A. Bouregba, Colloque Européen, Liens familiaux \& détention, Transitions nr. 39, Paris, 1996, p. $201-206$.

- IJzendoom, M.H. van, I. Tavecchio, F. Goossens en M. Vergeer, Opvoeden in geborgenheid: Eem kritische analyse van Bowlby's attachmenttheorie, Van Loghum Slaterus, Deventer 1985 , $2 \mathrm{e}$ herz. dr..

- Isarin, J., De prikpil, symbool van onvrijheid, Nemesis. 1986/4, p. 159-160

- Isarin, J., Een vrouw ter beschikking gesteld: 'Van de goot in de afgrond'. Het verhaal achter de prikpil, Nemesis $1987 / 4$, p. 189-201.

- Jackson, J., The loss of parental rights as a consequence of conviction and imprisonment: unintended punishment, New England Journal on Prison Law, 1979/6, p. 61-112.

- Janse de Jonge, J.A., Om de persoon wan de dader; over straftheorieën en voorlichting door de reclassering, Willem Pompe Instituut, Gouda Quint, Arnhem, 1991.

- Jansen, $I_{\text {, }}$ De positie van de minderjarigen in enige gezondheidsrechtelijke voorstellen, FJR 1993/1, p. 68-71.

- Jonsen, I., Europees Verdrag inzake de uitoefening van rechten van kinderen, FJR 1996/6, p.132-138.

- Jansser, J., Latijnsamerikaanse drugskoeriersters in detentie: exels of zondebokken?, Willem Pompe Instituut, Gouda Quint, Arnhem, 1904.

- Jansen, OJ.D.M.L., De koude uitsluiting van het penitentiair bestuursrecht. Enkele opmerkingen over het wetsvoorstel Penitentiaire Beginselenwet, NJB 1995, p. 1107-1114.

- Jong, M. de, "Mannen en vrouwen samen: humanere detentievorm", Vrij Spraak 1990/6, p. 6-7.

- Jonge, G. de, Bajes-baby's, FJR 1993/5, p. 98-101 met naschrift van C. van Wamelen.

- Jonge $G$. de, Strafwerk. Over de arbeidsverhouding tussen gedetineerden en Justitie, uitg. De papicren tijger, Breda, 1994. 


\section{Literotuur}

- Jonge, $G$. de, Een geregeld lewen. Enkele opmerkingen ower de rechtspositie van gedetineerden in de beoogde Penitentiaire Beginselenwet, in: Symposium Nreuwe Wetgeving voor gedetineerden, Opleidingen Sociaal Recht, Utrecht, 12 juni 1996, p. 91-101.

- Jonge, $G_{n}$ de en $R$ Vepalen, Bajesbock, Handboek voor gedetineerden en ter beschikking gestelden, witg. De papieren tijger, Breda, 1992, 4e druk.

- Jong H. de, Een fatsoenlijk regiem, in: MJ.M. Verpalen, Druk en tegendruk, Constructieve bijdragen aan de discussie over het cellentekort, Willem Pompe Instituut, Gouda Quint, Arnhem, 1994.

- Jongh, JI. de, Verzameling wan wetten, decreten, besluiten, reglementen, instructiën en be palingen, betreffende het gevangeniswezen in de Nederlanden, eerste deel ${ }_{3}$ (1791-1844), Leeuwarden, $1846_{*}$ no. 84 .

- Jonker-de Putter, I, Als je kind misbruikt is: analyse van factoren die het gedrag wan de moeder beinvloeden voor, tijdens en na het ontdekken van seksueel misbruik van haar kind, An Dekker, Amsterdam, 1991.

- Junger-Tas, J, Sociale controle of sociale binding, TwCr 1985/5, p. 244-265.

- Junger-Tas, J., Boekbespreking C. Rutenfrans, Criminaliteit en sexe, RM Themis 1992/1, p. 34-36.

- Junger-Tas, $J$., Het raadsel van de vrouwencriminaliteit, in: Gevangen vrowwen. Over criminaliteit en detentie, Nemesis-essays 1995/2, p. 20-42.

- Junger-Tas, J., Gezinsbeleid vanuit cen justiticel perspectief, JV 1996/6, p. $17-37$.

- Junger, M., G.J. Terlouw, P. van der Heijden en $C_{n}$ Rutenframs, Zelfcontrolle, ongevallen en criminaliteit, TvCr 1995/1, p. 2-21.

- Kaller, N., Long-Term Effects of Divorce on Children; a Developmental Vulnerability Model, in: American Journal of Orthopsychiatry 57(4), 1987, p. 587-600.

- Kannegieter, $G$, Ongelijkheid in de straftoemeting. De invloed van de sociale positie van de verdachte op strafrechlelijke beslisingen, Geschriften van de juridische faculteit der Rijksuniversiteit Groningen, 1994.

- Kanter, R.M., Men and women of the corporation, Basic Books, New York, 1977.

- Kelk, $C$, Grondrechten voor gedetineerden: een schamel licht in cen duisterbestaan, in: J.B.M. ten Berge e.a. (red.), Recht als norm en aspiratie, Opstellen over recht en samenleving ter gelegenheid van het 350-jarig bestaan van de Utrechtse juridische faculteit, Ars Aequi Libri, Nujmegen, 1986 , p. 329-347.

- Kelk, C., De medische zorg voor gedetineerden, Tijdschrift voor gezondheidsrecht, 1989/1, p. 2-21. (1)

- Kelk, $C$, De beperkte betekenis van grondrechten in de strafexecutie, DD 1989/6, p. 573-588. (2)

- Kelk, $C$., Straftoemeting een proces wan wikken en wegen. De waarde van de gemengde strafrechtstheorie, Trema, 1992/3, p. 113-125.

- Kelk, C., Kort begrip van het detentierecht, Ars Aequi Libri, Nijmegen, 1993. (3e druk). (1)

- Kelk, C., Totale instituties verdienen een zeer behoedzaam gebruik, in: J.A. Janse de Jonge, $M$.

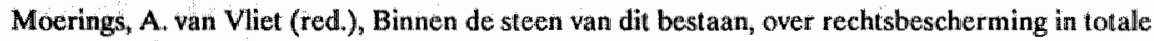
instituties, Willem Pompe Instituut, Goudla Quint, Arnhem, 1993, p. 7-29. (2)

- Kelk, $C$, Het grote belang wan een goed gestructureerde en rijke detentiefasering, Sancties 1993, p. 69-81. (3)

- Kelk, C., Van clementie tot compensatie, in: M.J.M. Verpalen (red.), Druk en tegendruk, Constructieve bijdragen aan de discussie over het cellentekort, Pompe Instituut, Gouda Quint, Arnhem, 1994 , p. 51-70.

- Kelk, C., Een mieuwe Penitentiaire Beginselenwet in aantocht, DD 1995/10, p. 1031-1040. 
- Kerstem, $J_{2}$, The institutional control of girls and boys, an attempt at a gender-specific approach, in: M. Cain, Growing up good, policing the behavior of girls in Europe, Sage, London, 1989, p. 129-144.

- Kersten, J., Mixed detention, in: Proccedings International Seminar on Women in detention, perspectives for change, Noordwijk. 1992, p. 31-41.

- Kester, J.G.C. en J. Junger-Tas, Criminaliteit en strafrechtelijke reactie. Ontwikkelingen en samenhangen, WODC, Gouda Quint, Arnhem, 1994.

- Kesteren, M. van, Kinderen in gesloten vrouweninrichtingen, Een onderzoek naar de mening wan gedetineerde moeders en p.i.w.ers over kinderen in gesloten penitentiaire inrichtingen voor vrowwen, Ministerie van Justitie, DJI, afd. Beleidsinformatie, "s-Gravenhage, 1996.

- Ketelaars, G., Vrouwen in detentie, Clara Wichmann Instituut, Amsterdam, 1991.

- Ketelaars, $G_{. .}$en $K$ de Graaff, 'Anders bederf ik iets moois', Proces, september 1992, p. 182-190.

- Keuzenkamp, S., Emancipatiebelend en de levensloop van vrouwen, Babylon-De Geus, Amsterdam, 1995.

- Knijn, T. en C. Verheijen, Tussen plicht en ontplooiing, het welbevinden van jonge moeders met kinderen in een veranderende cultuur, ITS, Nijmegen, 1988.

- Krijn, $T$, en C. Verheijen, Kiezen of delen. Veranderingen in de beleving van het moederschap, uitg. An Dekker, Amsterdam, 1991.

- Knijn, $T$., Op zichzelf teruggeworpen? Variatie, verantwoordelijkheid en de zorg voor kinderen, in: A. Meulenbelt (red), Het kind en het badwater, Van Gennep, Hogeschool Amsterdam, 1992, p. 75-91.

- Knijm, $T$, Een zwaluw maakt nog geen zomer. Lezing voor de Associatie voor herverdelling van betaalde en onbetaalde arbeid, Amsterdam, 1993.

- Koens, M.J.C., Artikel 8 EVRM en (voortgezet) verblijf van buitenlandse gezins- en familieleden, FJR 1990/5, p. 98-103.

- Koens, MJ.C., Jeugdigen in de knel. Maatregellen van jeugdbescherming in de toekomst, Kluwer, Deventer, 1994.

- Koens, MJ.C, en G. de Jonge, Het nieuwe strafrecht en strafprocesrecht voor jeugdigen, Gouda Quint, Arnhem, 1995.

- Kohberg L., in: W. Edelstein en G. Nunner-Winkler, Zur Bestimmung der Moral, Suhrkamp, Frankfurt am Main, 1986, p. 205-241.

- Kok, E.H., Een (motte-)ballentheorie over vrouwencriminaliteit? TvCr 1983/2, p. 90-95.

- Komen, $M$, Gehoorzaamheid en zelfcontrole, Ontwikkelingen op het terrein van de justitiële kinderbescherming, gezinnen en jeugderiminaliteit, $\mathrm{TvCr} 1995 / 1$, p. 22-42.

- Komter, A., De macht van de vanzelfsprekendheid tussen mannen en vrouwen, Vuga, Den Haag, 1985.

- Komter, A., Geestelijke gezondheid: Verschillende maatstaven voor vrouwen en mannen? Een onderzoek naar sekse-stereotypie bij psychotherapeuten, Psychologie en maatschappij

- Kool-Smit, J., Het onbehagen van de vrouw, De Gids, 1967 9/10, p. 267-281.

- Kousbroek, R. Voorwoord in: M. Roscam Abbing, Het babymuseum, de archaïsche neiging om je eigen kinderen groot te brengen, Prometheus, Amsterdam, 1992.

- Kraanwinkel, $M_{*,}$ Het gelijkheidsrecht: van open normen naar compensatierecht, in: B. Hesssel (red.), De knikkers van het spel. Facultaire gedachten over materiële rechtvaardigheid, uitg. LEMMA BV, Utrecht, 1993, p. 309-319.

- Kmol $S_{x}$ en S. Sevenhuijsen, Ethics and Morality in Feminism. An Interdisciplinary Bibliography, Anna Schuurman Centrum, Utrecht, 1992.

- Krooi, H., Kinderen bij ouders in detentie: dubbel gestraft?!, FJR 1994/4, p. 78-84. 
- Kruithof, B., 'Familie duurt een mensenleven lang'. Ouders en kinderen in historisch perspectief, in: T. Zwaan (red), Familie, huwelijk en gezin in West-Europa, Boom, Open Universiteit, Amsterdam, Heerlen, 1993, p. 297-339.

- Kruuk, A. en W. Verhoeven, De weg naar hel scenarioteam. Informatiemap voor signaleerders van (seksuele) kindermishandeling, Provinciaal Incest Team Noord Brabant, Tilburg, 1995.

- Lacey, L., Mandatory mariage 'for the sake of the children". a feminist reply to Elizabeth Scott, Tulane Review 1992, p. 1435-1467.

- Laing R.D. en A. Esterson. Gezin en waanzin, Boom, Meppel, 1972 (3e druk).

- Lambrechts, M., Michel Foucaull, excerpten en kritieken, SUN, 1982.

- Lampo, A., Le parent terrible, maltraitant ou abuseur, in: A. Bouregba, Colloque Europén, Liens familiaux \& détention, Transitions nr. 39, Paris, 1996, p. 195-199.

- Langerh, M. de, De betekenis van artikel 8 EVRM voor het familierecht, Pré-advies Nederlandse Juristen Vereniging, Tjeenk Willink, Zwolle, 1990, p. 85-183.

- Langem, $M$. de, Overheidszorg voor kinderen. Over de legitimatie en grenzen van owerheidsbemoeienis met het gezins- en kinderleven, Gouda Ouint, Arnhem, 1993.

- Lasch, $C$., De cultuur van het narcisme. Leven in een tijd van afnemende verwachtingen, De Arbeiderspers, Amsterdam, 1980.

- Layton MacKenzie, D., J.W. Robinson en C.S. Campbell, Long-term incarceration of female offenders, Criminal justice and behavior, vol. 16, no.2, June 1989, p. 223-238.

- Leander, $K$., The Normalization of Swedish Prisons, in: V. Ruggiero, M. Ryan and J. Sim (ed.), Western European Penal Systems. A Critical Anatomy, Sage, London, 1995, p. 167-193.

- Leeuw, A. de, De criminaliteit der Vrouw 1813, in :-Wettelijke positie en - criminaliteit der vrouw en Gevangeniswezen in 1813, uitgegeven door de Historische Commissie ter gelegenheid van de Tentoonstelling 'De Vrouw 1813-1913'.

- Leijten, J., Bescherming is ook niet alles. Voorwoord in: A. Groen en A. van Montfoort, Kinderen beschermen en jeugd hulp verlenen, Gouda Quint, Arnhem, 1993.

- Leijten, $J_{\text {., }}$ We need stories, Afscheidscollege KU Nijmegen, Tjeenk Willink, Zwolle, 1991.

- Leenen, H.J.J, Handboek gezondheidsrecht, deel 1. Rechten van mensen in de gezondheidszorg, Samson, Tjeenk Willink, Alphen aan de Rijn, 1994. (3e druk)

- Leonard, E.B., Women, Crime and Society. A critique of theoretical criminology theory, Longman, London/New York, 1982.

- Lier, P. warn, Grenzen aan het kind! Opvoeden in werschillende culturen, Orze Wereld, juli/augustus 1994, p. 8-13.

- Lijnzaad, $L$, Over rollenpatronen en de rol van het Verdrag, in: A.W. Heringa, J. Hes en L. Lijnzaad (red.), Het Vrouwenverdirag; een beeld van een verdrag....., MAKLU, Antwerpen/Apeldloorn, 1994, p. 43-57.

- Linde, $M$. van der en S. van Walsum, De problematiek van zwarte en migrantenvrouwen, in: A.W. Heringa, J. Hes en L. Lijnzaad (red.), Het Vrouwenverdrag een beeld van een verdrag, MAKLU, Antwerpen/Apeldoorn, 1994, p. 273-286.

- Linden, B. wan der, Middellanggestraften, een vergelijking tussen twee gevangenisregiems, WODC 's-Gravenhage, 1981.

- Lissenberg $E$, Vrouwen uit detentie, Sancties 1992/5, p. 267-271.

- Lissenberg, E., Vrouwen, mannen en moraal, JV 1993/2, p. 103-119.

- Lissenberg $E$, Vrouwencriminaliteit en feminisme in de criminologie, in: Gevangen vrouwen. Over criminaliteit en detentie, Nemesis-esssays $1995 / 2$, p. 6-18. (1)

- Lissenbeng E., Vrouwen, mannen, misdaad en straf, Sancties $1995 / 4$, p. 226-232. (2)

- Lloyd, E., Children visiting Holloway Prison, The Save the Children Fund, London, 1992. 
- Lloyd, E., Prisoners' Children, research, policy and practice, Save the Children, London, 1995.

- Loenen, T., Verschil in gelijkheid. De conceptualisering van het juridisch gelijkheidsbeginsel met betrekking tot vrouwen en mannen in Nederland en de Verenigde Staten, Tjeenk Willink, Zwolle, 1992. (1)

- Loenen, $T$, Recht en differentiatie: verschil als uitsluitingsmechanisme. Enkele beschouwingen naar aanleiding van Martha Minow, Making all the difference, Recht en Kritiek 1992/3, p. 215-234.

(2)

- Laenen, T., Het discriminatiebegrip, in: A.W. Heringa, J. Hes en L. Lijnzaad (red.), Het Vrouwenverdrag: een beeld van een verdrag....., MAKLU Antwerpen/Apeldoorn, 1994, p. 1-13. (1)

- Loenen, T., Mensenrechtelijke aspecten van de leefvormenproblematiek 1: familierecht, NJCMbulletin $1994 / 3$, p. 207-227. (2)

- Loenen, $T$., Recht en het onvervulbare verlangen naar individuele gerechtigheid. Over verfijning van regelgeving, vage of open normen en de concrete toetsing aan grondrechten, RM Themis, $1996 / 4$, p. $123-136$.

- Loosjes, C. Bijdrage tot de studie van de criminaliteit der vrouw, De erven Loosjes, Haarlem, 1894.

- Lundstrom, $F$., The affective responses of women prisoners to two discrepant penal systems, Criminal justice and behavior, Vol. 14, 1988/4, p. 411-432.

- Lünnemann, $K$, Geweld tegen vrouwen als strafbaar feit. Hoe reageert het Openbaar Ministerie op zaken van geweld tegen vrouwen binnen een heteroseksuele relatie of ex-relatie?, Working Paper 40, Onderzoekscentrum Recht en Beleid Rijksuniversiteit Leiden, 1992.

- Lünnemann, K.D., Vrouwenmishandelingstrafrechtelijk afgedaan? Strafrechtelijke regulering van mannelijk geweld tegen vrouwen in de privésfeer, Gouda Quint, Deventer, 1996.

- Maas, S. van der, Detentie en Gezondheidszorg, Dubbele onzichtbaarheid van vrouwen?, Wetenschapswinkel Rechten, Rijksuniversiteit Utrecht, 1994.

- MacDonald, E., Schiet eerst de vrouwen neer, Geuzenpocket 39, De Geus. Breda, 1994,

- Maelicke, B., Einrichtungen im Strafvollzug zwischen Resozialisierung der Mutter und Wohl des Kindes, ZtStVo, 1983, p. 144-147.

- Maelicke, B. en V. Birtsch, Mütter und Kinder in Gefängnissen. Ergebnisse eines Forschungsprojekts zu Mutter-Kind-Einrichtungen im Strafvollzug, ZtStVo 1988/6, p. 352-353.

Maelicke, $H_{\text {., }}$ Frauenkriminalität, Frauenstrafvollzug und ambulante alternativen. Für einen eigenständigen Umgang mit Frauenkriminalität, ZtStVo 1993/4, p. 226-230.

- Maelicke, H., Der Frauenstrafwollzug in den Bundesländern, Neue Krimimalpolitïk, 1995/1, p. $37-41$.

- Mahoney, $M$., Legal images of battered women: Redefining the issue of separation, Michigan Law Review, $1990 / 1$, p. $1-94$.

- Malmberg M.J.M.M, Overheid en gezin. Een spannende rellatie, JV 1996//6, p. 8-16.

- Melk, G.D., Is resocialisatie in de gevangenis mogelijk? DD 23(1993), afl. 8, p. 780-791.

- Meulenbell, A. (red.), Het kind en het badwater, Hogeschool Amsterdam, Van Gennep, 1993.

- Miller, A., Het drama van het begaafde kind. Een studie over het narcisme, Het Wereldvenster, Houten, 1991, 4e dr..

- Minow, M., Making All the Difference. Inclusion, exclusion and American Law, Cormell University Press, Ithaca, London, 1990.

- Moerings, M., De sleutelpositie van de gevangenisdirecteur. Selectieve aandacht voor de Penitentiaire Beginselenwet, in: J.A. Janse de Jonge (red.), Binnen de steen van dit bestaan.. Over rechtsbescherming in totale instituties, Gouda Ouint, Arnhem, 1993, p. 105-122.

Moller Okin, S., Justice, Gender and the Family, Basic Books, New York, 1989.

- Mols, G.P.M.F., Getuigen in strafzaken, Nieuwenhoflezing VI, Maastricht, Kluwer, Deventer, 1993 


\section{Literatuur}

- Mols, G.P.F.M., Het telehoren van verdachten en getuigen. Een rechtswergelijkende beschrijwing van de toepassing van telecommunicatie in het strafproces, Metro, Rijksuniversiteit Limburg, Maastricht, 1995.

- Monster, M. Bescherming van het moederschap, Onderzoek naar de regelgewing inzake zwangerschap, bevalling en arbeid, Ars Aequi Libri, Nijmegen, 1995.

- Moruster, M. en M.P. Timmers-de Vim, Positierecht, rechtspositie van zwangere en pas bevallen werkneemsters, Samson, Tjeenk Willink, CW, Alphen aan de Rijn, 1989.

- Moonem, S en G. Postma, Met inachineming van het geslacht van de dader, Proces, november 1992, p. 222-230.

- Moré, $M$.,Een illusie van economische zelfstandigheid, in: C. Boww (red.), Macht en onbehagen, Amsterdam, 1991, p. 101-113.

- Moré, $M_{.,}$Mijn kinderen hebben er niets van gemerkt. Buitenshuis werkende moeders tussen 1950 en nu, Van Arkel, Utrechi, 1992.

- Morris, A., Sex and sentencing, The Criminal Law Review, 1988/3, p. 163-171.

- Mozes-Philips $M$, en F. Westers, Zorgen voor de tockomst; een onderzoek naar carrièreperspectieven van verzorgende vaders, Ministerie SZA, VUGA, 's-Gravenhage, 1993.

- Mulder, $L$., Minderheden als nieuwe bewolkingsgroepen. De verwezenlijking van gellijkheid en verscheidenheid, AAe Libri, Nijmegen, 1993.

- Mulder, $L$, Migrantenvrouwen en mensenrechten: het maagdenvlies het ziekenfonds uit?, in: Publiek geheim. Deprivatisering van het vrouwenleven, Nemesis-essays, 1995/1, p. 61-79.

- Naeye, J, De reikwijdie van fundamentele rechten an strafzaken-enkele thema's, Pre-advies Nederlandse Juristen Vereniging, Tjeenk Willink, Zwolle, 1995 * p. 223-302.

- Naffine, $N$., and $F_{0}$ Gale, Testing the nexus: crime, gender and unemployment, British Journal of Criminology, 1989/2, p. 144-156.

- Nagel, W.H., De funkties van de vrijheidsstraf, Samson, Alphen aan de Rijn, 1977.

- Nationale Raad voor de Volksgezondheid, Beleid inzake poliovaccinatie, nr. 40, 1993.

- Nederlandsch Genootschap tot zedelijke verbetering der gevangenen, Rapport over de rijks-, strafen opvoedingsgestichten voor vrouwen en meisjes, Amsterdam, 1935.

- Nicholson D, aud R. Shangri, Battered women and provocation: The implications of R. v. Ahluwalia, The Criminal Law Review 1993, p. 728-738.

- Nicolai, N., De hordenloop door de instituties, Vrouw en Gezondheidszorg, maart-april 1992, p. 3-6.

- Niehof, A, Het duveltje uit de zwarte doos" de ongemakkelijke relatie tussen gender en huishouden, Landbouwuniversiteit Wageningen, 1994.

- Nienhuis, A.C., De gedetineerde vrouw, scriptie Rijksuniversiteit Utrecht, 1992.

- Nijboer, J., Klachtrecht van gedetineerden, in: R.W. Jongman (red.), De armen van Vrouwe Justitia, Ars Aequi Libri, Nijmegen, 1993, p. 297-315.

- Nijboer, J., 'Hlet meten van delinquentie door middel wan self-report', TVCr 1995/3, p. 273-280.

- Nijboer, J.F., De positie van de deskundige in het Amerikaanse strafprocesrecht: een voorbeeld om na te volgen?, Recht en Kritiek 1992/3, p. 259-274.

- Nijman, $G$. 'Als je lekker in je vel zit, kom je niet met justitie in aanraking, Opzij, oktober 1983.

- Nijnatten, C. wan, De psychologische gevalgen van vaderlijke detentie, Proces, 1996/5, p. 99-104.

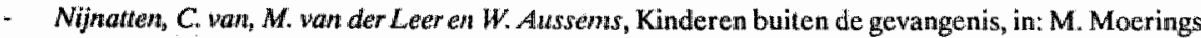
en G. ter Haar, Buiten de muren, Relaties van gedetineerden, Willem Pompe Instituut, Gouda Quint, Arnheim, 1990, p. 77-92.

- NJCM-commentaar op het wetsontwerp Penitentiaire Beginselenwet, Leiden, 1996.

Noomant, L., m.m.v. B. de Wit, "Je mag niet eens aardig zijn voor elkaar', DIVA, 1983. 
- Nola Beleidswraagstukken Gevangeniswezen (Nota Zeevalking), 's-Gravenhage, 1976.

- Nota 'Het Nederiandse Gevangeniswezen' (mota Scholten), "s-Gravenhage, 1964.

- Nota Taak en toekomst van het Nederlands gevangentiswezen, TK 1981-1982, 17539, nrs. 1-2

- Nota Samenleving en Criminaliteit. Een beleidsplan woor de komende jaren, Ministerie van Justitie, 1985.

- Nota "Werkzame detentie", TK 1993-1994, 22999, nrs. 10-11.

- Nota 'Zorg ingesloten". De organisatie van de medische zorg in de penitentiaire inrichtingen van het gevangeniswezen, Ministerie van Justitie, DJI, 's-Gravenhage, 1995.

- Nota Om de kwaliteit van arbeid en zorg: investeren in werlof, Ministerie van Sociale Zaken en Werkgelegenheid, TK 1995-1996, 24332.

- Notitie Leefvormen in het familierecht, Ministerie van Justitie, TK. 1994-1995, 22.700 nr. 5.

- Nussbaum, M., Justice for Women! Susun Moller Okin's, Justice, Gender and the Family, in: Women: a cultural review, Oxford University Press, 1993/3, p. 328-340.

- O'Neill, $O$. Children's rights and children"s lives, International Journal and the Family, 1992/6, p. $24-42$.

- Oberlies, D., Der Versuch das Ungleiche zu vergleïchen, Tötungsdelikte zwischen Männern und Frauen und die rechtliche Reaktion, Kritische Justiz 1990/3, p. 318-331.

- OCAS-rapport, Alternatieve sancties, sancties met het oog op de toekomst, 1991.

- Olsen, F. The Family and the Market, A Study of Ideology and Legal Reform. Harvard Law Review 1983, p. 1499-1528.

- Olsen, F., Children's rights: some feminist approaches to the United Nations Convention on the Rights of the Child, International Journal of Law and the Family 1992/6, p. 192-220.

- Ondenwater, A., De onverbrekelijke band tussen ouders en kinderen. Over de denkbeelden van Ivan Boszormenyi-Nagy en Helm Sterlin, Swets en Zeitlinger, Lisse, 1986.

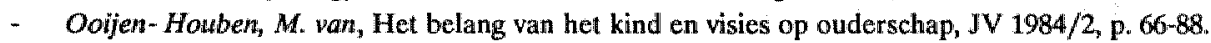

- Oord, J.WJ. van den, Verdaagde rechten. Een wisie op rechtsgelijkheid van vrouwen en mannen vanuit Derrida's fillosofie van sexuelle differenties, Sanders Instituut, Gouda Quint, Arnhem, 1994.

- Oord, J.WI. van den, Universaliteit van vrouwenrechten? Een Derridiaanse benadering, in: Vechten om de grenzen. Beschouwingen bij het Joegoslavië Tribunaal, Nemesis-essays 3, 1996, p. 40-63.

- Otten, T., en W. King, Zo vrij als een vogel..., of vogelvrij?, 10 jaar Vereniging Relaties van (exgedetineerden, in: M. Moerings en G. ter Haar, Buiten de muren, Relaties van gedetineerden, Pompe Instituwt, Gouda Quint, Arnhem, 1990, p. 11-15.

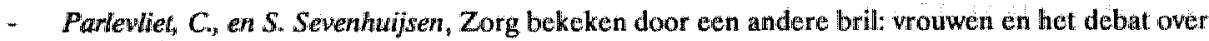
'Keuzen in de zorg", Werkgroep Vrouwienstudies, SW, UK, 1992

- Platek, M., Introduction to the socio-economic position of women in detention, in: Proceedings of the international seminar on women in detention; perspectives for change, Noordwijk, 1992 , p. $61-63$.

- Pelzer, A. en L. Pot, Kinderopvang, vrouwenarbeid en verzorgingsargumenten, SMA 1992/3, p. 141-153.

- Pépic, D., Imprisonment of Mothers, Punishment for Children: the Situation in the Federal Republic of Germany, and a Law Proposal, in: B. Rolston and M. Tomlinson (ed.), The Expansion of European Prison Systems, Working Papers in European Criminolgy no. 7, Belfast, 1986, p. 133-136.Pessers, D., Vaderrechten, moederrechten, verzorgersrechten, Nemesïs 1987/1, p. 1-2.

- Pessers, D., Double bind, Gelijkheid, werschill en dilemma's van het recht. Nemesis $1988 / 1$, p. 14-18.

- Pessers, D., Rechten zonder illusies, Kroniek Feminisme en Recht NJB 1991, p. 999-1008. 


\section{Literatuur}

- Pessers, D., De vrijheid van de oorverdovende expressie, NJB 1991, p. 1782-1786.

- Pessers, D., Volkskrant, 5 januari 1993.

- Pessers, D., De wet van het hart, Balans, 1994.

- Pessers, D., Homoseksucel ouderschap. De rechtswraag van de feiten, NJB 1995, p. 1291-1297.

- Pessers, D.WI.M., Liefde is niet genoeg. De betekenis wan het werwantschapssysteem, JV 1996/8, p. 46-55.

- Pol, L van de, Vrouwencriminaliteit in Amsterdam in de tweede helft wan de $17 e$ eeur, TVCr. $1987 / 5$, p. 148-155.

- Pol, U. won de, Vermoegde vrijlating van buitenlandse vrouwen, PI 1988/5, p. 157-159.

- Pol, U. van de, Nieuwe 'vormen van detentie', PI 1989/4, p. 123-124.

- Pol, $U$. wan de, Kiezen tussen kwaden, over selectie en differentiatie in het gevangeniswezen, Sancties 1990/1, p. 15-17.

- Pol, U. van de, De Penitentiaire Beginselenwet, in: Symposium Nieuwe Wetgeving voor gedetineerden, Opleidingen Sociaal Recht Utrecht, 12 juni 1996, p. 53-81.

- Poldervaart, S. e.a., Vrouwenstudies, en inleiding, SUN, Nijmegen, 1983.

- Póso, $T_{*}$. Family relations of women in detention, in: Proceedings of the international seminar on Women in detention, perspectives for change, Noordwijk, 1992, p. 104-108.

- Pijl-van Andel, J.N. wan der, Huisarrest, Proces, oktober 1990, p. 291-294.

- Proceedlings of the seminar on women in detention; perspectives for change, Noordwijk, 1992.

- Proces, Themanummer Gedetineerde ouders en hun kinderen, Proces 1996/5.

- Productbeschrijwingen Gevangeniswezen, afd. DJI, Ministerie van Iustitie, 's-Gravenhage, 1996,

- Quant-Worms, $P_{.,}$Diskriminatie van vrouwen in het Nederllands gevangeniswezen, Proces 1972, p. 156-162.

- Quispel, Y.M., Criminaliteit van vrouwen: een zaak voor de politie of woor de psychiater?, TvCr. $1979 / 5$, p. 232-242.

- Raad woor het Jeugabeleid, Ouderschap zonder onderscheid. Een beleidsadvies over de belangen van kinderen bij verantwoord ouderschap en kunstmatige voortplanting, Ministerie van Welzijn, Volksgezondheid en Cultuur, 1988.

- Raad woor het jeugdbeleid, Afstamming, adoptie en sociaal ouderschap, 1990.

- Raad voor het Jeugdbeleid, Opgroeien 2000: inspiratie door combinatie, Advies over 'Onbeltaalde zong gelijk verdeeld', rapport van de commissie 'Toekomstscenario's herverdleling onbetaalde arbeid', Amisterdam, 1996.

- Raes, $K_{\text {, }}$ De slinger van het recht, Recht en kritiek 1989/4, p. 323-327.

- Raes, $K$, Variaties op het verschil-dilemma. Voorbij universele wersehillen van particuliere rechtstheorie, Nemesis $1991 / 5$, p. 5-21.

- Raes, $K$, Grondrechten en sociale solidariteit, Recht en Kritiek 1992/2, p. 102-125.

- Raes, $K$, Afzonderlijk wonend samealeven, in: L. Boeykensen K. Francois, Familic, een humanistische benadering, VUB Press, Brussel, 1994, p. 223-243.

- Ramsbeek, H. van, Introduction to "Women in detentiom- perspectives for change", in: Proceedings of the International seminar on Women in detention, Noordwijk, 1992, p. 19-28.

- Ransbeek, H. van, Oplevende vergelding, Vrouwen in detentie, Nemesis 1994/2, p. 52-53.

- Rapport Commissie doelstelling en functie huis van bewaring, 's-Gravenhage, 1977.

- Rappont van de stuurgroep Herziening differentiatiestelsel, Ministerie van Justitie, afd. D. en J., "sGravenhage, 1991.

- Rapport van de Werkgroep Vrouwen in defentie, Ministerie van Justitie, afd. D. en J., "s-Gravenhage, 1991. 
- Rapport van de Werkgroep inteme en exteme differentiatie, Ministerie van Justitie, afd. D. en J., "s-Gravenhage, 1991.

- Rawls, J., A Theory of Justice, Oxford University Press, Londion, 1973.

- Reekum, A. van, Vrouwen welbevonden, een onderzoek naar de invloed van sociale rollen op de geestelijke gezondheid van mannen en wrouwen, MGV, 1988/1, p. 31-39.

- Regt, A. de, Arbeiders, burgers en boeren: gezinsleven in de negentiende eeuw, in: T, Zwaan (red.), Familie, huwelijk en gezin in West-Europa, Open Universiteit, Boom, Heerlen/Amsterdam, 1993, p. 193-218.

- Reijntjes, J.M., Voorarrest, Tjeenk Willink, Zwolle, 1994.

- Relais Enfonts Parents, Foundation Bernard van Leer, Presentations des rapports des troïs groupes de travail, Atelier Européen, Bruxelles, 1993.

- Relais Enfants Parents, Compte Rendu de la reunion de Heerhugowaard, Parijs, 1996.

- Richards, M., The separation of children and parents, some issues and problems, in: R. Shaw, Prisoners' children, what are the issues?, London, 1992.

- Rickard, B., Children in custody program at Tarrengower Prison, Keypoints 1990/12, p. 10-13.

- Rodgers MC Corthy, B., Inmate mothers: The Problem of Separation and Re-Integration, Journal of Offender Counseling, Services and Rehabilitation, Vol. 4(3), Spring 1980, p. 189-212.

- Roede, M., Women and Anthropology, Implication of Gender for Health. An introduction to the theme, coll. Anthropology $1992 / 1$, p. 31-44.

- Römkens, R., Slachtoffers tot het bittere eind?, Nemesis 1992/6, p. 10-15.

- Römkens, $R$., De partnerdoodster als statistische rariteit, in: Gevangen vrouwen. Over criminalititeit en detentie, in: Nemesis-essays 1995/2, p. 44-57.

- Rooie vnouwen in de PvdA, Protest-aktie Bijlmerbajes, 1978/6, p. 7-8.

- Rooks $A$, Subculturen in penitentiaire inrichtingen, JV $1983 / 10$ p. 5-38.

- Roos, Th. de, Vrouwenstudies strafrecht: geen isolement, maar confrontatie, in: E.A. Alkema en A.Ph.C.M. Jaspers, Lof der verscheidenheid. Rechtsgeleerden over vrouwen en rechl, Tjeenk Willink, Zwolle, 1993, p. 167-178.

- Roose, T., Halfway in Denemarken kostbaar goed, Vrijspraak 1996/5, p. 8-9.

- Rosenkranz, J., Kinder hinter Gittern, ZtStVo 1985, p. 77-82.

- Ruiter, J. de, Het weglopen van minderjarigen als opgave voor thet jeugdrecht,in: Jeugdrecht op een keerpunt, bundel opstellen aangeboden aan Prof.mr. J. Wiarda, Tjeenk Willink, Zwolle, 1974, p. 178-195.

- Ruiter, J. de, Manipulaties met leven. Pre-advies Nederlandse Juristen Vereniging, Zwolle, 1993, p. 7-128.

- Ruiter, J. de, Het kind en de grondrechten, in: A. Groen en A. van Montfoort, Kinderen beschermen en jeugd hulp verlenen, Gouda Quint, Arnhem, 1993, p. 187.

- Ruijter, $S$. de, Detentie van minderjarige asielzoekers in het grenshospitum, Migrantenrecht 1992/6, p. 123-126.

- Ruller, S. wan, Hett rendement van gevangeniswezen, Proces 1993/10, p. 151-154.

- Rutenfrans C., Hirschi, Opp en wrouwencriminaliteit, TwCr 1983/2, p. 82-89.

- Rutenfrans C., Roltheorie, emancipatie en criminaliteit van vrouwen, TvCr 1984/1, p. 3-17.

- Rutenfrans, CJ.C., Criminaliteit en sexe, Een verklaring voor de verschillen in het criminele gedrag van vrouwen en mannen, Gouda Quint, Arnhem, 1989.

- Rutenfrans, C., De totalitaire verleiding, Kinderverdrag geen juridische basis woor werregaande staalsinmenging, Nemesis $1992 / 3$, p. $24-27$.

- Rutten-Roos, A., Waar haalt de jeugd het recht vandaan?, Kluwer, Deventer, 1992.

- Ruten-Roos, A., Vrouw en familierecht, in: E.A.Alkema en A. Ph. C. M. Jaspers, Lof der verseheidenheid. Rechtsgeleerden over wrouw en en recht, Tjeenk Willink, Zwolle, 1993, p. 179-189. 


\section{Literatuur}

- Save the childten, Setting up a prison visitors centre, prepared jointly by the Home Orfuce, the Prison Service, the Save the Children Fund and the Federation of Prisoners" Families Support Groups.

- Save the children, Working internationally: Planning for improved performance. A seminar within the United Kingdom-Nigeria Technical Co-operation Training Programme, London, 1991.

- Schaeffer, E.H. en R. Koole, Cellen niet berekend op insluiting moeder en baby. Verhoorkamer ingericht als kinderkamer, Algemeen Politieblad, 1991/3, p. 17-18.

- Schaik, S. van, Criminaliteit in 18e-eeuws Utrecht, DinaMiek, 1996, 1/2. p. 4-14.

- Schie, E. van, en T. Whllemsen, Reacties op criminaliteit en probleemgedrag van meisjes en jongens, Leiden, 1988.

- Schmitz-Rossner, E, Le jeune enfant vivant auprès de sa mère in carcerce, in: Bouregba (1996), p. 171-174.

- Scholten, C.M. en B.W. Frijling, Allochtoon in de pleegrorg, in: K. de Hoog en J.A.C. van Ophem (red.), Changes in daily life, Agricultural Uniwersity Wageningen, 1994, p. 221-233.

*. Schutte, S., Vrijwilligers bekommeren zich om kinderen van gedetineerden, VrijSpraak, 1996/1, p. 8-9.

- Schuy, $C$, Tussen macht en moraal. Over de plaats van het recht in verzorgingsstaat en democratie, Samson, Alphen aan de Rijn, 1983.

- Schuyt, C., Rechtssociologie, een terreinverkenning, 1991.

- Schuyt, $K$, Emancipatie en autonomie. Een wijsgerig-sociologische reflectie op een oud probleem, in: Publiek geheim. Deprivatisering van het vrouwenleven, Nemesis-essays, 1995/1, p. 15-29.

- Schwarz Conan, R., More work for Mother, The Ironies of Houschold Technology from the open Hearth to the microwave, New York, 1983.

- Schwegman M. en J. Wichwis, Moederschap: van springplank tot obstakel. Vrouwen, natie en burgerschap in twintigste-eeuws Nederland, in: G. Duby en M. Perrot(red.), Geschiedenis van de vrouw, deel 5, De twintigste eeuw (onder red. van F. Thebaud), Amsterdam, Agon, 1993, p. 557-583.

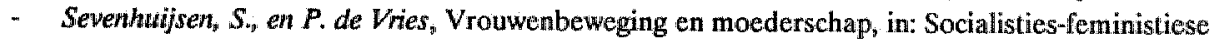
teksten 4 , Amsterdam, 1980.

- Sevenhuijsen, S.L., De orde van het vaderschap, Politieke debatten over ongehwwd moederschap, afstamming en het huwelijk in Nederland 1870-1900, I.I.S.G.-studies en essays, Amsterdam, 1987.

- Sevenhuijsen, $S .$, Vrouwelijkheid als bron voor politieke wijsheid. Amerikaanse politieke filosofen over het moederschap, Amsterdams Sociologisch Tijdschrift, 1988/2, p. 208-234.

- Sevenhuijsen $S_{*}$. Rechtvaardigheid, moreel redeneren en politiek van ouderlijke macht, in: Zorgtaken who cares, lezingen JOV-studiedag, Groningen 1990, p. 15-33.

- Sevenhuijsen, S., Zorg en emancipatie, Nemesis 1993/2, p. 35-38. (1)

- Sevenhuijsen $S$., De macht van verhalen, Nemesis 1993/4, p. 131-134. (2)

- Shaw, M., Is there a feminist future for women's prisons?, in: R. Matthews and P. Francis(ed.), Prisons 2000. An international perspective on the current state and future of imprisonment, MacMillan Press Ltd, London, St, Martin`s Press Inc. New York, 1996, p. 179-200.

- Shaw, $\boldsymbol{R}$., Imprisoned fathers and the orphans of justice, in: R. Shaw, Prisoner's children. What are the issues? Routlegde, London, NY, 1992, p. 41-49.

- Shoemaker, $D J$., Theories of delinquency: an examination of explanations of delinquent behavior, Oxford University Press, Oxford, 1984.

- Siekmann, G., Männer und Frauen in derselben Haftanstalt; Ein neues Modell im Hamburger Strafvollzug, Zeitschrift für Strafvollzag 1985/1, p. 11-15.

- Singer, E., Kinderopvang en de moeder-kindrelatie. Pedagogen, psychologen en sociale hervormers over moeders en jonge kinderen, Van Loghum Slaterus, Deventer, 1989. 
- Singer, $E$, Opvoedingsonzekerheid en opwoedingswetenschap, in: J. Gerris (red), Ouderschap en ouderlijk funktioneren, Swets en Zeitlinger, Ansterdam, 1991, p. 171-184;

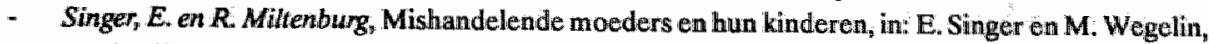
De familieband verbroken. Opstellen over gezinsgeweld, autonomie en loyaliteit, Utrecht, 1991, p. 89-101.

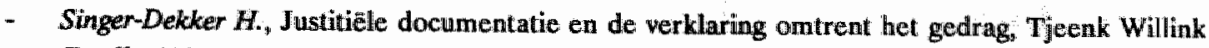
Zwolle 1991.

- Sloot, B.P., Over positieve actie en positieve discriminatie, Pré-advies Nederlandse Juristen Vereniging Tjeenk Willink Zwolle, 1989, p. 1-56.

- Slotboom, $H$, Veilig in de armen van de Staat of: Wat heeft het strafrecht slachtoffers van vrouwenmishandeling te bieden?, Nemesis 1994/3, p. 62-74.

- Stuiter, M., Gedetineerde en vrije artsenkeuze, Tijdschrift voor gezondheidsrecht, juli 1993, p. 271-282.

- Smaers, G., Gedetineerden en mensenrechten, Metro/MAKLU, Maastricht, 1994.

- Smaers, G., Kan de nieuwe penitentiaire beginselenwet de toets van de grondrechten doorstaan?, NJCM-bulletin 1996/4, p. 495-511.

- Smar, C., Women, Crime and Criminology. A feminist critique, Routledge and Regan Paul, London, 1976.

- Smart, C., Feminism and the Power of Law, Routledge, London, 1989.

- Smart, $C$., The woman in the legal discourse, Rijksuniversiteit Utrecht, 1991. (1)

- Smant, C, Cultural factors in the meaning and experience of the femalle body, in: C. Forder en R. Wolleswinkel (red.), The truth about women's bodies, Maastricht, 1991. (2)

- Smart, C., The Legal and Morall Ordening of Child Custody, Journal of Law and Sociely, 1991/4, p. $485-500$. (3)

- Smaus, G., Reproduktion der Frauenrolle im Gefängnis, Streit 1992/1, p. 23-33.

- Smit, J., Zoekt de vrouw. Een beschouwing over vrouwen van gedetineerden, in: M. Moerings en G. ter Haar(red.), Buiten de muren. Relaties van gedetineerden, Willem Pompe Instituut, Gouda Quint, Arnhem, 1990.

- Soetenhorst, J., Alleen maar aaien door het luikje. Vrouwentoren in de Bijlmerbajes, Opzij, juni 1978, p. 10-11.

- Soetenhorst, J., Vrouwen in onvrijheid (gevangenschap en dwangopname), in: Van Maarseveen, Pessers en Gunning (red.), Internationaal Recht en vrouwen: de betekenis van het Internationalle récht voor vrouwen, Zwolle, 1987, p. 453-463.

- Soetenhorst-de Savomin Lohman, $J_{\text {.y }}$ Doe wel en zie om. Maatschappelijke hulpverlening in relativ tot het recht, Swets en Heiliger, Amsterdam/Lisse, 1990.

- Soetenhorst-de Savomin Lohman, J., Recht, ethiek en onderwijs, NTOR, maart 1992, p. 5-12.

- Solidariteitsgroep Vroutwelijke Gevangenen, Zwartboek over de vrouwengevangenis, Amsterdam, 1979.

- Salidariteitsgroep Vrouwelijke Gevangenen, Vrouwen in de bajes, uitg. De Strijdijzers, Amsterdam, 1983.

- Splunteren, C. van, Interview met Marie-Andrée Bertrand, De Canadese criminologe over haar vergelijkende studie van vrouwengevangenissen, in: Gevangen vrouwen. Ower criminaliteit en detentie, Nemesis-essays, 1995/2, p. 134-141.

- Spronken, T., Arbeidsloon vrouwelijke gedelineerde, Nemesis 1987/3, p. 148-150.

- Spronken, $T_{, 4}$ en $R$. Wolleswinkel, Gedetineerd: extra gepakt?, Nemesis 1987/5, p. 346-350.

- Stark, A., "Waarom werken Nederlandse mannen?", Savante, winter 1993, p. 21.

- Steffensmeier, D., J. Kranner, C. Streifel, Gender and imprisonment decisions, Criminology 1993/3, p. $411-446$.

- Stegeren, T. van, De buitenwereld was ineens mijlenver, Sekstant 1979/10, p. 8-10. 
- Stockle-Niclas, C., Das Gefängnis, eine eingeschlechtliche Institution, Forwm Verlag Godesberg. Bonn, 1989.

- Stalk, B. wast en C. Wouters, Vrouwen in tweestrijd, Van Loghwm Slaterus, Deventer, 1983.

- Swaum, A. de, Zorg en de Staat, Welzijn, onderwijs en gezondheidszorg in Europa en de Verenigde Staten in de nieuwe tijd, Bert Bakker, Amsterdam, 1989.

- Swauningen, R. van en G. die Jonge, The Dutch Prison System and Penal Policy in the 1990s: from Humanitarian Paternalism to Penal Business Management, in: V. Ruggiero, M. Ryan and J Sim (edi), Western European Penal Systems. A Critical Anatomy, Sage, London, 1995, p. 24-45.

- Swataningen, R wan, European Critical Criminologies. A Future for Social Justice, Erasmus Universiteit Rotterdam, 1995.

- Tabak, $L$, De integratie van vrouwenhulpverlening is de doodsklap woor het autonome circuit, Vrouw en gezondheidszorg, maart-april 1992, p. 1-2.

- Taiffel, H. en C. Fraser, Introductory Social Psychology, Penguin Hammondsworth, 1978

- Thomassen, $W$, Familierecht en onderdrukking van vrouwen in verband met het wetsontwerp omgangsrecht, Recht en Kritiek 1982, p. 128-162.

- Thomassen, W.M.E., Owerleid en gezinsleven. De grenzen van interventic in familierelaties, NJB 1993, p. 1165-1169.

- Thooft, L., Beter af zonder man, Opzij, december 1991.

- Tigchelaar, J., Zorgen over rechtwaardigheid, in: B. Hessel(red), De knikkers van het spel. Facultaire gedachten over materiële rechtvaardigheid, Lemma, Utrecht, 1993, p. 287-308.

- Tigchelaar, J., De (over)gevocligheid van het recht. Overmacht bij partnerdoding en cuthanasie, $1995 / 1$, p. 1-2.

- Timmermans, $H_{\text {, }}$ en G. Beembroek, Sekse en straftoemeting, TwCr, 1985/2, p. 88-97.

- Tulkens, HJJ., Graden van vrijheid, Gouda Quint, Arnhem, 1988.

- Tulkens, JJJ., Vanuit het oogpunt van de gevangene, Het detentieplan en de programma-inrichting, in: Th. van Veen en G. van Essen, Sanctietoepassing, een nieuwe ordening, Opstellen aangeboden aan G.H. Veringa, Gouda Quint, Arnhem, 1991.

- Vandenbroucke, M., Le parent terrible, maltraitant ou abuseur, in: A. Bouregba, Colloque Europeen, Liens familiaux \& détention, Transitions mr. 39, Paris, 1996, p. 207-211.

- Veen, Th. W. van, De grondrechten en detentie, in: GJ.M. Corstens e.a. (red.), Straffen in gerechtigheid, Gouda Quint, Arnhem, 1987. p. 195-204.

- Veeman, T., De prikpil en het recht, Nemesis 1987/4, p. 180-188.

- Vegter $\boldsymbol{P}_{\text {., }}$ Vormen wan detentie, Een onderzoek naar verschillen bij de tenuitwoerlegging van de gevangenisstraf en de bemoeienis van de strafrechter, Gouda Quint Armhem, 1989.

- Vegter, P., De toename van lange gevangenisstraffen: malaise voor het gevangeniswezen, NJB 1993, p. 1041-1043.

- Veldkamp, A.W.M.n ent T.P.A.M. Bogers, Recht op vaccinatie, een uitgemaakte zaak, NJB 1993, p. 1170-1173, met reakties en naschrift, op p. 1626-1627.

- Weldnam, A., De bescheiden functie van het juridisch gelijkheidsbeginsel. Het fundamentele verschil tussen juridische leerstukken en wetenschappelijke concepten binnen wrouw en recht, Nemesis $1996 / 2$, p. $31-38$.

- Veshagen, J., Mag het ietsje meer zijn?, Proces, 1994/6, p. 123-126.

- Verhagen, JJ.C.M., Veranderingen in de gedetineerdenpopulatie in de afgelopen tien jaar, JV 1989/2, p. 7-16.

-Verheij, L.F.M., Artikel 5 EVRM: vrijheidsberoving en horizontale werking, EHRM, 28 nowember 1988: de zaak Nielsen, NJCM-bulletin 1989/5, p. 611. 
- Vepalen, M.J.M., Aanpassing van vrijheidsstraffen, in: M.J.M. Verpalen (red.), Druk en tegendruk, Constructieve bijdragen aan de discussie over het cellentekort, Willem Pompe Instutuut, Gouda Quint, Arnhem, 1994, p. 71-84.

- Verrijn Stuart, H, Vrouwelijke gevangenen: Crimineel en in verzet; Lover 1981/4, p: 164-170.

- Vemijn Stuart, $H$., Waarheid is ook maar een gevoel. Over waarheid en bewijs in sexueel geweldszaken, Nemesis $1990 / 5$, p. 223-225.

- Vemin Stuart, H., Conclusion, in: Proceedings of the International seminar on Women in deteition, Noordwijk 1992 . (1)

- Vernijh Stuart, H., Gevangen in onzichtbaarheid. Vrouwen in detentie, Nemesis 1992/2, p. 1-4. (2)

- Verrijn Stuart, H., Gewangen vrouwen. Naar een detentiebeleid yoor vrouwen als vrouwen, Proces 1992/9, p. 170-181. (3)

- Verrijn Stuart, H., Via onschuld naar macht. Slachtoffers in thet strafproces, JV $1994 / 2, p .94-114$

- Verrijn Stuart, H.M., Meer dan vrees alleen. Partnerdoding in noodweer, in: Gevangen vrowwen. Over criminaliteit en detentie, Nemesis essays $1.995 / 2$, p. 160-182.

- Viering M., Het EVRM in de rechtspraak van de beroepscommissic. Het eerste decennium, DD $1988 / 1$, p. $40-52$.

- Vintgens, $K$, Filosofie als passie, Het denken van Simone de Beauvoir, Prometheus, Amsterdam, 1992.

- Visser, $Y_{n,}$ Met recht een zorg. Een beschrijwing wan het onderzoek naar zorg, mede met het oog op de juridische toepasbaarheid ervan, Emancipatieraad, 's-Gravenhage, 1994.

- Viet, F. wan, Afstamming en ouderlijke zorg: whe niet zaait zal ook niet oogsten? NJB 1987, p. 614-817.

- Viet, F. van, Waar een wil is, is een wet!, in: M. Moerings en A. Matthijssen(red.), Homosexwaliteit en recht, Willem Pompe Instituut, Gouda Quint, Arnhem, 1992, p. 97-124.

- Vogler, R., The child, the imprisoned parent and the law, in: R. Shaw, Prisoner's children. What are the issues?, Routledge, London, 1992, p. 101-113.

- Vries, G.H. de, Medische technologie en morele twijfel, diësrede Rijksuniversiteit Limburg, 1992.

- Vries, J. de, Vrouwen in de criminologische theorievorming in Nederland, TVCr, 1979/5, p. 211-220.

- Vrouwenkrant, Special, Tussen drie muren en een deur, Vrouwen in de bajes, 1978, nr. 58.

- Vrouwentongen, Gevangen vrouwen, 1978, 5/6, p. 7-8.

- Walker L., The battered woman syndrome, Springer Publishing Company, New York, 1984.

- Walsum, S, van, Het VN-Vrouwenverdrag en het Nederlandse vreemdelingenrechi, CWI, Amsterdan, 1996.

- Wanelen, C, van, Ouderschap en ouderlijk gezag na echtscheiding, Tjeenk Willink Zwölle, 1987.

- Wamelen, C. van, Woonouderschap en ouderlijk gezag, FJR 1992/5, p. 113-116.

- Wanelen, $C$. van, Het tekort in het familierecht. In het bijzonder in het afstammingsrecht, NJB 1996, p. $1093-1102$.

- Wegelin, $M$., Moeders en vaders, scheiden en delen, constructies van gelijkkheid in de verdcling van het ouderschap na echtscheiding, Thesis Publishers, Amsterdam, 1990.

Wegelin, M. Familiale loyaliteit, in: E. Singer en M. Wegelin, De familieband verbroken. Opstellen over gezinsgeweld, autonomie en loyaliteit, Utrecht, 1991, p. 23-37.

- Wegelin, M., De biologische vader buiten spel: kan dat en mag dat? in: A. Meulenbelt(red), Het kind en thet badwater, Van Gennep, Hogeschool Amsterdam, 1992, p. 18-38.

- Wegelin, M., Pappie loop toch niet zo snell De jacht naar de identiteit van donorkinderen, Tijdschrift voor Vrouwenstudies, $1993 / 2$, p. $188-202$. 


\section{Literotuur}

- Welzen, H.A.M.F. en MJ. Zomer, Dilemma's in het omgaan met seksualiteit en intímiteit in een forensisch-psychiatrische kliniek, JV 1989/9, p. 52-62.

- Wevtholt, $K$, Arbeid en zorg: Een verkenning vanuit het gelijkheidsbeginsel van de rechtspasitie van werknemers met gezinsverantwoordelijkheid, Themis Publishers, Amsterdam, 1990.

- Wentholt, $K_{\text {fi }}$ Rekening houden met zorgtaken, een ander perspectief voor het gelijkheidsbeginsel, Recht en Kritiek 1991/3, p. 367-382.

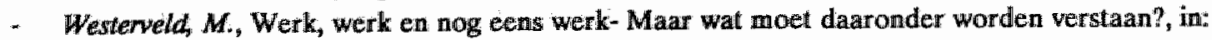
Publiek geheim. Deprivatisering van vrouwenlevens, Nemesis Essays 1, 1995, p. 93-103.

- Wilte, S., Mothers in Custody and the Punishment of Children, Probation Journal 1989/3, p. 106-109.

- Wichnanun, $C$, De criminaliteil der vrouw, in het bijzonder in Nederland, in: De Vrouw, de vrouwenbeweging en het vrourwenvraagstuk, deel $2,1918$.

- Wersinga, $H_{\text {. }}$, Syndroom en rechtspraak, NJB 1993, p. 1353-1355.

- Wiewel, P.G., Arrestantenzorg in politiebureaus, Sancties 1994/2, p. 77-85.

- Wild, A.H. de, Ouderschap, Jeugdbeleid, het belang van het kind en rechten van jeugdigen ${ }_{n}$ FJR $1992 / 5$, p. 104-106.

- Willekens, H., Dwarsliggende beschouwingen over sociale en juridische egalisering en emancipatie van 'man' en 'vrouw', Pré-advies Vereniging voor Wijsbegeerte van het Recht, R.en R., 1987/1, p. 7-25.

- Willems, $J_{x}$, Ouderbescherming en Kinderbescherming: Wordt het geen tijd voor een meldplicht? NJB 1990, p. 1243-1247.

- Willems, J., Van parentiarchie naar Vadertje Staat, over het verwekken, mishandelen en beschermen van kinderen, Nemesis 1992/3, p. 8-23.

- Willems, $L$., Vechten om de grenzen. Vrouwenrechten zijn mensenrechten, in: Vechten om de grenzen. Beschouwingen bij het Joegoslavië Tribunaal, Nemesis-essays 3, 1996, p. 6-21.

- Witteveen, $W$., Het verhaal in het recht, in: F. Ankersmit e.a., Op werhaal komen. Over narrativiteit in de mens- en cultuurwetenschappen, Kampen, 1990, p. 179-203.

- Wijck, $M$. van, Etikettering en stigmatisering van gedetineerden, De Woelrat, Boskoop/Utrecht, 1982.

- Wijk, $H$. wan, Ouderlijke verantwoordelijkheid en het recht van het jonge kind op eerbiediging van 'family life", in: M. de Boer e.a., De kant wan het kind, Arnhem, 1992, p. 147-158.

- Wolleswinkel, R., Bezoekregeling langgestrafte vrouwen, Nemesis 1988/6, p. 229.

- Wolleswinkel, R., Gevangen in moederschap, in: M. Moerings en G. ter Haar (red.), Buiten de muren, Relaties van gedetineerden, Willem Pompe Instituut, Gouda Quint, Arnhem, 1990, p. $93-99$.

- Wolleswinkel, R., Vrouwen in handen van justitie, Sancties 1992/4, p. 228-238.

- Wolleswinkel, M.W., Gedetineerde vrouwen: een aparte categorie?, in: M.H.R. Nuy en E.H. van de Lisdonk (red.), Medicus en maatschappij. Leerboek complexe maatschappelijke problematiek ten behoeve van geneeskundigen in opleiding, SWP, Utrecht, $1995_{*}$ p. 173-188.

- Wolleswinkel, $R$, Gewangene van het systeem en cipier van het gezin. Over moeders en detentie, in: Gewangen vrouwen, Over criminaliteit en detentie, Nemesis-essays 1995/2, p $1116-132$.

- Woodrow, $J_{\text {, }}$ Mothers inside, children outside. What happens to the dependent children of female inmates?, in: $\mathbb{R}$. Shaw, Prisoner's children, what are the isssues?, London, 1992, p. 29-41.

- Wurzer-Leenhouts S.M., Verslag van de voorjaarsvergadering van de vereniging voor Penitentiair Recht en Pemologie, Sancties 1992/4, p. 239-243.

- Wurzer-Leenhouts, S.M., Het voorontwerp Penitentiaire Beginselenwet, Sancties 1994/1, p. 41-46.

- Youncenar, M., Met open ogen, Gesprekken met Matthieu Galey, Ambo Rainbow Pocket, Baarn, 1991. 
- 7 jeugdrechtspecialistem, Rechten van jeugdigen en gezag van ouders, NJB 1975, p. 97-104.

- Zwaan, $T$., De verschuivende hoeksteen, Jeugd en Samenleving $1994 / 12$, p. 660-675.

- Zwaan, $T$, De verbroken viereenheid: een interpretatie van recente transities, in: T. Zwaan (red.), Familie, huwelijk en gezin in West-Europa, Boom, Open Uniwersiteit, Amsterdan, Heerlen, 1993, p. $265-296 .(1)$

- Zwaan, T., Familie, huwelijk en gezin in ontwikkelingsperspectief, in: T. Zwaan (red.), Familie, huwelijk en gezin in West-Europa, Boom, Open Universiteil, Amsterdam, Heerlen, 1993, p. 340-359. (2)

- Zwaard, J. van der, Hoe vrouwen moederen. Buurtgesprekken over opwoeding, SWP, Utrecht, 1995.

- Zwering, A., Om een hoekje gekeken, een blik op resocialisatiebeleid in een vrouwengevangenis, scriptie UvA, Amsterdam, 1988.

- Zwering A., Vrouwen in detentie. Net als thuis, Nemesis $1989 / 2$, p. $48-54$. 


\section{Jurisprudentieregister}

\section{Europese Hof voor de Rechten wan de Mens}

EHRM \& juni 1976 Engel and others, Series A. wol. 22, NJ 1978, 223.

EHRM 13 juni 1979, Marckx v. België, Series A, vol. 32, NJ 1980, 462, m.n. EAA.

EHRM 6 november 1980 Guzzardi, Series A, vol. 39.

EHRM 28 november 1984, Rasmussen v. Denemarken, Series A, vol. 87, NJ 1986, 4, m.n. EAA en EAAL.

EHRM 28 mei 1985 Ashingdane, Series A, vol 114

EHRM 18 december 1986, Johnston v. Ierland, Series A, vol. 112 , NJ 1989, 11, m.n. EAA.

EHRM. 21 juni 1988, Berrehab v. Nederland, Series A, vol. 138, NJ 1988, 746, m.n. EAA, NJCM bulletin, 1988, p. 579-586, m.n. H. Steenbergen, FJR 1988, p. 193-196, m.n. J.E. Doek, RVR 1992, 183, m.n. SvW.

EHRM 28 nowember 1988, Nielsen w. Denemarken, Series A, vol. 144, NJ 1991, 541, m.n. EAA, NJCM bulletin 1989, p. 595-612, m.n. L.F.M. Verhey, FJR 1990, p. 112-144, m.n. M.L.C.C de Bruijn-Lückers.

EHRM 22 juni 1989, Eriksson v. Zweden, Series A, vol. 156, NJ 1992, 705 m.m. EAA, FJR 1990, p. 83-88, m.n. M.J.C. Koens.

EHRM 29 oktober 1992, Y. w. Het Verenigd Koninkrijk, Series A, vol. 247A, NJCM bulletin 1993,

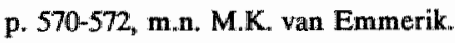

EHRM, 25 maart 1993, Costello-Roberts v. het Verenigd Koninkrijk, Series A, wol. 247C, NJ 1995, 725 m.n. EAA, NJCM bulletin 1993, p. 572-583, m.n. M.L. van Emmerik.

EHRM 26 mei 1994, Keegan w. Ierland, Series A, vol. 290, NJ 1995, 247, m.n. JdB, NJCM-bulletin 1995, p. 37-44, m.n. M. de Bruijri-Lückers, RN 1995, 469.

EHRM 23 september 1994, Hokkanen v. Finland, Series A. vol.299A, NICM-bulletin 1995, p. 100-105.

EHRM 27 oktober 1994, Kroon e.a.v. Nederland, Series A, vol. 297C, NJ 1995, 248, m.n. JdB, NJCMbulletin 1995, p. 45-53, m n. C. Forder, RN 1995, 470, m.n. Titia Loenen. 
Jurisprudentieregister

Europese Commissie voor de Rechten wan de Mens

ECRM 5 oktober 1987, RV 1987, 93, m.n. P. Boeles.

ECRM 19 mei 1992, Herz v. Noorwegen, NJCM-bulletin 1993, p. 65-73, m.n. T. Loenen.

\section{Hoge Raad}

HR 13 meil 1958, NJ 1958, 325, m.n. Röling (moord te Heer).

HR 4 mei 1984, NJ 1985, 510, m.n. EAA en EAAL (gezamenlijk ouderlijk gezag).

HR 21 maart 1986, NJ 1986, 585, m.n.EAA en EAAL (gezamenlijk ouderlijk gezag).

HR 8 april 1988 , NJ 1989,170 (doorbreking veto).

HR 10 maart 11989, NJ 1990,24 (voogdijwijziging, pleegouders).

HR 23 maart 1990, NJ 1991, 149 (wijziging verblijfplaats, opvangouders).

HR 23 maart 1990, NJ 1991, 150, m.n. EAAL (wijziging verblijfplaats, grootouders).

HR 8 mei 1992, NJ 708, m.n. AHJS, NJCM-bulletin 1992/7, p. 759-765, m.n. P. Boeles (uitzetting).

HR 26 mei 1992, NJ 1992, 681, RN 1994, 374 (battered women).

HR 18 juni 1993, NJ 1993, 347, m.n. EAA en CHJB, NJCM bulletin 1993, p. 786-792, m.n. L.F.M. Verhey (Aidstest).

HR 15 aprill 1994, NJ 1994, 608, m.n. H.-S., NJCM bulletin 1994, p. 652-658, m.n. L.F.M. Verhey, RN 1994, 430, m.n. N. Holtrust (Valkenhorsit).

HR 23 mei 1995, niet gepubliceerd (battered women).

HR 23 juni 1995, NJ 1996, 17, m.n. JdB (family life, belang van het kind).

HR 22 december 1995, NJ, 1996, 419, NJCM bulletin 1996/3, p. 423-427, m.n. T. Loenen ("Jeroen"), RN 1996, 554.

\section{Gerechtshoven}

Hof "s-Gravenhage 31 oktober 1985, PI 1986, 46 (loonregeling).

Hof 's-Gravemhage, 16 maart 1992, RN 1992, 293 (Pistool in linnenkast). 
Hof Amsterdam, 30 december 1992, RN 1994, 408 (Stoeptegelmoord).

\section{Rechtbanken}

Rb Arnhem, 15 april 1993, RN 1994, 375 (partnerdoding).

Rb Amsterdam 28 juli 1995, RN 1996, 607, m.n. S. van der Maas (partnerdoding).

Rb Maastricht 22 augustus 1995, RN 1996, 608, m.n. S. wan der Maas (partnerdoding).

Beroepscommissie van de Centrale Raad voor Strafrechtstoepassing

BC 25 oktober 1985, PI 1982, 14 (bezoek zonder toezicht).

BC 20 november 1987, NJCM-bulletin 1989, p. 3642, m.n. P. Vegter (visitatie).

BC 17 maart 1988, PI 1988, 57 (bezoekregeling langgestrafte).

BC 25 november 1988, PI 1988, 114, RVR, 208, m.n. R. Wolleswinkel (zorg voor kinderen).

BC 30 november 1990, Sancties 1991, 31, m.n. H. van der Neut (bezoek zonder toezicht).

BC 13 december 1990, Sancties 1991, 40 (bezoek zonder toezicht).

BC 16 april 1990, RN 284, m.n. R. Wolleswinakel (inwoer cosmetica).

BC 4 januari 1991, Sancties 1991, 42 (geen controle post kinderbescherming).

BC 1 juni 1994, RN 452, m.n. R. Wolleswinkel (verzoek tot overplaatsing, reisafstand).

BC 24 junĭ 1994, RN 451, m.n. M. Driessen en R. Wolleswinkel (zwangerschapsuitkering).

BC 7 december 1995, Sancties 1996, 27 (telefoneren met gedetineerde partner). 


\section{Trefwoordenregister}

\author{
Aangifte $22,26,126$ \\ Abortus 41, 51, 128, 130, 182, 223, 249, \\ 291
}

Accomodatie 104

Accomodaties 95

Advocaat $26,27,138,148,150,153,160$, 306,309

Adrocaten 148, 150, 151, 305

Affectieve relaties $5,89,220$

Afstammingsdiscussic 255

Afstammingsrecht 255,258

Afstammingsrellatie 257,258

Afwijkend gedrag $8,22,31,39,44,47,245$

Agressie 30, 38, 63, 71, 295

Alleenstaande $9,15,67,168,186,190$, $191,206,207,310$

Allochtone ouders 190

Alternatieve sancties $112,312,313$

Alternatieve straf $77,305,314$

Alternatieve straffen $101,102,307,312$, 314

Anticonceptie 128

Arbeid $65,72,94,103,105,107,122,125$, $127,130,147,156,157,162,169$, $184,185,186,188,191,219,222$, $229,231,234,235,253,310,312$, 322

Arbeidsmarkt $72,127,182,193,205,207$, $234,236,281$

Arbeidsparticipatie $176,207,229,234$

Arbeidsplicht 234

Arbeidswerhoudingen 92, 281

Armoede 5, 50, 118, 177, 210, 219, 263, $292,310,313$

Arrest $26,27,259,260,276,326$

Arrestatie $32,50,117,282,300,330$

Asielverlening 146

Atmosfeer 68,180
Attachmentheorie 196

Autonomie $5,7,41,43,45,98,145,189$, $198,200,211,220,242,252,271$, 280

Battered woman syndrome $24,27,28,314$

Behandelingsovereenkomst $158,241,242$

Beklagrecht $91,138,139$

Belangenafweging $145,168,253,260,261$, 279

Belangenbehartiging 317

Belangentegenstelling 165,216

Beleidsworming $8,98,121,298$

Bemiddeling 117, 139, 142, 217, 271, 278, 282

Beperkingsclausules 142,143

Beperkingsdoeleinden 143,144

Beperkte gemeenschap 102,154

Berechting 22

Beroepscode 306

Beroepscommissie 92, 138, 139, 143, 144, $151,154,158,159,161$

Beroepsgeheim 306

Beroepsinstantie 153

Beroepsprocedure 153

Beschavingstheorie 90

Beschikbaarheidscriterium 263

Bestaansverhaal 203

Bevalling $19,74,75,107,147,158,222$, 253,256

Bevallingsverlof $108,234,318$

Beveiliging. 100, 102, 109, 130, 132, 137, $144,310,321$

Bewaarders $62,70-72,83,91,107,130$

Bewegingswrijheid 142, 275, 324

Bezoek zonder toezicht $99,104,119,133$, $149,150,320$

Bezoekfaciliteiten 119, 319

Bezoekmiddagen 150,315 
Bezoekregeling 104, 151

Büjzonder verlof 319

Bimenshuis $18,42,81,82,179,189,270$

Biologische theorieën 37,38

Bloedverwantschap $199,258,278$

Briefwisseling, 145, 147, 148, 162, 169

Buifenlandse gedetineerden 66,302

Buitenlandse moeders 74, 75, 111, 298

Buitenlandse vrouwen $12,62,65,74,78$, $79,80,109,113,117,123,124,156$, $299,300,308,322$

Buitenshuis $18,42,43,46,82,111,175$, $177,185-189,201,202,204,207$, $219,270,323,327$

Burgerlijke staat 23,33

Buurt $46,81,100,202,294,302,303,320$

Cellenbouw 101, 102

Cellencapaciteit 57,312

Cellentekort 32

Comdetentie 164, 165, 167, 168, 171, 226, $228,235,275,286,287,292,323$, $324,325-327,330$

Collectieve voorzieningen 230,288

Consultatie 159, 281, 293

Consultatierecht 277,320

Contextgerichte benadering 280

Continuilteit 114-116, 133, 141, 168, 178, $201,205,247,269,270,273,281$, $289,302,304,313,314$

Contradictoire procedure 139

Correspondentie 148

Crèche $114-116,118,236,302,307,322$, 328,329

Crèchebegeleider 114

Crisisbedden 303

Crisisopvang 110

Crisissituatie $294,303,304$

Cultuurowerdracht 201,239

Culluurpatroon 146

Culltuurrelativisme 239

Dagatctiviteiten 114

Dagbesteding $62,68,72,95$

Dagdetentic 57-59, 101,121, 126, 155, 157 , 318

Dagloon 157

Dagprogramma 76,150

Decriminalisering 99

Deelnemingsvormen 12
Deeltijdwerk 185,319

Deprivatie 90

Deprivatiemodel $84,85,87,90$

Deprivatieverschijnselen 85

Detentieduur 2, 35, 53, 85

Detentiefasering $101,109,112,132,147$, $153,156,169,307,308,315,318$

Detentieplan $109,307,318$

Detentieschade $2,83,85,91,312$

Detentiesituatic $100,128,135,139-141$, $148,164,168,219,285,291,293$, 316

Detentieverblijf 322

Dienstverleningsprojecten 312

Differentiatie $1,56-59,98,102,105-107$, $108,121,132,144,153,154,156$, $162,167,181,193,221,331$

Differentiatiestelsel 101, 102, 108, 137

Differentiedenken 251

Directeur 106, 107, 118, 130, 138-140, 143, $148,149-154,157-159,163,165$ $166,167,286,314,321,323$

Dominante norm 144

Drugs $11,20,62,64,65,90,96,158,292$, 300

Drugskoerier 300

Drugswerslaafden 65,132

Drugswrije afdeling $60,65,108,110,133$

Dwangmedicatie 159

Echtscheiding $174,200,246,252,259,265$, $268,271,272,274,279,281,294$

Echtscheidingsconllicten 280

Elektronisch toezicht 153, 313

Emancipatie $7,8,43,44,91,92,125,139$, $182,187,218,234,284$

Emancipatieopvattingen 103

Emancipatieproces 90,91

Emancipatietheorie 42, 43, 95

Enanciperende functie 139

Ervaringsdleskundigen 172

Euthanasic 3,28

Executie 23, 297, 312

Executiefase 83, 311, 315

Executierechter 311

Experiment $57-59,101,107,112-116,118$, $121,122,123,184,236,313,323$

Familie $4,15,18,46,62,73,74,78,79,82$, $87,106,111,115,117,120$, 
$124,136,145,147,152,154$, $174,176,177,178,190,194$; $199,201,209,229,230,247$, $258,276,281,285,288,294$, $297, \quad 300-302,304,306,318$, $319,320,326$

Familiebanden $34,96,119,120,196,322$ Familierelaties 1, 2, 4, 8, 95, 111, 119-121, $133,168,171,175,176,247,277$. $281,314,315,318,326$

Feitelijke zorg 242, 262, 264, 269, 272, $282,284,296,305,306,308,330$

Feminisering 5,252

Flexibiliteit 185, 234

Fouilleren 149, 167

Gastgezin 162

Gedetineerde mannen $11,51,88,111,121$, $133,144,295,296,315-317,330$

Gedetineerdenvertrouwenspersoon 92, 159

Geintegreerd model 88

Geldboete 32, 305

Gelijke behandeling $105,125,132,133$, $142,144,161,163,221,223,239$, $242,253,260,290,291$

Gelijkheidsbeginsel $5,7,144,161,169$, $219,223,253,264,256,272$

Gemengd regiem 58

Gemengde detentie $57,59,107,121-123$, $124-126,133,155,213,237,318$

Gender $5,7,19,41,48,50,90,144,152$, 231,253

Genderneutraal 51,219

Genderrelativisme 146

Genderspecifiek $20,32,141,145,147,169$, $170,171,187,243,264,293,309$

Gesloten $3,4,56,57,73,76,106,112,113$, $116,118,119,128,136,148,150$, $151,164,205,227,286,287,295$, $301,311,322,324,327,328$

Gesloten setting 112,286

Getuige $25,302,304,306$

Getuigeverhoor 306

Gevangeniscultuur $8,53,62,82,84,95$, 124,324

Gevangenisdirecteur 3

Gevangenishervorming 92,95

Gevangenissysteem 92
Gevangeniswezen $57,59,90-92,99,103$, $105,107,108,117,121,126,131$, $135,138,147,311,323,324$

Geweldsdelict 64,80

Geweldsdelicten $2,11,36$

Gezagswerhoudingen: 245

Gezinsleven $2,51,86,147,165,168,174$, $175,194,215,224,228,234,240$, $242,245,247,256,258-260,264$, $268,275,277,278,280,284,305$, 318

Gexinstherapie 316

Gezondheidsrisico's 241, 256

Gezondheidszorg. 175, 210, 222, 229, 230, $233,239,240,244,291$

Godsdienstvrijheid 239, 240

Gratie 155,309

Gratiëring 308,318

Gratieverzoek 155, 156

Grondrechten $6,7,9,137,142-144,146$; $209,212,213,215,216,218,228$, $233,238,263,275,284,286,289$, 290

Halfopen inrichting $56,106,107$, 109, 113, $133,167,171,322$

Halfweghuis 318

Hechtingsfiguur 201

Hechtingsrelatie 167

Heteroseksualiteit 1, 124, 246

Heteroseksuele $6,19,88,119,197,275$, 291,320

Historie $98,174,256$

Homoseksualiteit 90

Homoseksucle 87, 119

Huis van bewaring $56,99,138,154,276$, 285,307

Huisarrest $57,101,292,313$

Huisregels $139,149,151,163,166$

Huisvrouw $40,188,318$

Huisvrouwensyndroom 221

Hulpverlening $23,70,101,115,128,130$, $135,191-193,207,273,274,299$, $302,303,317$

Humanisering 93, 100, $118,135,311,312$ Identificatieproces 197,256

Identiteit $9,82,88,95,177,183,184,197$, $198,202,203,206,230,245,255$, $264,289,331$ 


\section{Trefwoordenregister}

Identiteítsbewijs 301

Identiteitserises 88,95

Identiteitsproblemen 88,200

Illegale wrouwen $59,62,300$

Importmodell 84, 87

Incest $54,128,316$

Individualisering $110,174,176,178,182$, 187,234

Individualiseringstendens $\mathbf{1 1 0}$

Individuele begeleidingsafdeling 60,110

Indrustriëlle revolutie $14,51,174$

Infantilisering 101, 329

Inrichtingsarts 158, 159, 328

Inrichtingswerker 131

Intimiteit $62,81,82,89,95,106,126,128$, 196

Jeugd $50,102,197,203$

Jeugdbeleid 193, 194, 196, 206, 235, 245, $257,276,285,286,289,290$

Jeugdhulpverlening $117,167,206,216$, $231,246,299$

Jeugdland 203

Jeugdombudspersoon 216

Jeugdstrafrecht 246

Juridisering $55,92,140,141,165,217,229$, 275

Justitie $11,12,17,19,20,33,53,57,59$, $60,71,72,86,87,92,101,105$, $107,109,114,131,137,155,156$, $158,159,247,284,287,298,299$, $302,303,311-313$

Justitiële autoriteiten 32,148

Kerngezin $173,176,231,288$

Kinderbescherming $117,148,163,165$, 166, 190, 191, 206, 216, 246, 269, $271,299,303,313,323$

Kinderbeschermingsmaatregel 240

Kinderdagverblijff 114, 1.33, 162, 193, 201, 236,241

Kinderopvang 114, 124, 131, 141, 155,162 , $167,182,184,185,193,202,204$, $207,218,233,235-237,239,244$, $270,313,320,324,329,331$

Kinderopvangplaatsen 236

Kinderopvangvoorzieningen 193,236

Kinderrechten $210,211,217,218,220,243$

Klachtrecht $135,137-139,142,160,216$, 224
Kortgestrafte $58,86,149$

Kostwinner 34, 181, 184, 187

Krazmhulp 158

Kranten 99, 148

Kwalificatie 30

Kwalificeren 54

Langgestrafte $11,56,58,59,86,109,112$, $127,149,154,156$

Leefeenheden 99

Leefgemeenischap 106

Leefsysteemgerichte benadering 287,288 , 330

Leeftijdscriterium 167

Leeftijdsgrens 19, 76, 112, 164, 235

Leerplicht 233, 239

Legaliteitsbeginsel 143

Legitimiteit 139, 143, 144, 168, 255

Lesbische contactem 86,123

Lesbische relaties 104

Levenscyclus 291

Levensloopbaan 12,186

Lichamelijke integriteit 142, 167, 229, 275

Lijfstraffen 225,238

Loonregeling $57,108,156$

Loyaliteit $87,177,199,200,208,211$

Luchten $65,68,72,75,127,150$

Luchtplaats 80

M.m.k. unit 58, 113, 114, 171, 311, 314

Maandcommissaris 138

Maatschappelijk werk $70,138,160,177$, 303, 306

Machtsconcepten 232

Machtsongelijkheid $31,246,251$

Machtstheorieën 47,210

Machtswerhoudingen $5,46,48,49,93,97$, 129,229

Mannelijke gedetineerden $62,80,82,91$, $99,104,110,111,143,145,285$

Mannenafdelingen 80

Manneninrichtingen $87,93,103,104,140$, 149

Mantelzorg 179

Marginale toetsing 143

Marktkapitalisme 175,229

Medicalisering $128,169,229$

Medicijngebruik 69, 90, 109

Medische dienst $69,70,90$

Medische klachten 69, 128 
Medische vragen 128

Medische zorg $128,129,148,157,158$, $160,162,169$

Mensbeeld $48,141,210,232,264$

Menstruatie 21, 39, 125

Mentorproject $119,295,296,299,314$, 317,321

Migratie $207,263,288,292,302$

Minderjarige $17,21,35,215,218,242$, $245,264,265,275,276,285,297$, 304

Misdaadbestrijding 48

Mishandelde vrouwen $24,25,28$

Mishandeling 11, 18, 26, 27, 30, 42, 46, 51, 191, 298

Mishandelingsgeschiedenis $26,27,29,30$

Modelgevangene 70

Modelgevangenschap 83

Moederrol 3, 133, 170, 182, 188, 207, 221, $243,292,322$

Moederschap 1, 4, 8, 9, 12, 37, 50, 51, 82, $93,94-96,114,121,130,147,161$, $168,174,181-185,187,188,191$, $205,207,221,222,243,250,255$, $264,282,287,290-292,316,330$

Moederschapsideologie 51 .

Nazorg $115,118,324$

Nestwarmte 205

Netwerken $14,84,85,176,179,208,213$, $220,232,243,288,292$

Netwidening 92, 94, 118, 311

Noodweer 28, 29

Noodweerexces 26,27

Normalisering 92,316

Ombudsman 148, 217

Omgangsrecht $214,256,258,277$

Omgangsregelingen 325

Onderhandeling 140

Onderhandelingspositie 91

Ondertoezichtstelling $240,241,267$

Onderwijs $127,189,210,212,218,229$, $233,238,239,244$

Onderwijswoorrangsgebieden 206

Ontoerekeningswatbaar 24

Ontwenningsprogramma 153

Ontzwangering 243

Open inrichting $56-58,71,76,105,113$, $115,119,122,127,157,328$
Open regiem 104, 328

Openbaar vervoer $59,78,113,154,318$

Opiumwet 11, 53, 109

Opsporing 17, 148, 233

Opsporingsfase 22

Opwoeding 4, 6, 8,9, 41, 46, 94, 139, 163 , $165,168,175-177,179,180,182$, $183,184-187,191-194,200,201$, $203,205-207,233,238,243,246$, $255,257,263,264,266-269,272$, $274,279,290,292,316$

Opvoedingsondersteuning 292,324

Opvoedingsproblematiek $\mathbf{1 1 4}$

Opvoedingstheorieèn 195,245

Opwoedingsverantwoordelijkheid 191,257

Opzet 30, 126

Ouderlijk gezag $164,165,172,212,215$, $228,241,264-266,274-276,279$, $280,286,305,319$

Ouderrol 147, 291, 292, 309, 323

Ouderschapsverlof $111,112,234,235,318$, 319

Overgangsklachtem 128

Overheid $1,2,5-9,20,111,137,139,141$, $142,165,168,171,172,175,182$ $185,186-188,192,193,207,209$, $210,214,216,218,224,225,227$, $228,229-231,233-241,243,247$, $248,251,263,264,266,275,279$, $280,282-286,288-290,293,295$, 297, 309

Overheidsbeleid $98,103,181,228,234$, 244,309

Overheidsingrijpen $175,241,287,289$

Overlevingsstrategie $85 ; 86,178$

Parentificatie 295

Participerende observatie 61,62

Partnerdoding 23, 28, 29, 297, 302, 311

Partnerrelatic 18, 270

Paviljoensysteem 105

Pedagogische 111, 112, 114, 115, 167, 170, $173,180,192,195,208,226,228$, $236,237,238,247,268,287,294$, 330

Penitentiair programma 102, 132, 137

Penologisch onderzoek 84, 96

Pers 1.50

Persoonlijkheidskenmerken 39, 101 
Peuterspeelzalen 193, 206

Plaatsing $56,58,101,109,113,122,153$, $154,303,325,328$

Pletggezin $73,76,260,268,279$

Pleegouders $265,277,278,280,326$

Poliowaccinatie 240

Politieambtenaar 305

Politiebureau \$6, 117, 136, 137, 276, 303, 305

Politiecel $56,117,276,285$

Politiegegevens 16, 17

Positieve discriminatie 253

Positieve verplichting 171, 221, 224, 225, $230,282,284,289$

Presumptie van onschuld 307

Preventie 27, 136, 146, 192, 241, 291, 312

Preventief gehechten 149, 159, 312, 323

Preventieve fase $299,302,305,330$

Primaire verzorgers $145,170,219,283$, $296,297,299,302,308,319,330$

Prisonatieversichijnselen 86

Privacy $46,81,82,85,89,95,106,122$, $128,142,143,145,147,167,175$, $179,209,213,243,245,248,254$, $259,261,262,264,275,277,283$, $285,290,297,317$

Privatisering 230

Professionalisering 99

Promiscuïteilt 38

Proportionaliteit $27,143,144,168,240$, 244,284

Prostitutie $14,16,18,19,38,41,129$

Psychiatrisch circuit 23

Psychiatrisch ziektebeeld 23

Psychiatrische hulpverlening 23

Psychiatrische ziekenhuizen $3,129,160$

Psychiatrisering 22-24, 27

Psychische belasting 62, 66

Psychische overmacht 28

Psychoanallyse 197, 199, 249

Psychologische factoren 40

Psychosociale gezondheid 100, 101

Psychosociale hulp 110

Psychosociale kwaliteit 100, 101

Psychosociale vaardigheden 100

Psychosomatische klachten 128

Rechtsbeginselen 139,230

Rechtsbijstand 153
Rechtsverfijning 252

Rechtvaardigheidsethiek $250,251,280$

Rechtvaardigingsgrond $29,276,285$

Recidive $16,34,36,83,91,99,118,309$, 312,313

Recidivecijfers $41,99,285$

Recidivekansen 326

Recidivepatronen 84

Recidivisten 16

Reclassering $77,94,102,117,157,300$, $302,305,306,309,313$

Recreatie $79,107,127,151,184$

Recreatietijd 72,322

Reflexief recht 251

Regiem $58,64,83,89,102,104,109,110$, $113,118,136,144,147,152,154$, $225,308,318,328,331$

Regiemsdifferentiatie 101, 121, 155

Regionalisering $108,109,147,153-155$, $162,169,302,318$

Registraties $16-19,37,52$

Reïntegratie $101,147,153,155,169,312$, 323

Reisafstand 78,154

Reisduur 59, 78

Reiskosten 154, 318, 320

Resocialisatic $2,83,85,101,103,132,135$, $169,307,312,313$

Ridderlijkheidshypothese 32

Rolpatronen 44, 47, 86, 103, 161

Samenlevingsconstellaties 246

Schaamte 3,22

Scholing 107, 125, 147, 156, 1.57, 169, 173, 292,322

Schoolprestaties 188, 207, 295

Schuldigverklaring 314

Schulduitsluiting 25

Second opinion 166,309

Seksespecifieke $19,21,51,88,93,95,106$, $129,130,160,161,170,204,222$, $270,274,291$

Seksestereotypering $93,95,169,222,284$, $287,290-292,313,316,331$

Sekseverschillen $21,41,44,48,198,231$

Seksualiteit $1,8,9,12,19,37,51,54,61$. $62,81,82,89,95,96,104,106$, $124,126,171,176,203,207,264$, 291 
Selksueel misbruik $19,40,50,51,191,200$,

Selectiecriteria 115,132

Selectiemechanismen 311

Selfhelpgroepen 317

Selfreportstudies 16,17

Sensitieve responsiviteit 196,289

Slachtofferstandpunt 18

Sociaal ouderschap $191,243,257,278,293$

Sociaalcultureel $99,127,132$

Sociaaleconomisch $43,183,190,231$

Sociale controle $13,22,42,45,46,49,51$, 85

Sociale isolatie 99

Sociale omgeving 38,51

Sociale politiek 205,231

Sociale vernieuwing 193,206

Socialisatie $2,19,23,42,45,49,88,103$, $122,128,176,178,187,189,199$, $204,222,270,288,291,324$

Socialisatieproces 239

Sociallisatietheorieën $41,42,47,51,190$

Sociotherapie 89,99

Solidariteit $63,97,177,230,237,252,292$

Speldeskundige 114

Straf 2, 14-16, 20, 25, 55-58, 63-65, 71, 77, $83,86,91,94,98,113,119,136$, $138,147,152,154,155,168,225$, $238,287,300,301,305,307-309$, $310-312,314,318,323,326,328$

Strafklimaat 314

Strafmaat 307,309

Strafprocedure 309

Straftoemeting $22,23,33-36,50,88,92$, $94,118,282,298,300,307,309$, 314,330

Strafuitsluiting 29

Strafvermindering $19,308,314$

Strafverminderingsgronden 308

Subculturen 85,87

Subsidiariteit $143,240,244,284$

Symbiose 197,313

Symptoombestrijding 128

Taakstraffen 101, 313

Taalproblemen 114

Telefoneren 74, 75, 79, 137, 147, 151, 169

Tenuitwoerlegging $71,83,98,136,143$, $144,147,156,282,301,305,308$, 312,318
Therapie $68,195,317$

Thuismanagement 263

Thuismoeder 185

Thuissituatie 116, 187, 201, 292, 300, 319

Toestemmingsvereiste 165,319

Totale institutie $85,95,115,130,132,178$

Trajectbegeleiding $107,127,128,147,169$

Uitplaatsing 113,166

Vacantiedorp 319

Vaccinatieplicht 240

Veiligheid $2,86,89,122,142-144,148-150$, $153,158,163,164,166,241,246$, $284,285,312,323$

Veiligheidsaspect 99

Verblijfplaats $112,168,213,226,252,265$, $268,269,275,280,281$

Verhoorstudio 306

Verkeersdelicten 20

Verlof $112,113,119,120,147,151,152$ $162,163,235,319$

Verloffaciliteiten 156,319

Verlofregeling 152

Vermogensdelicten 11

Veroordeling 56, 244, 265, 305, 307

Verschoningsrecht 306

Verslavingsproblematiek 23

Vertrouwenspersoon $142,304,306$

Vertrouwensurouw 126

Vervangende verzorger 3

Vervolging $17,22,233$

Vervroegde invrijheidsstelling 53,135 , $155,315,318$

Verwantschapsnetwerk $256,258,263,289$, 292

Verzorgende ouder $1,6,163,168,216$, $219,243,253,262,272,273,287$, $289,309,326$

Verzorgingsarrangementen $181,213,302$, $320,325,326$

Verzorgingsforfait 235

Verzorgingsstaat $182,228-230,302$

Verzorgingsverlof $235,243,319$

Visitatie 143

Voogdij 246, 252, 265, 269, 272

Voogdijtoewijzingen 272

Voorarrest $56,227,305,307,328$

Voorbedachte rade $27,29,30$

Voorbehoedmiddelen 182,291 


\section{Trefwoondenregister}

Voorllichtingsrapportage 300

Voorlopige hechtenis $11,56,58,105,108$, $109,153,166,305,319$

Voorlopige voorzieningen 306,319

Voortplanting $11,5,6,8,9,51,54,128$, $176,178,207,237,291$

Vreemdelingenbewaring 59,136

Vrijetifdsbesteding $85_{1} 177,180,214,222$

Vrijheidsbeneming $132,143,144,155,287$, $292,305,312,313,322$

Vrijhbeidsberoving $164,227,228,275,286$, 287

Vrourwengevangenis $8,60,94,104,106$, $107,123,126,317,321$

Vrouwenhulpwerlening $86,107,128-130$, 322

Vrouwenmishandeling 146

Vrouwenstudies $4,5,7,9,55,161,203$, 222,248

Vruchtbare leeftijd 21

Vruchtbare periode 88

Waarheidsbeginsel 256

Wilsbeschikking 165

Willssoevereiniteilt $178,218,220$

Woonouderschap 258, 268,275
Zedelijkheidswetgeving 19

Zelfbeeld 202, 329

Zelfmeiders 58

Zelfopoffering 198,254

Zelfzorg 329

Zoging 243, 255

Zoogperiode 203

Zoogrecht 111

Zorgethiek $251,261,268$

Zorgopdracht 266-268

Zorgperspectief 248

Zorgplicht $186,206,233,241$

Zorgrelatie $268,272,275,282,309$

Zorgtaken $5,34,88,119,125,147,152$, $155,169,172,186,219,221,234$, $235,246,281,308,330$

Zorgverantwoordelijkheid 310

Zorgzaamheidsethiek 249-251, 254, 280

Zuigelingenfase 111

Zwangerschap $21,54,70,75,107,111$, $130,147,161,162,222,237,243$, $249,253,255,256$

Zwangerschapswerlof $111,156,329$

Zwartboek 105 


\section{Bijlagen}

\section{Nationale regelgeving}

\section{Artikel 31 Gevangenismaatregel:}

"1. Indien de moeder wordt gedetineerd, kan het kind, dat niet van haar kan worden gescheiden, mede in het gesticht wordien opgenomen.

2. Het verblijf van dit kind, alsook wan het kind dat in het gesticht wordt geboren, wordt beëindigd, zodra het de zorg van de moeder kan ontberen.

3. Voorzover de gedetineerde niet zelf in de behoeften van het met haar in het gesticht verblijvende kind kan voorzien, geschiedt zulks van rijkswege".

Art. 12 PBW (ontwerp TK 1994-1995, nr. 24263).

1. Onze Minister wijst de inrichtingen of de afdelingen aan waarin kinderen tot een in de aanwijzing aangegeven leeftijd kunnen worden ondergebracht.

2. Indien een gedetineerde een kind in de inrichting of afdeling, bedoeld in het eerste lid, wil onderbrengen teneinde het aldaar te verzorgen en op te voeden behoeft hij de toestemming van de directeur. De directeur kan deze toestemming geven, voor zover dit verblijf zich verdraagt mett de volgende belangen:

a. de bescherming van de persoonlijke veiligheid of de geestelijke of lichamelijke ontwikkeling van het kind;

b. de handhaving van de orde en veiligheid in de inrichting.

3. De directeur kan aan de toestemming voonwaarden verbinden met het oog op het belang als bedoeld in het tweede lid.

4. De directeur kan over een door them voorgenomen onderbrenging van een kind in de inrüchting of afdeling het advies inwinnen van de Raad voor de Kinderbescherming.

5. De directeur kan de toestenming intrekken, indien dit noodzakelijk is met het oog op een belang als bedoeld in het derde lid of indien de gedetineerde een bepaalde voonwaarde niet nakomt. Indien de directeur een nader onderzoek nodig cordeelt, kan hij de medewerking van de Raad voor de Kinderbescherming inroepen.

6. De directeur is verplicht de toestemming in te trekken, indien de onderbrenging van het kind in de inrichting in strijd komt met enige op het gezag over her kind betrekking hebbende beslissing.

7. In de huisregels worden nadere regels gesteld omtrent het werblijf van kinderen in de inrichting.

8. De kosten van de verzorging van het kind komen woor rekening van het Rijk, voor zover de gedetineerde miet zelf in die kosten kan voorzien. 
art. 8 EWRM:

1. Een lieder heeft recht op respect voor zïn priveleven, van zijn familie- en gezinsleven, zijn woning en zijn: correspondentie.

2. Geen inmenging van enig openbaar gezag is toegestaam in de uitoefening van dit recht, daun voor zover bij de wet is woorzien en in een democratische samenleving noodzakelijk is in het belang van de nationale velligheid, de openbare velligheid of het economisch welzijn van het land, he: voorkomen van wanordelijkheden en strafbare feiten, de bescherming van de gezondheid of de goede zeden of voor de bescherming van de rechten en vrijheden van anderen:

art. 2 VN Kindervardrag:

1. De Staten die partij zijn bij dit Verdrag, eerbiedigen en waarborgen de in het Verdrag beschreven rechten voor ieder kind onder hun rechtsbevoegdheid zonder discriminatie van welke aard ook, ongeacht ras; hwidskleur, geslacht, tat, godsdienst, politick of andere overtuiging nationale, etnische of matschappelijke afkomst, welstand, handicap, geboorte of andere omstandigheid van het kind of van zijn of haar ouder of wettige woogd.

2. De Staten die partij zijn, nemen alle passende maatregelen om te waarborgen dat het kind wordt beschermd tegen alle vormen van discriminatic of bestraffing op grond van de omstandighedlen of activiteiten van, de meningen geuit door of de overtuigingen van de ouders, wettige voogden of familieleden wan het kind.

\section{art. 3 VN Kinderverdrag:}

1. Bij alle matregelen betreffende kinderen, ongeacht of deze worden genomen dioor openbare of particuliere instellingen voor maatschappelijk welzijn of door rechterlijke instanties, bestuurlijke autoriteiten of wetgevende lichamen, vormen de belangen van het kind de eerste overweging.

2. De Staten die partij zijn, verbinden zich ertoe het kind te verzekeren van de bescherming en de zorg die nodig zijn voor zijn of haar welzijn, rekening houdend met de rechten en plichten van zijn of haar ouders, wettige voogden of amderen die wettelijk verantwoordelijk voor het kind zijn, en nemen hiertoe alle passende wettelijke en bestuurlijke maatregelen.

3. De Staten die partij zijn, waarborgen dat de instellingen, diensten en voorzieningen die verantwoordelijk zijn woor de zorg voor of de bescherming van kinderen voldoen aan de door de bevoegde autoriteiten, wasigestelde normen, met mame ten aanzien van de veiligheid, gezondheid, het aantal personeelsleden en hun geschiktheid, alsmedle bevoegd toezicht.

\section{art. 9 VN Kinderverduag:}

1. De Staten die partij zijn, waarborgen dat een kind niet wordt gescheiden van zijn of haar ouders tegen hun wil, tenzij de bewoegde autoriteiten, onder voorbehoud van de mogelijkheid van rechterlijke toetsing, in overeenstemming met het toepasselijke recht en de toepasselijke procedures, beslissen dat dexe scheiding noodzakelijk is in het belang van het kind. Een dergelijke beslissing kan noodzakelijk zijn in een bepaald geval, zoals wanneer er sprake is van misbruik of verwaarlozing van het kind door de ouders, of wanneer de ouders gescheiden leven en er een beslissing moet worden genomen ten aanzien van de verblijfplaats van het kind. 
2. In procedures ingewolge het eerste lid wan dit artikel dienen alle betrokken partijen de gelegentheid te krijgen aan de procedures deel te memen en hun standpunten naar woren te brengen.

3. De Staten die partij zijn, eerbiedigen het recht van het kind dat van een ouder of beide ouders is gescheiden, op regelmatige basis persoonljijke betrekkingen en rechtstreeks contact met beide ouders te onderhouden, tenziij dit in strijd is met het belang van het kind.

4. Indien een dergelijke scheiding voortvloeit uit een matregel genomen door een Staat die partij is, zoals de inhechtenisneming, gevangenneming, verbanning, deportatie, of uit een maatreged het overlijden ten gevolge hebbend (met inbegrip wan overlijden, door welke oorzaak ook, terwijl de betrokkene door de Staat in bewaring wordt gehouden) van eên ouder of beide ouders of van het kind, werstrekt die Staat, op verzoek, aan de ouders, aan het kind of, indien van toepassing, aan een ander familielid van het kind de noodzakelijke inlichtingen over waar het afwezige lid van helt gezin zich bevindt of waar de afwezige leden van het gezin zich bevinden, tenzij het verstrekken van die inlichtingen het welzijn van het kinư zou schaden. De Staten die partij zijn, waarborgen voorts dat het indienen van een dergelijk verzoek op zich geen nadelige gevolgen heeft voor de betrokkene( $(\mathrm{n})$.

\section{art. 4 VN Vrouwenwerdrag:}

1. Wanneer Staten die partij zijn bij dit Verdrag, tijdelijk bijzondere maatregelen nemen die gericht zijn op versnelling van feitelijke gelijkstelling van mannen en vrouwen wordt dit niet beschouwd als discriminatie, als omschreven in dit Verdrag, maar het mag geenszins leiden tot handhaving van ongelijke of afzonderlijke normen; deze maatregelen dienen buiten werking te worden gesteld zodra de doelstellingen ter zake van gelijke kansen en gelijke behandeling zijn verwezenlijkt.

2. Wanneer de Staten die partij zijn bij dit Verdrag, bijzondere matregelen treffen, met inbegrip van de in dit Verdrag vervatte maatregelen, die zijn gericht op bescherming van het moederschap wordt dit niet beschouwd als discriminerend.

\section{art. 5 VN Vrouwenwerdrag:}

De Staten die partij zijn bij dit verdrag, nemen alle passende maatregelen om:

a. het sociale en culturele gedragspatroon van de man en de vrouw te veranderen ten einde te komen thot uitbanning van vooroordelen, van gewoonten en van alle andere gebruiken, die zijn gebaseerd op de gedachte van de minderwaardigheid of meerderwaardigheid van én van beide geslachten of op de stereotiepe rollen van mannen en vrouwen;

b. ervoor zorg te dragen dat onderwijs over het gezin een juist begrip van het moederschap als sociale functie, en de erkenning van de gezamenlijke verantwoordelijkheid van mannen en vrouwen bij het grootbrengen en de ontwikkeling van hum kinderen bevat, met dien verstande dat het belang wan de kinderen in alle gevallen voorop staat.

Met name in de Standard Minimum Rules for the Treatment of Prisoners (UN) en de European Prison Rules wordt ook aandacht aan de specifieke positie van vrouwen geschonken. Het betreft echter aanbevelingen aan staten, waaraan gedetineerden formeel geen rechten kunnen ontlenen. Bowendien wordt aan staten de vrijheid gegeven "te experimenteren teneinde de behandeling van gedietineerden nog werder te verbeteren". 


\section{Biflugen}

Standard Minimum Rules (VN, 1977):

art. $8:$

Verschillende cattegorieên gedetineerden worden in aparte inrichtingen of delen van inrichtingen opgenomen al naar gelang hun sekse,lleeftijd, crimineel verleden, de gerechtelijke reden voor hun detentie en de gewenste behandeling.

(1) Mannen en virouwen moeten zoveel mogelijk in aparte inrichtingen worden opgenomen. In een inrichting waar zowel mannen als wrowwen verblijuen, moeten de gebouwen bestemd voor vrowwen geheel afgescheiden zijn.

art. 23:

(1) In vrouweninrichtingen moeten speciale woorzieningen aanwezig zijn woor prenatale en postnatale zorg en behandeling. Indien dat praktisch gezien mogelijk is, moet geregeld worden dat kinderen in een ziekenhuis buiten de inrichting worden geboren. Als een kind in de gevangenis wordt geboren, dient dat niet in de geboorte-akte te worden aangegeven.

(2) Indien kleine kinderen in de inrichting bij hun moeder mogen verblijven, moet er een kinderbewaarplaats zijn met gekwalificeerd personeel, waar de kinderen kunnen verblijven als zij niet bij hun moeder zijn.

art. 53:

(1) In een inrichting waar zowel mannen als vrouwen verblijven, moet het gedeelte van de gebouwen dat voor vrouwen is bestemd onder gezag wan een wrouwelijke beambte staan die de sleutels van dat deel wan de gebouwen onder haar hoede heeft.

(2) Slechts onder begeleiding van een vrouwelijke beambte mogen mannelijke leden van de staf het verblijf van de vrouwelijke gedetineerden betreden.

(3) Vrouwelijke gedetineerden mogen slechts door vrotwelijke beambten worden bejegend. Mannelijke stafleden, zoals artsen en onderwijzers, kunnen wel hun functie uitoefenen.

art. 66:

(1) Teneinde te bevorderen dat gedetineerden weer zelfrespect en verantwoordelijkheidsgevoel ontwikkelen, dienen alle geeigende middelen (bijwoorbeeld vakopleiding, geestelijke verzorging en matschappelijk werk) te worden gebruikt in owereenkomst met de individuele behoeften van een gedetineerde. Hierbij dient wel rekening te wordlen gehouden met de sociale en criminele achtergrond, de geestelijke en lichamelijke wermogens, de persoonlijke aard, de duur van de straf en de matschappelijke voornitzichten na invrijheidsstelling van de gedetineerde.

De Penal Reform International (PRI) heeft aanbevelingen gedaan om de invulling van de Standard Minimum Rules verder te concretiseren (Penal Reform International, Making standards work, 's-Gravenhage, 1994, p. 97-99).

85. Female prisoners, because of their traditionally small numbers, in nearly all countries are disadvantaged compared to male prisoners: They are generally allocated to a prison far from their home towns. In this respect efforts should be made to implement Principle no. 20 of the U.N. Body 
of Principles, urging that a prisoner if (he) so requests. shall if possible be kept in a place of detention or imprisonment reasonably near his usual place of residence.

86. Prisons are not differentiated and as a result the amount of security is mostly high, certainly far higher than what is generally necessary for women. Because of their traditional role in society, work for women is little and uninteresting. Prisons are built for men and often hardly adapted to special needs of women, not even to their vital needs with respect to menstruation, pregnancy and motherhood, as it is mentioned in "The Human Rights Watch Global Report on Prisons". Compared to men, women having committed crimes, are easier considered "bad women" and looked upon despisingly. And still more often than not their offenses are committed because of men or because of their family.

87. It therefore would have been recommendable if the SMR would have been paid even more to female prisoners. In particular attention should have been paid to the availability of gynaecological care for female prisoners as a general provision. It certainly would have been in accordance with SMR's basic principle of no discrimination (Rule 6, see Section 1), if it would have been specified that no discrimination means, that specific needs - physical and psychological -of specific categories of prisoners should be formulated and met, in order to awoid kind of 'equality" in prison, which is in fact discriminative uniformity.

88. The SMR however at least have emphasized the most urgent needs of special provisions for pregnant women and mothers with babies.

Rulle $23(1)$

In women's institutions there shall be special accommodation for all necessary pre-natal and post-natal care and treatment. Arrangements shall be made wherewer practicable for children to be born in a hospital outside the institution. If a child is born in prison, this fact shall not be mentioned in the birth certificate.

Where nursing infants are allowed to remain in the institution with their mothers, provision shall be made for a nursery staffed by qualified persons, where the infants shall be placed when they are not in the care of their mothers.

89. Although in different countries different viewpoints are held about the best solutions, some very basic provisions should be guaranteed. The recommendations of the Human Rights Watch Report deserve to be quoted:

- Female inmates should be given sanitary napkins or substitutes and have daily access to showers or their equivalent during menstruation;

- work and educational opportunities should be available on a equal basis to both men and women;

- where visits to female inmates are severely limited because of the long distances relatives must travel, the authorities must make efforts to compensate (by subsidizing relatives" travel or through some other system);

- pregnant prisoners should be given regular pre-natal check-ups and a adequate diet;

- nursing mothers should get an adequate diet; 
- efforts should be made to facilitate mothers's contacts with their children and their right to dired their upbringing."

European Prison Rules (Comile Van Ministers, Raad van Europa, 1987)

art. 11:

Bij de plaatsing wan gedetineerden in verschillende inrichtingen of onder een bepaald regiem, dient naar behoren rekening to worden gehouden met hun gerechtelijke en juridische status, met de specifieke vereisten voor hun behandeling, hun medische behoeften, geslacht en leeftijd.

Mannen en wrouwen dienen in principe afzonderlijk to worden ingesloten, hoewel zij wel, in het kader van een vastgesteld bejegeningsprogramma, gezamenlijk aan geonganiseerde activiteiten kunnen deelnemen.

art. 65 lid d:

Al het mogelijke dient to worden gedaan om to waarborgen dat de regiems van de inrichtingen zodanig zjjn opgezet en worden gehanteerd, dat gedetineerden mogelijkheden geboden krijgen om vaardigheden en bekwaamheden to ontwikkelen, die hun vooruitzichten op een geslaagde wederopneming in de maatschappij, na hun wrijlating verbeteren.

Recommendation on the European Prison Rules of the Committee of Ministers of the Council of Europe

art. 11:

(1) In allocating prisoners to different institutions or regimes, due account shall be taken of their judicial and legal situation (untried or convicted prisoner, first offender or habitual offender, short sentence or long sentence), of the special requirements of their treatment, of their medical needs, their sex and age.

(2) Males and females shall in principle be detained separately, although they may participate together in organised activities as part of an established treatment programme.

art. 28:

(1) Arrangements shall be madle wherever practicable for children to be born in a hospital outside the institution. However, unless special arrangements are made, there shall in penal institutions be the necessary staff and accommodation for the confinement and post-natal care of pregnant women. If a child is borm in prison, this fact shall not be mentioned in the birth certificate.

(2) Where infants are allowed to remain in the institution with their mothers, special provision shall be made for a nursery staffed by qualified persons, where the infants shall be placed when they are not in the care of their mothers.

Ontwerp resolutie EG over vrouwen en kinderen in de gevangenis (Publicatieblad 26-6-1989, nr. C $158 / 512)$. 
Het Europees Parlement verzoekt de lidstaten erwoor te zorgen dat:

a. - er comfort op een aanwardbaar niveau wordt geboden en passende sanitaire voorzieningen;

- er waarborgen zijn woor de privacy van de gevangenen;

- moeder en baby-units speciaal woor dat doel worden ontworpen;

b. - er waarborgen zijn dat regelmatig bezoek kan worden ontvangen en dat; indien de omstandigheden dat toelaten, bezoekjes en langer verblijf thuis worden uitgebreid;

- de vrouwen het bezoek van hun familieleden mogen ontwangen en aan dezen, indien zij niet wonen in de plaats waar de gevangen vrouwen hun straf uitzitten, de reiskosten worden vengoed;

- aan de facto koppels bezoeken en reiswergoedingen worden toegestaan zonder discriminatie op grond van afkomst, ras of seksuele geaardheid;

- brieven kunnen worden geschreven en telefoongesprekken kunnen worden gevoerd en wel ongecensureerd, maar onder normale veiligheidscontrole;

- nieuws en informatie wij toegankellijk is;

- voorzien wordt in gespecialiseerde opleiding en ontwikkeling van het personeel en hiertoe de nodige middelen worden uitgetrokken; deze opleiding dient gericht te zijn op de beste praktijken in de Europese Gemeenschap;

c. - er behoorlijke voorzieningen voor gezondheidszorg bestaan en dat infor matie wordt gegeven; - medicijnen nooit worden gebruikt voor straf, onder de duim houden of in het gareel brengen;

- gevangenen het recht hebben desgewenst door vrouwen onderzocht en behandeld te worden;

- beslissingen die de gezondheid of lichaamsbeweging van gevangenen betreffen, niet door met tuchtmaatregelen belast personeel worden genomen;

- rekening gehouden wordt met de wensen en medische voorschriften inzake voeding;

- psychisch zieke vrouwen niet in cen gevangenis worden opgesloten; het gebrek aan passende verzorging en accommodatie in de Gemeenschap mag geen reden zijn voor gevangenzetting;

- de vrouwelijke gevangenen worden aangemoedigd aan lichaamsoefeningen en sport te doen en hun derhalve aangepaste uitrusting ter beschikking wordt gesteld;

d. - geen vrouwelijke gevangene wordt blootgesteld aan enige vorm van discriminatie of pesterijseksueel, racistisch of religieus;

- bezoekraden en reclasseringsraden in hun etnische samenstelling een weerspiegeling zijn van specifieke gevangenisgemeenschappen;

- racisme bij gevangenispersoneel als een ernstig vergrijp wordt beschouwd;

e. - aan de praktijk van visitatie een eind wordt gemaakt;

f. - alle faciliteiten voor kinderwerzorging zo zijn opgezet dat zij woldoen aan de behoeften van het kind en niet aan de eisen van het gevangenisregime;

kleine kinderen in de gevangenis bij hun moeder blijven, wanneer de mogelijkheid bestaat dat zij op gezondheidsgebied behoorlijk worden verzorgd en psychisch nief te lijden hebben; kleine kinderen in de gevangenis buiten de gevangenis naar een normale school gaan; het personeel op de moeder en baby-units uit gediplomeerde kinderverzorgsters bestaat: het personeel op de moeder en baby-units geen uniform draagt; kind en moeder nooit voor straf worden gescheiden; 


\section{Bijlagen}

g. - stafulair vastgelegde termijnen in acht worden genomen waarbinnen een zaak voor de rechter komt en nog niet veroordeelde gevangenen slechts in verzekerde bewaring worden gehouden zolang zij een reêle en duurzame bedreiging voor de buttenwereld vormen;

- aangezien in vrouwengevangenissen geen opstanden of ontsnappingen plaatsvinden en voor zover de omstandigheden het toellaten, de vrouwen in vrijheid onder controle kunnen worden gelaten, vooral wanneer het om niet ernstige misdrijven gaat;

h. - hun werk wordt toevertrouwd dat zoveel mogelijk bevrediging schenkt en naar behoren wordt beloond.

Opdat wrouwelijke gevangenen voorbereid zijn op hun terugkeer in de burgermaatschappij:

a. verzoekt de Commissie de lid-staten ervoor te zorgen dat gevangenen de kans krijgen te studeren en/of te werken;

b. verzoekt de Commissie bepaalde gedeelten van de kredieten van de EG te bestemmen voor het opleiden van de vrouwen, eventueal het personeel, in moderne techniek en werk in traditioncel niet-vrouwelijke beroepen.

Het Europese Parlement verzoekt de Commissie samen met de lid-staten het onderzoek te coördineren naar:

a. het strafbeleid en wat daarmee samenhangt op het terrein van jeugdige delinquenten;

b. vergelijkende statistieken over zaken die delinquenten uit etnische minderheidsgroepen betreffen;

c. de gevolgen op lange termijn voor kinderen die met hun moeder in de gevangenis hebben gezeten en waarvan het gezin ontwricht is doordat de moeder in de gevangenis zat;

d. de mogelijkheid dat de vrouwen op gezette tijden het bezoek kunnen ontvangen van parlementsleden en dat, wanneer een in de gevangenis zittende vrouw om het bezoek van een parlementslid vraagt, hiertegen geen enkel bezwaar wordt gemaakt; dit verzoek kan zij rechtstreeks tot de nationale parlementen of tot het Europese Parlement richten; de gevangen wrouwen dienen van dit voorrecht naar behoren op de hoogte te worden gesteld;

e. indien de tijd die zij in gevangenschap doorbrengt alvorens te worden veroordeeld, langer is dan de duur van de haar opgelegde straf, zal zal recht hebben op een financiële vergoeding. 
Pedagogische toelatingscriteria woor het meenemen wan een kind asar de inrichting.

(Uit: Experiment moeders met kinderen in gevangenis Ter Peel, 1995)

Door de ervaring die de begeleidingscommissie in de loop van de twee jaar met het opvangen van een kind in de inrichting heeft opgedaan, heeft zij een aantal pedagogische voelatingscriteria besproken waaraan een inrichting diemt te voldoen. Deze criteria worden hieronder besproken.

Eerst dient te worden bekeken of een kind wel of niet mee genomen dient te worden naar de inrichting.

Dit wordi gedaan aan de hand van de volgende uitgangspunten:

- het kind hoort niet thuis in de inrichting, dus alleen indien elders geen andere mogelijkheid aanwerig is;

- de situatie dient aan te sluiten bij de 'thuis'situatie. Dit houdt in dat wanneer het kind voor detentie van de moeder al bij een pleeggezin was, het kind niet met de moeder mee mag naar de inrichting. Dit sluit namelijk niet aan bij de 'thuissituatie' (Tenzij het om een detentiefaseerder gaat die na ontslag voor het kind gaat zorgen).

Naast de hiervoor genoemde uitgangspunten dienen in de inrichting een aantal faciliteiten aanwezig te zijn. Deze faciliteiten zijn:

- een eigen afdeling voor de moeders die met hun kind in de inrichting zijin;

- privacy voor de moeder met het kind met betrekking tot slapen, eten, wonen en wassen. Dus éen woon-slaapkamer voor de moeder en én hiermee verbonden slaapkamer voor het kind;

- woldoende (speel)ruimte binnen, op hel terrein van de inrichting;

- voldoende (speel)ruimte buiten, op het terrein van de imrichting;

- faciliteiten voor vrijetijdsbesteding zoals fietsen met een kinderstoel, opblaasbaar zwembadje voor het kind, een zandbak, enz;

- laagdrempelige opvoedingsondersteuning in de worm van bijwoorbeelld een speelmiddag voor moeder en kind.

De kinderen dienen in verband met het dagprogramma van de moeder overdag opgevangen te worden.

De inrichting dient in het belang van de kinderen gebruik te maken van professionele kinderopvang.

Deze biedt:

- integratie met kinderen buiten de inrichting,

- sociale omgang met woldoende leeftijdsgenootjes;

- structuur en dagritme;

- speelgoed aangepast aan de ontwikkelingsfase van het kind;

- professionele begeleiding van kind en moeder;

- versterking ouder-kind band via observaties en open uitwisseling;

- vroegtijdige signalering van problemen bij een kind.

(dit zijn randwoorwaarden die in feite los staan van de doelgroep van de commissie, maar in z'n algemeenheid gelden voor kinderdagverblijven en die de commissie als zeer waardevol heef ervaren) Als de inrichting voldoet aan de bovenstaande woorwaarden, dient er daarnaast, met het oog op het kind en in aansluiting op de "thuis'situatic, nog met het volgende rekening te worden gehouden:

- weekendwerlof voor bijwoorbeeld verjaardagen, kleren kopen, enz;

- contact met de familie (sociaal netwerk);

- de zorg voor continuiteit via nazorg/servioeverlening door middel van kinderopvang en/of reclassering.

Al deze pedagogische randwoorwaarden worden individuecl ingevuld. Ze zijn afhankelijk van de leeftijd, aard, intelligentie en culturele achtergrond van het kind (en de moeder). 


\section{Naschrift}

Leren is een luxe. Met leren je kost verdienen is wellicht een nog grotere luxe. De faculteit vraagt niet alleen om kennis te verwerven, maar ook om die over te dragen. In mijn geval komt die kennisoverdracht bijna altijd te vroeg. Zelfs bij de publicatie van dit boek. De voorbereidingen zijn nooit af, er is altijd meer en nieuwe informatie en het kan natuurlijk beter... Gelukkig hebben de faculteit en in het bijzonder mijn promotoren me op het juiste moment en op de juiste manier uitgedaagd en me een hart onder de riem gestoken.

Het doen van onderzoek is, vooral aan een juridische faculteit, een solistische bezigheid. Het is daarom bijzonder prettig een 'thuisbasis' te hebben. Dat thuis heb ik ten volle gevonden bij de vakgroep Strafrecht en Criminologie. Het secretariaat vormt daarin door de jaren heen de spil. De gezichten van respectievelijk Josta Mommertz, Agnes Martijn, Margot de Boer en Riny Bodifée hoorden en horen daarbij. Maar ook in de onderzoekschool Rechten van de Mens en de deelprojecten Vrouw en Recht en Penitentiair Recht en Mensenrechten kreeg het onderzoek steeds een vaste plek.

Aan het maatschappelijk nut van mijn onderzoek heb ik nooit getwijfeld. 'Als vanzelf werd ik bij de praktijk betrokken, bijvoorbeeld via de begeleidingsgroep van het experiment met moeders en kinderen in de halfopen gevangenis Ter Peel. In 1993 benaderde Henriëtte Heimgaertner van de Bernard van Leer Foundation me om voor een workshop in Brussel over de problematiek van kinderen van gedetineerden een Nederlandse delegatie samen te stellen. Er ontstond zelfs een Europees netwerk dat onlangs een eerste rapport uitbracht. De samenwerking in het Nederlandse "clubje" is daarbij heel vruchtbaar geweest. Ik noem met name Bernadette van Dam, directeur van de penitentiaire inrichting voor vrouwen in Heerhugowaard en Gerian Holwerda, coördinator van het Mentorproject voor kinderen van gedetineerden. Ten aanzien van het wetenschappelijk nut van het onderzoek had ik well eens twijfels. Het zoeken over de grenzen van het vak heen en het betrokken zijn bij de praktijk stimuleerden me enorm. Van de wetenschappelijke waarde daarvan moest ik me soms door anderen laten overtuigen. Met name mijn promotor, Gerard Mols, benadrukte steeds dat ik "het debat oproep". Zijn commentaren waren opbouwend, bemoedigend en inspirerend. Ook de stimulans van collega's-vrouwenstudies binnen en buiten de Universiteit Maastricht was belangrijk. De Nemesis-special met essays 
die we over "Gevangen vrouwen" schreven was én van die collectieve activiteiten die me moed en zin gaven om door te gaan.

Toen het eerste concept er lag, toonde Peter Bal zich bereid om het hele geactualiseerde stuk, hoofdstuk voor hoofdstuk, met me door te nemen. Het waren intensieve, inspirerende en ontspannen sessies, mede dankzij zijn relativerende humor.

De maand die ik moest wachten op het oordeel van de beoordelingscommissie was de moelijikste periode wan het hele onderzoek. Ik realiseerde me hoe zeer mensen zich 'opgezadeld' kunnen voelen met zo'n taak. En ik ben blij dat ze dat toch maar gedaan hebben en die tijd niet langer hebben laten duren dan noodzakelijk was. De laatste loodjes kon ik ín plezierige samemwerking met anderen afmaken: de omslag met het moole schilderij van Siiri Spronken, de vertalingen van de samenvattingen door Catherine Miginiac en Wies Rayar en het camera-ready maken van de tekst door Riny Bodifee. Ik vond het geweldig om de voorpret rond de voorbereidingen voor de drieëntwintigste mei te delen met twee maatjes uit Maastricht, Els Landerloo en Taru Spronken. Beiden zijn woor mij al vele jaren een bron van inspiratie, met name door de professionele wijze waarop zij in hun werk staan. Els als directeur wan de stichting Kinderopwang in Maastricht en Taru als advocalt en collega-docent en -onderzoeker. Ik bedoel daarmee dat zij primair gedreven zijn door de aard en de inhoud van hun werk en niet door status, geld of relaties.

Tot slot: bij het schrijven van dit boek heb ik me vele malen gerealiseerd hoe zeer ik geboft heb met het nest warin ik ben geboren en met dat waaraan ik zelf met André heb kunnen bouwen. "Elkaar de ruimte laten" is vanaf mijn vroege jeugd een gevleugelde uitdrukking. De ene boom plant je niet in de schaduw van de andere. Je kunt in dezelfde grond wortelen, maar je moet je eigen weg tot groei en bloei vinden. Het is een mirakel dat mijn vader de wording en voltooing van het boek, van verre, heeft kunnen meemaken. Mijn moeder helaas niet, maar toch was zij, ook in het licht van het onderwerp, in gedachten vaak heel dicht bij me. 


\section{Curriculum vitae}

Ria Wolleswinkel is geboren op 20 juli 1953 in Renswoude. Zij groeide op in de Gelderse Vallei. Haar ouders hadden daar een boerenbedrijf. Het HBS-A diploma behaalde zij aan het Christelijk Lyceum te Veenendaal. Na korte tijd Sociologie te hebben gestudeerd, stapte zij over naar het tweede jaar van de Sociale Akademie De Nijenburgh, eerst in Baarn, later in Culemborg gevestigd. Van 1976-1982 werkte zij als maatschappelijk werkster in het psychiatrisch ziekenhuis Duin en Bosch te Castricum. In 1982 behoorde zij tot de eerste lichting studenten aan de Faculteit der Rechtsgeleerdheid in Maastricht. Zij studeerde daar in 1986 cum laude af. Vervolgens werkte zij als toegevoegd docent en later als universitair docent Vrouw en Recht aan deze faculteit. $\mathrm{Zij}$ is lid van de vakgroep Strafrecht en Criminologie. Binnen het onderwijs geeft zij het keuzeblok Slachtoffers en het (straf)recht. Daarnaast houdt zij zich onder meer bezig met docentenprofessionalisering in het probleemgestuurd onderwijs. In het kader van haar onderzoek maakte zij deel uit van de begeleidingscommissie van de moeder-met-kind-unit in de halfopen gevangenis in Sevenum. Ook participeert zij in het European Action Research Committee on the Children of Imprisoned Parents. Zij zit in het bestuur van de Stichting Kinderopvang in Maastricht en is daarvan voorzitter sinds 1992. Haar partner is André Knottnerus. Samen kregen zij twee zonen, Bart (1981) en Pieter (1985). 